\title{
Summary of Information on Aquatic Biota and Their Habitats in the Willamette Basin, Oregon, through 1995
}

By BOB ALTMAN, AVIFAUNA NORTHWEST; COLLEEN M. HENSON, U.S. FISH AND WILDLIFE SERVICE; AND IAN R. WAITE, U.S. GEOLOGICAL SURVEY

U.S. GEOLOGICAL SURVEY

Water-Resources Investigations Report 97-4023

Prepared in cooperation with the U.S. FISH AND WILDLIFE SERVICE

and as part of the National Water-Quality Assessment Program 


\section{U.S. DEPARTMENT OF THE INTERIOR \\ BRUCE BABBITT, Secretary}

U.S. GEOLOGICAL SURVEY

Gordon P. Eaton, Director

The use of firm, trade, and brand names in this report is for identification purposes

only and does not constitute endorsement by the U.S. Geological Survey.

For additional information write to:

Copies of this report can be purchased from:

District Chief

U.S. Geological Survey

10615 South East Cherry Blossom Drive

Portland, Oregon 97216

E-mail: info-or@usgs.gov
U.S. Geological Survey

Branch of Information Services

Box 25286

Denver, CO 80225-0286

Telephone: (303) 202-4210

Information regarding the National Water-Quality Assessment (NAWQA) Program is available on the Internet via the World Wide Web. You may connect to the NAWQA Home Page at the Universal Resource Locator (URL):

<http://wwwrvares.er.usgs.gov/nawqa/nawqa_home.html>

Information regarding the Willamette NAWQA is available on the Internet by connecting to the Willamette NAWQA Home Page at:

<http://oregon.usgs.gov/projs_dir/pn366/nawqa.html>

Information regarding Oregon District Activities is available on the Internet by connecting to the Oregon District Home Page at:

$<$ http://oregon.usgs.gov/> 


\section{FOREWORD}

The mission of the U.S. Geological Survey (USGS) is to assess the quantity and quality of the earth resources of the Nation and to provide information that will assist resource managers and policymakers at Federal, State, and local levels in making sound decisions. Assessment of water-quality conditions and trends is an important part of this overall mission.

One of the greatest challenges faced by waterresources scientists is acquiring reliable information that will guide the use and protection of the Nation's water resources. That challenge is being addressed by Federal, State, interstate, and local water-resource agencies and by many academic institutions. These organizations are collecting water-quality data for a host of purposes that include: compliance with permits and water-supply standards; development of remediation plans for specific contamination problems; operational decisions on industrial, wastewater, or watersupply facilities; and research on factors that affect water quality. An additional need for water-quality information is to provide a basis on which regionaland national-level policy decisions can be based. Wise decisions must be based on sound information. As a society we need to know whether certain types of water-quality problems are isolated or ubiquitous, whether there are significant differences in conditions among regions, whether the conditions are changing over time, and why these conditions change from place to place and over time. The information can be used to help determine the efficacy of existing waterquality policies and to help analysts determine the need for and likely consequences of new policies.

To address these needs, the U.S. Congress appropriated funds in 1986 for the USGS to begin a pilot program in seven project areas to develop and refine the National Water-Quality Assessment (NAWQA) Program. In 1991, the USGS began full implementation of the program. The NAWQA Program builds upon an existing base of water-quality studies of the USGS, as well as those of other Federal, State, and local agencies. The objectives of the NAWQA Program are to:

- Describe current water-quality conditions for a large part of the Nation's freshwater streams, rivers, and aquifers.

- Describe how water quality is changing over time.
- Improve understanding of the primary natural and human factors that affect water-quality conditions.

This information will help support the development and evaluation of management, regulatory, and monitoring decisions by other Federal, State, and local agencies to protect, use, and enhance water resources.

The goals of the NAWQA Program are being achieved through ongoing and proposed investigations of 60 of the Nation's most important river basins and aquifer systems, which are referred to as study units. These study units are distributed throughout the Nation and cover a diversity of hydrogeologic settings. More than two-thirds of the Nation's freshwater use occurs within the 60 study units and more than twothirds of the people served by public water-supply systems live within their boundaries.

National synthesis of data analysis, based on aggregation of comparable information obtained from the study units, is a major component of the program. This effort focuses on selected water-quality topics using nationally consistent information. Comparative studies will explain differences and similarities in observed water-quality conditions among study areas and will identify changes and trends and their causes. The first topics addressed by the national synthesis are pesticides, nutrients, volatile organic compounds, and aquatic biology. Discussions on these and other waterquality topics will be published in periodic summaries of the quality of the Nation's ground and surface water as the information becomes available.

This report is an element of the comprehensive body of information developed as part of the NAWQA Program. The program depends heavily on the advice, cooperation, and information from many Federal, State, interstate, Tribal, and local agencies and the public. The assistance and suggestions of all are greatly appreciated.

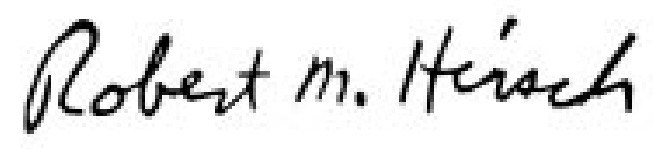

Robert M. Hirsch Chief Hydrologist 


\section{CONTENTS}

Abstract

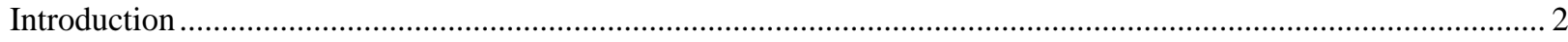

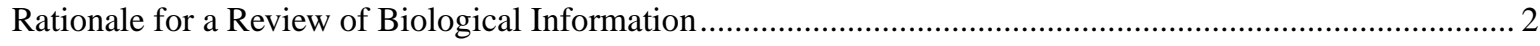

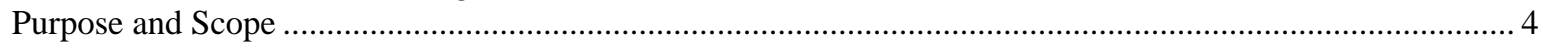

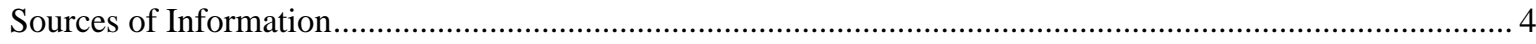

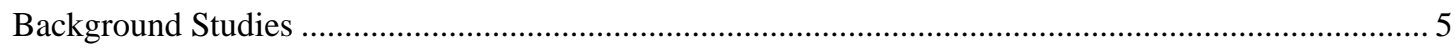

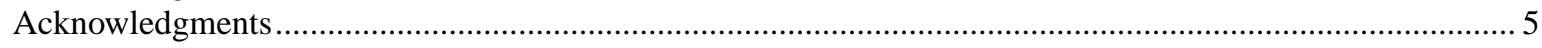

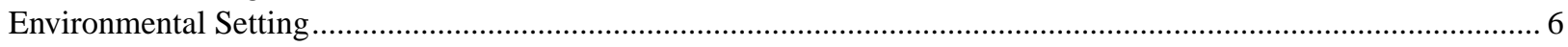

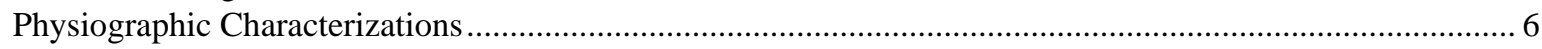

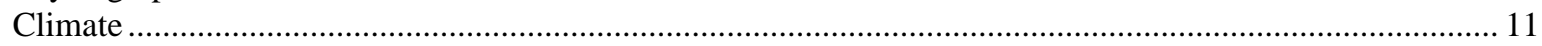

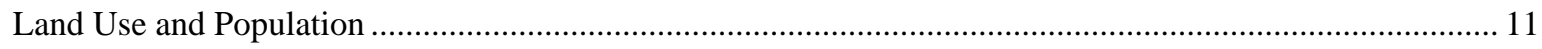

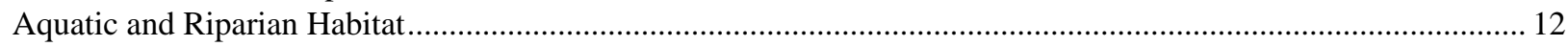

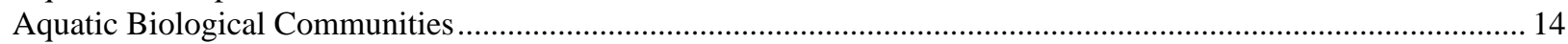

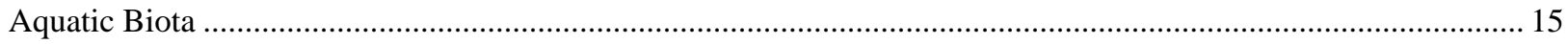

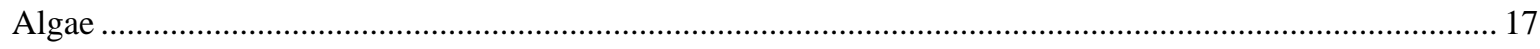

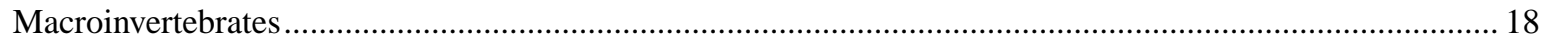

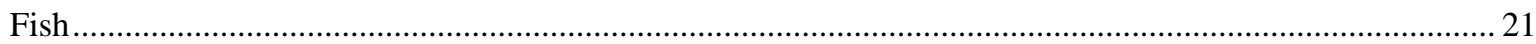

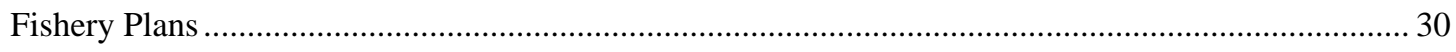

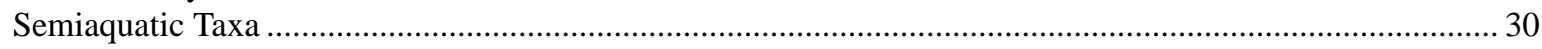

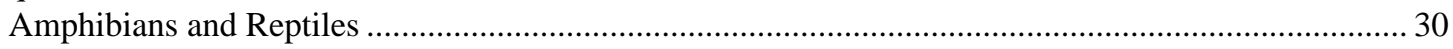

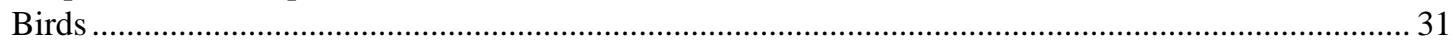

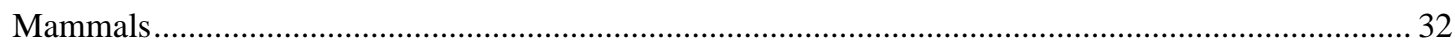

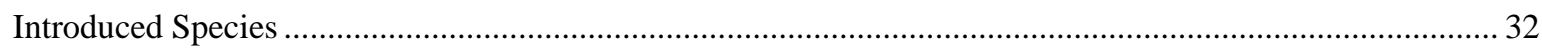

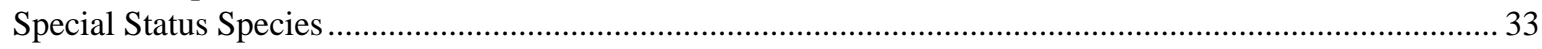

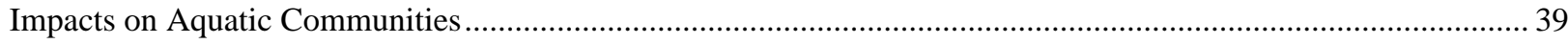

Sources of Impacts on Aquatic Communities ............................................................................................ 41

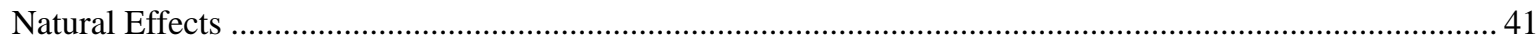

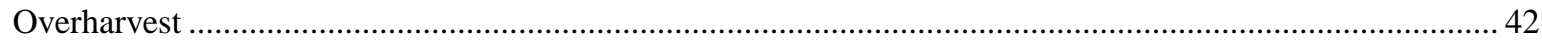

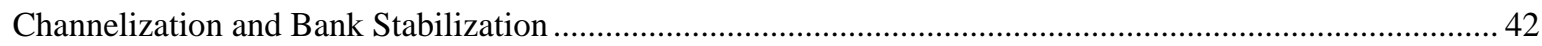

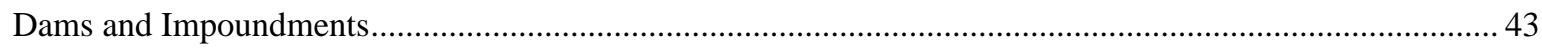

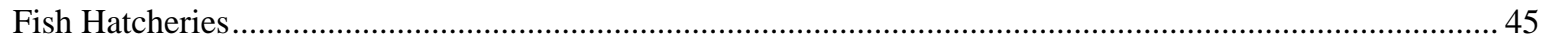

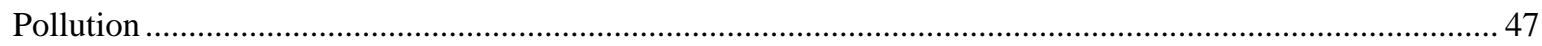

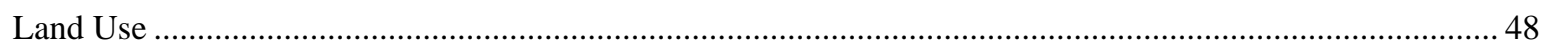

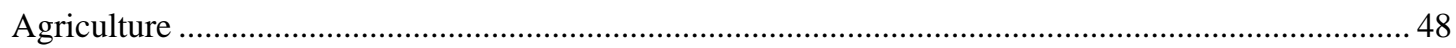

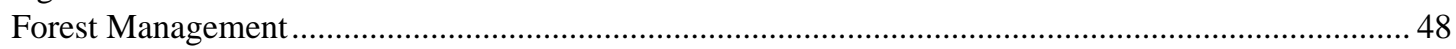

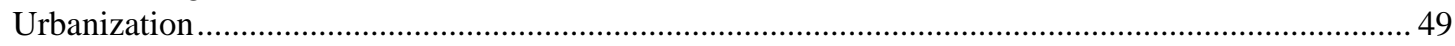

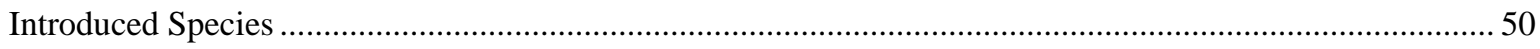

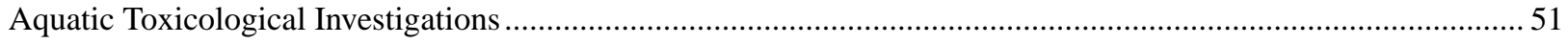

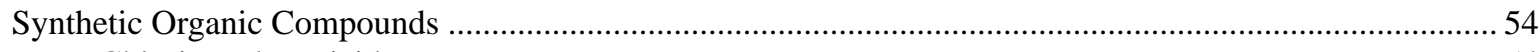

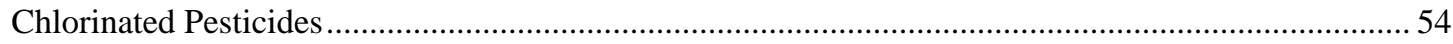

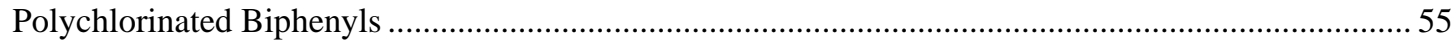

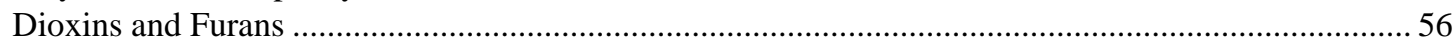

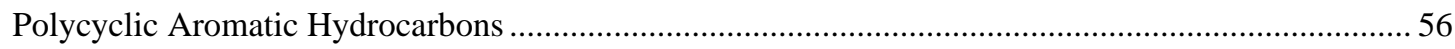

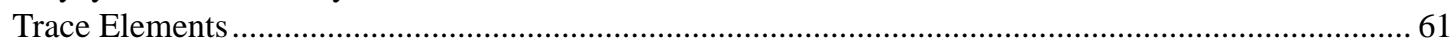

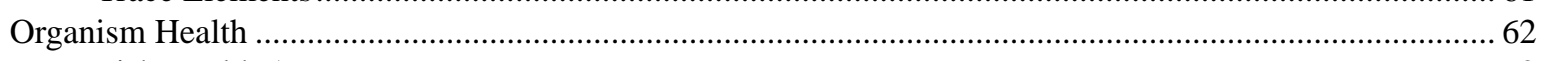

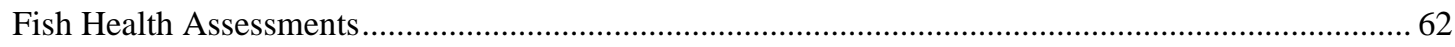

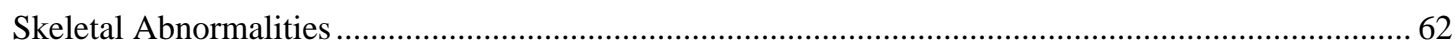

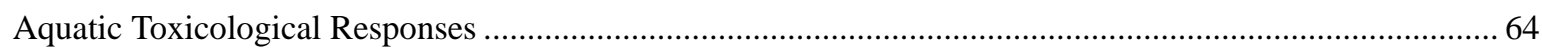

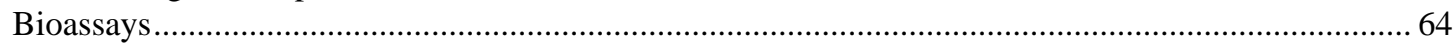

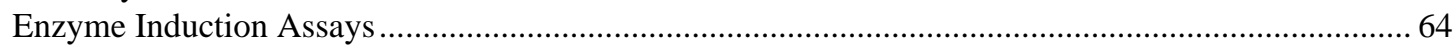

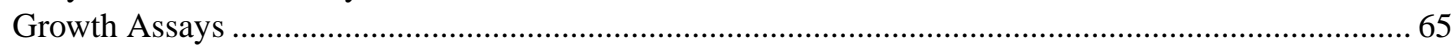




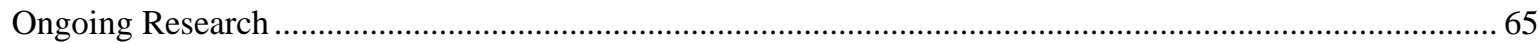

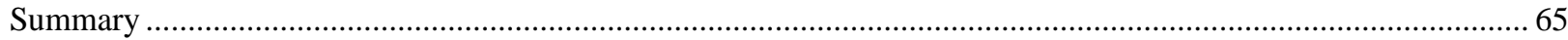

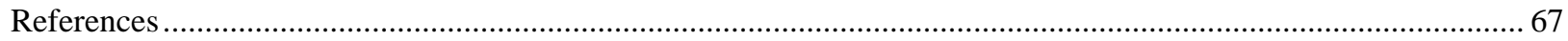

Appendix A. Investigations of aquatic biota in the Willamette Basin, Oregon ................................................. 89

B. Algae reported from aquatic environments in the Willamette Basin, Oregon .................................. 97

C. Macroinvertebrates reported from aquatic environments in the Willamette Basin, Oregon ........... 108

D. References on the effects of dams (proposed or operating) on aquatic habitat and biota,

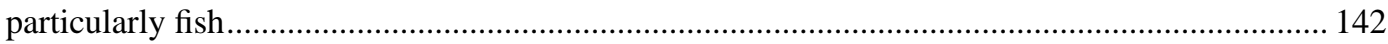

E-1. Chlorinated pesticides in tissue of aquatic biota from the Willamette Basin, Oregon .................... 144

E-2.Chlorinated pesticides in tissue of aquatic biota from the Willamette Basin, Oregon ..................... 150

E-3.Chlorinated pesticides in tissue of aquatic biota from the Willamette Basin, Oregon ..................... 156

F. Polychlorinated biphenyls in tissue of aquatic biota from the Willamette Basin, Oregon ............. 158

G-1.Trace elements in tissue of aquatic biota from the Willamette Basin, Oregon ................................. 165

G-2.Trace elements in tissue of aquatic biota from the Willamette Basin, Oregon ................................. 169

\section{FIGURES}

1. Location of the Willamette Basin, Oregon.................................................................................................. 3

2. Profile and hydrologic reaches of the Willamette River, Oregon ................................................................. 7

3. Fish hatcheries and major lakes and reservoirs in the Willamette Basin, Oregon .......................................... 9

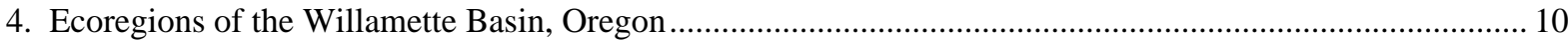

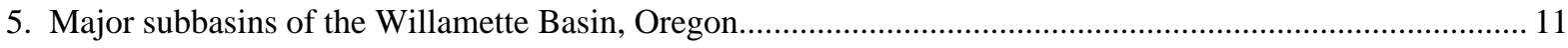

\section{TABLES}

1. U.S. Army Corps of Engineers reservoirs in the Willamette Basin, Oregon .................................................. 8

2. Fish management plans prepared by the Oregon Department of Fish and Wildlife for species and

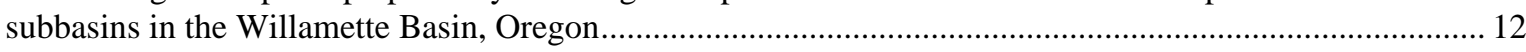

3. Origin, trophic group, and relative tolerance to pollution for fish species occurring in the Willamette

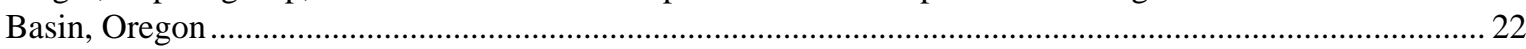

4. Distribution of fish species in major rivers of the Willamette Basin, Oregon ................................................ 25

5. Aquatic fauna with special status that are documented to occur in the Willamette Basin, Oregon.................. 34

6. Aquatic mollusc species of concern in the Willamette Basin, Oregon ........................................................... 37

7. Stocks of salmon and trout that are extinct or at risk of extinction in the Willamette Basin, Oregon............. 38

8. Fish hatcheries and holding/rearing ponds in the Willamette Basin, Oregon ................................................. 46

9. Aquatic toxicology investigations in the Willamette Basin, Oregon ……................................................... 52

10. Eggshell thickness data for great blue herons in the Pacific Northwest........................................................ 55

11a. Dioxins and furans in tissue of aquatic biota from the Willamette Basin, Oregon.......................................... 57

11b. Dioxins and furans in tissue of aquatic biota from the Willamette Basin, Oregon .........................................59

12. Percent abnormal external and internal features in fish from the Willamette Basin, Oregon .......................... 63

CONVERSION FACTORS, ABBREVIATED WATER-QUALITY AND TOXICOLOGICAL UNITS, FREQUENTLY REFERENCED STREAMS AND LAKES, AND ACRONYMS AND ABBREVIATIONS

\begin{tabular}{lcl}
\hline Multiply & By & \multicolumn{1}{c}{ To Obtain } \\
\hline acre & 4,407 & square meter \\
foot (ft) & 0.3048 & meter \\
inch (in.) & 25.4 & millimeter \\
mile (mi) & 1.609 & kilometer \\
square mile $\left(\mathrm{mi}^{2}\right)$ & 2.59 & square kilometer \\
\hline
\end{tabular}

Temperature in degrees Fahrenheit $\left({ }^{\circ} \mathrm{F}\right)$ can be converted to degrees Celsius $\left({ }^{\circ} \mathrm{C}\right)$ as follows:

$$
{ }^{\circ} \mathrm{C}=5 / 9\left({ }^{\circ} \mathrm{F}-32\right)
$$




\section{Abbreviated Water-Quality and Toxicological Units}

$\begin{array}{ll}\overline{\mathrm{x}} & \text { mean } \\ < & \text { less than } \\ > & \text { greater than } \\ \alpha & \text { alpha } \\ \beta & \text { beta } \\ \gamma & \text { gamma } \\ \Delta & \text { delta } \\ \mu \mathrm{g} / \mathrm{g} & \text { micrograms per gram } \\ \mathrm{nmol} / \mathrm{mg} \text {-protein/min } & \text { nanomoles per milligram protein per minute } \\ \mathrm{pg} / \mathrm{g} & \text { picogram per gram }\end{array}$

\section{Frequently Referenced Streams and Lakes}

$\begin{array}{ll}\text { Stream } & \text { Subbasin } \\ \text { Berry Creek } & \text { Luckiamute } \\ \text { Conser Slough } & \text { Willamette River } \\ \text { Johnson Creek } & \text { Willamette River } \\ \text { Oak Creek } & \text { Marys } \\ \text { Rock Creek } & \text { Tualatin }\end{array}$

\section{Acronyms and Abbreviations}

$\begin{array}{ll}\text { AHH } & \text { Aryl hydrocarbon (benzo[a]pyrene) hydrolase } \\ \mathrm{Al} & \text { Aluminum } \\ \mathrm{As} & \text { Arsenic } \\ \mathrm{Ba} & \text { Barium } \\ \mathrm{Be} & \text { Beryllium } \\ \mathrm{BLM} & \text { Bureau of Land Management } \\ \mathrm{Cd} & \text { Cadmium } \\ \mathrm{Cr} & \text { Chromium } \\ \mathrm{Cu} & \text { Copper } \\ \mathrm{DDD} & \text { Dichlorodiphenyldichloroethane } \\ \mathrm{DDE} & \text { Dichlorodiphenyldichloroethylene } \\ \mathrm{DDT} & \text { Dichlorodiphenyltrichloroethane } \\ \text { EPT } & \text { Ephemeroptera, Plecoptera, Trichoptera } \\ \text { EROD } & \text { Ethoxyresorufin O-deethylase } \\ \text { FDA } & \text { Food and Drug Administration } \\ \text { Fe } & \text { Iron } \\ \text { FEMAT } & \text { Forest Ecosystem Management Assessment Team } \\ \text { HCB } & \text { Hexachlorobenzene } \\ \text { HCBP } & \text { Hexachlorobiphenyl } \\ \text { HCH } & \text { Hexachlorocyclohexane } \\ \text { Hg } & \text { Mercury } \\ \text { HpCDD } & \text { Heptachlorodibenzo- } p \text {-dioxin } \\ \text { HpCDF } & \text { Heptachorodibenzofuran } \\ \text { HxCDD } & \text { Hexachlorodibenzo-p-dioxin }\end{array}$




\section{Acronyms and Abbreviations-Continued}

$\begin{array}{ll}\text { HxCDF } & \text { Hexachlorodibenzofuran } \\ \text { Mg } & \text { Magnesium } \\ \text { Mn } & \text { Manganese } \\ \text { Mo } & \text { Nolybdenum } \\ \text { NAWQA } & \text { National Water-Quality Assessment } \\ \text { NCBP } & \text { Nickel } \\ \text { Ni } & \text { National Marine Fisheries Service } \\ \text { NMFS } & \text { Oregon Department of Environmental Quality } \\ \text { ODEQ } & \text { Oregon Department of Fish and Wildlife } \\ \text { ODFW } & \text { Oregon Rivers Information System } \\ \text { ORIS } & \text { Oregon State University } \\ \text { OSU } & \text { Oregon Water Resources Department } \\ \text { OWRD } & \text { Polycyclic aromatic hydrocarbon } \\ \text { PAH } & \text { Lead } \\ \text { Pb } & \text { Pentachloroamisole } \\ \text { PCA } & \text { Polychlorobiphenyl } \\ \text { PCB } & \text { Pentachlorbiphenyl } \\ \text { PCBP } & \text { Polychlorodibenzo- } p \text {-dioxin } \\ \text { PCDD } & \text { Polychlorodibenzofuran } \\ \text { PCDF } & \text { Pentachlorodibenzo- } p \text {-dioxin } \\ \text { PeCDD } & \text { Pentachlorodibenzofuran } \\ \text { PeCDF } & \text { Planar halogenated hydrocarbons } \\ \text { PHH } & \text { Portland State University } \\ \text { PSU } & \text { River mile } \\ \text { RM } & \text { Selenium } \\ \text { Se } & \text { Tetrachlorobiphenyl } \\ \text { TCBP } & \text { Tetrachlorodibenzo- } \text {-dioxin } \\ \text { TCDD } & \text { Tetrachlorodibenzofuran } \\ \text { TCDF } & \text { Toxicity Equivalency Concentration } \\ \text { TEC } & \text { Thallium } \\ \text { Tl } & \text { U.S. Army Corps of Engineers } \\ \text { USACE } & \text { U.S. Environmental Protection Agency } \\ \text { USEPA } & \text { U.S. Forest Service } \\ \text { USFS } & \text { U.S. Fish and Wildife Service } \\ \text { USFWS } & \text { U.S. Geological Survey } \\ \text { USGS } & \text { Willamette River Basin Water Quality Study } \\ \text { WRBWQS } & \text { Willamette River Toxics Study } \\ \text { WRTS } & \text { Zinc } \\ \text { Zn } & \end{array}$




\title{
A Review of Aquatic Biological and Habitat Information in the Willamette Basin, Oregon, through 1995
}

\author{
By Bob Altman, Colleen M. Henson, and lan R. Waite
}

\section{ABSTRACT}

Available information on aquatic biota of the Willamette Basin was reviewed and summarized to describe current and historical conditions as part of the U.S. Geological Survey's National WaterQuality Assessment Program. Biological parameters emphasized include the status, distribution, and trends of aquatic biota, particularly algae, macroinvertebrates, and fish; the condition of aquatic and riparian habitat in which these biota reside; and the response of these biota to natural and human-associated impacts, including the level, type, and effect of contaminants.

Considerable data are available on aquatic biota in the Willamette Basin, although the information is highly uneven relative to taxa and spatial scope. Extensive information exists for highprofile taxa, such as salmonid fishes, but less information is available for macroinvertebrates, and relatively little data exist for algae. Additionally, some areas such as the H.J. Andrews Experimental Forest and the main stem Willamette River have been extensively studied, whereas data are limited for many other areas.

The basin supports a diverse aquatic macroinvertebrate fauna. Available data indicate a relatively high diversity of taxa and a high richness of Ephemeroptera, Plecoptera, Trichoptera (EPT) taxa in the upper reaches of the basin. In the lower main stem reaches, macroinvertebrate assemblages are dominated by pollution tolerant organisms and those adapted to low dissolved oxygen levels. Most of the limited data on algae are from sampling in the main stem Willamette River.
Diatoms and blue-green algae are the dominant algal forms.

Approximately 61 fish species occur in the basin, although nearly half are introduced. Species richness and distribution are highly correlated with elevation, stream gradient, and water temperature. High elevation, cold water, mountain streams are characterized by a few species of salmonids, sculpins, suckers, and whitefish. Low elevation, main stem reaches of major rivers and streams are dominated by warm water species, such as bass, catfish, and several species in the panfish group. The only species of fish listed as threatened or endangered is the Oregon chub (Oregonichthys crameri).

The effect of an expanding human presence in the Willamette Basin has substantially altered aquatic and riparian habitats, and the biota that use or reside in these habitats. Construction of dams, channelization and bank stabilization of rivers, species introductions, supplementations of fisheries through aquaculture, timber harvesting, agricultural activities, and urbanization have contributed to changes in aquatic habitats and biota from historical conditions.

Aquatic toxicological investigations in the basin have focused primarily on fish. These studies have addressed chlorinated pesticides, polychlorinated biphenyls (PCBs), dioxins and furans, polycyclic aromatic hydrocarbons (PAHs), and trace elements in aquatic tissue, as well as fish health assessments, skeletal abnormalities, and aquatic toxicological responses. Several pesticides exceeded U.S. Environmental Protection Agency and State water-quality criteria for the protection 
of aquatic life. Elevated PCB, dioxin, and furan concentrations were associated with point sources, such as pulp and paper mills. Elevated concentrations of mercury in aquatic tissue were associated with several reservoirs. Fish health assessments and skeletal abnormality studies detected high levels of abnormalities in fish from the main stem Willamette River. Few investigations have examined aquatic toxicological responses, such as enzyme induction assays, growth assays, and biomarker studies.

\section{INTRODUCTION}

The National Water-Quality Assessment (NAWQA) Program was initiated in 1991 by the U.S. Geological Survey (USGS) to (1) describe the status and trends of water quality of a representative portion of the Nation's surface- and ground-water resources and (2) provide a sound, scientific understanding of the primary natural and human factors affecting the quality of these resources (Cohen and others, 1988; Hirsch and others, 1988; Leahy and others, 1990; Wentz and McKenzie, 1991). The program is designed to provide nationally consistent and technically sound water-quality information useful to water managers, local policy makers, and the general public.

The NAWQA Program incorporates standardized approaches and protocols for collection of data on physical, chemical, and biological components in a multidisciplinary, integrated assessment of water quality across a wide range of spatial scales. The principal study units are hydrological basins or aquifer systems that provide information at a regional scale, opportunities for comparisons among study units, and a mechanism to synthesize data for multiple study units on a national scale. The Willamette Basin, which includes the Willamette and Sandy River Basins (fig. 1), was selected as one of the first 20 NAWQA study units for full-scale implementation.

An important component of the NAWQA

Program is a retrospective analysis that reviews and summarizes information on various constituents associated with water quality. The current report on aquatic biological information complements similar retrospective reports on physical and chemical constituents conducted as part of the assessment of water quality and aquatic ecosystem health in the Willamette Basin. This report will be useful in evaluating the NAWQA study design in terms of selection of sampling locations and biological constituents most important for understanding water-quality conditions from a basinwide perspective. Gurtz (1993) summarizes the reasons for including biological components in the NAWQA Program.

\section{Rationale for a Review of Biological Information}

Protection and enhancement of water quality and aquatic biota are considered to be critical long-term resource management issues in Oregon (Oregon Department of Environmental Quality, 1990). The Clean Water Act of 1972 is the regulatory driving force to "...restore and maintain the chemical, physical, and biological integrity of the Nation's waters...". The U.S. Environmental Protection Agency (USEPA) is the Federal agency and the Oregon Department of Environmental Quality (ODEQ) is the State agency responsible for administration of the act to ensure the availability of clean water for beneficial uses such as recreation (fishing, swimming, boating), drinking, navigation, hydroelectric power, agriculture, and fish and wildlife habitat. To address this responsibility, the ODEQ is required to prepare a report every 2 years assessing the status of water quality in the State. Specific information on the status and trends of water quality in the Willamette Basin is included in the most recent report (Oregon Department of Environmental Quality, 1994a).

The quality of surface water in the Willamette Basin is dependent upon numerous natural and humanassociated factors. Changes that affect the physical, chemical, or biological processes in surface water can cause changes in the biological communities. Thus, measuring condition and change of biological communities provides an index of surface-water quality (Mulvey and others, 1992).

Development of biological criteria for stream habitats is a useful means of assessing water quality (Karr, 1991). Biological criteria are measurements of ecological and physiological characteristics of organisms and communities that can be used to assess the biological integrity of a stream relative to a "reference stream" that has been minimally impacted by human activities (Hughes and others, 1986; Plafkin and others, 1989). The use of biological criteria in bioassessments of aquatic ecosystems is integral to the USEPA Rapid Bioassessment Protocol (Plafkin and others, 1989) and 


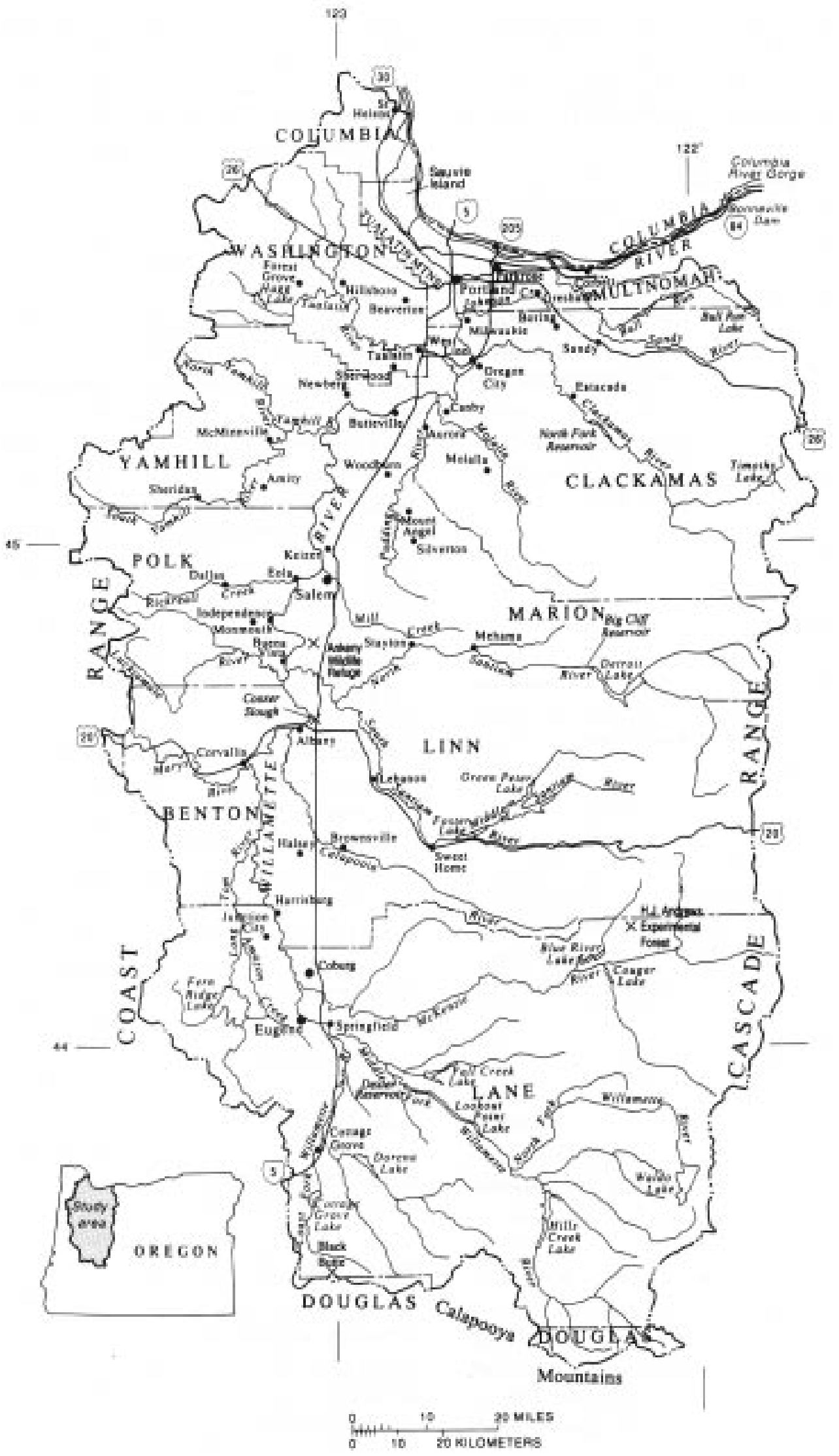

Figure 1. Location of the Willamette Basin, Oregon. 
other programs, including those used by the ODEQ (Mulvey and others, 1992). Additionally, biological criteria have been used in protocols for monitoring of wadable streams in the Pacific Northwest (Hayslip, 1993).

Assessment of water quality using biological criteria is based on an analysis of multiple metrics. A metric is a characteristic of biota that changes in some predictable way with perturbations in human or natural influences (Barbour and others, 1995). The metrics used for macroinvertebrates in the Willamette River Basin Water Quality Study (WRBWQS) include measures of species and community richness, composition, tolerance, and trophic levels (Tetra Tech, Inc., 1992b; 1994). Examples include percent Ephemeroptera, Plecoptera, Trichoptera (EPT) taxa, number of Chironomidae taxa, percent Oligochaeta, and percent scrapers.

\section{Purpose and Scope}

This report reviews and summarizes available information on aquatic biological communities in the Willamette Basin through 1995. Specifically, the report describes (1) the distribution, abundance, and trends of three taxonomic groups-algae, macroinvertebrates, and fish — and, to a lesser degree, other selected semiaquatic taxa (i.e., taxa frequenting but not living wholly in water), including amphibians and reptiles, birds, and mammals, (2) the types of aquatic and riparian habitat that support and influence aquatic communities and their biotic constituents, (3) the natural and humanassociated impacts on that habitat and associated biological communities, and (4) the levels of environmental contaminants to which biological communities and specific biota are exposed. The information in this report is intended to aid in the identification of data gaps relative to taxa and geographic areas, and to stimulate collaboration and increase coordination in present and future ecological research in the Willamette Basin.

For consistency with other investigations conducted as part of the Willamette Basin NAWQA Program, biological data have been reviewed for the entire Sandy River Basin and for the Willamette River Basin upstream from river mile (RM) 12.8 (Morrison Street Bridge). The latter site, known as the Willamette River at Portland, is a long-term streamflow and waterquality data collection site sampled by the USGS and ODEQ (Bonn and others, 1995). Downstream from
RM 12.8 to the mouth of the Willamette River at Kelly Point Park, only data from the main stem have been considered. Thus, data from the Multnomah Channel and from the Columbia Slough are not included in this review.

\section{Sources of Information}

Numerous sources were contacted and documents reviewed for this report. Readily available technical reports and environmental documents from government agencies and nongovernmental organizations were a principal source of data. Additionally, an attempt was made to acquire in-house and unpublished agency reports and available consultant reports. To facilitate this effort, assistance was solicited via a letter request and phone calls to appropriate individuals on potential sources of information.

Another source of data included student theses and dissertations, and research reports of university faculty and staff from Portland State University (PSU), University of Oregon, and, particularly, Oregon State University (OSU). At OSU, researchers from several programs, including the Cooperative Wildlife and Fisheries Units of the U.S. Fish and Wildlife Service (USFWS), the Systematic Entomology Laboratory, the Water Resources Research Institute, and the multidisciplinary "Stream Team" have conducted studies throughout the Willamette Basin for a number of years.

Several reports were used that reviewed aquatic biota at different scales. These documents include a status and trends report for fauna of the Pacific Northwest (Smith and Collopy, in press), a review of biota in the Tualatin subbasin (Li and Gregory, 1993), bibliographies of research publications from the H.J. Andrews Experimental Forest (HJAEF) in the McKenzie subbasin, and compilations of invertebrate occurrences at the HJAEF (Anderson and others, 1982; Parsons and others, 1991) and Berry Creek in the Luckiamute subbasin (Anderson and Hansen, 1987).

Most of the information on fish of the Willamette Basin was obtained from research, monitoring, and investigative studies conducted by the Oregon Department of Fish and Wildlife (ODFW). This information was documented in reports from their Processed Report, Information Report, and Progress Report series, and from other ODFW publications.

Principal data bases used in this report include the Oregon Rivers Information System (ORIS) for fish 
species distribution (Oregon Department of Fish and Wildlife, 1994), a USFWS data base on threatened and endangered species, and the Oregon Natural Heritage Program data base, which houses information on the occurrence and distribution of rare, threatened, and endangered plants and animals in Oregon (Oregon Natural Heritage Program, 1995). Additionally, a literature search was conducted of appropriate scientific publications and several agency publication data bases.

\section{Background Studies}

Several large-scale studies have been conducted that provide information on the aquatic biological resources of the Willamette Basin. The Willamette River Environmental Survey was conducted in 1958 and 1959 by the Fish Commission of Oregon to determine environmental conditions detrimental to anadromous fish runs in the Willamette River system (Willis and others, 1960). This study provides a detailed account of the physical habitat features, pollution problems, obstructions to fish passage, and fish species present for 17 major river systems and their tributaries.

The Oregon State Game Commission's Basin Investigations Section conducted field work in the 1960s to define water problems and needs associated with Willamette Basin fish and wildlife resources. The results of these investigations were documented in three reports: Lower Willamette Basin (Hutchison and Aney, 1964), Middle Willamette Basin (Oregon State Game Commission, 1963), and Upper Willamette Basin (Hutchison and others, 1966a). Another comprehensive review of the aquatic resources within the basin was provided by the Willamette Basin Comprehensive Study (Willamette Basin Task Force, 1969).

The USGS conducted an extensive water-quality assessment program in the early 1970 s "...to develop and document methods for evaluating basin-development alternatives in terms of potential impacts on water quality..." (Rickert and Hines, 1975). This study focused on (1) dissolved oxygen depletion, (2) algal problems, (3) trace element occurrence, and (4) the impact of land-use activity on erosion. Results of the study were published as USGS Circular 715 series (Chapters A-M) entitled "River-Quality Assessment of the Willamette River Basin, Oregon".

A recently completed Willamette River Toxics Study (WRTS) investigated the presence and effect of toxic pollutants in the Willamette River and selected tributaries (Oregon Department of Environmental Quality, 1994b). Data were collected on contaminant levels in sediment and fish from numerous sites and evaluated using bioassays and other aquatic-life toxicity testing methods.

An ongoing comprehensive study that complements the NAWQA Program is the WRBWQS. This 6year cooperative USGS and ODEQ study initiated in 1990 is evaluating ecological conditions, contaminants, and dissolved oxygen levels. The goal of the study is "... to develop a complete data base for the river basin coupled with water quality models that will enable Federal, State, and local agencies to cooperatively ensure the preservation and beneficial uses of the Willamette River Basin and its associated biota..." (Tetra Tech, Inc., 1993a). The study includes biological field investigations on benthic macroinvertebrates, fish, and algal communities. Data collected for the WRBWQS will be used to assist in the development of biological criteria for monitoring water quality, and to develop predictive mathematical models for assessing water quality and ecological health of aquatic biota. A listing of reports generated by the WRBWQS is presented in Tetra Tech, Inc., (1995a).

Much of the information presented here for aquatic resources in forested ecosystems of the basin is a result of research conducted at the HJAEF (fig. 1), which has been designated as one of 17 Long Term Ecological Research sites in the United States by the National Science Foundation (Parsons and others, 1991). This approximately 16,000 -acre site is located about 50 miles east of Eugene within the western Cascade Range of the Willamette Basin. Elevations range from 1,345 to 5,350 feet, and about 45 percent of the forest is old growth. The HJAEF was established in 1948, and early research efforts focused on efficiency of logging and road systems and on the success of forest regeneration (McKee and others, 1987). The research focus shifted in the 1960s to watershed studies and in the 1970s to ecosystem studies and community dynamics. Current research emphasis is shared between ecosystem and silvicultural studies. The HJAEF has become one of the most intensively studied forests in the world, as evidenced by more than 800 listings in a bibliography of research publications through 1987 (McKee and others, 1987; Blinn and others, 1988). Since 1977, the site has been jointly administered by the U.S. Forest Service (USFS) and OSU. 


\section{Acknowledgments}

Numerous individuals assisted in the development and preparation of this document, and several people deserve recognition. Dennis Wentz, Chief of the USGS Willamette Basin NAWQA Program, provided guidance and oversight throughout the project, including technical input, review, and assistance in production. Carmen Thomas, USFWS, conducted the initial compilation of available information including literature searches, data base retrievals, and contacts with appropriate individuals and agencies. Gloria Bourne, ODFW Research Librarian, assisted in locating several reports. Ron Rhew, USFWS, assisted in use of the ORIS data base and reviewed some sections of the report. Dorie Brownell, Donita Parker, and Mark Uhrich, USGS, prepared the figures, Thelma Parks, USGS, formatted the report; and Ronnie Nelson, USFWS, assisted with the references. The report has benefitted greatly from the comments of several reviewers, including Jeremy Buck, Ron Garst, Carol Schuler, and Marv Yoshinaka, USFWS; Dave Ward, ODFW; Steve Lawrence, USGS; and Peter Bayley, OSU.

\section{ENVIRONMENTAL SETTING}

The Willamette Basin NAWQA Study Unit includes the Willamette and Sandy River Basins and comprises approximately 12,000 square miles of land between the crest of the Cascade and Coast Ranges in northwestern Oregon (Wentz and McKenzie, 1991; Bonn and others, 1995) (fig. 1). The basin contains between 9,000 and 10,000 miles of streams (Willamette Basin Task Force, 1969), and over 2,000 lakes, totaling more than 60,000 acres (Oregon Department of Environmental Quality, 1992).

The basin is roughly rectangular in shape, approximately 125 miles in length, and ranging from 50-100 miles in width. It includes the broad alluvial plain of the Willamette Valley floor (approximately 3,500 square miles), and is bounded by mountain slopes and foothills on three sides and by the Columbia River on the north. The Cascade Range accounts for more than 60 percent of the basin area (Rickert and others, 1977). Elevation ranges from slightly above sea level at the mouth of the Willamette River near Portland to approximately 11,500 feet in the Cascade Mountains (Shearman, 1976).
The drainage system of the Willamette Basin is dominated by the northward-flowing Willamette River and its 13 major tributaries (fig. 1), which combined account for 93 percent of the basin area. The headwaters of the Willamette River arise in two forks- the Coast Fork and the Middle Fork-which flow northward from the Calapooya and Cascade Mountains, respectively, to form the main stem Willamette River near Eugene. Major westward flowing tributaries from the Cascade Mountains include (from south to north) the McKenzie River, Calapooia River, Santiam River, Molalla River, and Clackamas River. These tributaries have relatively steep gradients and high base flows sustained by melting snows and ground-water discharge (U.S. Army Corps of Engineers, 1991a). Principal tributaries flowing eastward from the Coast Range include (from south to north) the Long Tom River, Marys River, Luckiamute River, Rickreall Creek, Yamhill River, and Tualatin River (fig. 1). These tributaries have steep gradients only in the upper reaches, a slow meandering character in the foothills and valley floor, and low base flows during the summer months (U.S. Army Corps of Engineers, 1991a).

The main stem Willamette River is the predominant hydrologic feature in the Willamette Basin. The river flows north from Eugene for approximately 187 river miles through the Willamette Valley before entering the Columbia River near Portland (Gleeson, 1972; Shearman, 1976; Hines and others, 1977). The Willamette River is the 13th largest river in the contiguous United States in terms of total discharge (Kammerer, 1990), the largest tributary to the Columbia River below the Snake River (Parkhurst and others, 1950; Galbreath, 1965), and the largest river in the country entirely within one state (Clady, 1971). Stream gradient is relatively gentle, averaging less than 2.5 feet per mile, including a single drop of about 45 feet at Willamette Falls near Oregon City (RM 26.5) (fig. 2).

Currently, flows in the Willamette River and its major tributaries are highly regulated by dams and reservoirs. There are 13 U.S. Army Corps of Engineers (USACE) reservoirs on the major tributaries of the Willamette River (table 1 and fig. 3). The only hydroelectric project on the main stem Willamette River is Portland General Electric's Sullivan Plant at Willamette Falls. On tributaries throughout the basin, there are numerous small projects that provide water for hydroelectric generation and irrigation. 

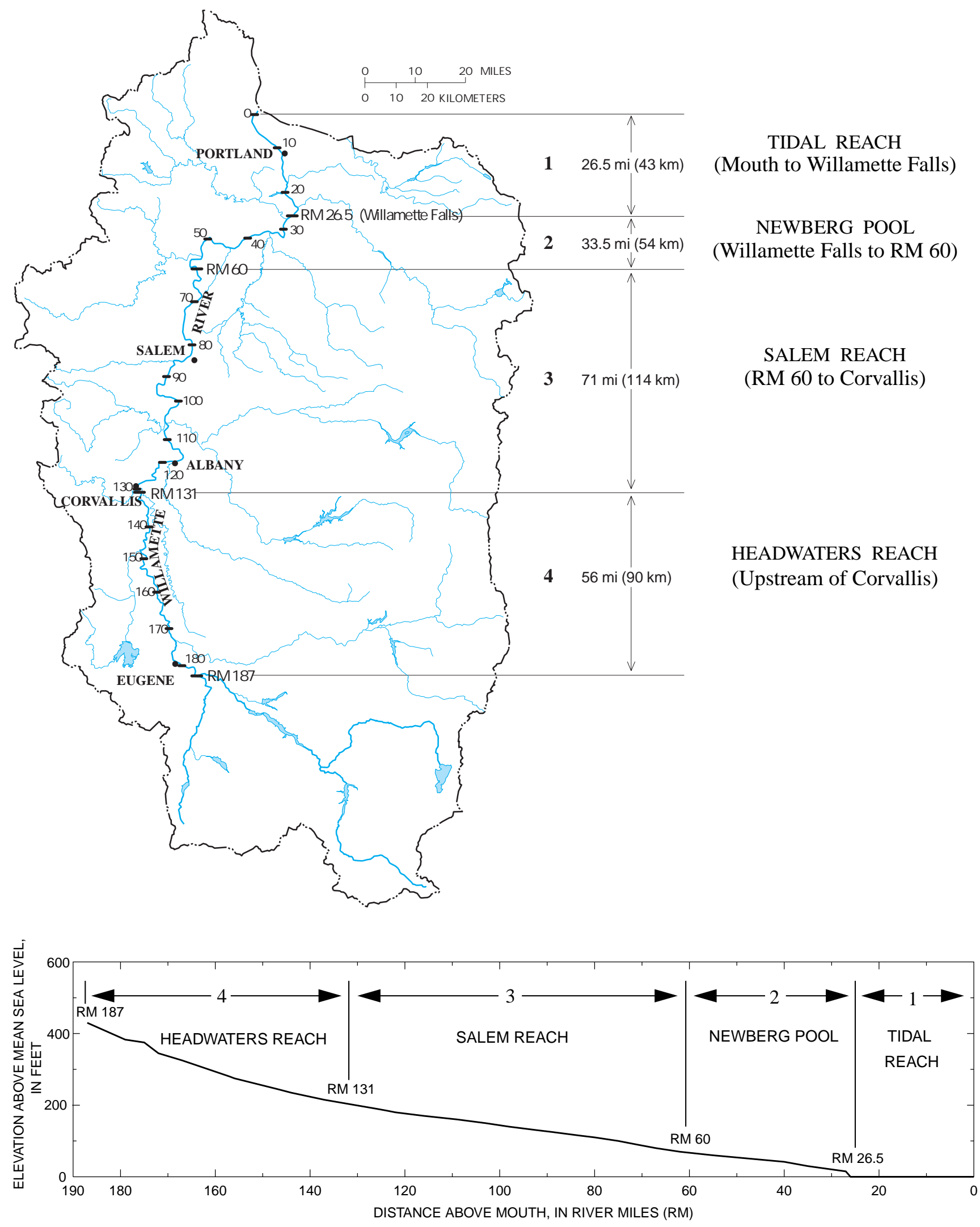

Figure 2. Profile and hydrologic reaches of the Willamette River, Oregon. 
Table 1. U.S. Army Corps of Engineers reservoirs in the Willamette Basin, Oregon

[Sources: U.S. Army Corps of Engineers (1982, 1991b). Storage capacity is usable capacity for low-flow augmentation]

\begin{tabular}{lcclc}
\hline \multicolumn{1}{c}{ Name } & $\begin{array}{c}\text { Year } \\
\text { completed }\end{array}$ & $\begin{array}{c}\text { Storage } \\
\text { capacity } \\
\text { (acre-feet) }\end{array}$ & \multicolumn{1}{c}{ River } & Subbasin \\
\hline Fern Ridge Lake & 1941 & 110,000 & Long Tom River & Long Tom \\
Cottage Grove Lake & 1942 & 30,060 & Coast Fork Willamette River & Coast Fork \\
Dorena Lake & 1949 & 70,500 & Row River & Coast Fork \\
Dexter Reservoir & 1954 & 4,800 & Middle Fork Willamette River & Middle Fork \\
Lookout Point Lake & 1953 & 349,400 & Middle Fork Willamette River & Middle Fork \\
Fall Creek Lake & 1962 & 115,000 & Fall Creek & Middle Fork \\
Hills Creek Lake & 1962 & 249,000 & Middle Fork Willamette River & Middle Fork \\
Cougar Lake & 1964 & 165,100 & South Fork McKenzie River & McKenzie \\
Blue River Lake & 1968 & 85,000 & Blue River & McKenzie \\
Foster Lake & 1966 & 33,600 & Middle Santiam River & Santiam \\
Green Peter Lake & 1966 & 333,000 & South Santiam River & Santiam \\
Detroit Lake & 1953 & 340,000 & North Santiam River & Santiam \\
Big Cliff Reservoir & 1953 & 2,430 & North Santiam River & Santiam \\
\hline
\end{tabular}

\section{Physiographic Characterizations}

The Willamette Basin includes all of one physiographic province (Willamette Valley), and parts of three other provinces (Western Cascades, High Cascades, and Coast Range) (Franklin and Dyrness, 1973). It is commonly divided into three sections for reference; the Upper, Middle, and Lower Basins (Willamette Basin Task Force, 1969; Oregon Water Resources Department, 1992). The Upper Basin is bounded on the south by the Calapooya Mountains and on the north by the divide between the Calapooia/Santiam and McKenzie drainages east of the valley floor and the Long Tom and Marys River drainage divide west of the valley floor. The Middle Basin includes all lands that drain into the Willamette River between the Long Tom and Marys River drainage divide and Fish Eddy, a point three miles below the mouth of the Molalla River. The Lower Basin includes all lands that drain into the Willamette River from Fish Eddy to the mouth of the Willamette River.

The Willamette Basin has also been divided into ecoregions (Omernik and Gallant, 1986; Omernik, 1987) and subecoregions (Clarke and others, 1991). Ecoregions are defined on the basis of similarities of characteristics such as land use, potential vegetation, soils, land forms, precipitation, and biological communities. The Willamette Basin includes three ecoregions (Willamette Valley, Cascade Range, and Coast Range) and two subecoregions of the Willamette Valley (flat, agricultural plains and the Coast Range and Cascade Range foothills) (Clarke and others, 1991) (fig. 4). Whittier and others (1988) identified similarities in streams within ecoregions in Oregon on the basis of data on physical habitat, water quality, and biological communities (fish, macroinvertebrates, and periphyton). Ecoregion divisions can be useful in water-quality assessment because they provide relatively distinct partitioning of areas with common climatic, hydrologic, geologic, and biologic features. Such partitioning is useful for evaluating the condition of aquatic biological communities, particularly if minimally impacted reference sites exist. These reference sites establish a baseline against which to compare sites where aquatic biological communities are potentially impacted. In Oregon, ecoregions have been used to describe geographic distribution of fish populations (Hughes and others, 1987).

Another physiographic delineation that is used extensively in this document is subbasins. These are based on hydrologic boundaries, and they correspond to the major tributaries of the Willamette River. Subbasins are useful for biological distinctions because streams within the defined geographic regions of watersheds or subbasins tend to be more similar to each other than those of streams within watersheds of a different geographic region. In the Willamette Basin, 15 major subbasins have been delineated on the basis of hydrologic boundaries (fig. 5). The area designated as "direct drainage to the Willamette River" includes 


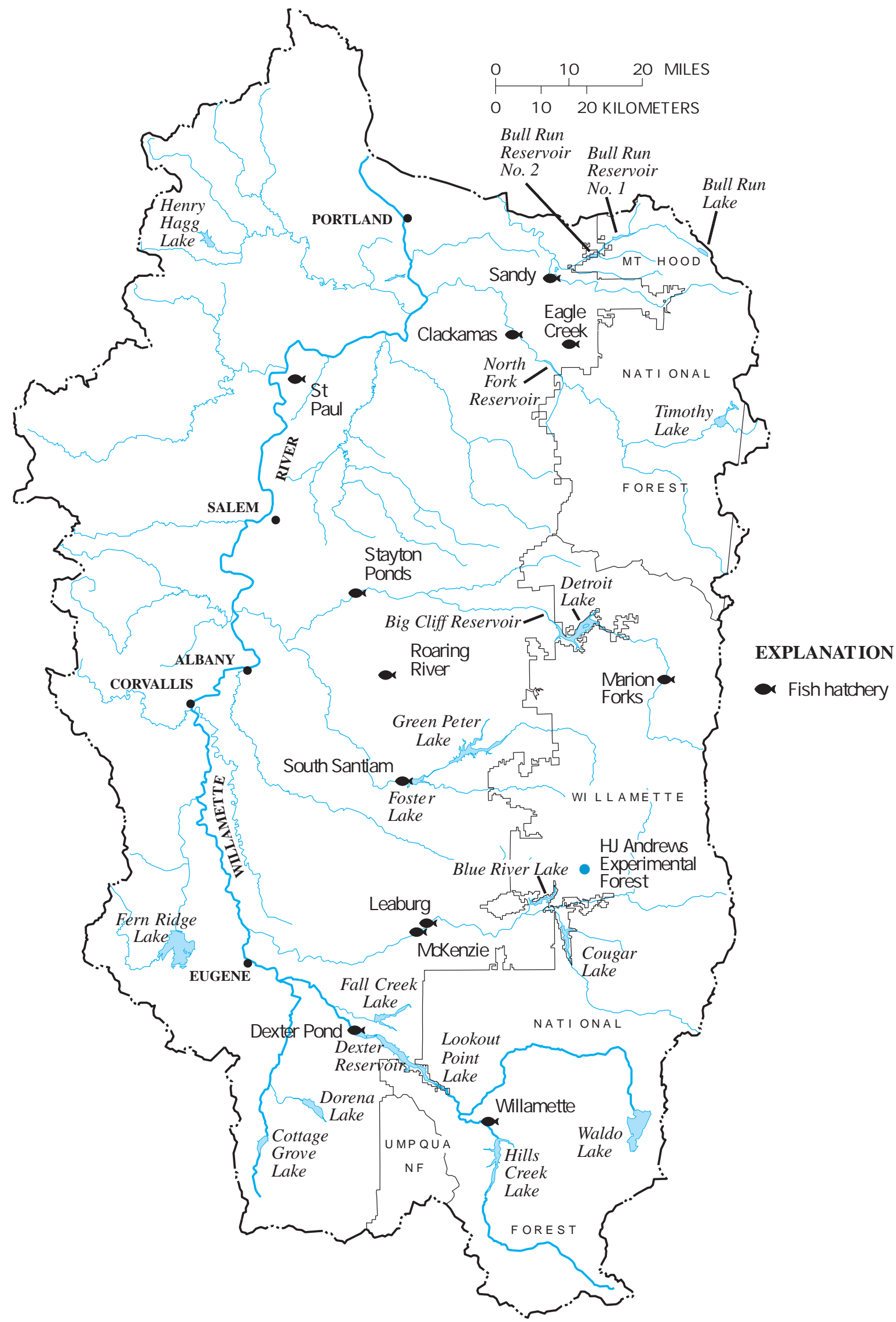

Figure 3. Fisheries and major lakes and reservoirs in the Willamette Basin, Oregon. 


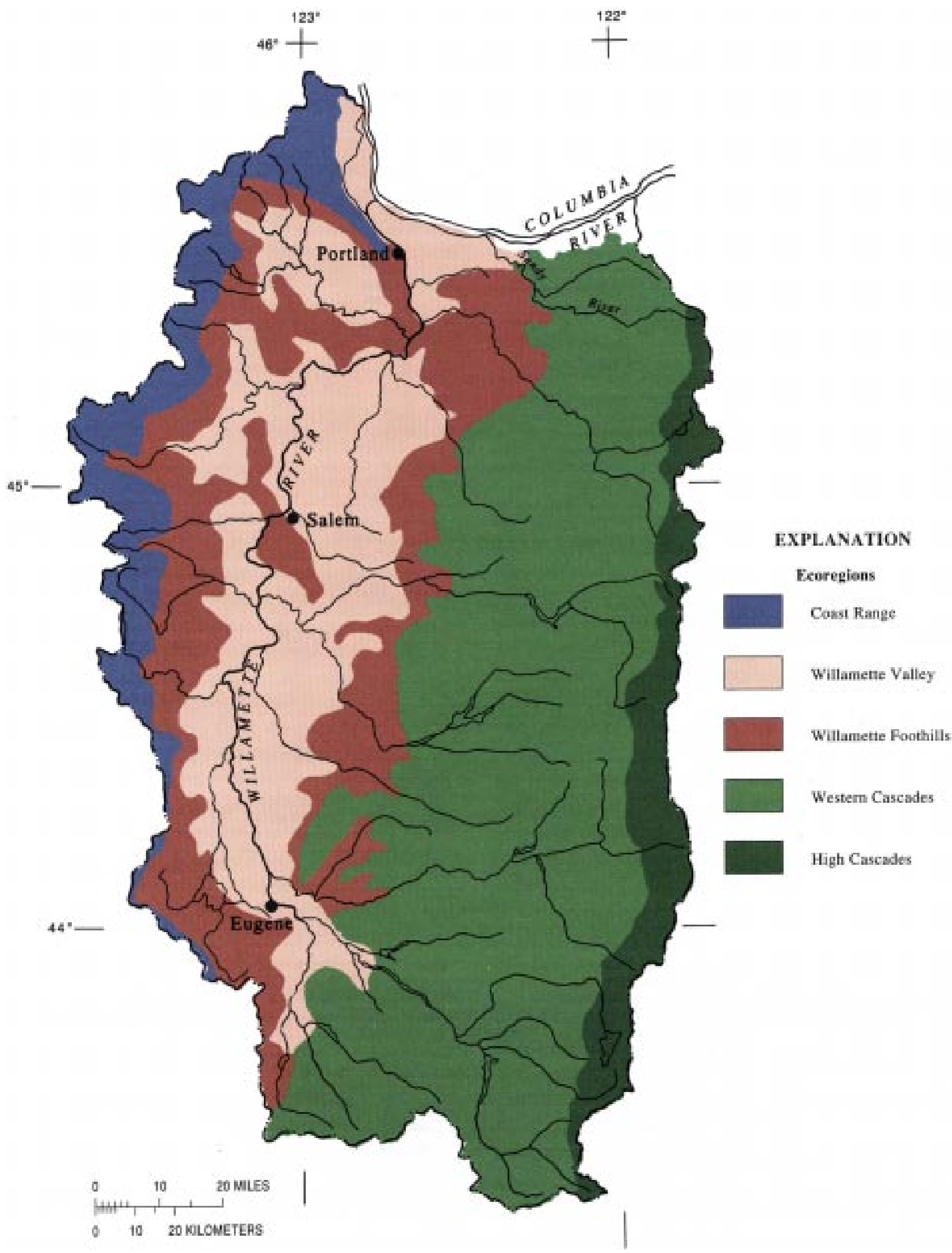

Figure 4. Ecoregions of the Willamette Basin, Oregon. (Modified from Clarke and others, 1991.) 


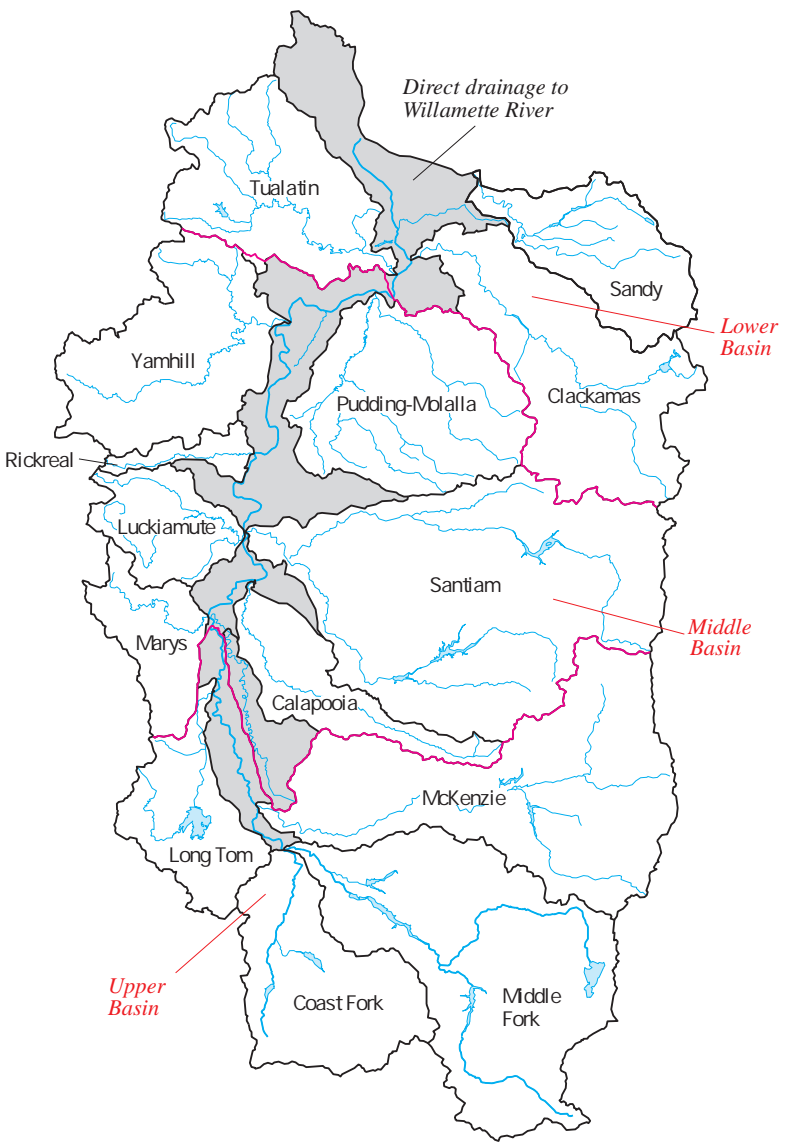

Figure 5. Major subbasins of the Willamette Basin, Oregon.

the main stem Willamette River and numerous small and (or) unnamed tributaries, backwater sloughs, and abandoned channels. Physical descriptions of each subbasin are provided in OWRD $(1991,1992)$ and in each of the subbasin fish management plans (table 2).

The main stem Willamette River has also been characterized in terms of four reaches (Rickert and others, 1975; Gregory, 1993) based on channel characteristics. The reaches are the Headwaters Reach (just above Eugene [RM 187] to Corvallis [RM 131]), the Salem Reach (Corvallis [RM 131] to above Newberg [RM 60]), the Newberg Pool (above Newberg [RM 60] to Willamette Falls [RM 26.5]), and the Tidal Reach (Willamette Falls [RM 26.5] to the Columbia River) (fig. 2). Tetra Tech, Inc., (1992a) provides physical descriptions and biological characterizations of each reach.

\section{Climate}

The climate of the Willamette Basin is maritime temperate with cool, wet winters and warm, dry sum- mers (Wentz and McKenzie, 1991); however, climatic conditions change with elevation. Precipitation ranges from approximately 35-40 inches of rainfall annually at lower elevations to approximately 175 inches (a high percentage as snowfall) in the mountains (Bonn and others, 1995). Rainfall decreases from north to south (Franklin and Dyrness, 1973), and approximately 90 percent of the average annual rainfall occurs between October and April. The seasonal dry period from May through September historically had an adverse impact on summer-early fall streamflow and water quality of the Willamette River.

\section{Land Use and Population}

The Willamette Basin is 70 percent forested (primarily in tributary subbasins), 22 percent agricultural (primarily on the valley floor), and 5 percent urbanized (Bonn and others, 1995). The basin includes 11 of the 12 largest cities in the State, including the five largest (Center for Population Research and Census, 1992), and approximately 2 million people or 70 percent of Oregon's population (Oregon Department of Environmental Quality, 1988; Bonn and others, 1995). Historically, the basin has supported most of Oregon's economic activity, including extensive timber, agricultural, industrial, and recreational economies (Shearman, 1976). Most of the agricultural activities occur in the midvalley counties of Linn, Benton, Polk, and Marion (fig. 1). The timber industry is an important part of the economy in Lane County in the southern part of the basin, and throughout the Cascade and Coast Range Mountains. Greater diversification in terms of trade, service, and manufacturing industries occurs in the northern part of the basin in Multnomah, Clackamas, and Washington Counties (U.S. Army Corps of Engineers, 1991a). Some sand and gravel mining activities occur adjacent to and within the main stem Willamette River and major tributaries, such as the Clackamas River.

The basin also has important fish and wildlife habitat (Shearman, 1976) and has historically been a favored hunting and sport fishing area (Willamette Basin Task Force, 1969). The main stem Willamette River near Portland provides recreational fishing to a major metropolitan population for resident fish such as black crappie (Pomoxis nigromaculatus), white crappie (Pomoxis annularis), smallmouth bass (Micropterus dolomieui), largemouth bass (Micropterus salmoides), and walleye (Stizostedion vitreum), and anadromous salmonids, including steelhead trout 
Table 2. Fish management plans prepared by the Oregon Department of Fish and Wildlife (ODFW) for species and subbasins in the Willamette Basin, Oregon

[Coast Range Subbasin includes the Luckiamute, Marys, Rickreall, and Yamhill Subbasins]

\begin{tabular}{|c|c|c|}
\hline Plan & Date & Reference \\
\hline \multicolumn{3}{|l|}{ Basin/Subbasin Plans } \\
\hline Clackamas Subbasin Fish Management Plan & January 1992 & Murtagh and others (1992a) \\
\hline Coast Fork Willamette Subbasin Fish Management Plan & December 1991 & Connolly and others (1991) \\
\hline Coast Range Subbasin Fish Management Plan & March 1992 & Wevers and others (1992a) \\
\hline Long Tom Subbasin Fish Management Plan & March 1992 & $\begin{array}{l}\text { Connolly and others } \\
\text { (1992a) }\end{array}$ \\
\hline Main stem Willamette Subbasin Fish Management Plan & March 1992 & Rien and others (1992) \\
\hline McKenzie Subbasin Fish Management Plan & April 1988 & Howell and others (1988) \\
\hline Middle Fork Willamette Subbasin Fish Management Plan & March 1992 & $\begin{array}{l}\text { Connolly and others } \\
\text { (1992b) }\end{array}$ \\
\hline Molalla and Pudding Subbasin Fish Management Plan & March 1992 & Wevers and others (1992b) \\
\hline North Fork of Middle Fork Willamette River Fish Management Plan & 1979 & ODFW (1979) \\
\hline Santiam and Calapooia Subbasin Fish Management Plan & March 1992 & Wevers and others $(1992 \mathrm{c})$ \\
\hline Tualatin River Subbasin Fish Management Plan & January 1992 & Murtagh and others (1992b) \\
\hline Willamette Basin Fish Management Plan & June 1980 & ODFW (1980) \\
\hline Willamette Basin Fish Management Plan: Status and Progress 1979-85 & October 1986 & Howell (1986) \\
\hline Willamette Basin Fish Management Plan (updated) & March 1988 & ODFW (1988) \\
\hline Willamette Basin Fish Management Plan (updated) & October 1991 & ODFW (1991) \\
\hline \multicolumn{3}{|l|}{ Species Plans } \\
\hline Coho Salmon Plan & June 1982 & ODFW (1982a) \\
\hline Coho Salmon Plan Status Report & February 1985 & ODFW (1985) \\
\hline $\begin{array}{l}\text { Comprehensive Plan for Production and Management of Oregon's } \\
\text { Anadromous Salmon and Trout }\end{array}$ & June 1982 & ODFW (1982c) \\
\hline Implementation Plan for Spring Chinook Salmon & June 1993 & ODFW (1993) \\
\hline Steelhead Plan & July 1986 & ODFW (1986) \\
\hline Steelhead Plan (updated) & 1995 & ODFW (1995c) \\
\hline Trout Plan & November 1987 & ODFW (1987a) \\
\hline Warmwater Game Fish Plan & August 1987 & ODFW (1987b) \\
\hline
\end{tabular}

(Oncorhynchus mykiss gairdneri), coho salmon (Oncorhynchus kisutch), American shad (Alosa sapidissima), and white sturgeon (Acipenser transmontanus) (Farr and Ward, 1993). The main stem of the Willamette River, particularly below Willamette Falls, also provides the largest recreational spring chinook salmon (Oncorhynchus tshawytscha) fishery in the State (Oregon Department of Fish and Wildlife, 1990).

\section{AQUATIC AND RIPARIAN HABITAT}

The type, distribution, and quality of aquatic and riparian habitat in the Willamette Basin is highly vari- able as a result of the diversity of environmental factors (topography, geomorphology, soils, climate, vegetation) and human-related factors (habitat perturbations, land use activities) that exist within the surrounding landscape. Since aquatic biological communities are affected not only by water quality but also by the physical features of aquatic and riparian habitat, condition of the physical habitat can be used as an indicator of the composition and condition of the biological community. A summary of the parameters used to evaluate aquatic and riparian habitat in the Pacific Northwest is presented in Tetra Tech, Inc., (1995b). The parameters include several measured variables of substrate, in- 
stream cover, channel morphology, and riparian conditions.

Aquatic habitats may be broadly classified as running-water or slackwater systems (Holland, 1994). Running-water habitat in the main stem Willamette River differs substantially between the upper and lower reaches (Oregon Department of Fish and Wildlife, 1990). Gravel and cobble are the common substrate in the upper reaches, whereas the lower reaches are characterized by sand and finer sediment from the accumulated effects of sedimentation (Hughes and Gammon, 1987). Aquatic stream margin and floodplain slack-water areas, such as sloughs and backwater pools, are important for rearing juvenile fishes, invertebrate production, terrestrial organic input (leaf fall), and as a refuge during disturbances such as large floods (Moore, 1987; Naiman and others, 1988; Gregory and others, 1989; Sedell and others, 1990). Root masses of trees and emergent vegetation within slackwater aquatic habitat provides unique microhabitats for aquatic fauna (Holland, 1994).

Riparian habitat is the interface between aquatic and terrestrial ecosystems and is characterized by vegetation that is adapted to a high water table and periodic flooding (Gregory and others, 1991). Examples of important functions of riparian vegetation for stream ecosystems include shading, bank stabilization, uptake of nutrients, input of leaves and needles, retention of particulate organic matter during high flows, and contribution of large woody debris (Gregory and others, 1989). Riparian forests serve as buffers to adjacent habitats during floods (Holland, 1994) and also function to lessen the inflow of contaminant runoff into the aquatic community.

The riparian canopy in streams of the Cascade Mountains plays a dominant role in the abundance of most aquatic biota (Gregory, 1980; Murphy and Hall, 1981; Hawkins and others, 1983), often masking effects of substrate character (Murphy and others, 1981). The relationship between stream shading and biota in mountain streams of the basin has been investigated for fish (Aho, 1976; Murphy and others, 1981; Hawkins and others, 1983; Wilzbach, 1984), invertebrates (Grafius, 1977; Murphy and others, 1981; Hawkins and others, 1982), and salamanders (Hawkins and others, 1983). The results of these studies are discussed in a later section of this report (see "Forest Management").

Considerable work has been done in the basin on the ecological role of woody debris in streams
(Swanson and others, 1976), particularly in providing habitat for fish (Hall and Baker, 1982; Triska and others, 1982), and food resources for aquatic invertebrates (Swanson and others, 1982; Triska and others, 1982). The removal of woody debris from rivers in the basin for navigational and other purposes, and the fragmentation or elimination of riparian forests that provide woody debris sources, has rendered these aquatic habitats less complex and less suitable for some organisms, particularly salmonid fishes (Hicks and others, 1991).

As the human population has increased in the Willamette Basin, much of the aquatic and riparian habitat has been fragmented or eliminated. For example, the floodplain of the main stem Willamette River was once covered by dense woodland extending approximately 1-2 miles on either side of the river, but most of this forest has been cleared for farmland or timber (Sedell and Froggatt, 1984).

The earliest systematic and comprehensive attempt to evaluate aquatic and riparian habitat for anadromous fishes in the Willamette Basin was made between 1934 and 1942 as part of a program undertaken by the USFWS Bureau of Fisheries (now the National Marine Fisheries Service [NMFS]) to survey all tributaries in the Columbia River Basin (Rich, 1948). Data were collected on salmon and steelhead trout populations along with information on sources of pollution, impassable waterfalls, log and debris jams, and irrigation diversions. Another early assessment of stream conditions relative to the breeding, rearing, and migration of anadromous fishes was for the Sandy River and its tributaries (Craig and Suomela, 1940). Parkhurst and others (1950) reported the results of a several year survey of all the major tributaries of the Willamette River system. They described stream types and surrounding landforms, flows, barriers to fish, spawning habitat, and sources of pollution. Willis and others (1960) conducted an extensive evaluation of stream habitat characteristics, pollution problems, and fish passage problems for 17 river systems in the Willamette Basin. Another comprehensive assessment of stream habitat, spawning areas, and barriers to fish movement in the Willamette Basin was a cooperative effort by the Oregon State Game Commission, Fish Commission of Oregon, and USFWS Bureau of Commercial Fisheries (Thompson, 1965; Hutchison and others, 1966b).

The habitat surveys conducted by the USFWS Bureau of Fisheries between 1934 and 1942 (Rich, 1948) have been summarized in McIntosh and others 
(1995). These surveys represent the earliest and most comprehensive documentation available on the condition and extent of anadromous fish habitat prior to hydropower development. Comparisons of historical riparian habitat conditions (as defined by these surveys) with present conditions have been the focus of recent research along the McKenzie River (Minear, 1994), and for 30 streams throughout the Willamette Basin (Bruce McIntosh, Oregon State University, oral commun., 1995). Another example of an attempt to compare historic and existing riparian habitat was a study along a section of the lower McKenzie River (EA Engineering, Science and Technology, Inc., 1991a).

State and Federal resource management and regulatory agencies, such as the USFS, ODFW, ODEQ, USEPA, and Bureau of Land Management (BLM), often conduct habitat surveys of streams to assess conditions relative to proposed or implemented management activities or specific project needs. These data are contained within project or program files or sometimes summarized in reports, such as Heller and Baker (1974) and Armantrout and Shula (1975). Some examples of project-related assessments of instream and riparian habitat of portions of the McKenzie River include Hawk and Zobel (1974), Hardin-Davis, Inc., (1988), and EA Engineering, Science and Technology, Inc., (1991a). Additionally, the majority of investigations of aquatic biota in the basin include some degree of instream and/or riparian habitat assessment.

Historically, there has been a lack of standardized methods and protocols on the type and level of aquatic and riparian habitat assessment. Several protocols have recently been developed to correct this deficiency. The USEPA has developed guidelines to evaluate the impacts of forest management on streams in the Pacific Northwest (MacDonald and others, 1991). The USFS Region 6 Level II protocol uses visual estimation methods established by Hankin and Reeves (1988) to estimate fish abundance and habitat area in small streams. The ODFW has developed standardized methodology to quantify the habitat condition of streams for its Aquatic Inventory Project (Oregon Department of Fish and Wildlife, 1995a). This methodology was developed in conjunction with other governmental and nongovernmental entities to be compatible with existing stream habitat assessment methodologies. The USEPA Index of Biotic Integrity protocol uses fish communities, and the Rapid Bioassessment Procedure uses stream habitat characteristics and mac- roinvertebrate communities, to evaluate ecological integrity of aquatic habitats by comparing study sites to an unimpaired or minimally disturbed site. The ODEQ has developed a protocol for monitoring nonpointsource pollution using macroinvertebrates and habitat (Mulvey and others, 1992).

Protocols for habitat evaluation of large rivers, such as the main stem Willamette River and its major tributaries, are less developed owing to several factors, including difficulties in sampling deep flowing waters, high diversity in communities, and high temporal variability in environmental conditions (Bain, 1992). Tetra Tech, Inc., (1995b) used a combination of habitat parameters specified in other Federal and State protocols, such as those in Plafkin and others (1989), Mulvey and others (1992), Hayslip (1993), and Simonson and others (1994), for its habitat evaluation of the Willamette River as part of the WRBWQS. Because Tetra Tech, Inc.'s habitat evaluation was intended to support biological assessments, they used habitat parameters that emphasized the most biologically significant habitat features. They reported that the combination of metrics and scoring criteria selected were generally effective for determining biological condition. The NAWQA Program has also developed habitat protocols that can be used in small and large river systems (Meador and others, 1993).

\section{AQUATIC BIOLOGICAL COMMUNITIES}

Assessment of aquatic biological communities within a large watershed such as the Willamette Basin requires the recognition that physical and chemical changes to aquatic habitats result in changes in biological assemblages. From the high gradient, shallow headwater streams of the Cascades and Coast Range, to the low gradient, deep-water reaches of the lower Willamette River, there are extreme differences in environmental conditions (water flow, temperature, and dissolved oxygen content) and human-associated impacts. The occurrence and health of biota within these riverine aquatic communities is dependent upon, and varies as a result of, a combination of many sitespecific and landscape factors including both upstream and downstream phenomena (Vannote and others, 1980). Similarly, the biota of larger water bodies (natural lakes and reservoirs) in the basin varies, from those characteristic of nutrient-poor, low productivity, "oligotrophic" montane lakes of the Cascades, to those of the warmer, more productive, "eutrophic" lakes of 
lower elevations, which typically support a high biomass of algae but a low diversity of aquatic fauna.

Most aquatic biological investigations in the Willamette Basin have focused on fish and particularly on salmonids because of their importance in sport and commercial fisheries. Information on macroinvertebrates is less extensive, and information on algae is considerably less extensive, particularly with regard to the historic occurrence of these taxa and their responses to physical, chemical, and biological impacts. Additionally, few aquatic macroinvertebrate and algal investigations have been spatially extensive (except for the WRBWQS), whereas several fish community studies have been spatially extensive, including Dimick and Merryfield (1945), Hughes and Gammon (1987), and Tetra Tech, Inc., (1993b).

Whittier and others (1988) provide a broad-scale characterization of aquatic biological communities in the Willamette Valley, relative to the seven other ecoregions in Oregon, based on assemblages of fish, invertebrates, and algae. In general, Willamette Valley streams had the greatest fish species richness and diversity, the most introduced species, and the fewest salmonids. Periphyton assemblages also had the greatest taxa richness and diversity, but macroinvertebrate assemblages had low richness and diversity, were lacking several common insect families, and had the highest proportion of noninsects.

\section{AQUATIC BIOTA}

The aquatic biota emphasized in this document are algae, macroinvertebrates, and fish. The importance of these taxa in the NAWQA Program is their role as indicators of water quality, and their use, particularly of fish, in contaminant analyses.

Algae are chlorophyll-containing photosynthetic organisms that range in size from microscopic single cells to long filamentous strands. They occur in rivers, lakes, and reservoirs, usually suspended in the water column (phytoplankton) or attached to a submerged substrate (periphyton). Algae, particularly diatoms, play an important role in aquatic ecosystems as the basis of production for aquatic food webs. Diatoms are considered to be of high food value for various aquatic fauna (Johnson and others, 1985).

Algal communities are useful in water-quality assessments because they are sensitive to changes in nutrient and dissolved oxygen concentrations, $\mathrm{pH}$, and water temperature. Algae have short life cycles, which makes them particularly responsive to environmental changes (Lowe and Pan, 1996) and have restricted mobility, which allows inferences to be drawn based on nearby sources of pollution (Tetra Tech, Inc., 1993a). The community composition and abundance of certain algae also provide a measure of trophic state or productivity in aquatic systems. Johnson and others (1985) list and describe algae used as indicators of aquatic conditions in Oregon lakes: Anabaena spp., Aphanizomenon flos-aquae, and Stephanodiscus astraea were found in eutrophic lakes, and Chromulina spp., Cyclotella stelligera, and Sphaerocystis schroeteri occurred in oligotrophic lakes.

Macroinvertebrates serve various functions in aquatic ecosystems, particularly as secondary consumers in many food chains (Healy, 1984) and as recyclers of organic matter (Merritt and others, 1984). They also are important organisms in the diet of fish, particularly trout and salmon. The macroinvertebrate community of streams, rivers, and lakes usually includes some or all of the following: insects, flatworms, crustaceans, and mollusks.

Macroinvertebrates are often used in assessments of the health of the aquatic community because they are relatively sessile, generally easily collected and identified, relatively abundant, and sensitive to physical and chemical changes in the water. Further, their responses to changing water conditions can be measured, and they often serve as the primary food source for many recreationally and commercially important fish (Plafkin and others, 1989; Mulvey and others, 1992). Macroinvertebrate communities also tend to have greater diversity than fish communities, and the natural integrity of the community is less compromised than that of fish communities, which are affected by fish stocking, sport fishing, and introduced species (Mulvey and others, 1992).

Several generalizations are recognized regarding the relationship between aquatic macroinvertebrates and water quality. High taxonomic diversity of aquatic macroinvertebrates is usually, but not always, indicative of healthy aquatic conditions. A metric commonly used to assess stream health is the ratio of EPT taxa (Orders Ephemeroptera, mayflies; Plecoptera, stoneflies; and Trichoptera, caddisflies) to chironomid midge larvae (Family Chironomidae). EPT taxa are generally classified as intolerant because of their sensitivity to degraded water conditions, and chironomids are generally considered tolerant for the opposite rea- 
son. Organisms of the EPT orders generally require relatively large dissolved oxygen concentrations, minimal turbidity, and low water temperatures. Streams with high overall and high EPT taxa richness, a high EPT:chironomid ratio, and a lack of dominance by one or two taxa are considered to have good water quality (Smith and Collopy, in press).

The occurrence, abundance, and condition of fish species are frequently used to assess water quality, the health of the aquatic community, and the effects of land-use practices. Fish are used for these assessments because they are relatively easy to collect and identify, are widely distributed, and include representatives of many trophic levels. Additionally, species life histories are generally known, data are generally available from previous studies for temporal comparisons, and descriptive analyses of fish communities are relatively easy to understand (Karr and others, 1986). Because fish are consumed by humans, knowing the types and amount of contaminants accumulated is also important for assessing human health risks (Tetra Tech, Inc., 1995c).

Fish community composition depends on many factors, including habitat characteristics, water quality, and the availability of food sources. Kruse (1988) described the relationship between fish species distributions and assemblages in several Willamette Basin streams on the basis of gradients of habitat type (pools to riffles), cover (instream and riparian canopy cover), and stream discharge. One species assemblage (northern squawfish [Ptychocheilus oregonensis], largescale sucker [Catostomus macrocheilus], redside shiner [Richardsonius balteatus], and speckled dace [Rhinichthys osculus]) was most often found in pools, and another assemblage (longnose dace [Rhinichthys cataractae], and juvenile and adult torrent sculpin [Cottus rhotheus]) was found in riffles. Cutthroat trout (Oncorhynchus clarki) had a significant preference for instream and canopy cover, and longnose dace preferred areas with a lack of instream and canopy cover. The fish occurring in riffle habitats included longnose dace and various sculpin species, while northern squawfish and cutthroat trout were found in pools and runs.

Species interactions strongly affect fish community structure. Localized interactions among fishes using similar habitats results in shifts in microhabitat use (Li and others, 1987). For example, competitive dominance among salmonid species determines localized distribution patterns and microhabitat use. Coho salmon are competitively dominant over steelhead trout, cutthroat trout, and chinook salmon respectively (Li and others, 1987). Similarly, the presence of torrent sculpin altered habitat use by the reticulate sculpin (Cottus perplexus) and Paiute sculpin (Cottus beldingi) in Marys River (Finger, 1982)

Fish community structure may also be affected by interspecific predation. Predation by the northern squawfish, the dominant piscivore in the basin, on juvenile anadromous salmonids was studied in free-flowing sections of the Willamette, Santiam, and McKenzie Rivers (Buchanan and others, 1981). Most of the fish preyed upon were sculpin, not salmonids, and predation was not as great as has been reported in lakes or immediately below dam tailraces or at hatchery release sites. Ward and others (1994) reported that only 12.3 percent of the 505 northern squawfish examined from the Portland Harbor contained juvenile salmonids. Beamsderfer and Reiman (1991) reported that northern squawfish are the principal predator of juvenile salmonids in the Columbia River system.

Information on selected semiaquatic amphibians and reptiles, birds, and mammals is also presented in this report to provide a thorough assessment of aquatic biota in the Willamette Basin. Although these taxa are not studied as part of the NAWQA Program, and they often are only semiaquatic, some of these organisms may be useful as indirect biological indicators of water quality, such as bald eagles (Haliaeetus leucocephalus) and osprey (Pandion haliaetus) for contaminant levels (Melancon, 1995; Blus, 1996), and American dipper (Cinclus mexicanus) for invertebrate abundance and community composition (John Loegering, Oregon State University, oral commun., 1995). These taxa are also often conspicuous and important biota in community ecology, often as top predators in food webs, and many species have important recreational (wildlife viewing) or economic value (waterfowl hunting). The presentation of information on these taxa focuses on selected species that are ecologically (as a foraging base) tied to NAWQA taxa, species used in contaminant studies, and/or species of management or research interest.

Considerable data are available on aquatic biota in the Willamette Basin, although our knowledge of the status of aquatic biota is highly uneven relative to taxa and spatial scope. Extensive information exists on high-profile taxa, such as anadromous salmonids, but relatively little information is available for many other aquatic taxa. Additionally, some areas have been studied extensively (e.g., the main stem Willamette River, the HJAEF and adjacent areas in the McKenzie subba- 
sin, the Bull Run watershed and other sites in the Mt. Hood National Forest, and Oak Creek and Berry Creek near Corvallis on the eastern slope of the Coast Range), whereas many other areas in the basin have received very little attention.

The following sections enumerate or describe studies relating to the distribution, abundance, and trends of aquatic biota in the basin. Additional information on the spatial and temporal coverage of these studies is presented in appendix A. The algae and macroinvertebrate species lists compiled from available data (appendices B and C, respectively) do not represent a thorough assessment of taxon distribution or community diversity in the basin, but do provide a reference source for taxon occurrence as reported in studies reviewed for this document. This information is presented to assist in future studies by providing a baseline of existing information on distribution of algae and aquatic macroinvertebrates in the Willamette Basin.

\section{Algae}

Information on the abundance and distribution of algae in the Willamette Basin is limited in scope and is spatially uneven. Most of the algal sampling in the basin has been conducted in the main stem Willamette River. Some of the initial information was from USGS sampling (Rickert and others, 1977; Rinella and others, 1981), graduate student research (Wille, 1976), and water-quality monitoring (U.S. Public Health Service, 1964). Recent algal sampling was conducted to examine the effects of effluent discharge from a pulp and paper mill on aquatic biota (HMS Environmental, Inc., and Miller, 1988), and to examine impacts on dissolved oxygen concentrations as part of the WRBWQS (Gregory, 1993; and Tetra Tech, Inc., 1993c).

Results from sampling in 1973 and 1974 indicate that diatoms, particularly the genera Melosira, Stephanodiscus, Cymbella, Achnanthes, Nitzschia, and Fragilaria, dominated the taxa of the lower Willamette River between RMs 7 and 50 (Wille, 1976; Rickert and others, 1977). This dominance of diatoms in the lower river was consistent with results from sampling in 1963 (U.S. Public Health Service, 1964) despite a significant reduction in levels of organic pollution during the intervening time (Gleeson, 1972; Rickert and others, 1975). In a subsequent study, Rinella and others (1981) also reported diatoms, in both periphyton and phytoplankton samples, as the dominant algal form in the main stem Willamette River. Below RM 50 (Newberg Pool and Tidal Reach; fig. 2), diatoms were primarily phytoplankton, whereas above RM 50, they were primarily periphyton. Rinella and others (1981) identified 86 species of algae throughout the main stem Willamette River and 54 species in the lower reaches of the Santiam River, with no major differences in abundance or diversity of algae from the previous studies of the U.S. Public Health Service (1964) and Rickert and others (1977). They also noted that phytoplankton abundance and diversity generally increased downstream. In the slower moving current of the Tidal Reach of the Willamette River (downstream from RM 26.5), the diatom Stephanodiscus hantzschii was the predominant alga.

As part of the WRBWQS, extensive algal sampling in the Willamette River was recently conducted by Gregory (1993). He identified 35 genera of algae from 23 sampling sites in the main stem Willamette River, 5 sites in the Coast Fork Willamette River, and 1 site each in the Middle Fork Willamette, McKenzie, Calapooia, Santiam, Yamhill, Molalla, and Tualatin Rivers near their junctions with the Willamette River. Blue-green algae accounted for more than 80 percent of the genera in the samples, and diatoms accounted for most of the remainder. The dominant genera of blue-green algae were Anabaena, Aphanocapsa, and Chroococcus. The dominance of blue-green algae decreased in the lower main stem of the Willamette River, and the proportion of diatoms increased.

Several other investigations of algal distribution and abundance have been done in streams of the Willamette Valley floor and foothills. The most abundant species of algae in the Willamette River near Halsey were the diatoms Gomphoneis herculeana and Fragilaria capucina (HMS Environmental, Inc., and Miller, 1988). They accounted for over 90 percent of the species composition of samples. Jackson (1973) sampled blue-green algae in the Willamette River and Middle Fork Willamette River, and Dever (1962) reported on algal composition of a controlled-flow section of Berry Creek. Carter (1975) sampled the middle course of the Tualatin River and reported that benthic forms were dominant in the upper river and planktonic forms were dominant in the lower river (downstream from Hillsboro). Algal sampling in the Tualatin River in 1976 indicated that benthic pennate diatoms were most common (Carter and others, 1976). The principal species were Melosira granulata, Stephanodiscus hantzschii, and Melosira distans. However, a shift in dominant taxa below RM 33 was observed, with the blue-green 
alga Aphanizomenon spp. dominant in 1976 (Carter and others, 1976), and centric filamentous diatoms, such as Melosira spp. most abundant in 1987 ( $\mathrm{Li}$ and Gregory, 1993). The USGS conducted algal sampling in four tributaries of the Molalla River during the drought year of 1977 (Miller, 1979): diatoms were the dominant algae, including the genera Achnanthes, Gomphonema, Cymbella, and Cocconeis.

Few studies have investigated algal composition of rivers of the Willamette Basin outside of the Willamette Valley floor and foothills. In streams of the HJAEF, Lyford and Gregory (1975) and Rounick and Gregory (1981) reported that open sites supported higher standing crops of periphyton than shaded sites. In six streams of the Bull Run watershed (Sandy River subbasin), the periphyton community was characterized by a high percentage of diatoms from June to October over a 6-year period, 1978-1983 (Clifton, 1985). The dominant periphyton were the diatom species Achnanthes minutissima and Achnanthes lanceolata. On the basis of a comparison with data from Hansmann and Phinney (1973) from Oregon coastal streams, Clifton (1985) suggested that the occurrence and/or abundance of several taxa, such as Ulothrix spp., Chlamydomonas spp., Spirogyra spp., Achnanthes spp., and Cocconeis placentula euglypta, may be useful in monitoring the impact of logging.

Algal studies in Willamette Basin reservoirs in the 1970s indicated that phytoplankton composition was similar to that of oligotrophic lakes in the Cascade Mountains (U.S. Army Corps of Engineers, 1991b). Diatoms such as Asterionella formosa, Fragilaria crotonensis, Synedra ulna, Stephanodiscus astraea, and Melosira granulata were dominant. The most common blue-green algae were Eudorina elegans, Straurastrum longiradiatum, and Sphaerocystis spp. The USACE also noted that phytoplankton blooms occurred regularly at some of the larger lakes, such as Lookout Point and Hills Creek.

In the Delta Ponds of Eugene adjacent to the Willamette River, the most common periphyton was the filamentous green alga Rhizoclonium hieroglyphicum, which is commonly associated with highly fertilized waters (Fetrow Engineering and Scientific Resources, 1989). Prescott (1923) and Lippert (1957) also provide information on species present in ponds in the floodplain of the Willamette River near Eugene.

Other investigations of algae in lakes and ponds include Burns (1993) for several high elevation mountain lakes in the Mt. Hood National Forest, Bullock and others (1988) for Timothy Lake and Raymond (1983) for Bull Run Lake in the Mt. Hood National Forest, and Scheidt and Nichols (1976) for Hills Creek Lake in the Willamette National Forest. A series of county-based USGS reports from the mid-1970s includes information on the dominant algae in many of the lakes within the basin. The Willamette Basin counties covered by these reports were Columbia (Sanderson and others, 1973); Benton and Polk (Shulters, 1974); Multnomah, Washington, and Yamhill (Shulters, 1975); Clackamas (Shulters, 1976); and Marion (Rinella, 1977). Johnson and others (1985) provide similar information on algal composition of 41 lakes within the basin.

Chlorophyll $a$ is an algal pigment used as an indicator of productivity through an estimation of algal biomass. As part of the WRBWQS, chlorophyll $a$ was sampled throughout the Willamette River (Gregory, 1993). Concentrations tended to increase in a downstream direction, with higher concentrations in the Newberg Pool and Tidal Reach compared to the upstream sections of the river. Chlorophyll $a$ concentrations have also been measured in mountain lakes (Sanderson and others, 1973; Shulters, 1974; 1975; 1976; Rinella, 1977; Johnson and others, 1985), an experimental stream section of Berry Creek (Reese, 1966), and streams of the western Cascades (Gregory, 1980; Murphy and Hall, 1981; Hawkins and Sedell, 1981; Rounick and Gregory, 1981).

\section{Macroinvertebrates}

The description of macroinvertebrate distributions and abundances in a systematic manner in the Willamette Basin is difficult because there is (1) unequal representation in sampling effort throughout the basin, (2) different sampling methodologies and protocols used in studies, and (3) varying taxonomic levels of identification. Thus, comparisons among studies are often precluded because of these inconsistencies.

The Willamette Basin supports a diverse aquatic macroinvertebrate fauna. In general, the Upper Basin within the Cascade Mountains is characterized by streams and rivers with a high diversity of taxa and a high richness of EPT taxa (Anderson, 1992; Whittier and others, 1988). The upper reach of the Willamette River (approximately equal to the Headwaters Reach) is also characterized by a high richness of EPT taxa (Johnson and others, 1989). Within the slow-current 
reaches of the lower main stem Willamette River (Portland Harbor), the typical invertebrates are those that can tolerate low dissolved oxygen concentrations, such as oligochaetes (segmented worms), cladocerans (water fleas), amphipods (scuds), odonates (dragonflies and damselflies), and chironomid midges (Ward and others, 1988). The low gradient Tualatin River showed higher species diversity and greater richness of EPT taxa following installation of wastewater treatment plants (Li and Gregory, 1993).

Studies by researchers in the Entomology Department at OSU often provide the most detailed information on macroinvertebrate abundance and distribution in the Willamette Basin. Distribution and abundance of macroinvertebrates in the Willamette Basin also have been reported as part of studies on fish communities. Unlike studies of algae, investigations of macroinvertebrate communities have occurred in the foothills and mountains of the basin as often as in the main stem Willamette River and throughout the valley floor.

The compilation of species lists from long-term research at particular sites provides excellent information on taxon occurrence. For example, Anderson and Hansen (1987) summarize the occurrence records of 325 taxa from over 25 years of research in Berry Creek, and Parsons and others (1991) provide an annotated list of invertebrate species (terrestrial and aquatic) that have been collected during 41 years of research at the HJAEF. Tetra Tech, Inc., (1993d) compiled a benthic macroinvertebrate species list for the Willamette River based on reports from four sampling efforts.

One of the most spatially extensive studies of aquatic macroinvertebrates in the Willamette Basin was conducted as part of the WRBWQS (Tetra Tech, Inc., 1994). Sampling occurred at 15 locations in the Willamette River between RMs 57 and 185, 2 locations in the McKenzie River near its confluence with the Willamette, and 1 location in the Tualatin River. The results indicated that water-quality degradation, rather than habitat degradation, appeared to account for biological impairment of downstream macroinvertebrate communities relative to upstream reference sites (Tetra Tech, Inc., 1994). Additionally, macroinvertebrate species composition was less diverse and less abundant in soft-bottom habitats than in riffle/run habitat. However, a comparison of macroinvertebrate community structure and composition within the two upper reaches of the Willamette River (Headwaters Reach and Salem Reach) did not reveal any significant differences based on location by river mile within or between the two reaches.

Some macroinvertebrate studies in the Willamette River have been conducted to assess the relationship between pollution and macroinvertebrates. Deschamps (1952) conducted macroinvertebrate sampling throughout the entire main stem Willamette River and lower portions of several tributaries to assess the use of macroinvertebrates as biological indicators of pollution. The two most common macroinvertebrates in the Willamette River near Halsey (RM 142 to 150) during sampling above and below a pulp and paper effluent site in the summer of 1988 were a midge, Rheotanytarsus spp., and a caddisfly, Hydropysche spp. (HMS Environmental, Inc., and Miller, 1988). Both taxa are pollution tolerant organisms. However, at the same location, a total of 40 macroinvertebrate taxa were identified, and nearly half were EPT taxa, which indicates a high quality of water (Johnson and others, 1989).

Several agencies have reported on macroinvertebrate populations in streams in the lower and mid-elevations of the basin. The USGS conducted benthic macroinvertebrate sampling in four tributaries of the Molalla River during the drought year of 1977 (Miller, 1979). Caddisflies, mayflies, stoneflies, and midges were the dominant macroinvertebrates. Within the first three orders the dominant genera were Cheumatopsyche (Trichoptera), Paraleptophlebia and Baetis (Ephemeroptera), and Nemoura (Plecoptera). The ODEQ conducted macroinvertebrate sampling in 1975 and 1976 as part of a biological assessment of the major tributaries of the Tualatin River system (Sutherland, 1976). The BLM has reported on macroinvertebrate sampling in nine streams of the McKenzie subbasin and one stream in the Middle Fork Willamette subbasin (Mangum, 1991a), and two streams in the Santiam subbasin (Mangum, 1991b). The USFS reported on macroinvertebrate sampling in Still Creek in the Mt. Hood National Forest (Mangum, 1990).

A comprehensive sampling program of macroinvertebrates in the lower McKenzie River was conducted to examine the influence of two hydroelectric projects that divert water from 13 miles of the river (EA Engineering, Science and Technology, Inc., 1990a). The results did not indicate any significant differences in taxon richness, EPT richness, or percent of the dominant taxon between diverted and undiverted reaches. 
Several investigations of macroinvertebrates have been conducted in the high elevation, highgradient streams in and adjacent to the HJAEF. Hawkins and Sedell (1981) studied longitudinal and seasonal changes in macroinvertebrate communities. Lamberti and others (1991) and Anderson (1992) described the effects of a natural disturbance (debris torrent), and Wustenberg (1954) and Murphy and others (1981) evaluated the effects of logging on macroinvertebrate communities. Hawkins and others (1982) reported that streams without shading had higher abundances of invertebrates than shaded streams. Wilzbach and others (1986) studied the relationship between prey (macroinvertebrates) availability and cutthroat trout populations in logged and unlogged sites. Hawkins and Furnish (1987) discuss correlations of stream macroinvertebrate taxa with abundance of the snail Juga silicula. Other investigations that provide information on the distribution and abundance of macroinvertebrate taxa in and adjacent to the HJAEF include Anderson and others (1978) and Murphy and Hall (1981).

Macroinvertebrate sampling in four streams within the Bull Run watershed near Portland was conducted from 1978 to 1983 (Clifton, 1985). The dominant taxa were Chironomidae (midges), Hydracarina (water mites), and Baetis spp. (a mayfly). In November 1994, the most abundant taxon (over one-third of the composition) in a riffle of the Bull Run River was the plecopteran Yoraperla brevis; whereas, in pool habitat, plecopterans of the genus Sweltsa comprised nearly one-third of the individuals collected (TW Environmental, Inc., 1994). The amphipod Hyalella azteca was the most common macroinvertebrate collected in lakeshore substrate of Bull Run Lake in 1992 (Wisseman, 1992a).

Aquatic macroinvertebrate communities in lake/ reservoir ecosystems within the Willamette Basin are less studied than those of riverine ecosystems. Investigations reporting on the presence of aquatic macroinvertebrates in Cascade lakes include Timothy Lake (Bullock and others, 1988), Bull Run Lake (Wisseman, 1992a), and Squaw Lakes (Wisseman, 1992b) in the Mt. Hood National Forest.

Several investigations have focused on the life history and ecology of specific macroinvertebrate taxa or groupings of similar taxa in streams of the Willamette Basin. Probably the most studied group is caddisflies (Trichoptera), which are well known because they are a principal food of trout and are imitated as flyfishing lures for trout. They have been a research focus of the Aquatic Entomology program at OSU, particularly at the HJAEF, where at least 99 species from 14 families have been recorded (Anderson and others, 1982), and in Benton County where 120 species have been recorded primarily from work in Berry and Oak Creeks (Anderson, 1976). The exhaustive work of Anderson (1976) summarizes information on the systematics, ecology, and distribution of this group of aquatic insects in Oregon.

Other taxon-specific studies have occurred at Oak Creek, where insect drift or seasonal occurrence have been studied for Trichoptera (Anderson and Wold, 1972; Anderson and Bourne, 1974), Epheme-roptera (Lehmkuhl, 1968, 1969; Lehmkuhl and Anderson, 1971), and Plecoptera (Ball, 1946; Kerst, 1969; Kerst and Anderson, 1974, 1975). Also in Oak Creek, Lehmkuhl (1968) reported on the life history of four species of Epeorus (Ephemeroptera), and Lehmkuhl and Anderson (1970) studied the biology of Cinygmula reticulata (Ephemeroptera). In Berry Creek, Azam (1969) studied the life history and production of Sialis californica (Megaloptera), and Grafius and Anderson (1979) studied the utilization of deciduous leaves as food by Lepidostoma quercina (Trichoptera). Studies of taxa associated with woody debris include craneflies of the genus Lipsothrix (Diptera) (Dudley and Anderson, 1987) in the Greasy Creek watershed of the Coast Range and the Quartzville Creek watershed of the Cascade Mountains, and the mayfly species Cinygma integrum in Berry Creek (Periera, 1980). Speir (1976) studied four blackfly (Diptera) species in Berry, Oak, and Soap Creeks near OSU. Steedman (1983) and Steedman and Anderson (1985) reported on the ecology of the aquatic beetle Lara avara (Coleoptera) in Berry and Yew Creeks. Taxon-specific studies on snails include the population dynamics of Juga plicifera in Oak and Berry Creeks (Diamond, 1982); growth, production, and distribution of Juga silicula in Oak Creek (Furnish, 1989); and production of Oxytrema silicula in Berry Creek (Earnest, 1967).

Some investigations have focused on macroinvertebrate composition of specific habitats. Aquatic macroinvertebrates associated with woody debris in forest streams of the basin was the focus of research by Anderson and others (1978). They reported that the three species most closely associated with woody debris were the aquatic beetle, Lara avara; a caddisfly, Heteroplectron californicum; and a snail, Oxytrema silicula. Based on additional work, Dudley and Anderson (1982) list 37 taxa of invertebrates closely associated 
with woody debris in the Willamette Basin and 67 taxa as facultatively associated. Species composition of summer-dry headwater streams in the Oak Creek watershed included at least 27 species (Dieterich, 1992). Tew (1970) reported 58 species in a similar investigation of an intermittent stream in the Berry Creek watershed. Moore (1987) describes invertebrate assemblages associated with stream margins and backwaters of mountain streams. Hjort and others (1984) studied macroinvertebrate assemblages at revetments in the Willamette River and reported that the predominant taxa were organisms such as the polychaete worm Manayunkia speciosa, which attached to the substrate, or organisms such as the amphipod Anisogammarus spp., which were protected within interstitial spaces.

Freshwater clams, mussels, and snails are a conspicuous component of the aquatic macroinvertebrate fauna of the basin, and some were historically important as food items in the diet of Native Americans. Some clams also are harvested for bait and collected and sold by biological supply houses as classroom study specimens (Oregon Department of Fish and Wildlife, 1980). Thorough accounts of freshwater mollusc species were prepared for the Forest Ecosystem Management Assessment Team (FEMAT) report (Frest and Johannes, 1993). They reported 57 freshwater mollusc taxa within the range of the northern spotted owl (includes all forested parts of the Willamette Basin), many of which likely occur in the basin. Numerous other species not listed in the FEMAT report occur only in the Willamette Valley portion of the basin (Terrence Frest, Deixis Consultants, Seattle, Washington, written commun., 1995).

Crayfish are among the larger, more conspicuous aquatic macroinvertebrates in the basin. They are noteworthy because of their importance as fish forage, recreational use as bait, and commercial harvest for food in restaurants (Gladson, 1979; Oregon Department of Fish and Wildlife, 1980). Two species, Pacifastacus leniusculus and Pacifastacus trowbridgii, occur in the Willamette Basin (Gladson, 1979). The only study directed at crayfish within the basin occurred in Berry Creek (Mason, 1963).

Systematic long-term data collection at specific sites is lacking (except for the HJAEF, and Oak and Berry Creeks) to assess trends in macroinvertebrate community health in the basin. Biomonitoring programs for aquatic invertebrate communities have been recently implemented in several Cascade Mountain streams of the Mt. Hood National Forest (Wisseman, 1992b; 1995). The Xerces Society, in cooperation with several Federal and State agencies, has recently initiated an aquatic macroinvertebrate monitoring program designed to (1) assimilate and disseminate existing monitoring data, (2) evaluate the effectiveness of macroinvertebrate monitoring as a tool to determine watershed condition, and (3) produce a document describing monitoring programs and their effectiveness at assessing biotic integrity within watersheds (Sue Mauger, Xerces Society, Portland, Oregon, written commun., 1995).

\section{Fish}

Fish resources, particularly salmon and trout, have played a major cultural role in the lifestyle and economy of the Willamette Basin probably since Native American settlement of the area. Sport and commercial fisheries of salmon and trout historically sustained many local communities. The fisheries resource continues to be integral to Willamette Basin industry, recreation, and culture. On the basis of statewide estimates for 1980, sport fishing in the Willamette Basin generates approximately $\$ 63$ million in personal income annually (Howell, 1986).

The Willamette Basin supports a diverse and extensive fish community, which has changed since human occupation due to numerous factors, including habitat degradation, fish passage issues, aquaculture, and introductions of nonnative species. The ODFW (1988) listed 54 species of fish as being present within the Willamette Basin, and an additional 7 species have been reported from other sources (table 3 ). They include members of 16 families, including 9 anadromous species. Nearly half (48 percent) are introduced, nonnative species. T Hughes and others (1987) identified 15 fish species as characteristic of the western Cascades/Willamette River Basin ichthyogeographic region (table 3). Two of the species, Oregon chub (Oregonichthys crameri) and sand roller (Percopsis transmontana), are considered the most distinct fish species of this ichthyogeographic region, with little to no occurrence in other regions.

As a general rule, throughout the Willamette Basin and the Pacific Northwest, fish species richness tends to increase from the smaller, high elevation, steep gradient, cold water, headwater areas to the larger, low elevation, low gradient, warm water, main stem channels ( $\mathrm{Li}$ and others, 1987; Beecher and others, 1988). 
Table 3. Origin, trophic group, and relative tolerance to pollution for fish species occurring in the Willamette Basin, Oregon

[Sources: Friesen and Ward (1996); Hughes and Gammon (1987); Oregon Department of Fish and Wildlife (1988); Scott and Crossman (1973); Wydoski and Whitney (1979)]

\begin{tabular}{|c|c|c|c|c|}
\hline Species & Scientific name & Origin & $\begin{array}{l}\text { Trophic } \\
\text { group }^{1}\end{array}$ & $\begin{array}{l}\text { Pollution } \\
\text { tolerance }\end{array}$ \\
\hline Bullhead catfishes & Ictaluridae & & & \\
\hline Black bullhead & Ameiurus melas & Introduced & Omnivore & Tolerant \\
\hline Brown bullhead & Ameiurus nebulosus & Introduced & Omnivore & Tolerant \\
\hline Yellow bullhead & Ameiurus natalis & Introduced & Omnivore & Tolerant \\
\hline Channel catfish & Ictalurus punctatus & Introduced & Piscivore & Tolerant \\
\hline White catfish & Ameiurus catus & Introduced & Omnivore & Tolerant \\
\hline Flounders & Pleuronectidae & & & \\
\hline Starry flounder ${ }^{2}$ & Platichthys stellatus & Native & Piscivore & Tolerant \\
\hline Herrings & Clupeidae & & & \\
\hline American shad ${ }^{3}$ & Alosa sapidissima & Introduced & Omnivore & Intermediate \\
\hline Lampreys & Petromyzontidae & & & \\
\hline River lamprey ${ }^{3}$ & Lampetra ayresi & Native & Parasitic & Tolerant \\
\hline Western brook lamprey ${ }^{4}$ & Lampetra richardsoni & Native & $\left({ }^{5}\right)$ & Intermediate \\
\hline Pacific lamprey ${ }^{3}$ & Lampetra tridentata & Native & Parasitic & Intermediate \\
\hline Livebearers & Poeciliidae & & & \\
\hline Mosquitofish & Gambusia affinis & Introduced & Insectivore & Tolerant \\
\hline Minnows & Cyprinidae & & & \\
\hline Chiselmouth ${ }^{4}$ & Acrocheilus alutaceus & Native & Herbivore & Intermediate \\
\hline Goldfish & Carassius auratus & Introduced & Omnivore & Tolerant \\
\hline Common carp & Cyprinus carpio & Introduced & Omnivore & Tolerant \\
\hline Peamouth & Mylocheilus caurinus & Native & Insectivore & Intermediate \\
\hline Oregon chub ${ }^{4,6}$ & Oregonichthys crameri & Native & Insectivore & Intermediate \\
\hline Fathead minnow & Pimephales promelas & Introduced & Omnivore & Tolerant \\
\hline Northern squawfish ${ }^{4}$ & Ptychocheilus oregonensis & Native & Piscivore & Tolerant \\
\hline Longnose dace ${ }^{4}$ & Rhinichthys cataractae & Native & Insectivore & Intermediate \\
\hline Leopard dace & Rhinichthys falcatus & Native & Insectivore & Intermediate \\
\hline Speckled dace & Rhinichthys osculus & Native & Insectivore & Intermediate \\
\hline Redside shiner & Richardsonius balteatus & Native & Insectivore & Intermediate \\
\hline Tench & Tinca tinca & Introduced & Insectivore & Tolerant \\
\hline Perches & Percidae & & & \\
\hline Yellow perch & Perca flavescens & Introduced & Insectivore & Intermediate \\
\hline Walleye & Stizostedion vitreum & Introduced & Piscivore & Intermediate \\
\hline$\underline{\text { Sculpins }}$ & Cottidae & & & \\
\hline Prickly sculpin & Cottus asper & Native & Insectivore & Intermediate \\
\hline Mottled sculpin ${ }^{4}$ & Cottus bairdi & Native & Insectivore & Intolerant \\
\hline Paiute sculpin 4 & Cottus beldingi & Native & Insectivore & Intolerant \\
\hline Shorthead sculpin ${ }^{4}$ & Cottus confuscus & Native & Insectivore & Intolerant \\
\hline Riffle sculpin & Cottus gulosus & Native & Insectivore & Intolerant \\
\hline Reticulate sculpin ${ }^{4}$ & Cottus perplexus & Native & Insectivore & Tolerant \\
\hline Torrent sculpin 4 & Cottus rhotheus & Native & Insectivore & Intolerant \\
\hline Smelts & Osmeridae & & & \\
\hline Eulachon & Thaleichthys pacificus & Native & $\left({ }^{7}\right)$ & Intolerant \\
\hline
\end{tabular}


Table 3. Origin, trophic group, and relative tolerance to pollution for fish species occurring in the Willamette Basin, Oregon-Continued

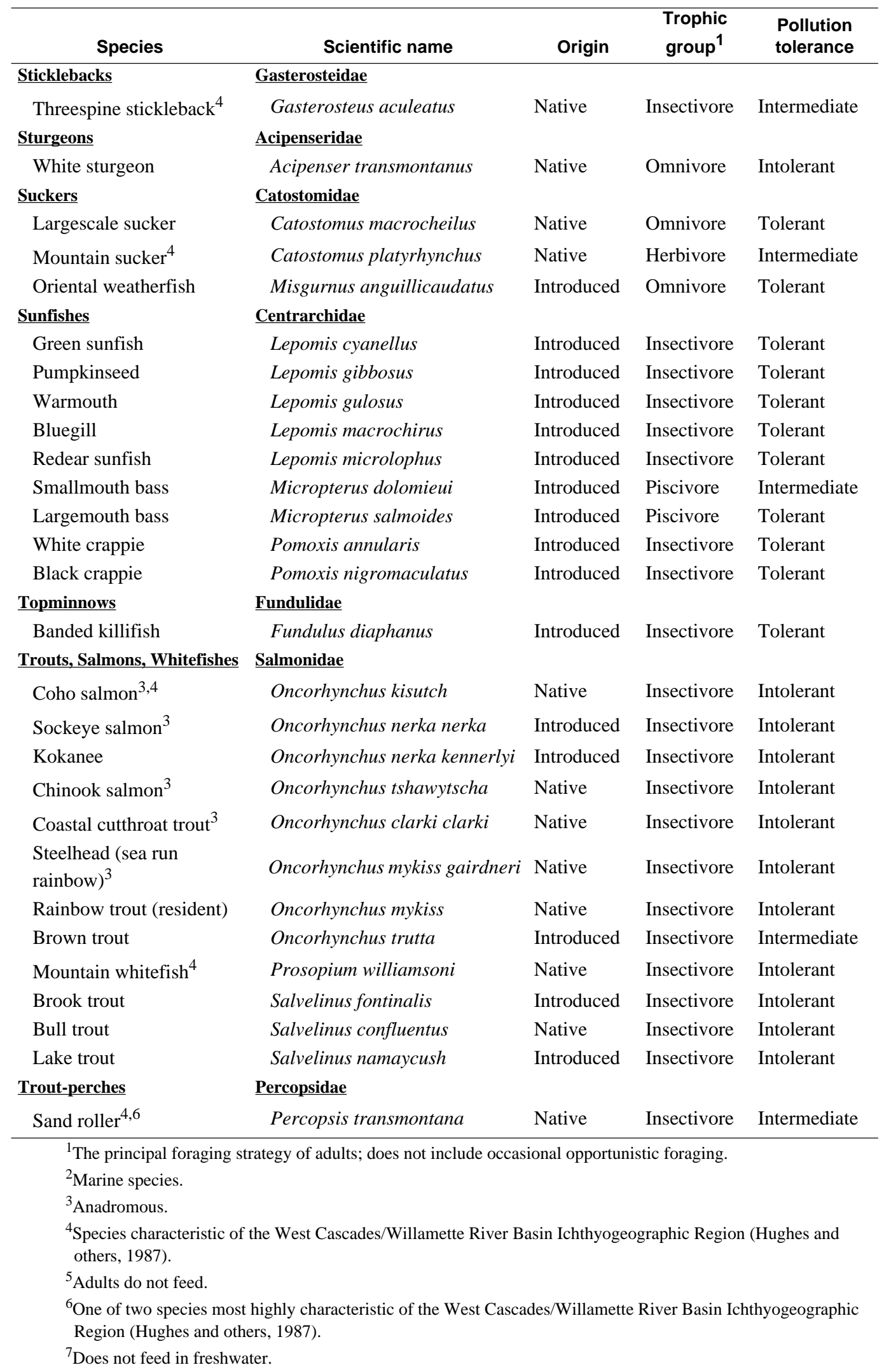


The fish of mid to high elevation tributaries and lakes in the basin tend to be dominated by a few cold water salmonid species, such as coho salmon and cutthroat trout, and a few species of suckers, minnows, and sculpins, and the mountain whitefish (Prosopium williamsoni). Species composition in low elevation reaches of the major rivers of the Willamette Valley and foothills includes numerous warm water fish such as bass (Micropterus spp.), catfish (Ictalurus spp.), and several species in the sunfish group. The fish fauna of the Willamette River is presently dominated by nonnative species, whereas in mountain streams, there is better representation of native species.

The transition from high elevation, cold water streams to low elevation, warm water streams and rivers also is characterized by ecological niche replacement among similar species. For example, mountain suckers (Catastomus platyrhynchus) are gradually replaced by largescale suckers as gradient decreases and water temperatures increase ( $\mathrm{Li}$ and others, 1987). This type of change is also apparent in foraging guilds, which gradually change from mostly surface-insect feeders in the headwaters to large-invertebrate feeders in the low elevation tributaries and main stem Willamette River (Li and others, 1987).

The ORIS database (Oregon Department of Fish and Wildlife, 1994), which was used to develop table 4, includes information on fish species distribution in the Willamette Basin. This information is most valuable for a coarse assessment of stream conditions based on fish species composition and diversity, and in determining species of widespread distribution for use in comparative studies, particularly toxicological studies. The ORIS database also includes fish species distribution information at a much greater resolution (tributaries and subtributaries of the major rivers) than presented in table 4.

Willamette Basin fish species distribution and abundance have been described by numerous sources, including the Willamette Basin Task Force (1969) and Oregon Department of Fish and Wildlife (1990). Historical information on the distribution of fishes in the basin includes a letter by Abernethy (1886), and reports by Snyder (1908) and Rich and Holmes (1929). The first extensive sampling of fish distributions in the Willamette River below Willamette Falls was conducted in 1941 and 1942 by Craig and Townsend (1946) for the USACE. Dimick and Merryfield (1945) conducted the first extensive sampling throughout nearly the entire main stem Willamette River. They reported 34 species of fish upstream from RM 15 on the basis of their sampling and the previous work of others. A report by the Oregon Game Commission in the late 1950s provides information on fish species occurring in the Willamette Basin at that time (Willis and others, 1960). A series of reports in the 1960s by the Oregon State Game Commission described fish resources for the entire basin (Thompson and others, 1966), Lower Willamette Basin (Hutchison and Aney, 1964), Middle Willamette Basin (Oregon State Game Commission, 1963), and Upper Willamette Basin (Hutchison and others, 1966a).

Two recent investigations throughout the entire main stem Willamette River (Hughes and Gammon, 1987; Tetra Tech, Inc., 1993b) provide information on changes in species assemblages based on comparisons with Dimick and Merryfield (1945). Hughes and Gammon (1987) reported more fish species, but fewer species tolerant of poor habitat than Dimick and Merryfield (1945). They attributed differences in fish assemblages between 1945 and 1986 primarily to changes in the physical habitat and improvements in water quality. They also characterized four distinct fish assemblages (Upper River, Middle River, Newberg Pool, and Portland Metro) corresponding to the major sections of the river.

Tetra Tech, Inc., (1993b) conducted fish sampling in 1992 with the same techniques and in most of the same locations as Hughes and Gammon (1987). They reported similar trends in fish assemblages throughout the river, and suggested that fish communities in the lower river may have become more robust (healthier) since 1983. They reported significant differences in fish communities between upstream (Eugene) and downstream (Portland) locations, although they could not statistically differentiate the two upstream communities (Upper River and Middle River) with regard to fish composition.

Friesen and Ward (1996) described fish assemblages in the lower Tualatin subbasin as part of a study to assess the impacts of urbanization on native fish populations. They suggested that native fish assemblages were moderately unhealthy on the basis of a high percentage of introduced species, a relatively low number of species intolerant to pollution and warm water, and a relatively large number of sites having a high proportion of fish with parasites or physical anomalies. Reticulate sculpin comprised nearly 70 percent of the individuals captured during sampling. 
Table 4. Distribution of fish species in major rivers of the Willamette Basin, Oregon

[ Sources: Dodge and Armantrout (1994); Hjort and others (1984); Hughes and Gammon (1987); Farr and Ward (1993); Friesen and Ward (1996); Li and Gregory (1993); Markle (1994a); Oregon Department of Fish and Wildlife (1994); W. Hunt (Oregon Department of Fish and Wildlife, written commun., 1995); S. Mamoyac (Oregon Department of Fish and Wildlife, written commun., 1995);

T. Murtagh (Oregon Department of Fish and Wildlife, written commun., 1995); M. Wade (Oregon Department of Fish and Wildlife, written commun., 1995). Species listed include all documented occurrences regardless of size or distribution of the population within the river, or whether they are from wild or hatchery stocks; --, not known to occur; C.F., Coast Fork; M.F., Middle Fork; X, present]

\begin{tabular}{|c|c|c|c|c|c|c|c|c|c|c|c|c|c|c|c|c|}
\hline \multirow[b]{2}{*}{ Species } & \multicolumn{16}{|c|}{ Major Rivers in the Willamette Basin } \\
\hline & $\begin{array}{l}\text { Cala- } \\
\text { pooia }\end{array}$ & $\begin{array}{l}\text { Clack- } \\
\text { amas }\end{array}$ & $\begin{array}{c}\text { C.F. } \\
\text { Willa- } \\
\text { mette }\end{array}$ & $\begin{array}{l}\text { Long } \\
\text { Tom }\end{array}$ & $\begin{array}{l}\text { Luck- } \\
\text { iamute }\end{array}$ & Marys & $\begin{array}{c}\text { Mc- } \\
\text { Kenzie }\end{array}$ & $\begin{array}{c}\text { M.F. } \\
\text { Willa- } \\
\text { mette }\end{array}$ & Molalla & $\begin{array}{l}\text { Pud- } \\
\text { ding }\end{array}$ & $\begin{array}{l}\text { Rick- } \\
\text { reall }\end{array}$ & Sandy & $\begin{array}{l}\text { San- } \\
\text { tiam }\end{array}$ & $\begin{array}{l}\text { Tual- } \\
\text { atin }\end{array}$ & $\begin{array}{l}\text { Willa- } \\
\text { mette }\end{array}$ & Yamhill \\
\hline \multicolumn{17}{|l|}{ Bullhead Catfishes } \\
\hline Black bullhead & -- & -- & -- & -- & -- & -- & -- & -- & -- & -- & -- & -- & -- & $\mathrm{X}$ & $\mathrm{x}$ & --- \\
\hline Brown bullhead & $\mathrm{X}$ & $\mathrm{X}$ & $\mathrm{X}$ & $\mathrm{X}$ & $\mathrm{X}$ & $\mathrm{x}$ & $\mathrm{x}$ & $\mathrm{x}$ & -- & $\mathrm{x}$ & $\mathrm{x}$ & -- & $\mathrm{x}$ & $\mathrm{x}$ & $\mathrm{x}$ & $\mathrm{X}$ \\
\hline Yellow bullhead & $\mathrm{X}$ & $\mathrm{X}$ & $\mathrm{X}$ & $\mathrm{X}$ & -- & -- & -- & -- & -- & $\mathrm{X}$ & -- & -- & $\mathrm{X}$ & $\mathrm{X}$ & $\mathrm{X}$ & -- \\
\hline Channel catfish & -- & $\mathrm{X}$ & -- & $\mathrm{X}$ & -- & -- & -- & -- & -- & $\mathrm{X}$ & -- & -- & -- & $\mathrm{X}$ & $\mathrm{X}$ & $\mathrm{X}$ \\
\hline White catfish & -- & -- & -- & -- & -- & -- & -- & -- & -- & -- & -- & -- & -- & $\mathrm{X}$ & -- & -- \\
\hline \multicolumn{17}{|l|}{ Flounders } \\
\hline Starry flounder & -- & $\mathrm{X}$ & -- & -- & -- & -- & -- & -- & -- & -- & -- & -- & -- & $\mathrm{X}$ & $\mathrm{X}$ & -- \\
\hline \multicolumn{17}{|l|}{ Herrings } \\
\hline American shad & -- & $\mathrm{X}$ & -- & -- & -- & -- & -- & -- & -- & -- & -- & $\mathrm{X}$ & -- & -- & $\mathrm{X}$ & -- \\
\hline \multicolumn{17}{|l|}{ Lampreys } \\
\hline Western brook lamprey & -- & $\mathrm{X}$ & -- & $\mathrm{X}$ & -- & $\mathrm{x}$ & $\mathrm{x}$ & $\mathrm{X}$ & $\mathrm{X}$ & $\mathrm{X}$ & -- & -- & -- & $\mathrm{X}$ & $\mathrm{X}$ & $\mathrm{X}$ \\
\hline Pacific lamprey & $\mathrm{X}$ & $\mathrm{X}$ & -- & $\mathrm{X}$ & $\mathrm{x}$ & $\mathrm{x}$ & $\mathrm{x}$ & $\mathrm{X}$ & $\mathrm{X}$ & $\mathrm{X}$ & $\mathrm{x}$ & $X^{1}$ & $\mathrm{x}$ & $\mathrm{X}$ & $\mathrm{X}$ & $\mathrm{X}$ \\
\hline River lamprey & $\mathrm{X}$ & -- & -- & -- & -- & -- & $\mathrm{x}$ & -- & -- & -- & -- & -- & -- & -- & $\mathrm{X}$ & -- \\
\hline \multicolumn{17}{|l|}{ Livebearers } \\
\hline Mosquitofish & $\mathrm{X}$ & -- & -- & $\mathrm{X}$ & $\mathrm{X}$ & $\mathrm{x}$ & $\mathrm{x}$ & $\mathrm{x}$ & -- & -- & $\mathrm{X}$ & -- & $\mathrm{x}$ & $\mathrm{X}$ & -- & $\mathrm{X}$ \\
\hline \multicolumn{17}{|l|}{ Minnows } \\
\hline Chiselmouth & $\mathrm{X}$ & $\mathrm{X}$ & $\mathrm{X}$ & $\mathrm{X}$ & -- & $\mathrm{X}$ & $\mathrm{X}$ & $\mathrm{X}$ & $\mathrm{X}$ & -- & -- & -- & $\mathrm{X}$ & $\mathrm{X}$ & $\mathrm{X}$ & -- \\
\hline Common carp & $\mathrm{X}$ & $\mathrm{x}$ & -- & $\mathrm{X}$ & -- & $\mathrm{x}$ & $\mathrm{x}$ & $\mathrm{x}$ & -- & $\mathrm{x}$ & -- & -- & -- & $\mathrm{X}$ & $\mathrm{x}$ & $\mathrm{X}$ \\
\hline Oregon chub & -- & -- & -- & -- & -- & $\mathrm{x}$ & -- & $\mathrm{x}$ & -- & -- & -- & -- & $\mathrm{x}$ & -- & -- & -- \\
\hline Peamouth & $\mathrm{X}$ & $\mathrm{X}$ & $\mathrm{X}$ & $\mathrm{X}$ & -- & $\mathrm{x}$ & $\mathrm{x}$ & $\mathrm{X}$ & $\mathrm{X}$ & $\mathrm{x}$ & -- & -- & $\mathrm{x}$ & $\mathrm{X}$ & $\mathrm{x}$ & -- \\
\hline Fathead minnow & -- & -- & -- & -- & -- & -- & -- & -- & -- & -- & -- & -- & -- & $\mathrm{X}$ & -- & -- \\
\hline Northern squawfish & $\mathrm{X}$ & $\mathrm{X}$ & $\mathrm{X}$ & $\mathrm{x}$ & -- & $\mathrm{X}$ & $\mathrm{X}$ & $\mathrm{x}$ & $\mathrm{X}$ & $\mathrm{X}$ & -- & $\mathrm{X}$ & $\mathrm{X}$ & $\mathrm{X}$ & $\mathrm{X}$ & -- \\
\hline Goldfish & -- & $\mathrm{x}$ & -- & -- & -- & -- & -- & -- & -- & $\mathrm{x}$ & -- & -- & -- & $\mathrm{X}$ & $\mathrm{X}$ & -- \\
\hline Longnose dace & -- & $\mathrm{X}$ & $\mathrm{X}$ & $\mathrm{X}$ & -- & -- & -- & $\mathrm{X}$ & -- & -- & -- & $\mathrm{X}$ & $\mathrm{X}$ & $\mathrm{x}$ & $\mathrm{x}$ & -- \\
\hline Leopard dace & $\mathrm{X}$ & -- & $\mathrm{X}$ & $\mathrm{X}$ & -- & -- & -- & $\mathrm{X}$ & -- & -- & -- & -- & $\mathrm{X}$ & -- & $\mathrm{X}$ & -- \\
\hline Speckled dace & $\mathrm{X}$ & $\mathrm{X}$ & $\mathrm{X}$ & -- & -- & $\mathrm{X}$ & $\mathrm{X}$ & $\mathrm{X}$ & $\mathrm{X}$ & $\mathrm{X}$ & $\mathrm{X}$ & $\mathrm{X}$ & $\mathrm{X}$ & $\mathrm{X}$ & $\mathrm{X}$ & -- \\
\hline
\end{tabular}


Table 4. Distribution of fish species in major rivers of the Willamette Basin, Oregon-Continued

\begin{tabular}{|c|c|c|c|c|c|c|c|c|c|c|c|c|c|c|c|c|}
\hline \multirow[b]{2}{*}{ Species } & \multicolumn{16}{|c|}{ Major Rivers in the Willamette Basin } \\
\hline & $\begin{array}{l}\text { Cala- } \\
\text { pooia }\end{array}$ & $\begin{array}{l}\text { Clack- } \\
\text { amas }\end{array}$ & $\begin{array}{c}\text { C.F. } \\
\text { Willa- } \\
\text { mette }\end{array}$ & $\begin{array}{l}\text { Long } \\
\text { Tom }\end{array}$ & $\begin{array}{l}\text { Luck- } \\
\text { iamute }\end{array}$ & Marys & $\begin{array}{c}\text { Mc- } \\
\text { Kenzie }\end{array}$ & $\begin{array}{l}\text { M.F. } \\
\text { Willa- } \\
\text { mette }\end{array}$ & Molalla & $\begin{array}{l}\text { Pud- } \\
\text { ding }\end{array}$ & $\begin{array}{l}\text { Rick- } \\
\text { reall }\end{array}$ & Sandy & $\begin{array}{l}\text { San- } \\
\text { tiam }\end{array}$ & $\begin{array}{l}\text { Tua- } \\
\text { latin }\end{array}$ & $\begin{array}{l}\text { Willa- } \\
\text { mette }\end{array}$ & Yamhill \\
\hline \multicolumn{17}{|l|}{ Minnows-Continued } \\
\hline Redside shiner & $\mathrm{X}$ & $\mathrm{X}$ & $\mathrm{X}$ & $X$ & $X$ & $\mathrm{X}$ & $\mathrm{X}$ & $\mathrm{X}$ & $\mathrm{X}$ & $\mathrm{X}$ & $\mathrm{X}$ & $\mathrm{X}$ & $X$ & $\mathrm{X}$ & $\mathrm{X}$ & $\mathrm{X}$ \\
\hline Tench & -- & -- & -- & -- & -- & -- & -- & -- & -- & -- & -- & -- & -- & -- & $\mathrm{X}$ & -- \\
\hline \multicolumn{17}{|l|}{ Perches } \\
\hline Yellow perch & -- & $X^{1}$ & -- & -- & $\mathrm{X}$ & $\mathrm{X}$ & -- & -- & -- & $\mathrm{X}$ & $\mathrm{X}$ & $\mathrm{X}^{1}$ & -- & $\mathrm{X}$ & $\mathrm{X}$ & $\mathrm{X}$ \\
\hline Walleye & -- & $X^{1}$ & -- & -- & -- & -- & -- & $\mathrm{X}$ & -- & -- & -- & $X^{1}$ & -- & $\mathrm{X}$ & $\mathrm{X}$ & -- \\
\hline \multicolumn{17}{|l|}{$\underline{\text { Sculpins }}$} \\
\hline Prickly sculpin & -- & $X$ & -- & $X$ & -- & $\mathrm{X}$ & $X$ & -- & -- & -- & -- & $X$ & $X$ & $X$ & $\mathrm{X}$ & -- \\
\hline Mottled sculpin & -- & -- & -- & -- & -- & -- & $\mathrm{X}$ & $\mathrm{X}$ & -- & -- & -- & -- & $\mathrm{X}$ & -- & -- & -- \\
\hline Paiute sculpin & $X$ & -- & $\mathrm{X}$ & $X$ & -- & $\mathrm{X}$ & $X$ & $\mathrm{X}$ & $X$ & $\mathrm{X}$ & -- & -- & $X$ & -- & $\mathrm{X}$ & --- \\
\hline Shorthead sculpin & -- & -- & -- & -- & -- & -- & $\mathrm{X}$ & $\mathrm{X}$ & -- & -- & -- & -- & $\mathrm{X}$ & -- & -- & -- \\
\hline Reticulate sculpin & $\mathrm{X}$ & $\mathrm{X}$ & $\mathrm{X}$ & $\mathrm{X}$ & $\mathrm{X}$ & $\mathrm{X}$ & $\mathrm{X}$ & $\mathrm{X}$ & $\mathrm{X}$ & $\mathrm{X}$ & $\mathrm{X}$ & $\mathrm{X}$ & $\mathrm{X}$ & $\mathrm{X}$ & $\mathrm{X}$ & $\mathrm{X}$ \\
\hline Torrent sculpin & $\mathrm{X}$ & $\mathrm{X}$ & $X$ & $X$ & $X$ & $\mathrm{X}$ & $\mathrm{X}$ & $X$ & $\mathrm{X}$ & $X$ & $X$ & $\mathrm{X}$ & $X$ & $X$ & $\mathrm{X}$ & -- \\
\hline Riffle sculpin & $\mathrm{X}$ & -- & -- & $X$ & -- & -- & -- & -- & -- & -- & -- & -- & -- & -- & $\mathrm{X}$ & -- \\
\hline \multicolumn{17}{|l|}{$\underline{\text { Smelts }}$} \\
\hline Eulachon & -- & -- & -- & -- & -- & -- & -- & -- & -- & -- & -- & $\mathrm{X}$ & -- & -- & $\mathrm{X}$ & -- \\
\hline \multicolumn{17}{|l|}{$\underline{\text { Sticklebacks }}$} \\
\hline Threespine stickleback & $\mathrm{X}$ & $X$ & -- & -- & -- & $X$ & $X$ & $X$ & -- & -- & -- & -- & $X$ & $X$ & $X$ & -- \\
\hline \multicolumn{17}{|l|}{$\underline{\text { Sturgeons }}$} \\
\hline White sturgeon & -- & $\mathrm{X}$ & -- & -- & -- & -- & $\mathrm{X}$ & $\mathrm{X}$ & -- & -- & -- & $\mathrm{X}^{1}$ & -- & $\mathrm{X}$ & $\mathrm{X}$ & -- \\
\hline \multicolumn{17}{|l|}{$\underline{\text { Suckers }}$} \\
\hline Largescale sucker & $X$ & $\mathrm{X}$ & $\mathrm{X}$ & $X$ & $X$ & $\mathrm{X}$ & $\mathrm{X}$ & $\mathrm{X}$ & $X$ & $\mathrm{X}$ & $\mathrm{X}$ & $X$ & $\mathrm{X}$ & $\mathrm{X}$ & $\mathrm{X}$ & $\mathrm{X}$ \\
\hline Mountain sucker & -- & $\mathrm{X}$ & $X$ & $X$ & -- & $\mathrm{X}$ & $\mathrm{X}$ & $\mathrm{X}$ & $\mathrm{X}$ & $\mathrm{X}$ & -- & -- & $\mathrm{X}$ & $\mathrm{X}$ & $X$ & -- \\
\hline Oriental weatherfish & -- & $\mathrm{X}$ & -- & -- & -- & -- & -- & -- & -- & -- & -- & -- & -- & -- & -- & -- \\
\hline \multicolumn{17}{|l|}{$\underline{\text { Sunfishes }}$} \\
\hline Green sunfish & -- & -- & -- & -- & -- & -- & -- & -- & -- & $\mathrm{X}$ & -- & -- & -- & $\mathrm{X}$ & -- & -- \\
\hline Pumpkinseed & $X$ & $\mathrm{X}$ & -- & $\mathrm{X}$ & $\mathrm{X}$ & $\mathrm{X}$ & -- & -- & -- & $\mathrm{X}$ & $\mathrm{X}$ & -- & $X$ & $\mathrm{X}$ & $\mathrm{X}$ & $\mathrm{X}$ \\
\hline Warmouth & $\mathrm{X}$ & $X$ & -- & $X$ & $\mathrm{X}$ & $\mathrm{X}$ & -- & -- & -- & $\mathrm{X}$ & $\mathrm{X}$ & -- & $\mathrm{X}$ & $\mathrm{X}$ & $\mathrm{X}$ & $\mathrm{X}$ \\
\hline
\end{tabular}


Table 4. Distribution of fish species in major rivers of the Willamette Basin, Oregon-Continued

\begin{tabular}{|c|c|c|c|c|c|c|c|c|c|c|c|c|c|c|c|c|}
\hline \multirow[b]{2}{*}{ Species } & \multicolumn{16}{|c|}{ Major Rivers in the Willamette Basin } \\
\hline & $\begin{array}{l}\text { Cala- } \\
\text { pooia }\end{array}$ & $\begin{array}{l}\text { Clack- } \\
\text { amas }\end{array}$ & $\begin{array}{l}\text { C.F. } \\
\text { Willa- } \\
\text { mette }\end{array}$ & $\begin{array}{l}\text { Long } \\
\text { Tom }\end{array}$ & $\begin{array}{l}\text { Luck- } \\
\text { iamute }\end{array}$ & Marys & $\begin{array}{c}\text { Mc- } \\
\text { Kenzie }\end{array}$ & $\begin{array}{l}\text { M.F. } \\
\text { Willa- } \\
\text { mette }\end{array}$ & Molalla & $\begin{array}{l}\text { Pud- } \\
\text { ding }\end{array}$ & $\begin{array}{l}\text { Rick- } \\
\text { reall }\end{array}$ & Sandy & $\begin{array}{l}\text { San- } \\
\text { tiam }\end{array}$ & $\begin{array}{l}\text { Tua- } \\
\text { latin }\end{array}$ & $\begin{array}{l}\text { Willa- } \\
\text { mette }\end{array}$ & Yamhill \\
\hline \multicolumn{17}{|l|}{ Sunfishes-Continued } \\
\hline Bluegill & $\mathrm{X}$ & $\mathrm{X}$ & $X$ & $\mathrm{X}$ & $\mathrm{X}$ & $\mathrm{X}$ & $X$ & $\mathrm{X}$ & -- & $\mathrm{X}$ & $\mathrm{X}$ & $\mathrm{X}$ & $\mathrm{X}$ & $\mathrm{X}$ & $X$ & $X$ \\
\hline Redear sunfish & -- & -- & -- & -- & -- & -- & -- & -- & -- & -- & -- & -- & -- & -- & $X$ & -- \\
\hline Smallmouth bass & $\mathrm{X}$ & $\mathrm{X}$ & -- & -- & -- & $\mathrm{X}$ & -- & $\mathrm{X}$ & -- & -- & $\mathrm{X}$ & $\mathrm{X}$ & $\mathrm{X}$ & $\mathrm{X}$ & $\mathrm{X}$ & $\mathrm{X}$ \\
\hline Largemouth bass & $\mathrm{X}$ & $\mathrm{X}$ & $\mathrm{X}$ & $\mathrm{X}$ & $\mathrm{X}$ & $\mathrm{X}$ & $\mathrm{X}$ & $\mathrm{X}$ & -- & $\mathrm{X}$ & $\mathrm{X}$ & $\mathrm{X}$ & $\mathrm{X}$ & $\mathrm{X}$ & $\mathrm{X}$ & $X$ \\
\hline White crappie & $\mathrm{X}$ & $\mathrm{X}$ & -- & $\mathrm{X}$ & $\mathrm{X}$ & $\mathrm{X}$ & $X$ & $\mathrm{X}$ & -- & $\mathrm{X}$ & $\mathrm{X}$ & $\mathrm{X}$ & $\mathrm{X}$ & $\mathrm{X}$ & $X$ & $\mathrm{X}$ \\
\hline Black crappie & $\mathrm{X}$ & $\mathrm{X}$ & -- & $\mathrm{X}$ & $\mathrm{X}$ & $\mathrm{X}$ & -- & $\mathrm{X}$ & -- & $X$ & $\mathrm{X}$ & $\mathrm{X}$ & $\mathrm{X}$ & $\mathrm{X}$ & $X$ & $\mathrm{X}$ \\
\hline \multicolumn{17}{|l|}{ Topminnows } \\
\hline Banded killifish & -- & $X$ & -- & -- & -- & -- & -- & -- & -- & -- & -- & -- & -- & $X$ & $\mathrm{X}$ & -- \\
\hline \multicolumn{17}{|l|}{ Trout and Salmon } \\
\hline Coho salmon & -- & $X$ & -- & -- & $\mathrm{X}$ & $X$ & $\mathrm{X}^{1}$ & -- & $X$ & $X$ & $X$ & $X$ & $\mathrm{X}^{1}$ & $X$ & $\mathrm{X}$ & $X$ \\
\hline Sockeye salmon & -- & -- & -- & -- & -- & -- & -- & -- & -- & -- & -- & -- & $\mathrm{X}^{1}$ & -- & $X$ & -- \\
\hline Kokanee & -- & $\mathrm{X}$ & -- & -- & -- & -- & -- & -- & -- & -- & -- & -- & $\mathrm{X}$ & -- & -- & -- \\
\hline Spring chinook salmon & $\mathrm{X}$ & $\mathrm{X}$ & -- & -- & -- & -- & $\mathrm{X}$ & $\mathrm{X}$ & $\mathrm{X}$ & $\mathrm{X}$ & -- & $\mathrm{X}$ & $\mathrm{X}$ & -- & $\mathrm{X}$ & -- \\
\hline Fall chinook salmon & -- & $\mathrm{X}$ & $X^{1}$ & -- & -- & -- & $\mathrm{X}$ & $\mathrm{X}$ & $\mathrm{X}$ & $X^{1}$ & $X^{1}$ & $\mathrm{X}$ & $\mathrm{X}$ & $X^{1}$ & $\mathrm{X}$ & $X^{1}$ \\
\hline Mountain whitefish & $\mathrm{X}$ & $\mathrm{X}$ & -- & $\mathrm{X}$ & $\mathrm{X}$ & $\mathrm{X}$ & $\mathrm{X}$ & $\mathrm{X}$ & $\mathrm{X}$ & -- & -- & $\mathrm{X}$ & $\mathrm{X}$ & $\mathrm{X}$ & $\mathrm{X}$ & -- \\
\hline Cutthroat trout & $\mathrm{X}$ & $\mathrm{X}$ & $\mathrm{X}$ & $\mathrm{X}$ & $\mathrm{X}$ & $\mathrm{X}$ & $\mathrm{X}$ & $\mathrm{X}$ & $\mathrm{X}$ & $\mathrm{X}$ & $\mathrm{X}$ & $\mathrm{X}$ & $\mathrm{X}$ & $\mathrm{X}$ & $\mathrm{X}$ & $\mathrm{X}$ \\
\hline Summer steelhead trout & -- & $\mathrm{X}$ & -- & -- & -- & -- & $X$ & $\mathrm{X}$ & $X$ & -- & -- & $X$ & $X$ & -- & $X$ & -- \\
\hline Winter steelhead trout & $\mathrm{X}$ & $X$ & $\mathrm{X}^{1}$ & $X$ & $X$ & $\mathrm{X}$ & $X^{1}$ & $\mathrm{X}$ & $\mathrm{X}$ & $\mathrm{X}$ & $X$ & $\mathrm{X}$ & $X$ & $\mathrm{X}$ & $\mathrm{X}$ & $\mathrm{X}$ \\
\hline Rainbow trout & $\mathrm{X}$ & $\mathrm{X}$ & $\mathrm{X}$ & -- & $\mathrm{X}$ & -- & $\mathrm{X}$ & $\mathrm{X}$ & $\mathrm{X}$ & $X$ & $\mathrm{X}$ & $\mathrm{X}$ & $\mathrm{X}$ & $\mathrm{X}$ & $\mathrm{X}$ & $\mathrm{X}$ \\
\hline Brown trout & -- & $\mathrm{X}$ & -- & -- & -- & -- & -- & -- & -- & -- & $\mathrm{X}$ & -- & -- & -- & -- & -- \\
\hline Brook trout & -- & $\mathrm{X}$ & -- & -- & -- & -- & $\mathrm{X}$ & $\mathrm{X}$ & -- & -- & -- & $\mathrm{X}$ & $\mathrm{X}$ & -- & -- & -- \\
\hline Bull trout & -- & $x^{2}$ & -- & -- & -- & -- & $X$ & $\mathrm{X}$ & -- & -- & -- & -- & -- & -- & -- & -- \\
\hline Lake trout ${ }^{3}$ & -- & -- & -- & -- & -- & -- & -- & -- & -- & -- & -- & -- & -- & -- & -- & -- \\
\hline \multicolumn{17}{|l|}{ Trout-perches } \\
\hline Sand roller & $\mathrm{X}$ & $\mathrm{X}$ & $\mathrm{X}$ & $\mathrm{X}$ & $\mathrm{X}$ & $\mathrm{X}$ & $\mathrm{X}$ & $X$ & $\mathrm{X}$ & $X$ & $X$ & -- & $\mathrm{X}$ & $\mathrm{X}$ & $\mathrm{X}$ & $X$ \\
\hline
\end{tabular}

${ }^{1}$ Rare; only a small population exists.

${ }_{3}^{2}$ Possibly extinct; no records since the early 1970s.

${ }^{3}$ Occurs in high elevation lakes only. 
In the lower Willamette River, Ward and Nigro (1991) and Farr and Ward (1993) described fish assemblages in the Portland Harbor, from the confluence of the Willamette River with the Columbia River to RM 15. They found significant relationships between habitat and fish assemblages. Overall, northern squawfish were the dominant species, followed by black crappie, white crappie, largemouth bass, smallmouth bass, and walleye. Ward and others (1991) summarized information on the status and biology of white and black crappie in the lower Willamette River.

Anadromous salmonids are considered the most valuable fish in the Willamette Basin in terms of commercial and sport fisheries (Willamette Basin Task Force, 1969; U.S. Army Corps of Engineers, 1982). The historical value of the Willamette River to anadromous fish, particularly chinook salmon and steelhead trout, was primarily as a passageway to tributaries where spawning grounds were located (Parkhurst and others, 1950; Oregon State Game Commission, 1963; Willamette Basin Task Force, 1969). Spring chinook salmon and winter steelhead trout were able to negotiate Willamette Falls during high flows (Collins, 1968), but fall runs were likely absent or minimal above Willamette Falls due to low water conditions at that time of the year (Oregon Department of Fish and Wildlife, 1990). Below Willamette Falls, particularly in the Clackamas River, large runs of fall chinook salmon occurred prior to extermination caused by oxygen depletion in the water from pollution, particularly during the low flow period when these fish were migrating to spawning grounds (Holmes and Bell, 1960). Other historically common anadromous fish in the Willamette River were coho salmon and American shad (Hutchison and Aney, 1964).

The ODFW reports annually on the composition and abundance of anadromous fish passage at several locations. These have been summarized for Willamette Falls since the mid-1950s (Howell, 1986) and Leaburg Dam since 1970 (Downey and others, 1993). ODFW (1980) and Howell (1986) summarize, for each anadromous species, the sport catch, releases of hatchery stock in various rivers, and passage counts at Willamette Falls and other dams. Similar information is available in subbasin fish management plans (table 2). The ODFW also provides annual summaries of populations of various salmonid species in the Willamette River (Downey and others, 1993).

Most salmonid spawning in the basin occurs in tributaries of the Willamette River, except for the rees- tablished runs of fall chinook salmon, which spawns from RM 50 (Newberg) through RM 187 (Springfield) of the main stem Willamette River (Oregon Department of Fish and Wildlife, 1990), and the mountain whitefish, which spawns throughout the river (Miller and others, 1991). It has also been reported that a few spring chinook salmon spawn in the Willamette River near Harrisburg (U.S. Army Corps of Engineers, 1982). Steelhead trout and chinook salmon also use the Willamette River for migration and juvenile rearing, and native cutthroat trout spawn in the upper tributaries and use it for juvenile rearing. Anadromous nonsalmonids such as white sturgeon and American shad spawn primarily in the main stem (Miller and others, 1991).

Despite the historic and current focus on salmonids and game fish, recent emphasis on investigations of entire aquatic ecosystems (Gregory and others, 1991; Reeves and Sedell, 1992) has resulted in more effort being focused on the effects of habitat loss and degradation on nonsalmonids and other nongame fish. Additionally, an increasing emphasis is being placed on aquatic biota and conservation efforts within the context of watersheds to account for the interrelated functions among aquatic, riparian, and upland habitats.

Because of the size and diversity of waters in the Willamette Basin, nearly all species of resident fish found in Oregon occur here (U.S. Army Corps of Engineers, 1982). In most cases, population size has not been adequately documented for resident fish species, although often these may be the most abundant fish in a particular area (U.S. Army Corps of Engineers, 1982). Angler effort and catch is most frequently used to provide an indication of the relative importance of resident fish. Most concern regarding nongame resident fish, such as suckers, northern squawfish, and common carp (Cyprinus carpio) has focused on their competition with desirable game species, and extensive efforts have been made to reduce or eliminate certain species where they compete with game fish.

Several investigations have reported on anadromous fish movements in major rivers and streams of the basin. Sams and Conover (1969) summarized data on the timing of migration of fall chinook and coho salmon in the lower Willamette River. Migratory characteristics of chinook salmon have also been reported in the lower Willamette River near Portland (Knutsen and Ward, 1991) and on the McKenzie River (EA Engineering, Science and Technology, Inc., 1991b). Timing of migration of Willamette River spring chinook salmon was summarized from tagging studies 
and catch data by Galbreath (1965). Streamflows affected movement (upstream during periods of low flow and downstream during periods of high flow) and mortality rates (higher during summer and fall low flows) of cutthroat trout in a controlled flow section of Berry Creek (Nickelson, 1974). A variety of movement patterns were evident for coastal cutthroat trout during a tagging and recovery study (Moring and others, 1986). Radiotracking of winter steelhead on the Clackamas River has been conducted to monitor movement, distribution, and habitat use (Shibahara and Lumianski, 1995).

A few studies have investigated fish movements in and near impoundments. Massey $(1965,1967$ a, 1967b) captured juvenile salmon and steelhead near the industrial area at Willamette Falls and reported on the abundance, timing, and size of the downstream migrants. The size of juvenile coho salmon was related to their length of stay in North Fork Reservoir (Hreha, 1967). Larger individuals moved more quickly out of the reservoir after migration began in the spring than did smaller individuals. Zakel and Reed (1984) studied the timing of downstream migration of fish at Leaburg Dam on the McKenzie River. Hasselman and Garrison (1957) reported that northern squawfish moved from the main part of Lookout Point Lake to the upper end for spawning.

Numerous studies in the basin have been directed at specific taxa or groupings of similar taxa. These taxa include dace (Rhinichthys spp.) (Zirges, 1972; Dodge, 1994), sculpin (Bond, 1963; Finger, 1982), bull trout (Salvelinus confluentus) (Goetz, 1994), Oregon chub (Long, 1982; Markle and others, 1989; Pearsons, 1989; Markle and others, 1991; Scheerer and others, 1992, 1993, 1994, 1995), kokanee (Oncorhynchus nerka kennerlyi) (Wetherbee, 1965), cutthroat trout (Wustenberg, 1954; Wyatt, 1959; Warren and others, 1964; McIntyre, 1967; Nickelson, 1974; Aho, 1976; Wilzbach, 1984; Frissell and others, 1985; Wilzbach and others 1986: Moore, 1987; Moore and Gregory, 1989; House, 1995; Oregon Department of Fish and Wildlife, 1995b), chinook salmon (Mattson 1962), redside shiner (Rodnick, 1983), northern squawfish (Hasselman and Garrison, 1957; Buchanan and others, 1981), winter steelhead trout (Shibahara and Lumianski, 1995), and rainbow trout (Oncorhynchus mykiss) (Moore and Gregory, 1989).

Summaries of information on taxon distribution and abundance in the basin have also been compiled in status reports and literature reviews. These taxa include cutthroat trout (Nicholas, 1978), chinook salmon (Mattson and Dimick, 1952; Mattson, 1963; Wevers, 1994), coho salmon in the Clackamas subbasin (Cramer and Cramer, 1994), steelhead trout in the Willamette River (Clady, 1971), and kokanee in Detroit Lake (Wetherbee, 1965).

A few investigations have been conducted on fisheries resources in lakes of the Willamette Basin. These studies include the effects of water withdrawal on fisheries resources in Bull Run Lake (Beak Consultants Inc., 1993), fish sampling in Detroit Lake (Wetherbee, 1962), and a study on the northern squawfish in Lookout Point Lake and Dexter Reservoir (Hasselman and Garrison, 1957).

Fish species assemblages associated with revetments (bank-stabilization structures) in the mid-Willamette River have been studied by Hjort and others (1984) and Li and others (1984). Hjort and others (1984) reported higher densities of fish at revetments than natural banks, but $\mathrm{Li}$ and others (1984) indicated that natural banks had higher densities of fish. The fish species that Hjort and others (1984) identified that benefit from the invertebrate and algae populations associated with revetments include prickly sculpin (Cottus asper), redside shiner, northern squawfish, largescale sucker, and chiselmouth (Acrocheilus alutaceus).

A few studies have reported on fish species distribution and abundance outside of the Willamette River. For example, in Cascade Mountain streams in and adjacent to the HJAEF, studies have been conducted by Hawkins and others (1983), Moore (1987), and Moore and Gregory (1989). Fish populations were the focus of an investigation by Everest and others (1985) in Fish Creek in the Mt. Hood National Forest. Fish species distribution and abundance in the lower elevations of the basin have been reported by Friesen and Ward (1996) for the lower Tualatin subbasin, and Baker and others (1995) for the Clackamas subbasin.

In the Willamette River near Halsey, three species of sculpin — prickly, torrent, and reticulate - were captured during sampling in the summers of 1988 and 1989 (HMS Environmental, Inc., and Miller, 1988; Johnson and others, 1989). Distribution of sculpin are of particular interest because this genus was used extensively by the Willamette NAWQA study unit for analysis of organochlorine compounds and trace elements in tissue during 1992-93 (Dennis Wentz, U.S. Geological Survey, oral commun., 1996).

In a field verification study of fish distribution and species composition within the Clackamas River 
subbasin (Baker and others, 1995), sampling revealed a 45-percent overestimate (based on river miles in which a species occurred) of a "best guess" distribution based on available information. This finding exemplifies that, despite the extensive research that has been done on fish resources, existing data are still inadequate in some instances.

\section{Fishery Plans}

Management of fish populations and habitat within the Willamette Basin is guided by the objectives and priorities initially set forth in the Willamette Basin Fish Management Plan (Oregon Department of Fish and Wildlife, 1980) and subsequent revisions (Oregon Department of Fish and Wildlife, 1988; 1991). The Willamette Basin Fish Management Plan: Status and Progress 1979-1985 (Howell, 1986) describes progress made on the objectives of the initial plan through 1985.

One of the high priorities of the initial plan was the preparation of a fish management plan for each subbasin. Ten subbasin plans have been completed (table 2). A fish management plan for the Sandy subbasin is being prepared (Tom Murtagh, Oregon Department of Fish and Wildlife, written commun., 1995). Separate plans have also been prepared for important reservoirs and lakes within the subbasins and for spring chinook salmon throughout the basin (Oregon Department of Fish and Wildlife, 1993). Additionally, the ODFW has completed statewide species management plans for coho salmon (Oregon Department of Fish and Wildlife, 1982a), steelhead trout (Oregon Department of Fish and Wildlife, 1986; 1995c), trout (Oregon Department of Fish and Wildlife, 1987a), and warm water game fish (Oregon Department of Fish and Wildlife, 1987b) (table 2). These plans were intended to guide the development of localized plans for river basins and subbasins.

In addition to fish management plans, production plans for anadromous fish have been prepared for the Willamette Basin and 11 subbasins: Clackamas, Coast Range, Coast Fork Willamette, Long Tom, McKenzie, Middle Fork Willamette, Molalla and Pudding, Sandy, Santiam and Calapooia, Tualatin, and main stem Willamette (Oregon Department of Fish and Wildlife, 1990). These plans provide the basis for salmon and steelhead production objectives and strategies in the Northwest Power Planning Council's Columbia River Fish and Wildlife Program. The plans include comprehensive information on fish resources in each of the subbasins, including natural production, hatchery production, and harvest.

\section{Semiaquatic Taxa}

The following sections enumerate or describe studies relating to the distribution, abundance, and trends of selected semiaquatic (i.e., taxa frequenting but not living wholly in water) amphibians and reptiles, birds, and mammals. A complete list of semiaquatic wildlife species occurring in the Willamette Basin was prepared for the WRBWQS (Tetra Tech, Inc., 1993d).

\section{Amphibians and Reptiles}

Semiaquatic native amphibians and reptiles in the Willamette Basin include two species of turtle, and several species of frogs and salamanders. Most of the species use both aquatic and riparian habitats. Three salamanders, Pacific giant (Dicamptodon tenebrosus), Dunn's (Plethodon dunni), and northwestern (Ambystoma gracile), and one frog, tailed (Ascaphus truei), are considered riparian obligates (Anthony and others, 1987; Bury, 1988).

The most intensive inventory of amphibians and reptiles in the Willamette Valley was conducted in 1984-87 (St. John, 1987). The inventory included the valley floor and foothills of the Coast Range and Cascade Mountains, but not the upper elevations of the Willamette Basin. Amphibian and reptile inventories are also conducted on an opportunistic and periodic basis in the forests of the Willamette Basin by the USFS and BLM. Methods and protocols for inventorying amphibians and reptiles have been described by Applegarth (1994). Survey protocols also have been recently developed for five salamander species strongly associated with old-growth forests as part of the requirements of the Northwest Forest Plan (Olson, 1996).

Species-specific studies on the distribution and status of amphibians and reptiles in the basin have been reported for the spotted frog (Rana pretiosa) (Marshall, 1989; Hayes, 1994), Larch Mountain salamander (Plethodon larselli) (Kirk, 1983), roughskinned newt (Taricha granulosa) (Kelley, 1951), and western pond turtle (Clemmys marmorata marmorata) (Holland, 1991; 1994). Blaustein and others (1995) provide detailed information on current status, ecology, behavior, and range of semiaquatic amphibians and reptiles inhabiting old-growth forests of the Pacific 
Northwest. The occurrence of salamanders and frogs associated with streams in the Cascade Mountains has been reported by Hawkins and others (1983). The occurrence of amphibian species in the Mt. Hood National Forest is reported annually by volunteers participating in the Wetland Wildlife Watch program (Corkran, 1995).

The giant salamanders (Dicamptodon spp.) of the Willamette Basin include two species, Cope's giant salamander (Dicamptodon copei), and the Pacific giant salamander. Adult Pacific giant salamanders are relatively common in the moist coniferous forests of the basin, but are nocturnal and secretive (Blaustein and others, 1995). Only three adult Cope's giant salamanders have been described (Leonard and others, 1993), and Cope's giant salamander has only been reported from the Mt. Hood National Forest in the Willamette Basin (Marshall and others, 1996). Little is known about the larvae of either species, although they are apparently sensitive to land management practices (Corn and Bury, 1989).

Painted turtles (Chrysemys picta) inhabit shallow waters of ponds or small lakes, and slow-moving, backwater areas of streams and rivers in the Willamette Basin (Nussbaum and others, 1983). They prefer soft, muddy bottoms with considerable aquatic vegetation. The current status of painted turtle populations in the basin is unknown, although populations are likely declining due to unsuccessful recruitment (Gaddis and Corkran, 1985).

\section{Birds}

Semiaquatic birds in the Willamette Basin include numerous species of waterfowl, shorebirds, herons, and gulls, along with one passerine bird, American dipper, and two raptors, osprey and bald eagle. Principal breeding species of waterfowl in the Willamette Valley are mallard (Anas platyrhynchos) and wood duck (Aix sponsa). Small populations of nesting harlequin ducks (Histrionicus histrionicus), goldeneyes (Bucephala spp.), and mergansers (Mergus spp.) occur in higher elevations of the basin. Wintering waterfowl are extensive in the Willamette Valley, including mallard, pintail (Anas acuta), teal (Anas spp.), ring-necked duck (Aythya collaris), and several subspecies of Canada geese (Branta canadensis). In general, there has been a change in wintering waterfowl abundance because species adapted to feeding on agricultural crops, such as Canada geese, are now more abundant than aquatic plant and animal feeders (Puchy and Marshall, 1993). Popular waterfowl hunting areas in the Willamette Valley include the Sauvie Island Wildlife Management Area and three National Wildlife Refuges (Finley, Baskett Slough, and Ankeny) in the mid-Willamette Valley.

The American dipper is a small resident bird that is closely associated with high gradient, montane streams in the Cascade and Coast Range Mountains. Dippers are significant components of the aquatic ecosystem because they forage within streams for aquatic insect larvae, particularly EPT taxa and Diptera (Mitchell, 1968), and some small fish, snails, and adult insects. Thus, they compete either directly or indirectly for food with fish and amphibians. Some researchers suggest they are important as bioindicators of stream quality because they are integrally tied to the aquatic invertebrate community, particularly EPT taxa (John Loegering, Oregon State University, oral commun., 1995). The only investigation of American dipper in the Willamette Basin was a winter time and energy budget study in the Cascade Range (Parsons, 1975). Ongoing research on the habitat selection and breeding season ecology of dippers in coastal streams of Oregon (John Loegering, Oregon State University, oral commun., 1995) will likely provide information applicable to dipper populations in the Willamette Basin.

The great blue heron (Ardea herodias) is a colonial nester (rookeries) in large trees along large streams, rivers, and lakes. Several studies have reported on population trends in the Willamette Basin. Henny and Bethers (1971) studied a colony near Albany and concluded that the population was stable on the basis of a comparison of productivity with that necessary to maintain a stable population. The ODFW has conducted basinwide inventories for nesting rookeries and populations of great blue heron (English, 1978; Ellingson, 1988). There were 40 more active nests counted in 1977 despite the fact that 17 more colonies were located in the 1988 census (Ellingson, 1988). Within the 24 rookeries active in both years, there was an 11 percent decrease in the number of nests. Colony fragmentation and/or a more comprehensive survey in 1988 were suggested as reasons for the differences.

The osprey is a fish-eating raptor that nests adjacent to or within a short distance of major rivers and reservoirs in the Willamette Valley. A long-term study of osprey populations along the Willamette River revealed that the number of nesting pairs in 1976 (13) increased to 78 pairs in 1993 (Henny and others, 1978; 
Henny and Kaiser, 1996). It also revealed a change in nesting structures from live or dead trees (all 13 nests in 1976) to utility structures or nesting platforms (66 of 78 nests in 1993). Thus, the population nesting in the apparently small number of suitable nesting trees remained relatively unchanged (13 nests in 1976 and 12 in 1993). Factors suggested by Henny and Kaiser (1996) for the population increase include the learned response to use utility structures, a reduction in DDTrelated reproductive problems, improved water conditions and fish populations in the Willamette River, and reduced shooting of adults.

\section{Mammals}

Semiaquatic mammals in the Willamette Basin include beaver (Castor canadensis), river otter (Lutra canadensis), mink (Mustela vison), muskrat (Ondatra zibethica), nutria (Myocastor coypu), Steller sea lion (Eumetopias jubatus), and Pacific water shrew (Sorex pacificus). Most of the species use both aquatic and riparian habitats and several depend upon aquatic fauna as prey. For example, mink use both riparian and instream habitat, and primarily depend upon aquatic prey, such as crayfish and fish. The Pacific water shrew is a riparian obligate species (Anthony and others, 1987; Gomez, 1992; McComb and others, 1993) that is endemic to the coastal Pacific Northwest. It is mostly found in or near water (Christenson and Larrison, 1982).

Beaver are keystone species in aquatic and riparian habitats, and are responsible for natural disturbances to aquatic systems. Their dens and lodges are used as dens and rest sites for species such as river otter and provide habitat for other smaller species, including salamanders, mice, and voles. Pools created by beaver dams are also important habitat for a number of aquatic species.

The modern aquatic furbearer industry is small, particularly compared to the historical extent of the industry. Populations of aquatic furbearers have declined due to historic overexploitation from trapping and from habitat loss and degradation due to several factors associated with an expanding human population. Historical data on aquatic furbearer harvest is presented in the Basin Investigation Report for the upper Willamette Basin (Hutchison and others, 1966a). A study of the population status of the river otter in western Oregon included data from trapping conducted in the Willamette Basin during 1970-1972 (Tabor, 1974).
Population management of aquatic furbearers is based on harvest regulations set by the ODFW.

\section{Introduced Species}

Numerous introduced (nonnative) species are present and have established populations in the Willamette Basin. Many introductions were intentional (several game fish), some species escaped from confinement (nutria, red-eared slider [Pseudemys scripta elegans]), and some species immigrated following introductions elsewhere (walleye). Additionally, the use of live bait for fishing has resulted in some fish introductions. Puchy and Marshall (1993) list suspected or known sources of introductions for fish in the basin.

The widest variety of introduced species occurs in lowland rivers, lakes, and ponds that support warm water ecosystems similar to the native habitats of most of these species (Bond and others, 1988). Additionally, the increase in slow-moving, deep-water habitat created by dam construction and bank revetments has likely contributed to the establishment and population increases for many of these species (Hjort and others, 1984; Farr and Ward, 1993).

An early history of fish introductions in the Willamette Basin is included in Lampman (1946). The timing of several fish introductions into the lower Willamette River is discussed in Farr and Ward (1993). Logan and others (in press) recently documented the occurrence of the nonnative aquarium fish, oriental weatherfish (Misgurnus anguillicaudatus), in the Clackamas subbasin. Within the Willamette River, Hughes and Gammon (1987) reported that the number of native fish species in the lower river was approximately half that in the upper river. Over half of the fish species recorded in the Portland Harbor were introduced to the Willamette River system (Farr and Ward, 1993).

Black crappie and white crappie are introduced warm water fishes occurring in lakes, impoundments, and relatively stagnant areas of rivers. Black crappie were estimated to be four times as abundant as white crappie in the lower Willamette River near Portland (Ward and others, 1991). Large individuals of both species have been reported to prey upon juvenile salmonids in the Willamette Basin (Grenfell, 1962; Ward and others, 1991), although the predation level is probably low (Ward and others, 1991). 
The common carp is one of the most notorious introduced fish species and is widely regarded as a pest species that is difficult to eradicate or control. Common carp were introduced into the Pacific Northwest in the early 1880 s as a food fish (Wydoski and Whitney, 1979). They occur throughout lowland aquatic habitats in the basin. The mosquito fish (Gambusia affinis) also has been introduced in lowland aquatic habitats, particularly urban and residential areas, for mosquito control.

The bullfrog (Rana catesbeiana) was introduced into the western United States to be farmed for sale in food markets, and spread rapidly in lowland aquatic habitats to where they are often the dominant species (Bury and Whelan, 1984). They have been directly or indirectly implicated in the decline or extirpation of a number of native amphibians and reptiles, particularly other Rana frogs (Bury and Whelan, 1984; Hayes and Jennings, 1986). The bull frog is believed to be the principal cause of extirpation of the spotted frog from the Willamette Valley (St. John, 1987; Marshall and others, 1996).

Since the introduction of escaped or fur-farm released nutria, this species has spread rapidly throughout the basin. They are semiaquatic and use the instream and shoreline habitat of lowland lakes, ponds, and slow-moving rivers in the basin. They are considered nuisance animals because of their ecological competition with beaver and muskrat, and the adverse physical effect (erosion) of their burrowing activities on streambanks. Peloquin (1969) studied growth and reproduction of nutria near Corvallis.

The Asiatic clam (Corbicula fluminea) was first introduced to the United States early this century, probably along the west coast in San Francisco Bay. Its hermaphroditic reproductive mode has allowed it to spread rapidly in most rivers throughout the west coast. Asiatic clams are found in the main stem Willamette River and in the lower sections of most tributaries. Where present, it is the recommended taxon for analysis of organochlorine compounds and trace elements in the NAWQA Program (Crawford and Luoma, 1993)

The aquatic macrophyte, Eurasian watermilfoil (Myriophyllum spicatum), is discussed here because it affects water quality and aquatic biota. The presence of this aggressive species is relatively recent to the Willamette Basin. Its occurrence in the Pacific Northwest dates from the late 1960s in British Columbia (Geiger, 1986). Within the Willamette Basin, the USACE (1982) documented the occurrence of the species in the Delta Ponds near Eugene, and Halse and DennisJohnston (1981) reported its presence in the Coast Fork Willamette River near Eugene, at Fern Ridge Lake, and at Clear Lake. Its dominance in the Delta Ponds of Eugene was reported by Fetrow Engineering and Scientific Resources (1989). It is well established now in the Willamette River above Delta Ponds.

\section{Special Status Species}

Special status species are defined here as species designated by the USFWS or ODFW as threatened or endangered, USFWS candidate species or species of concern, ODFW and USFS sensitive species, or species considered species of special concern by recognized experts, such as malacologists for mollusc species. A listing of special status aquatic fauna that are suspected or documented to occur in the Willamette Basin is presented in table 5. A separate listing of mollusc species of concern is presented in table 6 .

There are no threatened or endangered species of aquatic macroinvertebrates in the Willamette Basin. However, 16 species of aquatic macroinvertebrates in the basin have special status, including 14 Federal species of concern (table 5). Twelve of the 16 species are caddisflies. This high number is partly due to the amount of information on caddisflies, but also due to their sensitivity to stream degradation. Other special status aquatic macroinvertebrate species include a stonefly, beetle, snail, and clam (table 5). In general, not enough is known about the status of aquatic macroinvertebrate species to adequately determine if they should be removed from the list or upgraded to candidate status.

Surveys have been conducted for special status caddisflies on the Mt. Hood National Forest (Wisseman, 1989) and Willamette National Forest (Wisseman, 1992c). Wisseman (1990) presents an overview of the ecology of several invertebrate special status species occurring on the Mt. Hood National Forest.

Frest and Johannes (1993) list 10 freshwater mollusc species of concern (8 snails and 2 clams) known or suspected to occur in the Willamette Basin table 6). Factors primarily responsible for the special status include impacts from dams/impoundments (such as alteration of flows), fluctuations in water temperatures, and degradation/loss of habitat; other factors are increases in siltation, nutrient enrichment, pollution, channelization and dredging, and land use practices 
Table 5. Aquatic fauna with special status that occur in the Willamette Basin, Oregon

[USFWS, U.S. Fish and Wildlife Service; USFS, U.S. Forest Service; ODFW, Oregon Department of Fish and Wildlife; --, No status or plans, trend unknown]

\begin{tabular}{|c|c|c|c|c|c|c|c|}
\hline \multirow[b]{2}{*}{ Species } & \multirow[b]{2}{*}{ Scientific Name } & \multicolumn{3}{|c|}{ Status } & \multirow[b]{2}{*}{ Trend $^{4}$} & \multirow[b]{2}{*}{ Plans $^{5}$} & \multirow[b]{2}{*}{ Reasons for Status ${ }^{6}$} \\
\hline & & USFWS $^{1}$ & USFS $^{2}$ & ODFW $^{3}$ & & & \\
\hline \multicolumn{8}{|l|}{$\underline{\text { Mammals }}$} \\
\hline Steller sea lion & Eumetopias jubatus & $\mathrm{T}$ & -- & $\mathrm{V}$ & -- & -- & Unknown; prey loss; disturbance \\
\hline \multicolumn{8}{|l|}{$\underline{\text { Birds }}$} \\
\hline Aleutian Canada goose & Branta canadensis leucopareia & $\mathrm{T}$ & -- & $\mathrm{E}$ & -- & -- & -- \\
\hline Bald eagle & Haliaeetus leucocephalus & $\mathrm{T}$ & $\mathrm{X}$ & $\mathrm{T}$ & -- & yes & -- \\
\hline Barrow's goldeneye & Bucephala islandica & -- & -- & $\mathrm{U}$ & -- & -- & Limited distribution; forestry practices \\
\hline Bufflehead & Bucephala albeola & -- & -- & $\mathrm{U}$ & -- & -- & Limited distribution; forestry practices \\
\hline Harlequin duck & Histrionicus histrionicus & $\mathrm{SC}$ & $\mathrm{X}$ & $\mathrm{U}$ & $\mathrm{U}^{7}$ & -- & Limited distribution \\
\hline \multicolumn{8}{|l|}{$\underline{\text { Fish }}$} \\
\hline River lamprey & Lampetra ayresi & $\mathrm{SC}$ & -- & -- & $\mathrm{D}$ & -- & -- \\
\hline Pacific lamprey & Lampetra tridentata & $\mathrm{SC}$ & -- & $\mathrm{V}$ & $\mathrm{U}$ & -- & -- \\
\hline $\begin{array}{l}\text { Lower Columbia River coho } \\
\text { salmon }\end{array}$ & Oncorhynchus kisutch & PT & $\mathrm{X}$ & $\mathrm{C}$ & -- & -- & $\begin{array}{l}\text { Stream barriers; forestry practices; } \\
\text { introductions; overutilizations }\end{array}$ \\
\hline Coastal cutthroat trout & Oncorhynchus clarki clarki & -- & -- & $\mathrm{C}$ & -- & -- & $\begin{array}{l}\text { Forestry practices; stream barriers; } \\
\text { livestock grazing; urban development }\end{array}$ \\
\hline $\begin{array}{l}\text { Lower Columbia River fall } \\
\text { chinook salmon }\end{array}$ & Oncorhynchus tshawytscha & -- & -- & $\mathrm{C}$ & -- & -- & Forestry practices; stream barriers \\
\hline Oregon chub & Oregonichthys crameri & $\mathrm{E}$ & $\mathrm{X}$ & $\mathrm{C}$ & -- & yes & $\begin{array}{l}\text { Introductions; wetland draining; } \\
\text { channelization; stream barriers }\end{array}$ \\
\hline Bull trout & Salvelinus confluentus & $\mathrm{C}$ & $\mathrm{X}$ & $\mathrm{C}$ & $\mathrm{D}$ & $\left({ }^{8}\right)$ & $\begin{array}{l}\text { Forestry practices; overutilizations; } \\
\text { introductions; passage barriers; chemical } \\
\text { treatment projects }\end{array}$ \\
\hline \multicolumn{8}{|l|}{ Amphibians and Reptiles } \\
\hline Western pond turtle & $\begin{array}{l}\text { Clemmys marmorata } \\
\text { marmorata }\end{array}$ & $\mathrm{SC}$ & $X$ & $\mathrm{C}$ & $\mathrm{U}$ & -- & $\begin{array}{l}\text { Farming practices; wetland loss; } \\
\text { introductions; urban development }\end{array}$ \\
\hline Painted turtle & Chrysemys picta & -- & $\mathrm{X}$ & $\mathrm{C}$ & -- & -- & Unknown; introductions; wetland loss \\
\hline Clouded salamander & Aneides ferreus & -- & -- & $\mathrm{U}$ & -- & -- & Forestry practices \\
\hline Cope's giant salamander & Dicamptodon copei & -- & $\mathrm{X}$ & $\mathrm{U}$ & -- & -- & -- \\
\hline
\end{tabular}


Table 5. Aquatic fauna with special status that occur in the Willamette Basin, Oregon-Continued

\begin{tabular}{|c|c|c|c|c|c|c|c|}
\hline \multirow[b]{2}{*}{ Species } & \multirow[b]{2}{*}{ Scientific Name } & \multicolumn{3}{|c|}{ Status } & \multirow[b]{2}{*}{ Trend $^{4}$} & \multirow[b]{2}{*}{ Plans $^{5}$} & \multirow[b]{2}{*}{ Reasons for Status ${ }^{6}$} \\
\hline & & USFWS $^{1}$ & USFS $^{2}$ & ODFW $^{3}$ & & & \\
\hline \multicolumn{8}{|l|}{ Amphibians and Reptiles-Continued } \\
\hline Larch Mountain salamander & Plethodon larselli & $\mathrm{SC}$ & $\mathrm{X}$ & $\mathrm{V}$ & -- & -- & $\begin{array}{l}\text { Limited distribution; threat from forestry } \\
\text { practices }\end{array}$ \\
\hline Oregon slender salamander & Batrachoseps wrighti & -- & -- & $\mathrm{U}$ & -- & -- & Forestry practices \\
\hline Cascade torrent (seep) salamander & Rhyacotriton cascadae & -- & -- & $\mathrm{V}$ & -- & -- & Forestry practices \\
\hline $\begin{array}{l}\text { Columbia torrent (seep) } \\
\text { salamander }\end{array}$ & Rhyacotriton kezeri & -- & -- & $\mathrm{C}$ & -- & -- & Forestry practices \\
\hline $\begin{array}{l}\text { Southern torrent (seep) } \\
\text { salamander }\end{array}$ & Rhyacotriton variegatus & $\mathrm{SC}$ & -- & $\mathrm{C}$ & $\mathrm{D}$ & -- & Forestry practices \\
\hline Western toad & Bufo boreas & -- & -- & $\mathrm{V}$ & -- & -- & -- \\
\hline Tailed frog & Ascaphus truei & $\mathrm{SC}$ & -- & $\mathrm{V}$ & $\mathrm{D}$ & -- & Forestry practices \\
\hline Northern red-legged frog & Rana aurora aurora & $\mathrm{SC}$ & $\mathrm{X}$ & $\mathrm{U}$ & $\mathrm{U}$ & -- & Unknown \\
\hline Foothill yellow-legged frog & Rana boylii & $\mathrm{SC}$ & -- & $\mathrm{V}$ & $\mathrm{D}$ & -- & Unknown \\
\hline Cascades frog & Rana cascadae & $\mathrm{SC}$ & -- & $\mathrm{V}$ & $\mathrm{U}$ & -- & $\begin{array}{l}\text { Drought; fish introductions: pathogens; } \\
\text { habitat loss }\end{array}$ \\
\hline Spotted frog & Rana pretiosa & $\mathrm{C}$ & -- & $\mathrm{C}$ & $\mathrm{U}$ & -- & Unknown; introductions \\
\hline \multicolumn{8}{|l|}{$\underline{\text { Invertebrates }}$} \\
\hline Beer's false water penny beetle & Acneus beeri & $\mathrm{SC}$ & $\mathrm{X}$ & -- & $\mathrm{U}$ & -- & -- \\
\hline California floater & Anodonta californiensis & $\mathrm{SC}$ & -- & -- & $\mathrm{D}$ & -- & Dams and impoundments \\
\hline $\begin{array}{l}\text { Columbia River pebblesnail or } \\
\text { spire snail }\end{array}$ & Fluminicola columbianus & $\mathrm{SC}$ & -- & -- & $\mathrm{U}$ & -- & Dams and impoundments \\
\hline Cascades apatanian caddisfly & Apatania tavala & $\mathrm{SC}$ & $\mathrm{X}$ & -- & $\mathrm{U}$ & -- & -- \\
\hline Vertrees's ceraclean caddisfly & Ceraclea vertreesi & $\mathrm{SC}$ & -- & -- & $\mathrm{U}$ & -- & -- \\
\hline $\begin{array}{l}\text { Mt. Hood primitive brachycentrid } \\
\text { caddisfly }\end{array}$ & Eobrachycentrus gelidae & $\mathrm{SC}$ & $\mathrm{X}$ & -- & $\mathrm{U}$ & -- & -- \\
\hline Mt. Hood farulan caddisfly & Farula jewetti & $\mathrm{SC}$ & $\mathrm{X}$ & -- & $\mathrm{U}$ & -- & -- \\
\hline $\begin{array}{l}\text { Tombstone Prairie farulan } \\
\text { caddisfly }\end{array}$ & Farula reaperi & $\mathrm{SC}$ & $\mathrm{X}$ & -- & $\mathrm{U}$ & -- & -- \\
\hline Fort Dick limnephilus caddisfly & Limnephilus atercus & SC & $X$ & -- & $\mathrm{U}$ & -- & -- \\
\hline
\end{tabular}


Table 5. Aquatic fauna with special status that occur in the Willamette Basin, Oregon-Continued

\begin{tabular}{|c|c|c|c|c|c|c|c|}
\hline \multirow[b]{2}{*}{ Species } & \multirow[b]{2}{*}{ Scientific Name } & \multicolumn{3}{|c|}{ Status } & \multirow[b]{2}{*}{ Trend 4} & \multirow[b]{2}{*}{ Plans $^{5}$} & \multirow[b]{2}{*}{ Reasons for Status ${ }^{6}$} \\
\hline & & USFWS $^{1}$ & USFS $^{2}$ & ODFW $^{3}$ & & & \\
\hline \multicolumn{8}{|l|}{ Invertebrates-Continued } \\
\hline $\begin{array}{l}\text { Columbia Gorge neothremman } \\
\text { caddisfly }\end{array}$ & Neothremma andersoni & $\mathrm{SC}$ & $\mathrm{X}$ & -- & $\mathrm{U}$ & -- & -- \\
\hline $\begin{array}{l}\text { Alsea ochrotrichian micro } \\
\text { caddisfly }\end{array}$ & Ochrotrichia alsea & -- & $\mathrm{X}$ & -- & -- & -- & -- \\
\hline $\begin{array}{l}\text { Tombstone Prairie } \\
\text { oliogophlebodes caddisfly }\end{array}$ & Oligophlebodes mostbento & $\mathrm{SC}$ & $\mathrm{X}$ & -- & $\mathrm{U}$ & -- & -- \\
\hline Haddock's rhyacophilan caddisfly & Rhyacophila haddocki & $\mathrm{SC}$ & $\mathrm{X}$ & -- & $\mathrm{U}$ & -- & -- \\
\hline One-spot rhyacophilan caddisfly & Rhyacophila unipunctata & $\mathrm{SC}$ & $\mathrm{X}$ & -- & $\mathrm{U}$ & -- & -- \\
\hline Siskyou caddisfly & Tinodes siskiyou & $\mathrm{SC}$ & $\mathrm{X}$ & -- & $\mathrm{U}$ & -- & -- \\
\hline Wahkeena Falls flightless stonefly & Zapada wahkeena & -- & $\mathrm{X}$ & -- & $\mathrm{U}$ & -- & -- \\
\hline
\end{tabular}

${ }^{1}$ Sources: U.S. Fish and Wildlife Service (1994a, 1994b; G. Miller, U.S. Fish and Wildlife Service, written commun., 1996); E, Endangered; T, Threatened; PT, Proposed Threatened; C, Candidate; SC, Species of Concern.

${ }^{2}$ Source: U.S. Forest Service (1989); X, Sensitive.

${ }^{3}$ Source: C. Puchy (Oregon Department of Fish and Wildlife, written commun., 1995); E, Endangered; T, Threatened; C, Critical; V, Vulnerable; U, Undetermined.

${ }^{4}$ Source: U.S. Fish and Wildlife Service (1994b); Throughout the species range, D, Declining; U, Unknown.

5 Includes recovery plans for threatened and endangered species, and management plans or conservation strategies/agreements for other species.

w

Frest and Johannes (1993) for California floater and Columbia River spire snail; Blaustein and others (1994) for foothill yellow-legged frog; and Scheerer and others (1995) for Oregon chub.

${ }^{7}$ Cassirer and others (1993) indicated a stable to declining trend in western North America.

${ }^{8}$ The McKenzie/Middle Fork Willamette bull trout working group is developing a conservation strategy (J. Ziller, Oregon Department of Fish and Wildlife, oral commun., 1995) 
Table 6. Aquatic mollusc species of concern in the Willamette Basin, Oregon [Source: Frest and Johannes (1993), except two Federal species of concern, Fluminicola columbianus and Anodonta californiensis, which are listed in table 8]

\begin{tabular}{|c|c|c|c|}
\hline Common Name & Scientific Name & Distribution & Status \\
\hline \multicolumn{4}{|l|}{ Snails } \\
\hline Barren juga & Juga (Juga) hemphilli hemphilli & $\begin{array}{l}\text { Multnomah County; east of Willamette } \\
\text { River in Sandy Subbasin }\end{array}$ & Species of concern \\
\hline None & Juga (Juga) hemphilli n. subsp. & $\begin{array}{l}\text { Multnomah County; Mount Hood National } \\
\text { Forest }\end{array}$ & Species of concern \\
\hline Brown juga & Juga (Juga) n. sp. 1 & $\begin{array}{l}\text { Multnomah County; Mount Hood National } \\
\text { Forest }\end{array}$ & Species of concern \\
\hline Tall juga & Juga (Juga) n. sp. 3 & $\begin{array}{l}\text { Multnomah County: Mount Hood National } \\
\text { Forest }\end{array}$ & Species of concern \\
\hline Columbia duskysnail & Lyogyrus $n . s p .1$ & $\begin{array}{l}\text { Multnomah County; Mount Hood National } \\
\text { Forest }\end{array}$ & Species of concern \\
\hline Rotund physa & Physella (Physella) columbiana & $\begin{array}{l}\text { Near Columbia River in Columbia and } \\
\text { Multnomah Counties }\end{array}$ & Species of concern ${ }^{2}$ \\
\hline Nerite rams-horn & Vorticifea neritoides & $\begin{array}{l}\text { Near Columbia River in Columbia and } \\
\text { Multnomah Counties }\end{array}$ & Species of concern \\
\hline
\end{tabular}

$\underline{\text { Clams }}$

Willamette floater Anodonta wahlametensis

Lower Willamette and Columbia Rivers in Species of concern ${ }^{1,2}$ Columbia, Multnomah, and Clackamas

Counties

\footnotetext{
${ }^{1}$ Impacted by dams and impoundments.

2 May be extirpated from the Willamette and Columbia Rivers.
}

such as grazing and logging. Frest and Johannes (1993) and Roth (1993) caution on the completeness of mollusc faunal lists because malacological research and knowledge is minimal, and it is likely that many new species and even genera remain to be discovered and described.

Currently, the only species of fish occurring in the Willamette Basin whose population is listed as threatened or endangered is Oregon chub (U.S. Fish and Wildlife Service, 1993) (table 5). Lower Columbia River coho salmon has been proposed for listing as a threatened species, and bull trout is a Candidate species (Gary Miller, U.S. Fish and Wildlife Service, written commun., 1996). Two species of fish are Federal species of concern; river lamprey (Lampetra ayresi) and Pacific lamprey (Lampetra tridentata). Two other species, coastal cutthroat trout and lower Columbia River fall chinook salmon, are listed as sensitive by the ODFW.

The decline of anadromous fish stocks throughout the Pacific Northwest, including the Willamette Basin, has been recognized for many years. The mag- nitude and extent of these declines were documented in an American Fisheries Society report by Nehlsen and others (1991). They identified over 100 stocks of anadromous salmon and trout as extinct, 102 stocks with a high risk of extinction, 58 with a moderate risk of extinction, and 54 of special concern due to low numbers and/or restricted distribution. For the Willamette Basin, two stocks were identified as already extinct, two at a high risk of extinction, two at a moderate risk of extinction, and two of special concern due to low numbers and/or restricted distribution (table 7). Declines in the Willamette Basin are further exemplified by a report that indicated that none of the 121 healthy native stocks of anadromous salmonids identified in the Pacific Northwest and California were within the Willamette Basin (Huntington and others, 1994). Documentation of declines of salmonids is problematic due to natural fluctuations in populations due to oceanic conditions (Lawson, 1993), and the lack of long-term data sets for many species/stocks.

The Oregon chub endemic to the Willamette Valley (Markle and others, 1991), was listed by the 
Table 7. Stocks of salmon and trout that are extinct or at risk of extinction in the Willamette Basin, Oregon [Source: Nehlsen and others (1991) for all except bull trout (Ratliff and Howell, 1992). Threat codes: 1, destruction, modification, and loss of habitat (includes passage and flow problems and predation in reservoirs); 2, overutilization for commercial, recreational, scientific, or educational purposes; 3 , other factors, including hybridization, introduction of nonnative species, competition, and poor ocean survival conditions]

\begin{tabular}{cllc}
\hline \multicolumn{1}{c}{ Species } & \multicolumn{1}{c}{ Stock/Population } & \multicolumn{1}{c}{ Risk } & Threats \\
\hline Chinook salmon & Willamette River, spring race & Special concern & $1,2,3$ \\
& Willamette River, fall race & Extinct & $?$ \\
& Sandy River, spring race & Extinct & 1,3 \\
& Sandy River, fall race & High & 1,2 \\
Coho salmon & Clackamas River & Moderate & $1,2,3$ \\
& Sandy River & High & $1,2,3$ \\
Steelhead trout & Clackamas River & Moderate & $1,2,3$ \\
& Calapooia River & Special concern & 1 \\
Bull trout & Middle Fork Willamette River & High & $1,2,3$ \\
& South Fork McKenzie River & Moderate & 1,2 \\
& McKenzie River, Anderson Creek & Moderate & $1,2,3$ \\
& Trailbridge Reservoir & High & $1,2,3$ \\
& Carmen Reservoir & Probably extinct & $1,2,3$ \\
& North Santiam River & Probably extinct & $1,2,3$ \\
& South Santiam River & Probably extinct & 2,3 \\
& Clackamas River & Probably extinct & $1,2,3$ \\
\hline
\end{tabular}

USFWS as an endangered species in 1993 (U.S. Fish and Wildlife Service, 1993). Historically, it occurred in ponds and quiet waters of backwater reaches of the Willamette River and its tributaries. Oregon chub populations have been reduced drastically from former levels primarily due to predation by introduced species, particularly largemouth bass (Markle and others, 1989), and loss of habitat due to alteration of the hydrography of the Willamette River (Marshall and others, 1996). Water-quality degradation, habitat loss due to flood control, draining of wetlands, and channelization of the main stem Willamette River have also likely contributed to the species decline (Pearsons, 1989; Rien and others, 1992; Scheerer and others, 1995). Surveys have been conducted since 1990 by the ODFW throughout the Willamette Basin to quantify existing populations, search for unknown populations, and evaluate potential reintroduction sites (Scheerer and others, 1992, 1993, 1994, 1995). Current known localities include several areas in or adjacent to the Middle Fork Willamette River, Dry Muddy Creek in Linn County, the Finley National Wildlife Refuge, and a small section of the Santiam River (Marshall and others, 1996). Since 1970, no Oregon chub has been found in the main stem Willamette River (Rien and others, 1992). Other status and distributional studies include Long (1982), Bond and Long (1984), Pearsons (1989), and Markle and others $(1989 ; 1991)$. A multiagency Conservation Agreement provides guidelines for management and reintroduction of the Oregon chub in the
Willamette Basin (Oregon Department of Fish and Wildlife, 1992).

Bull trout is listed as a Federal candidate species (U.S. Fish and Wildlife Service, 1994b). It spawns in the cold water of headwater tributaries of the basin and migrates downstream into larger tributaries in the same subbasin (Goetz, 1989). Historic and current distribution of the bull trout in the Willamette Basin has been described by Ratliff and Howell (1992) and Goetz (1994). The only known current locations of bull trout in the basin are three populations in the McKenzie subbasin and one population in the Middle Fork Willamette River. The population viability at all the sites is considered to be of moderate to high risk for extinction (Ratliff and Howell, 1992), and no individuals have been recorded from the Middle Fork Willamette River since 1992 (Mark Wade, Oregon Department of Fish and Wildlife, oral commun., 1995). Historical populations in the Clackamas River and the North and South Santiam Rivers are believed to be extinct. Factors contributing to the current population status include passage barriers, habitat degradation, overharvest, and hybridization and competition with brook trout (Salvelinus fontinalis) (Ratliff and Howell, 1992).

There are no threatened or endangered amphibians and reptiles in the Willamette Basin. However, 15 species of amphibians and reptiles have special status: 2 turtles, 5 frogs, 1 toad, and 6 salamanders (table 5). Of particular concern within the Willamette Basin are widespread declines of frogs of the genus Rana (Hayes 
and Jennings, 1986), including four of the five special status frog species: spotted frog, a Federal candidate species; and Cascades frog (Rana cascadae), foothill yellow-legged frog (Rana boylii), and red-legged frog (Rana aurora), Federal species of concern.

Several semiaquatic amphibians and reptiles have experienced basinwide declines that mirror those experienced at larger scales, including globally (Blaustein and Wake, 1990). Additionally, some species have experienced range reductions with extirpations of populations from specific areas of the Pacific Northwest, including the Willamette Basin (Corn and Bury, 1989). For example, the northern red-legged frog has been extirpated from much of the Willamette Valley (Blaustein and others, 1994), and the spotted frog has apparently been completely extirpated from the Willamette Valley, in addition to most if not all of the Willamette Basin (Hayes, 1994). Within the Willamette Basin, these declines, range reductions, and population extirpations have likely resulted from a number of factors, particularly habitat loss, insecticides and pollution, and predation by introduced predators (St. John, 1987).

The spotted frog is listed as a Federal candidate species (U.S. Fish and Wildlife Service, 1994b). The spotted frog is an obligate aquatic species found in marshes near the edges of ponds and lakes (Nussbaum and others, 1983). Its historical range included all of the Willamette Basin, but it is believed to be extirpated from the Willamette Valley, and has not been found west of the Cascade Range in Oregon since the early 1970s (McAllister and others, 1993). Suggested causes for the decline include predation by the introduced bullfrog (Nussbaum and others, 1983; St. John, 1987), toxics (Kirk, 1988), introduced warm water fishes (Hayes and Jennings, 1986), and degradation and elimination of wetland habitats.

The western pond turtle is a Federal species of concern. It is absent from much of its former range in the Willamette Valley (Holland, 1991; Marshall and others, 1996; Bury and Holland, in press), and where present, there is often little evidence of reproduction. It inhabits ponds, sloughs, marshes, and slow-moving sections of rivers where basking sites (logs, exposed tree roots or rocks, vegetation mats) are present (Nussbaum and others, 1983). Because of the length of time to reach maturity (8-11 years), depleted populations rebound slowly. Factors likely contributing to declines include degradation and loss of habitat, predation by introduced species such as bullfrog and largemouth bass, drought, and diseases (Marshall and others, 1996; Bury and Holland, in press). The most comprehensive and current information on the status and ecology of the western pond turtle in the Willamette Basin is provided in Holland (1994). Research has been conducted on the potential effects of improvements to the Beltline Highway in Eugene on western pond turtles (Fishman Environmental Services, 1994; $\mathrm{CH}_{2} \mathrm{M}$ Hill, 1994; Beak Consultants, Inc., 1994); and inventory, trapping, and movements of northwestern pond turtles at Fern Ridge Lake (Beal and Thaut, 1994).

Two semiaquatic bird species occurring in the Willamette Basin are federally listed as threatenedthe bald eagle and the Aleutian Canada goose (Branta canadensis leucopareia) — and one species, the harlequin duck (Histrionicus histrionicus), is a Federal species of concern (table 5). Two other species, bufflehead (Bucephala albeola) and Barrow's goldeneye (Bucephala islandica), are listed as sensitive by the ODFW.

The harlequin duck is a Federal species of concern that nests along whitewater mountain streams of the Cascade Mountains and winters along the coast (Marshall and others, 1996). There is limited historical information on the species (Latta, 1992), but the distribution and abundance has likely always been relatively low based on the limited available habitat. Latta (1992) compiled historical and recent sightings in the Cascade Mountains, and Thompson and others (1993) reported on abundance, distribution, and habitat associations.

Recent breeding has been confirmed at a few locations on the Mt. Hood National Forest (Marshall and others, 1996), and along the Molalla, Santiam, and McKenzie Rivers (Thompson and others, 1993; Marshall and others, 1996). A graduate student project initiated in 1994 is examining productivity and breeding season habitat use in the Cascade Mountains (Howard Bruner, Oregon State University, oral commun., 1995).

The only special status semiaquatic mammal occurring in the Willamette Basin is the Steller sea lion. It occurs in small numbers in the Willamette River, particularly below Willamette Falls, where it is attracted to runs of spring chinook salmon and winter steelhead trout.

\section{IMPACTS ON AQUATIC COMMUNITIES}

Since European settlement of the Willamette Basin in the early 1800s, environmental changes have resulted in substantial changes to the aquatic commu- 
nities of the basin. In general, as aquatic habitats disappeared or were degraded, aquatic biota dependent upon them declined or were extirpated, and there has been a general trend in reduction of biotic diversity (Holland, 1994).

Several recent aquatic ecosystem assessments describe the condition of aquatic communities in the Willamette Basin. The FEMAT (1993) report indicated that 95 percent of the streams surveyed in Oregon in 1988 were moderately to severely impaired. The ODEQ (1992) reported that only 4 percent of the 14,113 acres of lakes, and 32 percent of the 4,714 miles of streams and rivers surveyed in the Willamette Basin were listed as fully supporting potential beneficial uses. Recent work as part of the WRBWQS indicated that the Willamette River is "slightly to moderately impaired" compared to upstream locations on the basis of fish and invertebrate community composition (Tetra Tech, Inc., 1993b). The USFS (1993) compared current aquatic ecosystem conditions with the range of natural conditions for five rivers in the Willamette Basin (Clackamas, North Santiam, South Santiam, McKenzie, and Middle Fork Willamette) using two primary indicators, maximum water temperature and frequency of large pool habitat. They reported that most streams exhibit significant signs of degraded conditions, including being below the range of natural variability in pools per mile, and exceeding the natural range of maximum summer water temperatures.

Aquatic communities in the Willamette Basin are impacted by numerous natural (floods, fires, landslides, beaver activity) and human-related factors. The effects of these impacts are variable and must be assessed within the substantial spatial environmental variability (soils, slope, climate, vegetation) that exists within the basin. Multiple impacts can be cumulative, and many of the impacts also have secondary impacts, such as dams and introduced fish, and dams and fish disease. Additionally, the response of an individual organism to impacts that alter water quality and (or) the physical habitat in which it exists may be lethal or sublethal, such as effects on behavior, physiology, physical development, or reproduction. Thus, assessment of impacts on aquatic resources is complex and a determination of cause and effect can be difficult. In general, the cumulative effect of the many physical changes has been to simplify biological communities and increase the dominance of species most tolerant of altered conditions.
Although some sources of impact on aquatic communities are the result of naturally occurring events, the principal impacts in the Willamette Basin have resulted from human activities. Historically, one of the most extensive changes in aquatic/riparian habitat within the Willamette Valley occurred as a result of channelization and constrainment of the main stem Willamette River (Sedell and Froggatt, 1984). These changes were greatest in the southern half of the river, which historically was a braided system of numerous oxbows, sloughs, ponds, and small side-channels and a broad floodplain with extensive marshlands and riparian gallery forests. Two other human impacts on aquatic communities were massive clearing of riparian forests and draining and filling of wetland habitats. Extensive discussion on the impact of humans in these habitats within the Willamette Basin is presented in Holland (1994).

Impacts on aquatic communities also occur when land-use activities greatly accelerate natural processes of sedimentation and erosion, and when artificial elements, such as toxic chemicals or channelization, are introduced or alter the stream (Bottom and others, 1985). Several land use activities, such as irrigation, power generation, and municipal and industrial uses, also require water withdrawals, which have contributed to decreased streamflows and increased water temperatures in tributaries and upper reaches of the main stem Willamette River. Historically, municipal and industrial point source discharges were the principal impacts on water quality (Gleeson, 1972). Recently, most concern regarding water quality has focused on nonpoint source pollution caused by landuse activities such as agriculture, urbanization, logging, and road construction. A summary of land-use activities in the Willamette Basin, and their contributions as nonpoint sources of pollution, is provided in Tetra Tech, Inc., (1992c).

During the last 150 years, a variety of human impacts have seriously reduced the capacity of rivers and streams in the Pacific Northwest, including in the Willamette Basin, to support anadromous salmonids (Huntington and others, 1994). Responses of salmonid populations to these perturbations, particularly timber harvesting, have been investigated extensively (Hicks and others, 1991; Meehan, 1991). Bottom and others (1985) provides an overview of the impact of land-use practices on salmonid habitat and production in Oregon, and techniques to reduce these impacts. Hall and Baker (1982) also describe impacts on salmonid habi- 
tat, and review methods to rehabilitate and enhance stream habitat.

Declining anadromous fish stocks in the Willamette Basin and elsewhere in the Pacific Northwest have been attributed to numerous factors, including loss and degradation of freshwater and riparian habitats; poor management and hatchery practices; introduction of nonnative fish species; construction and operation of dams and their affects on habitat, water flows, temperature, predation, mortality, and passage; and management of land uses, such as timber harvesting, grazing, and agriculture. Overfishing late in the 19 th century also contributed to declines in anadromous fish runs (Willamette Basin Task Force, 1969), particularly for summer run chinook salmon ( $\mathrm{Li}$ and others, 1987). Unlike resident fishes, anadromous salmonids are also subject to stresses encountered outside of the Willamette Basin, which have likely contributed to their declines (Lawson, 1993).

Impacts on anadromous salmonid populations in the Pacific Northwest have been estimated by several investigators. Approximately 16 million wild salmon and steelhead were produced annually in the Columbia Basin (including the Willamette Basin) 120 years ago (Wevers, 1994). This compares to the approximately 2 million produced today, about 80 percent of which are hatchery fish. The Northwest Power Planning Council (1986) further estimated that salmonid production in the Columbia Basin has declined 75-85 percent since settlement of the region by Europeans, with a reduction in wild fish production of about 95 percent. Similar reports of drastic declines have been reported for the Puget Sound (Bledsoe and others, 1989), Oregon coastal streams (Nickelson and others, 1992), California (Moyle, 1994), and northern California (Higgins and others, 1992).

The assessment of impacts on aquatic biota, particularly land-use impacts, can be complicated by natural variation in populations. Hall and Knight (1981) reported that year-to-year natural variation in salmonid population densities can be up to several orders of magnitude. House (1995) reported a substantial fluctuation (as much as two-fold between years) in populations of cutthroat trout populations over an 11-year period in the Pudding/Molalla subbasin, despite similar habitat conditions from year to year and an absence of management activities. He suggests caution regarding the development of conclusions on the effect of management activities based on short-term data collection. In addition, wide natural fluctuations in populations can mask declines, and the increase in releases of hatchery fish complicates assessment of population status and trends of native stocks. Global and regional weather patterns, such as El Niño, can also significantly affect fish populations (Nickelson and Lichatowich, 1983; Mysak, 1986), particularly anadromous fish species, thus emphasizing the need to assess impacts in the context of long-term trends.

\section{SOURCES OF IMPACTS ON AQUATIC COMMUNITIES}

\section{Natural Effects}

Some natural features within the Willamette Basin impact aquatic biota in regular and predictable ways. Willamette Falls at Oregon City on the main stem Willamette River served as a complete barrier to upstream migration of salmonids during the low flows of summer and fall, and a partial barrier at other times of the year, prior to improvements in fish ladders in the late 19th century (Holmes and Bell, 1960; Hutchison and Aney, 1964; Willamette Basin Task Force, 1969; Clady, 1971; Frazier, 1989). The first crude fish ladder to aid in the passage of salmonids at Willamette Falls was constructed from rock in 1885 (Holmes and Bell, 1960; Sams, 1977). It was followed by a more effective fish ladder in the mid-1890s and by others over the next 60 years as engineering and technological advancements occurred (Holmes and Bell, 1960; Oregon Department of Fish and Wildlife, 1982b). Holmes and Bell (1960) provide a history of the use of the falls to generate power and of the development and construction of fishways. Completion of the present fishway in 1971 has not only enhanced existing salmonid runs, but has allowed for the development of new summer and fall runs, including fall chinook salmon, coho salmon, and summer steelhead (U.S. Army Corps of Engineers, 1982).

Since 1946, the ODFW has reported annually on counts of fish passing through the fishway at Willamette Falls (Pulford, 1955; Holmes and Bell, 1960; Collins, 1968; Bennett, 1982; Frazier, 1989). Annual reports on counts of spring chinook salmon runs below Willamette Falls have also continued since 1946 (Bennett, 1985, 1995). A summary of the annual passage of spring chinook salmon, fall chinook salmon, coho salmon, sockeye salmon (Oncorhynchus nerka nerka), winter steelhead trout, and summer steelhead trout at 
Willamette Falls from 1946-1981 is presented in USACE (1982).

Several studies have been conducted in the basin on the effects of natural disturbances on aquatic biota. The effects on biota from a catastrophic natural debris torrent caused by severe flooding in a Cascade Mountain stream near the HJAEF (Quartz Creek) were the complete, but relatively short-term, decimation of faunal populations (Lamberti and others, 1991; Anderson, 1992). Anderson (1992) noted the short-term elimination of insect fauna in a 300-meter reach of the stream. However, recovery was rapid, with emergence density and taxonomic richness similar to an upstream control site within one year, although effects on community structure persisted into the second year (Lamberti and others, 1991). Populations of cutthroat trout were decimated by the disturbance, but also recovered to predisturbance densities by the following year (Lamberti and others, 1991). Habitat surveys conducted in 1965 to determine the effect of floods on fish habitat in tributaries of the Clackamas River indicated that the greatest damage was loss of salmonid rearing habitat (Sams, 1965). Insect drift from fall floods in Oak Creek displaced large numbers of individuals, but overall biomass increased due to fall hatching and colonization from upstream areas (Anderson and Lehmkuhl, 1968; Lehmkuhl, 1969). They also noted that the disruption and temporary loss of habitat and allochthonous food may be more detrimental to aquatic insect populations than direct mortality caused by the floods.

When nutrient levels are excessive, nuisance algal blooms may develop in streams, ponds, lakes, and slackwater habitats. Thick mats of algae, particularly filamentous forms, can develop and adversely affect aquatic fauna by depleting oxygen in the water column (Johnson and others, 1985).

Beaver removal of trees along stream courses has various affects on aquatic communities and biota. Beaver dams modify stream hydrology, accumulate sediment, and increase wetted surface area. They are also important in creating habitat for coho salmon (Everest and Sedell, 1983), and the flooded areas create wetland habitat for many species of wildlife. Tree felling by beavers has a positive impact on pond turtle habitat by increasing the suitability of a given area for basking and providing tree trunks in the water for turtle basking, foraging, and refuge sites (Holland, 1994).

Steller sea lions prey upon migrating salmonids in the lower Willamette River, particularly below Willamette Falls. The ODFW is exploring nonlethal alter- natives to control their impact on declining populations of spring chinook salmon and winter steelhead trout, including blocking access to the fish ladder, hazing techniques, and capture and removal.

\section{Overharvest}

The salmon fisheries of the Pacific Northwest have been heavily exploited since early settling of the area, including intensive fishing by native Americans at natural barriers (McKernan and others, 1950). A deleterious affect of overfishing for summer run chinook salmon throughout the Columbia Basin (includes the Willamette Basin) was documented in the late 1800s, even prior to commercial fishing ( $\mathrm{Li}$ and others, 1987). An ecological impact from overharvest of anadromous salmonids is a substantial reduction in primary productivity in natal streams resulting from a reduction in the nutrients otherwise provided by carcass decomposition ( $\mathrm{Li}$ and others, 1987). This decrease in primary productivity likely transfers to secondary and tertiary production.

Populations of other aquatic fauna in the basin have also been reduced from overharvest. Aquatic furbearer populations have been substantially reduced, initially due to overharvest. In fact, extensive trapping of beaver was probably the first form of nonnative human exploitation of aquatic resources in the basin, and was the initial reason for settlement of the area (Holland, 1994).

\section{Channelization and Bank Stabilization}

Extensive channelization of the Willamette River since the late 1800s has reduced a historic river of meandering, braided channels with numerous sloughs and backwater areas and a broad floodplain (average width 1-2 miles wide) to essentially a single channel (Hjort and others, 1984; Sedell and Froggatt, 1984; Li and others, 1987). This channelization was partially done by closing off side channels with felled cottonwoods (Populus spp.) from the riparian zone. Channelization of the Willamette River was essentially complete by 1946 , and it is estimated that 75 percent of the original shoreline has been lost to channelization (Sedell and Froggatt, 1984). The reasons for channelization were to facilitate river navigation, reduce land erosion, and increase land available for farming (Sedell and Froggatt, 1984; Pearsons, 1989). 
The extensive channelization of the main stem Willamette River has resulted in a much simplified ecosystem and the loss of much of the original fish habitat. There has been a reduction in the number of side channels and off-channel refugia conducive for salmon and trout spawning and juvenile rearing. In 1854, the 15.6 mile distance between Harrisburg and the McKenzie River had over 156 miles of shoreline, but today there is less than 40 miles (Sedell and Froggatt, 1984). Dredging and channelization have also resulted in reduced organic material (leaf litterfall, downed trees) inputs (Sedell and Froggatt, 1984), increased water turbidity and bottom siltation, and removal of valuable spawning gravel (Willamette Basin Task Force, 1969).

Bank stabilization projects on the Willamette River and portions of most of the major tributaries were implemented to stabilize stream channels for navigation and flood control. Several types of bank stabilization techniques and materials have been tried since the first revetment on the Willamette River in 1888 (Thornber, 1965), although stone (rip-rap) has been the most extensively used revetment type. Well over 100 miles of stone revetments have been constructed in the Willamette Basin (Forbes and others, 1976), and 11 percent of the Willamette River shoreline is riprapped (Hughes and Gammon, 1987). Most construction of revetments within the basin has been conducted by the USACE since the 1930s as part of the Willamette River Basin Bank Protection Project (U.S. Army Corps of Engineers, 1975).

Stone revetments impact aquatic resources through changes in the physical environment of shoreline substrate, shoreline gradient, and water velocity (Hjort and others, 1984). The principal change in shoreline substrate is the reduction in riparian vegetation and large woody debris (Hjort and others, 1984; Bottom and others, 1985). Revetment construction also results in the loss of secondary side channels, backwater areas, and oxbows, which are important habitat for juvenile anadromous salmonids and the Oregon chub, a Federally endangered species ( $\mathrm{Li}$ and others, 1987). Specific impacts from revetments have been the focus of several studies at PSU (Forbes and others, 1976), including investigations on birds (Perry, 1978) and mammals (Willis, 1981).

Fish assemblages at stone revetments on the Willamette River below Salem were characterized by lower species richness and diversity than at natural banks, but higher densities of smaller fish (Hjort and others, 1984). Five species positively associated with revetments were prickly sculpin, redside shiner, northern squawfish, largescale sucker, and chiselmouth (Hjort and others, 1984; Li and others, 1984). Fish species associated positively with revetments are likely attracted by the high densities of invertebrate prey living in the interstices (Li and others, 1984). Higher densities of macroinvertebrates were found at revetments than at natural banks, particularly species adapted to exploit interstitial spaces between rocks as habitat or to cling to rock surfaces in fast water ( $\mathrm{Li}$ and others, 1984). The stability of the bank and moderate water currents also likely reduce susceptibility of displacement and thus benefit macroinvertebrates at the revetments.

\section{Dams and Impoundments}

Although dams have been constructed in the basin since the mid 1800s, extensive Federal government flood-control efforts began in the 1930s, particularly on the main stem Willamette River (Sedell and Froggatt, 1984). Most of the dams were constructed by the USACE between 1941 and 1968 (U.S. Army Corps of Engineers, 1982). Twenty-five major dams currently operate in the Willamette Basin (Oregon Water Resources Department, 1992). Eleven are single purpose hydroelectric projects operated by public and private utilities, one is a multipurpose project managed by the Tualatin Valley Irrigation District for the BLM, and 13 are multipurpose reservoirs operated by the USACE. The year completed, storage capacity, and subbasin for the 13 USACE dams/impoundments are presented in table 1; locations are given in figure 3.

The principal reason for construction of USACE dams was flood control (U.S. Army Corps of Engineers, 1991a). Dams and reservoirs are also operated for power generation, recreation, irrigation, public water supply, navigation, pollution abatement, and anadromous fish propagation. Summer water flows in the Willamette River are controlled primarily by releases from impoundments on the major tributaries. This results in higher summer flows and lower water temperatures than those occurring prior to construction of dams (Hines and others, 1977). When combined with passage improvements at Willamette Falls and hatchery inputs, this improved water quality has resulted in the establishment of anadromous runs of summer steelhead trout, coho salmon, fall chinook 
salmon, and sockeye salmon above Willamette Falls, which historically did not support these runs.

The construction of dams has affected aquatic resources, particularly fish, upstream and downstream of the dam in both beneficial and harmful ways. Favorable effects include control of floods, which has reduced siltation, and augmentation of historic low flows in the summer with cooler water (Willamette Basin Task Force, 1969; U.S. Army Corps of Engineers, 1982). Additionally, impoundments have increased recreational fishing opportunities by providing lake or reservoir habitat for some species of fish that otherwise would not be present in these areas.

The principal negative impact of dams is the inundation of spawning areas and physical blockage of migration to upstream spawning areas ( $\mathrm{Li}$ and others, 1987). Approximately 400 miles of previously important spawning and rearing habitat for salmon are no longer accessible (Foster, 1991). Other negative impacts include increased water temperature fluctuations and extremes, reduction of production and rearing habitat for some species of fish, alteration of natural hydrologic functions of seasonal flooding and recruitment of spawning gravel, and mortality in turbines at the dams (Buchanan and Wade, 1982; Bottom and others, 1985). Dams have also created conditions that may exacerbate disease problems, and the impoundments favor warm water introduced fishes that have proliferated, often at the expense of native fish ( $\mathrm{Li}$ and others, 1987). Buchanan and others (1981) suggests that northern squawfish may concentrate at dams to feed on migrating juvenile salmonids.

Dams and the impoundments associated with them basically change a riverine ecosystem into a lake ecosystem. In general, dams in the Willamette Basin have impounded fast-moving, cold water rivers that were favorable to cold water fish into slow moving, warm water lakes that are favorable to warm water fish. Impoundments are favorable habitats for pond or lake species, such as most Centrarchidae-sunfish, crappie, and bass; some Ictaluridae-catfish and bullheads; and some Percidae - perch. Small impoundments tend to mimic natural riverine pool habitat; thus, they may act to increase the extent of pool-type habitat and increase the abundance and distribution of species associated with this habitat.

Numerous investigations have been conducted to evaluate the effects of dams (proposed or operating) in the Willamette Basin on aquatic habitat and biota, particularly fish. A description of these studies is beyond the scope of this section, but a list of reports addressing the effects of the major dams and impoundments is presented in appendix D. In addition to the major dams and impoundments, numerous small dams and impoundments are present on tributaries of the major rivers within the basin. However, only a few investigators have examined their effect on fish resources. Korn and others (1967) reported on the effect of a small dam (North Fork) on the Clackamas River on the behavior of juvenile anadromous salmonids. They reported that movement of juvenile salmonids within the impoundment was correlated with floods and high flows in the winter and water temperatures in the spring. Li and others (1983) assessed the impact of small dams on the distribution of resident fishes in the Calapooia River. They suggest that dams located on the upstream reaches of the river may have less negative impacts on fish distribution because there are fewer species of fish and fewer migrating fishes, especially salmonids.

Anadromous fish have been most seriously affected by passage problems at dams on tributaries of the Willamette River. Fish passage has been a major problem at Foster and Green Peter Dams on the South Santiam River; Leaburg Dam and the Leaburg and Walterville diversions on the McKenzie River; and Fall Creek Dam on Fall Creek, a tributary of the Middle Fork Willamette River (Howell, 1986; Oregon Department of Fish and Wildlife, 1988).

Artificial spawning channels and fishways have been constructed to mitigate the effects of blocked passage of anadromous salmonids to natural spawning grounds. Both methods have only been partially successful. Spawning channels were popular in the 1950s and 1960s, but most were not successful in adequately replacing production lost by blockage of passage to natural spawning grounds (Smith, 1993). Fishways are structures that allow passage of anadromous fish over natural and human-made obstructions to natural spawning areas and hatcheries. However, some migrating fish continue to have difficulties passing dams with fish passage facilities (Howell, 1986).

In addition to passage problems, installation of turbines for power generation has created a situation for potential injuries and mortalities. Sources of mortality include physical injuries and changes in water pressure from the bottom of the reservoirs to the receiving waters. Mortality of salmon and steelhead smolts has been identified as the most serious problem at Willamette Falls turbines (Oregon Department of Fish and 
Wildlife, 1980). In response to this problem, several studies have been conducted to assess mortalities and other injuries to downstream salmonid migrants at turbine installations near Willamette Falls (Oregon State Game Commission, 1960; 1961; Willis and others, 1960; Lichatowich, 1981; Williams, 1981). During 14 days of observation in the spring of 1981, 23 percent of the 5,202 steelhead trout examined were found to have sustained some bypass injury (Lichatowich, 1981). This is similar to the results of Williams (1981), who reported that 24 percent of steelhead trout examined sustained an abnormal amount of injury.

Mortality investigations at other fish passage facilities in the basin include those at North Fork Dam on the Clackamas River (Gunsolus and Eicher, 1970), Fall Creek Dam on Big Fall Creek (Smith and Korn, 1970), Cougar Dam on the South Fork of the McKenzie River (Ingram and Korn, 1969), Foster and Green Peter Dams on the South Santiam River (Wagner and Ingram, 1973), and Leaburg Dam on the McKenzie River (EA Engineering, Science and Technology, Inc., 1990b).

Dams and impoundments in the Willamette Basin have also been documented to adversely affect fish behavior and reproductive capacity. The presence of dams can delay migration of adult salmon and steelhead trout, particularly during the high flows of spring, when chinook salmon are reluctant to use fishways or have difficulty finding the entrance (Howell, 1986). Homolka and Downey (1995) also reported on the delay of migration for spring chinook salmon of the upper McKenzie River, apparently due to water temperature modifications caused by dams. The alteration of river flows below dams from drawdowns may negatively affect salmonid spawning habitat by exposing redds (Herb, 1972). Additionally, drawdowns have been reported to strand some fish (Herb, 1972).

\section{Fish Hatcheries}

Most fish hatcheries were built to mitigate for the loss of natural production of salmon due to habitat loss and degradation from construction of dams. Hatcheries were also constructed to increase adult returns to other stream areas where natural runs once thrived (Bennett, 1985). The first hatchery in the Willamette Basin was constructed on the Clackamas River in 1877 (Willamette Basin Task Force, 1969), and by 1900 all of the hatcheries in the Willamette Basin were under
Federal control (Oregon Department of Fish and Wildlife, 1982c). The location of fish hatcheries and holding/rearing ponds in the basin is shown in figure 3 , and information on species reared is included as part of table 8 . The only one of the 13 hatcheries/ponds in the basin not operated by the ODFW is Eagle Creek Fish Hatchery on the Clackamas River (operated by USFWS).

Protection and enhancement of wild fish stocks is given the highest priority in management of fish populations (Oregon Administrative Rule 635-07525) (Bottom and others, 1985). Hatchery stocks are released where necessary to provide optimum benefits from the resource. Hatchery production and releases are relied upon to compensate for the loss of wild production, to provide additional fish to the fisheries, and to sustain production of introduced stocks of coho salmon and summer steelhead (Howell, 1986). Successes of hatchery programs in meeting these objectives is tempered by their high cost; problems in maintaining genetic diversity; and potential adverse affects on wild stocks, including disease transmission, competition, and interbreeding. Most of the recent production in runs of salmon and steelhead trout in the Willamette Basin has been from hatchery stocks, except for native winter steelhead trout (Howell, 1986).

A series of Oregon Fish Commission reports in the 1960s described and evaluated the operation and production of several salmon hatcheries in the Willamette Basin. These include Marion Forks (Wallis, 1963; DeCew, 1969), McKenzie (Wallis, 1961a), South Santiam (Wallis, 1961b), Sandy (Wallis, 1962a), and Willamette (Wallis, 1962b).

A history of the stocking of hatchery fish within the basin is provided in subbasin fish management plans and anadromous fish production plans for each subbasin, along with others, such as Willis and others (1960), Oregon State Game Commission (1963), Hutchison and Aney (1964), Hutchison and others (1966a), Koski (1971), and Collins (1974). The focus of these programs has been biological, such as migration studies, stock hardiness, and restoration of natural runs; and recreational, such as increased angling opportunities and development of new fisheries for anglers. The methods and results of these efforts have been documented in numerous ODFW reports, such as those on spring chinook salmon in the Willamette River (Smith, 1977, 1979), spawning, hatching, and rearing success of transplanted coho salmon (Pearson 
Table 8. Fish hatcheries and holding/rearing ponds in the Willamette Basin, Oregon

[Sources: Oregon Department of Fish and Wildlife (1994); K. Bourne (Oregon Department of Fish and Wildlife, oral commun., 1995); A.G. Demaris (Oregon Department of Fish and Wildlife, oral commun., 1995); A. Smith (Oregon Department of Fish and Wildlife, oral commun., 1995); B. Zimmerman (Oregon Department of Fish and Wildlife, oral commun., 1995). Fish species: cc, channel catfish; chf, fall chinook; chs, spring chinook; co, coho salmon; ct, cutthroat trout; hb, hybrid bass; lb, largemouth bass; rt, rainbow trout; sb, smallmouth bass; sf, sunfish; sts, summer steelhead; stw, winter steelhead]

\begin{tabular}{lllll}
\hline \multicolumn{1}{c}{ Hatchery } & \multicolumn{1}{c}{ Stream Name } & \multicolumn{1}{c}{ Location } & \multicolumn{1}{c}{ Fish Species } & \multicolumn{1}{c}{ Subbasin } \\
\hline Eagle Creek ${ }^{1}$ & Eagle Creek & Estacada & co,stw & Clackamas \\
Sandy & Cedar Creek & Sandy & co & Sandy \\
Clackamas & Clackamas River & McIver State Park & chs,stw & Clackamas \\
St. Paul Ponds & Mission Creek & St. Paul & cc,hb,lb,sb,sf & Pudding \\
Stayton Ponds & North Santiam River & Stayton & chf & Santiam \\
Marion Forks & Marion Creek & Idanha & chs,ct,stw & Santiam \\
Roaring River & Roaring River & Scio & rt,sts & Santiam \\
South Santiam & South Santiam River & Sweet Home & chs,sts & Santiam \\
McKenzie & McKenzie River & Leaburg & chs,sts & McKenzie \\
Leaburg & McKenzie River & Leaburg & ct,rt,sts & McKenzie \\
Dexter Pond & Middle Fork Willamette River & Lowell & chs,sts & Middle Fork \\
Willamette & Salmon Creek & Oakridge & chs,stw,rt & Middle Fork \\
\hline
\end{tabular}

${ }^{1}$ Federal hatchery; all others are State hatcheries.

and others, 1967), releases of coho salmon in the Willamette River above Willamette Falls from 1952-1982 (Williams, 1983), and rainbow trout (Moring, 1976). The magnitude of hatchery releases in the Willamette Basin is exemplified by the numbers for 1988 , which included 5.1 million fall (subyearling) chinook salmon, 1.1 million coho salmon, 700,000 summer steelhead trout, and 400,000 winter steelhead trout (Knutsen and Ward, 1991).

A cooperative program between the NMFS and ODFW was initiated in 1971 to develop natural runs of fall chinook and coho salmon, and winter and summer steelhead trout above Willamette Falls, historically a barrier to these fish prior to development of a fishway. The rationale and methods of the program are described in Sams (1973). Results of the program have been reported annually (Hansen, 1977; Hansen and Williams, 1979; Buchanan and Wade, 1982; Wade and Buchanan, 1983).

Hatchery fish may lower the fitness of native populations through interbreeding, competition, and social stress, and through population reductions due to increased angler effort and catch associated with stock- ing programs (Nicholas and others, 1978). Hatchery salmonids may also usurp the territories of resident individuals and force them into less suitable habitat (Stein and others, 1972). Nicholas and others (1978) review the consequences of interbreeding and discuss four approaches to minimize the negative affects of interbreeding.

Hatchery fish are genetically and behaviorally distinct from their native progenitors (Nicholas and others, 1978; Li and others, 1987). Survival in the wild is lower for hatchery fish than wild fish (Reisenbichler and McIntyre, 1977; Chilcote and others, 1984; Nickelson and others, 1986). Moring (1982) evaluated three hatchery strains of rainbow trout used in stocking programs in the basin, and concluded that the Cape Cod variety yielded significantly better results in terms of higher returns to the angler at a lower cost to the State.

Another potential impact of fish hatcheries is the effect of hatchery effluent on water quality and biota in receiving waters. Discharged water from hatcheries may increase water temperature, $\mathrm{pH}$, chemical oxygen demand, and concentrations of nutrients, ammonia, and suspended solids (Kendra, 1991). Additionally, 
chemicals used to treat diseases and parasites which are discharged into receiving water may be harmful to aquatic biota. Kendra (1991) also reported that macroinvertebrate communities may respond to the organically enriched receiving waters by replacing sensitive taxa with more tolerant forms.

\section{Pollution}

Aquatic resources in the Willamette Basin are affected by point-source pollution (resulting from a discharge at a specific location) and nonpoint-source pollution (resulting from diffuse runoff associated with land use activities). Historical pollution problems in the Willamette River were primarily due to pointsource pollution from municipal and industrial point source discharges (Merryfield and Wilmot, 1945; Gleeson, 1972). Current point sources include industrial, municipal, domestic, and agricultural discharge types. Tetra Tech, Inc., (1992d) lists 320 minor and 33 major National Pollutant Discharge Elimination System permittees that discharge pollutants from point sources into waters of the Willamette Basin. Approximately one-third of the minor permittees and two-thirds of the major permittees discharge into the main stem Willamette River. Thus, most concern regarding the effects of point-source pollution on aquatic biota is within the valley floor, including the Willamette River and the lower reaches of its tributaries.

Most current pollution problems in the Willamette Basin are from nonpoint sources (Tetra Tech, Inc., 1995a). These sources include areas having a variety of land-use activities, such as urban development, forest practices, and agriculture. On the basis of results of the nonpoint-source model developed for the Willamette River as part of the WRBWQS, agricultural land is considered to be the largest source of nonpointsource pollution (Tetra Tech, Inc., 1995a). Tetra Tech, Inc., reported that most of the nonpoint-source pollution to the Willamette River is from the Pudding, Tualatin, Yamhill, and Long Tom subbasins.

The Willamette River has changed during the past 40 years from a river characterized as a conveyor of industrial and municipal sewage to a recreational and environmental asset. During the early to mid1900s, the Willamette River, particularly near Portland, was "...in about as unsatisfactory a condition as a river could be..." (Gleeson, 1972). Studies documenting pollution levels in the Willamette River were made as early as 1927 (U.S. Army Corps of Engineers, 1982), and numerous reports during this period documented the water quality of the river, including Langton and Rodgers (1929), Rodgers and others (1930), Gleeson (1936), Gleeson and Merryfield (1936), Craig and Townsend (1946), Fish and Rucker (1948), McKernan and Mattson (1950), Willis and others (1960), and Oregon State Game Commission (1963).

The most extensive documentation of the degree of pollution, particularly as it related to oxygen depletion and fish resources, was based on the work of Merryfield and Wilmot (1944) and Dimick and Merryfield (1945). They reported that the river contained high loadings of organic wastes, dense beds of algae, and floating and benthic sludge, which produced critically low dissolved oxygen concentrations that limited salmon migration. In some instances, the pollutant levels were lethal to local fish populations, including those of trout and salmon (Dimick and Merryfield, 1945; U.S. Army Corps of Engineers, 1982). Principal sources of pollution being discharged directly into the river were untreated sewage from municipalities and residences, and industrial wastes from canneries and paper product mills (Oregon State Game Commission, 1963; Hutchison and Aney, 1964). The discharge of sulphite pulp liquor from paper product mills was considered to be the most serious source of pollution affecting fishery resources because of its toxic effects (McKernan and Mattson, 1950; U.S. Army Corps of Engineers, 1982). In addition to the Willamette River, the lower portions of several tributaries, including Rickreall Creek and the Calapooia, Pudding, Tualatin, Yamhill, North and South Santiam, and Long Tom Rivers, also had high levels of pollution (Dimick and Merryfield, 1945; U.S. Army Corps of Engineers, 1982).

Gleeson (1972) provides an extensive discussion of the history of efforts to improve the water quality in the Willamette River, and their successes, from the late 1920 s through the 1960s. Since the 1950s, water-quality improvement throughout the river has been documented, particularly in Portland Harbor. This improvement resulted from extensive efforts in sewage treatment, chemical recovery processes by industries, and increased low-flow augmentation (Gleeson, 1972; Huff and Klingeman; 1976; Hines and others, 1977). In 1972, the Willamette River became the largest river in the United States to have all known wastewater point sources under secondary treatment (Rinella and others, 1981). 
The historic pollution load from domestic and industrial wastes discharged into the Willamette River was the most important factor contributing to the depletion of former great runs of anadromous fish (Fish and Rucker, 1948; Parkhurst and others, 1950; Oregon State Game Commission, 1963). In addition to the inherent toxic effects, the biochemical oxygen demand resulted in the lower reaches of the river being nearly devoid of oxygen. The dissolved oxygen requirements for salmonids in the lower Willamette River have been discussed by Sams and Conover (1969) and Alabaster (1988).

Several studies in the 1940-50s were conducted to ascertain the pollution status of the Willamette River and major tributaries by means of biological indicators. Noble (1952) assessed the sensitivity of fish to polluted habitat and reported that trout, salmon, whitefish, and sculpin were least tolerant of polluted conditions. Deschamps (1952) used the presence of benthic macroinvertebrates, along with certain physical and chemical conditions, as indicators of pollution at sites on the Willamette, McKenzie, South Fork Santiam, and Clackamas Rivers. Stoneflies, mayflies, and caddisflies were identified as least tolerant of pollution (Deschamps, 1952). Ziebell (1954) focused on invertebrate and fish communities at two sites on the South Fork Santiam River, and included the Order Odonata to the above list of least tolerant macroinvertebrates.

Some recent examinations of point-source pollution have been directed at specific effluent locations. Species richness and diversity of macroinvertebrates were similar, but the total number of individuals was significantly lower below the discharge of biologically treated effluent at a pulp and paper mill on the Willamette River near Halsey (HMS Environmental, Inc., and Miller, 1988). Species composition of periphyton was the same, but abundance and depth distribution were different below the effluent discharge. Hughes and Gammon (1987) found that point sources of pollution affected fish assemblages less than the gradual changes in water quality from the headwaters to the mouth of the river.

\section{Land Use}

Diverse land uses, particularly agriculture, forest management, and urbanization, have substantially affected aquatic resources in the Willamette Basin. These land uses impact stream habitat quality by reducing instream and riparian vegetation diversity and complexity, bank and channel structure and stability, the quality and quantity of spawning gravel, stream discharge and quality, and by exaggerating the natural processes of erosion and sedimentation (Bottom and others, 1985).

\section{Agriculture}

As more land in the basin has been brought into intensive cultivation, there has been increased demand for irrigation water. Water withdrawals are principally for agricultural purposes, but in some urban/residential areas water is withdrawn for industrial and municipal needs. The withdrawal and diversion of large volumes of surface water for irrigation has resulted in changes in flow characteristics of streams, including complete elimination of flow during the summer in some streams. Irrigation accounts for more than 90 percent of the agricultural water use in the basin (Oregon Water Resources Department, 1992). In 1987, there were 285,000 irrigated acres within the Willamette Basin compared with 27,000 acres in 1940 (Oregon Water Resources Department, 1992). These water demands have contributed to reduced flows in many streams and caused erratic water levels; conditions unlike those under which native aquatic biota evolved. Additionally, naturally occurring low flows of summer are often exacerbated by withdrawal of water for irrigation.

Chemical contamination of aquatic ecosystems in the basin has resulted from runoff and leaching of chemicals resulting from farming practices, such as the use of pesticides, herbicides, and fertilizers (Anderson and others, 1996). These can cause impairments in general water quality and may be toxic to some aquatic biota. Principal types of farming in the basin that use chemicals are crop production (grass seed, nuts, fruits), nurseries (ornamental shrubs and trees), and animal production (dairy and beef cattle, poultry).

\section{Forest Management}

Historic and ongoing logging and associated road construction throughout the Willamette Basin has had a substantial impact on aquatic and riparian habitat. Logging practices can change the basic community ecology of a stream by direct and indirect effects on the physical environment, which indirectly results in changes in the aquatic biota.

Extensive timber harvest in the Willamette Basin began in the late-19th century. The industry was essen- 
tially unregulated, and this resulted in (1) harvesting in the riparian zone, which adversely affected water quality and salmonid fish habitat and (2) the accumulation of large amounts of instream debris, which blocked anadromous fish migration to spawning areas (McKernan and others, 1950; Willamette Basin Task Force, 1969; Delarm and others, 1989). Additionally, logs were transported by streams in huge rafts from upstream harvests sites to downstream mills, which resulted in blockage of streams, scoured streambeds, and ruination of spawning areas (U.S. Army Corps of Engineers, 1982).

Timber harvesting throughout watersheds and destruction of riparian cover along streams can have multiple effects, including rapid runoff and siltation due to erosion; fluctuations in stream flows, temperature, and dissolved oxygen content; loss of spawning habitat from scouring of gravel; changes in pool/riffle ratios; reduction of organic matter input from loss of trees adjacent to the stream; stimulation of primary production of algae, moss, or macrophytes as a result of increased nutrients and solar radiation reaching the stream; and destruction of food organisms. The effects of these impacts within a specific location is dependent upon numerous physical factors, including watershed geomorphology, climate, stream size and gradient, and the biotic composition of the stream (Murphy and Hall, 1981).

Much of the research in the Willamette Basin on the effects of forest management practices on aquatic ecosystems has focused on the western slope of the Cascade Mountains, particularly the HJAEF. Removal of forest canopy within the riparian corridor of small, cold water, high-gradient streams in the Cascade Mountains tends to increase stream productivity, but the increased sedimentation tends to degrade physical habitat (Murphy and others, 1981).

The increase in solar radiation reaching the stream after forest canopy removal apparently increases periphyton production and aquatic production at all trophic levels (Gregory, 1980; Hawkins and others, 1982; Hawkins, and others, 1983; Murphy and Hall, 1981; Murphy and others, 1981). Cutthroat trout populations increased in a stream flowing through a recent clear-cut compared to another section of the stream in undisturbed old-growth forest (Aho, 1976; Murphy and others, 1981; Hawkins and others, 1983; Wilzbach, 1984). Insect emergence (Grafius, 1977), annual primary production (Gregory, 1980; Murphy and Hall, 1981), and density of invertebrates (Murphy and others, 1981; Hawkins and others, 1982) were also greater in clear-cut or open sections of streams. Wilzbach (1984) reported that, in spite of reduced cover, cutthroat trout had greater foraging success and growth rates in logged sections of the stream, where invertebrate drift in these unstable habitats provided a more reliable food source. However, Wilzbach and others (1986) cautions that any beneficial advantages of trout foraging efficiency in logged stream sections must be weighed against increased risk of mortality in these same stream sections from predation and physical disturbances due to reduction of shelter.

Conversely, other authors report on the degradation of physical habitat of streams after nearby timber harvesting, particularly through increased sedimentation from canopy removal during logging (Gibbons and Salo, 1973). In streams of the HJAEF, Wustenberg (1954) and Wyatt (1959) reported reduction or elimination of populations of cutthroat trout in some smaller tributaries and declines in aquatic insect populations for at least 1 year immediately following logging adjacent to the stream. In Minto Creek of the Santiam subbasin, Frissell and others (1985) reported a 40-percent reduction in trout density in a clear-cut segment of the stream compared to an unlogged segment. They also noted that the smallest size class of fish was absent, and large individuals were uncommon in the clear-cut section of the stream. They attributed the results to differences in the diversity of habitat types, particularly pool/ riffle habitat within the forested and clear-cut sections of the stream. The differences between the results of these studies and of those mentioned in the previous paragraph indicate that the response of fish populations to logging of riparian cover may be dependent upon several site-specific geomorphic features.

\section{Urbanization}

Urbanization has affected water quality and aquatic biota particularly through domestic water use and discharge, and streamside development. Runoff and discharge of trace elements, bacteria, nutrients, and suspended solids are high in urban areas of the basin. The most extensive urbanization has occurred along the Willamette River (particularly metropolitan Portland), but urbanization has also occurred along most of the larger tributaries of the main stem Willamette, particularly the Tualatin, Clackamas, and McKenzie. In the lower Willamette River at Portland Harbor, natural shoreline and nearshore habitat have been substantially altered by the construction of wharfs, piers, boat 
repair facilities, and the presence of rip-rapped shoreline. Rip-rap and pilings serve as current deflectors and create habitat that may affect the abundance and distribution of some sport fish, but also potentially increase predation on these fish by northern squawfish, who prefer areas of low velocity (Ward and Nigro, 1991).

The effects of urban development on juvenile salmonids in the lower Willamette River at Portland Harbor, as determined during a 4-year cooperative effort between the ODFW and the Port of Portland, were reported by Ward and others (1994). They identified few risks to juvenile salmonids from development in the harbor and did not detect significant changes in behavior at waterway developments. However, Farr and Ward (1993) suggested that development along the lower Willamette River may be adversely affecting populations of white sturgeon, a game fish.

The effects of urbanization on fish populations in the lower Tualatin subbasin were reported by Friesen and Ward (1996). Sites within the urban growth boundary near Portland were characterized as moderately unhealthy based on poor habitat quality and a large number of fish affected by parasites or physical anomalies. They also reported that species intolerant to pollution and relatively warm water temperatures occurred primarily at forested sections of streams that were unaffected by urban or agricultural influences.

\section{Introduced Species}

The intentional or accidental introduction of species into aquatic systems can cause dramatic changes. Community ecology may be altered directly through predation and disease, and indirectly through increases in competitive interactions ( $\mathrm{Li}$ and Moyle, 1981). In many cases, the biological consequences of these introductions are not known and cannot be accurately predicted, but interspecific competition with native species and introductions of diseases to aquatic biota are likely (Moyle, 1986).

In aquatic systems, most intentional fish enhancements have been implemented to improve sportfishing. This technique includes stocking of introduced species and the stocking of hatchery-reared indigenous fish species to reestablish or enhance populations. Much of the stocking in the Willamette Basin has occurred in major rivers and impoundments. Stocking of sport species, such as sunfish, crappie, and bass has occurred throughout ponds and smaller impoundments in the basin.

The effect of introduced species on native biota is particularly pronounced in lowland Willamette Valley aquatic ecosystems, where warmer water temperatures are conducive to species introduced from southern ecosystems. Because of stocking of introduced species and dam-related habitat changes that favor warm water fishes, the overall pattern in the Pacific Northwest is that fish fauna assemblages often resemble those found in the Midwest ( $\mathrm{Li}$ and others, 1987).

Introduced fish tend to dominate in highly disturbed habitats. In the Tualatin subbasin, introduced fish tend to be most numerous in low gradient, highly degraded (eroding banks) reaches, and in tributaries near urban and industrial areas where large ponds or marshes are present (Friesen and others, 1994).

The observance of declines of native fish following introduction of nonnative fish is widely reported. In the Willamette Basin, nonnative piscivorous fish, such as largemouth bass and bluegill (Lepomis macrochirus), have been implicated in the decline of the Oregon chub (Markle and others, 1989; Pearsons, 1989). Large black crappie and white crappie prey on small juvenile salmonids (Grenfell, 1962; Ward and others, 1991), although the predation level is unknown and probably low (Ward and others, 1991).

Other native aquatic biota in the basin, particularly amphibians, are also subject to high rates of predation because they did not evolve in the presence of the voracious predation of some introduced species, such as pumpkinseed (Lepomis gibbosus), largemouth bass, bluegill, and bullfrogs. For example, the bullfrog has been implicated in declines of the western pond turtle (Marshall and others, 1996) and spotted frog (Nussbaum and others, 1983). Additionally, diseases from introduced red-eared slider turtles have likely contributed to declines of the western pond turtle (Marshall and others, 1996).

Common carp can cause shallow waters of ponds, lakes, and marshes to become too turbid for good production of native plants important to waterfowl (Puchy and Marshall, 1993). Attempts to eliminate common carp and other unwanted fish with chemical treatments are expensive and often not successful (Johnson and others, 1985).

Stocking or escapement of introduced fish has also likely had negative effects on macroinvertebrate populations. However, the lack of historical or prein- 
troduction data on macroinvertebrate populations often precludes documentation of these effects. Like other aquatic biota, many endemic macroinvertebrates are likely not equipped to deal with introduced fish predators. This may be particularly common in some high altitude, Cascade Mountain lakes, which were naturally without fish.

Little is known of the impact of the Asiatic clam on native mussel and clam populations, though some displacement of native fauna is probable. In some tributaries to the Willamette River, it can be found in densities greater than 600 individuals per square meter (Ian Waite, U.S. Geological Survey, unpubl. data, 1996), whereas native mussels and clams are rare at the same sites.

Eurasian watermilfoil impacts aquatic resources by reducing the diversity of fish habitat and interfering with the healthy development of fish populations (Geiger and others, 1983). It is also considered a recreational nuisance because it grows in dense masses and provides an obstacle to boaters. Only chemical control has been effective in controlling the occurrence and spread of this species.

\section{AQUATIC TOXICOLOGICAL INVESTIGATIONS}

Chemical analysis of tissues can provide information on the occurrence and extent of contaminants in aquatic ecosystems because contaminants may be more concentrated in tissue than in surrounding water or sediment. Various studies addressing contaminant impacts on aquatic biota have been conducted in the Willamette Basin (table 9). Two comprehensive investigations include the WRBWQS (Tetra Tech, Inc., 1995d) and the WRTS (ODEQ, 1994b). The WRBWQS was initiated to develop the necessary technical and regulatory understanding and information base required to protect and enhance the water quality of the Willamette Basin. The study design includes the development of predictive water quality models and an assessment of various biological indices as measures of water quality. Modeling efforts focused on several water quality parameters, including dissolved oxygen, nutrients, chlorophyll, bacteria, toxic chemicals, and suspended sediment, and have addressed both point- and nonpoint-source categories. Biological indices were used to measure various ecological attributes of benthic invertebrates and fish assemblages as an assessment or bioindicator of water quality (Tetra Tech, Inc., 1995d).
The WRTS, conducted by the ODEQ in cooperation with OSU and the USEPA, recently completed a screening survey to investigate the presence and effect of toxic pollutants in the Willamette River and selected tributaries. The stated objectives of the study were to determine if bioaccumulative toxic pollutants were present in the sediments and fish tissue and to determine the possible effects of the pollutants present on the aquatic biota using bioassays and other aquatic-life toxicity testing methods (Oregon Department of Environmental Quality, 1994b). Information on contaminants in sediment and fish was gathered for the period 1988-91. Many of the sampling sites were used in previous toxics monitoring. They represented ambient (background) levels, effects of important industrial and municipal contaminant sources, and typical urban nonpoint source impacts.

The Willamette Basin has also been included in several national contaminant studies. The National Contaminant Biomonitoring Program (NCBP) was initiated in 1967 as part of the National Pesticide Monitoring Program under the auspices of the USFWS. The NCBP was established to document temporal and geographic trends in concentrations of persistent toxic chemicals that may threaten fish and wildlife resources. Since its inception, the program has expanded from an initial focus on organochlorine insecticides to include industrial chemicals, herbicides, and potentially toxic trace elements that accumulate in fish (Schmitt, 1990). A nationwide network of stations was established, one of which was located on the main stem Willamette River at Oregon City.

The USEPA also initiated a one-time screening investigation in 1986 to determine the prevalence of selected bioaccumulative pollutants in fish and to identify correlations with sources of these pollutants (U.S. Environmental Protection Agency, 1992a). This study, known as the National Study of Chemical Residues in Fish, was an outgrowth of the USEPA's National Dioxin Study, which detected elevated concentrations of 2,3,7,8-tetrachlorodibenzo- $p$-dioxin (TCDD) in fish from major watersheds in the United States, including the Willamette Basin. Dioxins, furans, polychlorinated biphenyls (PCBs), chlorinated pesticides, and mercury were analyzed in fish from selected sites thought to be influenced by a variety of point and nonpoint sources. Sampling sites were established at four locations along the main stem Willamette River (Portland, Halsey, Newberg Pool, and Wilsonville) and two locations on the Tualatin River (Cherry Grove and Cook Park). 
Table 9. Aquatic toxicology investigations in the Willamette Basin, Oregon

[Subbasins (see fig. 5): CF, Coast Fork Willamette; LT, Long Tom; LU, Luckiamute; MC, McKenzie; MF, Middle Fork Willamette; SA, Santiam; TU, Tualatin; WR, Willamette River; --, no data; PAH, polyaromatic hydrocarbons; PCB, polychlorinated biphenyls; TCDD, tetrachlorodibenzo- $p$-dioxin; TCDF, tetrachlorodibenzofuran]

\begin{tabular}{|c|c|c|c|c|c|c|c|c|}
\hline \multirow[b]{2}{*}{ Reference } & \multirow[b]{2}{*}{$\begin{array}{l}\text { Sub- } \\
\text { basin }\end{array}$} & \multirow[b]{2}{*}{$\begin{array}{l}\text { Temporal } \\
\text { coverage }\end{array}$} & \multirow[b]{2}{*}{ Spatial coverage } & \multirow[b]{2}{*}{ Topic } & \multicolumn{4}{|c|}{ Matrix studied } \\
\hline & & & & & Fish & Fauna & Water & $\begin{array}{l}\text { Sedi- } \\
\text { ment }\end{array}$ \\
\hline Allen and Curtis (1991) & $\mathrm{CF}$ & $1989-90$ & Cottage Grove Lake & $\begin{array}{l}\text { Environmental parameters affecting } \\
\text { mercury dynamics and } \\
\text { bioaccumulation in fish }\end{array}$ & $\mathrm{X}$ & -- & $\mathrm{X}$ & $\mathrm{X}$ \\
\hline Curtis and others (1993) & WR & $\begin{array}{c}\text { July, October } \\
1990\end{array}$ & $\begin{array}{l}\text { Willamette River } \\
\text { (RM 7-195) }\end{array}$ & $\begin{array}{l}\text { Cytochrome P450-1A1 induction in } \\
\text { fish as a biomarker for TCDD and } \\
\text { TCDF; organochlorines, PAHs }\end{array}$ & $\mathrm{X}$ & -- & -- & $\mathrm{X}$ \\
\hline Curtis and Siddens (1995) & WR & Spring 1994 & Newberg Pool (RM 56) & Teratogenic qualities of whole effluent & $\mathrm{X}$ & -- & $X$ & -- \\
\hline Hart Crowser (1988) & WR & 1980 's & Portland & $\begin{array}{l}\text { Remedial action plan for sediments; } \\
\text { PCBs in crayfish and sculpin }\end{array}$ & $\mathrm{X}$ & -- & -- & $\mathrm{X}$ \\
\hline $\begin{array}{l}\text { Henderson and others } \\
\text { (1969) }\end{array}$ & WR & $1967-68$ & Willamette River & $\begin{array}{l}\text { Organochlorine insecticide residues in } \\
\text { fish }\end{array}$ & $\mathrm{X}$ & -- & -- & -- \\
\hline Henny and Bethers (1971) & WR & Spring 1970 & Albany & Great blue heron nesting study & -- & $\mathrm{X}$ & -- & -- \\
\hline Kuehl and others (1989) & $\begin{array}{l}\text { MC,SA, } \\
\text { WR }\end{array}$ & 1983 & $\begin{array}{l}\text { Coburg, Jefferson, } \\
\text { Portland, Salem, }\end{array}$ & $2,3,7,8$-TCDD contamination in fish & $\mathrm{X}$ & -- & -- & -- \\
\hline Lowe and others (1985) & WR & $1978-81$ & Oregon City & $\begin{array}{l}\text { National study on trace element } \\
\text { residues in fish }\end{array}$ & $\mathrm{X}$ & -- & -- & -- \\
\hline Markle (1994b) & WR & 1993 & Newberg Pool, Corvallis & $\begin{array}{l}\text { Fish hybridization and skeletal } \\
\text { deformities }\end{array}$ & $\mathrm{X}$ & -- & -- & -- \\
\hline May and McKinney (1981) & WR & $1976-77$ & Oregon City & $\begin{array}{l}\text { National study on trace element } \\
\text { residues in fish }\end{array}$ & $\mathrm{X}$ & -- & -- & -- \\
\hline $\begin{array}{l}\text { Oregon Department of } \\
\text { Environmental Quality } \\
(1994 b)\end{array}$ & WR & 1988-91 & Willamette River & Willamette River toxics study & $\mathrm{X}$ & -- & -- & $\mathrm{X}$ \\
\hline Pastorok and others (1994) & WR & 1990-91 & Portland, Wilsonville & $\begin{array}{l}\text { Ecological risk assessment for river } \\
\text { sediments contaminated by creosote }\end{array}$ & $\mathrm{X}$ & -- & -- & $\mathrm{X}$ \\
\hline Schmitt and others (1981) & WR & 1970-74 & Oregon City & $\begin{array}{l}\text { National study on organochlorine } \\
\text { residues in fish }\end{array}$ & $\mathrm{X}$ & -- & -- & -- \\
\hline
\end{tabular}


Table 9. Aquatic toxicology investigations in the Willamette Basin, Oregon-Continued

\begin{tabular}{|c|c|c|c|c|c|c|c|c|}
\hline \multirow[b]{2}{*}{ Reference } & \multirow[b]{2}{*}{$\begin{array}{l}\text { Sub- } \\
\text { basin }\end{array}$} & \multirow[b]{2}{*}{$\begin{array}{l}\text { Temporal } \\
\text { coverage }\end{array}$} & \multirow[b]{2}{*}{ Spatial coverage } & \multirow[b]{2}{*}{ Topic } & \multicolumn{4}{|c|}{ Matrix studied } \\
\hline & & & & & Fish & Fauna & Water & $\begin{array}{l}\text { Sedi- } \\
\text { ment }\end{array}$ \\
\hline Schmitt and others (1983) & WR & $1976-79$ & Oregon City & $\begin{array}{l}\text { National study on organochlorine } \\
\text { residues in fish }\end{array}$ & $X$ & -- & -- & -- \\
\hline Schmitt and others (1985) & WR & $1980-81$ & Oregon City & $\begin{array}{l}\text { National study on organochlorine } \\
\text { residues in fish }\end{array}$ & $X$ & -- & -- & -- \\
\hline $\begin{array}{l}\text { Schmitt and Brumbaugh } \\
\text { (1990) }\end{array}$ & WR & $1976-84$ & Oregon City & $\begin{array}{l}\text { National study on trace element } \\
\text { residues in fish }\end{array}$ & $X$ & -- & -- & -- \\
\hline Schmitt and others (1990) & WR & $1976-84$ & Oregon City & $\begin{array}{l}\text { National study on organochlorine } \\
\text { residues in fish }\end{array}$ & $X$ & -- & -- & -- \\
\hline Tetra Tech, Inc. (1993b) & SA, WR & 1992 & $\begin{array}{l}\text { Willamette River, Santiam } \\
\text { River, Conser Slough }\end{array}$ & $\begin{array}{l}\text { Fish health assessments and skeletal } \\
\text { deformities }\end{array}$ & $X$ & -- & -- & -- \\
\hline Tetra Tech, Inc. (1995d) & LU, WR & 1992-94 & $\begin{array}{l}\text { Willamette River, } \\
\text { Luckiamute River }\end{array}$ & Skeletal deformities & $X$ & -- & -- & -- \\
\hline $\begin{array}{l}\text { U.S. Army Corps of } \\
\text { Engineers (1991b) }\end{array}$ & $\begin{array}{l}\mathrm{CF}, \mathrm{MF}, \\
\quad \mathrm{LT}\end{array}$ & 1983 & $\begin{array}{l}\text { Cottage Grove, Dorena, and } \\
\text { Fern Ridge Lakes, Dexter } \\
\text { Reservoir }\end{array}$ & Potential contaminants in reservoirs & $\mathrm{X}$ & -- & $\mathrm{X}$ & $\mathrm{X}$ \\
\hline $\begin{array}{l}\text { U.S. Environmental } \\
\text { Protection Agency (1992a) }\end{array}$ & WR & 1986 & $\begin{array}{l}\text { Willamette River, Tualatin } \\
\text { River }\end{array}$ & $\begin{array}{l}\text { National study of chemical residues in } \\
\text { fish }\end{array}$ & $\mathrm{X}$ & -- & -- & -- \\
\hline $\begin{array}{l}\text { U.S. Fish and Wildlife } \\
\text { Service (1994c) }\end{array}$ & TU & 1994 & Rock Creek near Sherwood & Chemical residues in fish & $X$ & -- & $X$ & $X$ \\
\hline Walsh and others (1977) & WR & $1971-73$ & Oregon City & $\begin{array}{l}\text { National study on trace element } \\
\text { residues in fish }\end{array}$ & $\mathrm{X}$ & -- & -- & -- \\
\hline Worcester (1979) & $\mathrm{CF}$ & $1974-75$ & Cottage Grove Lake & Mercury accumulation in fish & $\mathrm{X}$ & -- & -- & -- \\
\hline
\end{tabular}


A variety of contaminant guidelines and criteria have been established for the protection of aquatic life. Many of the cited investigations in this report compare tissue concentrations to water-quality criteria established by the USEPA and the State of Oregon for the protection of aquatic life (U.S. Environmental Protection Agency, 1986 and 1992b; Oregon Department of Environmental Quality, 1991). Action levels established by the Food and Drug Administration (FDA) for the protection of human health have also been used for comparison. An action level specifies the level below which the FDA exercises its discretion not to take enforcement action.

\section{Synthetic Organic Compounds}

Sources of synthetic organic compounds in aquatic systems include atmospheric deposition, industrial and municipal effluent, and nonpoint-source runoff. Synthetic organic compounds commonly adsorb on suspended particles, which settle on the stream bottom where they may be ingested by bottom-dwelling organisms. Many of these compounds are highly soluble in lipids, are persistent in the environment, and tend to bioaccumulate in biota. Bioaccumulation of chlorinated pesticides may result in eggshell thinning, reduced productivity, and the decline of certain populations of wildlife (Porter and Wiemeyer, 1969; Anderson and Hickey, 1972; Wiemeyer and others, 1984; Hoffman and others, 1995). The toxicity of synthetic organic compounds varies by species, sex, and age, and may be influenced by stress, chemical formulations used, and numerous other factors (Hoffman and others, 1995).

The majority of information on synthetic organic compounds in aquatic tissue in the Willamette Basin comes from the WRTS undertaken by the ODEQ (1994b) between 1988 and 1991. In this study, chemical residue analyses were performed on the tissue of collected species of fish and crayfish. The following constituents were analyzed: chlorinated pesticides, PCBs, dioxins and furans, polycyclic aromatic hydrocarbons (PAHs), and trace elements. Whole body, edible flesh, and liver of common carp, crayfish, cutthroat trout, largemouth bass, largescale sucker, mountain whitefish, and northern squawfish were collected for analysis. Species and tissue type collected varied among stations and years. All concentrations were assessed by species and river mile and compared to
Federal and State criteria for the protection of aquatic life and human health. Several other studies also assessed synthetic organic compounds in fish from the Willamette Basin (table 9).

\section{Chlorinated Pesticides}

Chlorinated pesticides in aquatic tissue are reported in appendices E-1, E-2, and E-3. The WRTS (Oregon Department of Environmental Quality, 1994b) detected 18 pesticides in 66 samples collected from the main stem Willamette River; 8 pesticides were detected in 30 samples collected from tributaries to the Willamette. Heptachlor, $p$, $p^{\prime}$-dichlorodiphenyldichloroethane (DDD), and $p, p^{\prime}$-dichlorodiphenyldichlorethylene (DDE) from the main stem, and $p, p^{\prime}$-DDE and $p, p^{\prime}$-dichlorodiphenyltrichloroethane (DDT) from the tributaries were detected in greater than 20 percent of the samples collected. Maximum concentrations for heptachlor, $p, p^{\prime}$-DDD, and $p, p^{\prime}$-DDE from the main stem exceeded the USEPA water-quality criteria for the protection of aquatic life. The dieldrin concentration in one main stem sample (RM 28, upstream from Oregon City) was above the FDA action level. These action levels are specific to edible parts of fish and shellfish but are not directly comparable to concentrations in whole fish (U.S. Environmental Protection Agency, 1992b).

Crayfish collected from Johnson Creek contained concentrations of $p, p^{\prime}$-DDD, $p, p^{\prime}$-DDE, and $p, p^{\prime}$-DDT above USEPA water quality criteria for the protection of aquatic life (appendix E-2). However, these concentrations were determined to be safe for human consumption.

Curtis and others (1993) assessed pesticide residues in fish at six sites along the main stem Willamette River. These sites (RMs 7, 72, 131, 148, 160, and 195) were exposed to different types of pollution such as a hydroelectric dam, bleached kraft pulp mill discharge, and sewage outfalls. Various pesticides were found in common carp, cutthroat trout, and northern squawfish (appendices E-1, E-2, and E-3). Detected pesticides included aldrin, $\alpha$-hexachlorocyclohexane $(\mathrm{HCH})$, $\beta-\mathrm{HCH}, \mathrm{DDD}, \mathrm{DDE}$, dieldrin, endosulfan I, endrin, heptachlor, and heptachlor epoxide. No patterns were found in contaminant distribution, except that higher DDE concentrations were found in whole northern squawfish at RMs 72, 131, and 148, as compared with the two more upstream sites. No correlations were seen between organochlorine concentrations 
in aquatic tissue and occurrences of lesions in liver, kidneys, spleen, gills, or gonads.

Concentrations of organic compounds in fish collected from Rock Creek near Sherwood (Tualatin subbasin) were below detection limits, with the exception of $p, p^{\prime}$-DDE (U.S. Fish and Wildlife Service, 1994c). Sculpin and three-spine stickleback (Gasterosteus aculeatus) had contained $p, p^{\prime}$-DDE concentrations ranging from 0.03 to 0.06 micrograms per gram $(\mu \mathrm{g} / \mathrm{g})$, wet weight. These concentrations are below the geometric mean $(0.19 \mu \mathrm{g} / \mathrm{g}$, wet weight $)$ of $p, p^{\prime}$-DDE found in fish sampled by the NCBP (Schmitt and others, 1990). The USEPA (1992a) also assessed organic compounds in crayfish, northern squawfish, and suckers from the main stem Willamette River and the Tualatin River. Results are reported in appendices E-1, E-2, and E-3.

In 1970, Henny and Bethers (1971) studied great blue herons nesting along the Willamette River near Albany. Two eggs from a single nest exhibited $p, p^{\prime}-$ DDE levels of 3.3 and $4.5 \mu \mathrm{g} / \mathrm{g}$, wet weight. These egg concentrations could be expected to impact production. Wiemeyer and others (1984) found that mean 5-year production for bald eagles was near normal for breeding areas where eggs contained $<3.0 \mu \mathrm{g} / \mathrm{g}$, wet weight, $p, p^{\prime}$-DDE; production dropped markedly for breeding areas where eggs contained $>5.1 \mu \mathrm{g} / \mathrm{g}$, wet weight, $p, p^{\prime}$-DDE; and nearly complete breeding failure occurred where egg levels exceeded $15 \mu \mathrm{g} / \mathrm{g}$, wet weight, $p, p^{\prime}$-DDE. DDE concentrations of $5 \mu \mathrm{g} / \mathrm{g}$, wet weight, were also associated with 10-percent shell thinning for bald eagles (Wiemeyer and others, 1984). A recently deceased day-old great blue heron chick with a $p, p^{\prime}$-DDE whole body concentration of $10.1 \mu \mathrm{g} / \mathrm{g}$, wet weight, was also collected from the Albany heronry. Prey species of fish found in the nests at the heronry included cutthroat trout, largescale sucker, northern squawfish, and white crappie. Previous studies on insecticide residues in fish from the Willamette River detected concentrations of DDT and its metabolites ranging from $0.29 \mu \mathrm{g} / \mathrm{g}$ (white crappie) to $2.65 \mu \mathrm{g} / \mathrm{g}$ (largescale sucker), and dieldrin levels ranging from $0.01 \mu \mathrm{g} / \mathrm{g}$ (white crappie and largescale sucker) to $0.03 \mu \mathrm{g} / \mathrm{g}$ (largescale sucker and northern squawfish) (Henderson and others [1969] as cited in Henny and Bethers [1971]).

Table 10 compares great blue heron eggshell thickness measurements between a Willamette River site (Henny and Bethers, 1971) and sites from throughout the Pacific Northwest (Anderson and Hickey,
Table 10. Eggshell thickness data for great blue herons in the Pacific Northwest

[Adapted from Henny and Bethers (1971). Thickness index = \{shell weight $(\mathrm{mg})\} /\{$ shell length $(\mathrm{mm}) \mathrm{x}$ shell width $(\mathrm{mm})$ \} from Ratcliffe (1967)]

\begin{tabular}{lrcl}
\hline \multicolumn{1}{c}{ Years } & $\begin{array}{c}\text { Sample } \\
\text { size }\end{array}$ & $\begin{array}{c}\text { Thickness } \\
\text { index }\end{array}$ & \multicolumn{1}{c}{ Reference } \\
\hline pre-1947 & 130 & $2.02 \pm 0.02$ & $\begin{array}{l}\text { Anderson and } \\
\text { Hickey (1972) }\end{array}$ \\
$1956-$ & 9 & $1.83 \pm 0.09$ & $\begin{array}{l}\text { Anderson and } \\
\text { Hickey (1972) } \\
1959\end{array}$ \\
1970 & 2 & $1.98 \pm 0.54$ & $\begin{array}{l}\text { Henny and } \\
\text { Bethers (1971) }\end{array}$ \\
\hline
\end{tabular}

1972). No significant difference in the eggshell thickness index (as defined by Ratcliffe [1967]) was detected between the two studies, although Anderson and Hickey (1972) reported a 9-percent decrease in eggshell thickness in eggs collected between 1956 and 1959 in the Pacific Northwest. Henny and Bethers (1971) concluded that despite documented elevated egg pesticide levels, great blue heron numbers were remaining fairly stable in western Oregon.

\section{Polychlorinated Biphenyls}

Several studies have reported PCB concentrations in fish from the Willamette Basin (Hart Crowser, 1988; Oregon Department of Environmental Quality, 1994b; U.S. Fish and Wildlife Service, 1994c). The ODEQ (1994b) collected tissue samples from aquatic biota from the main stem Willamette River and its tributaries for analysis of co-planar PCBs and arochlor PCBs. Detected PCBs are reported in appendix F. Maximum concentrations for both co-planar and arochlor PCBs were below FDA action levels but above the USEPA water-quality criteria for the protection of aquatic life. Curtis and others (1993) found PCB 1260 in northern squawfish at a majority of sampling sites on the main stem Willamette River. Few PCB congeners were detected in common carp or cutthroat trout (appendix F). The presence of PCBs in fish collected from RM 195 may suggest point-source contamination from the electrical components of a hydroelectric dam near the site. Total PCBs were not detected in fish samples collected from Rock Creek near Sherwood by the USFWS (1994c).

PCB sampling has also been conducted at the site of a former steam-powered electricity generating plant on the Willamette River in Portland. The plant was in operation from the early 1900s through 1975. 
PCB contamination of adjacent river sediments was discovered in the 1980s. Data were gathered on water, sediment, ground water, upland soils, and fish. PCB concentrations were assessed in 32 crayfish and 36 prickly sculpins collected from the river in the immediate vicinity of the plant (approximately RM 13) and 1 mile upriver (Hart Crowser, 1988). Arochlor 1260 concentrations in crayfish tissue at three sites were all less than the detection level of $0.04 \mu \mathrm{g} / \mathrm{g}$, wet weight. Arochlor 1260 concentrations in prickly sculpin tissue ranged from 0.19 to $0.63 \mu \mathrm{g} / \mathrm{g}$, wet weight, at the site and from 0.10 to $0.35 \mu \mathrm{g} / \mathrm{g}$, wet weight, at the upriver reference site (appendix F). Mean concentrations were not statistically different between contaminated and reference sites. Arochlor 1260 concentrations in prickly sculpin tissue samples exceeded the predator protection criterion for total PCBs $(0.1 \mu \mathrm{g} / \mathrm{g})$ instituted by the International Joint Commission (1988) of the Great Lakes. The predator protection criterion is determined for whole-body fish residue and should not be exceeded to protect birds and mammals that consume fish.

\section{Dioxins and Furans}

The ODEQ (1994b) and USEPA (1992a) analyzed tissues of aquatic biota from the main stem Willamette River and its tributaries for dioxin and furan concentrations (tables 11a and 11b). In the ODEQ study, 2,3,7,8-tetrachlorodibenzo- $p$-dioxin (TCDD) was detected in all but one sample, and 2,3,7,8-tetrachlorodibenzofuran (TCDF) was detected in all samples. All detected concentrations of TCDD were above the USEPA threshold value of 0.07 picogram per gram (pg/g), wet weight, and below the FDA action level, of $25 \mathrm{pg} / \mathrm{g}$, wet weight, as listed by ODEQ (1994b). Mountain whitefish collected upstream of RM 147, which is in the vicinity of a bleached kraft pulp mill, had median TCDD and TCDF concentrations of 0.53 and 2.55 (pg/g), wet weight, respectively. Mountain whitefish collected downstream of this location contained median TCDD and TCDF concentrations of 2.7 and $13.0 \mathrm{pg} / \mathrm{g}$, wet weight, respectively. Maximum concentrations of TCDD and TCDF differed in mountain whitefish collected in 1990 (7.9 pg/g, wet weight, TCDD; 30 pg/g, wet weight, TCDF) and 1991 (1.9 pg/ $\mathrm{g}$, wet weight, TCDD; $6.6 \mathrm{pg} / \mathrm{g}$, wet weight, TCDF). Concentrations of TCDD and TCDF also differed among species.

Tissue samples from aquatic biota were also collected from the McKenzie, Santiam, and main stem
Willamette Rivers as part of the USEPA's National Dioxin Strategy (Kuehl and others, 1989; tables 11a and $11 \mathrm{~b}$ ). TCDD was not detected at $1.0 \mathrm{pg} / \mathrm{g}$, wet weight, in the McKenzie and Santiam Rivers; concentrations in tissue of organisms from the main stem Willamette River ranged from $<1.0 \mathrm{pg} / \mathrm{g}$ to $1.8 \mathrm{pg} / \mathrm{g}$, wet weight. This national study determined that higher levels of TCDD in fish could be associated with the presence of pulp and paper manufacturing plants as compared to other sites.

Curtis and others (1993) collected common carp, cutthroat trout, and northern squawfish at six sites between RMs 7 and 195 on the main stem Willamette River for analysis of TCDD and TCDF concentrations. They found that whole-body TCDD and TCDF concentrations of northern squawfish were generally higher than for cutthroat trout. Differences were attributed to variations in prey base, body composition, or organochlorine elimination rates. Strong correlations $(r>0.80)$ were observed between common carp muscle TCDD or TCDF and biomarker responses (hepatic microsomal ethoxyresorufin O-deethylase[EROD] and total cytochrome P450-1A1) for individuals in which both types of analyses were performed. Contamination in fish and sediments was heavier at RM 7, which is located in Portland Harbor, than at upstream sites. TCDF to TCDD concentration ratios were also significantly higher $(\mathrm{p}=0.05)$ at this industrial area than at other sampling sites, highlighting the residual effects of past chemical production and usage near the site. Pastorok and others (1994) found the range of polychlorinated dibenzo- $p$-dioxin (PCDD) and polychlorinated dibenzofuran (PCDF) concentrations in crayfish and largescale sucker from RM 7 to be similar to that reported by the USEPA (1992a) for industrialized portions of the Willamette River.

\section{Polycyclic Aromatic Hydrocarbons}

Little information is available on PAHs in fish from the Willamette Basin. Between 1988 and 1991, the ODEQ (1994b) collected common carp, crayfish, cutthroat trout, largescale suckers, and northern squawfish from the main stem Willamette River (RMs 7 through 161) and major tributaries for analyses of PAHs. Benzo( $b$ )fluoranthene, acenaphthene, benzo $(k)$ fluoranthene, and benzo $(a)$ pyrene were detected in two common carp from RMs 7 and 74 on the main stem Willamette River. Concentrations of these chemicals ranged from 0.5 to $0.8 \mu \mathrm{g} / \mathrm{g}$, wetweight. Curtis and others (1993) found no detectable 
Table 11a. Dioxins and furans in tissue of aquatic biota from the Willamette Basin, Oregon

[River mile: --, not available; , approximately. Tissue type: wb, whole body; f, fillet; --, not available. Number samples: c, composite sample. Concentration range: pg,/g, picograms per gram;

ND, not detected, --, not analyzed; <, less than. References: ODEQ, Oregon Department of Environmental Quality; USEPA, U.S. Environmental Protection Agency]

\begin{tabular}{|c|c|c|c|c|c|c|c|c|c|c|c|c|c|c|}
\hline \multirow[b]{2}{*}{ River } & \multirow[b]{2}{*}{$\begin{array}{l}\text { River } \\
\text { mile }\end{array}$} & \multirow[b]{2}{*}{ Year } & \multirow[b]{2}{*}{ Species } & \multirow[b]{2}{*}{$\begin{array}{l}\text { Tissue } \\
\text { type }\end{array}$} & \multirow[b]{2}{*}{$\begin{array}{l}\text { Number } \\
\text { samples }\end{array}$} & & \multirow[b]{2}{*}{$\begin{array}{l}\text { Refer- } \\
\text { ence }\end{array}$} \\
\hline & & & & & & $\begin{array}{l}2,3,7,8- \\
\text { TCDD }\end{array}$ & $\begin{array}{l}\text { 1,2,3,7,8- } \\
\text { PeCDD }\end{array}$ & $\begin{array}{l}1,2,3,4,7,8- \\
\text { HxCDD }\end{array}$ & $\begin{array}{l}1,2,3,6,7,8- \\
\text { HxCDD }\end{array}$ & $\begin{array}{l}\text { 1,2,3,7,8,9- } \\
\text { HxCDD }\end{array}$ & $\begin{array}{l}\text { 1,2,3,4,6,7, } \\
\text { 8-HрCDD }\end{array}$ & $\begin{array}{l}\text { 2,3,7,8- } \\
\text { TCDF }\end{array}$ & $\begin{array}{l}\text { 1,2,3,7,8- } \\
\text { PeCDF }\end{array}$ & \\
\hline Willamette & $\sim 7$ & 1983 & $\begin{array}{l}\text { Bottom } \\
\text { feeder }\end{array}$ & wb & 1 or $\mathrm{c}$ & 1.8 & -- & -- & -- & -- & -- & -- & -- & $\begin{array}{l}\text { Kuehl } \\
\text { and } \\
\text { others } \\
\text { (1989) }\end{array}$ \\
\hline Willamette & $\sim 7$ & 1983 & $\begin{array}{l}\text { Bottom } \\
\text { feeder }\end{array}$ & $\mathrm{f}$ & 1 or $\mathrm{c}$ & 1.5 & -- & -- & -- & -- & -- & -- & -- & $\begin{array}{l}\text { Kuehl } \\
\text { and } \\
\text { others } \\
\text { (1989) }\end{array}$ \\
\hline Willamette & $\sim 7$ & 1987 & Crayfish & $w b$ & -- & 2.61 & 3.75 & $<2.64$ & 10.05 & 1.42 & 34.42 & 48.14 & 54.32 & $\begin{array}{l}\text { USEPA } \\
\text { (1992a) }\end{array}$ \\
\hline Willamette & $\sim 7$ & 1987 & $\begin{array}{l}\text { Largemouth } \\
\text { bass }\end{array}$ & $\mathrm{f}$ & $4 c$ & .74 & $<1.41$ & $<2.46$ & .82 & $<1.38$ & .43 & 1.09 & $<.84$ & $\begin{array}{l}\text { USEPA } \\
\text { (1992a) }\end{array}$ \\
\hline Willamette & $\sim 7$ & 1987 & Sucker & wb & $4 c$ & 2.25 & 3.31 & 1.10 & 4.06 & .61 & 16.57 & 3.35 & .91 & $\begin{array}{l}\text { USEPA } \\
\text { (1992a) }\end{array}$ \\
\hline $\begin{array}{l}\text { Willamette, } \\
\text { Halsey }\end{array}$ & -- & 1987 & $\begin{array}{l}\text { Mountain } \\
\text { whitefish }\end{array}$ & $\mathrm{f}$ & $5 c$ & 4.58 & 1.56 & .35 & 1.79 & $<1.35$ & 2.47 & 16.12 & $<.82$ & $\begin{array}{l}\text { USEPA } \\
\text { (1992a) }\end{array}$ \\
\hline $\begin{array}{l}\text { Willamette, } \\
\text { Halsey }\end{array}$ & -- & 1987 & Sucker & $w b$ & $4 c$ & .76 & .27 & $<2.46$ & $<1.84$ & $<1.37$ & .54 & 2.43 & $<.77$ & $\begin{array}{l}\text { USEPA } \\
\text { (1992a) }\end{array}$ \\
\hline $\begin{array}{l}\text { Willamette, } \\
\text { Wilsonville }\end{array}$ & -- & 1987 & Crayfish & wb & -- & $<1.11$ & $<.99$ & $<2.45$ & $<1.84$ & $<1.37$ & 3.33 & 1.77 & $<.77$ & $\begin{array}{l}\text { USEPA } \\
\text { (1992a) }\end{array}$ \\
\hline $\begin{array}{l}\text { Willamette, } \\
\text { Salem }\end{array}$ & -- & 1983 & $\begin{array}{l}\text { Bottom } \\
\text { feeder }\end{array}$ & $w b$ & 1 or $\mathrm{c}$ & $<1.0$ & -- & -- & -- & -- & -- & -- & -- & $\begin{array}{l}\text { Kuehl } \\
\text { and } \\
\text { others } \\
\text { (1989) }\end{array}$ \\
\hline Willamette & 141 & 1991 & $\begin{array}{l}\text { Mountain } \\
\text { whitefish }\end{array}$ & -- & 1 & 1.4 & .28 & .1 & .22 & .14 & .46 & 4.6 & .2 & $\begin{array}{l}\text { ODEQ } \\
\text { (1994b) }\end{array}$ \\
\hline Willamette & 141 & 1991 & $\begin{array}{l}\text { Common } \\
\text { carp }\end{array}$ & -- & 1 & .45 & $<.24$ & .13 & .34 & $<.093$ & .84 & .45 & .045 & $\begin{array}{l}\text { ODEQ } \\
(1994 b)\end{array}$ \\
\hline Willamette & 143 & 1990-91 & $\begin{array}{l}\text { Mountain } \\
\text { whitefish }\end{array}$ & -- & 2 & $\begin{array}{l}1.9- \\
7.9\end{array}$ & $\begin{array}{l}.45- \\
<1.8\end{array}$ & $<3.5$ & $\begin{array}{l}.37- \\
<3.1\end{array}$ & $\begin{array}{l}.17- \\
<.61\end{array}$ & $\begin{array}{l}.54- \\
<1.6\end{array}$ & $\begin{array}{l}6.6- \\
30\end{array}$ & $\begin{array}{l}.17- \\
<.52\end{array}$ & $\begin{array}{l}\text { ODEQ } \\
\text { (1994b) }\end{array}$ \\
\hline Willamette & 143 & 1991 & $\begin{array}{l}\text { Common } \\
\text { carp }\end{array}$ & -- & 1 & 0.57 & $<0.23$ & 0.14 & 0.5 & $<0.11$ & 1.2 & 0.56 & $<0.048$ & $\begin{array}{l}\text { ODEQ } \\
\text { (1994b) }\end{array}$ \\
\hline
\end{tabular}


Table 11a. Dioxins and furans in tissue of aquatic biota from the Willamette Basin, Oregon-Continued

\begin{tabular}{|c|c|c|c|c|c|c|c|c|c|c|c|c|c|c|}
\hline \multirow[b]{2}{*}{ River } & \multirow[b]{2}{*}{$\begin{array}{l}\text { River } \\
\text { mile }\end{array}$} & \multirow[b]{2}{*}{ Year } & \multirow[b]{2}{*}{ Species } & \multirow[b]{2}{*}{$\begin{array}{l}\text { Tissue } \\
\text { type }\end{array}$} & \multirow[b]{2}{*}{$\begin{array}{l}\text { Number } \\
\text { samples }\end{array}$} & \multicolumn{8}{|c|}{ Concentration range (pg/g, wet weight) } & \multirow[b]{2}{*}{$\begin{array}{l}\text { Refer- } \\
\text { ence }\end{array}$} \\
\hline & & & & & & $\begin{array}{l}2,3,7,8- \\
\text { TCDD }\end{array}$ & $\begin{array}{l}\text { 1,2,3,7,8- } \\
\text { PeCDD }\end{array}$ & $\begin{array}{l}1,2,3,4,7,8- \\
\text { HxCDD }\end{array}$ & $\begin{array}{l}1,2,3,6,7,8- \\
\text { HxCDD }\end{array}$ & $\begin{array}{l}1,2,3,7,8,9- \\
\text { HxCDD }\end{array}$ & $\begin{array}{l}\text { 1,2,3,4,6,7, } \\
\text { 8-HpCDD }\end{array}$ & $\begin{array}{l}\text { 2,3,7,8- } \\
\text { TCDF }\end{array}$ & $\begin{array}{l}\text { 1,2,3,7,8- } \\
\text { PeCDF }\end{array}$ & \\
\hline Willamette & 145 & $1990-91$ & $\begin{array}{l}\text { Mountain } \\
\text { whitefish }\end{array}$ & -- & 2 & $\begin{array}{l}2.5- \\
2.7\end{array}$ & $\begin{array}{l}.52- \\
<.7\end{array}$ & $\begin{array}{l}.19- \\
<.5\end{array}$ & $\begin{array}{l}.43- \\
<.63\end{array}$ & $\begin{aligned} & .19- \\
&<.52\end{aligned}$ & $\begin{array}{l}.62- \\
<1.3\end{array}$ & $\begin{array}{l}8.3- \\
13\end{array}$ & $\begin{array}{l}.12- \\
<.35\end{array}$ & $\begin{array}{l}\text { ODEQ } \\
\text { (1994b) }\end{array}$ \\
\hline Willamette & 145 & 1991 & $\begin{array}{l}\text { Common } \\
\text { carp }\end{array}$ & -- & 1 & .44 & .36 & .29 & 1 & $<.12$ & 2 & .54 & .12 & $\begin{array}{l}\text { ODEQ } \\
\text { (1994b) }\end{array}$ \\
\hline Willamette & 147 & 1990 & $\begin{array}{l}\text { Mountain } \\
\text { whitefish }\end{array}$ & -- & 2 & $\begin{array}{l}2.8- \\
4.6\end{array}$ & $1-1.6$ & $<.85$ & $<1.7$ & $<.82$ & $<1.8$ & $13-22$ & $\begin{array}{l}.29- \\
<.74\end{array}$ & $\begin{array}{l}\text { ODEQ } \\
\text { (1994b) }\end{array}$ \\
\hline Willamette & 161 & 1991 & $\begin{array}{l}\text { Common } \\
\text { carp }\end{array}$ & -- & 1 & .41 & .63 & .47 & 1.7 & .3 & 5.3 & .41 & .2 & $\begin{array}{l}\text { ODEQ } \\
\text { (1994b) }\end{array}$ \\
\hline Willamette & 161 & 1991 & $\begin{array}{l}\text { Mountain } \\
\text { whitefish }\end{array}$ & -- & 1 & .27 & .31 & .3 & .08 & .12 & .4 & 1.7 & .09 & $\begin{array}{l}\text { ODEQ } \\
\text { (1994b) }\end{array}$ \\
\hline Willamette & $\begin{array}{l}176- \\
177\end{array}$ & 1990 & $\begin{array}{l}\text { Mountain } \\
\text { whitefish }\end{array}$ & -- & 1 & .87 & 1.1 & $<.62$ & 1.3 & $<.23$ & 37 & 4 & $<.25$ & $\begin{array}{l}\text { ODEQ } \\
\text { (1994b) }\end{array}$ \\
\hline $\begin{array}{l}\text { Middle Fork } \\
\text { Willamette }\end{array}$ & 5 & 1990 & $\begin{array}{l}\text { Mountain } \\
\text { whitefish }\end{array}$ & -- & 1 & .57 & .63 & $<.36$ & .68 & $<.32$ & .97 & 2.7 & $<.19$ & $\begin{array}{l}\text { ODEQ } \\
(1994 b)\end{array}$ \\
\hline McKenzie & 3 & 1990 & $\begin{array}{l}\text { Mountain } \\
\text { whitefish }\end{array}$ & -- & 2 & $\begin{array}{r}<.5- \\
.57\end{array}$ & $<2$ & $<2.5$ & $<2.2$ & $<1$ & $<6.8$ & $\begin{array}{l}2.1- \\
2.4\end{array}$ & $\begin{array}{c}<.74- \\
.75\end{array}$ & $\begin{array}{l}\text { ODEQ } \\
(1994 b)\end{array}$ \\
\hline $\begin{array}{l}\text { McKenzie, } \\
\text { Coburg }\end{array}$ & -- & 1983 & $\begin{array}{l}\text { Bottom } \\
\text { feeder }\end{array}$ & $\mathrm{wb}$ & 1 or $\mathrm{c}$ & $<1.0$ & -- & -- & -- & -- & -- & -- & -- & $\begin{array}{l}\text { Kuehl } \\
\text { and } \\
\text { others } \\
(1989)\end{array}$ \\
\hline $\begin{array}{l}\text { Santiam, } \\
\text { Jefferson }\end{array}$ & -- & 1983 & $\begin{array}{l}\text { Bottom } \\
\text { feeder }\end{array}$ & $w b$ & 1 or $\mathrm{c}$ & $<1.0$ & -- & -- & -- & -- & -- & -- & -- & $\begin{array}{l}\text { Kuehl } \\
\text { and } \\
\text { others } \\
(1989)\end{array}$ \\
\hline $\begin{array}{l}\text { Santiam, } \\
\text { Jefferson }\end{array}$ & -- & 1983 & $\begin{array}{l}\text { Bottom } \\
\text { feeder }\end{array}$ & f & 1 or $\mathrm{c}$ & $<1.0$ & -- & -- & -- & -- & -- & -- & -- & $\begin{array}{l}\text { Kuehl } \\
\text { and } \\
\text { others } \\
(1989)\end{array}$ \\
\hline $\begin{array}{l}\text { Tualatin, } \\
\text { Cherry } \\
\text { Grove }\end{array}$ & -- & 1987 & Crayfish & $w b$ & 1 & $<.99$ & $<.92$ & $<2.47$ & $<1.85$ & $<1.38$ & .49 & $<.57$ & $<.78$ & $\begin{array}{l}\text { USEPA } \\
\text { (1992a) }\end{array}$ \\
\hline
\end{tabular}


Table 11b. Dioxins and furans in tissue of aquatic biota from the Willamette Basin, Oregon

[River mile: --, not available; , approximately. Tissue type: wb, whole body; f, fillet; --, not available. Number samples: c, composite sample. Concentration range: pg/g, picograms per gram; ND, not detected; --, not analyzed; <, less than. References: ODEQ, Oregon Department of Environmental Quality; USEPA, U.S. Environmental Protection Agency]

Concentration range $(\mathrm{pg} / \mathrm{g}$, wet weight)

\begin{tabular}{|c|c|c|c|c|c|c|c|c|c|c|c|c|c|c|}
\hline \multirow[b]{2}{*}{ River } & \multirow[b]{2}{*}{$\begin{array}{l}\text { River } \\
\text { mile }\end{array}$} & \multirow[b]{2}{*}{ Year } & \multirow[b]{2}{*}{ Species } & \multirow[b]{2}{*}{$\begin{array}{l}\text { Tis- } \\
\text { sue } \\
\text { type }\end{array}$} & \multirow[b]{2}{*}{$\begin{array}{l}\text { Number } \\
\text { samples }\end{array}$} & & \multirow[b]{2}{*}{$\begin{array}{l}\text { Refer- } \\
\text { ence }\end{array}$} \\
\hline & & & & & & $\begin{array}{c}\text { 2,3,4,7,8- } \\
\text { PeCDF }\end{array}$ & $\begin{array}{c}\text { 1,2,3,4,7,8- } \\
\text { HxCDF }\end{array}$ & $\begin{array}{c}\text { 1,2,3,6,7,8- } \\
\text { HxCDF }\end{array}$ & $\begin{array}{c}\text { 1,2,3,7,8,9- } \\
\text { HxCDF }\end{array}$ & $\begin{array}{c}2,3,4,6,7,8- \\
\text { HxCDF }\end{array}$ & $\begin{array}{c}\text { 1,2,3,4,6,7, } \\
\text { 8-HрCDF }\end{array}$ & $\begin{array}{c}\text { 1,2,3,4,7,8, } \\
\text { 9-HрCDF }\end{array}$ & TEC & \\
\hline Willamette & $\sim 7$ & 1987 & Crayfish & $\mathrm{wb}$ & -- & 19.02 & 18.85 & 10.15 & 0.23 & 0.87 & 6.44 & 1.76 & 26.11 & $\begin{array}{l}\text { USEPA } \\
(1992 a)\end{array}$ \\
\hline Willamette & $\sim 7$ & 1987 & $\begin{array}{l}\text { Largemouth } \\
\text { bass }\end{array}$ & $f$ & $4 c$ & .34 & $<2.83$ & $<2.84$ & $<2.77$ & $<1.96$ & .24 & $<2.61$ & 1.11 & $\begin{array}{l}\text { USEPA } \\
(1992 \mathrm{a})\end{array}$ \\
\hline Willamette & $\sim 7$ & 1987 & Sucker & $w b$ & $4 \mathrm{c}$ & 2.27 & 3.02 & $<2.79$ & $<2.72$ & 1.16 & 2.66 & $<2.56$ & 6.61 & $\begin{array}{l}\text { USEPA } \\
(1992 a)\end{array}$ \\
\hline $\begin{array}{l}\text { Willamette, } \\
\text { Halsey }\end{array}$ & -- & 1987 & $\begin{array}{l}\text { Mountain } \\
\text { whitefish }\end{array}$ & $f$ & $5 c$ & .45 & .60 & $<2.79$ & $<2.72$ & .36 & .40 & $<2.56$ & 7.54 & $\begin{array}{l}\text { USEPA } \\
\text { (1992a) }\end{array}$ \\
\hline $\begin{array}{l}\text { Willamette, } \\
\text { Halsey }\end{array}$ & -- & 1987 & Sucker & $w b$ & $4 c$ & $<.85$ & .40 & $<2.84$ & $<2.77$ & .25 & $<1.44$ & $<2.61$ & 1.21 & $\begin{array}{l}\text { USEPA } \\
\text { (1992a) }\end{array}$ \\
\hline $\begin{array}{l}\text { Willamette, } \\
\text { Wilsonville }\end{array}$ & -- & 1987 & Crayfish & $w b$ & -- & $<.84$ & $<2.82$ & $<2.83$ & $<2.76$ & $<1.95$ & $<1.44$ & $<2.60$ & .21 & $\begin{array}{l}\text { USEPA } \\
(1992 \mathrm{a})\end{array}$ \\
\hline Willamette & 141 & 1991 & $\begin{array}{l}\text { Mountain } \\
\text { whitefish }\end{array}$ & -- & 1 & .14 & .06 & .09 & .11 & .2 & .06 & .13 & 2.18 & $\begin{array}{c}\text { ODEQ } \\
(1994 b)\end{array}$ \\
\hline Willamette & 141 & 1991 & $\begin{array}{l}\text { Common } \\
\text { carp }\end{array}$ & -- & 1 & .14 & $<.037$ & $<.025$ & $<.052$ & .13 & .17 & $<.046$ & .78 & $\begin{array}{l}\text { ODEQ } \\
(1994 b)\end{array}$ \\
\hline Willamette & 143 & $\begin{array}{c}1990- \\
91\end{array}$ & $\begin{array}{l}\text { Mountain } \\
\text { whitefish }\end{array}$ & -- & 2 & $\begin{array}{l}.22- \\
<1.7\end{array}$ & $\begin{array}{l}.12- \\
<.8\end{array}$ & $\begin{array}{r}.09- \\
<.72\end{array}$ & $\begin{array}{l}.13- \\
<4.3\end{array}$ & $\begin{array}{l}.23- \\
<.53\end{array}$ & $\begin{array}{l}.12- \\
<.73\end{array}$ & $\begin{array}{l}.17- \\
<1.1\end{array}$ & $\begin{array}{r}3.04 \\
14.07\end{array}$ & $\begin{array}{c}\text { ODEQ } \\
(1994 b)\end{array}$ \\
\hline Willamette & 143 & 1991 & $\begin{array}{l}\text { Common } \\
\text { carp }\end{array}$ & -- & 1 & .14 & $<.045$ & $<.028$ & $<.025$ & .16 & .17 & $<.056$ & .93 & $\begin{array}{l}\text { ODEQ } \\
(1994 b)\end{array}$ \\
\hline Willamette & 145 & $\begin{array}{c}1990- \\
91\end{array}$ & $\begin{array}{l}\text { Mountain } \\
\text { whitefish }\end{array}$ & -- & 2 & $\begin{array}{r}.2- \\
<.42\end{array}$ & $\begin{array}{l}.13- \\
<.33\end{array}$ & $\begin{array}{l}.15- \\
<.25\end{array}$ & $<1.5$ & $\begin{array}{l}.22- \\
<.88\end{array}$ & $\begin{array}{l}.15- \\
<.43\end{array}$ & $\begin{array}{l}.15- \\
<.51\end{array}$ & $\begin{array}{l}3.85- \\
5.07\end{array}$ & $\begin{array}{c}\text { ODEQ } \\
(1994 b)\end{array}$ \\
\hline
\end{tabular}


Table 11b. Dioxins and furans in tissue of aquatic biota from the Willamette Basin, Oregon-Continued

\begin{tabular}{|c|c|c|c|c|c|c|c|c|c|c|c|c|c|c|}
\hline \multirow[b]{2}{*}{ River } & \multirow[b]{2}{*}{$\begin{array}{l}\text { River } \\
\text { mile }\end{array}$} & \multirow[b]{2}{*}{ Year } & \multirow[b]{2}{*}{ Species } & \multirow[b]{2}{*}{$\begin{array}{l}\text { Tis- } \\
\text { sue } \\
\text { type }\end{array}$} & \multirow[b]{2}{*}{$\begin{array}{l}\text { Number } \\
\text { samples }\end{array}$} & \multicolumn{8}{|c|}{ Concentration range (pg/g, wet weight) } & \multirow[b]{2}{*}{$\begin{array}{c}\text { Refer- } \\
\text { ence }\end{array}$} \\
\hline & & & & & & $\begin{array}{c}2,3,4,7,8- \\
\text { PeCDF }\end{array}$ & $\begin{array}{c}\text { 1,2,3,4,7,8- } \\
\text { HxCDF }\end{array}$ & $\begin{array}{c}\text { 1,2,3,6,7,8- } \\
\text { HxCDF }\end{array}$ & $\begin{array}{c}\text { 1,2,3,7,8,9- } \\
\text { HxCDF }\end{array}$ & $\begin{array}{c}2,3,4,6,7,8- \\
\text { HxCDF }\end{array}$ & $\begin{array}{c}\text { 1,2,3,4,6,7, } \\
\text { 8-HpCDF }\end{array}$ & $\begin{array}{c}\text { 1,2,3,4,7,8, } \\
\text { 9-HpCDF }\end{array}$ & TEC & \\
\hline Willamette & 145 & 1991 & $\begin{array}{l}\text { Common } \\
\text { carp }\end{array}$ & -- & 1 & 0.25 & 0.14 & 0.092 & $<0.057$ & 0.19 & 0.31 & $<0.061$ & 1.02 & $\begin{array}{c}\text { ODEQ } \\
(1994 b)\end{array}$ \\
\hline Willamette & 147 & 1990 & $\begin{array}{l}\text { Mountain } \\
\text { whitefish }\end{array}$ & -- & 2 & $\begin{array}{l}.56- \\
<.94\end{array}$ & $<.24$ & $<.21$ & $<.86$ & $\begin{array}{l}.22- \\
<.39\end{array}$ & $<.46$ & $<.31$ & $\begin{array}{l}5.21- \\
8.65\end{array}$ & $\begin{array}{l}\text { ODEQ } \\
(1994 b)\end{array}$ \\
\hline Willamette & 161 & 1991 & $\begin{array}{l}\text { Common } \\
\text { carp }\end{array}$ & -- & 1 & .46 & .22 & .18 & $<.032$ & .23 & .44 & $<.039$ & 1.39 & $\begin{array}{l}\text { ODEQ } \\
\text { (1994b) }\end{array}$ \\
\hline Willamette & 161 & 1991 & $\begin{array}{l}\text { Mountain } \\
\text { whitefish }\end{array}$ & -- & 1 & .13 & .08 & .07 & .08 & .21 & .07 & .1 & .77 & $\begin{array}{l}\text { ODEQ } \\
\text { (1994b) }\end{array}$ \\
\hline Willamette & $\begin{array}{l}176- \\
177\end{array}$ & 1990 & $\begin{array}{l}\text { Mountain } \\
\text { whitefish }\end{array}$ & -- & 1 & .56 & $<.22$ & $<.18$ & $<1.9$ & .33 & $<1.3$ & $<.46$ & 3.35 & $\begin{array}{l}\text { ODEQ } \\
(1994 b)\end{array}$ \\
\hline $\begin{array}{l}\text { Middle Fork } \\
\text { Willamette }\end{array}$ & 5 & 1990 & $\begin{array}{l}\text { Mountain } \\
\text { whitefish }\end{array}$ & -- & 1 & $<.24$ & $<.33$ & $<.25$ & $<1.1$ & $<.11$ & $<.24$ & $<.32$ & 1.62 & $\begin{array}{l}\text { ODEQ } \\
\text { (1994b) }\end{array}$ \\
\hline McKenzie & 3 & 1990 & $\begin{array}{l}\text { Mountain } \\
\text { whitefish }\end{array}$ & -- & 2 & $\begin{array}{l}.72- \\
<1.3\end{array}$ & $<.48$ & $<.44$ & $<5$ & $<2.4$ & $<.46$ & $<.74$ & $\begin{array}{l}3.49- \\
3.93\end{array}$ & $\begin{array}{l}\text { ODEQ } \\
\text { (1994b) }\end{array}$ \\
\hline $\begin{array}{l}\text { Tualatin, } \\
\text { Cherry } \\
\text { Grove }\end{array}$ & -- & 1987 & Crayfish & wb & 1 & $<.85$ & $<2.84$ & $<2.85$ & $<2.78$ & $<1.96$ & $<1.45$ & $<2.62$ & ND & $\begin{array}{l}\text { USEPA } \\
(1992 a)\end{array}$ \\
\hline
\end{tabular}


concentrations of 17 different PAHs in common carp muscle, whole cutthroat trout, or whole-body northern squawfish from 6 sites between RMs 7 and 195 on the main stem Willamette River at a detection limit of $0.030 \mu \mathrm{g} / \mathrm{g}$. Pastorok and others (1994) reported slightly elevated concentrations of PAHs in crayfish and largescale suckers collected near a creosoting company at RM 7 on the Willamette River compared with reference area concentrations. They suggested that ongoing exposure of the fish to PAHs in water and sediments near the site may be indicated because PAHs are normally metabolized quickly in fish.

\section{Trace Elements}

Trace elements can be lethal to aquatic organisms and fish over a wide range of concentrations. Anthropogenic sources in the Willamette Basin that may elevate trace elements above background levels in surface water include electroplating, smelting, and mining industries; industrial and municipal discharges and sewage; atmospheric deposition from combustion of fossil fuels and solid wastes; road surface runoff; and fertilizers, some pesticides, and erosion from agricultural areas. Natural mercury sources include deposits of cinnabar (mercuric sulfide) related to geothermal and volcanic activity.

Tissue samples from aquatic biota from both the main stem Willamette River and its tributaries have been analyzed for 18 major and trace elements by several investigators (appendices G-1 and G-2). Concentrations in tissue did not exceed aquatic-life criteria listed by ODEQ (1994b) for beryllium, chromium, nickel, or thallium, but arsenic and mercury concentrations sometimes exceeded the listed criteria.

The USEPA (1993) has developed fish-advisory screening values for cadmium $(10 \mu \mathrm{g} / \mathrm{g})$, mercury $(0.6$ $\mu \mathrm{g} / \mathrm{g})$, and selenium $(50 \mu \mathrm{g} / \mathrm{g})$. These values are meant to serve as an indication to government agencies that fish from the particular body of water may be potentially hazardous for human consumption. Mercury concentrations listed in appendices G-1 and G-2 sometimes exceeded the suggested fish-advisory screening value, but cadmium and selenium concentrations did not.

The USACE investigated the potential for the existence of contaminants in Willamette Basin reservoirs in 1983 (U.S. Army Corps of Engineers, 1991b). Dexter Reservoir, Cottage Grove, Dorena, and Fern Ridge Lakes were identified as having levels of certain water-quality constituents that impaired project pur- poses, violated Federal or State water quality standards, or threatened humans, fish, or wildlife. Naturally occurring arsenic and mercury were identified as potential contaminants at all four reservoirs. Elevated mercury concentrations in sediment at Cottage Grove Lake have been attributed to large cinnabar deposits in the Calapooya Mountains and the Black Butte area. These levels have been exacerbated by past mercury mining activities in the area. Studies indicate that fish in Cottage Grove Lake have elevated mercury concentrations when compared with fish from tributaries (Buhler and others [1973] as cited in Worcester [1979]; Worcester, 1979; Allen and Curtis, 1991; U.S. Army Corps of Engineers, 1991b). Worcester (1979) examined mercury concentrations in several fish species from Cottage Grove Lake between 1974 and 1976. The highest mercury concentrations were found in largemouth bass muscle collected in 1974 (0.15 to $1.44 \mu \mathrm{g} / \mathrm{g}$; appendix G-2). Due to elevated mercury levels in fish, the Oregon Department of Health has issued a health advisory for Cottage Grove Lake. Analyses of tissue from aquatic biota done in 1982 at Dexter Reservoir indicated that arsenic concentrations in northern squawfish and suckers were above USEPA water-quality criteria (U.S. Army Corps of Engineers, 1991b).

The ODEQ (1996) recently completed a report on mercury in Oregon lakes. Sediments and tissues of aquatic biota were assessed for mercury concentrations in areas with both known and unknown watershed sources of mercury. Areas assessed in the Willamette Basin included Cottage Grove Lake (cinnabar deposits and previous mercury mining), Dorena Lake (cinnabar deposits and gold mining), Fern Ridge Lake (no potential mercury sources identified), Henry Hagg Lake (no potential mercury sources identified), Willamette River Coast Fork (downstream of Cottage Grove Lake), and the Row River (downstream of Dorena Lake). Results from the study (appendix G-2) confirmed the relationship between elevated mercury concentrations in fish with cinnabar geology or historical mercury mining activity within the watershed. Higher tissue concentrations were also noted in older fish, and piscivorous fish tended to have higher body burdens of mercury.

In response to elevated mercury levels in several lakes and reservoirs throughout Oregon, a mercury working group was formed to address mercury concerns. Headed by the ODEQ, the group consists of representatives from ODFW, Oregon Department of Geology and Mineral Industries, Oregon Department of Human Resources - Health Division, OSU, USACE, 
BLM, USFS, USFWS, and USGS. Various studies are underway to document mercury concentrations in Oregon lakes.

In 1992, a nonviable egg from a bald eagle nest near Cottage Grove Lake was analyzed for trace elements. The nesting pair had previously produced young in 1989, 1990, and 1991. Although the majority of trace element concentrations were not at levels of concern, the mercury residues in the egg $(2.9 \mu \mathrm{g} / \mathrm{g}$, dry weight; $0.765 \mu \mathrm{g} / \mathrm{g}$, wet weight; U.S. Fish and Wildlife Service, Oregon State Office, unpubl. data, 1992) surpassed national averages for both unsuccessful $(0.15 \mu \mathrm{g} / \mathrm{g}$, fresh weight $)$ and successful bald eagle nests $(0.11 \mu \mathrm{g} / \mathrm{g}$, fresh weight) (Wiemeyer and others, $1984)$, as well as Columbia River averages $(0.20 \mu \mathrm{g} / \mathrm{g}$, wet weight) (Garrett and others, 1988). The mercury concentration in the egg also approached levels associated with reproductive impairment in other avian species (Heinz, 1979; Eisler, 1987).

\section{Organism Health}

\section{Fish Health Assessments}

Few studies have examined fish health in the Willamette River. The ODEQ (1994b) collected 10 to 20 northern squawfish from each of 5 sites in 1988 and from each of 4 sites in 1989. Sites were located on the main stem Willamette River, Santiam River, and Conser Slough. Tetra Tech, Inc., (1993b) also collected 12 to 20 northern squawfish or largescale suckers at each of 6 sites on the main stem Willamette River (RM 1, $6.5,25,49,128$, and 185) in 1992 for a fish health assessment. Both studies examined external features, internal features, and blood parameters following a fish health/condition assessment system that was originally developed for salmonid fishes (Goede, 1988; 1991). Table 12 presents a summary of some of the indices examined and the percent abnormalities observed. Due to the movement of fish throughout the river and the unknown applicability of the assessment to nonsalmonids, it is difficult to assess the relative health status of different river regions on the basis of these studies.

For both studies, northern squawfish had at least 25 percent abnormalities and suckers had at least 35 percent abnormalities for one or more indices at each of the sampling locations. The ODEQ study noted that fish from main stem sites were higher in percent abnormalities than those from two tributary sites (Oregon Department of Environmental Quality, 1994b). Of the eight organs examined, the gills, pseudobranchs, and liver had the highest percentage of abnormalities. Tetra Tech, Inc. (1993b) found that suckers collected from the two farthest upstream sites (RM 128 and 185) were markedly less healthy than suckers collected at the downstream sites (RM 1, 6.5, 25, and 49).

Blood parameters were only reported for the Tetra Tech, Inc., (1993b) study. Hematocrit, leucocrit, and plasma protein levels were difficult to assess because comparison values are unavailable for the species collected and analyzed. However, the coefficient of variation for hematocrit was relatively high (above 27 percent) at several sites for both northern squawfish and suckers. Levels above 15 percent indicate that some fish in the population may be unhealthy (Goede and Barton, 1990).

Curtis and others (1993) conducted a microscopic examination of common carp, cutthroat trout, and northern squawfish liver, gills, kidneys, spleen, stomach, and gonads. Fish were collected in 1990 from 6 sites between RMs 7 and 195 on the main stem Willamette River. No evidence of neoplasia, necrosis, or advanced organ failure was found. Mild degenerative changes, parasitism, and inflammation were detected, but these conditions varied randomly in degree among species and sites. No correlation was found between organochlorine concentrations in fish and the occurrence of liver, kidney, spleen, gill, or gonad lesions. Curtis and others (1993) noted that this lack of correlation suggests that existing organochlorine burdens in adult fish were not overtly toxic at any site.

Pastorok and others (1994) examined 249 largescale sucker livers collected from 4 sites near a creosoting company at RM 7, a downstream site (near RM 6), and an upstream site (near Wilsonville). The presence of mononuclear cell infiltrates, which indicate mild liver inflammation, was the most commonly observed abnormal condition (66 percent of the fish). However, this condition was not significantly different between RM 7 and the upstream location. No serious lesions were observed in any of the livers examined. Mild liver abnormalities that were noted were mononuclear cell infiltration, focal necrosis in hepatocytes, serosal inflammation, parasite-associated inflammation, nonuniform vacuolation of hepatocytes, and fat infiltration.

\section{Skeletal Abnormalities}

Studies of skeletal abnormalities have been conducted to a limited extent on the Willamette River. 
Table 12. Percent abnormal external and internal features in fish from the Willamette Basin, Oregon [--, not available; ODEQ, Oregon Department of Environmental Quality]

\begin{tabular}{|c|c|c|c|c|c|c|c|c|c|c|c|c|c|c|c|}
\hline \multirow[b]{2}{*}{ River } & \multirow[b]{2}{*}{$\begin{array}{l}\text { River } \\
\text { mile }\end{array}$} & \multirow[b]{2}{*}{ Years } & \multirow[b]{2}{*}{ Species } & \multirow[b]{2}{*}{$\begin{array}{l}\text { Number } \\
\text { samples }\end{array}$} & \multicolumn{11}{|c|}{ Percent abnormalities } \\
\hline & & & & & Eyes & Gills & $\begin{array}{l}\text { Pseudo- } \\
\text { branch }\end{array}$ & Thymus & Fins & Opercles & Spleen & Hindgut & Kidney & Liver & Reference \\
\hline Willamette & 1 & 1992 & $\begin{array}{l}\text { Northern } \\
\text { squawfish }\end{array}$ & 20 & 5 & 5 & 0 & 5 & 0 & 0 & 0 & 40 & 0 & 85 & $\begin{array}{l}\text { Tetra Tech, Inc. } \\
(1993 b, 1995 d)\end{array}$ \\
\hline Willamette & 6.5 & 1992 & $\begin{array}{l}\text { Largescale } \\
\text { sucker }\end{array}$ & 20 & 0 & 0 & 5 & 20 & 25 & 5 & 15 & 5 & 0 & 45 & $\begin{array}{l}\text { Tetra Tech, Inc. } \\
(1993 b, 1995 d)\end{array}$ \\
\hline Willamette & 7 & 1988 & $\begin{array}{l}\text { Northern } \\
\text { squawfish }\end{array}$ & 10 to 20 & 0 & 47 & 100 & 40 & -- & -- & 0 & 0 & 7 & 27 & ODEQ (1994b) \\
\hline Willamette & 25 & 1992 & $\begin{array}{l}\text { Largescale } \\
\text { sucker }\end{array}$ & 20 & 5 & 0 & 5 & 5 & 15 & 20 & 0 & 20 & 0 & 35 & $\begin{array}{l}\text { Tetra Tech, Inc. } \\
(1993 b, 1995 d)\end{array}$ \\
\hline Willamette & 38 & $\begin{array}{l}1988 \\
1989\end{array}$ & $\begin{array}{l}\text { Northern } \\
\text { squawfish }\end{array}$ & 10 to 20 & $\begin{array}{l}0 \\
0\end{array}$ & $\begin{array}{r}47 \\
0\end{array}$ & $\begin{array}{r}100 \\
0\end{array}$ & $\begin{array}{l}40 \\
20\end{array}$ & $\begin{array}{l}-- \\
--\end{array}$ & $\begin{array}{l}-- \\
--\end{array}$ & $\begin{array}{l}0 \\
0\end{array}$ & $\begin{array}{l}12 \\
67\end{array}$ & $\begin{array}{l}7 \\
0\end{array}$ & $\begin{array}{l}27 \\
20\end{array}$ & ODEQ (1994b) \\
\hline Willamette & 47 & $\begin{array}{l}1988 \\
1989\end{array}$ & $\begin{array}{l}\text { Northern } \\
\text { squawfish }\end{array}$ & 10 to 20 & $\begin{array}{l}8 \\
0\end{array}$ & $\begin{array}{l}69 \\
41\end{array}$ & $\begin{array}{r}100 \\
0\end{array}$ & $\begin{array}{l}46 \\
53\end{array}$ & -- & -- & $\begin{array}{l}8 \\
6\end{array}$ & $\begin{array}{l}0 \\
0\end{array}$ & $\begin{array}{r}8 \\
24\end{array}$ & $\begin{array}{l}69 \\
12\end{array}$ & ODEQ (1994b) \\
\hline Willamette & 49 & 1992 & $\begin{array}{l}\text { Northern } \\
\text { squawfish }\end{array}$ & 12 & 0 & 17 & 0 & 0 & 15 & 8 & 0 & 17 & 8 & 92 & $\begin{array}{l}\text { Tetra Tech, Inc. } \\
(1993 b, 1995 d)\end{array}$ \\
\hline Willamette & 49 & 1992 & $\begin{array}{l}\text { Largescale } \\
\text { sucker }\end{array}$ & 12 & 0 & 8 & 0 & 25 & 17 & 8 & 25 & 17 & 0 & 42 & $\begin{array}{l}\text { Tetra Tech, Inc. } \\
(1993 b, 1995 d)\end{array}$ \\
\hline Willamette & 74 & 1989 & $\begin{array}{l}\text { Northern } \\
\text { squawfish }\end{array}$ & 10 to 20 & 5 & 25 & 0 & 0 & -- & -- & 0 & 5 & 15 & 5 & ODEQ (1994b) \\
\hline Willamette & 115 & 1989 & $\begin{array}{l}\text { Northern } \\
\text { squawfish }\end{array}$ & 10 to 20 & 5 & 50 & 5 & 15 & -- & -- & 0 & 5 & 20 & 35 & ODEQ (1994b) \\
\hline Willamette & 128 & 1992 & $\begin{array}{l}\text { Largescale } \\
\text { sucker }\end{array}$ & 20 & 25 & 40 & 15 & 40 & 15 & 0 & 15 & 20 & 25 & 60 & $\begin{array}{l}\text { Tetra Tech, Inc. } \\
(1993 b, 1995 d)\end{array}$ \\
\hline Willamette & 185 & 1992 & $\begin{array}{l}\text { Largescale } \\
\text { sucker }\end{array}$ & 20 & 15 & 80 & 5 & 35 & 20 & 0 & 30 & 25 & 20 & 55 & $\begin{array}{l}\text { Tetra Tech, Inc. } \\
(1993 b, 1995 d)\end{array}$ \\
\hline Santiam & 0.5 & 1988 & $\begin{array}{l}\text { Northern } \\
\text { squawfish }\end{array}$ & 10 to 20 & 5 & 32 & 0 & 21 & -- & -- & 0 & 0 & 0 & 63 & ODEQ (1994b) \\
\hline $\begin{array}{l}\text { Conser } \\
\text { Slough }^{1}\end{array}$ & 0.1 & 1988 & $\begin{array}{l}\text { Northern } \\
\text { squawfish }\end{array}$ & 10 to 20 & 6 & 35 & 0 & 24 & -- & -- & 0 & 11 & 24 & 35 & ODEQ (1994b) \\
\hline
\end{tabular}

\footnotetext{
${ }^{1}$ Conser Slough is a tributary of the Willamette River near Albany, Oregon (Willamette River Subbasin).
} 
These types of studies are useful for determining the impacts of environmental pollutants on fish (Mayer and others, 1992). From 1992-94, Tetra Tech, Inc., (1993b; 1995d) examined skeletal abnormalities in juvenile northern squawfish collected from 18 locations along the main stem Willamette River between RMs 3 and 185. The incidence of skeletal abnormalities at RM 3 (less than 2.7 percent) and between RMs 125 and 185 (mean $=2.6$ percent) was consistently low and is within the range of 2-5 percent reported for unstressed natural fish populations and laboratory stocks (Gill and Fisk, 1966; Wells and Cowan [1982] as cited in Tetra Tech, Inc., [1995d]). Two sites were sampled between RMs 51 and 125.5. Elevated percentages of skeletal deformities occurred at RM 113 (22.2 percent) and RM 72 (21.7 percent) in 1994; these values are significantly higher than the values of upstream sampling locations. The highest incidence of deformities occurred within the Newberg Pool, which extends from RM 26.5 to RM 60 on the main stem Willamette River. Fish collected from the east bank of RM 49.7 exhibited 74 percent skeletal abnormalities in 1994. Studies of the Newberg Pool area in 1993 found a range of skeletal deformities from 22.6 percent to 52.0 percent, with values declining gradually in the downstream direction. Juvenile northern squawfish from a reference location on the Luckiamute River exhibited skeletal deformities at 1.6 percent.

Overall, the results of the Tetra Tech, Inc., (1995d) study have shown that a background deformity rate of up to 3 percent in the main stem Willamette River is not uncommon. Although no specific cause for juvenile northern squawfish deformities in the Newberg Pool was identified, Tetra Tech, Inc., (1995d) cites a variety of potential causes, including genetic factors, nutritional deficiencies, parasitism, elevated water temperatures, low dissolved oxygen concentrations, trace elements, pesticides, PCBs, bleached kraft pulp and paper mill effluent, and ore smelter effluent.

The role of hybridization in causing skeletal deformities in the Newberg Pool area was assessed by Markle (1994b). The occurrence of hybrids between northern squawfish and chiselmouth have been documented in the Willamette River, and skeletal deformities could be associated with hybridization. Northern squawfish specimens previously collected from the Newberg Pool area (RM 49.7) that had high levels of deformities and from the Corvallis area (RM 125.5) that had low levels of deformities, were further exam- ined to assess hybridization in the fish. Using multivariate analyses, Markle (1994b) suggested that hybridization contributed to, but was not the primary cause of, the observed pattern of deformities between the two sample sites. Markle (1994b) also noted that redside shiners, a nonhybrid species, from the Newberg Pool sample had high rates of deformities (26 percent of 76 fish). This information indicates that an area effect is present at the Newberg Pool, and lowers the probability that deformities were solely due to hybridization.

\section{Aquatic Toxicological Responses}

\section{Bioassays}

Tetra Tech, Inc., (1993b, 1995d) reported a higher incidence of skeletal deformities in juvenile northern squawfish from the Newberg Pool area (RM 26.5-60) on the main stem Willamette River than in northern squawfish from upstream or downstream sites. Effluents discharged near RM 56 were bioassayed by Curtis and Siddens (1995) to determine the teratogenicity of point sources of pollution. A fathead minnow (Pimephales promelas) embryo-larva survival and teratogenicity test was used for the assessment. The bioassay indicated that neither sewage-treatment-plant nor pulp-mill effluents were teratogenic. However, undiluted sewage treatment plant effluent was lethal to a high percentage (>90 percent) of embryos and larvae. The role of maternal transfer of contaminants to eggs or embryos and of male gamete damage was undetermined.

\section{Enzyme Induction Assays}

Various hydrocarbons have the potential to induce enzymatic activity in animals. Exposure to numerous aromatic compounds, including chlorinated organics such as dioxins, furans, and PCBs, induces cytochrome P450-1A1 activity in the liver. Induction of cytochrome P450-1A1, which catalyzes ethoxyresorufin O-deethylase (EROD) and aryl hydrocarbon (benzo[a]pyrene) hydrolase (AHH) activity, has been correlated with toxic potency of contaminants. Induction of cytochrome P450-1A1 may also be the most sensitive early indicator of exposure of organisms to toxic organic compounds. Determining the responses of these compounds (biomarkers) in animals that are sensitive to contaminant exposure allows a better estimate of exposure to chemicals or resultant effects and 
an assessment of environmental degradation (Huggett and others, 1992).

In 1990, enzyme induction assays were performed on liver samples from mountain whitefish collected from the main stem Willamette River (RM 143, 145, 147, and 176) Middle Fork Willamette River (RM 8), and McKenzie River (RM 3); (Oregon Department of Environmental Quality, 1994b). Five liver samples were collected at each of the six sample sites. Liver samples were analyzed for both EROD and AHH activity. Although there were no significant differences among site means for EROD or AHH activity, ODEQ (1994b) notes that results may have been affected by sample degradation. Control or reference EROD values for mountain whitefish were not available or not reported by ODEQ, and it is unknown if induction of the enzyme activities at the levels reported would be indicative of exposure to chlorinated organic compounds.

Curtis and others (1993) attempted to determine the sensitivity of cytochrome P450-1A1 induction in fish as a biomarker for distribution of TCDD and TCDF in the Willamette River. This study found good correlations between hepatic microsomal EROD activity and total cytochrome P450-1A1 content (quantified by Western blotting) in both common carp and cutthroat trout, but no evidence for positive biomarker responses in northern squawfish. Strong correlations were demonstrated between carp muscle TCDD or TCDF concentrations and hepatic EROD activity or total cytochrome P450-1A1 content. Common carp collected from Portland Harbor near RM 7 contained elevated TCDF in muscle tissue and contained significantly more total cytochrome P450-1A1 in hepatic microsomes than in fish from upstream locations (Curtis and others, 1993). No significant seasonal effects were found in the hepatic biomarkers for the fish evaluated in July and October 1990. These results suggest that common carp may be better indicators than northern squawfish to document exposure to chlorinated organic compounds based on hepatic biomarker responses. Additionally, common carp at RM 7 are exposed to these contaminants to a greater extent than common carp in other areas of the Willamette River.

\section{Growth Assays}

The ODEQ (1994b) conducted a growth assay on sculpin to determine if growth varied between contaminated and reference sites. Twelve to 18 sculpins were collected from RM 7 on the main stem Willamette River (a contaminated area) and from RM 2 on the
Clackamas River (an uncontaminated reference area). Three groups of four to six individuals from each site were fed at "fast", "moderate", or "slow" growth rations for 21 days. The study found no significant difference in growth between sculpins collected from contaminated and reference sites.

\section{Ongoing Research}

A variety of research is currently being conducted in the Willamette Basin that will aid in the understanding of contaminant impacts on aquatic biota. As part of a national study on endocrine disrupters in fish, the USGS, Biological Resources Division (BRD) are assessing the effects of contaminants on common carp endocrine systems in the Willamette River Basin (Steve Goodbred, oral commun., 1995). Sampling occurred in 1994 and 1995 in an off-channel pond adjacent to the Middle Fork Willamette River near Springfield and on the main stem Willamette River at Portland (RM 6). Three biomarkers are being assessed: hormones (estrogen and testosterone levels), vitellogenin, and histopathology.

Dr. Charles J. Henny with the USGS (BRD) in Corvallis, Oregon, has been investigating population changes and productivity of osprey in the Willamette Basin (oral commun., 1995). As part of this investigation, 10 osprey eggs and fish samples from 16 pools along the main stem Willamette River have been collected for analysis of organochlorine pesticides, congener specific PCBs, and dioxins and furans.

Carmen Thomas, a cooperative education student at Oregon State University, has been funded by the USFWS to assess contaminants in great blue heron colonies. Both fish prey and eggs have been collected from heronries along the Willamette River. These samples will be analyzed for a variety of contaminants, including organochlorine pesticides, congener PCBs, dioxins and furans, and trace elements. Eggs will also be used in a bioassay to assess exposure to planar halogenated hydrocarbons (PHHs) and to determine relative levels of cytochrome P450-1A1 and induction of EROD activity.

\section{SUMMARY}

This report reviews and summarizes available aquatic biological data for the Willamette and Sandy River Basins (Willamette Basin), Oregon, as part of 
the U.S. Geological Survey's National Water-Quality Assessment Program. This information will be used in conjunction with data on physical and chemical parameters in a multidisciplinary, integrated assessment of water quality to determine the status of aquatic environments and guide the design of future studies. Biological parameters emphasized include the status, distribution, and trends of aquatic biota; the condition of aquatic and riparian habitat, and the response of aquatic biota to natural and human-associated impacts, including the level, type, and effect of contaminants.

The aquatic biota emphasized are algae, macroinvertebrates, and fish because of their potential role as indicators of water quality and their potential role in contaminant analyses. Information on selected semiaquatic amphibians and reptiles, birds, and mammals is also presented to provide a more thorough assessment of aquatic biota in the Willamette Basin. Additional emphasis is placed on species designated as "special status species" by regulatory agencies.

The 12,000 square-mile Willamette Basin includes 15 major subbasins in 5 ecoregions. It also includes between 9,000 and 10,000 miles of streams and over 2,000 lakes. Elevations range from near sea level to approximately 11,500 feet. Land use is primarily forest and agriculture. The drainage system is dominated by the northward flowing Willamette River. Streamflow in the Willamette River and its major tributaries is highly regulated by dams and reservoirs that were constructed primarily for hydroelectric power generation.

The Willamette Basin contains a diversity of aquatic environments. High-elevation, headwater streams in the Cascade and Coast Range Mountains are high-gradient, fast-flowing, shallow, cold water streams. Streams and rivers of the lowlands are lowgradient, deep water habitats. Additionally, large water bodies, such as lakes and reservoirs, vary from nutrient-poor, low-productivity montane lakes to highly productive warm water lakes in the lowlands.

Considerable information is available on aquatic biota in the Willamette Basin, although the information is highly uneven relative to taxa and spatial scope. There is extensive information on high profile taxa such as salmonid fishes, but less information is available for macroinvertebrates, and relatively little data have been collected for algae. Additionally, some areas such as the H.J. Andrews Experimental Forest and the main stem Willamette River have been extensively studied, whereas there are limited data available for most other areas.

Information on the abundance and distribution of algae in the Willamette Basin is limited primarily to the main stem Willamette River and a few sites in other Willamette Valley streams and rivers. Diatoms were the dominant algae in the Willamette River in the 1960s and 1970s, but recent sampling as part of the Willamette River Basin Water Quality Study indicate that blue-green algae are important.

The basin supports a diverse aquatic macroinvertebrate fauna. Available data indicate a relatively high diversity of taxa and a high richness of EPT (Ephemeroptera, Plecoptera, Trichoptera) taxa in the upper reaches of the basin. In the lower main stem reaches, invertebrate assemblages are dominated by pollution tolerant organisms and those adapted to low dissolved oxygen levels. Extensive long-term studies by Oregon State University researchers at H.J. Andrews Experimental Forest, Berry Creek, and Oak Creek provide the most thorough information on macroinvertebrate diversity and abundance in the basin.

Approximately 61 fish species occur in the basin, although nearly half are introduced. They include nine anadromous species (primarily salmonids) and members of 16 families. Several species have special Federal status, including Oregon chub (endangered), lower Columbia River coho salmon (proposed threatened), bull trout (candidate), and river lamprey and Pacific lamprey (species of concern). Two additional salmonids, fall chinook salmon and coastal cutthroat trout, are considered critical by the State of Oregon.

The occurrence, distribution, and abundance of fish in the Willamette Basin have changed since human occupation, primarily due to habitat degradation, dams and other fish passage issues, hatcheries, and introduced species. Fish species richness and distribution are highly correlated with elevation, stream gradient, and water temperature. High elevation, cold water, mountain streams are characterized by a few species of salmonids, sculpin, suckers, and whitefish. Low elevation, main stem reaches of major rivers and streams are dominated by warm water species, such as bass, catfish, and several species in the panfish group. Many of the lowland rivers and lakes are now dominated by introduced warm water species.

Semiaquatic wildlife in the basin include a few species of mammals; numerous birds, such as waterfowl, shorebirds, herons, and gulls; and several species of frogs, salamanders, and turtles. These taxa are con- 
spicuous and important biota in aquatic communities, often as top predators, and some species, such as bald eagle and osprey, may be useful as indirect biological indicators of water quality. Twenty-one semiaquatic wildlife species have been designated as "special status species."

The effect of an expanding human presence in the Willamette Basin has substantially altered aquatic and riparian habitats, and the biota that use or reside in these habitats. Construction of dams, channelization and bank stabilization of rivers, species introductions, supplementations of fisheries through aquaculture, agricultural practices, timber harvest, and urbanization have contributed to changes in aquatic habitats and biota from historical conditions.

The extent of impacts on aquatic biota has been most apparent in declining populations of anadromous salmonids. Dam construction has resulted in the inundation and physical blockage of approximately 400 miles of salmonid spawning and rearing habitat. Development of fish passage facilities at dams and supplementation of native populations with hatchery fish have attempted to restore native runs. However, the successes have been minimal, and several species/stocks are extinct or at a moderate to high risk of extinction.

A variety of aquatic toxicological investigations, primarily focusing on fish, have been undertaken in the Willamette Basin. Two comprehensive investigations and several smaller studies have been conducted on the main stem Willamette River and selected tributaries. The Willamette River has also been included in several national contaminant studies administered by the U.S. Environmental Protection Agency and U.S. Fish and Wildlife Service. These studies have addressed chlorinated pesticides, polychlorinated biphenyls (PCBs), dioxins and furans, polycyclic aromatic hydrocarbons (PAHs), and trace elements in tissues of aquatic biota, as well as fish health assessments, skeletal abnormalities, and aquatic toxicological responses. Several pesticides exceeded USEPA and State water-quality criteria for the protection of aquatic life. Elevated PCB, dioxin, and furan concentrations were associated with point sources, such as pulp and paper mills. PAHs were seldom detected in fish. Elevated levels of mercury in fish tissue were associated with reservoirs in watersheds containing cinnabar deposits and in which there have been mercury and gold mining activities. Assessments of fish health indicated that abnormalities were higher in the main stem Willamette River than in its tributaries. Background skeletal deformity rates of about 3 percent were not uncommon in the main stem Willamette River, with abnormalities reaching 74 percent in the Newberg Pool. Bioassays, enzyme induction assays, growth assays, and biomarker studies have generally produced mixed results, with no indication of substantial contaminant impacts.

Contaminant information on semiaquatic wildlife is generally lacking, with the exception of a few site-specific studies. Concentrations of $p, p^{\prime}$-dichlorodiphenyldichloroethylene (DDE) at levels that could impair productivity have been reported in great blue heron eggs and a chick from Albany along the main stem Willamette River. Mercury concentrations that are associated with reproductive impairment have also been reported in a bald eagle egg from Cottage Grove Lake. Ongoing investigations include an examination of endocrine disruptors in fish, contaminants in osprey and great blue herons, and a summary of historical and current mercury concentrations in Oregon lakes.

\section{REFERENCES}

Abernethy, A.S., 1886, Salmon in the Clackamas River: U.S. Fish Commission Bulletin, v. 6, p. 332.

Aho, R.S., 1976, A population study of the cutthroat trout in an unshaded and shaded section of stream: Corvallis, Oregon State University, M.S. thesis, 87 p.

Alabaster, J.S., 1988, The dissolved oxygen requirements of upstream migrant chinook salmon, Oncorhynchus tshawytscha, in the lower Willamette River, Oregon: Journal of Fish Biology, v. 32, p. 635-636.

Allen, S.M., and Curtis, L.R., 1991, An ecoregion approach to mercury dynamics in three Oregon reservoirs: Corvallis, Oregon, unpublished final report submitted to Oregon Department of Environmental Quality, 24 p.

Anderson, C.W., Rinella, F.A., and Rounds, S.A., 1996, Occurrence of selected trace elements and organic compounds and their relation to land use in the Willamette River Basin, Oregon: U.S. Geological Survey WaterResources Investigations Report 96-4234, 68 p.

Anderson, D.W., and Hickey, J.J., 1972, Eggshell changes in certain North American birds: Proceedings of the International Ornithological Congress, v. 15, p. 514-540.

Anderson, N.H., 1976, The distribution and biology of the Oregon Trichoptera: Corvallis, Oregon State University, Agricultural Experiment Station Technical Bulletin, v. $134,152 \mathrm{p}$.

1992, Influence of disturbance on insect communities in Pacific Northwest streams: Hydrobiologia, v. 248, p. 79-92. 
Anderson, N.H., and Bourne, J.R., 1974, Bionomics of three species of glossosomatid caddisflies (Trichoptera:Glossosomatidae) in Oregon: Canadian Journal of Zoology, v. 52, p. 405-411.

Anderson, N.H., Cooper, G.M., and Denning, D.G., 1982, Invertebrates of the H.J. Andrews Experimental Forest, western Cascades, Oregon-II, An annotated checklist of caddisflies (Trichoptera): U.S. Forest Service, Pacific Northwest Forest and Range Experiment Station, Research Note PNW-402, November, 15 p.

Anderson, N.H., and Hansen, B.P., 1987, An annotated check list of aquatic insects collected at Berry Creek, Benton County, Oregon, 1960-1984: Corvallis, Oregon State University, Systematic Entomology Laboratory, Occasional Publication no. 2, September, 13 p.

Anderson, N.H., and Lehmkuhl, D.M., 1968, Catastrophic drift of insects in a woodland stream: Ecology, v. 49, no. 2, p. 198-206.

Anderson, N.H., Sedell, J.R., Roberts, L.M., and Triska, F.J., 1978, The role of aquatic invertebrates in processing of wood debris in coniferous forest streams: The American Midland Naturalist, v. 100, p. 64-82.

Anderson, N.H., and Wold, J.L., 1972, Emergence trap collections of Trichoptera from an Oregon stream: Canadian Entomology, v. 104, p. 189-201.

Anthony, R.G., Meslow, R.C., and deCalesta, D.S., 1987, The role of riparian zones for wildlife in westside Oregon forests-What we know and what we don't know: NCASI Technical Bulletin, no. 514, p. 5-12.

Applegarth, J.S., 1994, Wildlife surveying and monitoring methods - amphibians and reptiles of the Eugene District: Eugene, Oregon, Bureau of Land Management, August, 59 p.

Armantrout, N.B., and Shula, B., 1975, An inventory of fisheries and habitat on the Blue River Ranger District: Blue River, Oregon, U.S. Forest Service, Willamette National Forest, unpublished report, 4 p. and apps.

Azam, R.M., 1969, Life history and production studies of Sialis californica and Sialis rotunda (Megaloptera: Sialidae): Corvallis, Oregon State University, Ph.D. dissertation, $111 \mathrm{p}$.

Bain, M.B., 1992, Study designs and sampling techniques for community-level assessment of large rivers, in Biological assessments in large rivers-Fifth annual technical information workshop: Louisville, Kentucky, North American Benthological Society Publication, p. 63-69.

Ball, E.E., 1946, The seasonal succession of stoneflies (Plecoptera) in Willamette Valley trout streams: Corvallis, Oregon State University, M.S. thesis.

Baker, C.F., Shigematsu, D.T., Koskinen, H., and Shibahara, T., 1995, Where are all the fish? A resident fish distribution field verification study in the Clackamas River sub-basin, Clackamas County, Oregon, in 1994 Accomplishments Report for Clackamas River Fisheries Working Group: U.S. Forest Service, Mt. Hood
National Forest and Pacific Northwest Research Station, p. 4-42.

Baker, C.O., 1979, The impacts of log jam removal on fish populations and stream habitat in western Oregon: Corvallis, Oregon State University, M.S. thesis, 86 p.

Barbour, M.T., Stribling, J.B., and Karr, J.R., 1995, The multimetric approach for establishing biocriteria and measuring biological condition, in Davis, W., and Simon, T.P., eds., biological assessment and criteria-Tools for water resource planning and decision making: Boca Raton, Florida, Lewis Publishers, p. 63-80.

Beak Consultants, Inc., 1985, Sandy River instream flow study, Portland, Oregon, unpublished report submitted to the City of Portland, 67 p. and apps.

1993, Evaluation of the effects of water withdrawal on fisheries resources in Bull Run Lake, OregonImplications regarding the future use of the lake as a municipal water supply: unpublished report submitted to the City of Portland, $45 \mathrm{p}$.

1994, West Eugene parkway and beltline highwayCapture and recapture of western pond turtles: Portland, Oregon, unpublished report submitted to Oregon Department of Transportation, $20 \mathrm{p}$.

Beal, K., and Thaut, D., 1994, Western pond turtle survey, trapping, and telemetry report-Fern Ridge Reservoir: Portland, Oregon, U.S. Army Corps of Engineers, unpublished report, $70 \mathrm{p}$.

Beamsderfer, R.C., and Reiman, B.E., 1991, Abundance and distribution of northern squawfish, walleyes, and smallmouth bass in John Day Reservoir, Columbia River: Transactions of the American Fisheries Society, v. 120, p. 439-447.

Beecher, H.A., Dott, E.R., and Fernan, R.F., 1988, Fish species richness and stream order in Washington State streams: Environmental Biology of Fishes, v. 22, no. 3, p. 193-209.

Bennett, D.E., 1982, Fish passage at Willamette Falls in 1981: Portland, Oregon Department of Fish and Wildlife, Anadromous Fish Section, Annual report from January 1 to December 31, 1981, 17 p.

1985, 1984 Willamette River spring chinook salmon run: Portland, Oregon Department of Fish and Wildlife, Columbia River Management, 36 p.

1995, 1994 Willamette River spring chinook salmon run: Portland, Oregon Department of Fish and Wildlife, Columbia River Management, 47 p.

Blaustein, A.R., Beatty, J.J., Olson, D.H., and Storm, R.M., 1995, The biology of amphibians and reptiles in oldgrowth forests in the Pacific Northwest: U.S. Forest Service, Pacific Northwest Research Station, General Technical Report PNW-GTR-337, 98 p.

Blaustein, A.R., and Wake, D.B., 1990, Declining amphibian populations-A global phenomena?: Trends in Ecological Evaluations, v. 5, p. 203-204. 
Blaustein, A.R., Wake, D.B., and Sousa, W.P., 1994, Amphibian declines-Judging stability, persistence, and susceptibility of populations to local and global extinction: Conservation Biology, v. 8, p. 60-71.

Bledsoe, L.J., Somerton, D.A., and Lynde, C.M., 1989, The Puget Sound runs of salmon-An examination of changes in run size since 1986, in Levings, C.D., Holtby, L.B., and Henderson, M.A., eds., Proceedings of the National Workshop on Effects of Habitat Alteration on Salmonid Stocks: Canadian Special Publication of Fish Aquatic Science, v. 105, p. 50-61.

Blinn, T., Swanson, F.J., and McKee, A., 1988, Research publications of the H.J. Andrews Experimental Forest, Cascade Range, Oregon —-1988 supplement: U.S. Forest Service, General Technical Report PNW-GTR223, 26 p.

Blus, L.J., 1996, DDT, DDD, and DDE in birds, in W.N. Beyer, G.H. Heinz, and A.W. Redmon-Norwood, eds., Environmental contaminants in wildlife: New York, New York, Lewis Publishers, p. 49-71.

Bond, C.E., 1963, Distribution and ecology of freshwater sculpins, genus Cottus, in Oregon: Ann Arbor, University of Michigan, Ph.D. dissertation, $186 \mathrm{p}$.

Bond, C.E., and Long, J.J., 1984, Status of the Oregon chub, (Hybopsis crameri): Proceedings of the Annual Conference of Western Fish and Wildlife Agencies: v. 64, p. 483-486.

Bond, C.E., Rexstad, E., and Hughes, R.M., 1988, Habitat use twenty-five species of Oregon freshwater fishes: Northwest Science, v. 65, no. 2, p. 223-232.

Bonn, B.A., Hinkle, S.R., Wentz, D.A., and Uhrich, M.A., 1995, Analysis of nutrient and ancillary water-quality data for surface and ground water of the Willamette Basin, Oregon, 1980-90: U.S. Geological Survey Water-Resources Investigations Report 95-4036, 88 p.

Bottom, D.L., Howell, P.J., and Rodgers, J.D., 1985, The effects of stream alterations on salmon and trout habitat in Oregon: Portland, Oregon Department of Fish and Wildlife, $70 \mathrm{p}$.

Buchanan, D.V., Hooten, R.M., and Morin, J.R., 1981, Northern squawfish (Ptychocheilus oregonensis) predation on juvenile salmonids in sections of the Willamette River basin, Oregon: Canadian Journal of Fisheries and Aquatic Sciences, v. 38, no. 3, p. 360-364.

Buchanan, D.V., and Wade, M.G., 1982, Development and assessment of steelhead in the Willamette River basin: Portland, Oregon Department of Fish and Wildlife, Fish Division, Progress report, 23 p.

Buhler, D.R., Claeys, R.R., and Shanks, W.E., 1973, Mercury in aquatic species from the Pacific Northwest, in Buhler, D.R., ed., Mercury in the western environment: Corvallis, Oregon State University, p. 59-75.
Bullock, S.C., Carter, L.M., and Cramer, D.P., 1988, Timothy Lake Recreational Plan-Limnological assessment and factors limiting fish production: Portland, Oregon, Portland General Electric Company, 29 p.

Burns, G.W., 1993, A limnological analysis of ten mountain lakes: Portland, Oregon, Portland State University, M.S. thesis, 137 p.

Bury, R.B., 1988, Habitat relationships and the ecological importance of amphibians and reptiles, in Raedeke, K., ed., Proceedings of the Symposium, Streamside Management - Riparian Wildlife and Forestry Interactions: Seattle, Washington, University of Washington, p. 61-76.

Bury, R.B., and Holland, D.C., in press, Clemmys marmorata (Baird and Girard 1852), western pond turtle, in Rhodin, A., and Pritchard, P., eds., Conservation biology of freshwater turtles: IUCN Special Publication.

Bury, R.B., and Whelan, J.A., 1984, Ecology and management of the bullfrog: U.S. Fish and Wildlife Service, Resource Publication 155, 23 p.

Carter, L.M., 1975, The effect of human activity on the middle course of the Tualatin River, Oregon: Portland, Oregon, Portland State University, Ph.D. dissertation, $166 \mathrm{p}$.

Carter, L.M., Petersen, R.R., and Roe, D.K., 1976, An assessment of the effects of low-flow augmentation and improved sewage treatment on the lower reaches of the Tualatin River during the dry weather season of 1976: Portland, Oregon, Portland State University, Department of Environmental Science and Research, 85 p.

Cassirer, E.F., Breault, A., Clarkson, P., Genter, D.L., Goudie, R.I., Hunt, B., Latta, S.C., Mittelhauser, G.H., McCollough, M., Schirato, G., and Wallen, R.L., 1993, Status of harlequin ducks (Histronicus histronicus) in western North America: Lewiston, Idaho, Harlequin Duck Working Group, 83 p.

Center for Population Research and Census, 1992, Population estimates for Oregon 1980-1981: Portland, Oregon, Portland State University, $22 \mathrm{p}$.

$\mathrm{CH}_{2} \mathrm{M}$ Hill, 1994, Final northwestern pond turtle biological evaluation for the Beltline Highway, Eugene: Eugene, Oregon, unpublished report submitted to the City of Eugene, 56 p.

Chilcote, M.W., Leider, S.A., and Loch, J.J., 1984, Kalama River salmonid studies-1983 annual progress report: Olympia, Washington Department of Game, Fish Management Division Report 84-5, 131 p.

Christenson, J.R., and Larrison, E.J., 1982, Mammals of the Pacific Northwest-A pictoral introduction: Moscow, Idaho, University Press of Idaho, $166 \mathrm{p}$.

Clady, M.D., 1971, The biology of the winter steelhead of the Willamette River, Oregon, Progress Memorandum: Oregon State Game Commission, Research Division, Fisheries No. 5., September, 31 p. 
Clarke, S.E., White, D., and Schaedel, A.L., 1991, Oregon, USA, ecological regions and subregions for water quality management: Environmental Management, v. 15, no. 6 , p. 847-856.

Clifton, D.G., 1985, Analysis of biological data collected in the Bull Run watershed, Portland, Oregon, 1978 to 1983: U.S. Geological Survey Water-Resources Investigations Report 85-4245, 62 p.

Cohen, P., Alley, W.M., and Wilber, W.G., 1988, National water-quality assessment-Future directions of the U.S. Geological Survey: Water Research Bulletin, v. 46 , no. 6 , p. 1147-1151.

Collins, M.D., 1968, Escapement of salmon and steelhead over Willamette Falls, spring 1967: Portland, Fish Commission of Oregon, $16 \mathrm{p}$.

1974, Fish resources and management of the Sandy and Hood River systems within the Mt. Hood planning unit: Portland, Fish Commission of Oregon, Division of Management and Research, $55 \mathrm{p}$.

Connolly, P.J., Wade, M.G., Hutchison, J.M., and Ziller, J.S., 1991, Coast Fork Willamette subbasin fish management plan: Portland, Oregon Department of Fish and Wildlife, $54 \mathrm{p}$.

1992a, Long Tom subbasin fish management plan: Portland, Oregon Department Fish and Wildlife, 32 p.

-1992b, Middle Fork Willamette subbasin fish management plan: Portland, Oregon Department Fish and Wildlife, $77 \mathrm{p}$.

Corkran, C.C., 1995, Wetland Wildlife Watch annual program report, 1994: Portland, Oregon, Northwest Ecological Research Institute, unpublished report \#95-01, submitted to Mt. Hood National Forest, 4 p., 4 apps.

Corn, P. S., and Bury, R.B., 1989, Logging in western Oregon: responses of headwater habitats and stream amphibians: Forest Ecology and Management, v. 29, p. 39-57.

Craig. J.A., and Suomela, A.J., 1940, A survey of the Sandy River and its tributaries, 1940, with reference to fish management: U.S. Fish and Wildlife Service Special Science Report No. 14, 20 p.

Craig, J.A., and Townsend, L.D., 1946, An investigation of fish maintenance in relation to the Willamette Valley Project: U.S. Fish and Wildlife Service Special Science Report No. 33, 78 p.

Cramer, D.P., and Cramer, S.P., 1994, Status and population dynamics of coho salmon in the Clackamas River: Portland, Oregon, Portland General Electric Company, Technical Report, 105 p., 8 apps.

Crawford, J.K., and Luoma, S.N., 1993, Guidelines for studies of contaminants in biological tissues for the National Water-Quality Assessment Program: U.S. Geological Survey Open-File Report 92-492, 69 p.
Curtis, L.R., Carpenter, H.M., Donohoe, R.M., Williams, D.E., Hedstrom, O.R., Deinzer, M.L., Bellstein, M.A., Foster, E., and Gates, R., 1993, Sensitivity of cytochrome P450-1A1 induction in fish as a biomarker for distribution of TCDD and TCDF in the Willamette River, Oregon: Environmental Science and Technology, v. 27, no. 10, p. 2149-2157.

Curtis, L.R., and Siddens, B., 1995, Study of teratogenic qualities of whole effluent and Willamette River water near river mile 56: Corvallis, Oregon State University, Department of Fisheries and Wildlife, 10 p., 1 app.

DeCew, M.G., 1969, The Marion Forks hatchery steelhead trout rearing program and life history study of adult steelhead returning to Minto Pond: Portland, Oregon, Fish Commission of Oregon, $24 \mathrm{p}$.

Delarm, M.R.,Wold, E., and Smith, R.Z., 1989, Columbia River fisheries development program fishways and stream improvement projects: National Marine Fisheries Service, Technical Memorandum F/NWR-20, 78 p.

Deschamps, G., 1952, Bio-indices of pollution in the Willamette River: Corvallis, Oregon State College, M.S. thesis, $98 \mathrm{p}$.

Dever, J.E., 1962, Plant production in a woodland stream under controlled conditions: Corvallis, Oregon State University, M.S. thesis, 62 p.

Diamond, J.M., 1982, Stream geomorphology and benthic habitat predictability as determinants of the population dynamics and life history of the snail Juga plicifera: Journal of Freshwater Ecology, v. 6, no. 1, p. 577-588.

Dieterich, M., 1992, Insect community composition and physicochemical processes in summer-dry headwater streams of western Oregon: Corvallis, Oregon State University, Ph.D dissertation, 191 p.

Dimick, R.E., and Merryfield, F., 1945, The fishes of the Willamette River system in relation to pollution: Corvallis, Oregon State College, Engineering Experiment Station Bulletin Series No. 20, 58 p.

Dodge, K.L, 1994, Patterns of temporal and spatial habitat use by sympatric speckled dace (Rhinichthys osculus) and longnose dace (Rhinichthys cataractae) in an Oregon Cascades stream: Corvallis, Oregon State University, M.S. thesis, $101 \mathrm{p}$.

Dodge, K.L., and Armantrout, N.B., 1994, Mohawk/ McGowan watershed analysis-Fish habitat assessment: Eugene, Oregon, Bureau of Land Management, 15 p. and apps.

Downey, T.W., Homolka, K., and Day, W.H., 1993, Willamette River salmon studies: Portland, Oregon Department of Fish and Wildlife, Annual Progress Report, F-119-R-8, 21 p.

Dudley, T.L, 1982, Population and production ecology of Lipsothrix sp. (Diptera:Tipulidae): Corvallis, Oregon State University, M.S. thesis, 161 p. 
Dudley, T.L., and Anderson, N.H., 1982, A survey of invertebrates associated with wood debris in aquatic habitats: Melanderia, v. 39, p. 1-21.

-1987, The biology and life cycles of Lipsothrix sp. (Diptera: Tipulidae) inhabiting wood in western Oregon streams: Freshwater Biology, v. 17, p. 437-451.

EA Engineering, Science and Technology, Inc., 1990a, A study of the aquatic insects of the lower McKenzie River, Oregon: Lafayette, California, EA Engineering, Science and Technology, Inc., 17 p., 4 apps.

1990b, Fish passage studies at Leaburg Dam, McKenzie River, Oregon: Lafayette, California, EA Engineering, Science and Technology, Inc., 14 p., 1 app.

1991a, Evaluation of riparian vegetation along the lower McKenzie River, Lane County, Oregon: Lafayette, California, EA Engineering, Science and Technology, Inc., 22 p.

-1991b, Radio-tracking studies of adult spring chinook salmon migration behavior in the McKenzie River, Oregon: Lafayette, California, EA Engineering, Science and Technology, Inc., 18 p. and apps.

Earnest, R.D., 1967, Production of the snail Oxytrema silicula (Gould) in an experimental stream: Corvallis, Oregon State University, M.S. thesis, 51 p.

Eisler, R., 1987, Mercury hazards to fish, wildlife, and invertebrates-A synoptic review: U.S. Fish and Wildlife Service Biological Report, v. 85, no. 1.10, 90 p.

Ellingson, L., 1988, Inventory of great blue heron colonies in the Willamette River basin, Oregon, 1988: Corvallis, Oregon Cooperative Wildlife Research Unit, unpublished report submitted to Oregon Department of Fish and Wildlife, 9 p., 3 apps.

English, S.M., 1978, Distribution and ecology of Great blue heron colonies on the Willamette River, Oregon, in Sprunt A., Ogden, J.C., and Winkler, S. eds., Wading Birds: Natural Academy of Science Resource Report No. 7, p. 235-244.

Everest, F.H., Reeves, G.H., Sedell J.R., Wolfe, J., Hohler, D., and Heller, D.A., 1985, Abundance, behavior, and habitat utilization by coho salmon and steelhead trout in Fish Creek, Oregon, as influenced by habitat enhancement: Portland, Oregon, Bonneville Power Administration, Division of Fish and Wildlife, Annual Report, Project No. 84-11, contract No. DE-A17985BP16726, $100 \mathrm{p}$.

Everest, F.H. and Sedell, J.R, 1983, Natural propagation and habitat improvement, V. 1, Oregon Supplement A-Evaluation of fisheries enhancement projects on Fish Creek and Wash Creek: Portland, Oregon, Bonneville Power Administration, Division of Fish and Wildlife, Final Report, contract No. DE-A17983BP11968, 98 p.
Farr, R.A., and Ward, D.L., 1993, Fishes of the Lower Willamette River near Portland, Oregon: Northwest Science, v. 67, no. 1, p. 16-22.

Fetrow Engineering and Scientific Resources, 1989, Natural resource assessment-Delta Ponds, Eugene, Oregon: Lake Oswego, Oregon, Fetrow Engineering, Eugene and Science Research, Prepared for City of Eugene, 34 p. and apps.

Finger, T.R., 1982, Interactive segregation among three species of sculpins (Cottus): Copeia 1982, v. 3, p. 680-694.

Fish, F.F., and Rucker, R.R., 1948, Pollution in the lower Columbia Basin in 1948 with particular reference to the Willamette Basin: U.S. Fish and Wildlife Service, Special Science Report, Fisheries No. 30, 22 p.

Fishman Environmental Services, 1994, Final Northwestern pond turtle biological evaluation: Portland, Oregon, Environmental Services Division, unpublished report submitted to Oregon Department of Transportation, $27 \mathrm{p}$.

Forbes, R.B., Paquet, P.J., Perry,C.B., and Willis, R, 1976, Revetment clearing - Its influence on riparian wildlife communities: Portland, Oregon, final report submitted to the U.S. Army Corps of Engineers, Portland District.

Forest Ecosystem Management Assessment Team, 1993, Forest ecosystem management-An ecological, economic, and social assessment: Washington, D.C., U.S. Department of the Interior, U.S. Department of Agriculture, U.S. Department of Commerce, and U.S. Environmental Protection Agency, [variously paginated].

Foster, C.A., 1991, Fish passage at Willamette Falls in 1990: Portland, Oregon Department of Fish and Wildlife, Columbia River Management, Annual Report, 33 p.

Franklin, J.F., and Dyrness, C.T., 1973, Natural vegetation of Oregon and Washington: U.S. Forest Service, General Technical Report PNW-GTR-8, 417 p.

Frazier, P.A., 1989, Fish passage at Willamette Falls in 1988 - Annual report, January 1, - December 31, 1988: Portland, Oregon Department of Fish and Wildlife, Columbia River Management, 29 p.

Frest, T.J., and Johannes, E.J., 1993, Mollusc species of special concern within the range of the northern spotted owl: Seattle, Washington, Deixis Consultants, final report to Forest Ecosystem Management Working Group, 98 p.

Friesen, T.A., Neill, T.C., Ward, D.L., and Morrow, S.T., 1994, Distribution of fish and crayfish, and measurement of available habitat in the Tualatin River Basin: Clackamas, Oregon Department of Fish and Wildlife, Columbia River Coordination Program, $21 \mathrm{p}$.

Friesen, T.A., and Ward, D.L., 1996, Status and condition of fish assemblages in streams of the Tualatin River Basin, Oregon: Northwest Science, v. 70, no. 2, p. 120-130. 
Frissell, C.A., Corrarino, C.A., and Liss, W.J., 1985, Stream habitat, timber harvest, and distribution of cutthroat trout (Salmo clarki) in an Oregon Cascades streamApplication of a geomorphic habitat classification system: Corvallis, Oregon State University, M.S. thesis, $103 \mathrm{p}$.

Furnish, J.L., 1989, Factors affecting the growth, production, and distribution of the stream snail Juga silicula: Corvallis, Oregon State University, Ph.D. dissertation, 205 p.

Gaddis, P., and Corkran, C., 1985, Distribution and ecology of native turtles: Portland, unpublished report submitted to Oregon Department of Fish and Wildlife, 14 p.

Galbreath, J.L., 1965, Timing of the Willamette River spring chinook salmon through the lower Columbia River: Portland, Oregon, Fish Commission of Oregon, Research Briefs, v. 11, no. 1, p. 29-41.

Garrett, M., Anthony, R.G., Watson, J.W., and McGarigal, K., 1988, Ecology of bald eagles on the Lower Columbia River: U.S. Army Corps of Engineers contract No. DACW57-83-C-0100, 189 p.

Geiger, N.S., 1986, Submersed aquatic plant monitoring in the Columbia River Basin: Cheney, Washington, Paper presented at the 59th Annual Meeting of the Northwest Scientific Association, Eastern Washington University, $8 \mathrm{p}$.

Geiger, N.S., Foster, L., and Mulvihill, E.L., 1983, Blue Lake Clean Lakes Program -Phase I Diagnostic/ Feasibility Study: Portland, Oregon, prepared by Beak Consultants, Inc., for Multnomah County Department of Environmental Services, [variously paginated].

Gibbons, D.R., and Salo, E.O., 1973, An annotated bibliography of the effects of logging on fish of the western United States and Canada: U.S. Forest Service General Technical Report PNW-10, 145 p.

Gill, C.D., and Fisk, D.M., 1966, Vertebral abnormalities in sockeye, pink, and chum salmon: Transactions of the American Fisheries Society, v. 95, p. 177-182.

Gladson, J., 1979, The crayfish, Oregon's freshwater lobster: Oregon Wildlife, p. 3-7.

Gleeson, G.W., 1936, A sanitary survey of the Willamette River from Sellwood Bridge to the Columbia River: Corvallis, Oregon State University, Engineering Experiment Station Bulletin No. 6, 32 p.

1972, The return of a river-The Willamette River, Oregon: Corvallis, Oregon State University, Water Resources Research Institute, WRRI-13, 103 p.

Gleeson, G.W., and Merryfield, F., 1936, Industrial and domestic wastes of the Willamette Valley: Corvallis, Oregon State University, Engineering Experiment Station Bulletin No. 7, 63 p.

Goede, R. W., 1988, Fish health/condition assessment procedures: Logan, Utah Division of Wildlife Resources, Fisheries Experiment Station, $28 \mathrm{p}$.
1991, Fish health/condition assessment procedures: Logan, Utah Division of Wildlife Resources, Fisheries Experiment Station, 24 p. and apps.

Goede, R. W., and Barton, B.A., 1990, Organismic indices and an autopsy-based assessment as indicators of health and condition of fish: American Fisheries Society Symposium v. 8, p. 93-108.

Goetz, F.A., 1989, Biology of the bull trout, Salvelinus confluentus; a literature review: Eugene, Oregon, unpublished report submitted to the U.S. Forest Service, Willamette National Forest, $53 \mathrm{p}$.

1994, Distribution and juvenile ecology of the bull trout Salvelinus confluentus in the Cascade mountains: Corvallis, Oregon State University, M.S. thesis, 173 p.

Gomez, D.M., 1992, Small mammal and herptofauna abundance in riparian and upslope areas of five forest conditions: Corvallis, Oregon State University, M.S. thesis, $118 \mathrm{p}$.

Grafius, E.J., 1977, Bioenergetics and strategies of some Trichoptera in processing and utilizing allochthonous materials: Corvallis, Oregon State University, Ph.D dissertation, $186 \mathrm{p}$.

Grafius, E., and Anderson, N.H., 1979, Population dynamics, bioenergetics, and role of Lepidostoma quercina (Trichoptera:Lepidostomatidae) in an Oregon woodland stream: Ecology, v. 60, no. 2, p. 433-441.

Gregory, S.V., 1980, Effects of light, nutrients, and grazing on periphyton communities in streams: Corvallis, Oregon State University, Ph.D dissertation, 151 p. 1993, Willamette River Basin Study—Periphyton algal dynamics: Corvallis, Oregon State University, final report prepared for Oregon Department of Environmental Quality, Department of Fish and Wildlife, $112 \mathrm{p}$.

Gregory, S.V., Lamberti, G.A., and Moore, K.M.S, 1989, Influence of valley floor landforms on stream ecosystems, in D.L., Abell, ed., Proceedings for the California Riparian Systems Conference: Berkeley, California, U.S. Forest Service General Technical Report PSW110, p. 3-8.

Gregory, S.V., Swanson, F.J., McKee, W.A., and Cummins, K.W., 1991, An ecosystem perspective of riparian zones: Bioscience v. 41, p. 540-551.

Grenfell, R.A., 1962, Warm-water game fish: Oregon State Game Commission, Fish Division Annual Report 1962, p. 369-379.

Gunsolus, R.T., and Eicher, G.J., 1970, Evaluation of fish passage facilities at the North Fork of the Clackamas River in Oregon: Portland, Oregon, Fish Commission of Oregon and Portland General Electric Company, unpublished report, $104 \mathrm{p}$.

Gurtz, M.E., 1993, Design of biological components of the National Water-Quality Assessment (NAWQA) Program, in Loeb, S.L., and Spacie, A., eds., Biological monitoring of freshwater ecosystems: Boca Raton, Florida, Lewis Publishers, p. 1-22. 
Hall, J.D., and Baker, C.O., 1982, Rehabilitating and enhancing stream habitat-1. Review and evaluation-Influence of forest and rangeland management on anadromous fish habitat in western North America: U.S. Forest Service General Technical Report PNW$138,29 \mathrm{p}$.

Hall, J.D., and Knight, N.J., 1981, Natural variation in abundance of salmonid populations in streams and its implications for design of impact studies: U.S. Environmental Protection Agency, Ecological Research Service, EPA-600/53-81-9-021.

Halse, R., and Dennis-Johnston, L,1981, Draft reconnaissance report-Aquatic plant control: Portland, Oregon, U.S. Army Corps of Engineers, 21 p. and apps.

Hankin, D.G., and Reeves, G.H., 1988, Estimating total fish abundance and total habitat area in small streams based on visual estimation methods: Canadian Journal of Fisheries and Aquatic Science, v.45, p.834-844.

Hansen, H.L., 1977, Stock assessment and enhancement of fall salmon species in the Willamette River system: Portland, Oregon Department of Fish and Wildlife, Fish Division, Federal Aid Progress Report, 33 p.

Hansen, H.L., and, Williams, R.H., 1979, Stock assessment and enhancement of fall salmon species in the Willamette River system: Portland, Oregon Department of Fish and Wildlife, Fish Division, Federal Aid Progress Report, 28 p.

Hansmann, E.W., and Phinney, H.K., 1973, Effects of logging on periphyton in coastal streams of Oregon: Ecology, v. 54, p.194-199.

Hardin-Davis, Inc., 1988, A habitat survey of the McKenzie River from Leaburg Dam to the Walterville tailrace: Eugene, Oregon, prepared for Eugene Water and Electric Board, 4 p. and apps.

Hart Crowser, 1988, Volumes I and II, remedial action plan, Station "L" site, Willamette River sediments: Portland, Oregon, prepared for Portland General Electric Company, J-1942-07, v. 1, 79 p., 7 apps.

Hasselman, R., and Garrison, R., 1957, Studies on the squawfish (Ptychocheilus oregonensis) in Lookout Point and Dexter Reservoirs, 1957: U.S. Fish and Wildlife Service, unpublished Report, $41 \mathrm{p}$.

Hawk, G.M., and Zobel, D.B., 1974, Forest succession on alluvial landforms of the McKenzie River valley: Oregon, Northwest Science, v. 48, p. 245-265.

Hawkins, C.P., and Furnish, J.K., 1987, Are snails important competitors in stream ecosystems?: Oikos, v. 49, p. 209-220.

Hawkins, C.P., Murphy, M.L., and Anderson, N.H., 1982, Effects of canopy, substrate composition, and gradient on the structure of macroinvertebrate communities in the Cascade Range streams of Oregon: Ecology, v. 63, no. 6, p. 1840-1856.

Hawkins, C.P., Murphy, M.L., Anderson, N.H., and Wilzbach, M., 1983, Density of fish and salamanders in relation to riparian canopy and physical habitat in streams of the northwestern United States: Canadian Journal of Fisheries and Aquatic Science, v. 40, no. 8, p. 11731185 .

Hawkins, C.P., and Sedell, J.R, 1981, Longitudinal and seasonal changes in functional organization of macroinvertebrate communities in four Oregon streams: Ecology, v. 62 , no. 2 , p. 387-397.

Hayes, M.P., 1994, The spotted frog in western Oregon: Oregon Department of Fish and Wildlife, Wildlife Diversity Program, Technical Report 94-1-01, 30 p., 2 apps.

Hayes, M.P., and Jennings, M.R., 1986, Decline of ranid frog species in western North America - Are bullfrogs (Rana catesbeiana) responsible?: Journal of Herpetology, v. 20, p. 490-509.

Hayslip, G.A., 1993, U.S. Region 10 instream biological monitoring handbook: Seattle, U.S. Environmental Protection Agency, Region 10, Environmental Protection Division, $75 \mathrm{p}$.

Healey, M., 1984, Fish predation on aquatic insects, in Resh, V.H., and Rosenberg, D.M. eds., The ecology of aquatic insects: New York, Praeger Publishers, p. 196-254.

Heinz, G.H., 1979, Methylmercury-Reproductive and behavioral effects on three generations of mallard ducks: Journal of Wildlife Management, v. 53, no. 2, p. 418-428.

Heller, D.A., and Baker, C., 1974, An inventory of fisheries and habitat on selected forest streams: Willamette National Forest, 215 p.

Henderson, C., Johnson, W.L., and Inglis, A., 1969, Organochlorine insecticide residues in fish, 1967-1968: Pesticides Monitoring Journal, v. 3, p. 145-171.

Henny, C.J., and Bethers, M.R., 1971, Population ecology of the great blue heron with special reference to western Oregon: Canadian Field-Naturalist, v. 85, p. 205-209.

Henny, C.J., Collins, J.A., and Deibert, W.J., 1978, Osprey distribution, abundance, and status in western North America-The Oregon population: Murrelet v. 59, p. 14-25.

Henny, C.J., and Kaiser, J.L., 1996, Osprey population increase along the Willamette River, Oregon, and the role of utility structures, 1976-1993, in Bird, D.M., Varland, D.E., and Negro, J.J., eds., Raptor adaptations to human influenced environments: London, Academic Press, p. 97-108.

Herb, G.A., 1972, Effects of low flows below Big Cliff Reservoir, North Santiam River, on fish and other aquatic organisms: Portland, Oregon State Game Commission, Environmental Investigations, Special Report No. 4, $17 \mathrm{p}$.

Hicks, B.J., Hall, J.D., Bisson, P.A., and Sedell, J.R., 1991, Responses of salmonids to habitat changes, in Meehan, W.R. ed., Influences of forest and rangeland management on salmonid fishes and their habitats: Bethesda, Maryland, American Fisheries Society Special Publication 19, p. 453-518. 
Higgins, P., Dobush, S., and Fuller, D., 1992, Factors in northern California threatening stocks with extinction: American Fisheries Society, unpublished Report of Humbolt Chapter, 25 p.

Hines, W.G., McKenzie, S.W., Rickert, D.A., and Rinella, F.A., 1977, Dissolved-oxygen regimen of the Willamette River, Oregon, under conditions of basin-wide secondary treatment: U.S. Geological Survey Circular 715-I.

Hirsch, R.M., Alley, W.M., and Wilber, W.G, 1988, Concepts for a National Water-Quality Assessment Program: U.S. Geological Survey Circular 1021, 42 p.

Hjort, R.C., Hulett, P.L., LaBolle, L.D., and Li, H.W., 1984, Fish and invertebrates of revetments and other habitats in the Willamette River, Oregon: Vicksburg, Mississippi, Technical Report E-84-9, Oregon State University for U.S. Army Corps of Engineers, Waterways Experiment Station, $116 \mathrm{p}$.

HMS Environmental, Inc., and Miller, R.A., 1988, Biological sampling of aquatic organisms in the Willamette River above and below the Pope \& Talbot, Inc., bleached kraft pulp and paper plant, Halsey, Oregon: Portland, Oregon, HMS Environmental, Inc., and TAXON Aquatic Monitoring Company, preliminary report, $15 \mathrm{p}$.

Hoffman, D.J., Rattner, B.A., Burton, G.A. Jr., and Cairns, J. Jr., 1995, Handbook of ecotoxicology: Boca Raton, Florida, Lewis Publishers, CRC Press, Inc., 755 p.

Holland, D.C., 1991, A synopsis of the ecology and status of the western pond turtle (Clemmys marmorata): San Simeon, California, final report to the U.S. Fish and Wildlife Service, 180 p.

1994, The western pond turtle-Habitat and history: Portland, Oregon Department of Fish and Wildlife, prepared for Bonneville Power Administration, contract No. DE-BI79-92BP62137.

Holmes, H.B., and Bell, M.C., 1960, A study of the upstream passage of anadromous fish at Willamette Falls, with recommendations for improvements in fish-passage facilities: Portland, Oregon, report submitted to the Oregon Fish Commission, 126 p. and apps.

Homolka, K., and Downey, T.W., 1995, Assessment of the thermal effects on salmon spawning and fry emergence, upper McKenzie River, 1992: Portland, Oregon Department of Fish and Wildlife, Fish Division, Information Report 95-4, $31 \mathrm{p}$.

House, R., 1995, Temporal variation in an isolated population of cutthroat trout in western Oregon, 1981-1991: North American Journal of Fisheries Management, v. 15 , p. 33-41.

Howell, P.J., 1986, Willamette Basin fish management plan-Status and progress 1979-1985: Oregon Department of Fish and Wildlife, $47 \mathrm{p}$.

Howell, P., Hutchison, J., and Hooten, R., 1988, McKenzie subbasin fish management plan: Oregon Department of Fish and Wildlife, 109 p.
Hreha, L.H., 1967, The relationship between size of juvenile coho salmon and their time of emigration from three Oregon reservoirs: Oregon State Game Commission, Fish Commission, Research Briefs, v. 13, no. 1, p. $87-101$.

Huff, E.S., and Klingeman, P.C., 1976, Restoring the Willamette River-Costs and impacts of water quality control: Journal of the Water Pollution Control Federation, v. 48 , p. 2410-2415.

Huggett, R.J, Kimerle, R.A., Mehrle, P.M. Jr., and Bergman, H.L., (eds.), 1992, Biomarkers-Biochemical, physiological, and histological markers of anthropogenic stress: Chelsea, Michigan, Lewis Publishers, SETAC Special Publications Series, 347 p.

Hughes, R. M., and Gammon, J.R., 1987, Longitudinal changes in fish assemblages and water quality in the Willamette River, Oregon: Transactions of the American Fisheries Society, v. 116, p. 196-209.

Hughes, R.M., Larsen, D.P., and Omernik, J.M., 1986, Regional reference sites-A method for assessing stream potentials: Environmental Management, v. 10, no. 5, p. 629-635.

Hughes, R.M., Rexstad, E., and Bond, C.E., 1987, The relationship of aquatic ecoregions, river basins, and physiographic provinces to the ichthyogeographic regions of Oregon: Copiea, 1987, v. 2, p. 423-432.

Huntington, C.W., Nehlsen, W., and Bowers., J., 1994, Healthy native stocks of anadromous salmonids in the Pacific Northwest and California: Portland, Oregon Trout, 42 p., 3 apps.

Hutchison, J.M., and Aney, W.W., 1964, The fish and wildlife resources of the Lower Willamette Basin, Oregon, and their water use requirements: Oregon State Game Commission, Basin Investigations Section, report submitted to Oregon State Water Resources Board, 76 p.

Hutchison, J.M., Thompson, K.E., and Fortune, J.D. Jr., 1966a, The fish and wildlife resources of the upper Willamette Basin, Oregon, and their requirements: Portland, Oregon State Game Commission, 44 p.

Hutchison, J.M., Thompson, K.E., and Hattan, G.J., 1966b, Number and distribution of steelhead trout spawning in the Willamette Basin in 1966: Portland, Oregon State Game Commission, 17 p.

Ingram, P., and Korn, L., 1969, Evaluation of fish passage facilities at Cougar Dam on the South Fork of the McKenzie River in Oregon: Clackamas, Fish Commission of Oregon, U.S. Army Corps of Engineers contract No. DA-35-026-CIVEN G-64-295, 76 p.

International Joint Commission United States and Canada, 1988, Great Lakes Water Quality Agreement: Ottawa, Canada, Amended by protocol signed November 18, 1987.

Jackson, J.E. Jr., 1973, Thermal fidelity of blue-green algae: Eugene, University of Oregon, M.S. thesis, 73 p.

Johnson, B.M., Miller, R.A., Ellis, S.G., and VanSickle, J., 1989, Biological monitoring of aquatic organisms in the Willamette River above and below the Pope \& 
Talbot, Inc., bleached kraft pulp and paper plant, Halsey, Oregon: Portland, Oregon, HMS Environmental, Inc., and TAXON Aquatic Monitoring Company, 58 p.

Johnson, D.M., Peterson, R.R., Lycan, D.R., Sweet, J.W., Neuhaus, M.E., and Schaedel, A.L., 1985, Atlas of Oregon Lakes: Corvallis, Oregon State University Press, $317 \mathrm{p}$.

Kammerer, 1990, Largest Rivers in the United States: U.S. Geological Survey Open-File Report 87-242, 2 p.

Karr, J.R., 1991, Biological integrity-A long-neglected aspect of water resource management: Ecological Applications, v. 1, no. 1, p. 66-84.

Karr, J.R., Fausch, K.D., Angermeier, P.L., Yant, P.R., and Schlosser, I.J., 1986, Assessing biological integrity in running waters-A method and its rationale: Urbana, Illinois Natural History Survey, Special publication 5.

Kelly, R.W., 1951, A preliminary ecological survey of a temporary pond in a Douglas-fir forest association with emphasis on the food and feeding habitats of the Oregon newt, Triturus granulosus granulosus: Eugene, University of Oregon, M.S. thesis, 43 p.

Kendra, W., 1991, Quality of salmonid hatchery effluent during a summer low-flow season: Transactions of the American Fisheries Society, v. 120, p. 43-51.

Kerst, C.D., 1969, The seasonal occurrence and distribution of stoneflies (Plecoptera) of a western Oregon stream: Corvallis, Oregon State University, M.S. thesis, 80 p.

Kerst, C.D., and Anderson, N.H., 1974, Emergence patterns of Plecoptera in a stream in western Oregon, USA: Freshwater Biology, v. 4, p. 205-212.

-1975 , The plecoptera community of a small stream in Oregon, USA: Freshwater Biology, v. 5, p. 189-203.

Kirk, J.J., 1983, Distribution of the Larch Mountain salamander (Plethodon larselli) in Oregon-With notes on other plethodons: Oregon Department of Fish and Wildlife, Nongame Wildlife Program, Technical Report 83-7-01, $30 \mathrm{p}$.

-1988, Western spotted frog (Rana pretrosa) mortality following forest spraying of DDT: Herpetological Review, v. 19, p. 51-53.

Knutsen, C.J., and Ward, D.L., 1991, Behavior of juvenile salmonids migrating through the Willamette River near Portland, Oregon: Oregon Department of Fish and Wildlife, Fish Division, Information Report No. 91-5, $17 \mathrm{p}$.

Korn, L., Hreha, L.H., Montagne, R.G., Mullarkey, W.G., and Wagner, E.J., 1967, The effect of small impoundments on the behavior of juvenile anadromous salmonids: Portland, Oregon, Fish Commission of Oregon, Research Division, $127 \mathrm{p}$.

Koski, R.O., 1971, Stocking of trout and salmon by watershed, 1970: Portland, Oregon State Game Commission, May 1975, $50 \mathrm{p}$.

Kraft, G.F., 1963, Seasonal occurrence and distribution of insects in Berry Creek: Corvallis, Oregon State University, Ph.D. dissertation, 122 p.
Kruse, A.E., 1988, Relationships between fish species distribution and habitat in the Willamette River drainage in western Oregon: Corvallis, Oregon State University, M.S. thesis, $95 \mathrm{p}$.

Kuehl, D.W., Butterworth, B.C., McBride, A., Kroner, S., and Bahnick, D., 1989, Contamination of fish by 2,3,7,8-tetrachlorodibenzo-p-dioxin-A survey of fish from major watersheds in the United States: Chemosphere, v. 18, no. 9/10, p. 1997-2014.

Lamberti, G.A., Gregory, S.V., Askenas, L.R., Wildman, R.C., and Moore, K.M.S., 1991, Stream ecosystem recovery following a catastrophic debris flow: Canadian Journal of Fisheries and Aquatic Science, v. 48, p. 196-208.

Lampman, B.H., 1946, The coming of the pond fishes: Portland, Oregon, Binfords and Mort Publishers, $177 \mathrm{p}$.

Langton, C.V., and Rodgers, H.S., 1929, Preliminary report on control of stream pollution in Oregon: Corvallis, Oregon State University, Engineering Experiment Station Bulletin Series No. 1, 23 p.

Latta, S.C., 1992, Distribution and status of the harlequin duck (Histronicus histronicus) in Oregon: Eugene, Oregon, U.S. Forest Service, Willamette National Forest, unpublished report, 11 p., 2 apps.

Lawson, P.W., 1993, Cycles in ocean productivity, trends in habitat quality, and the restoration of salmon runs in Oregon: Fisheries, v. 18, no. 8, p. 6-10.

Leahy, P.P., Rosenshein, J.S., and Knopman, D.S., 1990, Implementation plan for the National Water-Quality Assessment Program: U.S. Geological Survey OpenFile Report 90-174, 10 p.

Lehmkuhl, D.M., 1968, Observations on the life history of four species of Epeorus in western Oregon (Ephemeroptera: Heptageniidae): Pan-Pacific Entomologist, v. 44, p. 128-137.

1969, Biology and downstream drift of some Oregon Ephemeroptera: Corvallis, Oregon State University, M.S. thesis, $110 \mathrm{p}$.

Lehmkuhl, D.M., and Anderson, N.H., 1970, Observations of the biology of Cinygmula reticulata McDunnough in Oregon (Ephemeroptera:Heptageniidae): Pan-Pacific Entomologist, v. 46, p. 268-274.

1971, Contributions to the biology and taxonomy of the Paraleptophlebia of Oregon (Ephemeroptera: Leptophlebidae): Pan-Pacific Entomologist, v. 47, p. 85-93.

Leonard, W.P., Brown, H.A., Jones, L.L.C., McAllister, K.R., and Storm, R.M., 1993, Amphibians of Washington and Oregon: Seattle, Washington, Seattle Audubon Society, $168 \mathrm{p}$.

Li, J., and Gregory, S.V., 1993, Issues surrounding the biota of the Tualatin River Basin: Corvallis, Oregon State University, Water Resources Research Institute, Tualatin River Basin Water Resources Management Report No. 8, 37 p. 
Li, H.W., and Moyle, P.B., 1981, Ecological analysis of species introductions into aquatic ecosystems: Transactions of the American Fisheries Society, v. 110, p. 772782.

Li, H.W., Schreck, C.B., Bond, C.E., and Rexstad, E., 1987, Factors influencing changes in fish assemblages of Pacific Northwest streams, in Matthews, W.J., and Hines, D.C., eds., Community and evolutionary ecology of North American stream fishes: Norman, University of Oklahoma Press, p. 193-202.

Li, H.W., Schreck, C.B., and Tubb, R.A., 1984, Comparison of habitats near spur dikes, continuous revetments, and natural banks for larval, juvenile, and adult fishes of the Willamette River: Corvallis, Oregon State University, Water Resources Research Institute, WRRI-95, 15 p.

Li, H.W., Schreck, C.B., Tubb, R.A., Rodnick, K., Alhgren, M., and Crook, A., 1983, The impact of small-scale dams on fishes of the Willamette River, Oregon and an evaluation of fish habitat models: Corvallis, Oregon State University, Water Resources Research Institute, WRRI-91, $81 \mathrm{p}$.

Lichatowich, T., 1981, Steelhead injury observations at the Portland General Electric's (PGE) Sullivan Plant: Corvallis, unpublished report of Oregon Department of Fish and Wildlife Research, 9 p.

Lippert, B.E., 1957, Plant succession and algal periodicity in temporary ponds of the Willamette Valley: Eugene, University of Oregon, M.S. thesis, 64 p.

Logan, D., Bibles, E.L., and Markle, D.F., in press, Recent collections of continental exotic fishes in Oregon and thermal tolerance of Misgurnus anguillicaudatus and Piaractus brachypomus: California Fish and Game.

Long, J.J., 1982, Status of the Oregon chub (Hybopsis crameri) on the Lowell Ranger District, Willamette National Forest: Corvallis, Oregon State University, unpublished final report submitted to the U.S. Forest Service, Willamette National Forest, Order No. 4304R-1-00049, 21 p.

Lowe, T.P., and Pan, Yangdong, 1996, Benthic algal communities as biological monitors, in Stevenson, R.J., Bothwell, M.L., and Lowe, R.L., eds., Algal ecologyFreshwater benthic systems: New York, Academic Press, p. 705-739.

Lowe, T.P., May, T.W., Brumbaugh, W.G., and Kane, D.A., 1985, National Contaminant Biomonitoring Program-Concentrations of seven elements in freshwater fish, 1978-1981: Archives of Environmental Contaminants and Toxicology, v. 14, p. 363-388.

Lyford, J.H. Jr., and Gregory, S.V., 1975, The dynamics and structure of periphyton communities in three Cascade Mountain streams: Verh. Inter. Ver. Limnology, v. 19, p. 1610-1616.
MacDonald, L.H., Smart A.W., and Wissmar, R.C., 1991, Monitoring guidelines to evaluate effects on streams in the Pacific Northwest and Alaska: Seattle, U.S. Environmental Protection Agency, Region 10, EPA 910/991-001, $166 \mathrm{p}$.

Mangum, F.A., 1990, Aquatic ecosystem inventory macroinvertebrate analysis: Frog Creek and Still Creek, Zigzag Ranger District, Mt. Hood National Forest, 1989-90: Provo, Utah, U.S. Forest Service, Intermountain Region, 47 p.

1991a, Aquatic ecosystem inventory macroinvertebrate analysis: Bureau of Land Management, Eugene District, 1991: Provo, Utah, U.S. Forest Service, Intermountain Region, 102 p.

1991b, Aquatic ecosystem inventory macroinvertebrate analysis: Bureau of Land Management, Salem District, 1991: Provo, Utah, U.S. Forest Service, Intermountain Region, 37 p.

Markle, D.F., 1994a, Oregon State University catalog of fishes: Corvallis, Department of Fisheries and Wildlife, $10 \mathrm{p}$.

1994b, Evaluation of fish identifications for the Willamette River Basin Water Quality Study Phase II-Skeletal deformities in northern squawfish: Portland, unpublished report prepared for Oregon Department of Environmental Quality, 14 p.

Markle, D.F., Pearsons, T.N., and Bills, D.T., 1989, Taxonomic status and distributional survey of the Oregon Chub: Corvallis, Oregon State University, Department of Fisheries and Wildlife, unpublished final report submitted to Oregon Department of Fish and Wildlife, $29 \mathrm{p}$.

1991, Natural history of Oregonichthys (Pices: Cyprinidae), with a description of a new species from the Umpqua River of Oregon: Copiea 1991, v. 2, p. 277-293.

Marshall, D.L., 1989, Status of the spotted frog in Oregon: Portland, final report for the Oregon Department of Fish and Wildlife, $12 \mathrm{p}$.

Marshall, D.B., Chilcote, M., and Weeks, H., 1996, Species at risk-Sensitive, threatened, and endangered vertebrates of Oregon, 2d ed.: Portland, Oregon Department of Fish and Wildlife.

Mason, J.C., 1963, Life history and production of the crayfish, Pacifastacus leniusculus trowbridgii (Stimpson), in a small woodland stream: Corvallis, Oregon State University, M.S. thesis, 204 p.

Massey, J.B., 1965, Determine timing as to daily and seasonal distribution of the downstream migration of young salmon and steelhead through the Willamette Falls Industrial Area: Portland, Oregon State Game Commission, Progress Report, 17 p. 
1967a, The downstream migration of juvenile anadromous fish at Willamette Falls, Oregon: Portland, Oregon State Game Commission, Fishery Division, Columbia River Fishery Development Program Progress Report, $17 \mathrm{p}$.

-1967b, Summary report on juvenile downstream migrant fish passage and protection studies at Willamette Falls, Oregon: Portland, Oregon State Game Commission, Columbia River Fishery Development Program Final Report, 59 p.

Mattson, C.R., 1962, Early life history of Willamette River spring chinook salmon: Portland, Fish Commission of Oregon, $50 \mathrm{p}$.

1963, An investigation of adult spring chinook salmon of the Willamette River system, 1946-1951: Portland, Fish Commission of Oregon, 39 p.

Mattson, C.R., and Dimick, J.B., 1952, The 1950 Willamette River spring chinook sport fishery: Fish Communities of Oregon Research Briefs, v. 4, no. 1, p. 31-39.

May, T.W., and McKinney, G.L., 1981, Cadmium, lead, mercury, arsenic, and selenium concentrations in freshwater fish, 1976-77-National Pesticide Monitoring Program: Pesticides Monitoring Journal, v. 15, no. 1, p. 14-38.

Mayer, F. L.,Versteeg, D. J., McKee, M.J., Folmar, L.C., Graney, R.L., McCume, D.C., and Rattner, B.A., 1992, Physiological and nonspecific biomarkers, in Huggett, R.J., Kimerle, R.A., Mehrle, P.M., and Bergman, H.L., eds., Biomarkers-Biochemical, physiological, and histological markers of anthropogenic stress: Chelsea, Michigan, Lewis Publishers, p. 5-85.

McAllister, K.R., Leonard, W., and Storm, R.M., 1993, Spotted frog (Rana pretiosa) surveys in the Puget Trough of Washington, 1989-1991: Northwestern Naturalist, v. 74, p. 10-15.

McComb, W.C., Chambers, C.L., and Newton, M., 1993, Small mammal and amphibian communities and habitat association in red alder stands, central Oregon Coast Range: Northwest Science, v. 67, no.3, p. 181-188.

McIntosh, B.A., Clarke, S.E., and Sedell., J.R., 1995, Summary report for Bureau of Fisheries stream habitat surveys Willamette River Basin 1934-1942: Corvallis, U.S. Forest Service, Pacific Northwest Research Station, $476 \mathrm{p}$.

McIntyre, J.D., 1967, Food relations and production of cutthroat trout, Salmo clarki clarki Richardson, in an experimental stream: Corvallis, Oregon State University, M.S. thesis, 68 p.

McKee, A., Stonedahl. G.M., Franklin, G.M., Frederick, J., (comps.), 1987, Research publications of the H.J. Andrews Experimental Forest, Cascade Range, Oregon, 1948 to 1986: Portland, U.S. Forest Service, General Technical Report PNW-GTR-201, 74 p.
McKernan, D.L., Johnson, D.R., and Hodges, J.I,. 1950, Some factors influencing the trends of salmon populations in Oregon, in Transactions of the 15th North American Wildlife Conference: Washington, D.C., Wildlife Management Institute, p.427-449.

McKernan, D.L., and Mattson, C.R., 1950, Observations on pulp and paper effluents and the probable effects of this pollutant on the fisheries resources of the Willamette River in Oregon: Fish Commission of Oregon, Research Briefs, v. 3, no.1, p. 14-21.

Meador, M.R., Hupp, C.R., Cuffney, T.F., and Gurtz, M.E., 1993, Methods for characterizing stream habitat as part of the National Water-Quality Assessment Program: U.S. Geological Survey Open-File Report 93-408, $48 \mathrm{p}$.

Meehan, W.R., 1991, Influences of forest and rangeland management on salmonid fishes and their habitats: Bethesda, Maryland, American Fisheries Society Special Publication 19, $751 \mathrm{p}$.

Melancon, M.J., 1995, Bioindicators used in aquatic and terrestrial monitoring, in D.J. Hoffman, B.A. Rattner, G.A. Burton, Jr., and J. Cairns, Jr., eds., Handbook of ecotoxicology: Boca Raton, Florida, Lewis Publishers, CRC Press, Inc., p. 220-240.

Merritt, R.W., Cummins, K.W., and Burton, T.M., 1984, The role of aquatic insects in the processing and cycling of nutrients, in Resh, V.H., and Rosenberg, D.M., eds., The ecology of aquatic insects: New York, Praeger Publishers, p. 134-163.

Merryfield, F., and Wilmot, W.G., 1944, Oxygen-block in the mainstem Willamette River: U.S. Fish and Wildlife Service, Special Science Report—Fisheries, No. 41, $19 \mathrm{p}$.

1945, 1945 progress report on pollution of Oregon streams: Corvallis, Oregon State University, Engineering Experiment Station Bulletin Series No. 19, $62 \mathrm{p}$.

Miller, R.A., Huntington, C., Hardin, T., and Garton, R., 1991, The biological resources of the Willamette River-Oxygen requirements of the most sensitive life forms and the application to the river of dissolved oxygen criteria and standards: Corvallis, Oregon, TAXON Aquatic Monitoring Company, Clearwater BioStudies Inc., Hardin-Davis Inc., and Garton Enterprises Inc., prepared for Association of Oregon Sewerage Agencies, $52 \mathrm{p}$.

Miller, T.L., 1979, Water-quality data from five Oregon stream basins: U.S. Geological Survey Open-File Report 79-1535, 98 p.

Minear, P.J., 1994, Historical change in channel form and riparian vegetation of the McKenzie River, Oregon: Corvallis, Oregon State University, M.S. thesis, 175 p. 
Mitchell, P.A., 1968, The food of the dipper on two western Montana streams: Missoula, University of Montana, M.A. thesis, $82 \mathrm{p}$.

Moore, K.M.S., 1987, Ecology of aquatic habitats associated with stream margins: Corvallis, Oregon State University, M.S. thesis, 130 p.

Moore, K.M.S., and Gregory, S.V., 1989, Geomorphic and riparian influences on the distribution and abundance of salmonids in a Cascade mountain stream, in Abell, D.L., ed., Proceedings California Riparian Systems Conference: Berkeley, U.S. Forest Service General Technical Report PSW-10, p. 256-261.

Moring, J.R., 1976, Catchable rainbow trout evaluation: Portland, Oregon Department of Fish and Wildlife, Federal Aid Progress Report F-94-R, 93 p.

1982, An efficient hatchery strain of rainbow trout for stocking Oregon streams: North American Journal of Fisheries Management, v. 2, no. 3, p. 209-215.

Moring, J.R., Youker, R.L., and Hooton, R.M., 1986, Movements of potamodromous coastal cutthroat trout Salmo clarki clarki, inferred from tagging and scale analyses: Fisheries Research, v. 4, p. 343-354.

Moyle, P.B., 1986, Fish introductions into North America-Patterns and ecological impacts, in Mooney, H.A., and Drake, J.A., eds., Ecology of biological invasions of North America and Hawaii: New York, SpringerVerlag Publishers, p. 27-43, (Reprinted from Ecological Studies, v. 58).

1994, The decline of anadromous fishes in California: Conservation Biology, v. 8, no. 3, p. 869-870.

Mulvey, M., L. Caton, and Hafele, R., 1992, Oregon nonpoint source monitoring protocols, stream bioassessment field manual for macroinvertebrates and habitat assessment: Portland, Oregon Department of Environment Quality, 39 p.

Murphy, M.L., and Hall, J.D., 1981, Varied effects of clearcut logging on predators and their habitat in small streams of the Cascade Mountains, Oregon: Canadian Journal of Fisheries and Aquatic Science, v. 38, p. 137145.

Murphy, M.L., Hawkins, C.P., and Anderson, N.H., 1981, Effects of canopy modification and accumulated sediment on stream communities: Transactions of the American Fisheries Society, v. 110, p. 469-478.

Murtagh, T., Rohrer, R., Gray, M., Olsen, E., Rien, T., and Massey, J., 1992a, Clackamas subbasin fish management plan: Portland, Oregon Department of Fish and Wildlife, $174 \mathrm{p}$.

Murtagh, T., Niles-Raethke, V., Rohrer, R., Gray, M., Rien, T., and Massey, J., 1992b, Tualatin River subbasin fish management plan: Oregon Department of Fish and Wildlife, $68 \mathrm{p}$.
Mysak, L.A., 1986, El Nino, interannual variability and fisheries in the Pacific Ocean: Canadian Journal of Fisheries and Aquatic Sciences, v. 43, p. 464-497.

Naiman, R.J., Decamps, H., Pastor, J., and Johnston, C.A., 1988, The potential importance of boundaries to fluvial ecosystems: Journal of North American Benthological Society, v. 7, p. 289-306.

Nehlsen, W., Williams, J.E., and Lichatowich, J.A., 1991, Pacific salmon at the crossroads-Stocks at risk from California, Oregon, Idaho, and Washington: Fisheries, v. 16 , no. 2, p. 4-21.

Nicholas, J.W., 1978, A review of literature and unpublished information on cutthroat trout of the Willamette watershed: Portland, Oregon Department of Fish and Wildlife, Information Report, Fisheries, no.78-1, 28 p.

Nicholas, J.W., Reisenbichler, R.R., and McIntyre, J.D., 1978, Genetic implications of stocking hatchery trout on native trout populations: Corvallis, Oregon, Proceedings of the wild trout and catchable trout symposium, J.L. Moring, ed., p. 189-192.

Nickelson, T.E., 1974, Population dynamics of coastal cutthroat trout in an experimental stream: Corvallis, Oregon State University, M.S. thesis, 38 p.

Nickelson, T.E., and Lichatowich, J.A., 1983, The influence of the marine environment on the interannual variation in coho salmon abundance-An overview, in Pearcy, W.G., ed., The influence of ocean conditions on the production of salmonids in the North Pacific, a workshop: Corvallis, Sea Grant College Program, Oregon State University, ORESU-W-83-001, p. 24-36.

Nickelson, T.E., Nicholas, J.W., McGie, A.M., Lindsay, R.B., Bottom, D.L., Kaiser, R.J, and Jacobs, S.E., 1992, Status of anadromous salmonids in Oregon coastal basins: Corvallis, Oregon Department of Fish and Wildlife, $83 \mathrm{p}$.

Nickelson, T.E., Solazzi, M.F., and Johnson, S.L., 1986, Use of hatchery coho salmon (Oncorhynchus kisutch) presmolts to rebuild wild populations in Oregon coastal streams: Canadian Journal of Fisheries and Aquatic Sciences, v. 43, no. 12, p. 2443-2449.

Nobel, R.E., 1952, The Willamette River fishes as biological indicators of pollution: Corvallis, Oregon State University, M.S. thesis, $131 \mathrm{p}$.

Northwest Power Planning Council, 1986, Compilation of information on salmon and steelhead losses in the Columbia Basin: Portland, Northwest Power Planning Council, $251 \mathrm{p}$.

Nussbaum, R.A., Brodie Jr., E.D., Storm, R.M., 1983, Amphibians and reptiles of the Pacific Northwest: Moscow, University Press of Idaho, $332 \mathrm{p}$.

Olson, D.H., 1996, Survey protocols for component/strategy 2 amphibian species: Corvallis, U.S. Forest Service, Pacific Northwest Research Station, 73 p. 
Omernik, J.M., 1987, Ecoregions of the conterminous United States: Map supplement, Annals of the Association of American Geographers, v. 77, no. 1, p. 118125.

Omernik, J.M., and Gallant, A.L., 1986, Ecoregions of the Pacific Northwest: U.S. Environmental Protection Agency, EPA/600/3-86/033, 39 p.

Oregon Department of Environmental Quality, 1988, Oregon environmental atlas: Portland, Oregon, 64 p. 1990, Oregon's 1990 water quality status assessment report [305(b) report]: Portland, Oregon Department Environmental Quality, prepared for the U.S. Environmental Protection Agency, [variously paginated].

1991, Regulations relating to water quality in Oregon, State-wide water quality management planBeneficial uses, policies, standards, and treatment criteria for Oregon: Oregon Administrative Rules, Chapter 340, Division 4.

1992, Oregon's 1992 water quality status assessment report [305(b) report]: Portland, Oregon Department of Environmental Quality, prepared for U.S. Environmental Protection Agency, [variously paginated].

1994a, Oregon's 1994 water quality status assessment report [305(b) report]: Portland, Oregon Department of Environmental Quality, prepared for U.S. Environmental Protection Agency, [variously paginated].

-1994b, Willamette River toxics study, 1988-1991: Portland, Water Quality Division, 10 p, 5 apps.

1996, Mercury in Oregon lakes: Portland, Water Quality Division, [variously paginated].

Oregon Department of Fish and Wildlife, 1979, Fish Management Plan North Fork of Middle Fork of Willamette River: Portland, Oregon Department of Fish and Wildlife, Fish Division.

1980, Willamette Basin fish management plan, Oregon Department of Fish and Wildlife, Fish Division, $93 \mathrm{p}$.

1982a, Comprehensive plan for production and management of Oregon's anadromous salmon and troutPart II, Coho salmon plan: Portland, Oregon Department Fish and Wildlife, Fish Division, Anadromous Fish Section, [variously paginated], 6 apps.

1982b, Fish passage at Willamette Falls in 1981Annual Report, January 1 - December 31, 1981: Oregon Department of Fish and Wildlife, Fish Division, Anadromous Fish Section, 17 p.

1982c, Comprehensive plan for production and management of Oregon's anadromous salmon and trout-Part I, General considerations: Portland, Oregon Department of Fish and Wildlife, Fish Division, Anadromous Fish Section, [variously paginated].

1985, Coho salmon plan status report: Portland, Oregon Department of Fish and Wildlife, 21 p.
1986, Comprehensive plan for production and management of Oregon's anadromous salmon and troutPart III, Steelhead plan, 1986-1992: Portland, Oregon Department of Fish and Wildlife, 57 p. and apps.

1987a, Trout plan: Portland, Oregon Department of Fish and Wildlife, $77 \mathrm{p}$.

1987b, Warmwater game fish management plan: Portland, Oregon Department of Fish and Wildlife, $60 \mathrm{p}$.

1988, Willamette Basin Fish Management Plan: Portland, Oregon Department of Fish and Wildlife, $72 \mathrm{p}$.

1990, Salmon and steelhead production plans (includes separate reports for Willamette River Basin and ten subbasins): Portland, Columbia Basin system planning, Oregon Department of Fish and Wildlife.

1991, Willamette Basin fish management plan: Portland, Oregon Department of Fish and Wildlife, [unpaginated].

1992, Conservation agreement for the Oregon Chub in the Willamette Valley, Oregon: Portland, Oregon Department of Fish and Wildlife, Oregon Department Parks and Recreation, U.S. Army Corps of Engineers, U.S. Bureau of Land Management, U.S. Fish and Wildlife Service, U.S. Forest Service, 22 p.

1993, Willamette basin implementation plan for management of spring chinook salmon: Oregon Department of Fish and Wildlife, 60 p.

1994, Oregon Rivers Information System (ORIS): Portland, Database managed by Oregon Department of Fish and Wildlife.

1995a, Aquatic inventory project-Methods for stream habitat surveys: Corvallis, Oregon Department of Fish and Wildlife, Research and Development Section, 33 p. and apps.

1995b, A study of cutthroat trout in the Mohawk River, 1992-1994: Springfield, Oregon Department of Fish and Wildlife, unpublished report, 23 p.

1995c, Comprehensive plan for production and management of Oregon's anadromous salmon and troutPart III, Steelhead trout: Portland, Oregon Department of Fish and Wildlife, Fish Division, Anadromous Fish Section, $58 \mathrm{p}$.

Oregon Natural Heritage Program, 1995, Rare, threatened, and endangered plants and animals of Oregon: Portland, Oregon Natural Heritage Program, 84 p.

Oregon State Game Commission, 1960, A study of mortalities to downstream migrant salmonid fish passed through some Willamette Falls turbines: Oregon State Game Commission, 3 p., 2 apps.

1961, Survey, investigation, and design for diversion screens on Willamette and other Columbia River tributaries in Oregon: Oregon State Game Commission, Closing Report, 44 p. 
1963, The fish and wildlife resources of the Middle Willamette Basin, Oregon, and their water use requirements: Portland, Oregon State Game Commission, Basin Investigations Section, report submitted to State Water Resources Board, 25 p., 15 apps.

Oregon Water Resources Department, 1991, Sandy River basin report: Salem, Oregon Water Resources Department, $74 \mathrm{p}$.

1992, Willamette River basin report: Salem, Oregon Water Resources Department, 350 p.

Parkhurst, Z.E., Bryant, F.G., and Nielson, R.S., 1950, Survey of the Columbia River and its tributaries Part 3: U.S. Fish and Wildlife Service, Special Science Report-Fisheries, No. 36, 103 p.

Parsons, D.R., 1975, Time and energy budgets of a population of dippers during winter in the Cascade Range of Oregon: Corvallis, Oregon State University, M.S. thesis, $29 \mathrm{p}$.

Parsons, G.L., Cassis, G., Moldenke, A.R., Lattin, J.D., Anderson, N.H., Miller, J.C., Hammond P., and Schowalter, T.D., 1991, Invertebrates of the H.J. Andrews Experimental Forest, western Cascade Range, Oregon-An annotated list of insects and other arthropods: U.S. Forest Service General Technical Report PNW290, 168 p.

Pastorok, R.A., Peek, D.C., Sampson, J.R., and Jacobson, M.A., 1994, Ecological risk assessment for river sediments contaminated by creosote: Environmental Toxicology and Chemistry, v. 13, no. 12, p. 1929-1941.

Pearson, L.S., Conover, K.R., and Haas, J.B., 1967, An evaluation of adult coho salmon transplants into Willamette River tributaries: Portland, Oregon State Game Commission, Fish Commission, Research Briefs, v. 13, no. 1, p. 25-38.

Pearsons, T.N., 1989, Ecology and decline of a rare western minnow-The Oregon Chub (Oregonichthys crameri): Corvallis, Oregon State University, M.S. thesis, 89 p.

Peloquin, E.P., 1969, Growth and reproduction of the feral nutria Myocastor coypus (Molina) near Corvallis, Oregon: Corvallis, Oregon State University, M.S. thesis, $55 \mathrm{p}$.

Pereira, C.R.D., 1980, Life history studies of Cinygma integrum Eaton (Ephemeroptera:Heptageniidae) and other mayflies associated with wood substrates in Oregon streams: Corvallis, Oregon State University, M.S. thesis, $92 \mathrm{p}$.

Perry, C.B., 1978, Bird use of revetted riverbanks in the Willamette Valley: Portland, Portland State University, M.S. thesis, $76 \mathrm{p}$.

Plafkin, J.L., Barbour, M.T., Porter, K.D., Gross, S.K., and Hughes, R.M., 1989, Rapid bioassessment protocols for use in streams and rivers-Benthic macroinvertebrates and fish: U.S. Environmental Protection Agency, EPA/444/4-89-001.
Porter, R.D., and Wiemeyer, S.N., 1969, Dieldrin and DDT - Effects on sparrow hawk eggshells and reproduction: Science, v. 16, p. 199-200.

Prescott, G.W., 1923, Studies in freshwater algae, with the description of some species in the flora of Eugene, Oregon: Eugene, University of Oregon, M.S. thesis, 73 p.

Puchy, C.A., and Marshall, D.B., 1993, Oregon wildlife diversity plan, 1993-1998: Portland, Oregon Department of Fish and Wildlife, 302 p.

Pulford, E.F., 1955, Escapement of spring chinook salmon and steelhead over Willamette Falls in 1953: Portland, Fish Commission of Oregon, Research Briefs, v. 6, no. 1, p. 19-28.

Ratcliffe, D.A., 1967, Decrease in eggshell weight in certain birds of prey: Nature, no. 215, p. 208-210.

Ratliff, D.E., and Howell, P.J., 1992, The status of bull trout populations in Oregon, in Howell, P.J., and Buchanan, D.V., eds., Proceedings of the Gearhart Mountain Bull Trout Workshop: Corvallis, Oregon Chapter of the American Fisheries Society, p. 10-17.

Raymond, R.B., 1983, The paleolimnology of Bull Run Lake- Disruption and stability in a natural system: Portland, Oregon, Portland State University, Ph.D. dissertation, $113 \mathrm{p}$.

Reese, W.H., 1966, Physiological ecology and structure of benthic communities in a woodland stream: Corvallis, Oregon State University, Ph.D. dissertation, 134 p.

Reeves, G.H., and Sedell, J.R., 1992, An ecosystem approach to the conservation and management of freshwater habitat for anadromous salmonids in the Pacific Northwest: Transactions of the North American Wildlife and Natural Research Conference, v. 57, p. 408415.

Reisenbichler, R.R., and McIntyre, J.D., 1977, Genetic differences in growth and survival of juvenile hatchery and wild steelhead trout, Salmo gairdneri: Journal of the Fisheries Research Board of Canada, v. 34, p. 123-128.

Rich, W.H., 1948, A survey of the Columbia River and its tributaries with special reference to the management of its fishery resources: U.S. Fish and Wildlife Service, Special Science Report No. 51, 25 p.

Rich, W.H., and Holmes, H.B., 1929, Experiments in marking young chinook salmon on the Columbia River, 1916 to 1927: Bulletin of the U.S. Bureau of Fisheries XLIV, p. 216-264.

Rickert, D.A., and Hines, W.G., 1975, A practical framework for river-quality assessment: U.S. Geological Survey Circular 715-A, $17 \mathrm{p}$.

Rickert, D.A., Hines, W.G., and McKenzie, S.W., 1975, Methods and data requirements for river-quality assessment: Water Resources Bulletin, v. 11, no. 5, p. 10131039 . 
Rickert, D.A., Peterson, R.R., McKenzie, S.W., Hines, W.G., and Wille, S.A., 1977, Algal conditions and the potential for future algal problems in the Willamette River, Oregon: U.S. Geological Survey Circular 715-G, 39 p.

Rien, T.A., Wevers, M.J., Massey, J., Wetherbee, J., Haxton, J., and Wade, M., 1992, Mainstem Willamette subbasin fish management plan: Portland, Oregon Department of Fish and Wildlife, 109 p.

Rinella, F.A., McKenzie, S.W., and Wille, S.A., 1981, Dissolved-oxygen and algal conditions in selected locations of the Willamette River Basin, Oregon: U.S. Geological Survey Open-File Report 81-529, 76 p.

Rinella, J.F., 1977, Lakes of Oregon: v. 5, Marion County: U.S. Geological Survey unnumbered Open-File Report, $96 \mathrm{p}$.

Rodgers, H.S., Mockmore, C.A., and Adams, C.D., 1930, A sanitary survey of the Willamette Valley: Corvallis, Oregon State University, Engineering Experiment Station Bulletin Series No. 2, 55 p.

Rodnick, K.J., 1983, Seasonal distribution and habitat selection by the redside shiner, Richardsonius balteatus, in a small Oregon stream: Corvallis, Oregon State University, M.S. thesis, $60 \mathrm{p}$.

Roth, B., 1993, Critical review of terrestrial mollusks associated with late-successional and old-growth forests in the range of the northern spotted owl: San Francisco, California, final report to the Forest Ecosystem Management Working Group, U.S. Forest Service, 42 p.

Rounick, J.S., and Gregory, S.V., 1981, Temporal changes in periphyton standing crop during an unusually dry winter in streams of the western Cascades, Oregon: Hydrobiologia, v. 83, p. 197-205.

St. John, A.D., 1987, The herpetology of the Willamette Valley, Oregon: Portland, Oregon Department of Fish and Wildlife, Nongame Wildlife Program, Technical Report 86-1-02. 41 p., 3 apps.

Sams, R.E., 1965, A study to determine the effects of the 1964-1965 floods on the fish habitat of Fish and Wash Creeks and Roaring River, tributaries of the Clackamas River: Portland, Fish Commission of Oregon, Proceedings Report, Watershed Development and Restoration, $12 \mathrm{p}$.

1973, Willamette River Development Program, Annual report: Portland, Fish Commission of Oregon, $42 \mathrm{p}$.

1977, Fish passage at Willamette Falls in 1976: Portland, Oregon Department of Fish and Wildlife Annual Report, 13 p.

Sams, R.E., and Conover, K.R., 1969, Water quality and the migration of fall salmon in the lower Willamette River: Portland, Fish Commission of Oregon, final report to the Northwest Pulp and Paper Association, 58 p.
Sanderson, R.B., Shulters, M.V., and Curtiss, D.A., 1973, Lakes of Oregon-Volume 1, Clatsop, Columbia, and Tillamook Counties: U.S. Geological Survey unnumbered Open-File Report 95 p.

Scheerer, P.D., Loerts,S., and Jones, K.K., 1995, Oregon chub investigations: Portland, Oregon Department of Fish and Wildlife, Fish Research Project, Progress Report EF-94 VII-1, 54 p.

Scheerer, P.D., Shafer, C.S., Stein, C.H., and Lones, K.K., 1992, Oregon chub investigations: Portland, Oregon Department of Fish and Wildlife, Fish Research Project, Progress Report EF-91 VII-1, 32 p.

Scheerer, P.D., Stein, C.H., and Jones, K.K., 1993, Oregon chub investigations: Portland, Oregon Department of Fish and Wildlife, Fish Research Project, Progress Report EF-92 VII-1, 41 p.

1994, Oregon chub investigations: Portland, Oregon Department of Fish and Wildlife, Fish Research Project, Progress Report EF-93 VII-1, 37 p.

Scheidt, R.C., and Nichols, J.L., 1976, Physiochemical and biological characteristics of Hills Creek Reservoir: Corvallis, Oregon State University, Water Resources Research Institute, WRRI-50, 42 p.

Schmitt, C.J., 1990, Persistent organochlorine and elemental contaminants in freshwater fish of the United States-The National Contaminant Biomonitoring Program, in Gray, R.H., ed., Environmental monitoring, restoration and assessment_-What have we learned? Proceedings of the 28th Hanford Symposium on Health and the Environment: Richland, Washington, U.S. Department of Energy, Pacific Northwest Laboratory, $342 \mathrm{p}$.

Schmitt, C.J., and Brumbaugh, W.G., 1990, National Contaminant Biomonitoring Program-Concentrations of arsenic, cadmium, copper, lead, mercury, selenium, and zinc in U.S. freshwater fish, 1976-1984: Archives of Environmental Contaminants and Toxicology, v. 19, p. 731-747.

Schmitt, C.J., Ludke, J.L., and Walsh, D.F., 1981, Organochlorine residues in fish-National Pesticide Monitoring Program, 1970-74: Pesticides Monitoring Journal, v. 14, no. 4, p. 136-206.

Schmitt, C.J., Ribick, M.A., Ludke, J.L., and May, T.W., 1983, National Pesticide Monitoring Program-Organochlorine residues in freshwater fish, 1976-79: U.S. Fish and Wildlife Service, Resource Publication 152, $62 \mathrm{p}$.

Schmitt, C.J., Zajicek, J.L., and Peterman, P.H., 1990, National Contaminant Biomonitoring Program-Residues of organochlorine chemicals in U.S. freshwater fish, 1976-1984: Archives of Environmental Contaminants and Toxicology, v. 19, p. 748-781.

Schmitt, C.J., Zajicek, J.L., and Ribick, M.A., 1985, National Pesticide Monitoring Program-Residues of organochlorine chemicals in freshwater fish, 1980-81: 
Archives of Environmental Contaminants and Toxicology, v. 14, p. 225-260.

Scott, W.B., and Crossman, E.J., 1973, Freshwater fishes of Canada: Ottawa, Fisheries Research Board of Canada, $966 \mathrm{p}$.

Sedell, J.R. and Froggatt, J.L., 1984, Importance of streamside forests to large rivers-The isolation of the Willamette River, Oregon, USA, from its floodplain by snagging and streamside forest removal: International Vereinigung fuer Theoretische und Angewandte Limnologie Verhandlungen, v. 22, p. 1828-1834.

Sedell, J.R., Reeves, G.H., Hauer, F.R., Stanford, J.A., Hawkins, C.P., 1990, Role of refugia in recovery from disturbances-Modern fragmented and disconnected river systems: Environmental Management, v. 14, p. 711-723.

Shearman, J.O., 1976, Reservoir-system model for the Willamette River Basin, Oregon: U.S. Geological Survey Circular 715-H, 22 p.

Shibahara, T., and Lumianski, J., 1995, Clackamas winter steelhead radio telemetry project, 1994, in 1994 accomplishment report for Clackamas River Fisheries Working Group: Corvallis, U.S. Forest Service, Pacific Northwest Research Station, p. 59-82.

Shulters, M.V., 1974, Lakes of Oregon-Volume 2, Benton, Lincoln, and Polk Counties: U.S. Geological Survey unnumbered Open-File Report, $71 \mathrm{p}$.

1975, Lakes of Oregon-Volume 3, Hood River, Multnomah, Washington, and Yamhill Counties: U.S. Geological Survey unnumbered Open-File Report 1975, 93 p.

-1976, Lakes of Oregon-Volume 4, Clackamas County: U.S. Geological Survey unnumbered OpenFile Report, 76 p.

Simonson, T.D., Lyons, J., and Kanehl, P.D., 1994, Guidelines for evaluating fish habitat in Wisconsin streams: St. Paul, Minnesota, U.S. Forest Service, North Central Forest Experiment Station, NC-GTR-164, 36 p.

Smith, E., 1977, Improving survival of spring chinook hatchery smolts in the Willamette River: Portland, Oregon Department of Fish and Wildlife, Fish Division, Federal Aid Progress Report, Fish, 24 p.

-1979, Improving survival of spring chinook hatchery smolts in the Willamette River: Portland, Oregon Department of Fish and Wildlife, Fish Division, Federal Aid Progress Report, Fish, 24 p.

Smith, E.M., and Korn, L., 1970, Evaluation of fish facilities and passage at Fall Creek Dam on Fall Creek in Oregon: Portland, Fish Commission of Oregon, Research Division, U.S. Army Corps of Engineers contract No. DA-35-026-CIVENG-66-400, 83 p.

Smith, J.P., and Collopy, M.W., in press: The Pacific Northwest, in Mack, M., and Opler, P., eds., National status and trends report: Washington D.C., National Biological Service.

Smith, M., 1993, A review of the Carmen-Smith spawning channel-Historical review and data analyses: Eugene, Oregon, Water and Electric Board, 16 p. and apps.

Snyder, J.O., 1908, The fishes of the coastal streams of Oregon and northern California: Bulletin of the U.S. Bureau of Fisheries, v. 27, p. 153-189.

Speir, J.A., 1976, The ecology and production dynamics of four black fly species (Diptera:Simulidae) in western Oregon streams: Corvallis, Oregon State University, Ph.D dissertation, $297 \mathrm{p}$.

Steedman, R.J., 1983, Life history and feeding role of the xylophagous aquatic beetle, Lara avara LeConte (Dryopoidea:Elmidae): Corvallis, Oregon State University, M.S. thesis, 106 p.

Steedman, R.J., and Anderson, N.H., 1985, Life history and ecological role of the xylophagous aquatic beetle, Lara avara: Freshwater Biology, v. 15, p. 535-546.

Stein, R.A., Reimers, P.E., and Hall, J.D., 1972, Social interaction between juvenile coho and fall chinook in Sixes River, Oregon: Journal of the Fisheries Research Board of Canada, v. 29, p. 1737-1748.

Sutherland, B., 1976, A biological assessment of the major tributaries of the Tualatin River using macroinvertebrates (1975-1976): Portland, Oregon Department of Environmental Quality, Technical memorandum, 11 p.

Swanson, F.J., Gregory, S.V., Sedell, J.R., and Campbell, A.G., 1982, Land-water interactions-The riparian zone, in Edmonds, R.L. ed., Analysis of coniferous ecosystems in the western United States: Stroudsburg, Pennsylvania, Hutchinson Ross Publishing Co., US/IBP Synthesis Series 14, p. 267-291.

Swanson, F.J., Lienkaemper, G.W., and Sedell, J.R., 1976, History, physical effects, and management implications of large organic debris in western Oregon streams: U.S. Forest Service, General Technical Report PNW-56, $15 \mathrm{p}$.

Tabor, J.E., 1974, Productivity, survival, and population status of the river otter in western Oregon: Corvallis, Oregon State University, M.S. thesis, $62 \mathrm{p}$.

Tetra Tech, Inc., 1992a, Willamette River Basin water quality study, Task 9-Characterization of Willamette River ecoregions: Redmond, Washington, prepared for Oregon Department of Environmental Quality, 21 p.

1992b, Willamette River Basin water quality study, Component 11-Water quality survey data: Redmond, Washington, prepared for Oregon Department of Environmental Quality, 56 p. and apps.

1992c, Willamette River Basin water quality study, Component 8-Literature review and summary of nonpoint source pollution in the Willamette River basin: Redmond, Washington, prepared for Oregon Department of Environmental Quality, 77 p. and apps. 
1992d, Willamette River Basin water quality study, Component 7-Point source discharges and waste loading to the Willamette River Basin during 1991: Redmond, Washington, prepared for Oregon Department of Environmental Quality, 61 p. and apps.

1993a, Willamette River Basin water quality study, summary report: Redmond, Washington, prepared for Oregon Department of Environmental Quality, June 30, 1993, [variously paginated].

1993b, Willamette River Basin water quality study, Component 9-Willamette River ecological systems investigation component report: Redmond, Washington, prepared for Oregon Department of Environmental Quality, 164 p. and apps.

1993c, Willamette River Basin water quality studyWillamette River nutrient and phytoplankton growth modeling component report: Redmond, Washington, prepared for Oregon Department of Environmental Quality, [variously paginated].

1993d, Willamette River Basin water quality study, Component 6-Willamette River Basin biological responses to stressors component report: Redmond, Washington, prepared for Oregon Department of Environmental Quality, 37 p. and apps.

1994, Willamette River Basin water quality study, Phase II, Ecological monitoring component-Benthic metric selection and data evaluation: Redmond, Washington, prepared for Oregon Department of Environmental Quality, 70 p. and apps.

-1995a, Willamette River Basin water quality study-A summary of recent scientific reports on the Willamette River: Redmond, Washington, prepared for Oregon Department of Environmental Quality, 14 p., 1 app.

1995b, Willamette River Basin water quality study, Phase II, Ecological monitoring component-Habitat assessment report: Redmond, Washington, prepared for Oregon Department of Environmental Quality, 62 p., 2 apps.

1995c, Willamette River Basin water quality study-Summary and synthesis of study findings: Redmond, Washington, prepared for Oregon Department of Environmental Quality, [variously paginated].

1995d, Willamette River Basin water quality study, Phase II, Ecological Monitoring Component-Assessment of aquatic communities and biological indices: Redmond, Washington, prepared for Oregon Department of Environmental Quality, [variously paginated].

Tew, M.P., 1970, The species composition and adaptations of insects in an intermittent stream in western Oregon: Corvallis, Oregon State University, M.S. thesis, 84 p.

Thompson, J., Goggans, R., Greenlee, P., and Dowlan, S., 1993, Abundance, distribution, and habitat associations of the harlequin duck (Histronicus histronicus) in the Cascade Mountains, Oregon, 1993: Portland, Oregon
Department of Fish and Wildlife, unpublished report, $37 \mathrm{p}$.

Thompson, K.E., 1965, A physical inventory of streams in the upper Willamette watershed above the confluence of the Middle and Coast Forks of the Willamette River: Portland, Oregon State Game Commission, Basin Investigations Section, Federal Aid to Fish Restoration Progress Report, Project F-69-R-2, Job No. 1., 174 p.

Thompson, K.E., Hutchison, J.M., Fortune, J.D., and Phillips, R.W., 1966, Fish resources of the Willamette Basin: Portland, Oregon State Game Commission, $161 \mathrm{p}$.

Thornber, C.H., 1965, Bank stabilization-Willamette and Columbia Rivers, in Symposium on channel stabilization problems, Volume 3: U.S. Army Corps of Engineers Technical Report No. 1.

Triska, F.J., Sedell, J.R., and Gregory, S.V., 1982, Coniferous forest streams: in Edmonds, R.L., ed., Analysis of coniferous forest ecosystems in the western U.S.:

Stroudsburg, Pennsylvania, Hutchinson Ross Publishers, US/IBP synthesis series, p. 293-332.

TW Environmental, Inc., 1994, Letter report from Steve Kucas, TW Environmental, Inc., to Janet Senior, City of Portland, Bureau of Water Works: 4 p. and attachments.

U.S. Army Corps of Engineers, 1975, Corps of Engineers actions affecting riverbanks and channels in Willamette River Basin, Oregon: Portland, Oregon, U.S. Army Corps of Engineers, Final Environmental Impact Statement, [variously paginated].

1982, Willamette River projects-Hydrologic and temperature effects, preliminary literature review and data analysis: Portland, Oregon, U.S. Army Corps of Engineers, [variously paginated].

1991a, Willamette River Basin review reconnaissance study, Volume 1: Portland, Oregon, U.S. Army Corps of Engineers, 11 p., 6 apps.

1991b, Willamette River Basin review reconnaissance study, Volume 2: Portland, Oregon, U.S. Army Corps of Engineers, Appendix E-Fish and Wildlife Studies, [variously paginated].

U.S. Environmental Protection Agency, 1986, Quality criteria for water 1986: Washington, D.C., U.S. Environmental Protection Agency 440/5-896-001, [unpaginated].

1992a, National study of chemical residues in fish: Washington, D.C., Office of Science and Technology, 2 v., (EPA 823-R-92-008a, 166 p., 2 apps., EPA 823R-92-008b, 2 apps.)

1992b, Water quality standards; establishment of numeric criteria for priority toxic pollutants; State's compliance; Final Rule: 40 CFR Part 131, v. 47, no. 246. 
-1993, Guidance for assessing chemical contaminant data for use in fish advisories, volume 1, fish sampling and analysis: Office of Water, EPA 823-R-93-002.

U.S. Fish and Wildlife Service, 1993, Endangered and threatened wildlife and plants-Determination of endangered status for the Oregon chub: Federal Register, v. 58(199):53800-53803, Final Rule.

1994a, Endangered and threatened wildlife and plants: Federal Register 50 CFR 17.11 and 17.12.

-1994b, Endangered and threatened wildlife and plants-Animal candidate review for listings as endangered or threatened species-Proposed rule: Federal Register v. 59(219).

1994c, Level II pre-acquisition contaminant survey for the south Sherwood unit of the Tualatin River National Wildlife Refuge: Portland, Oregon, U.S. Fish and Wildlife Service, $43 \mathrm{p}$.

U.S. Forest Service, 1989, Region 6 Sensitive animal list: Portland, Oregon, Interim directive No. 90-1, Chapter 2670 - Threatened, endangered, and sensitive plants and animals, [unpaginated].

1993, A first approximation of ecosystem healthNational Forest system lands, Pacific Northwest Region: Portland, U.S. Forest Service, Pacific Northwest Region, 109 p.

U.S. Public Health Service, 1964, Water pollution surveillance system-Annual compilation of data for October 1, 1962-September 30, 1963: Washington, D.C., v. 10, $179 \mathrm{p}$.

Vannote, R.L., Minshall, G.W., Cummins, K.W., Sedell, J.R., and Cushing, C.E., 1980, The river continuum concept: Canadian Journal of Fisheries and Aquatic Science v. 37, p. 130-137.

Wade, M.G., and Buchanan, D.V., 1983, Development and assessment of steelhead in the Willamette River basin: Portland, Oregon Department of Fish and Wildlife, Fish Division, Research project F-117-R-2, Progress report, $18 \mathrm{p}$.

Wagner, E., and Ingram, P., 1973, Evaluation of fish facilities and passage at Foster and Green Peter dams on the South Santiam River drainage in Oregon: Portland, Fish Commission Oregon, U.S. Army Corps of Engineers contract No. DACW-57-68-C-0013, 111 p.

Wallis, J., 1961a, An evaluation of the McKenzie River salmon hatchery: Clackamas, Oregon Fish Commission Research Laboratory, $56 \mathrm{p}$.

1961b, An evaluation of the South Santiam River salmon hatchery: Clackamas, Oregon Fish Commission Research Laboratory, $37 \mathrm{p}$.

1962a, An evaluation of the Sandy River salmon hatchery: Clackamas, Oregon Fish Commission Research Laboratory, $76 \mathrm{p}$.

1962b, An evaluation of the Willamette River salmon hatchery: Clackamas, Oregon Fish Commission Research Laboratory, 93 p.
1963, An evaluation of the North Santiam River salmon hatcheries: Clackamas, Oregon Fish Commission Research Laboratory, $66 \mathrm{p}$.

Walsh, D.F., Berger, B.L., and Bean, J.R., 1977, Mercury, arsenic, lead, cadmium, and selenium residues in fish, 1971-73 - National Pesticide Monitoring Program: Pesticides Monitoring Journal, v. 11, no. 1, p. 5-34.

Ward, D.L., Connolly, P.J., Farr, R.A., and Nigro, A.A., 1988, Feasibility of evaluating the impacts of waterway development on anadromous and resident fish in Portland Harbor: Portland, Oregon Department of Fish and Wildlife, Fish Research Project, Annual Progress Report, $58 \mathrm{p}$.

Ward, D.L., Knutsen, C.J., and Farr, R.A., 1991, Status and biology of black crappie and white crappie in the lower Willamette River near Portland, Oregon: Portland, Oregon Department of Fish and Wildlife, Fish Division, Information Report No. 91-3, 17 p.

Ward, D.L., and Nigro, A.A., 1991, Differences in fish assemblages among habitats found in the lower Willamette River, Oregon-Application of and problems with multivariate analysis: Fisheries Research v. 13 (1992), p. 119-132.

Ward, D.L., Nigro, A.A., Farr, R.A., Knutsen, C.J., 1994, Influence of waterway development on migrational characteristics of juvenile salmonids in the Lower Willamette River, Oregon: North American Journal of Fisheries Management, v. 14, p. 362-371.

Warren, C.E., Wales, J.H., Davis, G.E., and Doudoroff, P., 1964, Trout production in an experimental stream enriched with sucrose: Journal of Wildlife Management, v. 28, no.4, p. 617-660.

Wells, D.E., and Cowan, A.A., 1982, Vertebral dysplasia in salmonids caused by the herbicide trifluralin: Environmental Pollution (Series A), v. 29, p. 249-260.

Wentz, D.A., and McKenzie, S.W., 1991, National WaterQuality Assessment Program-The Willamette Basin, Oregon: U.S. Geological Survey Open-File Report 91-167, 2 p.

Wetherbee, J.J., 1962, Detroit Reservoir investigations; 1953-1961: Portland, Oregon Department of Fish and Wildlife, Central Willamette District, unpublished report, $14 \mathrm{p}$.

1965, A history of the kokanee in Detroit Reservoir: Portland, Oregon State Game Commission, unpublished report, $26 \mathrm{p}$.

Wevers, M.J., 1994, Life history and evolutionary adaptation of Pacific salmon and its application in management: Corvallis, Oregon State University, Ph.D dissertation, $128 \mathrm{p}$.

Wevers, M.J., Nemeth, D., Haxton, J., and Mamoyac, S., 1992a, Coast Range subbasin fish management plan: Portland, Oregon Department of Fish and Wildlife, $98 \mathrm{p}$. 
Wevers, M.J., Nemeth, D., and Haxton, J., 1992b, Molalla and Pudding subbasin fish management plan: Portland, Oregon Department of Fish and Wildlife, 133 p.

Wevers, M.J., Wetherbee, J., and Hunt, W., 1992c, Santiam and Calapooia subbasin fish management plan: Portland, Oregon Department of Fish and Wildlife, 174 p.

Whittier, T.R., Hughes, R.M., and Larsen, D.P., 1988, Correspondence between ecoregions and spatial patterns in stream ecosystems in Oregon: Canadian Journal of Fisheries and Aquatic Science, v. 45, p. 1264-1278.

Wiemeyer, S.N., Lamont, T.G., Bunck, C.M., Sindelar, C.R., Gramlich, F.J., Fraser, J.D., and Byrd, M.A., 1984, Organochlorine pesticide, polychlorobiphenyl, and mercury residues in bald eagle eggs, 1969-79, and their relationships to shell thinning and reproduction: Archives of Environmental Contaminants and Toxicology, v. 13, p. 529-549.

Willamette Basin Task Force, 1969, Willamette Basin comprehensive study - Water and related land resources, Appendix D_Fish and Wildlife: Willamette Basin Task Force, Pacific Northwest River Basins Commission, [variously paginated].

Wille, S.A., 1976, Influence of light on algal growth in the lower Willamette River: Portland, Oregon, Portland State University, M.A. thesis, 44 p.

Williams, R., 1981, Memo to Emery Wagner, June 1, 1981: Portland, Oregon Department of Fish and Wildlife, (Cited in Lichatowich [1981]).

1983, Releases of coho salmon into the upper Willamette River, Oregon: Corvallis, Oregon Department of Fish and Wildlife, Fish Division, Information Report 83-3, 47 p.

Willis, R.A., Collins, M.D., and Sams, R.E., 1960, Environmental survey report pertaining to salmon and steelhead in certain rivers of eastern Oregon and the Willamette River and its tributaries-Part II, Survey reports of the Willamette River and its tributaries: Clackamas, Fish Commission of Oregon, Research Division, 554 p., 3 apps.

Willis, R.E., 1981, Revetment clearing-Its influence on riparian mammal communities: Portland, Oregon, Portland State University, M.S. thesis, 47 p.

Wilzbach, M.A., 1984, Prey availability overrides cover in determining growth and abundance on stream-dwelling cutthroat trout: Corvallis, Oregon State University, Ph.D dissertation, $82 \mathrm{p}$.

Wilzbach, M.A., Cummins, K.W., and Hall, J.D., 1986, Influence of habitat manipulations on interactions between cutthroat trout and invertebrate drift: Ecology, v. 67, no. 4, p. 898-911.

Wisseman, R.W., 1989, Aquatic habitat surveys for threatened and endangered aquatic invertebrates in the vicinity of Timberline Lodge and Mt. Hood Meadows, Mt. Hood, Oregon: Corvallis, Oregon, Western Aquatic
Institute, unpublished report submitted to U.S. Forest Service, Mt. Hood National Forest.

1990, A review of the candidate, endangered, or threatened aquatic invertebrate species listed from the Mt. Hood National Forest, Oregon: Corvallis, Western Aquatic Institute, draft report, 17 p.

1992a, Near-shore benthic macroinvertebrate communities of Bull Run Lake: Corvallis, Aquatic Biology Associates, unpublished report submitted to U.S. Forest Service, Mt. Hood National Forest.

1992b, Benthic invertebrate biomonitoring, Estacada Ranger District, Mt. Hood National Forest, September 1991: Corvallis, Aquatic Biology Associates, unpublished report submitted to U.S. Forest Service, Estacada Ranger District, Mt. Hood National Forest, 9 p. and attachments.

1992c, UV light trap survey for sensitive caddisflies (Insecta:Trichoptera) on the Rigdon Ranger District, Willamette National Forest: Corvallis, Aquatic Biology Associates, unpublished report submitted to U.S. Forest Service, Willamette National Forest, 3 p. and attachments.

-1995, Benthic invertebrate biomonitoring, 19921993, Zigzag Ranger District, Mt. Hood National Forest: Corvallis, Aquatic Biology Associates, unpublished report submitted to U.S. Forest Service, Zigzag Ranger District, Mt. Hood National Forest, [variously paginated].

Worcester, T.C., 1979, Mercury accumulation in fish from Cottage Grove Reservoir and its tributaries: Corvallis, Oregon, Oregon State University, M.S. thesis, 88 p.

Wustenberg, D. W., 1954, A preliminary survey of the influences of controlled logging on a trout stream in the H.J. Andrews Experimental Forest, Oregon: Corvallis, Oregon State University, M.S. thesis, $51 \mathrm{p}$.

Wyatt, B., 1959, Observations on the movements and reproduction of the Cascade form of cutthroat trout: Corvallis, Oregon State University, M.S. thesis, 60 p.

Wydoski, R.S., and Whitney, R.R., 1979, Inland fishes of Washington: Seattle, University of Washington Press, $220 \mathrm{p}$.

Zakel, J.C., and Reed, D.W., 1984, Downstream migration of fish at Leaburg Dam, McKenzie River, Oregon, 1980 to 1983: Portland, Oregon Department of Fish and Wildlife, Fish Division, Information Report 84-13, $17 \mathrm{p}$.

Ziebell, C.D., 1954, Stream pollution in the South Santiam River, Oregon, as measured by biological indicators: Corvallis, Oregon State University, M.S. thesis, 113 p.

Zirges, M. H,. 1972, Morphological and meristic characteristics of ten populations of blackside dace, Rhinichthys osculus nubilus (GIRARD), from western Oregon: Corvallis, Oregon State University, M.S. thesis, 37 p. 
APPENDICES 


\section{APPENDIX A. INVESTIGATIONS OF AQUATIC BIOTA IN THE WILLAMETTE BASIN, OREGON}

[Includes references of field investigations that provide information on the distribution and abundance of algae, macroinvertebrates, and fish. Subbasins (see fig. 5): CA, Calapooia; CF, Coast Fork Willamette; CL, Clackamas; LT, Long Tom; LU, Luckiamute; MA, Marys; MC, McKenzie; MF, Middle Fork Willamette: PM, Pudding/Molalla; RI, Rickreall; SA, Santiam; SY, Sandy; TU, Tualatin; WR, Willamette River; WB, throughout the Willamette Basin; YH, Yamhill; RM, river mile; BLM, Bureau of Land Management; --, no data]

\begin{tabular}{|c|c|c|c|c|c|c|c|}
\hline \multirow[b]{2}{*}{ Reference } & \multirow[b]{2}{*}{ Subbasin } & \multirow[b]{2}{*}{ Temporal coverage } & \multirow[b]{2}{*}{ Spatial coverage } & \multirow[b]{2}{*}{ Topic } & \multicolumn{3}{|c|}{ Taxa } \\
\hline & & & & & Algae & $\begin{array}{l}\text { Inverte- } \\
\text { brates }\end{array}$ & Fish \\
\hline Aho (1976) & $\mathrm{MC}$ & $1973-74$ & Mack Creek & $\begin{array}{l}\text { Cutthroat trout populations in shaded and } \\
\text { unshaded stream sections }\end{array}$ & -- & $\mathrm{X}$ & $\mathrm{X}$ \\
\hline Anderson (1992) & $\mathrm{MC}$ & $1982-83$ and 1986 & $\begin{array}{l}\text { Mack, Quartz, and Grasshopper } \\
\text { Creeks }\end{array}$ & $\begin{array}{l}\text { Influence of disturbance on insect fauna; } \\
\text { riparian insect taxa }\end{array}$ & -- & $\mathrm{X}$ & -- \\
\hline $\begin{array}{l}\text { Anderson and Lehmkuhl } \\
\text { (1968) }\end{array}$ & MA & Fall 1965 and 1966 & Oak Creek & Catastrophic drift of insects & -- & $\mathrm{X}$ & -- \\
\hline $\begin{array}{l}\text { Anderson and Wold } \\
\text { (1972) }\end{array}$ & MA & $\begin{array}{l}\text { May } 1968- \\
\text { Dec.1980 }\end{array}$ & Oak Creek & Emergence trap collections of Trichoptera & -- & $\mathrm{X}$ & -- \\
\hline $\begin{array}{l}\text { Anderson and Bourne } \\
\text { (1974) }\end{array}$ & MA & $\begin{array}{l}\text { Aug. } 1970- \\
\text { July } 1971\end{array}$ & Oak Creek & $\begin{array}{l}\text { Life history of } 3 \text { caddisflies; Anagapetus } \\
\text { bernea, Glossosoma penitum, and Agapetus } \\
\text { bifidus }\end{array}$ & -- & $\mathrm{X}$ & -- \\
\hline $\begin{array}{l}\text { Anderson and others } \\
\text { (1978) }\end{array}$ & LU,MC & July 1976 & $\begin{array}{l}\text { Berry, Mack, Devils Club, and } \\
\text { Lookout Creeks; McKenzie River }\end{array}$ & $\begin{array}{l}\text { Role of invertebrates in wood processing in } \\
\text { streams }\end{array}$ & -- & $\mathrm{X}$ & -- \\
\hline Azam (1969) & LU,MA & $1966-68$ & Oak and Berry Creeks & $\begin{array}{l}\text { Life history and production of Sialis } \\
\text { californica and Sialis rotunda }\end{array}$ & -- & $\mathrm{X}$ & -- \\
\hline Ball (1946) & MA & unknown & Oak Creek & Seasonal succession of stoneflies & -- & $\mathrm{X}$ & -- \\
\hline Baker (1979) & MF & $1976-78$ & Big Fall and Hehe Creeks & $\begin{array}{l}\text { Impacts of logjam removal on fish populations } \\
\text { and stream habitat }\end{array}$ & -- & -- & $\mathrm{X}$ \\
\hline Baker and others (1995) & CL & Summer 1994 & $\begin{array}{l}\text { Collawash River watershed; other } \\
\text { sites in subbasin }\end{array}$ & $\begin{array}{l}\text { Field verification of fish distribution and } \\
\text { composition }\end{array}$ & -- & -- & $\mathrm{X}$ \\
\hline $\begin{array}{l}\text { Beak Consultants, Inc. } \\
\text { (1985) }\end{array}$ & SY & $\begin{array}{l}\text { July 1984; March } \\
1985\end{array}$ & $\begin{array}{l}\text { Sandy River between Bull Run River } \\
\text { and Columbia River }\end{array}$ & Fish species occurrence and abundance & -- & -- & $\mathrm{X}$ \\
\hline $\begin{array}{l}\text { Beak Consultants, Inc. } \\
\text { (1993) }\end{array}$ & SY & Oct. 1992 & Bull Run Lake and tributaries & $\begin{array}{l}\text { Effect of water withdrawal on fisheries } \\
\text { resources }\end{array}$ & -- & $\mathrm{X}$ & $\mathrm{X}$ \\
\hline $\begin{array}{l}\text { Buchanan and others } \\
\text { (1981) }\end{array}$ & MC,SA,WR & April-June 1976-77 & $\begin{array}{l}\text { Willamette, Santiam, and McKenzie } \\
\text { Rivers }\end{array}$ & Predation by squawfish on salmonids & -- & -- & $X$ \\
\hline Burns (1993) & CL & Summer 1991 & 10 Cascade Range lakes & Phytoplankton of mountain lakes & $\mathrm{X}$ & -- & -- \\
\hline Carter (1975) & $\mathrm{TU}$ & $\begin{array}{l}\text { July } 1972- \\
\text { Sept. } 1973\end{array}$ & Middle course of the Tualatin River & Algae occurrence and distribution & $X$ & -- & -- \\
\hline
\end{tabular}


APPENDIX A. INVESTIGATIONS OF AQUATIC BIOTA IN THE WILLAMETTE BASIN, OREGON-Continued

\begin{tabular}{|c|c|c|c|c|c|c|c|}
\hline \multirow[b]{2}{*}{ Reference } & \multirow[b]{2}{*}{ Subbasin } & \multirow[b]{2}{*}{ Temporal coverage } & \multirow[b]{2}{*}{ Spatial coverage } & \multirow[b]{2}{*}{ Topic } & \multicolumn{3}{|c|}{ Taxa } \\
\hline & & & & & Algae & $\begin{array}{l}\text { Inverte- } \\
\text { brates }\end{array}$ & Fish \\
\hline Carter and others (1976) & TU & $\begin{array}{l}\text { June-Oct. } \\
1976\end{array}$ & Tualatin River & Algae occurrence and distribution & $\mathrm{X}$ & -- & -- \\
\hline Clifton (1985) & SY & July-Aug. 1977-81 & Six streams in Bull Run watershed & $\begin{array}{l}\text { Periphyton and invertebrate distribution and } \\
\text { abundance }\end{array}$ & $\mathrm{X}$ & $\mathrm{X}$ & -- \\
\hline $\begin{array}{l}\text { Craig and Townsend } \\
\text { (1946) }\end{array}$ & $\begin{array}{l}\text { WR,MC,MF, } \\
\text { PM,SA }\end{array}$ & $1940-42$ & $\begin{array}{l}\text { Molalla, Santiam, McKenzie, } \\
\text { Willamette, and Middle Fork } \\
\text { Willamette Rivers }\end{array}$ & Effects of Willamette Valley Project on fish & -- & -- & $\mathrm{X}$ \\
\hline Deschamps (1952) & $\begin{array}{l}\text { CL,MC,SA, } \\
\text { WR }\end{array}$ & $\begin{array}{l}\text { July-Nov. } \\
1951\end{array}$ & $\begin{array}{l}\text { Willamette, McKenzie, Santiam, } \\
\text { and Clackamas Rivers }\end{array}$ & Invertebrate use as bio-indices of pollution & - & $\mathrm{X}$ & - \\
\hline Dever (1962) & LU & unknown & Berry Creek & Algae in a woodland stream & $\mathrm{X}$ & - & - \\
\hline Diamond (1982) & LU, MA & $\begin{array}{l}\text { June 1975-April } \\
1976\end{array}$ & Oak and Berry Creeks & Population dynamics of Juga plicifera & - & $\mathrm{X}$ & - \\
\hline Dieterich (1992) & LU,MA & $1987-88$ & MacDonald Forest & Insects of summer-dry headwater streams & - & $\mathrm{X}$ & - \\
\hline $\begin{array}{l}\text { Dimick and Merryfield } \\
\text { (1945) }\end{array}$ & $\begin{array}{l}\text { CA,CF,CL, } \\
\text { LT,LU,MA, } \\
\text { MC,MF,PM, } \\
\text { RI,SA,TU, } \\
\text { WR,YH }\end{array}$ & Aug.-Sept. 1944 & Willamette River and tributaries & $\begin{array}{l}\text { Fish distribution and abundance relative to } \\
\text { pollution }\end{array}$ & - & $\mathrm{X}$ & $\mathrm{X}$ \\
\hline Dodge (1994) & $\mathrm{MC}, \mathrm{MF}$ & June-Aug. 1992 & $\begin{array}{l}\text { Middle Fork Willamette River and } \\
\text { Lookout Creek }\end{array}$ & Habitat use by two species of dace & - & - & $\mathrm{X}$ \\
\hline Dudley (1982) & MA,SA & 1978 & $\begin{array}{l}\text { Marys River and sites in Santiam } \\
\text { watershed }\end{array}$ & Ecology of Lipsothrix sp. & - & $\mathrm{X}$ & - \\
\hline $\begin{array}{l}\text { Dudley and Anderson } \\
\text { (1982) }\end{array}$ & WB & 1978 and 1979 & $100+$ sites in WB (sites not listed) & $\begin{array}{l}\text { Invertebrates associated with wood debris in } \\
\text { aquatic habitats }\end{array}$ & - & $\mathrm{X}$ & - \\
\hline $\begin{array}{l}\text { Dudley and Anderson } \\
\text { (1987) }\end{array}$ & MA,MC & $\begin{array}{l}\text { Feb.1977-March } \\
1979\end{array}$ & $\begin{array}{l}\text { Greasy Creek and Quartzville Creek } \\
\text { watersheds }\end{array}$ & Wood inhabiting craneflies in streams & - & $\mathrm{X}$ & - \\
\hline $\begin{array}{l}\text { EA Engineering, Science } \\
\text { and Technology, Inc. } \\
\text { (1990a) }\end{array}$ & MC & Oct. 1989 & $\begin{array}{l}\text { Lower McKenzie River between } \\
\text { Springfield and Leaburg Dam }\end{array}$ & Aquatic insect distribution and abundance & - & $\mathrm{X}$ & - \\
\hline Earnest (1967) & LU & $\begin{array}{l}\text { Oct. } 1963- \\
\text { Oct. } 1965\end{array}$ & Berry Creek & Production of Oxytrema silicula & - & $\mathrm{X}$ & - \\
\hline $\begin{array}{l}\text { Everest and others } \\
\text { (1985) }\end{array}$ & $\mathrm{CL}$ & $1982-85$ & Fish Creek & $\begin{array}{l}\text { Salmon and steelhead abundance, behavior, } \\
\text { and habitat }\end{array}$ & - & - & $\mathrm{X}$ \\
\hline Farr and Ward (1993) & WR & Mar.-Nov. 1987-90 & Portland Harbor, RM 0.3-27.0 & Fish distribution & - & - & $\mathrm{X}$ \\
\hline
\end{tabular}


APPENDIX A. INVESTIGATIONS OF AQUATIC BIOTA IN THE WILLAMETTE BASIN, OREGON-Continued

\begin{tabular}{|c|c|c|c|c|c|c|c|}
\hline \multirow[b]{2}{*}{ Reference } & \multirow[b]{2}{*}{ Subbasin } & \multirow[b]{2}{*}{ Temporal coverage } & \multirow[b]{2}{*}{ Spatial coverage } & \multirow[b]{2}{*}{ Topic } & \multicolumn{3}{|c|}{ Taxa } \\
\hline & & & & & Algae & $\begin{array}{l}\text { Inverte- } \\
\text { brates }\end{array}$ & Fish \\
\hline $\begin{array}{l}\text { Fetrow Engineering and } \\
\text { Scientific Resources } \\
\text { (1989) }\end{array}$ & WR & $1988-89$ & Delta Ponds in Eugene & Phytoplankton distribution and abundance & $\mathrm{X}$ & - & - \\
\hline Finger (1982) & MA & $\begin{array}{l}\text { June 1977-Sept. } \\
1978\end{array}$ & Marys River & Segregation of three species of sculpin & - & - & $\mathrm{X}$ \\
\hline $\begin{array}{l}\text { Friesen and others } \\
\text { (1994) }\end{array}$ & TU & Summer-Fall 1993 & Tributaries of the Tualatin River & Distribution of fish and crayfish & - & $\mathrm{X}$ & $\mathrm{X}$ \\
\hline $\begin{array}{l}\text { Frissell and others } \\
\text { (1985) }\end{array}$ & SA & Aug. 27, 1984 & Minto Creek & $\begin{array}{l}\text { Trout densities and habitat use in logged and } \\
\text { forested stream sections }\end{array}$ & -- & -- & $\mathrm{X}$ \\
\hline Furnish (1989) & MA & $1982-85$ & Oak Creek & $\begin{array}{l}\text { Growth, production, and distribution of } \\
\text { Juga silicula }\end{array}$ & - & $X$ & - \\
\hline Goetz (1994) & $\mathrm{MC}, \mathrm{MF}$ & 1989-91 & $\begin{array}{l}\text { Anderson Creek, Trailbridge } \\
\text { Reservoir, McKenzie River }\end{array}$ & Distribution and juvenile ecology of bull trout & - & - & $\mathrm{X}$ \\
\hline Grafius (1977) & LU,MC & $\begin{array}{l}\text { April 1974-Feb. } \\
1975\end{array}$ & Berry and Mack Creeks & $\begin{array}{l}\text { Utilization and processing of leaves and } \\
\text { needles by Trichoptera }\end{array}$ & -- & $\mathrm{X}$ & -- \\
\hline $\begin{array}{l}\text { Grafius and Anderson } \\
\text { (1979) }\end{array}$ & LU & $\begin{array}{l}\text { Aug. } 1974-\text { Feb. } \\
1975\end{array}$ & Berry Creek & $\begin{array}{l}\text { Utilization of deciduous leaves as food by } \\
\text { Lepidostoma quercina }\end{array}$ & -- & $\mathrm{X}$ & -- \\
\hline Gregory (1980) & $\mathrm{MC}$ & $1974-75$ & Mack and Lookout Creeks & $\begin{array}{l}\text { Effects of light, nutrients, and grazing on } \\
\text { periphyton }\end{array}$ & $\mathrm{X}$ & -- & -- \\
\hline Gregory (1993) & $\begin{array}{l}\text { CA,CF,CL, } \\
\text { MC,MF,PM, } \\
\text { SA,TU,WR, } \\
\text { YH }\end{array}$ & Summer 1992 & $\begin{array}{l}\text { Main stem, Coast Fork, and Middle } \\
\text { Fork Willamette, McKenzie, } \\
\text { Calapooia, Santiam, Yamhill, } \\
\text { Molalla, Clackamas, and Tualatin } \\
\text { Rivers }\end{array}$ & Periphyton abundance and productivity & $\mathrm{X}$ & -- & -- \\
\hline $\begin{array}{l}\text { Hasselman and Garrison } \\
\text { (1957) }\end{array}$ & MF & Summer 1957 & Lookout Point and Dexter Reservoirs & Squawfish reproduction and movements & -- & -- & $\mathrm{X}$ \\
\hline $\begin{array}{l}\text { Hawkins and Sedell } \\
\text { (1981) }\end{array}$ & MC,MF & All seasons 1976 & $\begin{array}{l}\text { Devils Club, Mack, and Lookout } \\
\text { Creeks; McKenzie River }\end{array}$ & $\begin{array}{l}\text { Longitudinal and seasonal changes in } \\
\text { invertebrate communities }\end{array}$ & -- & $\mathrm{X}$ & -- \\
\hline $\begin{array}{l}\text { Hawkins and Furnish } \\
\text { (1987) }\end{array}$ & $\mathrm{MC}, \mathrm{MF}$ & $1978-79$ & Mack, Mill, and Fawn Creeks & $\begin{array}{l}\text { Correlations of stream taxa abundance with } \\
\text { Juga silicula }\end{array}$ & $\mathrm{X}$ & $\mathrm{X}$ & - \\
\hline $\begin{array}{l}\text { Hawkins and others } \\
\text { (1982) }\end{array}$ & $\mathrm{MC}$ & $1978-79$ & $\begin{array}{l}\text { Mack, Mill, Cougar, Fawn, and } \\
\text { North Fork Wycof Creeks }\end{array}$ & $\begin{array}{l}\text { Invertebrate community structure and } \\
\text { abundance }\end{array}$ & $\mathrm{X}$ & $\mathrm{X}$ & -- \\
\hline $\begin{array}{l}\text { Hawkins and others } \\
\text { (1983) }\end{array}$ & $\mathrm{MC}, \mathrm{MF}$ & $1978-79$ & Mack, Mill, and Fawn Creeks & $\begin{array}{l}\text { Fish abundance relative to food sources and } \\
\text { habitat features }\end{array}$ & -- & $\mathrm{X}$ & $\mathrm{X}$ \\
\hline
\end{tabular}


APPENDIX A. INVESTIGATIONS OF AQUATIC BIOTA IN THE WILLAMETTE BASIN, OREGON-Continued

\begin{tabular}{|c|c|c|c|c|c|c|c|}
\hline \multirow[b]{2}{*}{ Reference } & \multirow[b]{2}{*}{ Subbasin } & \multirow[b]{2}{*}{ Temporal coverage } & \multirow[b]{2}{*}{ Spatial coverage } & \multirow[b]{2}{*}{ Topic } & \multicolumn{3}{|c|}{ Taxa } \\
\hline & & & & & Algae & $\begin{array}{l}\text { Inverte- } \\
\text { brates }\end{array}$ & Fish \\
\hline Hjort and others (1984) & WR & June-Aug. 1992 & $\begin{array}{l}\text { Willamette River below Salem, } \\
\text { RM 58-66 }\end{array}$ & Fish and invertebrates of revetments & -- & $\mathrm{X}$ & $\mathrm{X}$ \\
\hline $\begin{array}{l}\text { HMS Environmental, } \\
\text { Inc., and Miller (1988) }\end{array}$ & WR & Summer 1988 & $\begin{array}{l}\text { Willamette River near Halsey, } \\
\text { RM } 142.3 \text { to } 147.9\end{array}$ & $\begin{array}{l}\text { Effects of pulp mill discharge on aquatic } \\
\text { organisms }\end{array}$ & $\mathrm{X}$ & $X$ & $X$ \\
\hline House (1995) & PM & Aug.-Sept. 1981-91 & Dead Horse Canyon Creek watershed & Cutthroat trout population variability & -- & -- & $X$ \\
\hline $\begin{array}{l}\text { Hughes and Gammon } \\
\text { (1987) }\end{array}$ & WR & August 1983 & Throughout Willamette River & Longitudinal changes in fish assemblages & -- & -- & $X$ \\
\hline $\begin{array}{l}\text { Hutchison and Aney } \\
\text { (1964) }\end{array}$ & CL,SY,TU & Summer 1963 & Lower Willamette Basin & Fish distribution & -- & -- & $X$ \\
\hline $\begin{array}{l}\text { Hutchison, Thompson, } \\
\text { and Fortune (1966) }\end{array}$ & $\begin{array}{l}\text { CF,LT,MC, } \\
\text { MF }\end{array}$ & 1964-66 & Upper Willamette Basin & Fish distribution & -- & -- & $\mathrm{X}$ \\
\hline $\begin{array}{l}\text { Johnson and others } \\
\text { (1989) }\end{array}$ & WR & Summer 1989 & $\begin{array}{l}\text { Willamette River near Halsey, } \\
\text { RM } 142.3 \text { to } 150.5\end{array}$ & $\begin{array}{l}\text { Effects of pulp mill discharge on aquatic } \\
\text { organisms }\end{array}$ & $\mathrm{X}$ & $X$ & $\mathrm{X}$ \\
\hline $\begin{array}{l}\text { Kerst (1969), Kerst and } \\
\text { Anderson }(1974,1975)\end{array}$ & MA & $\begin{array}{l}\text { June 1968-May } \\
1969\end{array}$ & Oak Creek & Occurrence and distribution of stoneflies & -- & $X$ & -- \\
\hline $\begin{array}{l}\text { Knutsen and Ward } \\
\text { (1991) }\end{array}$ & WR & 1987-90 & Portland Harbor, RM 0-16.8 & Juvenile salmonid migration behavior & -- & -- & $\mathrm{X}$ \\
\hline Korn and others (1967) & $\mathrm{CL}$ & $\begin{array}{l}\text { Feb. 1962-June } \\
1965\end{array}$ & $\begin{array}{l}\text { North Fork Reservoir of the } \\
\text { Clackamas River }\end{array}$ & $\begin{array}{l}\text { Effect of small impoundments on juvenile } \\
\text { anadromous salmonids }\end{array}$ & -- & -- & $X$ \\
\hline Kraft (1963) & LU & $\begin{array}{l}\text { Dec. 1959-Dec. } \\
1960\end{array}$ & Berry Creek & $\begin{array}{l}\text { Seasonal occurrence and distribution of aquatic } \\
\text { insects }\end{array}$ & -- & $\mathrm{X}$ & -- \\
\hline Kruse (1988) & $\begin{array}{l}\text { CA,MA,SA, } \\
\text { YH }\end{array}$ & $\begin{array}{l}\text { July-Sept. 1982; } \\
\text { June-Sept. } 1983\end{array}$ & $\begin{array}{l}\text { Calapooia River: Thomas, Rock, } \\
\text { Turner, Griffith, and Greasy Creeks }\end{array}$ & Fish distribution and habitat & -- & -- & $X$ \\
\hline $\begin{array}{l}\text { Lamberti and others } \\
\text { (1991) }\end{array}$ & $\mathrm{MC}$ & $\begin{array}{l}\text { Mar. 1986- Nov. } \\
1988\end{array}$ & Quartz Creek & $\begin{array}{l}\text { Stream ecosystem recovery after a catastrophic } \\
\text { debris flow }\end{array}$ & $X$ & $\mathrm{X}$ & $\mathrm{X}$ \\
\hline Lehmkuhl (1968) & MA & $\begin{array}{l}\text { Oct. 1965-Sept. } \\
1966\end{array}$ & Oak Creek & Life history of four species of Epeorus & -- & $X$ & -- \\
\hline Lehmkuhl (1969) & MA & $\begin{array}{l}\text { June } 1967- \\
\text { June } 1968\end{array}$ & Oak Creek & $\begin{array}{l}\text { Biology and downstream drift of six species of } \\
\text { Ephemeroptera }\end{array}$ & -- & $X$ & -- \\
\hline $\begin{array}{l}\text { Lehmkuhl and Anderson } \\
\text { (1970) }\end{array}$ & MA & $\begin{array}{l}\text { July 1967-June } \\
1968\end{array}$ & Oak Creek & Ecology of Cinygmula reticulata & -- & $X$ & -- \\
\hline $\begin{array}{l}\text { Lehmkuhl and Anderson } \\
\text { (1971) }\end{array}$ & MA & $\begin{array}{l}\text { July } 1967- \\
\text { June } 1968\end{array}$ & Oak Creek & Biology and taxonomy of Paraleptophlebia sp. & -- & $\mathrm{X}$ & -- \\
\hline
\end{tabular}


APPENDIX A. INVESTIGATIONS OF AQUATIC BIOTA IN THE WILLAMETTE BASIN, OREGON-Continued

\begin{tabular}{|c|c|c|c|c|c|c|c|}
\hline \multirow[b]{2}{*}{ Reference } & \multirow[b]{2}{*}{ Subbasin } & \multirow[b]{2}{*}{ Temporal coverage } & \multirow[b]{2}{*}{ Spatial coverage } & \multirow[b]{2}{*}{ Topic } & \multicolumn{3}{|c|}{ Taxa } \\
\hline & & & & & Algae & $\begin{array}{c}\text { Inverte- } \\
\text { brates }\end{array}$ & Fish \\
\hline Li and others (1983) & $\mathrm{MA}, \mathrm{CA}$ & 1981 & Greasy Creek; Calapooia River & $\begin{array}{l}\text { Fish distribution and habitat above and below } \\
\text { impoundments }\end{array}$ & -- & -- & $\mathrm{X}$ \\
\hline $\mathrm{Li}$ and others (1984) & WR & $\begin{array}{l}\text { Aug. 1983; April- } \\
\text { June } 1984\end{array}$ & Willamette River, RM 118-142 & Fish use of spur dikes and revetments & -- & -- & $\mathrm{X}$ \\
\hline $\begin{array}{l}\text { Logan and others (in } \\
\text { press) }\end{array}$ & CL & Aug. 1991 & Pond near Clackamas River & Capture of oriental weatherfish & -- & -- & $\mathrm{X}$ \\
\hline Long (1982) & MF & Aug. 17-25, 1981 & $\begin{array}{l}\text { Lowell Ranger District, } \\
\text { Willamette National Forest }\end{array}$ & Status and distribution of the Oregon chub & -- & -- & $\mathrm{X}$ \\
\hline Mangum (1990) & SY & $\begin{array}{l}\text { Oct. } 1989 \text { and May } \\
1990\end{array}$ & Still Creek & Macroinvertebrate sampling & -- & $\mathrm{X}$ & -- \\
\hline Mangum (1991a) & SA & Summer 1991 & 2 streams on Salem BLM District & Macroinvertebrate sampling & -- & $X$ & -- \\
\hline Mangum (1991b) & $\mathrm{MC}, \mathrm{MF}$ & Summer 1991 & 10 streams on Eugene BLM District & Macroinvertebrate sampling & -- & $\mathrm{X}$ & -- \\
\hline Markle and others (1989) & MF & $\begin{array}{l}\text { July-Sept. } \\
1987\end{array}$ & Middle Fork Willamette River & Distribution of the Oregon chub & -- & -- & $\mathrm{X}$ \\
\hline Markle and others (1991) & $\mathrm{MF}$ & $\begin{array}{l}\text { July-Sept. } \\
1987\end{array}$ & Middle Fork Willamette River & Distribution of the Oregon chub & -- & $\mathrm{X}$ & $\mathrm{X}$ \\
\hline Mason (1963) & LU & $1959-60$ & Berry Creek & Life history and production of the crayfish & -- & $\mathrm{X}$ & -- \\
\hline Massey (1967a;b) & WR & $\begin{array}{l}\text { Aug. 1964-Dec. } \\
1966\end{array}$ & Industrial area near Willamette Falls & $\begin{array}{l}\text { Juvenile fish abundance and timing of } \\
\text { downstream migration }\end{array}$ & -- & -- & $\mathrm{X}$ \\
\hline Mattson (1962) & PM,WR & $\begin{array}{l}\text { Feb.1947- } \\
\text { July } 1951\end{array}$ & $\begin{array}{l}\text { Willamette River near Lake Oswego; } \\
\text { Molalla River }\end{array}$ & Chinook salmon life history & -- & -- & $\mathrm{X}$ \\
\hline McIntyre (1967) & LU & 1964-66 & Berry Creek & Food relations and production of cutthroat trout & -- & $\mathrm{X}$ & $\mathrm{X}$ \\
\hline Miller (1979) & PM & July and Sept. 1977 & Four tributaries of the Molalla River & $\begin{array}{l}\text { Periphyton and benthic invertebrate abundance } \\
\text { and distribution }\end{array}$ & $\mathrm{X}$ & $\mathrm{X}$ & -- \\
\hline Moore (1987) & $\mathrm{MC}$ & $\begin{array}{l}\text { June } 1982- \\
\text { Feb. } 1984\end{array}$ & $\begin{array}{l}\text { Mack, Quartz, and Grasshopper } \\
\text { Creeks }\end{array}$ & $\begin{array}{l}\text { Species assemblages associated with stream } \\
\text { margins }\end{array}$ & $\mathrm{X}$ & $\mathrm{X}$ & $\mathrm{X}$ \\
\hline $\begin{array}{l}\text { Moore and Gregory } \\
\text { (1989) }\end{array}$ & $\mathrm{MC}$ & Summer, 1987 & Lookout Creek & $\begin{array}{l}\text { Riparian influences on distribution and } \\
\text { abundance of salmonids }\end{array}$ & -- & -- & $\mathrm{X}$ \\
\hline $\begin{array}{l}\text { Moring and others } \\
\text { (1986) }\end{array}$ & MC,SA,WR & $\begin{array}{l}\text { April 1976-May } \\
1979\end{array}$ & $\begin{array}{l}\text { Willamette, McKenzie, and Santiam } \\
\text { Rivers }\end{array}$ & Movements of coastal cutthroat trout & -- & -- & $\mathrm{X}$ \\
\hline Murphy and Hall (1981) & $\mathrm{MC}$ & $\begin{array}{l}\text { July-Oct. } \\
1976\end{array}$ & $\begin{array}{l}33 \text { sites in or near the H.J. } \\
\text { Andrews Experimental Forest }\end{array}$ & $\begin{array}{l}\text { Effects of clear-cut logging on predators and } \\
\text { their habitat }\end{array}$ & $\mathrm{X}$ & $\mathrm{X}$ & $\mathrm{X}$ \\
\hline $\begin{array}{l}\text { Murphy and others } \\
\text { (1981) }\end{array}$ & $\mathrm{MC}$ & June-Nov. 1978 & $\begin{array}{l}\text { Mack, Mill, Cougar, Fawn, and } \\
\text { Wycof Creeks }\end{array}$ & $\begin{array}{l}\text { Effects of canopy modification and } \\
\text { accumulated sediment }\end{array}$ & $\mathrm{X}$ & $\mathrm{X}$ & $\mathrm{X}$ \\
\hline
\end{tabular}


APPENDIX A. INVESTIGATIONS OF AQUATIC BIOTA IN THE WILLAMETTE BASIN, OREGON-Continued

\begin{tabular}{|c|c|c|c|c|c|c|c|}
\hline \multirow[b]{2}{*}{ Reference } & \multirow[b]{2}{*}{ Subbasin } & \multirow[b]{2}{*}{ Temporal coverage } & \multirow[b]{2}{*}{ Spatial coverage } & \multirow[b]{2}{*}{ Topic } & \multicolumn{3}{|c|}{ Taxa } \\
\hline & & & & & Algae & $\begin{array}{l}\text { Inverte- } \\
\text { brates }\end{array}$ & Fish \\
\hline Nickelson (1974) & $\mathrm{LU}$ & $\begin{array}{l}\text { Aug.1972- } \\
\text { Aug.1973 }\end{array}$ & Berry Creek & Population dynamics of coastal cutthroat trout & -- & -- & $\mathrm{X}$ \\
\hline Noble (1952) & $\begin{array}{l}\text { CL,MC,SA, } \\
\text { WR }\end{array}$ & $\begin{array}{l}\text { July-Nov. } \\
1951\end{array}$ & $\begin{array}{l}\text { Willamette, Clackamas, Santiam, } \\
\text { and McKenzie Rivers }\end{array}$ & Fish as biological indicators of pollution & -- & -- & $\mathrm{X}$ \\
\hline $\begin{array}{l}\text { Oregon Department of } \\
\text { Fish and Wildlife } \\
(1995 b)\end{array}$ & $\mathrm{MC}$ & 1992-94 & Mohawk River & $\begin{array}{l}\text { Relative abundance and timing of cutthroat } \\
\text { trout movements }\end{array}$ & -- & -- & $\mathrm{X}$ \\
\hline $\begin{array}{l}\text { Oregon State Game } \\
\text { Commission (1963) }\end{array}$ & $\begin{array}{l}\text { LU,MA,RI, } \\
\text { SA,YH }\end{array}$ & $1961-62$ & $\begin{array}{l}\text { Middle Willamette River Basin, } \\
\text { Coast Range subbasins }\end{array}$ & Fish distribution & -- & -- & $\mathrm{X}$ \\
\hline Pearsons (1989) & MF & $\begin{array}{l}\text { May 1986-Sept. } \\
1987\end{array}$ & $\begin{array}{l}\text { Shady Dell Pond; Buckhead Creek } \\
\text { Slough }\end{array}$ & Occurrence and habitat of the Oregon chub & $\mathrm{X}$ & $X$ & $\mathrm{X}$ \\
\hline Pereira (1980) & LU,MC & $\begin{array}{l}\text { July } 1979- \\
\text { June } 1980\end{array}$ & Berry and Mack Creeks & Life history of Cinygma integrum & -- & $\mathrm{X}$ & -- \\
\hline Raymond (1983) & SY & Summer 1979 & Bull Run Lake & Diatom and algae occurrence & $\mathrm{X}$ & -- & -- \\
\hline Reese (1966) & LU & $\begin{array}{l}\text { Feb. } 1964- \\
\text { Jan. } 1965\end{array}$ & Berry Creek & Structure of benthic communities & $X$ & -- & -- \\
\hline $\begin{array}{l}\text { Rickert and others } \\
\text { (1977) }\end{array}$ & WR & $\begin{array}{l}\text { June-Sept. } 1973 \text { and } \\
1974\end{array}$ & $\begin{array}{l}\text { Willamette River; RMs 7.0,12.8, } \\
21.2,35.0,50.0\end{array}$ & Algal distribution and abundance & $\mathrm{X}$ & -- & -- \\
\hline Rinella and others (1981) & SA,WR & August 1978 & Willamette and Santiam Rivers & Algal distribution and abundance & $X$ & -- & -- \\
\hline Rodnick (1983) & MA & $\begin{array}{l}\text { Aug. 1980- } \\
\text { July } 1981\end{array}$ & Greasy Creek & $\begin{array}{l}\text { Distribution and habitat selection of the redside } \\
\text { shiner }\end{array}$ & -- & -- & $\mathrm{X}$ \\
\hline $\begin{array}{l}\text { Rounick and Gregory } \\
\text { (1981) }\end{array}$ & $\mathrm{MC}$ & $\begin{array}{l}\text { Oct. 1976-March } \\
1977\end{array}$ & $\begin{array}{l}\text { Lookout, Mack, McCrae, and Arnold } \\
\text { Creeks }\end{array}$ & Effects of light and discharge on periphyton & $X$ & -- & -- \\
\hline $\begin{array}{l}\text { Scheidt and Nichols } \\
\text { (1976) }\end{array}$ & MF & $\begin{array}{l}\text { May } 1975- \\
\text { Feb. } 1976\end{array}$ & Hills Creek Reservoir & Algal abundance & $\mathrm{X}$ & -- & -- \\
\hline $\begin{array}{l}\text { Scheerer and others } \\
\text { (1992) }\end{array}$ & LT,MF,SA, & $\begin{array}{l}\text { Oct. 1990; May- } \\
\text { June } 1991\end{array}$ & $\begin{array}{l}\text { Middle Fork Willamette and Santiam } \\
\text { Rivers; Baskett Slough, Finley, and } \\
\text { Ankeny National Wildlife Refuges }\end{array}$ & Status and habitat of the Oregon chub & -- & -- & $X$ \\
\hline $\begin{array}{l}\text { Scheerer and others } \\
\text { (1993) }\end{array}$ & $\begin{array}{l}\text { CF,LU,MA, } \\
\text { MF4. }\end{array}$ & $\begin{array}{l}\text { May-June } \\
1992\end{array}$ & $\begin{array}{l}\text { Coast Fork and Middle Fork } \\
\text { Willamette River; Luckiamute River; } \\
\text { Oak Creek }\end{array}$ & Status and habitat of the Oregon chub & -- & -- & $\mathrm{X}$ \\
\hline $\begin{array}{l}\text { Scheerer and others } \\
\text { (1994) }\end{array}$ & $\begin{array}{l}\text { CF,LT,MF, } \\
\text { SA, }\end{array}$ & April-June 1993 & $\begin{array}{l}\text { Coast Fork and Middle Fork } \\
\text { Willamette River; Santiam River; } \\
\text { Finley and Ankeny National } \\
\text { Wildlife Refuges }\end{array}$ & Status and habitat of the Oregon chub & -- & -- & $\mathrm{X}$ \\
\hline
\end{tabular}


APPENDIX A. INVESTIGATIONS OF AQUATIC BIOTA IN THE WILLAMETTE BASIN, OREGON-Continued

\begin{tabular}{|c|c|c|c|c|c|c|c|}
\hline \multirow[b]{2}{*}{ Reference } & \multirow[b]{2}{*}{ Subbasin } & \multirow[b]{2}{*}{ Temporal coverage } & \multirow[b]{2}{*}{ Spatial coverage } & \multirow[b]{2}{*}{ Topic } & \multicolumn{3}{|c|}{ Taxa } \\
\hline & & & & & Algae & $\begin{array}{l}\text { Inverte- } \\
\text { brates }\end{array}$ & Fish \\
\hline $\begin{array}{l}\text { Scheerer and others } \\
\text { (1995) }\end{array}$ & $\begin{array}{l}\text { CF,MF,PM, } \\
\text { SA,WR }\end{array}$ & April-Sept. 1994 & $\begin{array}{l}\text { Numerous sites in middle and upper } \\
\text { Willamette Basin }\end{array}$ & Status and habitat of the Oregon chub & -- & -- & $\mathrm{X}$ \\
\hline $\begin{array}{l}\text { Shibahara and } \\
\text { Lumianski (1995) }\end{array}$ & CL & $\begin{array}{l}\text { May-June } \\
1994\end{array}$ & Lower Clackamas River & $\begin{array}{l}\text { Movement, distribution and habitat use of } \\
\text { winter steelhead }\end{array}$ & -- & -- & $\mathrm{X}$ \\
\hline Smith and Korn (1970) & MF & June $1966-70$ & $\begin{array}{l}\text { Big Fall Creek watershed and } \\
\text { reservoir }\end{array}$ & Fish species composition & -- & -- & $\mathrm{X}$ \\
\hline Speir (1976) & LU,MA & 1971 and 1972 & Berry, Oak, and Soap Creeks & $\begin{array}{l}\text { Ecology and production of four black fly } \\
\text { species }\end{array}$ & -- & $\mathrm{X}$ & -- \\
\hline $\begin{array}{l}\text { Steedman (1983); } \\
\text { Steedman and Anderson } \\
(1985)\end{array}$ & LU,MA & Oct. $1980-82$ & Berry and Yew Creeks & Ecology of the beetle, Lara avara & -- & $\mathrm{X}$ & -- \\
\hline Sutherland (1976) & TU & $\begin{array}{l}\text { Spring/summer } \\
1975-76\end{array}$ & 13 tributaries of Tualatin River & Invertebrate composition and distribution & -- & $\mathrm{X}$ & -- \\
\hline Tetra Tech, Inc. (1993b) & MC,WR & Aug.-Sept. 1992 & $\begin{array}{l}\text { Willamette River and lower } \\
\text { McKenzie River }\end{array}$ & Fish distribution and abundance & -- & -- & $\mathrm{X}$ \\
\hline Tetra Tech, Inc. (1994) & MC,TU,WR & $\begin{array}{l}\text { Aug.-Sept. 1992; } \\
\text { Oct. } 1993\end{array}$ & $\begin{array}{l}\text { Willamette, Tualatin, and McKenzie } \\
\text { Rivers }\end{array}$ & Invertebrate distribution and abundance & -- & $\mathrm{X}$ & -- \\
\hline Tew (1970) & LU & $1968-70$ & Tributary of Berry Creek & Insects of an intermittent stream & -- & $\mathrm{X}$ & -- \\
\hline Thompson (1965) & $\mathrm{CF}, \mathrm{MF}$ & Summer 1964 & $\begin{array}{l}\text { Coast and Middle Fork Willamette } \\
\text { River }\end{array}$ & Fish distribution and abundance & -- & -- & $\mathrm{X}$ \\
\hline $\begin{array}{l}\text { TW Environmental, Inc. } \\
\text { (1994) }\end{array}$ & SY & Nov. 8, 1994. & Bull Run River & Invertebrate sampling & -- & $\mathrm{X}$ & -- \\
\hline Ward and Nigro (1991) & WR & Mar.-June 1988-90 & Portland Harbor, RM 0-27 & Fish assemblages and habitat characteristics & -- & -- & $\mathrm{X}$ \\
\hline Ward and others (1988) & WR & Autumn 1986-87 & Lower Willamette River & $\begin{array}{l}\text { Migration, behavior, and survival of juvenile } \\
\text { salmonids }\end{array}$ & -- & -- & $\mathrm{X}$ \\
\hline Ward and others (1991) & WR & $\begin{array}{l}\text { Mar.-June 1988-89; } \\
\text { April-June } 1990\end{array}$ & $\begin{array}{l}\text { Lower Willamette River; } \\
\text { RM 0-16.8 }\end{array}$ & $\begin{array}{l}\text { Status and biology of black crappie and white } \\
\text { crappie }\end{array}$ & -- & -- & $\mathrm{X}$ \\
\hline Ward and others (1994) & WR & $\begin{array}{l}\text { Mar.-June and Nov. } \\
\text { 1987-90 }\end{array}$ & $\begin{array}{l}\text { Lower Willamette River up } \\
\text { to RM } 20\end{array}$ & $\begin{array}{l}\text { Migration behavior and habitat use of juvenile } \\
\text { salmonids, and predation on them by northern } \\
\text { squawfish }\end{array}$ & -- & -- & $\mathrm{X}$ \\
\hline Wetherbee (1962) & SA & $1953-61$ & Detroit Reservoir & Fish community sampling & -- & -- & $\mathrm{X}$ \\
\hline Wille (1976) & WR & Summer 1974 & $\begin{array}{l}\text { Willamette River KM 11,21,35,56, } \\
\text { and } 80\end{array}$ & Algal sampling & $\mathrm{X}$ & -- & -- \\
\hline
\end{tabular}


APPENDIX A. INVESTIGATIONS OF AQUATIC BIOTA IN THE WILLAMETTE BASIN, OREGON-Continued

\begin{tabular}{|c|c|c|c|c|c|c|c|}
\hline \multirow[b]{2}{*}{ Literature citation } & \multirow[b]{2}{*}{ Subbasin } & \multirow[b]{2}{*}{ Temporal coverage } & \multirow[b]{2}{*}{ Spatial coverage } & \multirow[b]{2}{*}{ Topic } & \multicolumn{3}{|c|}{ Taxa } \\
\hline & & & & & Algae & $\begin{array}{l}\text { Inverte- } \\
\text { brates }\end{array}$ & Fish \\
\hline Willis and others (1960) & WB & $1958-59$ & 17 major rivers and tributaries & Environmental survey & -- & -- & $\mathrm{X}$ \\
\hline Wilzbach (1984) & $\mathrm{MC}$ & $1982-83$ & Grasshopper Creek & $\begin{array}{l}\text { Effects of prey availability and cover on trout } \\
\text { abundance and growth }\end{array}$ & -- & $X$ & $X$ \\
\hline $\begin{array}{l}\text { Wilzbach and others } \\
\text { (1986) }\end{array}$ & $\mathrm{MC}$ & June-Aug. 1984 & Grasshopper Creek & $\begin{array}{l}\text { Effects of habitat manipulations on cutthroat } \\
\text { trout and invertebrate drift }\end{array}$ & -- & $X$ & $\mathrm{X}$ \\
\hline Wisseman (1989) & SY & Aug. 1988 & $\begin{array}{l}\text { Timberline Lodge, Mt Hood } \\
\text { National Forest }\end{array}$ & $\begin{array}{l}\text { Occurrence and habitat of threatened/ } \\
\text { endangered invertebrates }\end{array}$ & -- & $X$ & -- \\
\hline Wisseman (1992a) & SY & June 11, 1992 & $\begin{array}{l}\text { Timberline Lodge, Mt. Hood } \\
\text { National Forest }\end{array}$ & Inventory for sensitive caddisflies & -- & $X$ & -- \\
\hline Wisseman (1992b) & $\mathrm{CL}$ & Sept. 1991 & $\begin{array}{l}\text { Mt. Hood National Forest, Squaw } \\
\text { Lakes }\end{array}$ & Benthic invertebrate biomonitoring & -- & $X$ & -- \\
\hline Wisseman (1992c) & MF & 1990-91 & $\begin{array}{l}\text { Willamette National Forest, Rigdon } \\
\text { Ranger District }\end{array}$ & UV light trap survey for sensitive caddisflies & -- & $\mathrm{X}$ & -- \\
\hline Wisseman (1995) & SY & Fall 1992-93 & $\begin{array}{l}\text { Mt. Hood National Forest, Zigzag } \\
\text { Ranger District }\end{array}$ & Benthic invertebrate biomonitoring & -- & $X$ & -- \\
\hline Wustenberg (1954) & $\mathrm{MC}$ & $\begin{array}{l}\text { June-Oct. } 1951 \text { and } \\
1952\end{array}$ & Lookout Creek & Effects of logging on a trout stream & -- & $\mathrm{X}$ & $\mathrm{X}$ \\
\hline Wyatt (1959) & $\mathrm{MC}$ & $\begin{array}{l}\text { June 1956-Sept. } \\
1957\end{array}$ & Lookout Creek & Movements and reproduction of cutthroat trout & -- & -- & $X$ \\
\hline Zakel and Reed (1984) & MC & $\begin{array}{l}\text { Sept. 1980-Nov. } \\
1983\end{array}$ & Leaburg Dam on McKenzie River & Downstream migration of fish at Leaburg Dam & -- & -- & $\mathrm{X}$ \\
\hline Ziebell (1954) & SA & $\begin{array}{l}\text { Oct. 1952-Sept. } \\
1953\end{array}$ & South Santiam River below Lebanon & Biological evaluations of pollution conditions & -- & $\mathrm{X}$ & $\mathrm{X}$ \\
\hline Zirges (1972) & CF,LT,MA,RI & $\begin{array}{l}\text { Spring/ Summer } \\
1972\end{array}$ & $\begin{array}{l}\text { Rickreall Creek; Marys, Long Tom, } \\
\text { and Coast Fork Willamette Rivers }\end{array}$ & Morphological study of blackside dace & -- & -- & $X$ \\
\hline
\end{tabular}




\section{APPENDIX B. ALGAE REPORTED FROM AQUATIC ENVIRONMENTS IN THE WILLAMETTE BASIN, OREGON}

[Subbasins (see fig. 5): CF, Coast Fork Willamette; CL, Clackamas; LU, Luckiamute; MC, McKenzie; MF, Middle Fork Willamette; PM, Pudding/ Molalla; SA, Santiam; SY, Sandy; TU, Tualatin; WR, Willamette; YH, Yamhill. Sources: 1, Burns (1993); 2, Carter (1975); 3, Carter and others (1976); 4, Clifton (1985); 5, Fetrow Engineering and Scientific Resources (1989) (includes Delta Ponds as part of WR); 6, Gregory (1993); 7, HMS Environmental, Inc., and Miller (1988); 8, Johnson and others (1989); 9, Miller (1979);10, Raymond (1983); 11, Reese (1966); 12, Rickert and others (1977); 13, Rinella and others (1981); 14, Scheidt and Nichols (1976); 15, Wille (1976)]

\begin{tabular}{|c|c|c|c|}
\hline Family & Genus-Species & Subbasin & Source \\
\hline \multicolumn{4}{|c|}{ PHYLUM: Chlorophyta (Green Algae) } \\
\hline Chaetophoraceae & Stigeoclonium sp. & CF,CL,LU,TU,WR,YH & $2,6,11$ \\
\hline Characiaceae & Characium sp. & WR & 5 \\
\hline Chlamydomonadaceae & Chlamydomonas sp. & CF,CL,LU,SA,SY,TU,WR & $1,3,4,6,11,13$ \\
\hline \multirow[t]{4}{*}{ Chlorococcaceae } & Tetraedron sp. & CL,TU,WR & $1,2,5,6$ \\
\hline & Tetraedron caudatum & CL & 1 \\
\hline & Tetraedron minimum & CL,WR & 1,5 \\
\hline & Tetradron quadratum & MF & 4,13 \\
\hline Cladophoraceae & Cladophora sp. & TU & 3 \\
\hline \multirow[t]{2}{*}{ Closteriaceae } & Closterium sp. & $\mathrm{TU}$ & 2,3 \\
\hline & Roya obtusa & TU & 2 \\
\hline Coccomyxaceae & Elakatothrix gelatinosa & WR & 5 \\
\hline \multirow[t]{4}{*}{ Cosmariaceae } & Micrasterias sp. & $\mathrm{TU}$ & 2 \\
\hline & Staurastrum sp. & TU,WR & $2,3,5,8,13$ \\
\hline & Staurastrum gracile & CL,WR & 1,5 \\
\hline & Staurastrum paradoxum & MF & 4,13 \\
\hline Desmidiaceae & Cosmarium sp. & CL,LU,SA,TU,WR & $1,2,5,11,13$ \\
\hline \multirow[t]{3}{*}{ Dictyosphaeriaceae } & Botryococcus sp. & WR & 5 \\
\hline & Botryococcus braunii & CL,MF & 1,14 \\
\hline & Dictyosphaerium ehrenbergianum & CL,TU & 1,2 \\
\hline Hyalothecaceae & Spondylosium sp. & $\mathrm{TU}$ & 2 \\
\hline \multirow[t]{3}{*}{ Hydrodictyaceae } & Pediastrum sp. & TU,WR & $2,3,12,15$ \\
\hline & Pediastrum duplex & TU,WR & 2,5 \\
\hline & Pediastrum tetras & CL,TU,WR & $1,2,5,13$ \\
\hline Micractiniaceae & Micractinium pusillum & $\mathrm{TU}$ & 2,3 \\
\hline Mougeotiaceae & Mougeotia sp. & TU,WR & $2,3,5$ \\
\hline Oedogoniaceae & Oedogonium sp. & CF,PM,SA,TU,WR & $2,3,6,13$ \\
\hline \multirow[t]{5}{*}{ Oocystaceae } & Ankistrodesmus sp. & TU,WR & 3,6 \\
\hline & Ankistrodesmus falcatus & CL,MF,SA,TU,WR & $1,2,5,13,14$ \\
\hline & Chlorella sp. & CF,CL,MC,MF,PM,TU,WR & $3,6,13$ \\
\hline & Closteriopsis longissima & WR & 5 \\
\hline & Kirchneriella sp. & WR & 13 \\
\hline
\end{tabular}




\section{APPENDIX B. ALGAE REPORTED FROM AQUATIC ENVIRONMENTS IN THE WILLAMETTE BASIN, OREGON-Continued}

\begin{tabular}{|c|c|c|c|}
\hline Family & Genus-Species & Subbasin & Source \\
\hline \multicolumn{4}{|c|}{ PHYLUM: Chlorophyta (Green Algae)—Continued } \\
\hline \multirow[t]{11}{*}{ Oocystaceae-Continued } & Kirchneriella lunaris & $\mathrm{TU}$ & 2 \\
\hline & Nephrocytium sp. & WR & 5 \\
\hline & Oocystis sp. & SA,WR & $5,6,13$ \\
\hline & Oocystis lacustris & CL & 1 \\
\hline & Oocystis pusilla & CL,WR & 1,5 \\
\hline & Planktosphaeria gelatinosa & WR & 5 \\
\hline & Quadrigula closterioides & WR & 5 \\
\hline & Quadrigula lacustris & CL & 1 \\
\hline & Selenastrum sp. & CL,TU & 1,2 \\
\hline & Selenastrum minutum & CL,WR & $1,5,13$ \\
\hline & Zoochlorella sp. & $\mathrm{TU}$ & 2 \\
\hline \multirow[t]{2}{*}{ Palmellaceae } & Gloeocystis sp. & WR & 5,13 \\
\hline & Sphaerocystis schroeteri & CL,WR & 1,5 \\
\hline \multirow[t]{13}{*}{ Scenedesmaceae } & Actinastrum sp. & $\mathrm{TU}$ & 2 \\
\hline & Actinastrum gracilimum & $\mathrm{TU}$ & 2 \\
\hline & Coelastrum microporum & WR & 5 \\
\hline & Crucigenia sp. & TU,WR & 2,13 \\
\hline & Crucigenia crucifera & $\mathrm{CL}$ & 1 \\
\hline & Crucigenia quadrata & CL,WR & 1,13 \\
\hline & Crucigenia tetrapedia & WR & 13 \\
\hline & Scenedesmus sp. & CL,PM,TU,WR & $1,3,5,6,12,13,15$ \\
\hline & Scenedesmus abundans & WR & 5 \\
\hline & Scenedesmus bijuga & WR & 5 \\
\hline & Scenedesmus denticulatus & CL,WR & 1,5 \\
\hline & Scenedesmus obliquus & SA,WR & 8,13 \\
\hline & Scenedesmus quadricauda & SA,TU,WR & $2,5,13$ \\
\hline Tetrasporaceae & Tetraspora sp. & LU & 11 \\
\hline \multirow[t]{4}{*}{ Ulotrichaceae } & Stichococcus sp. & LU & 11 \\
\hline & Ulothrix sp. & PM,SY,TU,WR & $2,3,4,5,6,9,12$ \\
\hline & Ulothrix aequalis & WR & 13 \\
\hline & Ulothrix zonata & SY,WR & 4,6 \\
\hline \multirow[t]{3}{*}{ Volvocaceae } & Eudorina sp. & $\mathrm{TU}$ & 3 \\
\hline & Eudorina elegans & MF,TU,WR & $2,13,14$ \\
\hline & Gonium sp. & TU & 2,3 \\
\hline
\end{tabular}


APPENDIX B. ALGAE REPORTED FROM AQUATIC ENVIRONMENTS IN THE WILLAMETTE BASIN, OREGON-Continued

\begin{tabular}{|c|c|c|c|}
\hline Family & Genus-Species & Subbasin & Source \\
\hline \multicolumn{4}{|c|}{ PHYLUM: Chlorophyta (Green Algae)—Continued } \\
\hline \multirow[t]{4}{*}{ Volvocaceae-Continued } & Pandorina sp. & TU & 2,3 \\
\hline & Pandorina morum & MF,WR & 13,14 \\
\hline & Volvox sp. & TU & 2,3 \\
\hline & Volvox aureus & MF & 14 \\
\hline \multirow[t]{3}{*}{ Zygnemataceae } & Mougeotiopsis calospora & TU & 2 \\
\hline & Spirogyra sp. & SY,TU & $2,3,4$ \\
\hline & Spirogyra pseudo-floxidina & TU & 2 \\
\hline \multicolumn{4}{|c|}{ PHYLUM: Chrysophyta (Golden-brown algae) } \\
\hline \multirow[t]{2}{*}{ Chrysococcaceae } & Chrysococcus sp. & WR & 5 \\
\hline & Chrysococcus rufescens & CL,WR & 1,5 \\
\hline \multirow[t]{2}{*}{ Dinobryaceae } & Dinobryon sp. & CL,SY,TU,WR & $1,2,3,5,10$ \\
\hline & Dinobryon sertularia & CL,SA,WR & $1,5,13$ \\
\hline Ochromonadaceae & Ochromonas sp. & CF,CL,MC,PM,WR & $1,5,6$ \\
\hline Plagiotropidaceae & Plagiotropis sp. & WR & 6 \\
\hline Prymnesiaceae & Chrysochromulina sp. & CL & 1 \\
\hline \multirow[t]{4}{*}{ Synuraceae } & Chrysosphaerella sp. & CL & 1 \\
\hline & Chrysosphaerella longispina & TU & 2 \\
\hline & Mallomonas sp. & CL,MF,TU,WR & $1,2,3,5,14$ \\
\hline & Synura uvella & TU,WR & $2,3,5$ \\
\hline Vaucheriaceae & Vaucheria sp. & TU & 2 \\
\hline Xanthopyceae & Tribonema sp. & LU & 11 \\
\hline \multicolumn{4}{|c|}{$\begin{array}{l}\text { PHYLUM: Bacillariophyta } \\
\text { (Diatoms) }\end{array}$} \\
\hline \multirow[t]{11}{*}{ Achnanthaceae } & Achnanthes sp. & $\begin{array}{l}\text { CF,CL,LU,MC,MF,SA,SY, } \\
\text { TU,WR }\end{array}$ & $2,3,6,10,11,12,15$ \\
\hline & Achnanthes brevipes & $\mathrm{TU}$ & 2 \\
\hline & Achnanthes deflexa & WR & 8 \\
\hline & Achnanthes hauckiana & CL,WR & 1,5 \\
\hline & Achnanthes lewisiana & SA,SY,TU,WR & $3,10,12,13,15$ \\
\hline & Achnanthes linearis & PM,SA,SY,TU,WR & $3,4,8,9,10,13$ \\
\hline & Achnanthes minutissima & CL,PM,SA,SY,TU,WR & $1,3,4,5,9,10,12,13,15$ \\
\hline & Achnanthidium clevei & CL,SY & 1,10 \\
\hline & Achnanthidium exigum & SY,WR & 5,10 \\
\hline & Achnanthidium lanceolatum & CL,PM,SA,SY,TU,WR & $1,3,4,5,8,9,10,12,13,15$ \\
\hline & Achnanthidium minutissimum & CL,PM,SA,SY,TU,WR & $1,3,4,5,9,10,12,13,15$ \\
\hline
\end{tabular}




\section{APPENDIX B. ALGAE REPORTED FROM AQUATIC ENVIRONMENTS IN THE WILLAMETTE BASIN, OREGON-Continued}

\begin{tabular}{|c|c|c|c|}
\hline Family & Genus-Species & Subbasin & Source \\
\hline \multicolumn{4}{|c|}{$\begin{array}{l}\text { PHYLUM: Bacillariophyta } \\
\text { (Diatoms)-Continued }\end{array}$} \\
\hline \multirow[t]{7}{*}{ Achnanthaceae-Continued } & Cocconeis sp. & CF,LU,MC,MF,TU,WR & $2,6,11,12,15$ \\
\hline & Cocconeis pediculus & SA & 13 \\
\hline & Cocconeis placentula & CL,SA,SY,TU,WR & $1,3,5,10,13$ \\
\hline & Cocconeis placentula-euglypta & PM,SA,SY,WR & $4,8,9,13$ \\
\hline & Cocconeis placentula lineata & PM & 9 \\
\hline & Rhoicosphenia sp. & LU,WR & 6,11 \\
\hline & Rhoicosphenia curvata & PM,SA,TU,WR & $2,3,5,8,9,12,13,15$ \\
\hline \multirow[t]{4}{*}{ Amphipleuraceae } & Amphipleura pellucida & WR & 5 \\
\hline & Frustulia sp. & LU,SY & 10,11 \\
\hline & Frustulia rhomboides & TU,SY & 2,10 \\
\hline & Frustulia rhomboides saxonica & TU & 3 \\
\hline \multirow[t]{3}{*}{ Anomoeoneidaceae } & Anomoeoneis cf. sphaerophora & WR & 7 \\
\hline & Anomoeoneis serians & SY & 10 \\
\hline & Anomoeoneis vitra & TU & 3 \\
\hline \multirow[t]{3}{*}{ Bacillariaceae } & Denticula elegans & TU & 3 \\
\hline & Hantzschia sp. & WR & 6 \\
\hline & Hantzschia amphioxys & TU & 3 \\
\hline \multirow[t]{2}{*}{ Chromulinaceae } & Chromulina sp. & $\mathrm{CL}$ & 1 \\
\hline & Kephyrion sp. & $\mathrm{CL}$ & 1 \\
\hline \multirow[t]{14}{*}{ Coscinodiscaceae } & Cyclotella sp. & TU,WR & $2,8,12,15$ \\
\hline & Cyclotella atomus & SY,WR & 5,10 \\
\hline & Cyclotella comta & SY & 10 \\
\hline & Cyclotella glomerata & SY & 10 \\
\hline & Cyclotella kutzingiana & SY & 10 \\
\hline & Cyclotella meneghiniana & SA,SY,TU,WR & $3,5,10,12,13,15$ \\
\hline & Cyclotella ocellata & SY & 10 \\
\hline & Cyclotella pseudostelligera & SY,WR & 10,13 \\
\hline & Cyclotella stelligera & CL,SA,SY,TU,WR & $1,3,5,10,12,13,15$ \\
\hline & Cyclotella striata & SY & 10 \\
\hline & Melosira sp. & CL,LU,SA,SY,TU,WR & $1,6,7,10,11,12,13,15$ \\
\hline & Melosira ambigua & CL,SA,SY,WR & $1,5,10,13$ \\
\hline & Melosira distans & CL,SA,SY,TU,WR & $1,2,3,10,12,13,15$ \\
\hline & Melosira granulata & MF,TU,WR & $2,3,12,14,15$ \\
\hline
\end{tabular}




\section{APPENDIX B. ALGAE REPORTED FROM AQUATIC ENVIRONMENTS IN THE WILLAMETTE BASIN, OREGON-Continued}

\begin{tabular}{|c|c|c|c|}
\hline Family & Genus-Species & Subbasin & Source \\
\hline \multicolumn{4}{|c|}{$\begin{array}{l}\text { PHYLUM: Bacillariophyta } \\
\text { (Diatoms)—Continued }\end{array}$} \\
\hline \multirow[t]{8}{*}{ Coscinodiscaceae-Continued } & Melosira granulata angustissima & SA,WR & 13 \\
\hline & Melosira italica & CL,MF,SY,TU,WR & $1,2,10,12,13,14,15$ \\
\hline & Melosira varians & PM,SA,SY,TU,WR & $2,3,4,5,8,9,12,13,15$ \\
\hline & Stephanodiscus sp. & TU,WR & $2,6,12,15$ \\
\hline & Stephanodiscus astrea & SY,WR & $10,12,13,15$ \\
\hline & Stephanodiscus astrea minutula & MF,SA,WR & $5,13,14$ \\
\hline & Stephanodiscus dubius & SY & 10 \\
\hline & Stephanodiscus hantzschii & SY,TU,WR & $3,5,10,12,13,15$ \\
\hline \multirow[t]{21}{*}{ Cymbellaceae } & Amphora sp. & CF,LU,MF,PM,SA,SY,WR & $6,7,10,11$ \\
\hline & Amphora ovalis & SY,WR & $5,10,13$ \\
\hline & Amphora perpusilla & PM,SA,WR & $5,9,13$ \\
\hline & Cymbella sp. & CF,LU,MC,MF,SY,TU,WR & $2,3,6,10,11,12,15$ \\
\hline & Cymbella affinis & PM,SA,TU,WR & $3,5,9,13$ \\
\hline & Cymbella angustata & SY,WR & 5,10 \\
\hline & Cymbella aspera & TU & 2 \\
\hline & Cymbella cesatii & SY & 10 \\
\hline & Cymbella cistula & WR & 5,7 \\
\hline & Cymbella cymbiformis & SA,WR & 8,13 \\
\hline & Cymbella graecilis & TU & 3 \\
\hline & Cymbella lanceolata & $\mathrm{TU}$ & 3 \\
\hline & Cymbella lunata & SY & 10 \\
\hline & Cymbella microcephala & CL,WR & 1,5 \\
\hline & Cymbella minuta & CL,PM,SA,SY,TU,WR & $1,3,4,5,8,9,10,13$ \\
\hline & Cymbella perpusilla & TU & 3 \\
\hline & Cymbella prostrata & TU & 2,3 \\
\hline & Cymbella sinuata & PM,SA,SY,TU,WR & $3,8,9,10,12,13,15$ \\
\hline & Cymbella tumida & SA,TU,WR & $2,3,12,13,15$ \\
\hline & Cymbella turgidula & WR & 8 \\
\hline & Cymbella ventricosa & TU,WR & $2,12,15$ \\
\hline \multirow[t]{5}{*}{ Epithemiaceae } & Epithemia sp. & $\mathrm{TU}$ & 2,3 \\
\hline & Epithemia sorex & CL,SA,WR & $1,5,13$ \\
\hline & Epithemia turgida & WR & 5 \\
\hline & Epithemia sp. & $\mathrm{TU}$ & 2 \\
\hline & Rhopalodia sp. & TU & 2 \\
\hline
\end{tabular}




\section{APPENDIX B. ALGAE REPORTED FROM AQUATIC ENVIRONMENTS IN THE WILLAMETTE BASIN, OREGON-Continued}

\begin{tabular}{|c|c|c|c|}
\hline Family & Genus-Species & Subbasin & Source \\
\hline \multicolumn{4}{|c|}{$\begin{array}{l}\text { PHYLUM: Bacillariophyta } \\
\text { (Diatoms)—Continued }\end{array}$} \\
\hline Epithemiaceae-Continued & Rhopalodia gibba & WR & 5,13 \\
\hline \multirow[t]{11}{*}{ Eunotiaceae } & Eunotia sp. & LU,TU,WR & $2,3,5,11,13$ \\
\hline & Eunotia arcus & $\mathrm{TU}$ & 2 \\
\hline & Eunotia curvata & SY & 10 \\
\hline & Eunotia elegans & SY & 10 \\
\hline & Eunotia incisa & WR & 5 \\
\hline & Eunotia microcephala & SY & 10 \\
\hline & Eunotia pectinalis & $\mathrm{CL}$ & 1 \\
\hline & Eunotia rostellata & SY & 10 \\
\hline & Eunotia tridentula var. perminuta & $\mathrm{TU}$ & 2 \\
\hline & Eunotia tridentula var.persusilla & $\mathrm{TU}$ & 2 \\
\hline & Eunotia vanheurckii & SY & 10 \\
\hline \multirow[t]{21}{*}{ Fragilariaceae } & Asterionella formosa & $\mathrm{CL}, \mathrm{MF}, \mathrm{SA}, \mathrm{TU}, \mathrm{WR}$ & $1,2,3,5,12,13,14,15$ \\
\hline & Diatoma sp. & LU,WR & $11,12,15$ \\
\hline & Diatoma hiemale & SY,TU,WR & $2,3,10,12,15$ \\
\hline & Diatoma hiemale mesodon & PM,SY,WR & $4,9,13$ \\
\hline & Diatoma tenue elongatum & WR & 5 \\
\hline & Diatoma vulgare & TU,WR & $2,3,5,12,13,15$ \\
\hline & Diatoma vulgare linearis & WR & 8 \\
\hline & Fragilaria sp. & CF,LU,SY,TU,WR & $2,6,8,10,11,12,13,15$ \\
\hline & Fragilaria brevistriata & SY & 10 \\
\hline & Fragilaria capucina & $\mathrm{CL}, \mathrm{MF}, \mathrm{WR}$ & $1,5,7,14$ \\
\hline & Fragilaria capucina mesolepta & WR & 5 \\
\hline & Fragilaria construens & CL,SA,SY,TU,WR & $1,3,5,10,13$ \\
\hline & Fragilaria construens venter & CL,SY,WR & $1,5,8,10$ \\
\hline & Fragilaria crotonensis & MF,SA,TU,WR & $2,5,12,13,14,15$ \\
\hline & Fragilaria pinnata & CL,TU,WR & $1,3,5$ \\
\hline & Fragillaria vaucheria & SA,SY,WR & $4,5,8,10,13$ \\
\hline & Hannaea sp. & TU & 2 \\
\hline & Hannaea arcus & PM,SY,TU,WR & $2,3,4,9,10,12,13,15$ \\
\hline & Meridion sp. & LU & 11 \\
\hline & Meridion circulare & SY,TU & $2,3,10$ \\
\hline & Synedra sp. & LU,MF,SA,TU,WR & $2,3,6,11,12,13,15$ \\
\hline
\end{tabular}




\section{APPENDIX B. ALGAE REPORTED FROM AQUATIC ENVIRONMENTS IN THE WILLAMETTE BASIN, OREGON-Continued}

\begin{tabular}{|c|c|c|c|}
\hline Family & Genus-Species & Subbasin & Source \\
\hline \multicolumn{4}{|c|}{$\begin{array}{l}\text { PHYLUM: Bacillariophyta } \\
\text { (Diatoms)-Continued }\end{array}$} \\
\hline \multirow[t]{18}{*}{ Fragilariaceae-Continued } & Synedra acus & SY & 10 \\
\hline & Synedra cyclopum & CL & 1 \\
\hline & Synedra Cunningtonii & WR & 12,15 \\
\hline & Synedra delicatissima & TU,WR & 3,5 \\
\hline & Synedra goulardi & WR & 13 \\
\hline & Synedra mazamaensis & WR & $8,12,13,15$ \\
\hline & Synedra parasitica & SY,TU,WR & $3,10,13$ \\
\hline & Synedra radians & CL,WR & 1,5 \\
\hline & Synedra rumpens & SA,SY,TU,WR & $3,4,5,13$ \\
\hline & Synedra tenera & TU & 3 \\
\hline & Synedra ulna & PM,SA,SY,TU,WR & $2,3,5,9,10,12,13,15$ \\
\hline & Synedra ulna constricta & WR & 8 \\
\hline & Synedra ulna contracta & SA,TU,WR & $2,3,13$ \\
\hline & Synedra ulna ulna & WR & 8 \\
\hline & Tabellaria sp. & LU,TU & 2,11 \\
\hline & Tabellaria fenestrata & TU & 2,3 \\
\hline & Tabellaria flocculosa & SY & 10 \\
\hline & Tetracyclus lacustris & SY & 10 \\
\hline \multirow[t]{15}{*}{ Gomphonemaceae } & Gomphoneis sp. & WR & $8,12,15$ \\
\hline & Gomphoneis herculeana & SY,WR & 7,13 \\
\hline & Gomphoneis herculeana robusta & WR & 8 \\
\hline & Gomphonema sp. & $\begin{array}{l}\text { CF,CL,LU,MF,PM,SA,SY, } \\
\text { TU,WR }\end{array}$ & $\begin{array}{l}1,2,3,4,5,6,8,9,10,11, \\
12,13,15\end{array}$ \\
\hline & Gomphonema acuminatum & TU,WR & 3,5 \\
\hline & Gomphonema angustatum & CL,SA,SY,TU,WR & $1,3,4,5,10,13$ \\
\hline & Gomphonema constrictum & TU & 3 \\
\hline & Gomphonema gracile & SY,TU & 3,10 \\
\hline & Gomphonema olivaceum & WR & 5 \\
\hline & Gomphonema parvulum & PM,SA,TU,WR & $3,5,9,13$ \\
\hline & Gomphonema simus & TU & 3 \\
\hline & Gomphonema subclavatum & SA,WR & 5,13 \\
\hline & Gomphonema tenellum & PM,SA,WR & 9,13 \\
\hline & Gomphonema truncatum capitatum & WR & 8 \\
\hline & Gomphonema ventricosum & WR & 5 \\
\hline
\end{tabular}




\section{APPENDIX B. ALGAE REPORTED FROM AQUATIC ENVIRONMENTS IN THE WILLAMETTE BASIN, OREGON-Continued}

\begin{tabular}{|c|c|c|c|}
\hline Family & Genus-Species & Subbasin & Source \\
\hline \multicolumn{4}{|c|}{$\begin{array}{l}\text { PHYLUM: Bacillariophyta } \\
\text { (Diatoms)_Continued }\end{array}$} \\
\hline Naviculaceae & Amphiprora sp. & LU & 11 \\
\hline & Amphiprora ornata & TU & 2,3 \\
\hline & Caloneis sp. & LU,SY & 10,11 \\
\hline & Caloneis ventricosa & SY,TU & 3,10 \\
\hline & Diatomella balfouriana & SY & 10 \\
\hline & Diploneis elliptica & SY,TU & 3,10 \\
\hline & Diploneis finnica & SY & 10 \\
\hline & Diploneis oblongata & SY & 10 \\
\hline & Gyrosigma sp. & TU & 2 \\
\hline & Gyrosigma accuminatum & TU & 3 \\
\hline & Mastogloia sp. & MF,WR & 6 \\
\hline & Navicula sp. & $\begin{array}{l}\text { CF,CL,LU,MC,MF,PM,SA, } \\
\text { SY,TU,WR }\end{array}$ & $\begin{array}{l}1,2,3,5,6,8,10,11,12,13, \\
15\end{array}$ \\
\hline & Navicula capitata & WR & 13 \\
\hline & Navicula contenta biceps & WR & 5 \\
\hline & Navicula cryptocephala & PM,SA,WR & $5,9,13$ \\
\hline & Navicula cryptocephala veneta & WR & 5,13 \\
\hline & Navicula decussis & SA,WR & 8,13 \\
\hline & Navicula disputans & SY & 10 \\
\hline & Navicula exigua & SY,TU & 3,10 \\
\hline & Navicula gregaria & TU & 3 \\
\hline & Navicula inflexa & SY & 10 \\
\hline & Navicula meniscula & $\mathrm{PM}$ & 9 \\
\hline & Navicula menisculus upsaliensis & WR & 5 \\
\hline & Navicula minima & CL,WR & $1,5,8$ \\
\hline & Navicula mutica & TU,WR & $3,5,13$ \\
\hline & Navicula pelliculosa & WR & 5 \\
\hline & Navicula placenta & SY & 10 \\
\hline & Navicula placentula & SY & 10 \\
\hline & Navicula pupula & PM,SA,SY,TU,WR & $3,5,9,10,13$ \\
\hline & Navicula radiosa & WR & 5 \\
\hline & Navicula radiosa tenella & WR & 8 \\
\hline & Navicula rhynchocephala & WR & 5 \\
\hline
\end{tabular}




\section{APPENDIX B. ALGAE REPORTED FROM AQUATIC ENVIRONMENTS IN THE WILLAMETTE BASIN, OREGON-Continued}

\begin{tabular}{|c|c|c|c|}
\hline Family & Genus-Species & Subbasin & Source \\
\hline \multicolumn{4}{|c|}{$\begin{array}{l}\text { PHYLUM: Bacillariophyta } \\
\text { (Diatoms)—Continued }\end{array}$} \\
\hline \multirow[t]{16}{*}{ Naviculaceae-Continued } & Navicula salinarum & SA,WR & 13 \\
\hline & Navicula tripunctata & SA,WR & 5,13 \\
\hline & Navicula viridula & TU & 3 \\
\hline & Neidium sp. & TU & 3 \\
\hline & Neidium affine & SY & 10 \\
\hline & Neidium dubium & SY & 10 \\
\hline & Neidium iridis & WR & 13 \\
\hline & Pinnularia sp. & LU,SY,TU,WR & $2,3,5,10,11,13$ \\
\hline & Pinnularia mesolepta & SY & 10 \\
\hline & Pinnularia microstauron & TU & 3 \\
\hline & Pinnularia nobilis & SY & 10 \\
\hline & Pinnularia subcapitata & SY,TU & 3,10 \\
\hline & Pleurosigma sp. & LU & 11 \\
\hline & Stauroneis sp. & LU,SA,SY & $10,11,13$ \\
\hline & Stauroneis anceps & SY,TU & 3,10 \\
\hline & Stauroneis phoenicentron & SY & 10 \\
\hline \multirow[t]{17}{*}{ Nitzschiaceae } & Nitzschia sp. & $\begin{array}{l}\text { CL,LU,MC,PM,SA,SY,TU, } \\
\text { WR }\end{array}$ & $\begin{array}{l}1,2,3,5,6,8,9,10,11,12, \\
13,15\end{array}$ \\
\hline & Nitzschia acicularis & CL,TU & $1,2,3,10$ \\
\hline & Nitzschia aricularis & CL,SA,TU,WR & $1,3,5,13$ \\
\hline & Nitzschia acuta & SA,TU,WR & $2,3,13$ \\
\hline & Nitzschia amphibia & SA,SY,WR & $5,10,13$ \\
\hline & Nitzschia capitellata & TU,WR & 3,5 \\
\hline & Nitzschia dissipata & PM,SA,SY,TU,WR & $3,5,8,9,10,13$ \\
\hline & Nitzschia filiformis & TU & 2 \\
\hline & Nitzschia frustulum & SA,TU,WR & $3,5,13$ \\
\hline & Nitzschia frustulum perpusilla & WR & 8 \\
\hline & Nitzschia frustulum subsalina & SA,TU,WR & 3,13 \\
\hline & Nitzschia holsatica & WR & 8 \\
\hline & Nitzschia linearis & SY,TU,WR & $3,5,10,13$ \\
\hline & Nitzschia minima & WR & 13 \\
\hline & Nitzschia oregona & WR & 8 \\
\hline & Nitzschia palea & SA,SY,TU,WR & $3,5,10,13$ \\
\hline & Nitzschia palaceae & CL,SA,SY,WR & $1,4,5,13$ \\
\hline
\end{tabular}




\section{APPENDIX B. ALGAE REPORTED FROM AQUATIC ENVIRONMENTS IN THE WILLAMETTE BASIN, OREGON-Continued}

\begin{tabular}{|c|c|c|c|}
\hline Family & Genus-Species & Subbasin & Source \\
\hline \multicolumn{4}{|c|}{$\begin{array}{l}\text { PHYLUM: Bacillariophyta } \\
\text { (Diatoms)-Continued }\end{array}$} \\
\hline \multirow[t]{4}{*}{ Nitzschiaceae-Continued } & Nitzschia rectra & WR & 5 \\
\hline & Nitzschia sigma & TU & 2 \\
\hline & Nitzschia sigmoidea & TU & 2 \\
\hline & Nitzschia sublinearis & SY & 10 \\
\hline \multirow[t]{8}{*}{ Surirellaceae } & Cymatopleura solea & TU & 2 \\
\hline & Surirella sp. & LU,SY,TU & $2,10,11$ \\
\hline & Surirella angusta & TU & 3 \\
\hline & Surirella linearis constricta & TU & 3 \\
\hline & Surirella oregonica & SY & 10 \\
\hline & Surirella ovata & TU & 2,3 \\
\hline & Surirella ovata salina & TU & 3 \\
\hline & Surirella robusta & $\mathrm{TU}$ & 3 \\
\hline Tabellariaceae & Tetracyclus lacustris & SY & 10 \\
\hline \multicolumn{4}{|c|}{ PHYLUM: Cryptophyta } \\
\hline \multirow[t]{2}{*}{ Cryptochrysidaceae } & Chroomonas sp. & CL,WR & 1,5 \\
\hline & Rhodomonas minuta & CL,WR & 5,11 \\
\hline \multirow[t]{4}{*}{ Cryptomonadaceae } & Cryptomonas sp. & WR & 5,6 \\
\hline & Cryptomonas erosa & CL,WR & 1,5 \\
\hline & Cryptomonas ovata & WR & 5 \\
\hline & Cryptomonas obovoidea & MF & 14 \\
\hline \multicolumn{4}{|c|}{ PHYLUM: Cyanophyta (Blue-green algae) } \\
\hline \multirow[t]{9}{*}{ Chroococcaceae } & Anacystis sp. & SY & 4 \\
\hline & Anacystis marina & WR & 5 \\
\hline & Aphanocapsa sp. & $\begin{array}{l}\text { CF,CL,MC,MF,PM,SA,WR, } \\
\text { YH }\end{array}$ & 6 \\
\hline & Chroococcus sp. & $\begin{array}{l}\text { CF,CL,LU,MC,PM,SA,SY, } \\
\text { TU,WR }\end{array}$ & $2,4,5,6,11,13$ \\
\hline & Chroococcus minimus & WR & 5 \\
\hline & Chroococcus minutas & $\mathrm{PM}$ & 9 \\
\hline & Gloeocapsa sp. & MF,WR & 6 \\
\hline & Microcystis sp. & SA,TU & $2,3,13$ \\
\hline & Microcystis aeruginosa & WR & 5 \\
\hline \multirow[t]{2}{*}{ Nostocaceae } & Anabaena sp. & $\begin{array}{l}\text { CF,CL,LU,MC,MF,PM,SA, } \\
\text { TU,WR,YH }\end{array}$ & $3,5,6,9,11,12,13,14,15$ \\
\hline & Anabaena affinis & TU & 2 \\
\hline
\end{tabular}




\section{APPENDIX B. ALGAE REPORTED FROM AQUATIC ENVIRONMENTS IN THE WILLAMETTE BASIN, OREGON-Continued}

\begin{tabular}{|c|c|c|c|}
\hline Family & Genus-Species & Subbasin & Source \\
\hline \multicolumn{4}{|c|}{ PHYLUM: Cyanophyta (Blue-green algae)—Continued } \\
\hline \multirow[t]{4}{*}{ Nostocaceae-Continued } & Anabaena circinalis & MF,TU & 2,14 \\
\hline & Anabaena flos-aquae & $\mathrm{CL}$ & 1 \\
\hline & Aphanizomenon flos-aquae & TU & 2 \\
\hline & Phormidium sp. & CF,TU,WR & 2,6 \\
\hline \multirow[t]{6}{*}{ Oscillatoriaceae } & Lyngbya sp. & $\mathrm{CF}, \mathrm{MC}, \mathrm{MF}, \mathrm{SA}, \mathrm{WR}$ & 6,13 \\
\hline & Lyngbya versicolor & WR & 8 \\
\hline & Oscillatoria sp. & $\begin{array}{l}\text { CF,CL,LU,MC,MF,SA,TU,W } \\
\mathrm{R}\end{array}$ & $2,3,5,6,8,11,13$ \\
\hline & Oscillatoria agardhii & PM & 9 \\
\hline & Oscillatoria limnetica & WR & 13 \\
\hline & Spirulina sp. & $\mathrm{TU}$ & 2 \\
\hline Rivulariaceae & Amphithrix janthina & PM,SA,WR & 9,13 \\
\hline \multicolumn{4}{|c|}{ PHYLUM: Euglenophyta (Euglenoids) } \\
\hline \multirow[t]{14}{*}{ Euglenaceae } & Euglena sp. & LU,TU,WR & $2,3,5,6,11,13$ \\
\hline & Euglena acus & $\mathrm{TU}$ & 2 \\
\hline & Euglena tripleria & TU & 2 \\
\hline & Phacus sp. & CL,TU & $1,2,3$ \\
\hline & Phacus birgei & $\mathrm{TU}$ & 2 \\
\hline & Trachelomonas sp. & $\mathrm{CL}, \mathrm{SA}, \mathrm{TU}, \mathrm{WR}$ & $1,2,3,5,13$ \\
\hline & Trachelomonas acanthostoma & WR & 5 \\
\hline & Trachelomonas charkowensis & WR & 5 \\
\hline & Trachelomonas hispida & WR & 5 \\
\hline & Trachelomonas lacustris & WR & 5 \\
\hline & Trachelomonas pulchella & WR & 5 \\
\hline & Trachelomonas robusta & WR & 5 \\
\hline & Trachelomonas rotunda & WR & 5 \\
\hline & Trachelomonas volvocina & $\mathrm{CL}, \mathrm{WR}$ & 1,5 \\
\hline \multicolumn{4}{|c|}{ PHYLUM: Pyrrhophyta (Dinoflagellates) } \\
\hline \multirow[t]{2}{*}{ Ceratiaceae } & Ceratium sp. & TU & 3 \\
\hline & Ceratium hirundiniella & CL,MF,WR & $1,5,14$ \\
\hline Glenodiniaceae & Glenodinium sp. & $\mathrm{CL}, \mathrm{WR}$ & 1,13 \\
\hline Gymnodiniaceae & Gymnodinium sp. & $\mathrm{CL}, \mathrm{WR}$ & 1,13 \\
\hline \multirow[t]{2}{*}{ Peridiniaceae } & Peridinium sp. & $\mathrm{TU}$ & 2,3 \\
\hline & Peridinium cinctum & CL,WR & 1,5 \\
\hline
\end{tabular}




\section{APPENDIX C. MACROINVERTEBRATES REPORTED FROM AQUATIC ENVIRONMENTS IN THE WILLAMETTE BASIN, OREGON}

[This list is based on the references listed below and includes organisms identified to Order or a lower taxonomic level. It is not representative of taxon distribution due to disproportionate sampling effort throughout the Willamette Basin. The taxa are listed as identified to the highest taxonomic level from the original source (except for Anderson and Hansen (1987) and Parsons and others (1991) which are compilations from multiple sources), and misidentification or changes in taxonomy have not been addressed. Subbasin occurrence or source are not repeated for higher taxonomic levels (e.g., a source reporting Baetis bicaudatus is not repeated at the Family [Baetidae] or Order [Ephemeroptera] levels for that record). Genus and species are shown in italic. Subbasins (see fig. 5): CF, Coast Fork; CL, Clackamas; LT, Long Tom; LU, Luckiamute; MA, Marys; MC, McKenzie; MF, Middle Fork; PM, Pudding/Molalla; RI, Rickreall; SA, Santiam; SY, Sandy; TU, Tualatin; WR, Willamette River. Sources: 1, Aho (1976); 2, Anderson (1992); 3, Anderson and Hansen (1987); 4, Anderson and Wold (1972); 5, Ball (1946); 6, Clifton (1985); 7, EA Engineering, Science and Technology, Inc. (1990a); 8, J. Furnish (Bureau of Land Management, written commun., 1996); 9, Hawkins and others (1982); 10, Hawkins and Sedell (1981); 11, Hjort and others (1984); 12, HMS Environmental, Inc., and Miller (1988); 13, Johnson and others (1989); 14, Kerst (1969); 15, Lehmkuhl (1969); 16, Mangum (1990); 17, Mangum (1991a); 18, Mangum (1991b); 19, Miller (1979); 20, Moore (1987); 21, Parsons and others (1991); 22, Tetra Tech, Inc. (1994); 23, TW Environmental, Inc. (1994); 24, Wisseman (1995)]

\begin{tabular}{|c|c|c|c|}
\hline \multicolumn{2}{|c|}{ Taxon } & Subbasin & Source \\
\hline \multicolumn{4}{|l|}{ CLASS: HYDROZOA (Hydroids) } \\
\hline \multicolumn{2}{|l|}{ ORDER: Hydroida (Hydroids) } & WR & 13 \\
\hline \multicolumn{2}{|l|}{ CLASS: TURBELLARIA (Flatworms) } & SY & 23,24 \\
\hline \multicolumn{2}{|l|}{ ORDER: Tricladida } & MC,SY,TU,WR & $7,22,24$ \\
\hline \multicolumn{2}{|l|}{ FAMILY: Planariidae } & PM,SY,WR & $12,16,19$ \\
\hline & Planaria sp. & MC,PM,SA & $8,17,18$ \\
\hline \multicolumn{2}{|l|}{ CLASS: NEMATODA (Nematodes) } & MC,PM,SA,SY,WR & $7,8,12,13,16,17,18,24$ \\
\hline \multicolumn{4}{|l|}{ CLASS: POLYCHAETA (Marine worms) } \\
\hline FAMILY: Nereidae & Neris limnicola & WR & 22 \\
\hline FAMILY: Sabellidae & Manayunkia speciosa & WR & 11 \\
\hline \multicolumn{2}{|l|}{ CLASS: OLIGOCHAETA (Worms) } & LU,MC,PM,TU,SA,SY, WR & $\begin{array}{l}6,7,10,11,12,13,16,17,18,19 \\
20,22,23,24\end{array}$ \\
\hline \multicolumn{2}{|l|}{ CLASS: HIRUDINEA (Leeches) } & MC,WR & $7,12,13$ \\
\hline FAMILY: Erpobdellidae & Dina sp. & WR & 11 \\
\hline FAMILY: Glossiphonidae & Helobdella sp. & WR & 11 \\
\hline FAMILY: Hirudinidae & & MC,WR & 22 \\
\hline \multicolumn{2}{|l|}{ CLASS: GASTROPODA (Snails) } & MC & 1,7 \\
\hline \multirow[t]{6}{*}{ FAMILY: Ancylidae } & & MC,PM & 7,19 \\
\hline & Ferrissia sp. & WR & 11 \\
\hline & Ferrissia rivularis & MC,TU,WR & 22 \\
\hline & Juga sp. & MC,PM,WR & $8,11,13,20$ \\
\hline & Juga plicifera & MC,TU,WR & $9,10,22$ \\
\hline & Juga silicula & $\mathrm{MC}$ & 7 \\
\hline \multicolumn{2}{|c|}{ Taxon } & Subbasin & Source \\
\hline
\end{tabular}




\section{APPENDIX C. MACROINVERTEBRATES REPORTED FROM AQUATIC ENVIRONMENTS IN THE WILLAMETTE BASIN, OREGON-Continued}

\begin{tabular}{|c|c|c|c|}
\hline & Physella sp. & $\mathrm{MC}$ & 7 \\
\hline & Physella propinqua & MC,WR & 22 \\
\hline \multirow[t]{2}{*}{ FAMILY: Hydrobiidae } & Fluminicola sp. & PM,SY,WR & $8,11,19,24$ \\
\hline & Flumnicola virens & MC,TU,WR & 22 \\
\hline FAMILY: Lymnaeidae & Lymnaea sp. & MC,SY & 16,17 \\
\hline \multirow[t]{4}{*}{ FAMILY: Planorbidae } & & MC & 7 \\
\hline & Heliosoma anceps anceps & TU,WR & 22 \\
\hline & Vorticifex sp. & WR & 11 \\
\hline & Vorticifex effusa & MC & 22 \\
\hline FAMILY: Pleuroceridae & Goniobasis sp. & $\mathrm{PM}$ & 19 \\
\hline CLASS: BIVALVIA (Clams) & & SA & 18 \\
\hline \multirow[t]{2}{*}{ FAMILY: Corbiculidae } & Corbicula sp. & SY,WR & 11,16 \\
\hline & Corbicula fluminea & TU,WR & 22 \\
\hline FAMILY: Margaritiferidae & Margaritifera sp. & WR & 11 \\
\hline \multirow[t]{2}{*}{ FAMILY: Sphaeriidae } & & MC,PM,TU,WR & $8,11,13,22$ \\
\hline & & MC & 7 \\
\hline CLASS: TARDIGRADA (Water bears) & & MC & 20 \\
\hline \multicolumn{4}{|l|}{ CLASS: ARACHNIDA (Arachnids) } \\
\hline ORDER: Hydracarina (Water-mites) & & MC,MF,PM,SA,SY,TU,WR & $\begin{array}{l}6,7,8,10,16,17,18,19,20 \\
22,23,24\end{array}$ \\
\hline FAMILY: Arrenuridae & Arrenurus sp. & WR & 11 \\
\hline \multirow[t]{2}{*}{ FAMILY: Aturidae } & & WR & 11 \\
\hline & Aturus sp. & WR & 11 \\
\hline FAMILY: Eylaidae & Eylais sp. & LU & 8 \\
\hline FAMILY: Hygrobatidae & Attractides sp. & WR & 11 \\
\hline FAMILY: Lebertiidae & Lebertia sp. & WR & 11 \\
\hline FAMILY: Mideopsidae & Mideopsis sp. & WR & 11 \\
\hline \multirow[t]{2}{*}{ FAMILY: Pionidae } & Forelia sp. & WR & 11 \\
\hline & Piona sp. & WR & 11 \\
\hline FAMILY: Pisauridae & Dolomedes sp. & $\mathrm{MC}, \mathrm{WR}$ & 22 \\
\hline
\end{tabular}




\section{APPENDIX C. MACROINVERTEBRATES REPORTED FROM AQUATIC ENVIRONMENTS IN THE WILLAMETTE BASIN, OREGON-Continued}

FAMILY: Sperchonidae

FAMILY: Unionicolidae

CLASS: CRUSTACEA (Crustaceans)

ORDER: Amphipoda (Scuds)

FAMILY: Gammaridae

FAMILY: Talitridae

ORDER: Copepoda (Copepods)

FAMILY: Cyclopoda

ORDER: Decapoda (Crayfish)

FAMILY: Astacidae

ORDER: Isopoda (Sowbugs)

FAMILY: Asellidae

FAMILY: Ligiidae

ORDER: Ostracoda (Seed shrimp)

CLASS: INSECTA (Insects)

ORDER: Coleoptera (Beetles)

FAMILY: Carabidae

FAMILY: Dytiscidae
Sperchon sp.

Unionicola sp.

Anisogammarus sp.

Gammarus sp.

Hyalella azteca

Calanoida $\mathrm{sp.}$

Cyclopoida sp.

Harpactacoida sp.

Paciifastacus sp.

Pacifastacus leniusculus

Asellus sp.

Ligidium gracile

MC

MC,SY

Acilius semisulcatus

Agabinus glabrellus

Agabus confertus

Agabus lugens

Agabus lutosus

Deronectes griseostriatus

MC

MC

LU

LU

LU

LU
WR

WR

MC,SY,WR

SY

WR

MC,TU,WR

LU,WR

$\mathrm{MC}, \mathrm{PM}, \mathrm{SY}$

SY

LU

LU,MC,SY

SY

MC,PM

MC,WR

LU

TU,WR

MC

LU,MC,PM,SY,TU,WR
8,20

11

11

$1,7,12,13,16$

6

11

22

8,11

$1,6,7,8,10,16,17,24$

6

8

$6,8,20$

6

$7,10,11$

8

11,22

21

$1,6,7,8,11,16,17,20,22,24$

17,18

$1,7,17,20,24$

21

21

3

3

3 
APPENDIX C. MACROINVERTEBRATES REPORTED FROM AQUATIC ENVIRONMENTS IN THE WILLAMETTE BASIN, OREGON-Continued

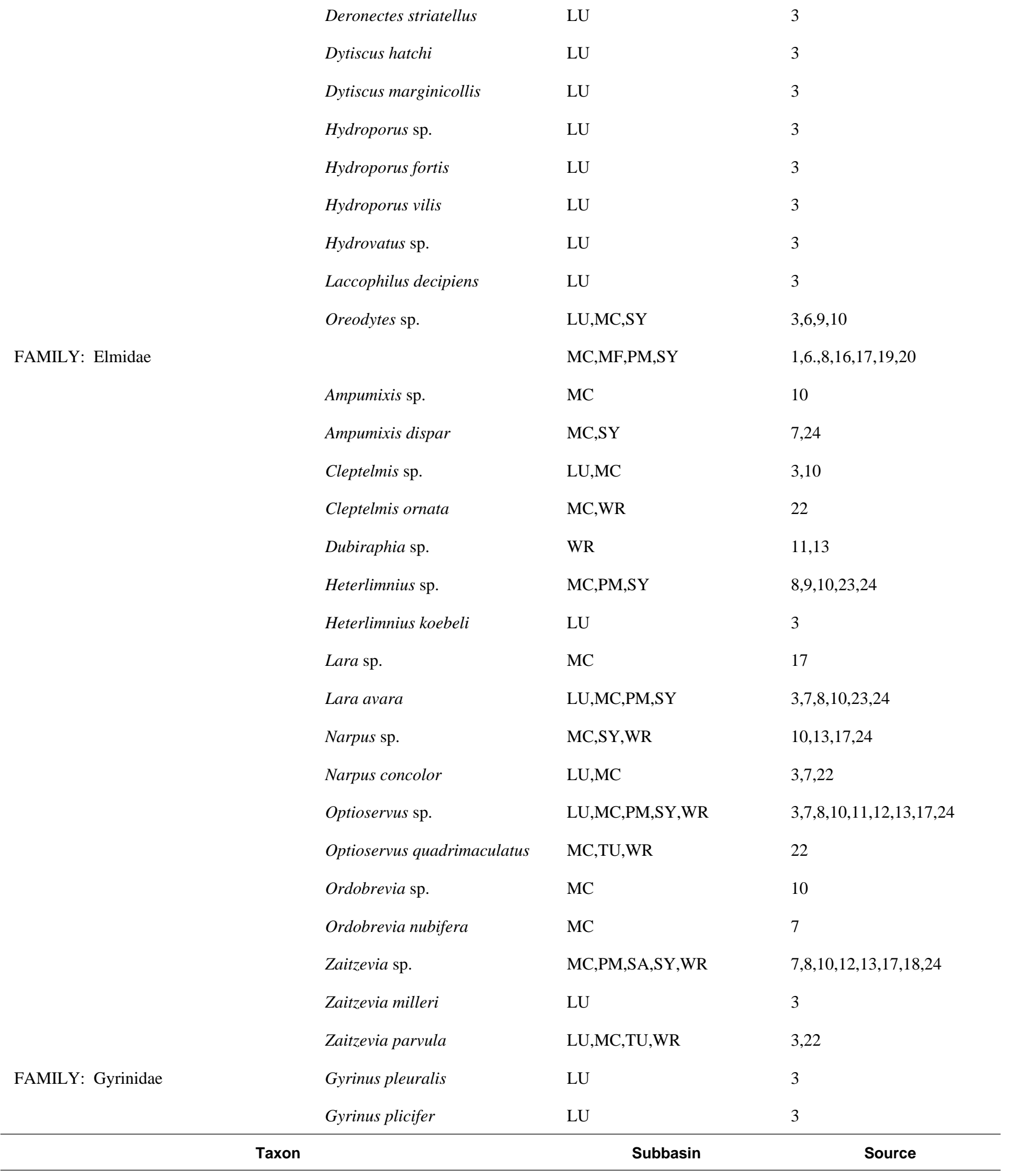

FAMILY: Elmidae 


\section{APPENDIX C. MACROINVERTEBRATES REPORTED FROM AQUATIC ENVIRONMENTS IN THE WILLAMETTE BASIN, OREGON-Continued}

FAMILY: Haliplidae

FAMILY: Helodidae

FAMILY: Histeridae

FAMILY: Hydraenidae

FAMILY: Hydrophilidae

FAMILY: Heteroceridae
Peltodytes callosus

Cyphon brevicollis

Cyphon concinnus

Elodes sp.

Elodes angusta

Elodes apicalis

Lanternarius brunneus

Stictostix californicus

Hydraena vandykei

Ochthebius rectus

Ametor latus

Ametor scabrosus

Anacaena limbata

Crenitis sp.

Crentis rufiventris

Crenitis seriellus

Crenitis snoqualmie

Cymbiodyta dorsalis

Cymbiodyta imbellus

Cymbiodyta pacifica

Helophorus sp.

Hydrobius sp.

Hydrochus sp.

Laccobius californicus

Laccobius carri

Tropisternus sp.

Acneus sp.
LU

MC

3

21

LU,MC $\quad 3,21$

LU,MC

3,21

$\mathrm{MC}$

21

MC

21

SY

MC

6

21

MC

21

SY

LU

LU

MC,SY

LU

MC

LU

MC

MC

LU

MC

MC

LU

LU

LU

WR

PM

LU

MC

LU

LU,MC,PM

\section{3}

21

3

10

21

3

21

21

3

3

3

22

8

3

21

3

$3,8,21$ 


\section{APPENDIX C. MACROINVERTEBRATES REPORTED FROM AQUATIC ENVIRONMENTS IN THE WILLAMETTE BASIN, OREGON-Continued}

FAMILY: Scarabaeidae

FAMILY: Staphylinidae

FAMILY: Tenebrionidae

ORDER: Collembola (Springtails)

FAMILY: Lophopodae

FAMILY: Sminthuridae

ORDER: Diptera (True flies)

FAMILY: Athericidae (Rhagionidae)

Atherix sp.

FAMILY: Blephariceridae

FAMILY: Ceratopogonidae
Aegialia blanchardi

Aegialia lacustris

Aegialia mantanus

Aegialia opaca

Dianous nitidulus

Neobisnius senilis

Stenus maritimus

Scaphidema pictum

Pectinatella magnifica

Agathon sp.

Agathon comstocki

Bibiocephala sp.

Blepharicera sp.

Blepharicera jordani

Blepharicera ostensackeni

Dioptopsis sp.

Dioptopsis aylmeri

Philorus californicus
MC

21

MC

21

$\mathrm{MC}$

21

MC

21

SY

6

MC

21

MC

21

MC

21

MC

21

PM,SY

6,8

TU

22

MC

20

MC

1

SY

6

LU,MC,SY

$3,7,16,17$

MC,PM,SY

$1,8,17,24$

MC

2

LU,MC

3,21

PM

8

SY,WR

16,22

MC

21

MC

21

SY

16

MC

21

MC

21

MC,PM,SY

$6,7,8,9,10,16,19,20,24$

Atrichopogon sp.

MC,PM

8,21

Atrichopogon epicautae

LU

3

Bezzia sp.

MC,SA

17,18

SY,WR

11,16

Bezzia-Probezzia 
APPENDIX C. MACROINVERTEBRATES REPORTED FROM AQUATIC ENVIRONMENTS IN THE WILLAMETTE BASIN, OREGON-Continued

\begin{tabular}{|c|c|c|c|}
\hline & Culicoides jamesi & $\mathrm{LU}$ & 3 \\
\hline & Forcipomyia sp. & $\mathrm{LU}$ & 3 \\
\hline & Johannsenomyia albibasis & $\mathrm{LU}$ & 3 \\
\hline & Mallochohelea sybleae & $\mathrm{LU}$ & 3 \\
\hline & Neurohelea nigra & $\mathrm{LU}$ & 3 \\
\hline & Palpomyia sp. & WR & 11 \\
\hline & Palpomyia aldrichi & $\mathrm{LU}$ & 3 \\
\hline & Palpomyia flavipes & LU & 3 \\
\hline & Serromyia barberi & $\mathrm{LU}$ & 3 \\
\hline FAMILY: Chaoboridae & & SY,WR & 6,11 \\
\hline \multirow[t]{21}{*}{ FAMILY: Chironomidae } & & MC,MF,PM,SA,SY,WR & $\begin{array}{l}1,6,7,8,9,11,12,16,17,18,19 \\
20,24\end{array}$ \\
\hline & Ablabesmyia sp. & WR & 11 \\
\hline & Acricotopus sp. & $\mathrm{LU}$ & 3 \\
\hline & Alotanypus venustus & $\mathrm{MC}$ & 21 \\
\hline & Arctopelopia flavifrons & $\mathrm{MC}$ & 21 \\
\hline & Boreochlus sp. & SY & 24 \\
\hline & Boreochlus sinuaticornis & $\mathrm{MC}$ & 21 \\
\hline & Boreohaptagyia sp. & SY & 24 \\
\hline & Boreoheptagyia lurida & $\mathrm{MC}$ & 21 \\
\hline & Brillia sp. & $\mathrm{MC}, \mathrm{SY}, \mathrm{WR}$ & $2,11,24$ \\
\hline & Brilla flavifrons & LU,MC & 3,21 \\
\hline & Brilla retifinis & $\mathrm{LU}$ & 3 \\
\hline & Brundiniella eumorpha & LU,MC & 3,21 \\
\hline & Bryophaenocladius sp. & $\mathrm{LU}$ & 3 \\
\hline & Cardocladius sp. & MC,TU,WR & 21,22 \\
\hline & Chaetocladius sp. & LU,MC & 3,21 \\
\hline & Chironomus sp. & WR & 11 \\
\hline & Chironomus jucundus & $\mathrm{LU}$ & 3 \\
\hline & Cladopelma sp. & WR & 11 \\
\hline & Cladotanytarsus sp. & $\mathrm{LU}$ & 3 \\
\hline & & Subbasin & Source \\
\hline
\end{tabular}


APPENDIX C. MACROINVERTEBRATES REPORTED FROM AQUATIC ENVIRONMENTS IN THE WILLAMETTE BASIN, OREGON-Continued

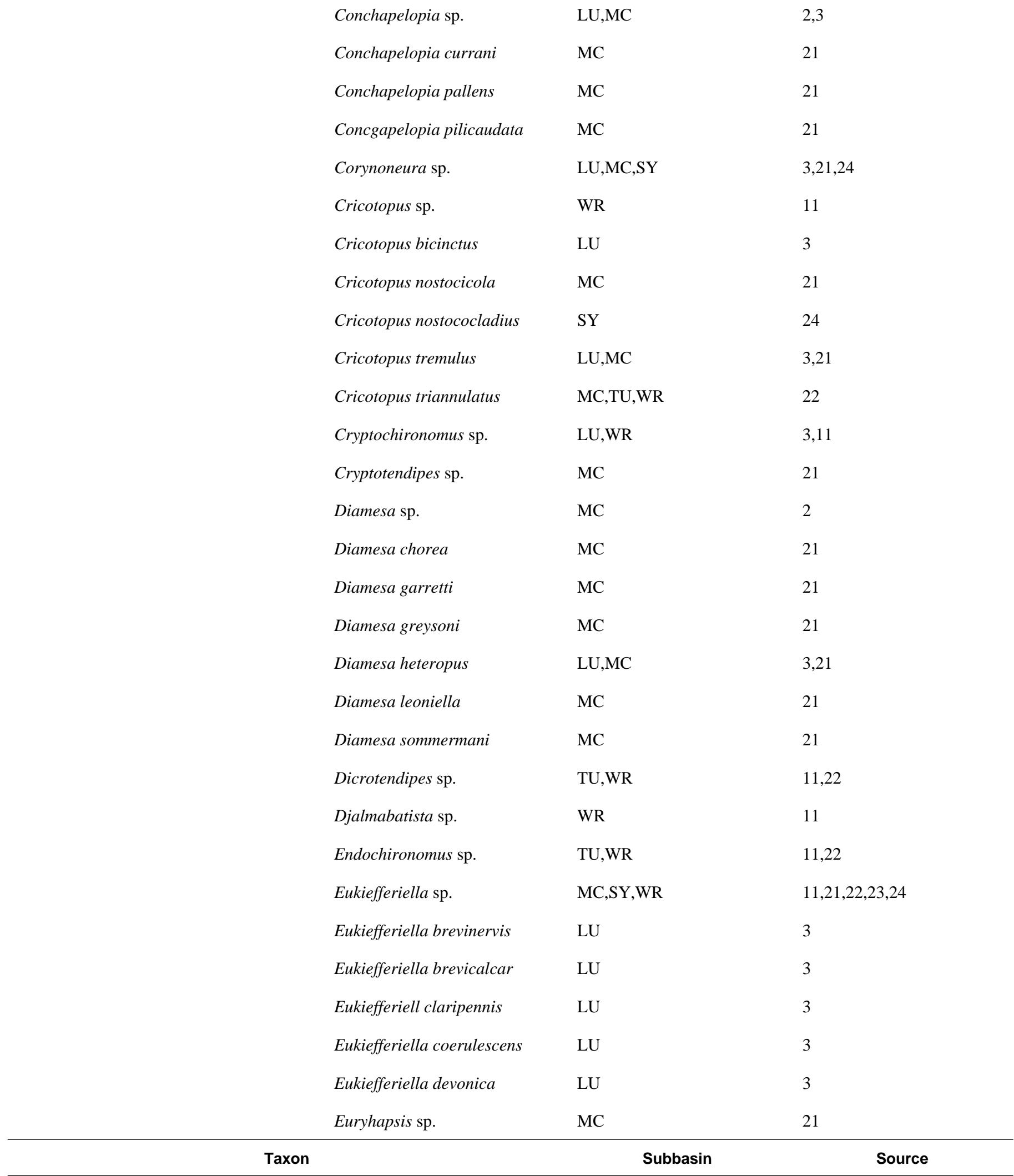


APPENDIX C. MACROINVERTEBRATES REPORTED FROM AQUATIC ENVIRONMENTS IN THE WILLAMETTE BASIN, OREGON-Continued

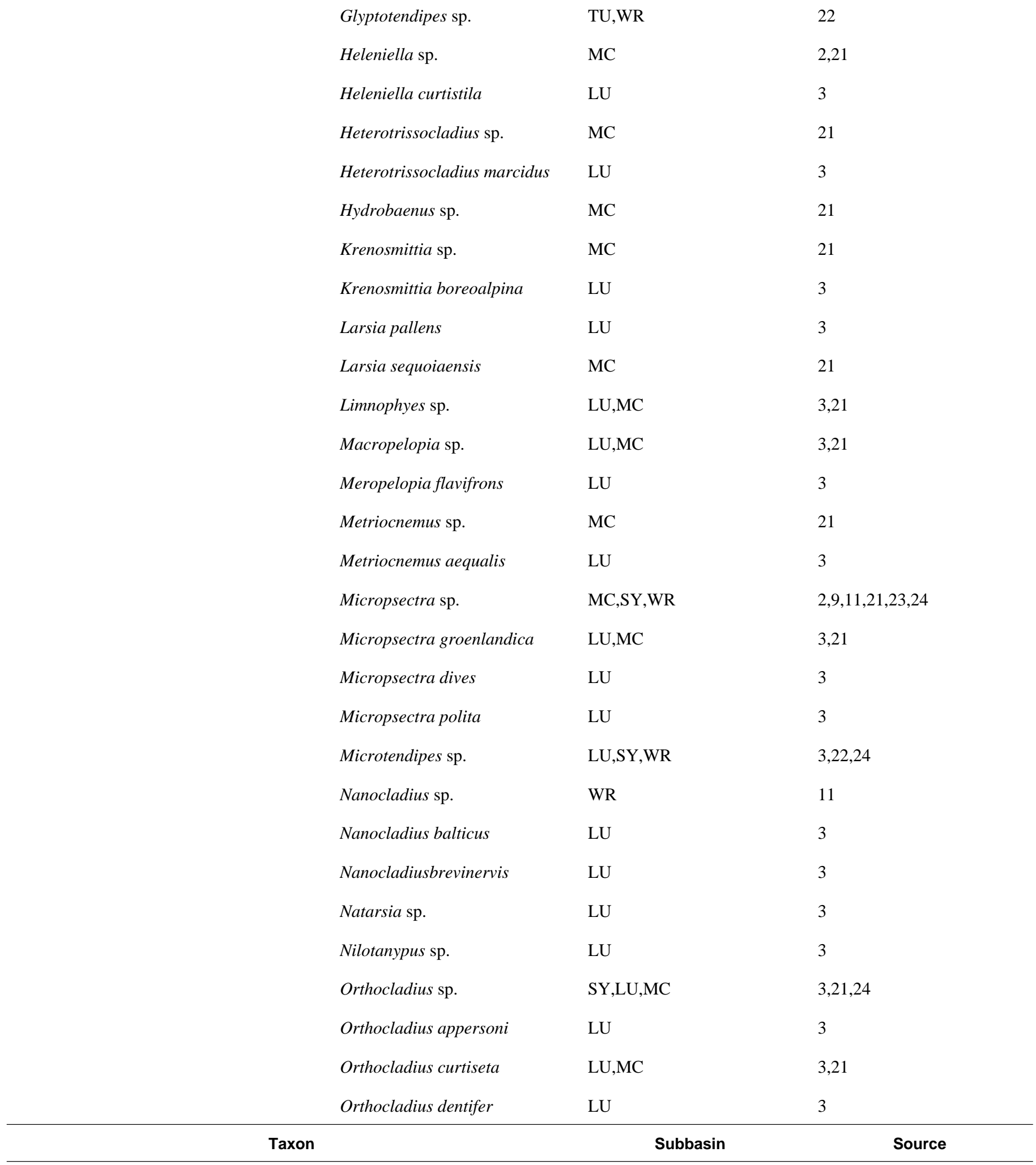


APPENDIX C. MACROINVERTEBRATES REPORTED FROM AQUATIC ENVIRONMENTS IN THE WILLAMETTE BASIN, OREGON-Continued

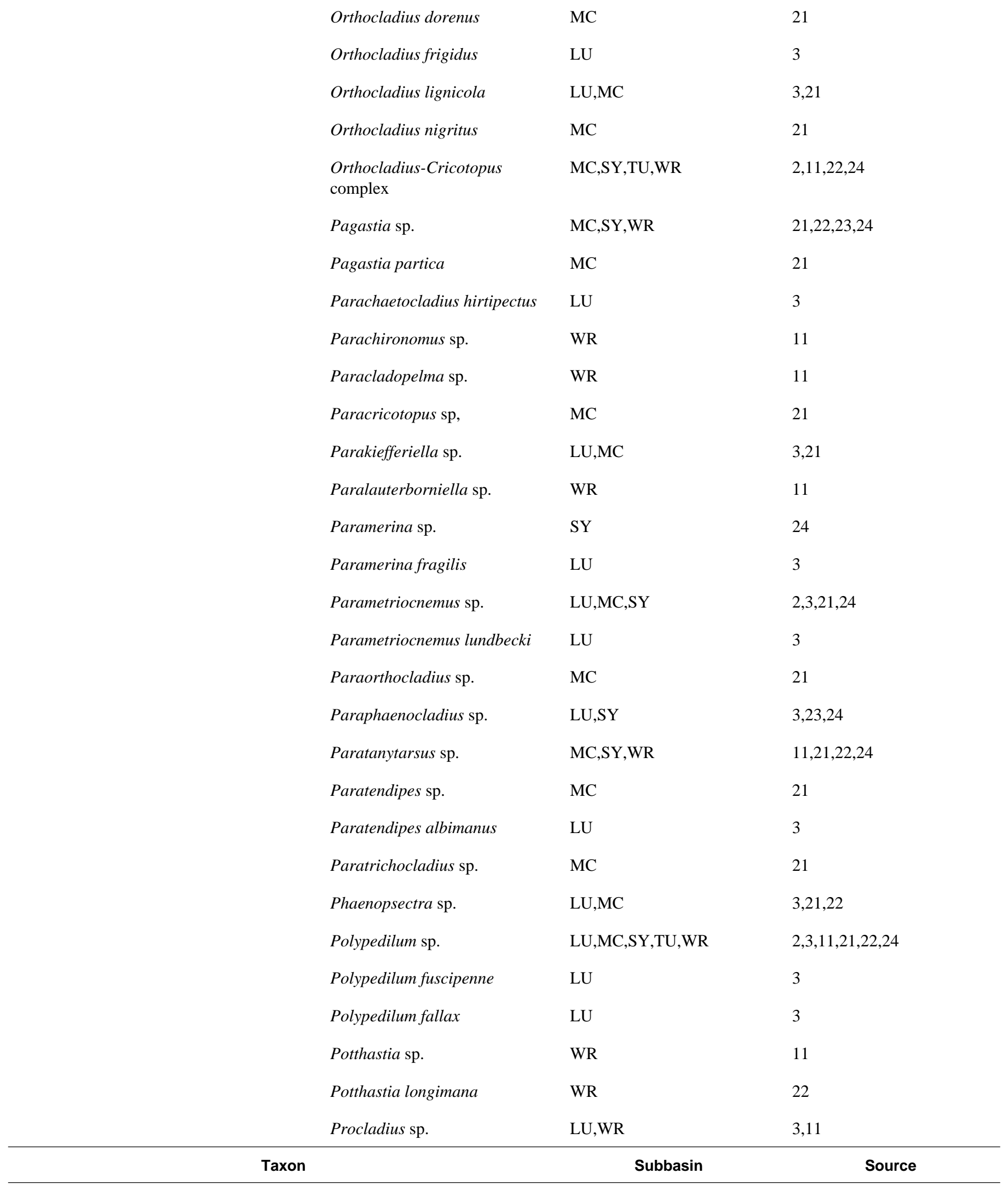


APPENDIX C. MACROINVERTEBRATES REPORTED FROM AQUATIC ENVIRONMENTS IN THE WILLAMETTE BASIN, OREGON-Continued

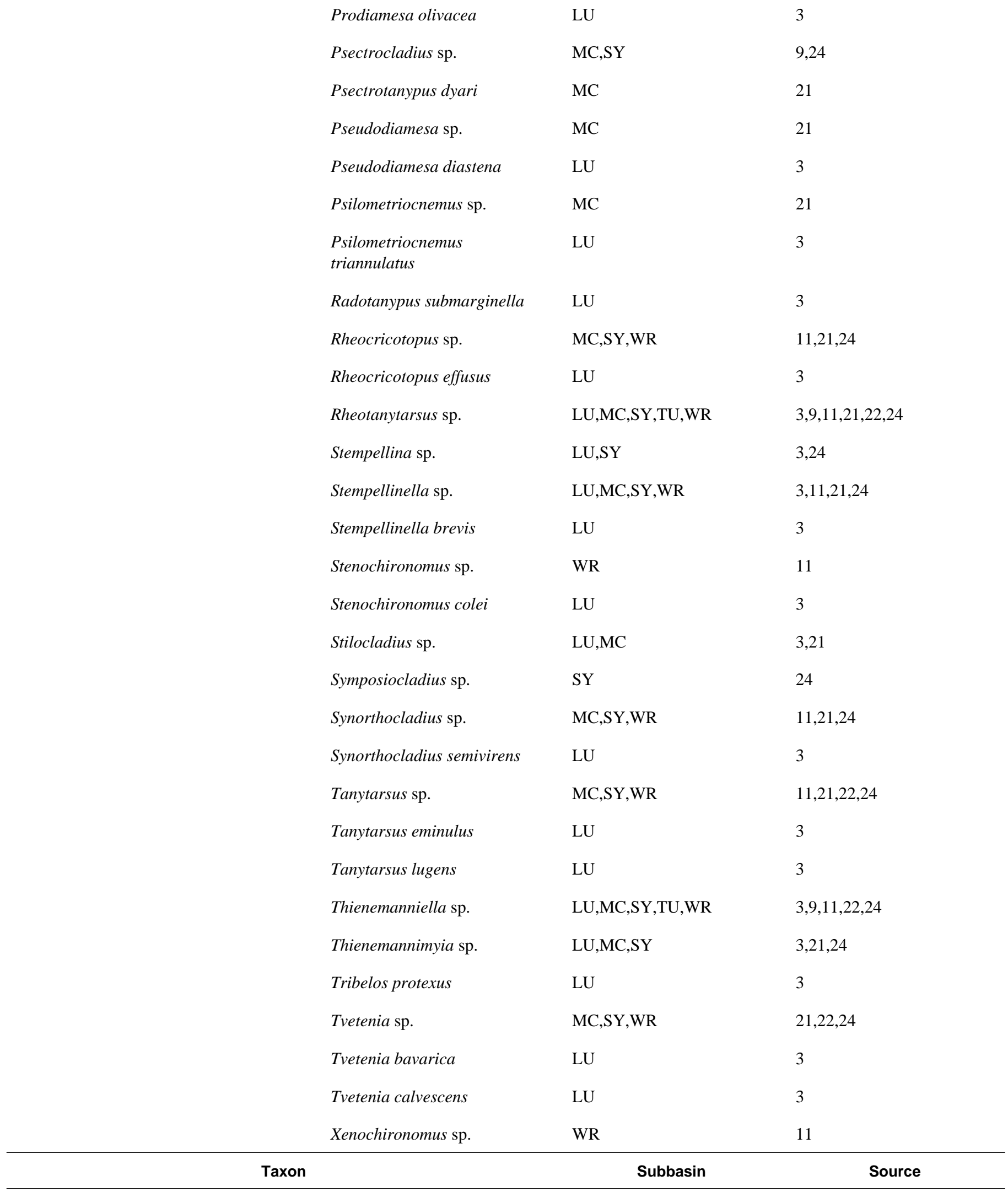


APPENDIX C. MACROINVERTEBRATES REPORTED FROM AQUATIC ENVIRONMENTS IN THE WILLAMETTE BASIN, OREGON-Continued

Zavrelia sp.

Zavrelimyia sp.

Zavrelimyia thryptica

FAMILY: Culicidae

FAMILY: Deuterophlebiidae

FAMILY: Dixidae

FAMILY: Dolichopodidae

FAMILY: Drosophilidae

FAMILY: Empididae

Dixa sp.

Dixa californica

Dixa johansenni

Dixa rhathyme

Meringodixa sp.

Argyra bimaculata

Dolichopus crenatus

Dolichopus duplicatus

Dolichopus grandis

Dolichopus nigricauda

Dolichopus tenuipes

Scaptomyza sp.
LU 3

LU,MC 2,3,21

LU,MC $\quad 3,21$

PM 19

$\begin{array}{lll}\text { Aedes sierrensis } & \text { MC }\end{array}$

$\begin{array}{lll}\text { Culiseta sp. } & \text { SY } & 6\end{array}$

MC 10

$\begin{array}{lll}\text { Deuterophlebia inyoensis } & \mathrm{MC} & 21\end{array}$

Deuterophlebia coloradensis $\quad$ MC $\quad 21$

MC,SY 1,6

MC,PM,SY $\quad 8,17,20,24$

LU

3

LU

3

LU

3

LU

3

PM

8

SY

6

LU

3

Campsicnemus claudicans

LU

3

Campsicnemus degener

LU

3

LU

3

LU

3

LU

3

LU

3

Dolichopus renidescens

LU

3

LU

3

$\mathrm{MC}$

21

MC,SY

$6,7,10,16,20$

Chelifera sp.

MC,PM,SY,TU,WR

$7,8,17,22,23,24$

Clinocera sp.

MC,PM,SY
$7,8,24$ 
APPENDIX C. MACROINVERTEBRATES REPORTED FROM AQUATIC ENVIRONMENTS IN THE WILLAMETTE BASIN, OREGON-Continued

Dolicocephala sp.

Hemerodromia sp.

Oreogeton sp.

Rhamphomyia sp.

Weidemannia sp.

FAMILY: Ephydridae

FAMILY: Mycetophilidae

FAMILY: Muscidae

FAMILY: Pelecorhynchidae

FAMILY: Psychodidae

FAMILY: Ptychopteridae

Hydrellia sp.

Hydrellia griseola

Parydra sp.

Philygria debilis

Philygria opposita

Psilopa compta

Scatella paludum

Symmerus sp.

Limnophora sp.

Glutops sp.

Glutops rossi

Maruina sp.

Pericoma sp.

Psychoda sp.
MC

21

LU,MC,SA,SY,WR

PM,SY

MC

MC

PM,WR

Ditricophora argyrostoma

Philygria nigrescens

Maruina lanceolata

Psychoda phalaenoides

Psychoda unbracola

Bittacomorpha clavipes

Ptychoptera sp.
$\mathrm{MC}$

LU

MC

$\mathrm{MC}$

$\mathrm{MC}$

MC

$\mathrm{MC}$

$\mathrm{MC}$

$\mathrm{MC}$

LU

PM

SY

LU,PM,SY

MC,MF,SY

MC,PM,SY

LU

LU,MC,SY

LU,SY

MC

$\mathrm{MC}$

SY

MC

MC
11,19

$3,7,11,16,17,18,21,22$

8,24

21

21

21

3

21

21

21

21

21

21

21

3

8

23,24

$3,8,23$

16,17

$8,10,17,24$

3

$3,10,16,17$

3,6

21

21

6

21

9 


\section{APPENDIX C. MACROINVERTEBRATES REPORTED FROM AQUATIC ENVIRONMENTS IN THE WILLAMETTE BASIN, OREGON-Continued}

Ptychoptera townesi

FAMILY: Sciaridae

FAMILY: Sciomyzidae

FAMILY: Simuliidae

FAMILY: Syrphidae

FAMILY: Tabanidae
LU

SY

$\mathrm{PM}, \mathrm{SY}$

LU

$\mathrm{MC}$

$\mathrm{MC}$

MC,MF,PM,SA,SY,WR

LU

$\mathrm{MC}$

MC

MC,PM

LU

LU

$\mathrm{MC}$

LU,MC

MC,SY,WR

LU,MC

LU

LU

LU,MC

LU

LU

LU

LU

LU

MC
$\mathrm{MC}$

$\mathrm{MC}$

MC

Chrysops excitans

Chrysops noctifer pertinax

Atolytus incisuralis

Chrysops asbestos

MC
3

6

6,8

3

21

21

$1,6,7,10,11,12,13,16,17$, $18,19,24$

3

21

21

7,8

3

3

21

3,21

$7,11,22,23,24$

3,21

3

3

3,21

3

3

3

3

3

10

21

21

21

21 
APPENDIX C. MACROINVERTEBRATES REPORTED FROM AQUATIC ENVIRONMENTS IN THE WILLAMETTE BASIN, OREGON-Continued

\begin{tabular}{|c|c|c|}
\hline Chrysops proclivis & $\mathrm{MC}$ & 21 \\
\hline Chrysops surdus & MC & 21 \\
\hline Hybomitra atrobasis & MC & 21 \\
\hline Hybomitra californica & MC & 21 \\
\hline Hybomitra captonis & $\mathrm{MC}$ & 21 \\
\hline Hybomitra fulvilateralis & MC & 21 \\
\hline Hybomitra melanorhina & $\mathrm{MC}$ & 21 \\
\hline Hybomitra procyon & MC & 21 \\
\hline Hybomitra rhombica & MC & 21 \\
\hline Hybomitra sequax & MC & 21 \\
\hline Hybomitra sonomensis & MC & 21 \\
\hline Hybomitra zygota & MC & 21 \\
\hline Pilmas californica & $\mathrm{MC}$ & 21 \\
\hline Silvius gigantulus & $\mathrm{MC}$ & 21 \\
\hline Tabanus sp. & $\mathrm{MC}$ & 20 \\
\hline Tabanus aegrotus & $\mathrm{MC}$ & 21 \\
\hline Tabanus fratellus & $\mathrm{MC}$ & 21 \\
\hline Tabanus kesseli & $\mathrm{MC}$ & 21 \\
\hline Tabanus monoesis & MC & 21 \\
\hline \multirow[t]{2}{*}{ Tabanus punctifer } & $\mathrm{MC}$ & 21 \\
\hline & $\mathrm{MC}$ & 7 \\
\hline \multirow[t]{2}{*}{ Thaumalea sp. } & MC,SY & 21,24 \\
\hline & MC,SY,WR & $1,6,11,20,23,24$ \\
\hline Antocha sp. & LU,MC,PM,SY,WR & $\begin{array}{l}3,6,7,8,10,11,12,13,17 \\
19,24\end{array}$ \\
\hline Antocha monticola & MC,SA,SY & $16,17,18,21$ \\
\hline Austrolimnophila badia & LU,MC & 3,21 \\
\hline Chionea sp. & MC & 21 \\
\hline Cladura macnabi & MC & 21 \\
\hline Dactylolabis sp. & MC & 21 \\
\hline Dicranoptycha stenophallus & $\mathrm{MC}$ & 21 \\
\hline
\end{tabular}

FAMILY: Tanyderidae

FAMILY: Thaumaleidae

FAMILY: Tipulidae 
APPENDIX C. MACROINVERTEBRATES REPORTED FROM AQUATIC ENVIRONMENTS IN THE WILLAMETTE BASIN, OREGON-Continued

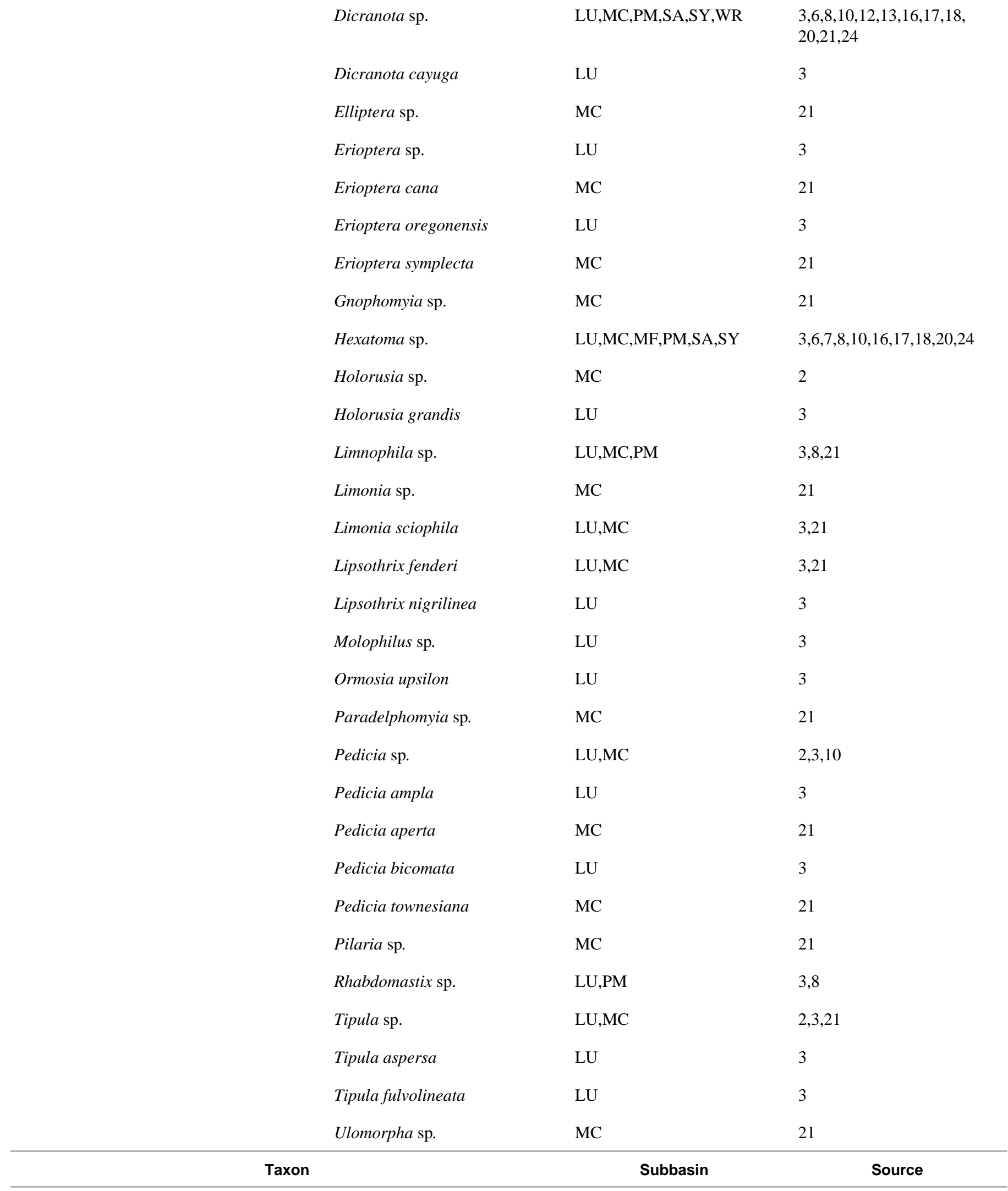




\section{APPENDIX C. MACROINVERTEBRATES REPORTED FROM AQUATIC ENVIRONMENTS IN THE WILLAMETTE BASIN, OREGON-Continued}

ORDER: Ephemeroptera (Mayflies)

FAMILY: Baetidae

FAMILY: Caenidae

FAMILY: Ephemerellidae
MC

SY

MC,MF,PM,SA,SY,WR

Baetis sp.

Baetis bicaudatus

Baetis hageni

Baetis insignificans

Baetis parvus

Baetis tricaudatus

Centroptilum sp.

Centroptilum elsa

Diphetor hageni

Pseudocleon sp.

Caenis sp.

Attenella sp.

Attenella delantala

Attenella margarita

Caudatella sp.

Caudatella cascadia

Caudatella edmundsi

Caudatella heterocaudata

Caudatella hystrix

Drunella sp.

Drunella coloradensis

Drunella coloradensis/

flavilinea

Drunella flavilinea

Drunella doddsi

Drunella pelosa

Drunella spinifera
LU,MA,MC,SY

LU,MC

MC,WR

MA,MC

LU,MA,MC,SY,TU,WR

MC,SY,WR

LU

MC,SY

MC,WR

WR

PM,WR

WR

MC,SY

MC,SY

SY

MC,SY

MC,SY

MC,SA

MC,SY

PM

MC,SA

SY

LU,MC

LU,MC,MF,SA,SY

MC

MC,SA,SY
1

6

$1,2,6,8,9,10,11,12,13,16,17$, $18,19,20,22$

$3,15,21,23$

3,21

22

9,15

$3,7,15,21,22,24$

$7,9,11,22,24$

3

21,24

7,11

11

8,13

12

7,24

21,24

24

21,23

21,24

$17,18,21$

$7,17,21,24$

8

18,21

23,24

3,21

$3,7,17,18,21,23,24$

21

$7,18,21,23,24$ 
APPENDIX C. MACROINVERTEBRATES REPORTED FROM AQUATIC ENVIRONMENTS IN THE WILLAMETTE BASIN, OREGON-Continued

\begin{tabular}{|c|c|c|c|}
\hline & Ephemerella sp. & MC,PM,WR,SY & $1,6,8,10,11,19,20,21$ \\
\hline & Ephemerella aurivilli & MC,WR & 22 \\
\hline & Ephemerella cascadia & SY & 16 \\
\hline & Ephemerella colorodensis & SY & 16 \\
\hline & Ephemerella delantala & SY & 16 \\
\hline & Ephemerella doddsi & MC,SY & 10,16 \\
\hline & Ephemerella drunella & SY & 6 \\
\hline & Ephemerella heterocaudata & SY & 16 \\
\hline & Ephemerella hystrix & SY & 16 \\
\hline & Ephemerella inermis & MC,MF,SA,SY & $7,16,17,18,24$ \\
\hline & $\begin{array}{l}\text { Ephemerella inermis/ } \\
\text { infrequens }\end{array}$ & SY & 23,24 \\
\hline & Ephemerella infrequens & LU,MC & 3,21 \\
\hline & Ephemerella initera & SY & 16 \\
\hline & Ephemerella margarita & SY & 16 \\
\hline & Ephemerella spinifera & SY & 16 \\
\hline & Ephemerella teresa & SY & 16 \\
\hline & Ephemerella tibialis & SY,WR & 13,16 \\
\hline & Serratella sp. & MC,PM,WR & $2,8,11,12,13$ \\
\hline & Serratella teresa & LU,MC & 3,21 \\
\hline & Serratella tibialis & LU,MC,MF,SA & $3,17,18,21$ \\
\hline & Serratella velmae & $\mathrm{MC}$ & 21 \\
\hline & Timpanoga hecuba & LU & 3 \\
\hline FAMILY: Ephemeridae & & SY & 6 \\
\hline \multirow[t]{7}{*}{ FAMILY: Heptageniidae } & & MC,WR & $7,12,13,20$ \\
\hline & Cinygma sp. & MC,SY & $6,10,16,20,22,23,24$ \\
\hline & Cinygma dimicki & $\mathrm{MC}$ & 21 \\
\hline & Cinygma integrum & LU,MC & 3,21 \\
\hline & Cinygmula sp. & MC,PM,SA,SY & $\begin{array}{l}1,2,6,7,8,9,10,16,17,18 \\
19,20,21,23,24\end{array}$ \\
\hline & Cinygmula par & MC & 21 \\
\hline & Taxon & Subbasin & Source \\
\hline
\end{tabular}


APPENDIX C. MACROINVERTEBRATES REPORTED FROM AQUATIC ENVIRONMENTS IN THE WILLAMETTE BASIN, OREGON-Continued

\begin{tabular}{|c|c|c|c|}
\hline & Cinygmula ramaleyi & $\mathrm{MC}$ & 21 \\
\hline & Cinygmula reticulata & LU,MA,MC & $3,15,21$ \\
\hline & Cinygmula uniformis & $\mathrm{MC}$ & 21 \\
\hline & Epeorus sp. & MC,MF,PM,SA,SY,WR & $\begin{array}{l}1,2,7,8,10,12,13,16,17 \\
18,19,24\end{array}$ \\
\hline & Epeorus albertae & LU,MC,WR & 3,22 \\
\hline & Epeorus deceptivus & LU,MC & 3,21 \\
\hline & Epeorus grandis & MC,SY & $7,21,24$ \\
\hline & Epeorus hesperus & MC & 21 \\
\hline & Epeorus iron & LU,SY & 3,6 \\
\hline & Epeorus longimanus & LU,MC & 3,21 \\
\hline & Heptagenia sp. & MC,MF,SA,SY,WR & $7,9,11,16,17,18,24$ \\
\hline & Ironodes sp. & MC,PM,SY & $2,8,16,23,24$ \\
\hline & Ironodes nitidus & LU,MC & 3,21 \\
\hline & Leucrocuta sp. & WR & 22 \\
\hline & Nixe sp. & MC,SY,WR & $12,13,22,24$ \\
\hline & Rhithrogena sp. & LU,MC,MF,PM,SY,WR & $\begin{array}{l}2,3,6,7,10,11,13,16,17 \\
19,23,24\end{array}$ \\
\hline & Rithrogenia morrisoni & LU,MC,WR & 3,22 \\
\hline & Rithrogenia robusta & MC & 21 \\
\hline & Stenonema sp. & MC,SY,WR & $6,11,12,13,22$ \\
\hline FAMILY: Leptophlebiidae & & PM,SY & 6,8 \\
\hline & Leptophlebia pacifica & LU & 3 \\
\hline & Paraleptophlebia sp. & LU,MC,PM,SA,SY,WR & $\begin{array}{l}1,2,3,6,7,9,10,11,13,16, \\
17,18,19,20,23,24\end{array}$ \\
\hline & Paraleptophlebia aquilina & MC & 21 \\
\hline & Paraleptophlebia bicornuta & LU,MC,SY,WR & $3,7,9,22,24$ \\
\hline & Paraleptophlebia debilis & LU,MA,MC & $3,15,21,22$ \\
\hline & Paraleptophlebia gregalis & LU,MC & 3,21 \\
\hline & Paraleptophlebia heterone & $\mathrm{MC}$ & 22 \\
\hline
\end{tabular}




\section{APPENDIX C. MACROINVERTEBRATES REPORTED FROM AQUATIC ENVIRONMENTS IN THE WILLAMETTE BASIN, OREGON-Continued}

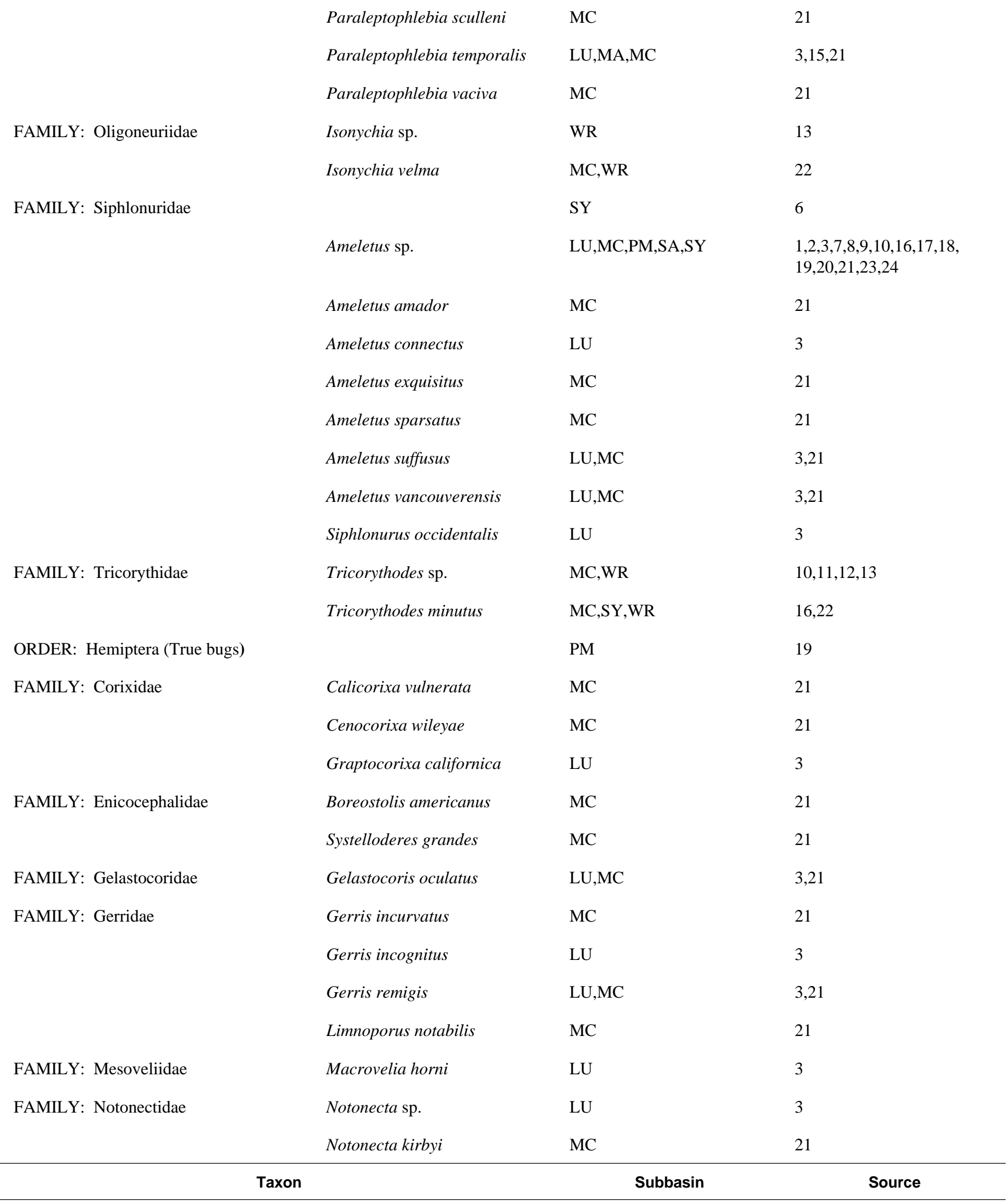


APPENDIX C. MACROINVERTEBRATES REPORTED FROM AQUATIC ENVIRONMENTS IN THE WILLAMETTE BASIN, OREGON-Continued

FAMILY: Saldidae

FAMILY: Veliidae

ORDER: Hymenoptera (Wasps)

FAMILY: Ichneumonidae

FAMILY: Sclaridae

ORDER: Lepidoptera (Caterpillars)

FAMILY: Pyralidae

ORDER: Megaloptera (Dobsonflies)

FAMILY: Corydalidae

FAMILY: Sialidae

FAMILY: Sisyridae

Climacia sp.

ORDER: Odonata (Dragonflies/Damselflies)

FAMILY: Aeshnidae

Aeshna interrupta

FAMILY: Coenagrionidae

Argia vivida

Enallagma sp.

Ischnura sp.

Saldula comatula
MC

21

$\mathrm{MC}$

21

MC

21

LU,MC

MC

21

LU,MC

3,21

LU

3

SY

LU

SY

MC,MF

17

MC,PM,SY,TU,WR

$7,8,11,13,16,22$

$\mathrm{MC}$

10

Protochauliodes spenceri

LU

3

MC

17,20

$\mathrm{MC}$

7,21

$\mathrm{MC}, \mathrm{WR}$

$1,7,10,11,12,13,22$

LU,MC

3,21

LU

3

WR

11

LU

3

MC

21

WR

11

MC

21

MC

21

MC
21 


\section{APPENDIX C. MACROINVERTEBRATES REPORTED FROM AQUATIC ENVIRONMENTS IN THE WILLAMETTE BASIN, OREGON-Continued}

FAMILY: Cordule-gastridae

FAMILY: Gomphidae

FAMILY: Libellulidae

FAMILY: Petaluridae

ORDER: Plecoptera (Stoneflies)

FAMILY: Capniidae

FAMILY: Chloroperlidae

Alloperla sp.
Alloperla borealis
Alloperla coloradensis
Alloperla delicata
Alloperla fidelis
Alloperla fraterna
Alloperla pallidula

Cordulegaster dorsalis

Gomphus sp.

Octogomphus sp.

Octogomphus specularis

Sympetrum corruptum

Tanypteryx hageni

Capnia melia

Capnia porrecta

Capnia pileata

Capnia projecta

Capnia promota

Capnia tumida

Eucanopsis brivicauda

Isocapnia abbreviata

Mesocapnia autumna

Mesocapnia porrecta

Mesocapnia projecta

Paracapnia oswegaptera

Taxon
MC

21

MC,WR

$7,12,13,17$

WR

22

MC

7

LU,MC

3,21

MC

21

MC

21

MC

1

MC,MF,PM,SY

$7,8,10,16,17,20,23,24$

MA,MC

5,21

MC

21

MA

14

LU

3

LU,MA

3,5

MA

5

MA

5

LU,MA,MC

$3,5,14,21$

MA

5

MC

21

MC

21

MC

21

MC

21

MC,PM,SA,SY

$1,6,8,10,16,17,18,20,24$

MC,PM

$2,9,19$

MA

5,14

MA

5,14

MA,MC

$5,14,21$

MA

5,14

MA,MC

$5,14,21$

MA
14 
APPENDIX C. MACROINVERTEBRATES REPORTED FROM AQUATIC ENVIRONMENTS IN THE WILLAMETTE BASIN, OREGON-Continued

\begin{tabular}{|c|c|c|c|}
\hline & Alloperla signata & MA & 5 \\
\hline & Hastoperla sp. & SY & 6 \\
\hline & Hastaperla brevis & MA & 5 \\
\hline & Hastaperla chilnualna & LU,MA & 3,14 \\
\hline & Kathroperla sp. & PM & 8,19 \\
\hline & Kathroperla perdita & LU,MA,MC,SY & $3,14,21,24$ \\
\hline & Paraperla sp. & PM,SY & 8,24 \\
\hline & Paraperla frontalis & MC & 21 \\
\hline & Plumiperla sp. & PM & 8 \\
\hline & Plumiperla diversa & $\mathrm{MC}$ & 21 \\
\hline & Suwallia sp. & PM,SA & 8,18 \\
\hline & Suwallia autumna & $\mathrm{MC}$ & 21 \\
\hline & Suwallia pallidula & MC & 21 \\
\hline & Sweltsa sp. & MC,MF,PM,SA,SY & $2,7,8,16,17,18,23,24$ \\
\hline & Sweltsa borealis & LU,MC & 3,21 \\
\hline & Sweltsa coloradensis & LU & 3 \\
\hline & Sweltsa exquisita & $\mathrm{MC}$ & 21 \\
\hline & Sweltsa fidelis & $\mathrm{MC}$ & 21 \\
\hline & Sweltsa fraterna & $\mathrm{LU}$ & 3 \\
\hline & Sweltsa oregonensis & $\mathrm{MC}$ & 21 \\
\hline & Sweltsa revelstoki & $\mathrm{MC}$ & 21 \\
\hline FAMILY: Leuctridae & & MC,PM,SA,SY & $1,8,10,16,17,18,20,24$ \\
\hline & Despaxia sp. & MC,PM & $2,8,9$ \\
\hline & Despaxia augusta & LU,MC & 3,21 \\
\hline & Leuctra augusta & MA & 14 \\
\hline & Leuctra forcipata & MA & 5,14 \\
\hline & Leuctra infuscata & MA & 5,14 \\
\hline & Leuctra occidentalis & MA & 5,14 \\
\hline & Leuctra sara & MA & 14 \\
\hline & Megaleuctra complicata & MA & 5 \\
\hline & & Subbasin & Source \\
\hline
\end{tabular}


APPENDIX C. MACROINVERTEBRATES REPORTED FROM AQUATIC ENVIRONMENTS IN THE WILLAMETTE BASIN, OREGON-Continued

\begin{tabular}{|c|c|c|c|}
\hline & Moselia sp. & MC,PM & 2,8 \\
\hline & Moselia infuscata & MC,SY & $21,23,24$ \\
\hline & Paraleuctra sp. & MC & 2 \\
\hline & Paraleuctra andersoni & $\mathrm{MC}$ & 21 \\
\hline & Paraleuctra forcipata & LU,MC & 3,21 \\
\hline & Paraleuctra jewetti & $\mathrm{MC}$ & 21 \\
\hline & Paraleuctra occidentalis & $\mathrm{MC}$ & 21 \\
\hline & Paraleuctra purcellana & MC & 21 \\
\hline & Paraleuctra sara & LU & 3 \\
\hline & Paraleuctra vershina & $\mathrm{MC}$ & 21 \\
\hline & Perlomyia sp. & $\mathrm{LU}$ & 3 \\
\hline & Perlomyia collaris & MA,MC & $5,14,21$ \\
\hline & Perlomyia utahensis & MA,MC & $5,14,21$ \\
\hline FAMILY: Nemouridae & & MC,PM,SY & $1,6,8,10,20,24$ \\
\hline & Amphinemura sp. & SA,SY & 16,18 \\
\hline & Malenka sp. & MC,PM,SY & $2,7,8,9,24$ \\
\hline & Malenka californica & LU,MC & 3,21 \\
\hline & Malenka cornuta & LU,MC & 3,21 \\
\hline & Neomoura sp. & PM & 19 \\
\hline & Nemoura californica & MA & 5,14 \\
\hline & Nemoura cinctipes & MA & 5,14 \\
\hline & Nemoura cornuta & MA & 14 \\
\hline & Nemoura dimicki & LU,MA & 5,8 \\
\hline & Nemoura foersteri & MA & 14 \\
\hline & Nemoura frigida & MA & 14 \\
\hline & Nemoura interrupta & MA & 5,14 \\
\hline & Nemoura obscura & LU,MA & $5,8,14$ \\
\hline & Nemoura oregonensis & LU,MA & $5,8,14$ \\
\hline & Nemoura producta & MA & 14 \\
\hline & Ostrocerca dimicki & $\mathrm{LU}$ & 3 \\
\hline & & Subbasin & Source \\
\hline
\end{tabular}


APPENDIX C. MACROINVERTEBRATES REPORTED FROM AQUATIC ENVIRONMENTS IN THE WILLAMETTE BASIN, OREGON-Continued

Ostracerca foersteri

Podmosta sp.

Podmosta obscura

Prostoia besametsa

Soyedina sp.

Soyedina interrupta

Soyedina producta

Visoka sp.

Visoka cataractae

Zapada sp.

Zapada cinctipes

Zapada columbiana

Zapada frigida

Zapada oregonensis

FAMILY: Peltoperlidae

FAMILY: Perlidae
MC

SY

LU

MC

MC,PM

LU,MC

LU,MC

PM,SY

MC,SY

MC,PM,SY,WR

LU,MC,MF,SA,SY

MC,SY

MC,SY

LU,MC,SA,SY

MC,SY

MC,PM

MA

MA

PM,SY

MC

LU

MC,PM,SA,SY

LU,MC,SY

MC,SY

MC,PM,SA,SY,WR

PM,SY

MA

MA

MA
21

16

3

21

2,8

3,21

3,21

8,16

$21,23,24$

$2,8,13,16,23,24$

$3,7,9,17,18,21,22,23,24$

$21,23,24$

21,24

$3,16,17,18,21,23,24$

$1,6,20$

10,19

5,14

14

8,24

21

3

$2,8,16,17,18$

$3,21,23,24$

21,23

$1,7,8,13,16,18,20,24$

6,19

5,14

5,14

14 
APPENDIX C. MACROINVERTEBRATES REPORTED FROM AQUATIC ENVIRONMENTS IN THE WILLAMETTE BASIN, OREGON-Continued

\begin{tabular}{|c|c|c|c|}
\hline & Calineuria sp. & MC,PM,SY & $2,6,8,16$ \\
\hline & Calineuria californica & LU,MC,MF,SA,SY & $3,7,9,10,17,18,21,24$ \\
\hline & Claasenia sp. & WR & 13 \\
\hline & Classenia sabulosa & MC,WR & 22 \\
\hline & Doroneuria sp. & SY & $16,23,24$ \\
\hline & Doroneuria baumanni & MC,SY & 16,21 \\
\hline & Doroneuria theodora & $\mathrm{MC}$ & 10 \\
\hline & Hesperoperla sp. & SY,WR & 12,16 \\
\hline & Hesperoperla pacifica & LU,MC,MF,SY,WR & $3,7,10,16,17,21,22,24$ \\
\hline \multirow[t]{22}{*}{ FAMILY: Perlodidae } & & MC,PM,SY,WR & $\begin{array}{l}1,7,8,10,12,13,16,20,22, \\
24\end{array}$ \\
\hline & Arcynopteryx sp. & $\mathrm{PM}$ & 19 \\
\hline & Calliperla luctuosa & MA & 14 \\
\hline & Cascadoperla trictura & $\mathrm{LU}$ & 3 \\
\hline & Chernokrilus misnomus & LU,MC & 3,21 \\
\hline & Cultus sp. & LU,MC,SY & $3,7,16,17$ \\
\hline & Frisonia picticeps & LU,MC & 3,21 \\
\hline & Isogenus sp. & $\mathrm{PM}$ & 19 \\
\hline & Isogenus misnomus & MA & 14 \\
\hline & Isogenus nonus & MA & 14 \\
\hline & Isoperla sp. & MC,MF,SA,PM,SY & $6,7,8,16,17,18,19,23,24$ \\
\hline & Isoperla ebria & MA & 14 \\
\hline & Isoperla bifurcata & $\mathrm{MC}$ & 21 \\
\hline & Isoperla gravitans & $\mathrm{MC}$ & 21 \\
\hline & Isoperla marmorata & LU,MA & 3,14 \\
\hline & Isoperla mormona & LU,MA & $3,5,14$ \\
\hline & Isoperla sobria & $\mathrm{LU}$ & 3 \\
\hline & Isoperla sordida & MA & 14 \\
\hline & Isoperla trictura & MA & 5,14 \\
\hline & Kogotus sp. & SY & 16 \\
\hline & Kogotus nonus & LU,MC,SY & $3,16,21$ \\
\hline & Taxon & Subbasin & Source \\
\hline
\end{tabular}


APPENDIX C. MACROINVERTEBRATES REPORTED FROM AQUATIC ENVIRONMENTS IN THE WILLAMETTE BASIN, OREGON-Continued

\begin{tabular}{|c|c|c|c|}
\hline & Megarcys sp. & PM,SA,SY & $8,16,18,23$ \\
\hline & Megarcys subtruncata & LU,MC & 3,21 \\
\hline & Perlinodes sp. & $\mathrm{MC}, \mathrm{SY}$ & 7,24 \\
\hline & Perlinodes aurea & $\mathrm{MC}, \mathrm{SY}$ & 21,24 \\
\hline & Rickera sorpta & $\mathrm{MC}$ & 21 \\
\hline & Setvena tibialis & $\mathrm{MC}$ & 21 \\
\hline & Skwala sp. & MC,WR,SY & $7,9,16,22,24$ \\
\hline & Skwala americana & MC,MF,SA & 17,18 \\
\hline & Skwala curvata & $\mathrm{MC}$ & 21 \\
\hline & Skwala parallela & LU,MC,SY & $3,16,21$ \\
\hline FAMILY: Pteronarcyidae & Pteronarcella sp. & $\mathrm{PM}$ & 8,19 \\
\hline & Pteronarcella regularis & LU,MA & $3,5,14$ \\
\hline & Pteronarcys sp. & MC,PM,SY,WR & $2,8,10,13,19,24$ \\
\hline & Pteronarcys californica & $\mathrm{MC}$ & 7 \\
\hline & Pteronarcys princeps & LU,MA,MC,SY & $3,5,14,21,23,24$ \\
\hline FAMILY: Taeniopterygidae & & $\mathrm{MC}, \mathrm{SY}$ & 1,24 \\
\hline & Brachyptera nigripennis & MA & 5,14 \\
\hline & Brachyptera oregonensis & MA & 5 \\
\hline & Brachyptera pacifica & MA & 5 \\
\hline & Doddsia occidentalis & $\mathrm{MC}$ & 21 \\
\hline & Taenionema sp. & $\mathrm{MC}, \mathrm{SY}$ & $2,7,16$ \\
\hline & Taenionema nigripennis & $\mathrm{LU}, \mathrm{MC}$ & 3,21 \\
\hline & Taenionema oregonensis & $\mathrm{LU}$ & 3 \\
\hline & Taenionema pallidum & $\mathrm{MC}$ & 21 \\
\hline & Taeniopteryx maura & LU,MA & 3,5 \\
\hline ORDER: Trichoptera (Caddisflies) & & $\mathrm{MC}$ & 1 \\
\hline FAMILY: Arctopsychidae & Arctopsyche grandis & $\mathrm{MC}$ & 21 \\
\hline & Parapsyche almota & MC & 21 \\
\hline & Parapsyche elsis & MC & 21 \\
\hline FAMILY: Brachycentridae & & $\mathrm{MC}, \mathrm{SY}$ & 1,6 \\
\hline & & Subbasin & Source \\
\hline
\end{tabular}


APPENDIX C. MACROINVERTEBRATES REPORTED FROM AQUATIC ENVIRONMENTS IN THE WILLAMETTE BASIN, OREGON-Continued

\begin{tabular}{|c|c|c|c|}
\hline & Amiocentrus sp. & $\mathrm{MC}$ & 10 \\
\hline & Amiocentrus aspilus & $\mathrm{MC}$ & 21 \\
\hline & Brachycentrus sp. & MC,SY,WR & $6,10,12,13,16,24$ \\
\hline & Brachycentrus americanus & MC,SY,WR & $7,21,22,24$ \\
\hline & Brachycentrus occidentalis & $\mathrm{MC}$ & 7 \\
\hline & Micrasema sp. & MC,MF,PM,SA,SY & $\begin{array}{l}6,7,8,10,16,17,18,20,23, \\
24\end{array}$ \\
\hline & Micrasema bactro & MA,MC & 4,21 \\
\hline & Micrasema dimicki & LU,MA & 3,4 \\
\hline & Micrasema onisca & MC & 21 \\
\hline & Micrasema oregona & $\mathrm{MC}$ & 21 \\
\hline FAMILY: Calamoceritidae & & $\mathrm{MC}, \mathrm{SY}$ & 1,6 \\
\hline & Heteroplectron sp. & MC & 17 \\
\hline & Heteroplectron californicum & LU,MA,MC,SY & $3,4,10,20,21,24$ \\
\hline FAMILY: Glossosomatidae & & MC,PM & 1,19 \\
\hline & Agapetus sp. & $\mathrm{MC}, \mathrm{SY}$ & 10,24 \\
\hline & Agapetus bifidus & LU,MA & 3,4 \\
\hline & Agapetus occidentis & MC & 21 \\
\hline & Anagapetus sp. & MC,PM & 8,10 \\
\hline & Anagapetus bernea & MA,MC & 4,21 \\
\hline & Glossosoma sp. & MA,MC,MF,SA,SY,WR & $\begin{array}{l}2,4,6,7,9,11,12,13,16,17,18 \\
22,23,24\end{array}$ \\
\hline & Glossosoma califica & $\mathrm{MC}$ & 21 \\
\hline & Glossosoma oregonense & MC & 21 \\
\hline & Glossosoma pentium & LU,MA,MC & $3,4,21$ \\
\hline & Glossosoma pyroxum & $\mathrm{MC}$ & 21 \\
\hline & Glossosoma traviatum & LU,MC & 3,21 \\
\hline & Glossosoma velona & MC & 21 \\
\hline & Glossosoma wenatchee & MC & 21 \\
\hline & Protoptila sp. & WR & 11 \\
\hline & Protoptila coloma & $\mathrm{MC}$ & 21 \\
\hline & & Subbasin & Source \\
\hline
\end{tabular}




\section{APPENDIX C. MACROINVERTEBRATES REPORTED FROM AQUATIC ENVIRONMENTS IN THE WILLAMETTE BASIN, OREGON-Continued}

FAMILY: Goeridae

FAMILY: Hydropsychidae

FAMILY: Hydroptilidae
Goera archaon
Goeracea genota

Arctopsyche sp.

Arctopsyche grandis

Cheumatopsyche sp.

Cheumatopsyche campyla

Homoplectra luchia

Hydropsyche sp.

Hydropsyche amblis

Hydropsyche andersoni

Hydropsyche californica

Hydropsyche centra

Hydropsycheoslari

Parapsyche sp.

Parapsyche almota

Parapsyche elsis

Agraylea multipunctata

Agraylea saltesea

Alisotrichia sp.

Hydroptila sp.

Hydroptila arctia

Leucotrichia sp.

Leucotrichia pictipes

Neotrichia okopa

Ochotrichia sp.

Paleagapetus sp.

Paleagapetus nearcticus
MC

21

MC

21

MC,PM,SY,WR

PM,SY

MC,MF,SA,SY

MA,MC,MF,PM,SY,TU,W $\mathrm{R}$

LU

MC

MA,MC,PM,SA,SY,TU,W

$\mathrm{R}$

LU,MA,MC

MC

LU

LU,MC

LU,MC

MA,MC,PM,SY

LU

MA,SY

MC,SY,WR

MC

MC

SY

LU,MC,SY,TU,WR

MC

WR

TU,WR

$\mathrm{MC}$

MA,MC,SY

PM,SY

MA,MC
$1,6,8,12,13,17$

$6,16,19$

$7,10,17,18,22,24$

$4,6,11,12,17,19,22$

3

21

$4,6,7,9,10,11,17,18,19$, 22,24

$3,4,21$

21

3

3,21

3,21

$4,8,10,16$

3

$4,16,23,24$

$6,10,12,13$

21

9,21

16

$3,7,11,16,22,24$

21

11

22

21

$4,6,21$

8,16

4,21 


\section{APPENDIX C. MACROINVERTEBRATES REPORTED FROM AQUATIC ENVIRONMENTS IN THE WILLAMETTE BASIN, OREGON-Continued}

\begin{tabular}{|c|c|c|c|}
\hline & Stactobiella delira & LU,MC & 3,21 \\
\hline \multirow[t]{12}{*}{ FAMILY: Lepidostomatidae } & & $\mathrm{MC}, \mathrm{SY}$ & 1,6 \\
\hline & Lepidostoma sp. & MC,PM,SA,SY,WR & $\begin{array}{l}2,7,8,9,10,12,13,17,18 \\
20,21,22,23,24\end{array}$ \\
\hline & Lepidostoma cinereum & LU & 3 \\
\hline & Lepidostoma hoodi & MA,MC & 4,21 \\
\hline & Lepidostoma jewetti & $\mathrm{MC}$ & 21 \\
\hline & Lepidostoma podager & $\mathrm{MC}$ & 21 \\
\hline & Lepidostoma quercina & LU,MA & 3,4 \\
\hline & Lepidostoma rayneri & $\mathrm{MC}$ & 21 \\
\hline & Lepidostoma recina & $\mathrm{MC}$ & 21 \\
\hline & Lepidostoma roafi & LU,MA,MC & $3,4,21$ \\
\hline & Lepidostoma unicolor & LU,MA,MC & $3,4,21$ \\
\hline & Lepidostoma veroda & $\mathrm{MC}$ & 21 \\
\hline \multirow[t]{8}{*}{ FAMILY: Leptoceridae } & & SY & 6 \\
\hline & Ceraclea sp. & $\mathrm{MC}, \mathrm{WR}$ & $7,11,22$ \\
\hline & Ceraclea annulicornis & $\mathrm{MC}$ & 21 \\
\hline & Ceraclea cancellata & $\mathrm{MC}$ & 21 \\
\hline & Mystacides alafimbriata & MC,TU,WR & 21,22 \\
\hline & Oecetis sp. & SY,WR & 6,11 \\
\hline & Oecetis inconspicua & $\mathrm{MC}$ & 21 \\
\hline & Triaenodes tarda & $\mathrm{MC}$ & 21 \\
\hline \multirow[t]{9}{*}{ FAMILY: Limnephilidae } & & MC,SA,SY & $1,6,7,16,18,24$ \\
\hline & Allocosmoecus sp. & $\mathrm{MC}$ & 2 \\
\hline & Allocosmoecus partitus & $\mathrm{MC}, \mathrm{SY}$ & 21,24 \\
\hline & Apatania sp. & MC,SY & 6,20 \\
\hline & Apatania sorex & $\mathrm{MC}$ & 21 \\
\hline & Chyranda centralis & LU,MA & 3,4 \\
\hline & Clostoeca disjuncta & $\mathrm{MC}$ & 21 \\
\hline & Cryptochia pilosa & $\mathrm{MC}$ & 21 \\
\hline & Dicosmoecus sp. & MC,PM,WR & $10,13,19$ \\
\hline
\end{tabular}


APPENDIX C. MACROINVERTEBRATES REPORTED FROM AQUATIC ENVIRONMENTS IN THE WILLAMETTE BASIN, OREGON-Continued

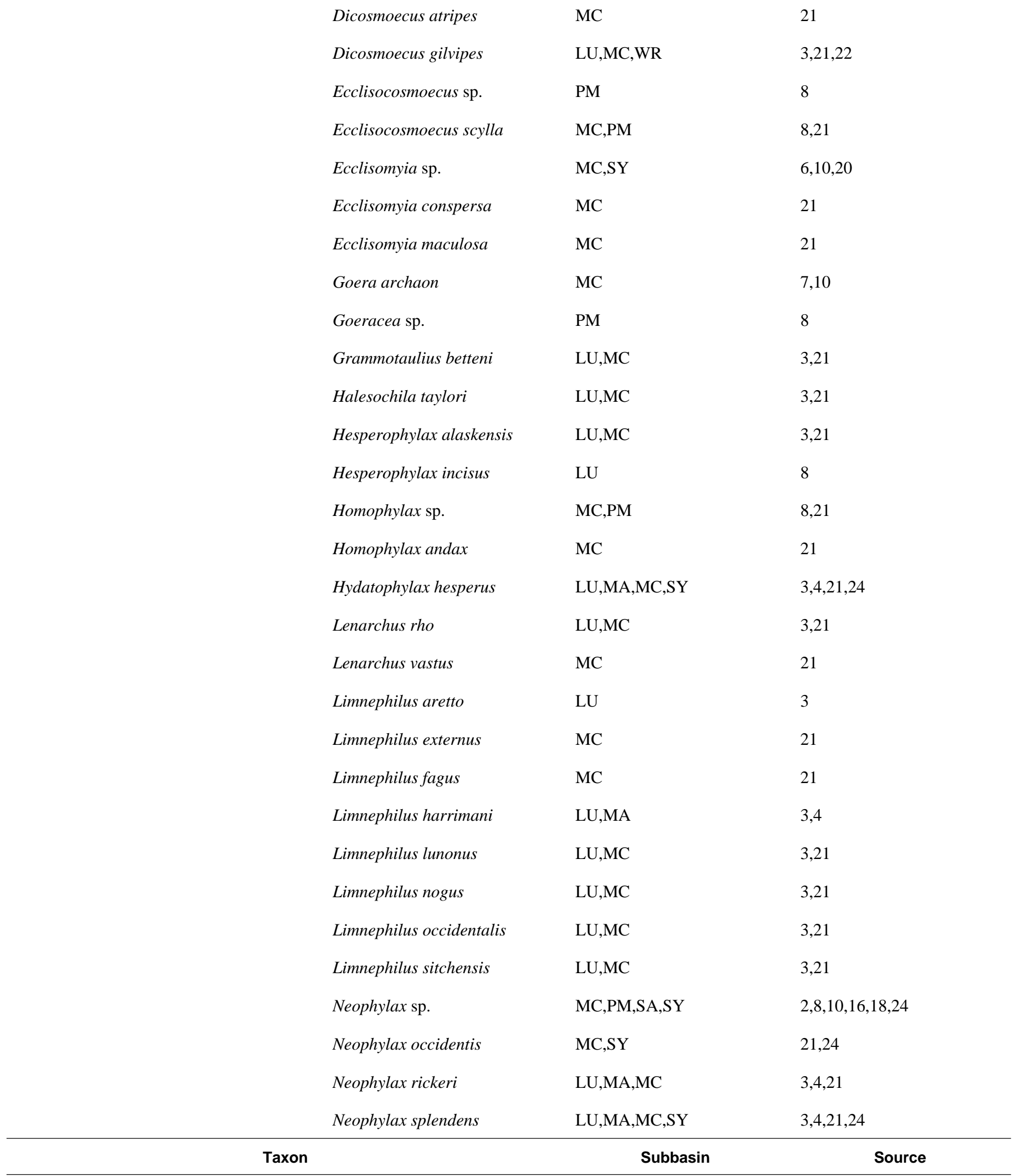


APPENDIX C. MACROINVERTEBRATES REPORTED FROM AQUATIC ENVIRONMENTS IN THE WILLAMETTE BASIN, OREGON-Continued

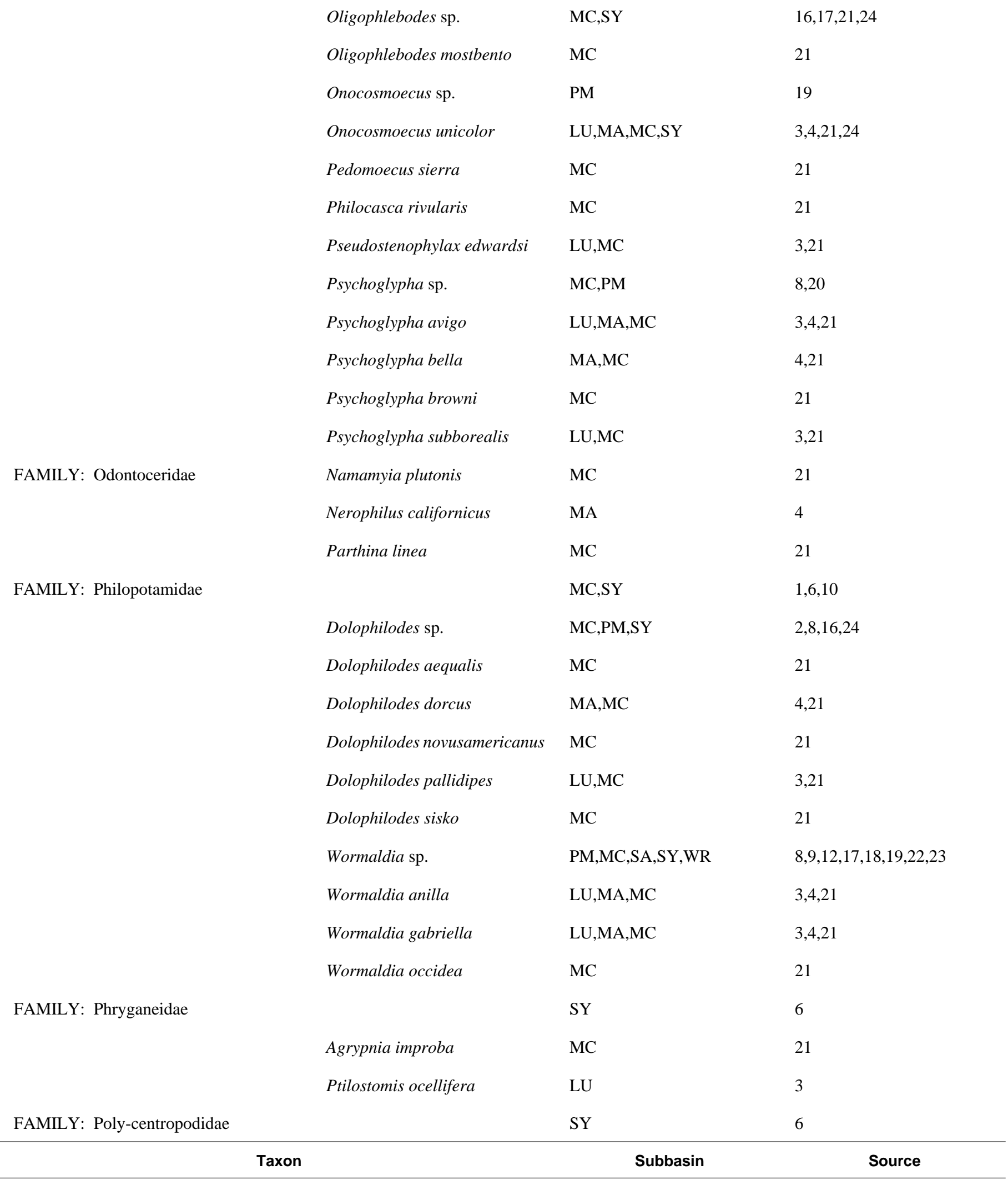




\section{APPENDIX C. MACROINVERTEBRATES REPORTED FROM AQUATIC ENVIRONMENTS IN THE WILLAMETTE BASIN, OREGON-Continued}

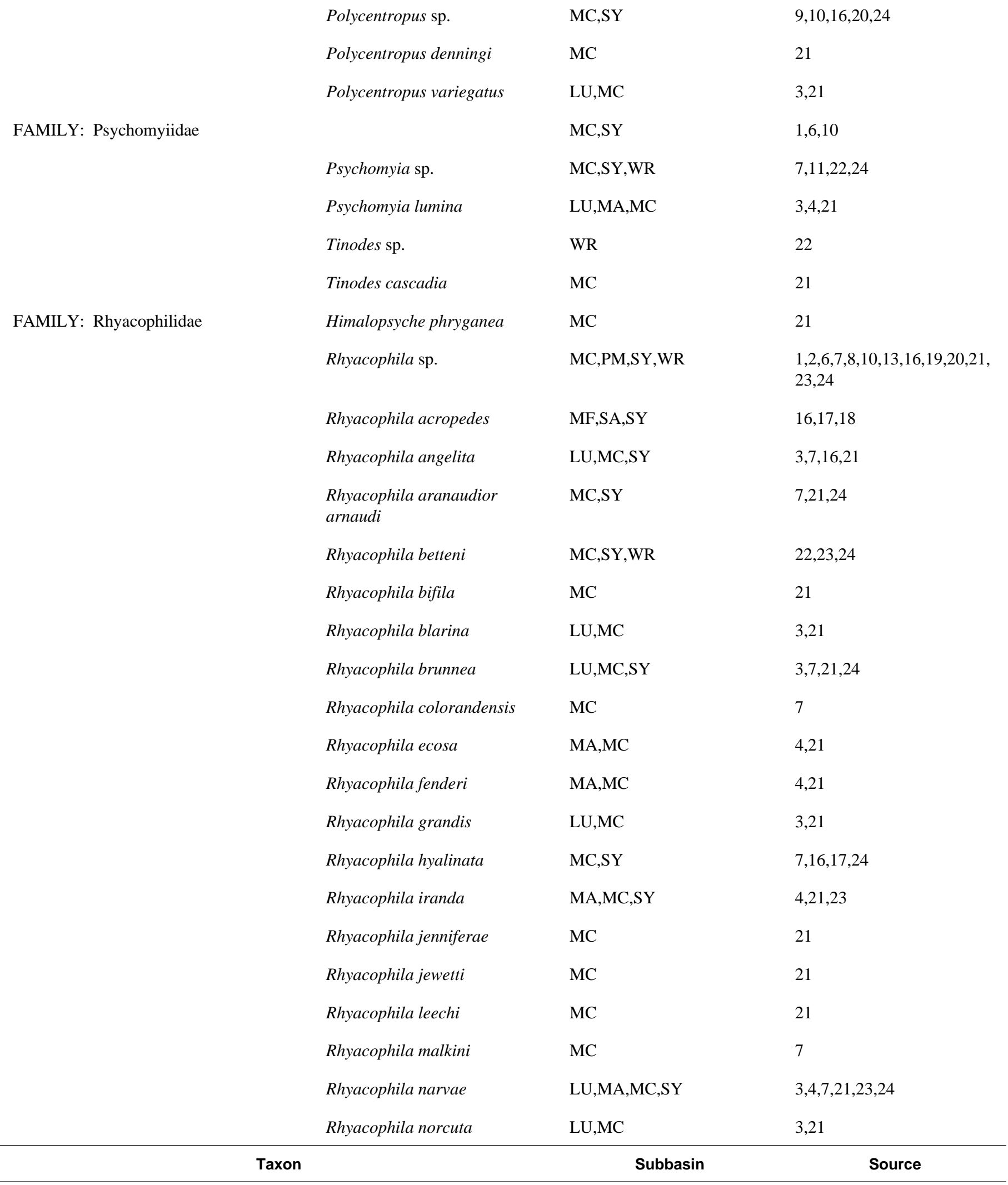


APPENDIX C. MACROINVERTEBRATES REPORTED FROM AQUATIC ENVIRONMENTS IN THE WILLAMETTE BASIN, OREGON-Continued

\begin{tabular}{|c|c|c|c|}
\hline & Rhyacophila oreta & $\mathrm{MC}$ & 21 \\
\hline & Rhyacophila pellisa & MA & 4 \\
\hline & Rhyacophila perda & $\mathrm{MC}$ & 21 \\
\hline & Rhyacophilia rotunda & SY & 16 \\
\hline & Rhyacophila sibirica & $\mathrm{MC}$ & 7 \\
\hline & Rhyacophila tucula & $\mathrm{MC}$ & 21 \\
\hline & Rhyacophila vaccua & LU,MA,MC,SY & $3,4,16,21$ \\
\hline & Rhyacophila vaefes & $\mathrm{MC}$ & 21 \\
\hline & Rhyacophila vagrita & LU,MC,MF,SA,SY & $3,16,17,18,21$ \\
\hline & Rhyacophila valuma & $\mathrm{MC}$ & 21 \\
\hline & Rhyacophila vao & LU,MA,MC & $3,4,21$ \\
\hline & Rhyacophila vedra & LU,MA,MC & $3,4,21$ \\
\hline & Rhyacophila vepulsa & SY & 16 \\
\hline & Rhyacophila verrula & $\mathrm{MC}$ & 2,21 \\
\hline & Rhyacophila vocala & LU,MC & 3,21 \\
\hline & Rhyacophila vuzana & LU,MA,MC & $3,4,21$ \\
\hline & Rhyacophila willametta & MA,MC & 4,21 \\
\hline FAMILY: Sericostomatidae & Gumaga sp. & $\mathrm{MC}, \mathrm{SY}$ & $7,16,21$ \\
\hline FAMILY: Uenoidae & Farula malkini & MA & 4 \\
\hline & Neothremma sp. & MC,PM,SY & $6,8,10$ \\
\hline & Neothremma didactyla & $\mathrm{MC}$ & 21 \\
\hline
\end{tabular}




\section{APPENDIX D. REFERENCES ON THE EFFECTS OF DAMS (PROPOSED OR OPERATING) ON AQUATIC HABITAT AND BIOTA, PARTICULARLY FISH, FOR THE WILLAMETTE BASIN, OREGON}

Bureau of Reclamation, 1965, Willamette River Project, Oregon: Boise, Idaho, Red Prairie Division, 72 p.

City of Portland, 1977, Portland hydroelectric project, Exhibit W-Environmental report prepared for the Federal Power Commission, October 1977: Portland, Oregon, 213 p.

Craig. J.A., and Suomela, A.J., 1940, A survey of the Sandy River and its tributaries, 1940, with reference to fish management: U.S. Fish and Wildlife Service Special Science Report No. 14, 20 p.

Cramer, D.P., 1988, An estimation of the effect of North Fork, Faraday, and River Mill Dams on survival of juvenile salmonids; for planning purposes: Estacada, Oregon, Portland General Electric, unpublished report, [variously paginated].

Eicher, G.J., 1977, Clackamas Dams and anadromous fish; a history of fish and dams on the Clackamas River: Portland, Oregon, Portland General Electric Company, 33 p.

Hutchison, J.M., and Aney, W.W., 1964, The fish and wildlife resources of the Lower Willamette Basin, Oregon, and their water use requirements: Portland, Oregon State Game Commission, Basin Investigations Section, report submitted to Oregon State Water Resources Board, 76 p.

Hutchison, J.M., and Claire, E.W., 1970, An outline of the fishery problems associated with hydroelectric and municipal developments on the Sandy River: Portland, Oregon State Game Commission, Basin Investigations Section, Special Report No. 2, 25 p.

Hutchison, J.M., Thompson, K.E., and Fortune, J.D. Jr., 1966, The fish and wildlife resources of the upper Willamette Basin, Oregon, and their requirements: Portland, Oregon State Game Commission, 44 p.

Ingram, P., and Korn, L., 1969, Evaluation of fish passage facilities at Cougar Dam on the South Fork of the McKenzie River in Oregon: Clackamas, Fish Commission of Oregon, U.S. Army Corps of Engineers contract No. DA-35-026-CIVEN G-64-295, 76 p.

Oregon Fish Commission, 1969, The status of salmon and steelhead in the Clackamas River, with emphasis on passage problems at dams: Portland, Oregon Fish Commission, Proceedings Report, Special Projects No. 3, 7 p.

Oregon State Game Commission, 1948, Fish and wildlife problems arising from the Willamette Valley Project: Portland, Oregon State Game Commission, Fish Commission of Oregon, 99 p.

1963, The fish and wildlife resources of the Middle Willamette Basin, Oregon, and their water use requirements, report submitted to State Water Resources Board: Portland, Oregon State Game Commission, Basin Investigations Section, 25 p., 15 apps.

Severdrup and VTN, 1982, Blue River dam power plant project: Eugene, Oregon, Water and Electric Board application for license for major project-Existing dam, FERC 3109.

Smith, E.M., and Korn, L., 1970, Evaluation of fish facilities and passage at Fall Creek Dam on Fal Creek in Oregon: Portland, Fish Commission of Oregon, Research Division, U.S. Army Corps of Engineers contract No. DA-35-026-CIVENG66-400, $83 \mathrm{p}$.

U.S. Army Corps of Engineers, 1970, Review report on Willamette River and tributaries, Oregon-Interim report 1, Calapooia River Basin: Portland, Oregon, 60 p. and attachments.

1982, Willamette River projects-Hydrologic and temperature effects, preliminary literature review and data analysis: Portland, Oregon, [variously paginated].

1988a, Dorena Lake plan of management and development, Upper Willamette Valley Projects master plan for resource use, Part 2C: Portland, Oregon, [variously paginated].

1991a, Willamette River Basin review reconnaissance study, Volume 1: Portland, Oregon, 11 p., 6 apps.

1991b, Willamette River Basin review reconnaissance study, Volume 2, Appendix E—Fish and Wildlife Studies:

Portland, Oregon, 9 p. 


\section{APPENDIX D. REFERENCES ON THE EFFECTS OF DAMS (PROPOSED OR OPERATING) ON AQUATIC HABITAT AND BIOTA, PARTICULARLY FISH, FOR THE WILLAMETTE BASIN, OREGON-Continued}

U.S. Fish and Wildlife Service, 1948, Willamette Valley Project, Oregon; preliminary evaluation report on fish and wildlife resources: Portland, Oregon, 70 p.

1959, A detailed report on fish and wildlife resources affected by Cougar Dam and reservoir project, Oregon: Portland, 15 p. and apps.

1962, A detailed report on fish and wildlife resources affected by Fall Creek dam and reservoir project, Fall Creek, Oregon: Portland, 22 p. and apps.

1965, A detailed report on fish and wildlife resources affected by Blue River dam and reservoir project, Blue River, Oregon: Portland, 15 p. and apps.

Wagner, E., and Ingram, P., 1973, Evaluation of fish facilities and passage at Foster and Green Peter dams on the South Santiam River drainage in Oregon: Portland, Fish Commission of Oregon, U.S. Army Corps of Engineers contract No. DACW57-68-C-0013, 111 p.

Willamette Basin Task Force, 1969, Willamette Basin comprehensive study_-Water and related land resources, Appendix DFish and wildlife: Portland, Oregon, Willamette Basin Task Force, Pacific Northwest River Basins Commission, [variously paginated]. 


\section{APPENDIX E-1. CHLORINATED PESTICIDES IN TISSUE OF AQUATIC BIOTA FROM THE WILLAMETTE BASIN, \\ OREGON}

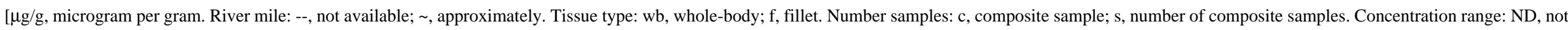

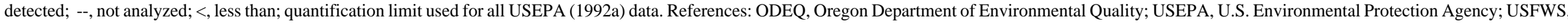
U.S. Fish and Wildlife Service]

Concentration range ( $\mu \mathrm{g} / \mathrm{g}$, wet weight)

\begin{tabular}{|c|c|c|c|c|c|c|c|c|c|c|c|c|c|c|c|}
\hline River & $\begin{array}{l}\text { River } \\
\text { mile }\end{array}$ & Year & Species & $\begin{array}{l}\text { Tis- } \\
\text { sue } \\
\text { type }\end{array}$ & $\begin{array}{l}\text { Number } \\
\text { samples }\end{array}$ & $\alpha-\mathrm{HCH}$ & $\beta-\mathrm{HCH}$ & $\Delta-\mathrm{HCH}$ & $\begin{array}{r}\text { Lindane } \\
(\gamma-\mathrm{HCH})\end{array}$ & Heptachlor & $\begin{array}{l}\text { Heptachlor } \\
\text { epoxide }\end{array}$ & $\begin{array}{l}\text { Endo- } \\
\text { sulfan I }\end{array}$ & $\begin{array}{l}\text { Endo- } \\
\text { sulfan II }\end{array}$ & $\begin{array}{l}\text { Endosulfan } \\
\text { sulfate }\end{array}$ & Reference \\
\hline $\begin{array}{l}\text { Willamette, } \\
\text { Newberg Pool }\end{array}$ & -- & 1987 & $\begin{array}{l}\text { Northern } \\
\text { squawfish }\end{array}$ & wb & $3-5 c$ & $<0.0025$ & -- & -- & $<0.0025$ & $<0.0025$ & $<0.0025$ & -- & -- & -- & USEPA (1992a) \\
\hline $\begin{array}{l}\text { Willamette, } \\
\text { Halsey }\end{array}$ & -- & 1987 & Sucker & wb & $4 c$ & .00403 & -- & -- & $<.0025$ & $<.0025$ & $<.0025$ & -- & -- & -- & USEPA (1992a) \\
\hline Willamette & $\sim 7$ & 1987 & Sucker & wb & $4 \mathrm{c}$ & .00717 & -- & -- & .0186 & $<.0025$ & $<.0025$ & -- & -- & -- & USEPA (1992a) \\
\hline Willamette & 7 & 1990 & $\begin{array}{l}\text { Northern } \\
\text { squawfish }\end{array}$ & wb & 3 & $<.006$ & $<0.006$ & $<0.006$ & $<.006$ & $<.006$ & $<.006$ & $<0.006$ & $<0.006$ & $<0.006$ & ODEQ (1994b) \\
\hline Willamette & 7 & 1990 & $\begin{array}{l}\text { Northern } \\
\text { squawfish }\end{array}$ & wb & 1 & .004 & $<.002$ & -- & $<.002$ & $<.002$ & $<.002$ & $<.002$ & -- & $<.002$ & $\begin{array}{l}\text { Curtis and others } \\
\text { (1993) }\end{array}$ \\
\hline$\vec{\Phi}$ Willamette & 7 & 1990 & Common carp & $\mathrm{f}$ & $3-5$ & $<.002$ & $<.002$ & -- & $<.002$ & $.0023 \pm .0004$ & $<.002$ & $<.002$ & -- & $<.002$ & $\begin{array}{l}\text { Curtis and others } \\
\text { (1993) }\end{array}$ \\
\hline Willamette & 7 & $\begin{array}{l}1989- \\
90\end{array}$ & Common carp & $\mathrm{f}$ & 6 & $<.003$ & $<.003$ & $<.003$ & $<.003$ & $<.003$ & $<.003$ & $<.003$ & $<.003$ & $<.002-.026$ & ODEQ (1994b) \\
\hline Willamette & 7 & 1988 & Common carp & $\mathrm{f}$ & $5 \mathrm{c}, 2 \mathrm{~s}$ & $<.003$ & $<.003$ & -- & $<.003$ & $<.003-.007$ & $<.003$ & -- & -- & -- & ODEQ (1994b) \\
\hline Willamette & 18 & 1989 & Common carp & $\mathrm{f}$ & $4 \mathrm{c}$ & $<.002$ & $<.002$ & $<.002$ & $<.002$ & $<.002$ & $<.002$ & $<.002$ & $<.002$ & $<.002$ & ODEQ (1994b) \\
\hline Willamette & 18 & 1989 & Sucker & $\mathrm{f}$ & $3 \mathrm{c}$ & $<.002$ & $<.002$ & $<.002$ & $<.002$ & $<.002$ & $<.002$ & $<.002$ & $<.002$ & $<.002$ & ODEQ (1994b) \\
\hline Willamette & $\sim 26$ & 1970 & Common carp & wb & $3-5 c$ & -- & -- & -- & -- & .0 & -- & -- & -- & -- & $\begin{array}{l}\text { Schmitt and } \\
\text { others (1981) }\end{array}$ \\
\hline Willamette & $\sim 26$ & 1970 & $\begin{array}{l}\text { Largescale } \\
\text { sucker }\end{array}$ & wb & $3-5 c$ & -- & -- & -- & -- & .0 & -- & -- & -- & -- & $\begin{array}{l}\text { Schmitt and } \\
\text { others (1981) }\end{array}$ \\
\hline Willamette & $\sim 26$ & 1970 & $\begin{array}{l}\text { Largescale } \\
\text { sucker }\end{array}$ & wb & $3-5 c$ & -- & -- & -- & -- & .0 & -- & -- & -- & -- & $\begin{array}{l}\text { Schmitt and } \\
\text { others (1981) }\end{array}$ \\
\hline Willamette & $\sim 26$ & 1971 & $\begin{array}{l}\text { Largescale } \\
\text { sucker }\end{array}$ & wb & $3-5 c$ & -- & -- & -- & -- & .0 & -- & -- & -- & -- & $\begin{array}{l}\text { Schmitt and } \\
\text { others (1981) }\end{array}$ \\
\hline Willamette & $\sim 26$ & 1971 & $\begin{array}{l}\text { Largescale } \\
\text { sucker }\end{array}$ & wb & $3-5 c$ & -- & -- & -- & -- & .0 & -- & -- & -- & -- & $\begin{array}{l}\text { Schmitt and } \\
\text { others (1981) }\end{array}$ \\
\hline Willamette & $\sim 26$ & 1971 & $\begin{array}{l}\text { Northern } \\
\text { squawfish }\end{array}$ & wb & $3-5 c$ & -- & -- & -- & -- & .0 & -- & -- & -- & -- & $\begin{array}{l}\text { Schmitt and } \\
\text { others (1981) }\end{array}$ \\
\hline
\end{tabular}


APPENDIX E-1. CHLORINATED PESTICIDES IN TISSUE OF AQUATIC BIOTA FROM THE WILLAMETTE BASIN, OREGON-Continued

\begin{tabular}{|c|c|c|c|c|c|c|c|c|c|c|c|c|c|c|c|}
\hline \multirow[b]{2}{*}{ River } & \multirow[b]{2}{*}{$\begin{array}{l}\text { River } \\
\text { mile }\end{array}$} & \multirow[b]{2}{*}{ Year } & \multirow[b]{2}{*}{ Species } & \multirow{2}{*}{$\begin{array}{l}\text { Tis- } \\
\text { sue } \\
\text { type }\end{array}$} & \multirow[b]{2}{*}{$\begin{array}{l}\text { Number } \\
\text { samples }\end{array}$} & \multicolumn{9}{|c|}{ Concentration range $(\mu \mathbf{g} / \mathbf{g}$, wet weight) } & \multirow[b]{2}{*}{ Reference } \\
\hline & & & & & & $\alpha-\mathrm{HCH}$ & $\beta-\mathrm{HCH}$ & $\Delta-\mathrm{HCH}$ & $\begin{array}{r}\text { Lindane } \\
(\gamma-\mathrm{HCH})\end{array}$ & Heptachlor & $\begin{array}{l}\text { Heptachlor } \\
\text { epoxide }\end{array}$ & $\begin{array}{l}\text { Endo- } \\
\text { sulfan I }\end{array}$ & $\begin{array}{l}\text { Endo- } \\
\text { sulfan II }\end{array}$ & $\begin{array}{l}\text { Endosulfan } \\
\text { sulfate }\end{array}$ & \\
\hline Willamette & $\sim 26$ & 1971 & $\begin{array}{l}\text { Northern } \\
\text { squawfish }\end{array}$ & wb & $3-5 c$ & -- & -- & -- & -- & 0.0 & -- & -- & -- & -- & $\begin{array}{l}\text { Schmitt and } \\
\text { others (1981) }\end{array}$ \\
\hline Willamette & $\sim 26$ & 1972 & $\begin{array}{l}\text { Largescale } \\
\text { sucker }\end{array}$ & wb & $3-5 c$ & -- & -- & -- & -- & .0 & -- & -- & -- & -- & $\begin{array}{l}\text { Schmitt and } \\
\text { others (1981) }\end{array}$ \\
\hline Willamette & $\sim 26$ & 1972 & $\begin{array}{l}\text { Largescale } \\
\text { sucker }\end{array}$ & wb & $3-5 c$ & -- & -- & -- & -- & .0 & -- & -- & -- & -- & $\begin{array}{l}\text { Schmitt and } \\
\text { others (1981) }\end{array}$ \\
\hline Willamette & $\sim 26$ & 1972 & $\begin{array}{l}\text { Channel } \\
\text { catfish }\end{array}$ & wb & $3-5 c$ & -- & -- & -- & -- & .0 & -- & -- & -- & -- & $\begin{array}{l}\text { Schmitt and } \\
\text { others (1981) }\end{array}$ \\
\hline Willamette & $\sim 26$ & 1972 & $\begin{array}{l}\text { Northern } \\
\text { squawfish }\end{array}$ & wb & $3-5 c$ & -- & -- & -- & -- & .0 & -- & -- & -- & -- & $\begin{array}{l}\text { Schmitt and } \\
\text { others (1981) }\end{array}$ \\
\hline Willamette & $\sim 26$ & 1973 & Common carp & wb & $3-5 c$ & -- & -- & -- & -- & .0 & -- & -- & -- & -- & $\begin{array}{l}\text { Schmitt and } \\
\text { others (1981) }\end{array}$ \\
\hline Willamette & $\sim 26$ & 1973 & $\begin{array}{l}\text { Largescale } \\
\text { sucker }\end{array}$ & wb & $3-5 c$ & -- & -- & -- & -- & .0 & -- & -- & -- & -- & $\begin{array}{l}\text { Schmitt and } \\
\text { others (1981) }\end{array}$ \\
\hline Willamette & $\sim 26$ & 1973 & $\begin{array}{l}\text { Largescale } \\
\text { sucker }\end{array}$ & wb & $3-5 c$ & -- & -- & -- & -- & .0 & -- & -- & -- & -- & $\begin{array}{l}\text { Schmitt and } \\
\text { others (1981) }\end{array}$ \\
\hline Willamette & $\sim 26$ & 1973 & $\begin{array}{l}\text { Northern } \\
\text { squawfish }\end{array}$ & wb & $3-5 c$ & -- & -- & -- & -- & .0 & -- & -- & -- & -- & $\begin{array}{l}\text { Schmitt and } \\
\text { others (1981) }\end{array}$ \\
\hline Willamette & $\sim 26$ & 1974 & Common carp & wb & $3-5 c$ & -- & -- & -- & -- & .0 & -- & -- & -- & -- & $\begin{array}{l}\text { Schmitt and } \\
\text { others (1981) }\end{array}$ \\
\hline Willamette & $\sim 26$ & 1974 & $\begin{array}{l}\text { Largescale } \\
\text { sucker }\end{array}$ & wb & $3-5 c$ & -- & -- & -- & -- & .0 & -- & -- & -- & -- & $\begin{array}{l}\text { Schmitt and } \\
\text { others (1981) }\end{array}$ \\
\hline Willamette & $\sim 26$ & 1974 & $\begin{array}{l}\text { Largescale } \\
\text { sucker }\end{array}$ & wb & $3-5 c$ & -- & -- & -- & -- & .0 & -- & -- & -- & -- & $\begin{array}{l}\text { Schmitt and } \\
\text { others (1981) }\end{array}$ \\
\hline Willamette & $\sim 26$ & 1974 & $\begin{array}{l}\text { Northern } \\
\text { squawfish }\end{array}$ & wb & $3-5 c$ & -- & -- & -- & -- & .0 & -- & -- & -- & -- & $\begin{array}{l}\text { Schmitt and } \\
\text { others (1981) }\end{array}$ \\
\hline Willamette & $\sim 26$ & 1976 & $\begin{array}{l}\text { Smallmouth } \\
\text { bass }\end{array}$ & wb & $3-5 c$ & 0.01 & -- & -- & 0.02 & .01 & -- & -- & -- & -- & $\begin{array}{l}\text { Schmitt and } \\
\text { others (1983) }\end{array}$ \\
\hline Willamette & $\sim 26$ & 1976 & Chiselmouth & wb & $3-5 c$ & .16 & -- & -- & .02 & .00 & -- & -- & -- & -- & $\begin{array}{l}\text { Schmitt and } \\
\text { others (1983) }\end{array}$ \\
\hline Willamette & $\sim 26$ & 1976 & Chiselmouth & wb & $3-5 c$ & .08 & -- & -- & .02 & .00 & -- & -- & -- & -- & $\begin{array}{l}\text { Schmitt and } \\
\text { others (1983) }\end{array}$ \\
\hline
\end{tabular}


APPENDIX E-1. CHLORINATED PESTICIDES IN TISSUE OF AQUATIC BIOTA FROM THE WILLAMETTE BASIN, OREGON-Continued

\begin{tabular}{|c|c|c|c|c|c|c|c|c|c|c|c|c|c|c|c|}
\hline \multirow[b]{2}{*}{ River } & \multirow[b]{2}{*}{$\begin{array}{c}\text { River } \\
\text { mile }\end{array}$} & \multirow[b]{2}{*}{ Year } & \multirow[b]{2}{*}{ Species } & \multirow{2}{*}{$\begin{array}{l}\text { Tis- } \\
\text { sue } \\
\text { type }\end{array}$} & \multirow[b]{2}{*}{$\begin{array}{l}\text { Number } \\
\text { samples }\end{array}$} & \multicolumn{9}{|c|}{ Concentration range ( $\mu \mathrm{g} / \mathrm{g}$, wet weight) } & \multirow[b]{2}{*}{ Reference } \\
\hline & & & & & & $\alpha-\mathrm{HCH}$ & $\beta$-HCH & $\Delta-\mathrm{HCH}$ & $\begin{array}{r}\text { Lindane } \\
(\gamma-\mathrm{HCH})\end{array}$ & Heptachlor & $\begin{array}{c}\text { Heptachlor } \\
\text { epoxide }\end{array}$ & $\begin{array}{l}\text { Endo- } \\
\text { sulfan I }\end{array}$ & $\begin{array}{l}\text { Endo- } \\
\text { sulfan II }\end{array}$ & $\begin{array}{l}\text { Endosulfan } \\
\text { sulfate }\end{array}$ & \\
\hline Willamette & $\sim 26$ & 1978 & $\begin{array}{l}\text { Northern } \\
\text { squawfish }\end{array}$ & wb & $3-5 c$ & 0.00 & -- & -- & 0.00 & 0.00 & -- & -- & -- & -- & $\begin{array}{l}\text { Schmitt and } \\
\text { others (1983) }\end{array}$ \\
\hline Willamette & $\sim 26$ & 1978 & Chiselmouth & wb & $3-5 c$ & .00 & -- & -- & .01 & .00 & -- & -- & -- & -- & $\begin{array}{l}\text { Schmitt and } \\
\text { others (1983) }\end{array}$ \\
\hline Willamette & $\sim 26$ & 1978 & Chiselmouth & wb & $3-5 c$ & .00 & -- & -- & .01 & .00 & -- & -- & -- & -- & $\begin{array}{l}\text { Schmitt and } \\
\text { others (1983) }\end{array}$ \\
\hline Willamette & $\sim 26$ & 1980 & $\begin{array}{l}\text { Largescale } \\
\text { sucker }\end{array}$ & wb & $3-5 c$ & .00 & -- & -- & .00 & .01 & -- & -- & -- & -- & $\begin{array}{l}\text { Schmitt and } \\
\text { others (1985) }\end{array}$ \\
\hline Willamette & $\sim 26$ & 1980 & $\begin{array}{l}\text { Largescale } \\
\text { sucker }\end{array}$ & wb & $3-5 c$ & .00 & -- & -- & .00 & .00 & -- & -- & -- & -- & $\begin{array}{l}\text { Schmitt and } \\
\text { others (1985) }\end{array}$ \\
\hline Willamette & $\sim 26$ & 1980 & $\begin{array}{l}\text { Northern } \\
\text { squawfish }\end{array}$ & wb & $3-5 c$ & .00 & -- & -- & .00 & .00 & -- & -- & -- & -- & $\begin{array}{l}\text { Schmitt and } \\
\text { others (1985) }\end{array}$ \\
\hline Willamette & $\sim 26$ & 1984 & $\begin{array}{l}\text { Northern } \\
\text { squawfish }\end{array}$ & wb & $3-5 c$ & $<.01$ & -- & -- & $<.01$ & $<.01$ & -- & -- & -- & -- & $\begin{array}{l}\text { Schmitt and } \\
\text { others (1990) }\end{array}$ \\
\hline Willamette & $\sim 26$ & 1984 & Peamouth & wb & $3-5 c$ & $<.01$ & -- & -- & $<.01$ & $<.01$ & -- & -- & -- & -- & $\begin{array}{l}\text { Schmitt and } \\
\text { others (1990) }\end{array}$ \\
\hline Willamette & $\sim 26$ & 1984 & Peamouth & wb & $3-5 c$ & $<.01$ & -- & -- & $<.01$ & $<.01$ & -- & -- & -- & -- & $\begin{array}{l}\text { Schmitt and } \\
\text { others (1990) }\end{array}$ \\
\hline Willamette & 27 & 1988 & Bass & f & $3 c$ & $<.005$ & $<0.005$ & -- & $<.005$ & $<.005$ & $<0.005$ & -- & -- & -- & ODEQ (1994b) \\
\hline Willamette & 27 & 1988 & Common carp & $\mathrm{f}$ & $3 \mathrm{c}, 2 \mathrm{~s}$ & $<.003$ & $<.003$ & -- & $<.003$ & $<.003$ & $<.003$ & -- & -- & -- & ODEQ (1994b) \\
\hline Willamette & 27 & 1988 & $\begin{array}{l}\text { Northern } \\
\text { squawfish }\end{array}$ & f & $3 c$ & $<.004$ & $<.004$ & -- & $<.004$ & $<.004$ & $<.004$ & -- & -- & -- & ODEQ (1994b) \\
\hline Willamette & 28 & 1989 & Common carp & f & 3 & .004 & $<.002$ & $0.002-.005$ & $<.002-.002$ & $<.002-.005$ & $<.002-.006$ & $<0.002-.002$ & $<0.002$ & $<0.002-.019$ & ODEQ (1994b) \\
\hline Willamette & 28 & 1989 & Common carp & liver & 2 & $<.002$ & $<.002$ & $<.002$ & $<.002$ & $<.002-.068$ & $<.002$ & $<.002-0.148$ & $<.002$ & $<.002$ & ODEQ (1994b) \\
\hline Willamette & 38 & 1989 & Sucker & $\mathrm{f}$ & $5 c$ & $<.002$ & $<.002$ & $<.002$ & $<.002$ & $<.002$ & $<.002$ & $<.002$ & $<.002$ & $<.002$ & ODEQ (1994b) \\
\hline Willamette & 38 & $\begin{array}{c}1988- \\
89\end{array}$ & $\begin{array}{l}\text { Northern } \\
\text { squawfish }\end{array}$ & $\mathrm{f}$ & $5 \mathrm{c}, 2 \mathrm{~s}$ & $<.008$ & $<.008$ & $<.002$ & $<.008$ & $<.008$ & $<.008$ & $<.002$ & $<.002$ & $<.002$ & ODEQ (1994b) \\
\hline Willamette & 38 & 1988 & Common carp & $\mathrm{f}$ & $3 c$ & $<.003$ & $<.003$ & -- & $<.003$ & $<.003$ & $<.003$ & -- & -- & -- & ODEQ (1994b) \\
\hline Willamette & 48 & $\begin{array}{c}1988- \\
89\end{array}$ & Common carp & $\mathrm{f}$ & 3 & $<.002$ & $<.002$ & $<.002$ & $<.002$ & $<.002$ & $<.002$ & $<.002$ & $<.002$ & $<.002$ & ODEQ (1994b) \\
\hline
\end{tabular}


APPENDIX E-1. CHLORINATED PESTICIDES IN TISSUE OF AQUATIC BIOTA FROM THE WILLAMETTE BASIN, OREGON-Continued

\begin{tabular}{|c|c|c|c|c|c|c|c|c|c|c|c|c|c|c|c|}
\hline \multirow[b]{2}{*}{ River } & \multirow[b]{2}{*}{$\begin{array}{l}\text { River } \\
\text { mile }\end{array}$} & \multirow[b]{2}{*}{ Year } & \multirow[b]{2}{*}{ Species } & \multirow[b]{2}{*}{$\begin{array}{l}\text { Tis- } \\
\text { sue } \\
\text { type }\end{array}$} & \multirow[b]{2}{*}{$\begin{array}{l}\text { Number } \\
\text { samples }\end{array}$} & \multicolumn{9}{|c|}{ Concentration range $(\mu \mathbf{g} / \mathbf{g}$, wet weight) } & \multirow[b]{2}{*}{ Reference } \\
\hline & & & & & & $\alpha-\mathrm{HCH}$ & $\beta-\mathrm{HCH}$ & $\Delta-\mathrm{HCH}$ & $\begin{array}{r}\text { Lindane } \\
(\gamma-\mathrm{HCH})\end{array}$ & Heptachlor & $\begin{array}{l}\text { Heptachlor } \\
\text { epoxide }\end{array}$ & $\begin{array}{l}\text { Endo- } \\
\text { sulfan I }\end{array}$ & $\begin{array}{l}\text { Endo- } \\
\text { sulfan II }\end{array}$ & $\begin{array}{l}\text { Endosulfan } \\
\text { sulfate }\end{array}$ & \\
\hline Willamette & 48 & 1989 & Common carp & liver & 2 & $<0.004$ & $0.003-<.004$ & $<0.004$ & $<0.004$ & $<0.004$ & $<0.004$ & $<0.004$ & $<0.004$ & $<0.004$ & ODEQ (1994b) \\
\hline Willamette & 48 & 1988 & $\begin{array}{l}\text { Northern } \\
\text { squawfish }\end{array}$ & $\mathrm{f}$ & $5 \mathrm{c}$ & $<.003$ & $<.003$ & -- & $<.003$ & $<.003$ & $<.003$ & -- & -- & -- & ODEQ (1994b) \\
\hline Willamette & 72 & 1990 & Common carp & $\mathrm{f}$ & 1 & $<.002$ & $<.002$ & -- & $<.002$ & .002 & $<.002$ & $<.002$ & -- & $<.002$ & $\begin{array}{l}\text { Curtis and others } \\
\text { (1993) }\end{array}$ \\
\hline Willamette & 74 & 1990 & $\begin{array}{l}\text { Northern } \\
\text { squawfish }\end{array}$ & wb & 3 & $<.002$ & $<.002$ & $<.002$ & $<.002$ & $<.002$ & $<.002$ & $<.002$ & $<.002$ & $<.002$ & ODEQ (1994b) \\
\hline Willamette & 74 & 1990 & Common carp & $\mathrm{f}$ & 6 & $<.003$ & $<.003$ & $<.003$ & $<.003$ & $.002-<.003$ & $<.003$ & $<.002-.004$ & $<.003$ & $<.003$ & ODEQ (1994b) \\
\hline Willamette & 74 & 1990 & Common carp & liver & 3 & $<.003-.039$ & $<.003-.006$ & $<.003$ & $<.003-.045$ & $<.003-.031$ & $<.003$ & $<.003$ & $<.003$ & $<.003$ & ODEQ (1994b) \\
\hline Willamette & 131 & 1990 & $\begin{array}{l}\text { Northern } \\
\text { squawfish }\end{array}$ & wb & 3 & $<.002$ & $<.002-.006$ & $<.003$ & $<.002$ & $<.002$ & $<.002$ & $<.002-.002$ & $<.002$ & $<.002$ & ODEQ (1994b) \\
\hline Willamette & 131 & 1990 & Common carp & $\mathrm{f}$ & 3 & $<.002$ & $<.002$ & $<.002$ & $<.002$ & $<.002$ & $<.002$ & $<.002$ & $<.002$ & $<.002$ & ODEQ (1994b) \\
\hline Willamette & 147 & 1990 & $\begin{array}{l}\text { Northern } \\
\text { squawfish }\end{array}$ & wb & 3 & $<.002$ & $<.002-.002$ & $<.002$ & $<.002$ & $<.002-.002$ & $<.002$ & $<.002$ & $<.002$ & $<.002$ & ODEQ (1994b) \\
\hline Willamette & 147 & 1990 & Cutthroat trout & wb & 5 & $<.002$ & $<.002$ & $<.002$ & $<.002$ & $<.002-.005$ & $<.002-.002$ & $.002-<.003$ & $<.002$ & $<.002$ & ODEQ (1994b) \\
\hline Willamette & 148 & 1990 & $\begin{array}{l}\text { Northern } \\
\text { squawfish }\end{array}$ & wb & 1 & $<.002$ & .002 & -- & $<.002$ & $<.002$ & $<.002$ & $<.002$ & -- & $<.002$ & $\begin{array}{l}\text { Curtis and others } \\
\text { (1993) }\end{array}$ \\
\hline Willamette & 148 & 1990 & Cutthroat trout & wb & $1-5$ & $<.002$ & $<.002$ & -- & $<.002$ & .0033 & $<.002$ & $<.002$ & -- & $<.002$ & $\begin{array}{l}\text { Curtis and others } \\
\text { (1993) }\end{array}$ \\
\hline Willamette & 148 & 1990 & Cutthroat trout & wb & 1 & $<.002$ & $<.002$ & -- & $<.002$ & $<.002$ & .002 & $<.002$ & -- & $<.002$ & $\begin{array}{l}\text { Curtis and others } \\
\text { (1993) }\end{array}$ \\
\hline Willamette & 148 & 1990 & Cutthroat trout & wb & $1-5$ & $<.002$ & $<.002$ & -- & $<.002$ & $<.002$ & $<.002$ & $.0020 \pm .0014$ & -- & $<.002$ & $\begin{array}{l}\text { Curtis and others } \\
\text { (1993) }\end{array}$ \\
\hline Willamette & 160 & 1990 & Cutthroat trout & wb & $1-5$ & $<.002$ & $<.002$ & -- & $<.002$ & $.0055 \pm .0022$ & $<.002$ & $<.002$ & -- & $<.002$ & $\begin{array}{l}\text { Curtis and others } \\
\text { (1993) }\end{array}$ \\
\hline Willamette & 160 & 1990 & Cutthroat trout & wb & 1 & $<.002$ & $<.002$ & -- & $<.002$ & $<.002$ & .002 & $<.002$ & -- & $<.002$ & $\begin{array}{l}\text { Curtis and others } \\
\text { (1993) }\end{array}$ \\
\hline Willamette & 161 & 1990 & $\begin{array}{l}\text { Northern } \\
\text { squawfish }\end{array}$ & wb & 3 & $<.002$ & $<.002$ & $<.002$ & $<.002$ & $<.002$ & $<.002$ & $<.002-.002$ & $<.002$ & $<.002$ & ODEQ (1994b) \\
\hline Willamette & 161 & 1990 & Cutthroat trout & $\mathrm{wb}$ & 5 & $<.002$ & $<.002$ & $<.002-.006$ & $<.002$ & $<.002-.008$ & $<.002-.002$ & $<.002$ & $<.002$ & $<.002$ & ODEQ (1994b) \\
\hline
\end{tabular}


APPENDIX E-1. CHLORINATED PESTICIDES IN TISSUE OF AQUATIC BIOTA FROM THE WILLAMETTE BASIN, OREGON-Continued

\begin{tabular}{|c|c|c|c|c|c|c|c|c|c|c|c|c|c|c|c|}
\hline \multirow[b]{2}{*}{ River } & \multirow[b]{2}{*}{$\begin{array}{l}\text { River } \\
\text { mile }\end{array}$} & \multirow[b]{2}{*}{ Year } & \multirow[b]{2}{*}{ Species } & \multirow[b]{2}{*}{$\begin{array}{l}\text { Tis- } \\
\text { sue } \\
\text { type }\end{array}$} & \multirow[b]{2}{*}{$\begin{array}{l}\text { Number } \\
\text { samples }\end{array}$} & \multicolumn{9}{|c|}{ Concentration range ( $\mu \mathbf{g} / \mathbf{g}$, wet weight) } & \multirow[b]{2}{*}{ Reference } \\
\hline & & & & & & $\alpha-\mathrm{HCH}$ & $\beta-\mathrm{HCH}$ & $\Delta-\mathrm{HCH}$ & $\begin{array}{r}\text { Lindane } \\
(\gamma-\mathrm{HCH})\end{array}$ & Heptachlor & $\begin{array}{l}\text { Heptachlor } \\
\text { epoxide }\end{array}$ & $\begin{array}{l}\text { Endo- } \\
\text { sulfan I }\end{array}$ & $\begin{array}{l}\text { Endo- } \\
\text { sulfan II }\end{array}$ & $\begin{array}{l}\text { Endosulfan } \\
\text { sulfate }\end{array}$ & \\
\hline Willamette & 195 & 1990 & Cutthroat trout & wb & $1-5$ & $<0.002$ & $<0.002$ & -- & $<0.002$ & $0.0055 \pm .0022$ & $<0.002$ & $<0.002$ & -- & $<0.002$ & $\begin{array}{l}\text { Curtis and others } \\
\text { (1993) }\end{array}$ \\
\hline $\begin{array}{l}\text { Middle Fork } \\
\text { Willamette }\end{array}$ & 8 & 1990 & $\begin{array}{l}\text { Northern } \\
\text { squawfish }\end{array}$ & wb & 3 & $<.002$ & $<.002$ & 0.002 & $<.002$ & $<.002$ & $<.002$ & $<.002$ & 0.002 & $<.002$ & ODEQ (1994b) \\
\hline $\begin{array}{l}\text { Middle Fork } \\
\text { Willamette }\end{array}$ & 8 & 1990 & Cutthroat trout & wb & 3 & $<.002$ & $<.002$ & .002 & $<.002$ & $<.002-.007$ & $<.002$ & $<.002$ & .002 & $<.002$ & ODEQ (1994b) \\
\hline Santiam & 0.5 & 1988 & $\begin{array}{l}\text { Northern } \\
\text { squawfish }\end{array}$ & f & 1 & $<.004$ & $<.004$ & -- & $<.004$ & $<.004$ & $<.004$ & -- & -- & -- & ODEQ (1994b) \\
\hline Tualatin & 8 & 1989 & Sucker & $f$ & 1 & $<.003$ & .005 & $<.003$ & $<.003$ & $<.003$ & $<.003$ & $<.003$ & $<.003$ & $<.003$ & ODEQ (1994b) \\
\hline $\begin{array}{l}\text { Tualatin, } \\
\text { Cherry Grove }\end{array}$ & -- & 1987 & Crayfish & wb & 1 & $<.0025$ & -- & -- & $<.0025$ & $<.0025$ & $<.0025$ & -- & -- & -- & USEPA (1992a) \\
\hline $\begin{array}{l}\text { Tualatin, Cook } \\
\text { Park }\end{array}$ & -- & 1987 & Sucker & $\mathrm{wb}$ & $3-5 c$ & $<.0025$ & -- & -- & .00934 & $<.0025$ & $<.0025$ & -- & -- & -- & USEPA (1992a) \\
\hline Yamhill & 5 & 1989 & Sucker & $\mathrm{f}$ & 1 & $<.002$ & $<.002$ & .002 & $<.002$ & $<.002$ & $<.002$ & $<.002$ & .002 & $<.002$ & ODEQ (1994b) \\
\hline $\begin{array}{l}\text { Conser } \\
\text { Slough }^{1}\end{array}$ & 0.1 & 1989 & Sucker & f & 1 & $<.002$ & $<.002$ & $<.002$ & $<.002$ & $<.002$ & $<.002$ & $<.002$ & $<.002$ & $<.002$ & ODEQ (1994b) \\
\hline Conser Slough & 0.1 & 1989 & $\begin{array}{l}\text { Northern } \\
\text { squawfish }\end{array}$ & $\mathrm{f}$ & 2 & $<.003$ & $<.003$ & $<.003$ & $<.003$ & $<.003$ & $<.003$ & $<.003$ & $<.003$ & $<.003$ & ODEQ (1994b) \\
\hline Conser Slough & 0.1 & 1988 & Bass & $\mathrm{f}$ & $2 \mathrm{c}$ & $<.003$ & $<.003$ & -- & $<.003$ & .005 & $<.003$ & -- & -- & -- & ODEQ (1994b) \\
\hline Conser Slough & 0.1 & 1988 & Common carp & f & $4 c$ & $<.003$ & $<.003$ & -- & $<.003$ & .005 & $<.003$ & -- & -- & -- & ODEQ (1994b) \\
\hline Johnson Creek & $--\left({ }^{2}\right)$ & 1991 & Crayfish & wb & 1 & $<.0025$ & $<.0025$ & $<.0025$ & $<.0025$ & $<.0025$ & $<.0025$ & $<.0025$ & $<.0025$ & $<.0025$ & ODEQ (1994b) \\
\hline Johnson Creek & $--\left({ }^{3}\right)$ & 1991 & Crayfish & wb & 1 & $<.0025$ & $<.0025$ & $<.0025$ & $<.0025$ & $<.0025$ & $<.0025$ & $<.0025$ & $<.0025$ & $<.0025$ & ODEQ (1994b) \\
\hline Johnson Creek & 6.1 & 1991 & Crayfish & wb & 1 & $<.0025$ & $<.0025$ & $<.0025$ & $<.0025$ & $<.0025$ & $<.0025$ & $<.0025$ & $<.0025$ & $<.0025$ & ODEQ (1994b) \\
\hline Johnson Creek & 8.3 & 1991 & Crayfish & wb & 1 & $<.0025$ & $<.0025$ & $<.0025$ & $<.0025$ & $<.0025$ & $<.0025$ & $<.0025$ & $<.0025$ & $<.0025$ & ODEQ (1994b) \\
\hline Johnson Creek & $\left.--^{4}\right)$ & 1991 & Crayfish & wb & 1 & $<.0025$ & $<.0025$ & $<.0025$ & $<.0025$ & $<.0025$ & $<.0025$ & $<.0025$ & $<.0025$ & $<.0025$ & ODEQ (1994b) \\
\hline Johnson Creek & 16.9 & 1991 & Crayfish & wb & 1 & $<.0025$ & $<.0025$ & $<.0025$ & $<.0025$ & $<.0025$ & $<.0025$ & $<.0025$ & $<.0025$ & $<.0025$ & ODEQ (1994b) \\
\hline Johnson Creek & -()$\left.^{5}\right)$ & 1991 & Crayfish & $\mathrm{wb}$ & 1 & $<.0025$ & $<.0025$ & $<.0025$ & $<.0025$ & $<.0025$ & $<.0025$ & $<.0025$ & $<.0025$ & $<.0025$ & ODEQ (1994b) \\
\hline
\end{tabular}


APPENDIX E-1. CHLORINATED PESTICIDES IN TISSUE OF AQUATIC BIOTA FROM THE WILLAMETTE BASIN, OREGON-Continued

\begin{tabular}{|c|c|c|c|c|c|c|c|c|c|c|c|c|c|c|c|}
\hline \multirow[b]{2}{*}{ River } & \multirow[b]{2}{*}{$\begin{array}{l}\text { River } \\
\text { mile }\end{array}$} & \multirow[b]{2}{*}{ Year } & \multirow[b]{2}{*}{ Species } & \multirow[b]{2}{*}{$\begin{array}{l}\text { Tis- } \\
\text { sue } \\
\text { type }\end{array}$} & \multirow[b]{2}{*}{$\begin{array}{l}\text { Number } \\
\text { samples }\end{array}$} & \multicolumn{9}{|c|}{ Concentration range $(\mu \mathbf{g} / \mathbf{g}$, wet weight) } & \multirow[b]{2}{*}{ Reference } \\
\hline & & & & & & $\alpha-\mathrm{HCH}$ & $\beta-\mathrm{HCH}$ & $\Delta-\mathrm{HCH}$ & $\begin{array}{l}\text { Lindane } \\
(\gamma-\mathrm{HCH})\end{array}$ & Heptachlor & $\begin{array}{l}\text { Heptachlor } \\
\text { epoxide }\end{array}$ & $\begin{array}{l}\text { Endo- } \\
\text { sulfan I }\end{array}$ & $\begin{array}{l}\text { Endo- } \\
\text { sulfan II }\end{array}$ & $\begin{array}{l}\text { Endosulfan } \\
\text { sulfate }\end{array}$ & \\
\hline Johnson Creek & $-\left({ }^{6}\right)$ & 1991 & Crayfish & wb & 1 & $<0.0025$ & $<0.0025$ & $<0.0025$ & $<0.0025$ & $<0.0025$ & $<0.0025$ & $<0.0025$ & $<0.0025$ & $<0.0025$ & ODEQ (1994b) \\
\hline Rock Creek ${ }^{7}$ & 1.5 & 1994 & Sculpin & wb & $15-20 \mathrm{c}$ & $<.01$ & -- & -- & -- & $<.01$ & -- & -- & -- & -- & USFWS (1994c) \\
\hline Rock Creek & $\begin{array}{l}1.7- \\
2\end{array}$ & 1994 & $\begin{array}{l}\text { Three-spined } \\
\text { stickleback }\end{array}$ & $\mathrm{wb}$ & $9 \mathrm{c}$ & $<.01$ & -- & -- & -- & $<.01$ & -- & -- & -- & -- & USFWS (1994c) \\
\hline Rock Creek & $\begin{array}{l}1.7- \\
2\end{array}$ & 1994 & Sculpin & wb & $6 c$ & $<.01$ & -- & -- & -- & $<.01$ & -- & -- & -- & -- & USFWS (1994c) \\
\hline
\end{tabular}

${ }^{1}$ Conser Slough is a tributary of the Willamette River near Albany, Oregon (Willamette River Subbasin).

${ }^{2}$ McLoughlin Boulevard.

${ }^{3} 44$ th Avenue and Umatilla Street.

${ }^{4}$ Jenne Road.

${ }^{5}$ Orient Drive.

$\overrightarrow{\vec{E}} \quad{ }^{6}$ Rock Creek is a

${ }^{7}$ Rock Creek is a tributary of the Tualatin River near Sherwood, Oregon (Tualatin Subbasin). 


\section{APPENDIX E-2. CHLORINATED PESTICIDES IN TISSUE OF AQUATIC BIOTA FROM THE WILLAMETTE BASIN, OREGON}

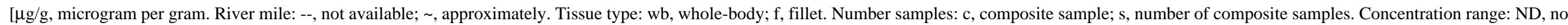

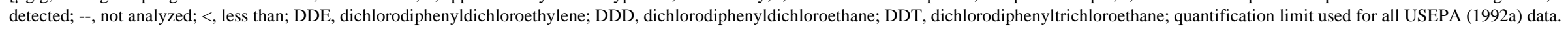
References: ODEQ, Oregon Department of Environmental Quality; USEPA, U.S. Environmental Protection Agency; USFWS, U.S. Fish and Wildlife Service]

\begin{tabular}{|c|c|c|c|c|c|c|c|c|c|c|c|c|c|c|c|c|}
\hline \multirow[b]{2}{*}{ River } & \multirow[b]{2}{*}{$\begin{array}{c}\text { River } \\
\text { mile }\end{array}$} & \multirow[b]{2}{*}{ Year } & \multirow[b]{2}{*}{ Species } & \multirow[b]{2}{*}{$\begin{array}{c}\text { Tissue } \\
\text { type }\end{array}$} & \multicolumn{11}{|c|}{ Concentration range $(\mu \mathrm{g} / \mathrm{g}$, wet weight) } & \multirow[b]{2}{*}{ Reference } \\
\hline & & & & & $\begin{array}{l}\text { Number } \\
\text { samples }\end{array}$ & Aldrin & Dieldrin & Endrin & $\begin{array}{l}\text { Endrin } \\
\text { alde- } \\
\text { hyde }\end{array}$ & $p, p^{\prime}-\mathrm{DDE}$ & $p, p^{\prime}-\mathrm{DDD}$ & $p, p^{\prime}$-DDT & $\begin{array}{l}\text { Methoxy- } \\
\text { chlor }\end{array}$ & $\begin{array}{l}\text { Chlor- } \\
\text { dane }\end{array}$ & $\begin{array}{l}\text { Toxa- } \\
\text { phene }\end{array}$ & \\
\hline $\begin{array}{l}\text { Willamette } \\
\text { Newberg Pool }\end{array}$ & -- & 1987 & $\begin{array}{l}\text { Northern } \\
\text { squawfish }\end{array}$ & wb & $3-5 c$ & -- & $<0.0025$ & $<0.0025$ & -- & 0.0435 & -- & -- & $<0.0025$ & -- & -- & USEPA (1992a) \\
\hline $\begin{array}{l}\text { Willamette } \\
\text { Halsey }\end{array}$ & -- & 1987 & Sucker & wb & $4 \mathrm{c}$ & -- & $<.0025$ & $<.0025$ & -- & .0358 & -- & -- & .0056 & -- & -- & USEPA (1992a) \\
\hline Willamette & $\sim 7$ & 1987 & Sucker & wb & $4 \mathrm{c}$ & -- & $<.0025$ & $<.0025$ & -- & .0371 & -- & -- & $<.0025$ & -- & -- & USEPA (1992a) \\
\hline Willamette & 7 & 1990 & $\begin{array}{l}\text { Northern } \\
\text { squawfish }\end{array}$ & wb & 3 & $<0.006$ & $<.006$ & $<.006$ & $<0.006$ & $\begin{array}{c}<.002- \\
.052\end{array}$ & $<0.002$ & $<0.002$ & $<.002$ & $<0.075$ & $<0.075$ & ODEQ (1994b) \\
\hline Willamette & 7 & $\begin{array}{l}1989- \\
90\end{array}$ & $\begin{array}{l}\text { Common } \\
\text { carp }\end{array}$ & $\mathrm{f}$ & 6 & $<.003$ & $<.003$ & $<.003$ & $<.003$ & $\begin{array}{c}<.002- \\
.066\end{array}$ & $\begin{array}{c}<.002- \\
.063\end{array}$ & $\begin{array}{c}<.002- \\
.019\end{array}$ & $<.003$ & $<.03$ & -- & ODEQ (1994b) \\
\hline Willamette & 7 & 1988 & $\begin{array}{l}\text { Common } \\
\text { carp }\end{array}$ & $\mathrm{f}$ & $5 \mathrm{c}, 2 \mathrm{~s}$ & $<.003$ & $<.003$ & $<.003$ & -- & .012 & $.004-.009$ & $<.003$ & $<.003$ & $<.003$ & -- & ODEQ (1994b) \\
\hline Willamette & 18 & 1989 & $\begin{array}{l}\text { Common } \\
\text { carp }\end{array}$ & $\mathrm{f}$ & $4 c$ & $<.002$ & $<.002$ & $<.002$ & $<.002$ & .028 & .018 & .009 & $<.002$ & $<.025$ & -- & ODEQ (1994b) \\
\hline Willamette & 18 & 1989 & Sucker & $\mathrm{f}$ & $3 \mathrm{c}$ & $<.002$ & $<.002$ & $<.002$ & $<.002$ & $<.002$ & $<.002$ & $<.002$ & $<.002$ & $<.025$ & -- & ODEQ (1994b) \\
\hline Willamette & $\sim 26$ & 1970 & $\begin{array}{l}\text { Common } \\
\text { carp }\end{array}$ & wb & $3-5 c$ & -- & .07 & .0 & -- & .34 & .35 & .11 & -- & -- & -- & $\begin{array}{l}\text { Schmitt and } \\
\text { others (1981) }\end{array}$ \\
\hline Willamette & $\sim 26$ & 1970 & $\begin{array}{l}\text { Largescale } \\
\text { sucker }\end{array}$ & wb & $3-5 c$ & -- & .04 & .0 & -- & .57 & .72 & .81 & -- & -- & -- & $\begin{array}{l}\text { Schmitt and } \\
\text { others (1981) }\end{array}$ \\
\hline Willamette & $\sim 26$ & 1970 & $\begin{array}{l}\text { Largescale } \\
\text { sucker }\end{array}$ & $\mathrm{wb}$ & $3-5 c$ & -- & .04 & .0 & -- & .64 & .77 & .44 & -- & -- & -- & $\begin{array}{l}\text { Schmitt and } \\
\text { others (1981) }\end{array}$ \\
\hline Willamette & $\sim 26$ & 1971 & $\begin{array}{l}\text { Largescale } \\
\text { sucker }\end{array}$ & wb & $3-5 c$ & -- & .01 & .0 & -- & .25 & .32 & .21 & -- & -- & .0 & $\begin{array}{l}\text { Schmitt and } \\
\text { others (1981) }\end{array}$ \\
\hline Willamette & $\sim 26$ & 1971 & $\begin{array}{l}\text { Largescale } \\
\text { sucker }\end{array}$ & wb & $3-5 c$ & -- & .02 & .0 & -- & .25 & .35 & .18 & -- & -- & .0 & $\begin{array}{l}\text { Schmitt and } \\
\text { others (1981) }\end{array}$ \\
\hline Willamette & $\sim 26$ & 1971 & $\begin{array}{l}\text { Northern } \\
\text { squawfish }\end{array}$ & wb & $3-5 c$ & -- & .01 & .0 & -- & .37 & .41 & .14 & -- & -- & .0 & $\begin{array}{l}\text { Schmitt and } \\
\text { others (1981) }\end{array}$ \\
\hline Willamette & $\sim 26$ & 1971 & $\begin{array}{l}\text { Northern } \\
\text { squawfish }\end{array}$ & wb & $3-5 c$ & -- & .01 & .0 & -- & .33 & .24 & .21 & -- & -- & .0 & $\begin{array}{l}\text { Schmitt and } \\
\text { others (1981) }\end{array}$ \\
\hline
\end{tabular}


APPENDIX E-2. CHLORINATED PESTICIDES IN TISSUE OF AQUATIC BIOTA FROM THE WILLAMETTE BASIN, OREGON-Continued

\begin{tabular}{|c|c|c|c|c|c|c|c|c|c|c|c|c|c|c|c|c|}
\hline \multirow[b]{2}{*}{ River } & \multirow[b]{2}{*}{$\begin{array}{c}\text { River } \\
\text { mile }\end{array}$} & \multirow[b]{2}{*}{ Year } & \multirow[b]{2}{*}{ Species } & \multirow[b]{2}{*}{$\begin{array}{c}\text { Tissue } \\
\text { type }\end{array}$} & \multicolumn{11}{|c|}{ Concentration range ( $\mu \mathrm{g} / \mathrm{g}$, wet weight) } & \multirow[b]{2}{*}{ Reference } \\
\hline & & & & & $\begin{array}{l}\text { Number } \\
\text { samples }\end{array}$ & Aldrin & Dieldrin & Endrin & $\begin{array}{l}\text { Endrin } \\
\text { alde- } \\
\text { hyde }\end{array}$ & $p, p^{\prime}-\mathrm{DDE}$ & $p, p^{\prime}-\mathrm{DDD}$ & $p, p^{\prime}-\mathrm{DDT}$ & $\begin{array}{l}\text { Methoxy- } \\
\text { chlor }\end{array}$ & $\begin{array}{l}\text { Chlor- } \\
\text { dane }\end{array}$ & $\begin{array}{l}\text { Toxa- } \\
\text { phene }\end{array}$ & \\
\hline Willamette & $\sim 26$ & 1972 & $\begin{array}{l}\text { Largescale } \\
\text { sucker }\end{array}$ & wb & $3-5 c$ & -- & 0.02 & 0.0 & -- & 0.40 & 0.16 & 0.00 & -- & -- & 0.0 & $\begin{array}{l}\text { Schmitt and } \\
\text { others (1981) }\end{array}$ \\
\hline Willamette & $\sim 26$ & 1972 & $\begin{array}{l}\text { Largescale } \\
\text { sucker }\end{array}$ & wb & $3-5 c$ & -- & .00 & .0 & -- & .50 & .29 & .51 & -- & -- & .0 & $\begin{array}{l}\text { Schmitt and } \\
\text { others (1981) }\end{array}$ \\
\hline Willamette & $\sim 26$ & 1972 & $\begin{array}{l}\text { Channel } \\
\text { catfish }\end{array}$ & wb & $3-5 c$ & -- & .06 & .0 & -- & .57 & .28 & .15 & -- & -- & .0 & $\begin{array}{l}\text { Schmitt and } \\
\text { others (1981) }\end{array}$ \\
\hline Willamette & $\sim 26$ & 1972 & $\begin{array}{l}\text { Northern } \\
\text { squawfish }\end{array}$ & wb & $3-5 c$ & -- & .02 & .0 & -- & .57 & .13 & .00 & -- & -- & .0 & $\begin{array}{l}\text { Schmitt and } \\
\text { others (1981) }\end{array}$ \\
\hline Willamette & $\sim 26$ & 1973 & $\begin{array}{l}\text { Common } \\
\text { carp }\end{array}$ & wb & $3-5 c$ & -- & .00 & .0 & -- & .35 & .00 & .00 & -- & -- & .0 & $\begin{array}{l}\text { Schmitt and } \\
\text { others (1981) }\end{array}$ \\
\hline Willamette & $\sim 26$ & 1973 & $\begin{array}{l}\text { Largescale } \\
\text { sucker }\end{array}$ & wb & $3-5 c$ & -- & .00 & .0 & -- & .31 & .15 & .00 & -- & -- & .0 & $\begin{array}{l}\text { Schmitt and } \\
\text { others (1981) }\end{array}$ \\
\hline Willamette & $\sim 26$ & 1973 & $\begin{array}{l}\text { Largescale } \\
\text { sucker }\end{array}$ & wb & $3-5 c$ & -- & .00 & .0 & -- & .21 & .11 & .00 & -- & -- & .0 & $\begin{array}{l}\text { Schmitt and } \\
\text { others (1981) }\end{array}$ \\
\hline Willamette & $\sim 26$ & 1973 & $\begin{array}{l}\text { Northern } \\
\text { squawfish }\end{array}$ & wb & $3-5 c$ & -- & .00 & .0 & -- & .53 & .14 & .00 & -- & -- & .0 & $\begin{array}{l}\text { Schmitt and } \\
\text { others (1981) }\end{array}$ \\
\hline Willamette & $\sim 26$ & 1974 & $\begin{array}{l}\text { Common } \\
\text { carp }\end{array}$ & wb & $3-5 c$ & -- & .03 & .0 & -- & .1988 & .33 & .00 & -- & -- & .0 & $\begin{array}{l}\text { Schmitt and } \\
\text { others (1981) }\end{array}$ \\
\hline Willamette & $\sim 26$ & 1974 & $\begin{array}{l}\text { Largescale } \\
\text { sucker }\end{array}$ & wb & $3-5 c$ & -- & .00 & .0 & -- & .15 & .03 & .02 & -- & -- & .0 & $\begin{array}{l}\text { Schmitt and } \\
\text { others (1981) }\end{array}$ \\
\hline Willamette & $\sim 26$ & 1974 & $\begin{array}{l}\text { Largescale } \\
\text { sucker }\end{array}$ & wb & $3-5 c$ & -- & .04 & .0 & -- & .50 & .15 & .17 & -- & -- & .0 & $\begin{array}{l}\text { Schmitt and } \\
\text { others (1981) }\end{array}$ \\
\hline Willamette & $\sim 26$ & 1974 & $\begin{array}{l}\text { Northern } \\
\text { squawfish }\end{array}$ & wb & $3-5 c$ & -- & .03 & .0 & -- & .19 & .06 & .00 & -- & -- & .0 & $\begin{array}{l}\text { Schmitt and } \\
\text { others (1981) }\end{array}$ \\
\hline Willamette & $\sim 26$ & 1976 & $\begin{array}{l}\text { Smallmouth } \\
\text { bass }\end{array}$ & wb & $3-5 c$ & -- & .04 & .00 & -- & .06 & .03 & .02 & -- & -- & .00 & $\begin{array}{l}\text { Schmitt and } \\
\text { others (1983) }\end{array}$ \\
\hline Willamette & $\sim 26$ & 1976 & $\begin{array}{l}\text { Chisel- } \\
\text { mouth }\end{array}$ & wb & $3-5 c$ & -- & .02 & .00 & -- & .07 & .07 & .00 & -- & -- & .00 & $\begin{array}{l}\text { Schmitt and } \\
\text { others (1983) }\end{array}$ \\
\hline Willamette & $\sim 26$ & 1976 & $\begin{array}{l}\text { Chisel- } \\
\text { mouth }\end{array}$ & wb & $3-5 c$ & -- & .02 & .00 & -- & .12 & .04 & .00 & -- & -- & .00 & $\begin{array}{l}\text { Schmitt and } \\
\text { others (1983) }\end{array}$ \\
\hline
\end{tabular}


APPENDIX E-2. CHLORINATED PESTICIDES IN TISSUE OF AQUATIC BIOTA FROM THE WILLAMETTE BASIN, OREGON-Continued

\begin{tabular}{|c|c|c|c|c|c|c|c|c|c|c|c|c|c|c|c|c|}
\hline \multirow[b]{2}{*}{ River } & \multirow[b]{2}{*}{$\begin{array}{l}\text { River } \\
\text { mile }\end{array}$} & \multirow[b]{2}{*}{ Year } & \multirow[b]{2}{*}{ Species } & \multirow[b]{2}{*}{$\begin{array}{l}\text { Tissue } \\
\text { type }\end{array}$} & \multicolumn{11}{|c|}{ Concentration range $(\mu \mathrm{g} / \mathrm{g}$, wet weight) } & \multirow[b]{2}{*}{ Reference } \\
\hline & & & & & $\begin{array}{l}\text { Number } \\
\text { samples }\end{array}$ & Aldrin & Dieldrin & Endrin & $\begin{array}{l}\text { Endrin } \\
\text { alde- } \\
\text { hyde }\end{array}$ & $p, p^{\prime}-\mathrm{DDE}$ & $p, p^{\prime}-\mathrm{DDD}$ & $p, p^{\prime}-\mathrm{DDT}$ & $\begin{array}{l}\text { Methoxy- } \\
\text { chlor }\end{array}$ & $\begin{array}{l}\text { Chlor- } \\
\text { dane }\end{array}$ & $\begin{array}{l}\text { Toxa- } \\
\text { phene }\end{array}$ & \\
\hline Willamette & $\sim 26$ & 1978 & $\begin{array}{l}\text { Northern } \\
\text { squawfish }\end{array}$ & $\mathrm{wb}$ & $3-5 c$ & -- & 0.00 & 0.00 & -- & 0.42 & 0.00 & 0.12 & -- & -- & 0.00 & $\begin{array}{l}\text { Schmitt and } \\
\text { others (1983) }\end{array}$ \\
\hline Willamette & $\sim 26$ & 1978 & $\begin{array}{l}\text { Chisel- } \\
\text { mouth }\end{array}$ & $\mathrm{wb}$ & $3-5 c$ & -- & .02 & .00 & -- & .09 & .05 & .00 & -- & -- & .00 & $\begin{array}{l}\text { Schmitt and } \\
\text { others (1983) }\end{array}$ \\
\hline Willamette & $\sim 26$ & 1978 & $\begin{array}{l}\text { Chisel- } \\
\text { mouth }\end{array}$ & $\mathrm{wb}$ & $3-5 c$ & -- & .02 & .00 & -- & .09 & .06 & .00 & -- & -- & .00 & $\begin{array}{l}\text { Schmitt and } \\
\text { others (1983) }\end{array}$ \\
\hline Willamette & $\sim 26$ & 1980 & $\begin{array}{l}\text { Largescale } \\
\text { sucker }\end{array}$ & $w b$ & $3-5 c$ & -- & .02 & .00 & -- & .15 & .05 & .01 & 0.00 & -- & .0 & $\begin{array}{l}\text { Schmitt and } \\
\text { others (1985) }\end{array}$ \\
\hline Willamette & $\sim 26$ & 1980 & $\begin{array}{l}\text { Largescale } \\
\text { sucker }\end{array}$ & $\mathrm{wb}$ & $3-5 c$ & -- & .01 & .00 & -- & .21 & .05 & .02 & -- & -- & .1 & $\begin{array}{l}\text { Schmitt and } \\
\text { others (1985) }\end{array}$ \\
\hline Willamette & $\sim 26$ & 1980 & $\begin{array}{l}\text { Northern } \\
\text { squawfish }\end{array}$ & $\mathrm{wb}$ & $3-5 c$ & -- & .01 & .00 & -- & .28 & .03 & .00 & .00 & -- & .1 & $\begin{array}{l}\text { Schmitt and } \\
\text { others (1985) }\end{array}$ \\
\hline Willamette & $\sim 26$ & 1984 & $\begin{array}{l}\text { Northern } \\
\text { squawfish }\end{array}$ & $w b$ & $3-5 c$ & -- & $<.01$ & $<.01$ & -- & .13 & .02 & .01 & -- & -- & $<.1$ & $\begin{array}{l}\text { Schmitt and } \\
\text { others (1990) }\end{array}$ \\
\hline Willamette & $\sim 26$ & 1984 & Peamouth & $w b$ & $3-5 c$ & -- & .01 & $<.01$ & -- & .03 & .01 & .01 & -- & -- & $<.1$ & $\begin{array}{l}\text { Schmitt and } \\
\text { others (1990) }\end{array}$ \\
\hline Willamette & $\sim 26$ & 1984 & Peamouth & wb & $3-5 c$ & -- & $<.01$ & $<.01$ & -- & .03 & .01 & $<.01$ & -- & -- & $<.1$ & $\begin{array}{l}\text { Schmitt and } \\
\text { others (1990) }\end{array}$ \\
\hline Willamette & 27 & 1988 & Bass & $\mathrm{f}$ & $3 \mathrm{c}$ & $<0.005$ & $<.005$ & $<.005$ & -- & $<.005$ & $<.005$ & $<.005$ & $<.005$ & $<0.005$ & -- & ODEQ (1994b) \\
\hline Willamette & 27 & 1988 & $\begin{array}{l}\text { Common } \\
\text { carp }\end{array}$ & $\mathrm{f}$ & $3 \mathrm{c}, 2 \mathrm{~s}$ & $<.003$ & $<.003$ & $<.003$ & -- & $\begin{array}{l}.013- \\
.073\end{array}$ & $\begin{array}{c}<.003- \\
.005\end{array}$ & $<.003$ & $<.003$ & $<.003$ & -- & ODEQ (1994b) \\
\hline Willamette & 27 & 1988 & $\begin{array}{l}\text { Northern } \\
\text { squawfish }\end{array}$ & $f$ & $3 \mathrm{c}$ & $<.004$ & $<.004$ & $<.004$ & -- & $<.004$ & $<.004$ & $<.004$ & $<.004$ & $<.004$ & -- & ODEQ (1994b) \\
\hline Willamette & 28 & 1989 & $\begin{array}{l}\text { Common } \\
\text { carp }\end{array}$ & f & 3 & $<.002$ & $\begin{array}{c}<.002- \\
.01\end{array}$ & $<.002$ & $\begin{array}{c}<0.002- \\
.025\end{array}$ & $\begin{array}{l}.061- \\
.102\end{array}$ & $\begin{array}{l}.02- \\
.05\end{array}$ & $\begin{array}{l}.01- \\
.018\end{array}$ & $<.002$ & $<.025$ & -- & ODEQ (1994b) \\
\hline Willamette & 28 & 1989 & $\begin{array}{l}\text { Common } \\
\text { carp }\end{array}$ & liver & 2 & $<.002$ & $\begin{array}{l}.086- \\
.352\end{array}$ & $\begin{array}{c}<.002- \\
.061\end{array}$ & $\begin{array}{c}<.002- \\
.088\end{array}$ & $\begin{array}{l}.127- \\
.266\end{array}$ & $\begin{array}{l}.141- \\
.144\end{array}$ & $\begin{array}{l}.092- \\
.216\end{array}$ & $\begin{array}{c}<.002- \\
.832\end{array}$ & $<.025$ & -- & ODEQ (1994b) \\
\hline Willamette & 38 & 1989 & Sucker & f & $5 \mathrm{c}$ & $<.002$ & $<.002$ & $<.002$ & $<.002$ & $<.002$ & $<.002$ & $<.002$ & $<.002$ & $<.002$ & $<0.002$ & ODEQ (1994b) \\
\hline Willamette & 38 & $\begin{array}{l}1988- \\
89\end{array}$ & $\begin{array}{l}\text { Northern } \\
\text { squawfish }\end{array}$ & $\mathrm{f}$ & $5 \mathrm{c}, 2 \mathrm{~s}$ & $<.008$ & $<.008$ & $<.008$ & $<.002$ & $<.008$ & $<.008$ & $<.008$ & $<.008$ & $<.008$ & $<.002$ & ODEQ (1994b) \\
\hline
\end{tabular}


APPENDIX E-2. CHLORINATED PESTICIDES IN TISSUE OF AQUATIC BIOTA FROM THE WILLAMETTE BASIN, OREGON-Continued

\begin{tabular}{|c|c|c|c|c|c|c|c|c|c|c|c|c|c|c|c|c|}
\hline \multirow[b]{2}{*}{ River } & \multirow[b]{2}{*}{$\begin{array}{l}\text { River } \\
\text { mile }\end{array}$} & \multirow[b]{2}{*}{ Year } & \multirow[b]{2}{*}{ Species } & \multirow[b]{2}{*}{$\begin{array}{l}\text { Tissue } \\
\text { type }\end{array}$} & \multicolumn{11}{|c|}{ Concentration range ( $\mu \mathrm{g} / \mathrm{g}$, wet weight) } & \multirow[b]{2}{*}{ Reference } \\
\hline & & & & & $\begin{array}{l}\text { Number } \\
\text { samples }\end{array}$ & Aldrin & Dieldrin & Endrin & $\begin{array}{l}\text { Endrin } \\
\text { alde- } \\
\text { hyde }\end{array}$ & $p, p^{\prime}-\mathrm{DDE}$ & $p, p^{\prime}-\mathrm{DDD}$ & $p, p^{\prime}-\mathrm{DDT}$ & $\begin{array}{l}\text { Methoxy- } \\
\text { chlor }\end{array}$ & $\begin{array}{l}\text { Chlor- } \\
\text { dane }\end{array}$ & $\begin{array}{l}\text { Toxa- } \\
\text { phene }\end{array}$ & \\
\hline Willamette & 38 & 1988 & $\begin{array}{l}\text { Ccommon } \\
\text { carp }\end{array}$ & f & $3 \mathrm{c}$ & $<0.003$ & $<0.003$ & $<0.003$ & -- & $<0.007$ & $<0.003$ & $<0.003$ & $<0.003$ & $<0.003$ & -- & ODEQ (1994b) \\
\hline Willamette & 48 & $\begin{array}{l}1988- \\
89\end{array}$ & $\begin{array}{l}\text { Common } \\
\text { carp }\end{array}$ & f & 3 & $<.002$ & $<.002$ & $<.002$ & $<.002$ & $\begin{array}{c}<.002- \\
.015\end{array}$ & $<.002$ & $<.002$ & $<.002$ & $<.025$ & -- & ODEQ (1994b) \\
\hline Willamette & 48 & 1989 & $\begin{array}{l}\text { Common } \\
\text { carp }\end{array}$ & Liver & 2 & $<.004$ & $<.004$ & $<.004$ & $<.004$ & $\begin{array}{c}<.004- \\
.063\end{array}$ & $<.004$ & $<.004$ & $<.004$ & $<.04$ & -- & ODEQ (1994b) \\
\hline Willamette & 48 & 1988 & $\begin{array}{l}\text { Northern } \\
\text { squawfish }\end{array}$ & f & $5 c$ & $<.003$ & $<.003$ & $<.003$ & -- & .005 & $<.003$ & $<.003$ & $<.004$ & $<.004$ & -- & ODEQ (1994b) \\
\hline Willamette & 72 & 1990 & $\begin{array}{l}\text { Common } \\
\text { carp }\end{array}$ & f & 1 & $<.002$ & $<.002$ & $<.002$ & $<.002$ & $<.002$ & .010 & $<.002$ & $<.002$ & $<.025$ & $<0.025$ & $\begin{array}{l}\text { Curtis and others } \\
\text { (1993) }\end{array}$ \\
\hline Willamette & 74 & 1990 & $\begin{array}{l}\text { Northern } \\
\text { squawfish }\end{array}$ & wb & 3 & $<.002$ & $<.002$ & $<.002$ & $<.002$ & $\begin{array}{l}.022- \\
.042\end{array}$ & $<.002$ & $<.002$ & $<.002$ & $<.025$ & $<.025$ & ODEQ (1994b) \\
\hline Willamette & 74 & 1990 & $\begin{array}{l}\text { Common } \\
\text { carp }\end{array}$ & f & 6 & $\begin{array}{l}<.002- \\
.02\end{array}$ & $<.003$ & $<.003$ & $<.003$ & $\begin{array}{l}.007- \\
.047\end{array}$ & $\begin{array}{c}<.002- \\
.013\end{array}$ & $\begin{array}{l}<.002- \\
.01\end{array}$ & $<.003$ & $<.003$ & $<.025$ & ODEQ (1994b) \\
\hline Willamette & 74 & 1990 & $\begin{array}{l}\text { Common } \\
\text { carp }\end{array}$ & Liver & 3 & $\begin{array}{l}<.002- \\
.103\end{array}$ & $<.003$ & $<.003$ & $\begin{array}{l}<.003- \\
.109\end{array}$ & $\begin{array}{c}<.003- \\
.073\end{array}$ & $\begin{array}{c}<.003- \\
.055\end{array}$ & $<.003$ & $\begin{array}{c}<.003- \\
.069\end{array}$ & $<.03$ & -- & ODEQ (1994b) \\
\hline Willamette & 131 & 1990 & $\begin{array}{l}\text { Northern } \\
\text { squawfish }\end{array}$ & wb & 3 & $<.002$ & $<.002$ & $<.002$ & $<.002$ & $\begin{array}{l}.015- \\
.022\end{array}$ & $\begin{array}{c}<.002- \\
.008\end{array}$ & $<.002$ & $<.002$ & $<.025$ & $<.025$ & ODEQ (1994b) \\
\hline Willamette & 131 & 1990 & $\begin{array}{l}\text { Northern } \\
\text { squawfish }\end{array}$ & $\mathrm{wb}$ & $1-5$ & $<.002$ & $<.002$ & $<.002$ & $<.002$ & $<.002$ & $\begin{array}{r}.0043 \\
\pm .0023\end{array}$ & $<.002$ & $<.002$ & $<.025$ & $<.025$ & $\begin{array}{l}\text { Curtis and others } \\
\text { (1993) }\end{array}$ \\
\hline Willamette & 131 & 1990 & $\begin{array}{l}\text { Common } \\
\text { carp }\end{array}$ & f & 3 & $<.002$ & $<.002$ & $<.002$ & $<.002$ & $\begin{array}{c}<.002- \\
.008\end{array}$ & $<.002$ & $<.002$ & $<.002$ & $<.025$ & $<.025$ & ODEQ (1994b) \\
\hline Willamette & 147 & 1990 & $\begin{array}{l}\text { Northern } \\
\text { squawfish }\end{array}$ & wb & 3 & $\begin{array}{c}<.002- \\
.004\end{array}$ & $<.002$ & $<.002$ & $<.002$ & $\begin{array}{l}.017- \\
.044\end{array}$ & $\begin{array}{c}<.002- \\
.002\end{array}$ & $<.002$ & $<.002$ & $\begin{array}{c}<.025- \\
.025\end{array}$ & $\begin{array}{c}<.025- \\
.025\end{array}$ & ODEQ (1994b) \\
\hline Willamette & 147 & 1990 & $\begin{array}{l}\text { Cutthroat } \\
\text { trout }\end{array}$ & wb & 5 & $<.002$ & $\begin{array}{l}<.002- \\
.002\end{array}$ & $\begin{array}{c}<.002- \\
.002\end{array}$ & $<.002$ & $\begin{array}{c}<.002- \\
.006\end{array}$ & $\begin{array}{c}<.002- \\
.002\end{array}$ & $\begin{array}{c}<.002- \\
.005\end{array}$ & $<.002$ & $<.025$ & $<.025$ & ODEQ (1994b) \\
\hline Willamette & 148 & 1990 & $\begin{array}{l}\text { Northern } \\
\text { squawfish }\end{array}$ & wb & 1 & .004 & $<.002$ & $<.002$ & $<.002$ & $<.002$ & $<.002$ & $<.002$ & $<.002$ & $<.025$ & $<.025$ & $\begin{array}{l}\text { Curtis and others } \\
\text { (1993) }\end{array}$ \\
\hline Willamette & 148 & 1990 & $\begin{array}{l}\text { Northern } \\
\text { squawfish }\end{array}$ & wb & 1 & $<.002$ & $<.002$ & $<.002$ & $<.002$ & $<.002$ & .002 & $<.002$ & $<.002$ & $<.025$ & $<.025$ & $\begin{array}{l}\text { Curtis and others } \\
\text { (1993) }\end{array}$ \\
\hline
\end{tabular}


APPENDIX E-2. CHLORINATED PESTICIDES IN TISSUE OF AQUATIC BIOTA FROM THE WILLAMETTE BASIN, OREGON-Continued

\begin{tabular}{|c|c|c|c|c|c|c|c|c|c|c|c|c|c|c|c|c|}
\hline \multirow[b]{2}{*}{ River } & \multirow[b]{2}{*}{$\begin{array}{l}\text { River } \\
\text { mile }\end{array}$} & \multirow[b]{2}{*}{ Year } & \multirow[b]{2}{*}{ Species } & \multirow[b]{2}{*}{$\begin{array}{l}\text { Tissue } \\
\text { type }\end{array}$} & \multicolumn{11}{|c|}{ Concentration range $(\mu \mathrm{g} / \mathrm{g}$, wet weight) } & \multirow[b]{2}{*}{ Reference } \\
\hline & & & & & $\begin{array}{l}\text { Number } \\
\text { samples }\end{array}$ & Aldrin & Dieldrin & Endrin & $\begin{array}{c}\text { Endrin } \\
\text { alde- } \\
\text { hyde }\end{array}$ & $p, p^{\prime}-\mathrm{DDE}$ & $p, p$ '-DDD & $p, p$ '-DDT & $\begin{array}{l}\text { Methoxy- } \\
\text { chlor }\end{array}$ & $\begin{array}{l}\text { Chlor- } \\
\text { dane }\end{array}$ & $\begin{array}{l}\text { Toxa- } \\
\text { phene }\end{array}$ & \\
\hline Willamette & 148 & 1990 & $\begin{array}{l}\text { Cutthroat } \\
\text { trout }\end{array}$ & wb & 1 & $<0.002$ & 0.002 & $<0.002$ & $<0.002$ & 0.022 & $<0.002$ & $<0.002$ & $<0.002$ & $<0.025$ & $<0.025$ & $\begin{array}{l}\text { Curtis and others } \\
\text { (1993) }\end{array}$ \\
\hline Willamette & 160 & 1990 & $\begin{array}{l}\text { Cutthroat } \\
\text { trout }\end{array}$ & wb & $1-5$ & $<.002$ & $\begin{array}{r}.0023 \\
\pm .0004\end{array}$ & $<.002$ & $<.002$ & $<.002$ & $<.002$ & $<.002$ & $<.002$ & $<.025$ & $<.025$ & $\begin{array}{l}\text { Curtis and others } \\
\text { (1993) }\end{array}$ \\
\hline Willamette & 160 & 1990 & $\begin{array}{l}\text { Cutthroat } \\
\text { trout }\end{array}$ & wb & 1 & $<.002$ & $<.002$ & $<.002$ & $<.002$ & .0022 & $<.002$ & $<.002$ & $<.002$ & $<.025$ & $<.025$ & $\begin{array}{l}\text { Curtis and others } \\
\text { (1993) }\end{array}$ \\
\hline Willamette & 161 & 1990 & $\begin{array}{l}\text { Northern } \\
\text { squawfish }\end{array}$ & wb & 3 & $<.002$ & $<.002$ & $<.002$ & $<.002$ & $\begin{array}{c}<.002- \\
.022\end{array}$ & $<.002$ & $<.002$ & $<.002$ & $<.025$ & $<.025$ & ODEQ (1994b) \\
\hline Willamette & 161 & 1990 & $\begin{array}{l}\text { Cutthroat } \\
\text { trout }\end{array}$ & wb & 5 & $<.002$ & $\begin{array}{c}<.002- \\
.003\end{array}$ & $\begin{array}{l}<.002- \\
.002\end{array}$ & $<.002$ & $\begin{array}{l}<.002- \\
.023\end{array}$ & $\begin{array}{c}<.002- \\
.003\end{array}$ & $\begin{array}{c}<.002- \\
.007\end{array}$ & $<.002$ & $<.025$ & $<.025$ & ODEQ (1994b) \\
\hline Willamette & 195 & 1990 & $\begin{array}{l}\text { Cutthroat } \\
\text { trout }\end{array}$ & wb & 1 & $<.002$ & $<.002$ & .002 & $<.002$ & $<.002$ & $<.002$ & $<.002$ & $<.002$ & $<.025$ & $<.025$ & $\begin{array}{l}\text { Curtis and others } \\
\text { (1993) }\end{array}$ \\
\hline $\begin{array}{l}\text { Middle Fork } \\
\text { Willamette }\end{array}$ & 8 & 1990 & $\begin{array}{l}\text { Northern } \\
\text { squawfish }\end{array}$ & $w b$ & 3 & $<.002$ & $<.002$ & $<.002$ & $<.002$ & $<.002$ & $<.002$ & $<.002$ & $<.002$ & $<.025$ & $<.025$ & ODEQ (1994b) \\
\hline $\begin{array}{l}\text { Middle Fork } \\
\text { Willamette }\end{array}$ & 8 & 1990 & $\begin{array}{l}\text { Cutthroat } \\
\text { trout }\end{array}$ & wb & 3 & $<.002$ & $<.002$ & $\begin{array}{l}<.002- \\
.002\end{array}$ & $<.002$ & $<.002$ & $<.002$ & $<.002$ & $<.002$ & $<.025$ & $<.025$ & ODEQ (1994b) \\
\hline Santiam & 0.5 & 1988 & $\begin{array}{l}\text { Northern } \\
\text { squawfish }\end{array}$ & $\mathrm{f}$ & 1 & $<.004$ & $<.004$ & $<.004$ & $<.004$ & -- & $<.004$ & $<.004$ & $<.004$ & $<.004$ & -- & ODEQ (1994b) \\
\hline $\begin{array}{l}\text { Tualatin, Cherry } \\
\text { Grove }\end{array}$ & -- & 1987 & Crayfish & wb & 1 & -- & $<.0025$ & $<.0025$ & -- & .00058 & -- & -- & $<.0025$ & -- & -- & USEPA (1992a) \\
\hline $\begin{array}{l}\text { Tualatin, Cherry } \\
\text { Grove }\end{array}$ & -- & 1987 & Sucker & wb & $3-5 c$ & -- & .0373 & $<.0025$ & -- & .463 & -- & -- & $<.0025$ & -- & -- & USEPA (1992a) \\
\hline Tualatin & 8 & 1989 & Sucker & $\mathrm{f}$ & 1 & $<.003$ & $<.003$ & $<.003$ & $<.003$ & .009 & .037 & $<.003$ & $<.003$ & $<.003$ & -- & ODEQ (1994b) \\
\hline Yamhill & 5 & 1989 & Sucker & f & 1 & $<.002$ & $<.002$ & $<.002$ & $<.002$ & .004 & .006 & $<.002$ & $<.002$ & $<.025$ & -- & ODEQ (1994b) \\
\hline Conser Slough ${ }^{1}$ & 0.1 & 1989 & Sucker & f & 1 & $<.002$ & $<.002$ & $<.002$ & $<.002$ & $<.002$ & $<.002$ & $<.002$ & $<.002$ & $<.025$ & -- & ODEQ (1994b) \\
\hline Conser Slough & 0.1 & 1989 & $\begin{array}{l}\text { Northern } \\
\text { squawfish }\end{array}$ & $\mathrm{f}$ & 2 & $<.003$ & $<.003$ & $<.003$ & $<.003$ & $<.003$ & $<.003$ & $<.003$ & $<.003$ & $<.03$ & -- & ODEQ (1994b) \\
\hline Conser Slough & 0.1 & 1988 & Bass & $\mathrm{f}$ & $2 \mathrm{c}$ & $<.003$ & .004 & .004 & -- & $<.003$ & $<.003$ & $<.003$ & $<.003$ & $<.003$ & -- & ODEQ (1994b) \\
\hline Conser Slough & 0.1 & 1988 & $\begin{array}{l}\text { Common } \\
\text { carp }\end{array}$ & $\mathrm{f}$ & $4 \mathrm{c}$ & $<.003$ & .004 & .004 & -- & $<.003$ & $<.003$ & $<.003$ & $<.003$ & $<.003$ & -- & ODEQ (1994b) \\
\hline
\end{tabular}


APPENDIX E-2. CHLORINATED PESTICIDES IN TISSUE OF AQUATIC BIOTA FROM THE WILLAMETTE BASIN, OREGON-Continued

\begin{tabular}{|c|c|c|c|c|c|c|c|c|c|c|c|c|c|c|c|c|}
\hline \multirow[b]{2}{*}{ River } & \multirow[b]{2}{*}{$\begin{array}{l}\text { River } \\
\text { mile }\end{array}$} & \multirow[b]{2}{*}{ Year } & \multirow[b]{2}{*}{ Species } & \multirow[b]{2}{*}{$\begin{array}{l}\text { Tissue } \\
\text { type }\end{array}$} & \multicolumn{11}{|c|}{ Concentration range $(\mu \mathrm{g} / \mathrm{g}$, wet weight) } & \multirow[b]{2}{*}{ Reference } \\
\hline & & & & & $\begin{array}{l}\text { Number } \\
\text { samples }\end{array}$ & Aldrin & Dieldrin & Endrin & $\begin{array}{l}\text { Endrin } \\
\text { alde- } \\
\text { hyde }\end{array}$ & $p, p^{\prime}-\mathrm{DDE}$ & $p, p^{\prime}-\mathrm{DDD}$ & $p, p$ '-DDT & $\begin{array}{l}\text { Methoxy- } \\
\text { chlor }\end{array}$ & $\begin{array}{l}\text { Chlor- } \\
\text { dane }\end{array}$ & $\begin{array}{l}\text { Toxa- } \\
\text { phene }\end{array}$ & \\
\hline Johnson Creek & $--\left({ }^{2}\right)$ & 1991 & Crayfish & wb & 1 & $<0.0025$ & $<0.0025$ & $<0.0025$ & $<0.0025$ & 0.011 & 0.0025 & 0.0077 & $<0.01$ & $<0.025$ & $<0.6$ & ODEQ (1994b) \\
\hline Johnson Creek & $--\left({ }^{3}\right)$ & 1991 & Crayfish & $\mathrm{wb}$ & 1 & $<.0025$ & $<.0025$ & $<.0025$ & $<.0025$ & .05 & $<.0025$ & .019 & $<.01$ & $<.025$ & $<.6$ & ODEQ (1994b) \\
\hline Johnson Creek & 6.1 & 1991 & Crayfish & $w b$ & 1 & $<.0025$ & $<.0025$ & $<.0025$ & $<.0025$ & .014 & .0051 & $<.0025$ & $<.01$ & $<.025$ & $<.6$ & ODEQ (1994b) \\
\hline Johnson Creek & 8.3 & 1991 & Crayfish & $w b$ & 1 & $<.0025$ & $<.0025$ & $<.0025$ & $<.0025$ & .045 & $<.0025$ & .007 & $<.01$ & $<.025$ & $<.6$ & ODEQ (1994b) \\
\hline Johnson Creek & $-\left(-{ }^{4}\right)$ & 1991 & Crayfish & $w b$ & 1 & $<.0025$ & $<.0025$ & $<.0025$ & $<.0025$ & .086 & .0042 & .062 & $<.01$ & $<.025$ & $<.6$ & ODEQ (1994b) \\
\hline Johnson Creek & 16.9 & 1991 & Crayfish & wb & 1 & $<.0025$ & $<.0025$ & $<.0025$ & $<.0025$ & .16 & .048 & .22 & $<.01$ & $<.025$ & $<.6$ & ODEQ (1994b) \\
\hline Johnson Creek & $--\left({ }^{5}\right)$ & 1991 & Crayfish & $\mathrm{wb}$ & 1 & $<.0025$ & $<.0025$ & $<.0025$ & $<.0025$ & .10 & $<.0025$ & .016 & $<.01$ & $<.025$ & $<.6$ & ODEQ (1994b) \\
\hline Johnson Creek & $--\left({ }^{6}\right)$ & 1991 & Crayfish & wb & 1 & $<.0025$ & $<.0025$ & $<.0025$ & $<.0025$ & .069 & $<.0025$ & .018 & $<.01$ & $<.025$ & $<.6$ & ODEQ (1994b) \\
\hline Rock Creek $^{7}$ & 1.5 & 1994 & Sculpin & wb & $15-20 \mathrm{c}$ & -- & -- & $<.01$ & -- & .0319 & $<.01$ & -- & -- & -- & $<.05$ & USFWS (1994c) \\
\hline Rock Creek & $\begin{array}{l}1.7- \\
2\end{array}$ & 1994 & $\begin{array}{l}\text { Three- } \\
\text { spined } \\
\text { stickle-back }\end{array}$ & wb & $9 \mathrm{c}$ & -- & -- & $<.01$ & -- & .0620 & $<.01$ & -- & -- & -- & $<.05$ & USFWS (1994c) \\
\hline Rock Creek & $\begin{array}{l}1.7- \\
2\end{array}$ & 1994 & Sculpin & wb & $6 \mathrm{c}$ & -- & -- & $<.01$ & -- & .0438 & $<.01$ & -- & -- & -- & $<.05$ & USFWS (1994c) \\
\hline
\end{tabular}

${ }^{1}$ Conser Slough is a tributary of the Willamette River near Albany, Oregon (Willamette River Subbasin).

${ }^{2}$ McLoughlin Boulevard.

${ }^{3} 44$ th Avenue and Umatilla Street.

${ }^{4}$ Jenne Road.

${ }^{5}$ Orient Drive.

${ }^{6} 145$ th Avenue.

${ }^{7}$ Rock Creek is a tributary of the Tualatin River near Sherwood, Oregon (Tualatin Subbasin). 


\section{APPENDIX E-3. CHLORINATED PESTICIDES IN TISSUE OF AQUATIC BIOTA FROM THE WILLAMETTE BASIN,}

\section{OREGON}

$[\mu \mathrm{g} / \mathrm{g}$, microgram per gram. River mile:--, not available; , approximately. Tissue type: wb, whole-body; f, fillet. Number samples: c, composite sample. Concentration range: HCB, hexachlorobenzene; PCA, pentachloroanisole; --, not analyzed; <, less than; quantification limit used for all USEPA (1992a) data. References: USEPA, U.S. Environmental Protection Agency; USFWS, U.S. Fish and Wildlife Service]

\begin{tabular}{|c|c|c|c|c|c|c|c|c|c|c|c|c|c|c|c|}
\hline \multirow[b]{2}{*}{ River } & \multirow[b]{2}{*}{$\begin{array}{l}\text { River } \\
\text { mile }\end{array}$} & \multirow[b]{2}{*}{ Year } & \multirow[b]{2}{*}{ Species } & \multirow[b]{2}{*}{$\begin{array}{c}\text { Tissue } \\
\text { type }\end{array}$} & \multirow[b]{2}{*}{$\begin{array}{l}\text { Number } \\
\text { samples }\end{array}$} & \multicolumn{9}{|c|}{ Concentration range $(\mu \mathrm{g} / \mathrm{g}$, wet weight) } & \multirow[b]{2}{*}{ Reference } \\
\hline & & & & & & Dacthal & HCB & $\begin{array}{l}\text { cis-Chlor- } \\
\text { dane }\end{array}$ & $\begin{array}{l}\text { trans- } \\
\text { Chlor- } \\
\text { dane }\end{array}$ & $\begin{array}{l}\text { cis-Nona- } \\
\text { chlor }\end{array}$ & $\begin{array}{l}\text { trans- } \\
\text { Nona- } \\
\text { chlor }\end{array}$ & $\begin{array}{l}\text { Oxychlor- } \\
\text { dane }\end{array}$ & Mirex & PCA & \\
\hline $\begin{array}{l}\text { Willamette } \\
\text { Newberg Pool }\end{array}$ & -- & 1987 & $\begin{array}{l}\text { Northern } \\
\text { squawfish }\end{array}$ & wb & $3-5 c$ & -- & $<0.0025$ & $<0.0025$ & $<0.0025$ & $<0.0025$ & $<0.0025$ & $<0.0025$ & $<0.0025$ & -- & $\begin{array}{l}\text { USEPA } \\
\text { (1992a) }\end{array}$ \\
\hline $\begin{array}{l}\text { Willamette } \\
\text { Halsey }\end{array}$ & -- & 1987 & Sucker & $w b$ & $4 \mathrm{c}$ & -- & $<.0025$ & $<.0025$ & $<.0025$ & $<.0025$ & $<.0025$ & $<.0025$ & $<.0025$ & -- & $\begin{array}{l}\text { USEPA } \\
\text { (1992a) }\end{array}$ \\
\hline Willamette & $\sim 7$ & 1987 & Sucker & $w b$ & $4 \mathrm{c}$ & -- & $<.0025$ & $<.0025$ & $<.0025$ & $<.0025$ & $<.0025$ & $<.0025$ & $<.0025$ & -- & $\begin{array}{l}\text { USEPA } \\
\text { (1992a) }\end{array}$ \\
\hline Willamette & $\sim 26$ & 1976 & $\begin{array}{l}\text { Smallmouth } \\
\text { bass }\end{array}$ & wb & $3-5 c$ & -- & .00 & .04 & .01 & .00 & .00 & -- & -- & -- & $\begin{array}{l}\text { Schmitt and } \\
\text { others (1983) }\end{array}$ \\
\hline Willamette & $\sim 26$ & 1976 & Chiselmouth & wb & $3-5 c$ & -- & .00 & .06 & .02 & .00 & .00 & -- & -- & -- & $\begin{array}{l}\text { Schmitt and } \\
\text { others (1983) }\end{array}$ \\
\hline Willamette & $\sim 26$ & 1976 & Chiselmouth & wb & $3-5 c$ & -- & .01 & .03 & .01 & .00 & .02 & -- & -- & -- & $\begin{array}{l}\text { Schmitt and } \\
\text { others (1983) }\end{array}$ \\
\hline Willamette & $\sim 26$ & 1978 & $\begin{array}{l}\text { Northern } \\
\text { squawfish }\end{array}$ & $w b$ & $3-5 c$ & 0.00 & .00 & .04 & .01 & .03 & .05 & .00 & -- & -- & $\begin{array}{l}\text { Schmitt and } \\
\text { others (1983) }\end{array}$ \\
\hline Willamette & $\sim 26$ & 1978 & Chiselmouth & wb & $3-5 c$ & .00 & .00 & .03 & .01 & .01 & .02 & .00 & -- & -- & $\begin{array}{l}\text { Schmitt and } \\
\text { others (1983) }\end{array}$ \\
\hline Willamette & $\sim 26$ & 1978 & Chiselmouth & $w b$ & $3-5 c$ & .00 & .00 & .03 & .01 & .01 & .02 & .00 & -- & -- & $\begin{array}{l}\text { Schmitt and } \\
\text { others (1983) }\end{array}$ \\
\hline Willamette & $\sim 26$ & 1980 & $\begin{array}{l}\text { Largescale } \\
\text { sucker }\end{array}$ & $w b$ & $3-5 c$ & .00 & .01 & .02 & .01 & .01 & .03 & .00 & .00 & 0.05 & $\begin{array}{l}\text { Schmitt and } \\
\text { others (1985) }\end{array}$ \\
\hline Willamette & $\sim 26$ & 1980 & $\begin{array}{l}\text { Largescale } \\
\text { sucker }\end{array}$ & $w b$ & $3-5 c$ & .00 & .00 & .01 & .01 & .01 & .02 & .00 & .01 & .02 & $\begin{array}{l}\text { Schmitt and } \\
\text { others (1985) }\end{array}$ \\
\hline Willamette & $\sim 26$ & 1980 & $\begin{array}{l}\text { Northern } \\
\text { squawfish }\end{array}$ & $\mathrm{wb}$ & $3-5 c$ & .00 & .00 & .01 & .01 & .01 & .03 & .00 & .00 & .02 & $\begin{array}{l}\text { Schmitt and } \\
\text { others (1985) }\end{array}$ \\
\hline
\end{tabular}


APPENDIX E-3. CHLORINATED PESTICIDES IN TISSUE OF AQUATIC BIOTA FROM THE WILLAMETTE BASIN, OREGON-Continued

\begin{tabular}{|c|c|c|c|c|c|c|c|c|c|c|c|c|c|c|c|}
\hline \multirow[b]{2}{*}{ River } & \multirow[b]{2}{*}{$\begin{array}{l}\text { River } \\
\text { mile }\end{array}$} & \multirow[b]{2}{*}{ Year } & \multirow[b]{2}{*}{ Species } & \multirow[b]{2}{*}{$\begin{array}{l}\text { Tissue } \\
\text { type }\end{array}$} & \multicolumn{10}{|c|}{ Concentration range $(\mu \mathrm{g} / \mathrm{g}$, wet weight) } & \multirow[b]{2}{*}{ Reference } \\
\hline & & & & & $\begin{array}{l}\text { Number } \\
\text { samples }\end{array}$ & Dacthal & HCB & $\begin{array}{l}\text { cis-Chlor- } \\
\text { dane }\end{array}$ & $\begin{array}{l}\text { trans- } \\
\text { Chlor- } \\
\text { dane }\end{array}$ & $\begin{array}{l}\text { cis-Nona- } \\
\text { chlor }\end{array}$ & $\begin{array}{l}\text { trans- } \\
\text { Nona- } \\
\text { chlor }\end{array}$ & $\begin{array}{l}\text { Oxychlor- } \\
\text { dane }\end{array}$ & Mirex & PCA & \\
\hline Willamette & $\sim 26$ & 1984 & $\begin{array}{l}\text { Northern } \\
\text { squawfish }\end{array}$ & wb & $3-5 c$ & $<0.01$ & $<0.01$ & 0.01 & $<0.01$ & 0.01 & 0.01 & $<0.01$ & $<0.01$ & 0.01 & $\begin{array}{l}\text { Schmitt and } \\
\text { others (1990) }\end{array}$ \\
\hline Willamette & $\sim 26$ & 1984 & Peamouth & wb & $3-5 c$ & $<.01$ & $<.01$ & .01 & $<.01$ & $<.01$ & .01 & $<.01$ & $<.01$ & .01 & $\begin{array}{l}\text { Schmitt and } \\
\text { others (1990) }\end{array}$ \\
\hline Willamette & $\sim 26$ & 1984 & Peamouth & wb & $3-5 c$ & $<.01$ & $<.01$ & .01 & $<.01$ & $<.01$ & .01 & $<.01$ & $<.01$ & .01 & $\begin{array}{l}\text { Schmitt and } \\
\text { others (1990) }\end{array}$ \\
\hline $\begin{array}{l}\text { Tualatin, Cherry } \\
\text { Grove }\end{array}$ & -- & 1987 & Crayfish & wb & 1 & -- & $<.0025$ & $<.0025$ & $<.0025$ & $<.0025$ & $<.0025$ & $<.0025$ & $<.0025$ & -- & $\begin{array}{l}\text { USEPA } \\
\text { (1992a) }\end{array}$ \\
\hline $\begin{array}{l}\text { Tualatin, } \\
\text { Cook Park }\end{array}$ & -- & 1987 & Sucker & wb & $3-5 c$ & -- & $<.0025$ & .0181 & .00653 & $<.0025$ & .0333 & $<.0025$ & $<.0025$ & -- & $\begin{array}{l}\text { USEPA } \\
\text { (1992a) }\end{array}$ \\
\hline Rock Creek $^{1}$ & 1.5 & 1994 & Sculpin & wb & $15-20 c$ & -- & $<.01$ & -- & -- & $<.01$ & $<.01$ & $<.01$ & -- & -- & $\begin{array}{l}\text { USFWS } \\
(1994 c)\end{array}$ \\
\hline Rock Creek & $\begin{array}{l}1.7- \\
2\end{array}$ & 1994 & $\begin{array}{l}\text { Three-spined } \\
\text { stickleback }\end{array}$ & wb & $9 \mathrm{c}$ & -- & $<.01$ & -- & -- & $<.01$ & $<.01$ & $<.01$ & -- & -- & $\begin{array}{l}\text { USFWS } \\
(1994 c)\end{array}$ \\
\hline Rock Creek & $\begin{array}{l}1.7- \\
2\end{array}$ & 1994 & Sculpin & wb & $6 \mathrm{c}$ & -- & $<.01$ & -- & -- & $<.01$ & $<.01$ & $<.01$ & -- & -- & $\begin{array}{l}\text { USFWS } \\
(1994 c)\end{array}$ \\
\hline
\end{tabular}

${ }^{1}$ Rock Creek is a tributary of the Tualatin River near Sherwood, Oregon (Tualatin Subbasin). 


\section{APPENDIX F. POLYCHLORINATED BIPHENYLS IN TISSUE OF AQUATIC BIOTA FROM THE WILLAMETTE BASIN, \\ OREGON}

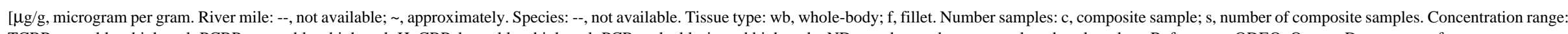
TCBP, tetrachlorobiphenyl; PCBP, pentachlorobiphenyl; HxCBP, hexachlorobiphenyl; PCB, polychlorinated biphenyls; ND, not detected; --, not analyzed; <, less than. References: ODEQ, Oregon Department of Environmental Quality; USEPA, U.S. Environmental Protection Agency]

\begin{tabular}{|c|c|c|c|c|c|c|c|c|c|c|c|c|c|c|c|c|c|}
\hline \multirow[b]{2}{*}{ River } & \multirow[b]{2}{*}{$\begin{array}{l}\text { River } \\
\text { mile }\end{array}$} & \multirow[b]{2}{*}{ Years } & \multirow[b]{2}{*}{ Species } & \multirow[b]{2}{*}{$\begin{array}{c}\text { Tissue } \\
\text { type }\end{array}$} & \multirow[b]{2}{*}{$\begin{array}{l}\text { Number } \\
\text { samples }\end{array}$} & \multicolumn{11}{|c|}{ Concentration range $(\mu \mathrm{g} / \mathrm{g}$, wet weight) } & \multirow[b]{2}{*}{$\begin{array}{l}\text { Refer- } \\
\text { ence }\end{array}$} \\
\hline & & & & & & $\begin{array}{c}3,3^{\prime}, 4,4^{\prime} \\
\text { TCBP }\end{array}$ & $\begin{array}{c}2,3,3^{\prime}, 4,4^{\prime} \\
\text { PCBP }\end{array}$ & $\begin{array}{c}3,3^{\prime}, 4,4^{\prime}, 5^{\prime} \\
\text { РСВP }\end{array}$ & $\begin{array}{c}3,3^{\prime}, 4,4^{\prime}, 5,5^{\prime} \\
\text { НхCВP }\end{array}$ & $\begin{array}{l}1221 \\
\text { PCB }\end{array}$ & $\begin{array}{l}1232 \\
\text { PCB }\end{array}$ & $\begin{array}{l}1242 \\
\text { PCB }\end{array}$ & $\begin{array}{l}1248 \\
\text { PCB }\end{array}$ & $\begin{array}{l}1254 \\
\text { PCB }\end{array}$ & $\begin{array}{l}1260 \\
\text { PCB }\end{array}$ & $\begin{array}{l}\text { Total } \\
\text { PCB }\end{array}$ & \\
\hline $\begin{array}{l}\text { Willamette, } \\
\text { Newberg Pool }\end{array}$ & -- & 1987 & $\begin{array}{l}\text { Northern } \\
\text { squawfish }\end{array}$ & wb & $3-5 c$ & -- & -- & -- & -- & -- & -- & -- & -- & -- & -- & $0.10274^{1}$ & $\begin{array}{l}\text { USEPA } \\
\text { (1992a) }\end{array}$ \\
\hline $\begin{array}{l}\text { Willamette, } \\
\text { Halsey }\end{array}$ & -- & 1987 & Sucker & wb & $3-5 c$ & -- & -- & -- & -- & -- & -- & -- & -- & -- & -- & $.0082^{1}$ & $\begin{array}{l}\text { USEPA } \\
\text { (1992a) }\end{array}$ \\
\hline Willamette & $\sim 7$ & 1987 & Sucker & wb & $3-5 c$ & -- & -- & -- & -- & -- & -- & -- & -- & -- & -- & $1.5369^{1}$ & $\begin{array}{l}\text { USEPA } \\
\text { (1992a) }\end{array}$ \\
\hline Willamette & 7 & 1990 & $\begin{array}{l}\text { Northern } \\
\text { squawfish }\end{array}$ & wb & 3 & $\begin{array}{c}<0.002- \\
.011\end{array}$ & $<0.002$ & $\begin{array}{c}<0.002- \\
.006\end{array}$ & $<0.002$ & $<0.125$ & $<0.05$ & $<0.025$ & -- & $<0.025$ & $\begin{array}{c}<0.025- \\
.209\end{array}$ & $\begin{array}{c}<.025- \\
.209\end{array}$ & $\begin{array}{l}\text { ODEQ } \\
(1994 b)\end{array}$ \\
\hline Willamette & 7 & 1990 & $\begin{array}{l}\text { Northern } \\
\text { squawfish }\end{array}$ & wb & 3 & .007 & $<.002$ & .006 & $<.002$ & $<.125$ & $<.050$ & $<.025$ & $<0.025$ & $<.025$ & .127 & -- & $\begin{array}{l}\text { Curtis and } \\
\text { others } \\
\text { (1993) }\end{array}$ \\
\hline Willamette & 7 & $\begin{array}{l}1989- \\
90\end{array}$ & Common carp & $\mathrm{f}$ & 6 & $\begin{array}{c}<.002- \\
.037\end{array}$ & $\begin{array}{c}<.002- \\
.006\end{array}$ & $\begin{array}{c}<.002- \\
.021\end{array}$ & $<.002$ & $<.15$ & $<.06$ & $<.03$ & -- & $\begin{array}{c}<.025- \\
.16\end{array}$ & $\begin{array}{l}<.025- \\
1.403\end{array}$ & $\begin{array}{l}<.025- \\
1.403\end{array}$ & $\begin{array}{l}\text { ODEQ } \\
(1994 b)\end{array}$ \\
\hline Willamette & 7 & 1990 & Common carp & $\mathrm{f}$ & 1 & .037 & .006 & .021 & $<.002$ & $<.125$ & $<.050$ & $<.025$ & $<.025$ & $<.025$ & 1.400 & -- & $\begin{array}{l}\text { Curtis and } \\
\text { others } \\
\text { (1993) }\end{array}$ \\
\hline Willamette & 7 & $\begin{array}{l}1988- \\
89\end{array}$ & Common carp & $\mathrm{f}$ & $5 \mathrm{c}, 2 \mathrm{~s}$ & -- & -- & -- & -- & $<.015$ & $<.006$ & $<.003$ & -- & $\begin{array}{l}<.003- \\
.16\end{array}$ & $\begin{array}{l}.044- \\
.066\end{array}$ & $\begin{array}{l}.044- \\
.16\end{array}$ & $\begin{array}{l}\text { ODEQ } \\
(1994 b)\end{array}$ \\
\hline $\begin{array}{l}\text { Willamette, } \\
\text { Station \#1 }\end{array}$ & $\sim 13$ & 1987 & Crayfish & wb & $3-4 c / 3 s$ & -- & -- & -- & -- & -- & -- & -- & -- & -- & $<.04$ & -- & $\begin{array}{l}\text { Hart } \\
\text { Crowser } \\
\text { (1988) }\end{array}$ \\
\hline $\begin{array}{l}\text { Willamette, } \\
\text { Station \#2 }\end{array}$ & $\sim 13$ & 1987 & Crayfish & wb & $3 \mathrm{c} / 2 \mathrm{~s}$ & -- & -- & -- & -- & -- & -- & -- & -- & -- & $<.04$ & -- & $\begin{array}{l}\text { Hart } \\
\text { Crowser } \\
\text { (1988) }\end{array}$ \\
\hline $\begin{array}{l}\text { Willamette, } \\
\text { Station \#3 }\end{array}$ & $\sim 13$ & 1987 & Crayfish & wb & $3-4 c / 4 s$ & -- & -- & -- & -- & -- & -- & -- & -- & -- & $<.04$ & -- & $\begin{array}{l}\text { Hart } \\
\text { Crowser } \\
(1988)\end{array}$ \\
\hline Willamette & $\sim 13$ & 1987 & $\begin{array}{l}\text { Prickly } \\
\text { sculpin }\end{array}$ & wb & $4 \mathrm{c} / 4 \mathrm{~s}$ & -- & -- & -- & -- & -- & -- & -- & -- & -- & $\begin{array}{r}0.19- \\
.63\end{array}$ & -- & $\begin{array}{l}\text { Hart } \\
\text { Crowser } \\
(1988)\end{array}$ \\
\hline
\end{tabular}


APPENDIX F. POLYCHLORINATED BIPHENYLS IN TISSUE OF AQUATIC BIOTA FROM THE WILLAMETTE BASIN, OREGON-Continued

\begin{tabular}{|c|c|c|c|c|c|c|c|c|c|c|c|c|c|c|c|c|c|}
\hline \multirow[b]{2}{*}{ River } & \multirow[b]{2}{*}{$\begin{array}{l}\text { River } \\
\text { mile }\end{array}$} & \multirow[b]{2}{*}{ Years } & \multirow[b]{2}{*}{ Species } & \multirow[b]{2}{*}{$\begin{array}{l}\text { Tissue } \\
\text { type }\end{array}$} & \multirow[b]{2}{*}{$\begin{array}{l}\text { Number } \\
\text { samples }\end{array}$} & \multicolumn{11}{|c|}{ Concentration range ( $\mu \mathrm{g} / \mathrm{g}$, wet weight) } & \multirow[b]{2}{*}{$\begin{array}{l}\text { Refer- } \\
\text { ence }\end{array}$} \\
\hline & & & & & & $\begin{array}{c}3,3^{\prime}, 4,4^{\prime} \\
\text { TCBP }\end{array}$ & $\begin{array}{c}2,3,3^{\prime}, 4,4^{\prime} \\
\text { PCBP }\end{array}$ & $\begin{array}{c}3,3^{\prime}, 4,4^{\prime}, 5^{\prime} \\
\text { PCBP }\end{array}$ & $\begin{array}{c}3,3^{\prime}, 4,4^{\prime}, 5,5^{\prime} \\
\text { HхCBP }\end{array}$ & $\begin{array}{l}1221 \\
\text { PCB }\end{array}$ & $\begin{array}{l}1232 \\
\text { PCB }\end{array}$ & $\begin{array}{l}1242 \\
\text { PCB }\end{array}$ & $\begin{array}{l}1248 \\
\text { PCB }\end{array}$ & $\begin{array}{l}1254 \\
\text { PCB }\end{array}$ & $\begin{array}{l}1260 \\
\text { PCB }\end{array}$ & $\begin{array}{l}\text { Total } \\
\text { PCB }\end{array}$ & \\
\hline Willamette & $\sim 14$ & 1987 & $\begin{array}{l}\text { Prickly } \\
\text { sculpin }\end{array}$ & $\mathrm{wb}$ & $4 \mathrm{c} / 5 \mathrm{~s}$ & -- & -- & -- & -- & -- & -- & -- & -- & -- & $\begin{array}{l}0.10- \\
.35\end{array}$ & -- & $\begin{array}{l}\text { Hart } \\
\text { Crowser } \\
\text { (1988) }\end{array}$ \\
\hline Willamette & 18 & 1989 & Common carp & $\mathrm{f}$ & $4 \mathrm{c}$ & -- & -- & -- & -- & $<0.125$ & $<0.05$ & $<0.025$ & -- & 0.36 & $<.025$ & 0.36 & $\begin{array}{l}\text { ODEQ } \\
(1994 b)\end{array}$ \\
\hline Willamette & 18 & 1989 & Sucker & $\mathrm{f}$ & $3 \mathrm{c}$ & -- & -- & -- & -- & $<.125$ & $<.05$ & $<.025$ & -- & $<.025$ & $<.025$ & $<.025$ & $\begin{array}{l}\text { ODEQ } \\
(1994 b)\end{array}$ \\
\hline Willamette & $\sim 26$ & 1970 & Common carp & wb & $3-5 c$ & -- & -- & -- & -- & -- & -- & -- & -- & 1.25 & -- & -- & $\begin{array}{l}\text { Schmitt and } \\
\text { others } \\
\text { (1981) }\end{array}$ \\
\hline Willamette & $\sim 26$ & 1970 & $\begin{array}{l}\text { Largescale } \\
\text { sucker }\end{array}$ & $w b$ & $3-5 c$ & -- & -- & -- & -- & -- & -- & -- & -- & 2.40 & -- & -- & $\begin{array}{l}\text { Schmitt and } \\
\text { others } \\
\text { (1981) }\end{array}$ \\
\hline Willamette & $\sim 26$ & 1970 & $\begin{array}{l}\text { Largescale } \\
\text { sucker }\end{array}$ & $w b$ & $3-5 c$ & -- & -- & -- & -- & -- & -- & -- & -- & 4.58 & -- & -- & $\begin{array}{l}\text { Schmitt and } \\
\text { others } \\
(1981)\end{array}$ \\
\hline Willamette & $\sim 26$ & 1971 & $\begin{array}{l}\text { Largescale } \\
\text { sucker }\end{array}$ & $w b$ & $3-5 c$ & -- & -- & -- & -- & -- & -- & -- & -- & 1.67 & -- & -- & $\begin{array}{l}\text { Schmitt and } \\
\text { others } \\
\text { (1981) }\end{array}$ \\
\hline Willamette & $\sim 26$ & 1971 & $\begin{array}{l}\text { Largescale } \\
\text { sucker }\end{array}$ & wb & $3-5 c$ & -- & -- & -- & -- & -- & -- & -- & -- & 1.35 & -- & -- & $\begin{array}{l}\text { Schmitt and } \\
\text { others } \\
(1981)\end{array}$ \\
\hline Willamette & $\sim 26$ & 1971 & $\begin{array}{l}\text { Northern } \\
\text { squawfish }\end{array}$ & $w b$ & $3-5 c$ & -- & -- & -- & -- & -- & -- & -- & -- & 2.37 & -- & -- & $\begin{array}{l}\text { Schmitt and } \\
\text { others } \\
(1981)\end{array}$ \\
\hline Willamette & $\sim 26$ & 1971 & $\begin{array}{l}\text { Northern } \\
\text { squawfish }\end{array}$ & wb & $3-5 c$ & -- & -- & -- & -- & -- & -- & -- & -- & 2.60 & -- & -- & $\begin{array}{l}\text { Schmitt and } \\
\text { others } \\
(1981)\end{array}$ \\
\hline Willamette & $\sim 26$ & 1972 & $\begin{array}{l}\text { Largescale } \\
\text { sucker }\end{array}$ & wb & $3-5 c$ & -- & -- & -- & -- & -- & -- & -- & -- & 2.80 & -- & -- & $\begin{array}{l}\text { Schmitt and } \\
\text { others } \\
(1981)\end{array}$ \\
\hline Willamette & $\sim 26$ & 1972 & $\begin{array}{l}\text { Largescale } \\
\text { sucker }\end{array}$ & wb & $3-5 c$ & -- & -- & -- & -- & -- & -- & -- & -- & 5.40 & -- & -- & $\begin{array}{l}\text { Schmitt and } \\
\text { others } \\
(1981)\end{array}$ \\
\hline
\end{tabular}


APPENDIX F. POLYCHLORINATED BIPHENYLS IN TISSUE OF AQUATIC BIOTA FROM THE WILLAMETTE BASIN, OREGON-Continued

\begin{tabular}{|c|c|c|c|c|c|c|c|c|c|c|c|c|c|c|c|c|c|}
\hline \multirow[b]{2}{*}{ River } & \multirow[b]{2}{*}{$\begin{array}{l}\text { River } \\
\text { mile }\end{array}$} & \multirow[b]{2}{*}{ Years } & \multirow[b]{2}{*}{ Species } & \multirow[b]{2}{*}{$\begin{array}{l}\text { Tissue } \\
\text { type }\end{array}$} & \multirow[b]{2}{*}{$\begin{array}{l}\text { Number } \\
\text { samples }\end{array}$} & \multicolumn{11}{|c|}{ Concentration range ( $\mu \mathrm{g} / \mathrm{g}$, wet weight) } & \multirow[b]{2}{*}{$\begin{array}{l}\text { Refer- } \\
\text { ence }\end{array}$} \\
\hline & & & & & & $\begin{array}{c}3,3^{\prime}, 4,4^{\prime} \\
\text { TCBP }\end{array}$ & $\begin{array}{c}2,3,3^{\prime}, 4,4^{\prime} \\
\text { PCBP }\end{array}$ & $\begin{array}{c}3,3^{\prime}, 4,4^{\prime}, 5^{\prime} \\
\text { РСВP }\end{array}$ & $\begin{array}{c}3,3^{\prime}, 4,4^{\prime}, 5,5^{\prime} \\
\text { HxCBP }\end{array}$ & $\begin{array}{l}1221 \\
\text { PCB }\end{array}$ & $\begin{array}{l}1232 \\
\text { PCB }\end{array}$ & $\begin{array}{l}1242 \\
\text { PCB }\end{array}$ & $\begin{array}{l}1248 \\
\text { PCB }\end{array}$ & $\begin{array}{l}1254 \\
\text { PCB }\end{array}$ & $\begin{array}{l}1260 \\
\text { PCB }\end{array}$ & $\begin{array}{l}\text { Total } \\
\text { PCB }\end{array}$ & \\
\hline Willamette & $\sim 26$ & 1972 & $\begin{array}{l}\text { Channel } \\
\text { catfish }\end{array}$ & wb & $3-5 c$ & -- & -- & -- & -- & -- & -- & -- & -- & 4.40 & -- & -- & $\begin{array}{l}\text { Schmitt and } \\
\text { others } \\
(1981)\end{array}$ \\
\hline Willamette & $\sim 26$ & 1972 & $\begin{array}{l}\text { Northern } \\
\text { squawfish }\end{array}$ & $\mathrm{wb}$ & $3-5 c$ & -- & -- & -- & -- & -- & -- & -- & -- & 3.00 & -- & -- & $\begin{array}{l}\text { Schmitt and } \\
\text { others } \\
(1981)\end{array}$ \\
\hline Willamette & $\sim 26$ & 1973 & Common carp & $\mathrm{wb}$ & $3-5 c$ & -- & -- & -- & -- & -- & -- & 0.0 & -- & .20 & 0.0 & -- & $\begin{array}{l}\text { Schmitt and } \\
\text { others } \\
(1981)\end{array}$ \\
\hline Willamette & $\sim 26$ & 1973 & $\begin{array}{l}\text { Largescale } \\
\text { sucker }\end{array}$ & wb & $3-5 c$ & -- & -- & -- & -- & -- & -- & .0 & -- & 2.40 & .0 & -- & $\begin{array}{l}\text { Schmitt and } \\
\text { others } \\
(1981)\end{array}$ \\
\hline Willamette & $\sim 26$ & 1973 & $\begin{array}{l}\text { Largescale } \\
\text { sucker }\end{array}$ & wb & $3-5 c$ & -- & -- & -- & -- & -- & -- & .0 & -- & 1.60 & .0 & -- & $\begin{array}{l}\text { Schmitt and } \\
\text { others } \\
(1981)\end{array}$ \\
\hline Willamette & $\sim 26$ & 1973 & $\begin{array}{l}\text { Northern } \\
\text { squawfish }\end{array}$ & wb & $3-5 c$ & -- & -- & -- & -- & -- & -- & .0 & -- & 2.80 & .0 & -- & $\begin{array}{l}\text { Schmitt and } \\
\text { others } \\
(1981)\end{array}$ \\
\hline Willamette & $\sim 26$ & 1974 & Common carp & wb & $3-5 c$ & -- & -- & -- & -- & -- & -- & .0 & -- & .00 & .1 & -- & $\begin{array}{l}\text { Schmitt and } \\
\text { others } \\
(1981)\end{array}$ \\
\hline Willamette & $\sim 26$ & 1974 & $\begin{array}{l}\text { Largescale } \\
\text { sucker }\end{array}$ & wb & $3-5 c$ & -- & -- & -- & -- & -- & -- & .0 & -- & 1.30 & .0 & -- & $\begin{array}{l}\text { Schmitt and } \\
\text { others } \\
(1981)\end{array}$ \\
\hline Willamette & $\sim 26$ & 1974 & $\begin{array}{l}\text { Largescale } \\
\text { sucker }\end{array}$ & wb & $3-5 c$ & -- & -- & -- & -- & -- & -- & 4.5 & -- & 2.70 & .0 & -- & $\begin{array}{l}\text { Schmitt and } \\
\text { others } \\
(1981)\end{array}$ \\
\hline Willamette & $\sim 26$ & 1974 & $\begin{array}{l}\text { Northern } \\
\text { squawfish }\end{array}$ & wb & $3-5 c$ & -- & -- & -- & -- & -- & -- & .0 & -- & 2.30 & .0 & -- & $\begin{array}{l}\text { Schmitt and } \\
\text { others } \\
(1981)\end{array}$ \\
\hline Willamette & $\sim 26$ & 1976 & $\begin{array}{l}\text { Smallmouth } \\
\text { bass }\end{array}$ & wb & $3-5 c$ & -- & -- & -- & -- & -- & -- & .0 & 0.0 & .40 & .2 & -- & $\begin{array}{l}\text { Schmitt and } \\
\text { others } \\
(1983)\end{array}$ \\
\hline Willamette & $\sim 26$ & 1976 & Chiselmouth & wb & $3-5 c$ & -- & -- & -- & -- & -- & -- & .0 & .0 & 2.00 & .3 & -- & $\begin{array}{l}\text { Schmitt and } \\
\text { others } \\
\text { (1983) }\end{array}$ \\
\hline
\end{tabular}


APPENDIX F. POLYCHLORINATED BIPHENYLS IN TISSUE OF AQUATIC BIOTA FROM THE WILLAMETTE BASIN, OREGON-Continued

\begin{tabular}{|c|c|c|c|c|c|c|c|c|c|c|c|c|c|c|c|c|c|}
\hline \multirow[b]{2}{*}{ River } & \multirow[b]{2}{*}{$\begin{array}{c}\text { River } \\
\text { mile }\end{array}$} & \multirow[b]{2}{*}{ Years } & \multirow[b]{2}{*}{ Species } & \multirow[b]{2}{*}{$\begin{array}{c}\text { Tissue } \\
\text { type }\end{array}$} & \multirow[b]{2}{*}{$\begin{array}{l}\text { Number } \\
\text { samples }\end{array}$} & \multicolumn{11}{|c|}{ Concentration range ( $\mu \mathrm{g} / \mathrm{g}$, wet weight) } & \multirow[b]{2}{*}{$\begin{array}{l}\text { Refer- } \\
\text { ence }\end{array}$} \\
\hline & & & & & & $\begin{array}{c}3,3^{\prime}, 4,4^{\prime} \\
\text { TCBP }\end{array}$ & $\begin{array}{c}\text { 2,3,3',4,4' } \\
\text { PCBP }\end{array}$ & $\begin{array}{c}3,3^{\prime}, 4,4^{\prime}, 5^{\prime} \\
\text { РСBP }\end{array}$ & $\begin{array}{c}3,3^{\prime}, 4,4^{\prime}, 5,5^{\prime} \\
\text { НхСВР }\end{array}$ & $\begin{array}{l}1221 \\
\text { PCB }\end{array}$ & $\begin{array}{l}1232 \\
\text { PCB }\end{array}$ & $\begin{array}{l}1242 \\
\text { PCB }\end{array}$ & $\begin{array}{l}1248 \\
\text { PCB }\end{array}$ & $\begin{array}{l}1254 \\
\text { PCB }\end{array}$ & $\begin{array}{l}1260 \\
\text { PCB }\end{array}$ & $\begin{array}{l}\text { Total } \\
\text { PCB }\end{array}$ & \\
\hline Willamette & $\sim 26$ & 1976 & Chiselmouth & $\mathrm{wb}$ & $3-5 c$ & -- & -- & -- & -- & -- & -- & 0.0 & 0.2 & 0.20 & 0.3 & -- & $\begin{array}{l}\text { Schmitt and } \\
\text { others } \\
(1983)\end{array}$ \\
\hline Willamette & $\sim 26$ & 1978 & $\begin{array}{l}\text { Northern } \\
\text { squawfish }\end{array}$ & wb & $3-5 c$ & -- & -- & -- & -- & -- & -- & .0 & .0 & .77 & .6 & -- & $\begin{array}{l}\text { Schmitt and } \\
\text { others } \\
(1983)\end{array}$ \\
\hline Willamette & $\sim 26$ & 1978 & Chiselmouth & wb & $3-5 c$ & -- & -- & -- & -- & -- & -- & .0 & .1 & .30 & .2 & -- & $\begin{array}{l}\text { Schmitt and } \\
\text { others } \\
(1983)\end{array}$ \\
\hline Willamette & $\sim 26$ & 1978 & Chiselmouth & wb & $3-5 c$ & -- & -- & -- & -- & -- & -- & .0 & .2 & .30 & .1 & -- & $\begin{array}{l}\text { Schmitt and } \\
\text { others } \\
(1983)\end{array}$ \\
\hline Willamette & $\sim 26$ & 1980 & $\begin{array}{l}\text { Largescale } \\
\text { sucker }\end{array}$ & wb & $3-5 c$ & -- & -- & -- & -- & -- & -- & -- & 1 & .3 & .3 & -- & $\begin{array}{l}\text { Schmitt and } \\
\text { others } \\
\text { (1985) }\end{array}$ \\
\hline Willamette & $\sim 26$ & 1980 & $\begin{array}{l}\text { Largescale } \\
\text { sucker }\end{array}$ & wb & $3-5 c$ & -- & -- & -- & -- & -- & -- & -- & .2 & .3 & .7 & -- & $\begin{array}{l}\text { Schmitt and } \\
\text { others } \\
(1985)\end{array}$ \\
\hline Willamette & $\sim 26$ & 1980 & $\begin{array}{l}\text { Northern } \\
\text { squawfish }\end{array}$ & wb & $3-5 c$ & -- & -- & -- & -- & -- & -- & -- & .0 & .2 & .6 & -- & $\begin{array}{l}\text { Schmitt and } \\
\text { others } \\
(1985)\end{array}$ \\
\hline Willamette & $\sim 26$ & 1984 & $\begin{array}{l}\text { Northern } \\
\text { squawfish }\end{array}$ & wb & $3-5 c$ & -- & -- & -- & -- & -- & -- & -- & $<.1$ & .2 & .1 & -- & $\begin{array}{l}\text { Schmitt and } \\
\text { others } \\
(1990)\end{array}$ \\
\hline Willamette & $\sim 26$ & 1984 & Peamouth & wb & $3-5 c$ & -- & -- & -- & -- & -- & -- & -- & $<.1$ & .1 & .1 & -- & $\begin{array}{l}\text { Schmitt and } \\
\text { others } \\
(1990)\end{array}$ \\
\hline Willamette & $\sim 26$ & 1984 & Peamouth & wb & $3-5 c$ & -- & -- & -- & -- & -- & -- & -- & $<.1$ & .1 & $<.1$ & -- & $\begin{array}{l}\text { Schmitt and } \\
\text { others } \\
(1990)\end{array}$ \\
\hline Willamette & 27 & 1988 & Bass & $\mathrm{f}$ & $3 \mathrm{c}$ & -- & -- & -- & -- & $<0.025$ & $<0.01$ & $<.005$ & -- & $<.005$ & $<.005$ & $<0.025$ & $\begin{array}{l}\text { ODEQ } \\
\text { (1994b) }\end{array}$ \\
\hline Willamette & 27 & 1988 & Common carp & $\mathrm{f}$ & $3 \mathrm{c}, 2 \mathrm{~s}$ & -- & -- & -- & -- & $<.015$ & $\begin{array}{r}<.006- \\
.0067\end{array}$ & $<.003$ & -- & $\begin{array}{r}<.003- \\
.205\end{array}$ & $\begin{array}{c}<.003- \\
.119\end{array}$ & $\begin{array}{c}<.015- \\
.324\end{array}$ & $\begin{array}{l}\text { ODEQ } \\
\text { (1994b) }\end{array}$ \\
\hline
\end{tabular}


APPENDIX F. POLYCHLORINATED BIPHENYLS IN TISSUE OF AQUATIC BIOTA FROM THE WILLAMETTE BASIN, OREGON-Continued

\begin{tabular}{|c|c|c|c|c|c|c|c|c|c|c|c|c|c|c|c|c|c|}
\hline \multirow[b]{2}{*}{ River } & \multirow[b]{2}{*}{$\begin{array}{c}\text { River } \\
\text { mile }\end{array}$} & \multirow[b]{2}{*}{ Years } & \multirow[b]{2}{*}{ Species } & \multirow[b]{2}{*}{$\begin{array}{c}\text { Tissue } \\
\text { type }\end{array}$} & \multirow[b]{2}{*}{$\begin{array}{l}\text { Number } \\
\text { samples }\end{array}$} & \multicolumn{11}{|c|}{ Concentration range ( $\mu \mathrm{g} / \mathrm{g}$, wet weight) } & \multirow[b]{2}{*}{$\begin{array}{l}\text { Refer- } \\
\text { ence }\end{array}$} \\
\hline & & & & & & $\begin{array}{c}3,3^{\prime}, 4,4^{\prime} \\
\text { TCBP }\end{array}$ & $\begin{array}{c}2,3,3^{\prime}, 4,4^{\prime} \\
\text { РCBP }\end{array}$ & $\begin{array}{c}3,3^{\prime}, 4,4^{\prime}, 5^{\prime} \\
\text { РСВР }\end{array}$ & $\begin{array}{c}3,3^{\prime}, 4,4^{\prime}, 5,5^{\prime} \\
\text { НхСВР }\end{array}$ & $\begin{array}{l}1221 \\
\text { PCB }\end{array}$ & $\begin{array}{l}1232 \\
\text { PCB }\end{array}$ & $\begin{array}{l}1242 \\
\text { PCB }\end{array}$ & $\begin{array}{l}1248 \\
\text { PCB }\end{array}$ & $\begin{array}{l}1254 \\
\text { PCB }\end{array}$ & $\begin{array}{l}1260 \\
\text { PCB }\end{array}$ & $\begin{array}{l}\text { Total } \\
\text { PCB }\end{array}$ & \\
\hline Willamette & 27 & 1988 & $\begin{array}{l}\text { Northern } \\
\text { squawfish }\end{array}$ & $\mathrm{f}$ & $3 \mathrm{c}$ & -- & -- & -- & -- & $<0.015$ & $<0.006$ & $<0.003$ & -- & $<0.003$ & $<0.003$ & $<0.015$ & $\begin{array}{l}\text { ODEQ } \\
(1994 b)\end{array}$ \\
\hline Willamette & 28 & 1989 & Common carp & $\mathrm{f}$ & 3 & -- & -- & -- & -- & $<.125$ & $<.05$ & $<.025$ & -- & $<.025$ & $<.025$ & $<.025$ & $\begin{array}{l}\text { ODEQ } \\
(1994 b)\end{array}$ \\
\hline Willamette & 28 & 1989 & Common carp & Liver & 2 & -- & -- & -- & -- & $<.125$ & $<.05$ & $<.025$ & -- & $<.025$ & $<.025$ & $<.025$ & $\begin{array}{l}\text { ODEQ } \\
(1994 b)\end{array}$ \\
\hline Willamette & 38 & 1989 & Sucker & $\mathrm{f}$ & $5 c$ & -- & -- & -- & -- & $<.125$ & $<.05$ & $<.025$ & -- & $<.025$ & $<.025$ & $<.05$ & $\begin{array}{l}\text { ODEQ } \\
(1994 b)\end{array}$ \\
\hline Willamette & 38 & $\begin{array}{l}1988- \\
89\end{array}$ & $\begin{array}{l}\text { Northern } \\
\text { squawfish }\end{array}$ & $\mathrm{f}$ & $5 \mathrm{c}, 2 \mathrm{~s}$ & -- & -- & -- & -- & $<.125$ & $<.05$ & $<.025$ & -- & $<.025$ & $<.025$ & $<.05$ & $\begin{array}{l}\text { ODEQ } \\
(1994 \mathrm{~b})\end{array}$ \\
\hline Willamette & 38 & 1988 & Common carp & $\mathrm{f}$ & $3 \mathrm{c}$ & -- & -- & -- & -- & $<.015$ & $<.006$ & $<.003$ & -- & $<.003$ & .015 & .015 & $\begin{array}{l}\text { ODEQ } \\
(1994 b)\end{array}$ \\
\hline Willamette & 48 & 1989 & Common carp & $\mathrm{f}$ & 2 & -- & -- & -- & -- & $<.125$ & $<.05$ & $<.025$ & -- & $<.025$ & $<.025$ & $<.125$ & $\begin{array}{l}\text { ODEQ } \\
(1994 b)\end{array}$ \\
\hline Willamette & 48 & 1989 & Common carp & Liver & 2 & -- & -- & -- & -- & $<.2$ & $<.08$ & $<.04$ & -- & $<.04$ & $<.04$ & $<.2$ & $\begin{array}{l}\text { ODEQ } \\
\text { (1994b) }\end{array}$ \\
\hline Willamette & 48 & 1988 & Common carp & $\mathrm{f}$ & $5 \mathrm{c}$ & -- & -- & -- & -- & $<.015$ & $<.006$ & $<.003$ & -- & .109 & .062 & .171 & $\begin{array}{l}\text { ODEQ } \\
(1994 b)\end{array}$ \\
\hline Willamette & 48 & 1988 & $\begin{array}{l}\text { Northern } \\
\text { squawfish }\end{array}$ & $\mathrm{f}$ & $5 \mathrm{c}$ & -- & -- & -- & -- & $<.02$ & $<.008$ & $<.004$ & -- & $<.004$ & $<.004$ & $<.02$ & $\begin{array}{l}\text { ODEQ } \\
\text { (1994b) }\end{array}$ \\
\hline Willamette & 72 & 1990 & $\begin{array}{l}\text { Northern } \\
\text { squawfish }\end{array}$ & wb & 3 & 0.003 & $<0.002$ & $<0.002$ & $<0.002$ & $<.125$ & $<.050$ & $<.025$ & $<0.025$ & $<.025$ & .040 & -- & $\begin{array}{l}\text { Curtis and } \\
\text { others } \\
\text { (1993) }\end{array}$ \\
\hline Willamette & 72 & 1990 & Common carp & $\mathrm{f}$ & 1 & .002 & $<.002$ & $<.002$ & $<.002$ & $<.125$ & $<.050$ & $<.025$ & $<.025$ & $<.025$ & .040 & -- & $\begin{array}{l}\text { Curtis and } \\
\text { others } \\
\text { (1993) }\end{array}$ \\
\hline Willamette & 74 & 1990 & $\begin{array}{l}\text { Northern } \\
\text { squawfish }\end{array}$ & $w b$ & 3 & $\begin{array}{c}<.002- \\
.005\end{array}$ & $<.002$ & $<.002$ & $<.002$ & $<.125$ & $<.05$ & $<.025$ & -- & $<.025$ & $\begin{array}{l}.026- \\
.058\end{array}$ & $\begin{array}{l}.026- \\
.058\end{array}$ & $\begin{array}{l}\text { ODEQ } \\
\text { (1994b) }\end{array}$ \\
\hline Willamette & 74 & $\begin{array}{l}1989- \\
90\end{array}$ & Common carp & $\mathrm{f}$ & 6 & $\begin{array}{c}<.002- \\
.002\end{array}$ & $<.002$ & $<.002$ & $<.002$ & $<.15$ & $<.06$ & $<.03$ & -- & $<.03$ & $<.03$ & $<.15$ & $\begin{array}{l}\text { ODEQ } \\
(1994 b)\end{array}$ \\
\hline Willamette & 74 & 1989 & Common carp & Liver & 3 & -- & -- & -- & -- & $<.15$ & $<.06$ & $<.03$ & -- & $<.03$ & $<.03$ & $<.15$ & $\begin{array}{l}\text { ODEQ } \\
(1994 b)\end{array}$ \\
\hline
\end{tabular}


APPENDIX F. POLYCHLORINATED BIPHENYLS IN TISSUE OF AQUATIC BIOTA FROM THE WILLAMETTE BASIN, OREGON-Continued

\begin{tabular}{|c|c|c|c|c|c|c|c|c|c|c|c|c|c|c|c|c|c|}
\hline \multirow[b]{2}{*}{ River } & \multirow[b]{2}{*}{$\begin{array}{l}\text { River } \\
\text { mile }\end{array}$} & \multirow[b]{2}{*}{ Years } & \multirow[b]{2}{*}{ Species } & \multirow[b]{2}{*}{$\begin{array}{c}\text { Tissue } \\
\text { type }\end{array}$} & \multirow[b]{2}{*}{$\begin{array}{l}\text { Number } \\
\text { samples }\end{array}$} & \multicolumn{11}{|c|}{ Concentration range ( $\mu \mathrm{g} / \mathrm{g}$, wet weight) } & \multirow[b]{2}{*}{$\begin{array}{l}\text { Refer- } \\
\text { ence }\end{array}$} \\
\hline & & & & & & $\begin{array}{c}3,3^{\prime}, 4,4^{\prime} \\
\text { TCBP }\end{array}$ & $\begin{array}{c}2,3,3^{\prime}, 4^{\prime} 4^{\prime} \\
\text { PCBP }\end{array}$ & $\begin{array}{c}3,3^{\prime}, 4,4^{\prime}, 5^{\prime} \\
\text { РCBP }\end{array}$ & $\begin{array}{c}3,3^{\prime}, 4,4^{\prime}, 5,5^{\prime} \\
\text { HxCBP }\end{array}$ & $\begin{array}{l}1221 \\
\text { PCB }\end{array}$ & $\begin{array}{l}1232 \\
\text { PCB }\end{array}$ & $\begin{array}{l}1242 \\
\text { PCB }\end{array}$ & $\begin{array}{l}1248 \\
\text { PCB }\end{array}$ & $\begin{array}{l}1254 \\
\text { PCB }\end{array}$ & $\begin{array}{l}1260 \\
\text { PCB }\end{array}$ & $\begin{array}{l}\text { Total } \\
\text { PCB }\end{array}$ & \\
\hline Willamette & 131 & 1990 & $\begin{array}{l}\text { Northern } \\
\text { squawfish }\end{array}$ & wb & 3 & $<0.002$ & $<0.002$ & $<0.002$ & $<0.002$ & $<0.125$ & $<0.05$ & $<0.025$ & -- & $<0.025$ & $<0.025$ & $<0.025$ & $\begin{array}{l}\text { ODEQ } \\
(1994 b)\end{array}$ \\
\hline Willamette & 131 & 1990 & $\begin{array}{l}\text { Northern } \\
\text { squawfish }\end{array}$ & wb & 3 & $<.002$ & $<.002$ & $<.002$ & $<.002$ & $<.125$ & $<.050$ & $<.025$ & $<0.025$ & $<.025$ & $<.025$ & -- & $\begin{array}{l}\text { Curtis and } \\
\text { others } \\
\text { (1993) }\end{array}$ \\
\hline Willamette & 131 & 1990 & Common carp & $\mathrm{f}$ & $1-5$ & $\begin{array}{r}.003 \\
\pm .001\end{array}$ & $<.002$ & $<.002$ & $<.002$ & $<.125$ & $<.050$ & $<.025$ & $<.025$ & $<.025$ & $<.025$ & -- & $\begin{array}{l}\text { Curtis and } \\
\text { others } \\
\text { (1993) }\end{array}$ \\
\hline Willamette & 131 & 1990 & Common carp & $\mathrm{f}$ & 3 & $\begin{array}{c}<.002- \\
.002\end{array}$ & $<.002$ & $<.002$ & $<.002$ & $<.125$ & $<.05$ & $<.025$ & -- & $<.025$ & $<.025$ & $<.025$ & $\begin{array}{l}\text { ODEQ } \\
(1994 b)\end{array}$ \\
\hline Willamette & 147 & 1990 & $\begin{array}{l}\text { Northern } \\
\text { squawfish }\end{array}$ & wb & 3 & $\begin{array}{c}<.002- \\
.003\end{array}$ & $<.002$ & $<.002$ & $<.002$ & $<.125$ & $<.05$ & $<.025$ & -- & $<.025$ & $\begin{array}{c}<.025- \\
.028\end{array}$ & $\begin{array}{r}<.05- \\
.028\end{array}$ & $\begin{array}{l}\text { ODEQ } \\
(1994 b)\end{array}$ \\
\hline Willamette & 147 & 1990 & $\begin{array}{l}\text { Cutthroat } \\
\text { trout }\end{array}$ & wb & 5 & $\begin{array}{c}<.002- \\
.003\end{array}$ & $<.002$ & $<.002$ & $<.002$ & $<.125$ & $<.05$ & $<.025$ & -- & $<.025$ & $<.025$ & $<.05$ & $\begin{array}{l}\text { ODEQ } \\
(1994 b)\end{array}$ \\
\hline Willamette & 148 & 1990 & $\begin{array}{l}\text { Northern } \\
\text { squawfish }\end{array}$ & wb & 3 & .003 & $<.002$ & $<.002$ & $<.002$ & $<.125$ & $<.050$ & $<.025$ & $<.025$ & $<.025$ & .028 & -- & $\begin{array}{l}\text { Curtis and } \\
\text { others } \\
\text { (1993) }\end{array}$ \\
\hline Willamette & 148 & 1990 & $\begin{array}{l}\text { Cutthroat } \\
\text { trout }\end{array}$ & wb & $1-5$ & $\begin{array}{r}.0023 \\
\pm .0004\end{array}$ & $<.002$ & $<.002$ & $<.002$ & $<.125$ & $<.050$ & $<.025$ & $<.025$ & $<.025$ & $<.025$ & -- & $\begin{array}{l}\text { Curtis and } \\
\text { others } \\
\text { (1993) }\end{array}$ \\
\hline Willamette & 160 & 1990 & $\begin{array}{l}\text { Northern } \\
\text { squawfish }\end{array}$ & wb & 3 & .003 & $<.002$ & .003 & $<.002$ & $<.125$ & $<.050$ & $<.025$ & $<.025$ & $<.025$ & .055 & -- & $\begin{array}{l}\text { Curtis and } \\
\text { others } \\
\text { (1993) }\end{array}$ \\
\hline Willamette & 160 & 1990 & $\begin{array}{l}\text { Cutthroat } \\
\text { trout }\end{array}$ & wb & 1 & .003 & $<.002$ & $<.002$ & $<.002$ & $<.125$ & $<.050$ & $<.025$ & $<.025$ & $<.025$ & $<.025$ & -- & $\begin{array}{l}\text { Curtis and } \\
\text { others } \\
\text { (1993) }\end{array}$ \\
\hline Willamette & 161 & 1990 & $\begin{array}{l}\text { Northern } \\
\text { squawfish }\end{array}$ & $w b$ & 3 & $\begin{array}{c}<.002- \\
.004\end{array}$ & $<.002$ & $\begin{array}{c}<.002- \\
.005\end{array}$ & $<.002$ & $<.125$ & $<.050$ & $<.025$ & -- & $<.025$ & $\begin{array}{l}.033- \\
.085\end{array}$ & $\begin{array}{l}.033- \\
.085\end{array}$ & $\begin{array}{l}\text { ODEQ } \\
(1994 b)\end{array}$ \\
\hline Willamette & 161 & 1990 & $\begin{array}{l}\text { Cutthroat } \\
\text { trout }\end{array}$ & wb & 5 & $\begin{array}{c}<.002- \\
.003\end{array}$ & $<.002$ & $<.002$ & $<.002$ & $<.125$ & $<.050$ & $<.025$ & -- & $<.025$ & $<.025$ & $<.025$ & $\begin{array}{l}\text { ODEQ } \\
\text { (1994b) }\end{array}$ \\
\hline Willamette & 195 & 1990 & $\begin{array}{l}\text { Cutthroat } \\
\text { trout }\end{array}$ & wb & 1 & .003 & $<.002$ & $<.002$ & $<.002$ & $<.125$ & $<.050$ & $<.025$ & $<.025$ & $<.025$ & $<.025$ & -- & $\begin{array}{l}\text { Curtis and } \\
\text { others } \\
\text { (1993) }\end{array}$ \\
\hline
\end{tabular}


APPENDIX F. POLYCHLORINATED BIPHENYLS IN TISSUE OF AQUATIC BIOTA FROM THE WILLAMETTE BASIN, OREGON-Continued

\begin{tabular}{|c|c|c|c|c|c|c|c|c|c|c|c|c|c|c|c|c|c|}
\hline \multirow[b]{2}{*}{ River } & \multirow[b]{2}{*}{$\begin{array}{c}\text { River } \\
\text { mile }\end{array}$} & \multirow[b]{2}{*}{ Years } & \multirow[b]{2}{*}{ Species } & \multirow[b]{2}{*}{$\begin{array}{l}\text { Tissue } \\
\text { type }\end{array}$} & \multirow[b]{2}{*}{$\begin{array}{l}\text { Number } \\
\text { samples }\end{array}$} & \multicolumn{11}{|c|}{ Concentration range ( $\mu \mathrm{g} / \mathrm{g}$, wet weight) } & \multirow[b]{2}{*}{$\begin{array}{c}\text { Refer- } \\
\text { ence }\end{array}$} \\
\hline & & & & & & $\begin{array}{c}3,3^{\prime}, 4,4^{\prime} \\
\text { TCBP }\end{array}$ & $\begin{array}{c}2,3,3^{\prime}, 4,4^{\prime} \\
\text { РСBP }\end{array}$ & $\begin{array}{c}3,3^{\prime}, 4,4^{\prime}, 5^{\prime} \\
\text { РСВP }\end{array}$ & $\begin{array}{c}3,3^{\prime}, 4,4^{\prime}, 5,5^{\prime} \\
\text { HхCBP }\end{array}$ & $\begin{array}{l}1221 \\
\text { PCB }\end{array}$ & $\begin{array}{l}1232 \\
\text { PCB }\end{array}$ & $\begin{array}{l}1242 \\
\text { PCB }\end{array}$ & $\begin{array}{l}1248 \\
\text { PCB }\end{array}$ & $\begin{array}{l}1254 \\
\text { PCB }\end{array}$ & $\begin{array}{l}1260 \\
\text { PCB }\end{array}$ & $\begin{array}{l}\text { Total } \\
\text { PCB }\end{array}$ & \\
\hline Willamette & 195 & 1990 & $\begin{array}{l}\text { Northern } \\
\text { squawfish }\end{array}$ & wb & 3 & 0.008 & 0.003 & 0.004 & $<0.002$ & $<0.125$ & $<0.050$ & $<0.025$ & $<0.025$ & $<0.025$ & 0.106 & -- & $\begin{array}{l}\text { Curtis and } \\
\text { others } \\
\text { (1993) }\end{array}$ \\
\hline $\begin{array}{l}\text { Middle Fork } \\
\text { Willamette }\end{array}$ & 8 & 1990 & $\begin{array}{l}\text { Northern } \\
\text { squawfish }\end{array}$ & wb & 3 & $\begin{array}{l}.005- \\
.011\end{array}$ & $\begin{array}{l}.002- \\
.004\end{array}$ & $\begin{array}{c}<.002- \\
.007\end{array}$ & $<.002$ & $<.125$ & $<.050$ & $<.025$ & -- & $<.025$ & $\begin{array}{l}.074- \\
.131\end{array}$ & $\begin{array}{c}0.074- \\
.131\end{array}$ & $\begin{array}{l}\text { ODEQ } \\
\text { (1994b) }\end{array}$ \\
\hline $\begin{array}{l}\text { Middle Fork } \\
\text { Willamette }\end{array}$ & 8 & 1990 & $\begin{array}{l}\text { Cutthroat } \\
\text { trout }\end{array}$ & wb & 3 & $\begin{array}{c}<.002- \\
.003\end{array}$ & $<.002$ & $<.002$ & $<.002$ & $<.125$ & $<.05$ & $<.025$ & -- & $<.025$ & $<.025$ & $<.025$ & $\begin{array}{l}\text { ODEQ } \\
(1994 b)\end{array}$ \\
\hline Santiam & 0.5 & 1988 & $\begin{array}{l}\text { Northern } \\
\text { squawfish }\end{array}$ & f & 1 & -- & -- & -- & -- & $<.02$ & $<.008$ & $<.004$ & -- & $<.004$ & $<.004$ & $<.02$ & $\begin{array}{l}\text { ODEQ } \\
(1994 b)\end{array}$ \\
\hline $\begin{array}{l}\text { Tualatin, } \\
\text { Cherry Grove }\end{array}$ & -- & 1987 & Crayfish & wb & $3-5 c$ & -- & -- & -- & -- & -- & -- & -- & -- & -- & -- & ND & $\begin{array}{l}\text { USEPA } \\
\text { (1992a) }\end{array}$ \\
\hline $\begin{array}{l}\text { Tualatin, } \\
\text { Cook Park }\end{array}$ & -- & 1987 & Sucker & wb & $3-5 c$ & -- & -- & -- & -- & -- & -- & -- & -- & -- & -- & .72201 & $\begin{array}{l}\text { USEPA } \\
\text { (1992a) }\end{array}$ \\
\hline Tualatin & 8 & 1989 & Sucker & $\mathrm{f}$ & $5 \mathrm{c}$ & -- & -- & -- & -- & $<.15$ & $<.06$ & $<.03$ & -- & $<.03$ & $<.03$ & $<.15$ & $\begin{array}{l}\text { ODEQ } \\
(1994 b)\end{array}$ \\
\hline Yamhill & 5 & 1989 & Unknown & $\mathrm{f}$ & $5 \mathrm{c}$ & -- & -- & -- & -- & $<.125$ & $<.05$ & $<.025$ & -- & $<.025$ & $<.025$ & $<.025$ & $\begin{array}{l}\text { ODEQ } \\
(1994 b)\end{array}$ \\
\hline Conser Slough $^{2}$ & 0.1 & 1989 & Sucker & $\mathrm{f}$ & 1 & -- & -- & -- & -- & $<.125$ & $<.05$ & $<.025$ & -- & $<.025$ & $<.025$ & $<.025$ & $\begin{array}{l}\text { ODEQ } \\
(1994 b)\end{array}$ \\
\hline Conser Slough & 0.1 & 1989 & $\begin{array}{l}\text { Northern } \\
\text { squawfish }\end{array}$ & $\mathrm{f}$ & $3-4 c, 2 s$ & -- & -- & -- & -- & $<.15$ & $<.06$ & $<.03$ & -- & $<.03$ & $<.03$ & $<.15$ & $\begin{array}{l}\text { ODEQ } \\
\text { (1994b) }\end{array}$ \\
\hline Conser Slough & 0.1 & 1988 & Bass & $\mathrm{f}$ & $2 \mathrm{c}$ & -- & -- & -- & -- & $<.15$ & $<.06$ & $<.225$ & -- & $<.003$ & $<.003$ & $<.225$ & $\begin{array}{l}\text { ODEQ } \\
(1994 b)\end{array}$ \\
\hline Conser Slough & 0.1 & 1988 & Common carp & $\mathrm{f}$ & $4 c$ & -- & -- & -- & -- & $<.15$ & $<.006$ & .242 & -- & .132 & $<.003$ & .374 & $\begin{array}{l}\text { ODEQ } \\
(1994 b)\end{array}$ \\
\hline
\end{tabular}

${ }^{1}$ Total PCB refers to the sum of concentrations of compounds with 1 to 10 chlorines.

${ }^{2}$ Conser Slough is a tributary of the Willamette River near Albany, Oregon (Willamette River Subbasin). 


\section{APPENDIX G-1. TRACE ELEMENTS IN TISSUE OF AQUATIC BIOTA FROM THE WILLAMETTE BASIN, OREGON}

$[\mu \mathrm{g} / \mathrm{g}$, micrograms per gram. River mile: --, not available; $\sim$, approximately. Tissue type: f, fillet; wb, whole-body. Number samples: c, composite sample; r, replicate sample; $s$, number of composite samples.

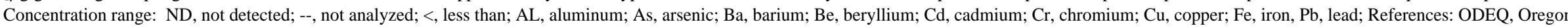
Department of Environmental Quality; USFWS, U.S. Fish and Wildlife Service]

\begin{tabular}{|c|c|c|c|c|c|c|c|c|c|c|c|c|c|c|c|}
\hline \multirow[b]{2}{*}{ River } & \multirow[b]{2}{*}{$\begin{array}{c}\text { River } \\
\text { mile }\end{array}$} & \multirow[b]{2}{*}{ Years } & \multirow[b]{2}{*}{ Species } & \multirow[b]{2}{*}{$\begin{array}{l}\text { Tissue } \\
\text { type }\end{array}$} & \multirow[b]{2}{*}{$\begin{array}{l}\text { Number } \\
\text { samples }\end{array}$} & \multicolumn{9}{|c|}{ Concentration range $(\mu \mathbf{g} / \mathbf{g}$, wet weight) } & \multirow[b]{2}{*}{$\begin{array}{l}\text { Refer- } \\
\text { ence }\end{array}$} \\
\hline & & & & & & Al & As & $\mathrm{Ba}$ & $\mathrm{Be}$ & Cd & $\mathrm{Cr}$ & $\mathrm{Cu}$ & $\mathrm{Fe}$ & $\mathrm{Pb}$ & \\
\hline Willamette & 7 & 1989 & Common carp & $f$ & 3 & -- & $<0.07$ & -- & -- & $\begin{array}{c}<0.01- \\
.02\end{array}$ & $<0.03$ & $\begin{array}{c}0.56- \\
.78\end{array}$ & -- & $<0.03$ & $\begin{array}{l}\text { ODEQ } \\
(1994 b)\end{array}$ \\
\hline Willamette & 7 & $\begin{array}{l}1988- \\
89\end{array}$ & Common carp & f & $5 c, 2 s$ & -- & $<.03$ & -- & -- & $<.01$ & $<.03$ & $\begin{array}{l}.16- \\
.20\end{array}$ & -- & $\begin{array}{l}.03- \\
<.05\end{array}$ & $\begin{array}{l}\text { ODEQ } \\
(1994 b)\end{array}$ \\
\hline Willamette & 18 & 1989 & Common carp & f & $4 c$ & -- & $<.07$ & -- & -- & $<.01$ & $<.03$ & .30 & -- & $<.03$ & $\begin{array}{l}\text { ODEQ } \\
\text { (1994b) }\end{array}$ \\
\hline Willamette & 18 & 1989 & Sucker & f & $3 \mathrm{c}$ & -- & $<.07$ & -- & -- & $<.01$ & $<.03$ & .27 & -- & $<.03$ & $\begin{array}{l}\text { ODEQ } \\
(1994 b)\end{array}$ \\
\hline Willamette & $\sim 26$ & 1971 & $\begin{array}{l}\text { Largescale } \\
\text { sucker }\end{array}$ & wb & $5 c$ & -- & .05 & -- & -- & $<.05$ & -- & -- & -- & ND & $\begin{array}{l}\text { Walsh and } \\
\text { others } \\
\text { (1977) }\end{array}$ \\
\hline Willamette & $\sim 26$ & 1971 & $\begin{array}{l}\text { Largescale } \\
\text { sucker }\end{array}$ & wb & $5 \mathrm{c}, \mathrm{r}$ & -- & .05 & -- & -- & $<.05$ & -- & -- & -- & $<.10$ & $\begin{array}{l}\text { Walsh and } \\
\text { others } \\
\text { (1977) }\end{array}$ \\
\hline Willamette & $\sim 26$ & 1971 & $\begin{array}{l}\text { Northern } \\
\text { squawfish }\end{array}$ & wb & $3 \mathrm{c}$ & -- & $<.05$ & -- & -- & $<.05$ & -- & -- & -- & $<.10$ & $\begin{array}{l}\text { Walsh and } \\
\text { others } \\
(1977)\end{array}$ \\
\hline Willamette & $\sim 26$ & 1971 & $\begin{array}{l}\text { Northern } \\
\text { squawfish }\end{array}$ & wb & $3 \mathrm{c}, \mathrm{r}$ & -- & $<.05$ & -- & -- & $<.05$ & -- & -- & -- & $<.10$ & $\begin{array}{l}\text { Walsh and } \\
\text { others } \\
\text { (1977) }\end{array}$ \\
\hline Willamette & $\sim 26$ & 1972 & $\begin{array}{l}\text { Channel } \\
\text { catfish }\end{array}$ & wb & $5 c$ & -- & $<.05$ & -- & -- & $<.05$ & -- & -- & -- & .10 & $\begin{array}{l}\text { Walsh and } \\
\text { others } \\
\text { (1977) }\end{array}$ \\
\hline Willamette & $\sim 26$ & 1972 & $\begin{array}{l}\text { Northern } \\
\text { squawfish }\end{array}$ & wb & $5 c$ & -- & $<.05$ & -- & -- & .13 & -- & -- & -- & .20 & $\begin{array}{l}\text { Walsh and } \\
\text { others } \\
\text { (1977) }\end{array}$ \\
\hline Willamette & $\sim 26$ & 1972 & $\begin{array}{l}\text { Largescale } \\
\text { sucker }\end{array}$ & wb & $5 c$ & -- & .14 & -- & -- & $<.05$ & -- & -- & -- & .10 & $\begin{array}{l}\text { Walsh and } \\
\text { others } \\
\text { (1977) }\end{array}$ \\
\hline Willamette & $\sim 26$ & 1972 & $\begin{array}{l}\text { Largescale } \\
\text { sucker }\end{array}$ & wb & $5 \mathrm{c}, \mathrm{r}$ & -- & $<.05$ & -- & -- & .02 & -- & -- & -- & .10 & $\begin{array}{l}\text { Walsh and } \\
\text { others } \\
\text { (1977) }\end{array}$ \\
\hline Willamette & $\sim 26$ & $\begin{array}{l}1976- \\
77\end{array}$ & Smallmouth & wb & $3 \mathrm{c}$ & -- & $<.25$ & -- & -- & $<.05$ & -- & -- & -- & .12 & $\begin{array}{l}\text { May and } \\
\text { McKinney } \\
\text { (1981) }\end{array}$ \\
\hline
\end{tabular}


APPENDIX G-1. TRACE ELEMENTS IN TISSUE OF AQUATIC BIOTA FROM THE WILLAMETTE BASIN,

\section{OREGON-Continued}

\begin{tabular}{|c|c|c|c|c|c|c|c|c|c|c|c|c|c|c|c|}
\hline \multirow[b]{2}{*}{ River } & \multirow[b]{2}{*}{$\begin{array}{c}\text { River } \\
\text { mile }\end{array}$} & \multirow[b]{2}{*}{ Years } & \multirow[b]{2}{*}{ Species } & \multirow[b]{2}{*}{$\begin{array}{c}\text { Tissue } \\
\text { type }\end{array}$} & \multirow[b]{2}{*}{$\begin{array}{l}\text { Number } \\
\text { samples }\end{array}$} & \multicolumn{9}{|c|}{ Concentration range $(\mu \mathrm{g} / \mathrm{g}$, wet weight) } & \multirow[b]{2}{*}{$\begin{array}{l}\text { Refer- } \\
\text { ence }\end{array}$} \\
\hline & & & & & & Al & As & $\mathrm{Ba}$ & $\mathrm{Be}$ & Cd & $\mathrm{Cr}$ & $\mathrm{Cu}$ & $\mathrm{Fe}$ & $\mathrm{Pb}$ & \\
\hline Willamette & $\sim 26$ & $\begin{array}{l}1976- \\
77\end{array}$ & Chiselmouth & wb & $5 \mathrm{c}$ & -- & 1.15 & -- & -- & 0.20 & -- & -- & -- & 0.85 & $\begin{array}{l}\text { May and } \\
\text { McKinney } \\
(1981)\end{array}$ \\
\hline Willamette & $\sim 26$ & 1978 & $\begin{array}{l}\text { Northern } \\
\text { squawfish }\end{array}$ & $\mathrm{wb}$ & $3-5 \mathrm{c}$ & -- & .05 & -- & -- & .01 & -- & 0.7 & -- & .10 & $\begin{array}{l}\text { Lowe and } \\
\text { others } \\
(1985)\end{array}$ \\
\hline Willamette & $\sim 26$ & 1978 & Chiselmouth & wb & $3-5 \mathrm{c}$ & -- & .13 & -- & -- & .03 & -- & 1.2 & -- & .23 & $\begin{array}{l}\text { Lowe and } \\
\text { others } \\
(1985)\end{array}$ \\
\hline Willamette & $\sim 26$ & 1978 & Chiselmouth & wb & $3-5 c$ & -- & .16 & -- & -- & .03 & -- & 1.6 & -- & .54 & $\begin{array}{l}\text { Lowe and } \\
\text { others } \\
(1985)\end{array}$ \\
\hline Willamette & $\sim 26$ & 1980 & $\begin{array}{l}\text { Largescale } \\
\text { sucker }\end{array}$ & $\mathrm{wb}$ & $3-5 c$ & -- & .07 & -- & -- & .01 & -- & .9 & -- & .15 & $\begin{array}{l}\text { Lowe and } \\
\text { others } \\
(1985)\end{array}$ \\
\hline Willamette & $\sim 26$ & 1980 & $\begin{array}{l}\text { Largescale } \\
\text { sucker }\end{array}$ & wb & $3-5 c$ & -- & .07 & -- & -- & .02 & -- & 1.0 & -- & .13 & $\begin{array}{l}\text { Lowe and } \\
\text { others } \\
(1985)\end{array}$ \\
\hline Willamette & $\sim 26$ & 1980 & $\begin{array}{l}\text { Northern } \\
\text { squawfish }\end{array}$ & wb & $3-5 c$ & -- & .06 & -- & -- & .01 & -- & 1.2 & -- & .10 & $\begin{array}{l}\text { Lowe and } \\
\text { others } \\
(1985)\end{array}$ \\
\hline Willamette & $\sim 26$ & 1984 & $\begin{array}{l}\text { Northern } \\
\text { squawfish }\end{array}$ & wb & $3-5 c$ & -- & .30 & -- & -- & .00 & -- & .57 & -- & .03 & $\begin{array}{l}\text { Schmitt and } \\
\text { Brumbaugh } \\
\text { (1990) }\end{array}$ \\
\hline Willamette & $\sim 26$ & 1984 & Peamouth & wb & $3-5 c$ & -- & .7 & -- & -- & .01 & -- & .50 & -- & .08 & $\begin{array}{l}\text { Schmitt and } \\
\text { Brumbaugh } \\
\text { (1990) }\end{array}$ \\
\hline Willamette & $\sim 26$ & 1984 & Peamouth & wb & $3-5 c$ & -- & .06 & -- & -- & .01 & -- & .59 & -- & .05 & $\begin{array}{l}\text { Schmitt and } \\
\text { Brumbaugh } \\
\text { (1990) }\end{array}$ \\
\hline Willamette & 27 & 1988 & Bass & f & $3 \mathrm{c}$ & -- & $<.05$ & -- & -- & $<.01$ & $<.03$ & .23 & -- & $<.03$ & $\begin{array}{l}\text { ODEQ } \\
(1994 b)\end{array}$ \\
\hline Willamette & 27 & 1988 & Common carp & $\mathrm{f}$ & $3 \mathrm{c}, 2 \mathrm{~s}$ & -- & $<.03$ & -- & -- & $<.01$ & $<.03$ & $\begin{array}{l}.13- \\
.16\end{array}$ & -- & $<.03$ & $\begin{array}{l}\text { ODEQ } \\
(1994 b)\end{array}$ \\
\hline Willamette & 27 & 1988 & $\begin{array}{l}\text { Northern } \\
\text { squawfish }\end{array}$ & $\mathrm{f}$ & $3 c$ & -- & $<.03$ & -- & -- & $<.01$ & $<.03$ & .24 & -- & $<.03$ & $\begin{array}{l}\text { ODEQ } \\
\text { (1994b) }\end{array}$ \\
\hline
\end{tabular}


APPENDIX G-1. TRACE ELEMENTS IN TISSUE OF AQUATIC BIOTA FROM THE WILLAMETTE BASIN,

\section{OREGON-Continued}

\begin{tabular}{|c|c|c|c|c|c|c|c|c|c|c|c|c|c|c|c|}
\hline \multirow[b]{2}{*}{ River } & \multirow[b]{2}{*}{$\begin{array}{c}\text { River } \\
\text { mile }\end{array}$} & \multirow[b]{2}{*}{ Years } & \multirow[b]{2}{*}{ Species } & \multirow[b]{2}{*}{$\begin{array}{c}\text { Tissue } \\
\text { type }\end{array}$} & \multirow[b]{2}{*}{$\begin{array}{l}\text { Number } \\
\text { samples }\end{array}$} & \multicolumn{9}{|c|}{ Concentration range $(\mu \mathrm{g} / \mathrm{g}$, wet weight) } & \multirow[b]{2}{*}{$\begin{array}{l}\text { Refer- } \\
\text { ence }\end{array}$} \\
\hline & & & & & & Al & As & $\mathrm{Ba}$ & $\mathrm{Be}$ & Cd & $\mathrm{Cr}$ & $\mathrm{Cu}$ & $\mathrm{Fe}$ & $\mathbf{P b}$ & \\
\hline Willamette & 28 & 1989 & Common carp & $\mathrm{f}$ & 3 & -- & $<0.07$ & -- & -- & $\begin{array}{c}<0.01- \\
.02\end{array}$ & $\begin{array}{c}<0.03- \\
.04\end{array}$ & $\begin{array}{c}0.41- \\
.54\end{array}$ & -- & $<0.03$ & $\begin{array}{l}\text { ODEQ } \\
(1994 b)\end{array}$ \\
\hline Willamette & 38 & 1989 & Sucker & $\mathrm{f}$ & $5 \mathrm{c}$ & -- & .06 & -- & -- & $<.01$ & $<.03$ & .2 & -- & $<.03$ & $\begin{array}{l}\text { ODEQ } \\
(1994 b)\end{array}$ \\
\hline Willamette & 38 & $\begin{array}{l}1988- \\
89\end{array}$ & $\begin{array}{l}\text { Northern } \\
\text { squawfish }\end{array}$ & $\mathrm{f}$ & $5 \mathrm{c}, 2 \mathrm{~s}$ & -- & $<.06$ & -- & -- & $<.01$ & $<.03$ & $\begin{array}{l}.24- \\
.31\end{array}$ & -- & $<.03$ & $\begin{array}{l}\text { ODEQ } \\
(1994 b)\end{array}$ \\
\hline Willamette & 38 & 1988 & Common carp & $\mathrm{f}$ & $3 c$ & -- & $<.03$ & -- & -- & $<.01$ & $<.03$ & .19 & -- & $<.03$ & $\begin{array}{l}\text { ODEQ } \\
(1994 b)\end{array}$ \\
\hline Willamette & 48 & 1989 & Common carp & $\mathrm{f}$ & 2 & -- & $\begin{array}{c}<.07 \\
.1\end{array}$ & -- & -- & $<.01$ & $<.03$ & $\begin{array}{l}.15- \\
.33\end{array}$ & -- & $<.03$ & $\begin{array}{l}\text { ODEQ } \\
\text { (1994b) }\end{array}$ \\
\hline Willamette & 48 & 1988 & Common carp & $\mathrm{f}$ & $5 c$ & -- & $<.03$ & -- & -- & $<.01$ & $<.03$ & .22 & -- & $<.03$ & $\begin{array}{l}\text { ODEQ } \\
(1994 b)\end{array}$ \\
\hline Willamette & 48 & 1988 & $\begin{array}{l}\text { Northern } \\
\text { squawfish }\end{array}$ & $\mathrm{f}$ & $5 c$ & -- & $<.03$ & -- & -- & $<.01$ & $<.03$ & .17 & -- & $<.03$ & $\begin{array}{l}\text { ODEQ } \\
\text { (1994b) }\end{array}$ \\
\hline Willamette & 74 & 1989 & Common carp & $\mathrm{f}$ & 3 & -- & $<.07$ & -- & -- & $<.01$ & $<.03$ & $\begin{array}{l}.36- \\
.54\end{array}$ & -- & $<.03$ & $\begin{array}{l}\text { ODEQ } \\
\text { (1994b) }\end{array}$ \\
\hline Santiam & 0.5 & 1988 & $\begin{array}{l}\text { Northern } \\
\text { squawfish }\end{array}$ & $\mathrm{f}$ & 1 & -- & $<.03$ & -- & -- & .01 & .06 & .27 & -- & $<.03$ & $\begin{array}{l}\text { ODEQ } \\
(1994 b)\end{array}$ \\
\hline $\begin{array}{l}\text { Conser } \\
\text { Slough }^{1}\end{array}$ & 0.1 & 1989 & Sucker & $\mathrm{f}$ & $5 c$ & -- & $<.06$ & -- & -- & $<.01$ & $<.03$ & .28 & -- & $<.03$ & $\begin{array}{l}\text { ODEQ } \\
(1994 b)\end{array}$ \\
\hline $\begin{array}{l}\text { Conser } \\
\text { Slough }\end{array}$ & 0.1 & 1989 & $\begin{array}{l}\text { Northern } \\
\text { squawfish }\end{array}$ & $\mathrm{f}$ & $3 c$ & -- & $<.06$ & -- & -- & $<.01$ & $<.03$ & .36 & -- & $<.03$ & $\begin{array}{l}\text { ODEQ } \\
\text { (1994b) }\end{array}$ \\
\hline $\begin{array}{l}\text { Johnson } \\
\text { Creek }\end{array}$ & 1.5 & 1991 & Crayfish & wb & 1 & -- & $<1.52$ & 2.65 & $<0.01$ & .02 & .08 & 10.5 & -- & .18 & $\begin{array}{l}\text { ODEQ } \\
\text { (1994b) }\end{array}$ \\
\hline $\begin{array}{l}\text { Johnson } \\
\text { Creek }\end{array}$ & 3 & 1991 & Crayfish & wb & 1 & -- & $<1.52$ & 2.72 & $<.01$ & .04 & .06 & 15.47 & -- & .13 & $\begin{array}{l}\text { ODEQ } \\
(1994 b)\end{array}$ \\
\hline $\begin{array}{l}\text { Johnson } \\
\text { Creek }\end{array}$ & 6.1 & 1991 & Crayfish & wb & 1 & -- & $<1.27$ & 2.37 & $<.09$ & .02 & $<.03$ & 12.17 & -- & .05 & $\begin{array}{l}\text { ODEQ } \\
\text { (1994b) }\end{array}$ \\
\hline $\begin{array}{l}\text { Johnson } \\
\text { Creek }\end{array}$ & 8.3 & 1991 & Crayfish & wb & 1 & -- & $<1.66$ & 5.75 & $<.11$ & .02 & $<.04$ & 19.89 & -- & .07 & $\begin{array}{l}\text { ODEQ } \\
(1994 b)\end{array}$ \\
\hline $\begin{array}{l}\text { Johnson } \\
\text { Creek }\end{array}$ & -- & 1991 & Crayfish & wb & 1 & -- & $<1.62$ & 5.62 & $<.11$ & .02 & .07 & 17.93 & -- & .09 & $\begin{array}{l}\text { ODEQ } \\
(1994 b)\end{array}$ \\
\hline $\begin{array}{l}\text { Johnson } \\
\text { Creek }\end{array}$ & 16.9 & 1991 & Crayfish & $w b$ & 1 & -- & $<1.75$ & 7.22 & $<.12$ & .05 & .05 & 18.17 & -- & $<.07$ & $\begin{array}{l}\text { ODEQ } \\
(1994 b)\end{array}$ \\
\hline
\end{tabular}


APPENDIX G-1. TRACE ELEMENTS IN TISSUE OF AQUATIC BIOTA FROM THE WILLAMETTE BASIN, OREGON-Continued

\begin{tabular}{|c|c|c|c|c|c|c|c|c|c|c|c|c|c|c|c|}
\hline \multirow[b]{2}{*}{ River } & \multirow[b]{2}{*}{$\begin{array}{c}\text { River } \\
\text { mile }\end{array}$} & \multirow[b]{2}{*}{ Years } & \multirow[b]{2}{*}{ Species } & \multirow[b]{2}{*}{$\begin{array}{l}\text { Tissue } \\
\text { type }\end{array}$} & \multirow[b]{2}{*}{$\begin{array}{l}\text { Number } \\
\text { samples }\end{array}$} & \multicolumn{9}{|c|}{ Concentration range ( $\mu \mathrm{g} / \mathrm{g}$, wet weight) } & \multirow[b]{2}{*}{$\begin{array}{l}\text { Refer- } \\
\text { ence }\end{array}$} \\
\hline & & & & & & Al & As & $\mathrm{Ba}$ & $\mathrm{Be}$ & Cd & $\mathrm{Cr}$ & $\mathrm{Cu}$ & $\mathrm{Fe}$ & $\mathbf{P b}$ & \\
\hline $\begin{array}{l}\text { Johnson } \\
\text { Creek }\end{array}$ & 21 & 1991 & Crayfish & $\mathrm{wb}$ & 1 & -- & $<1.64$ & 4.14 & $<0.11$ & 0.06 & $<0.04$ & 14.17 & -- & $<0.07$ & $\begin{array}{l}\text { ODEQ } \\
\text { (1994b) }\end{array}$ \\
\hline $\begin{array}{l}\text { Johnson } \\
\text { Creek }\end{array}$ & -- & 1991 & Crayfish & wb & 1 & -- & $<1.55$ & 5.15 & $<.11$ & .02 & .04 & 17.51 & -- & .08 & $\begin{array}{l}\text { ODEQ } \\
\text { (1994b) }\end{array}$ \\
\hline Rock Creek ${ }^{2}$ & 1.5 & 1994 & $\begin{array}{l}\text { Three-spined } \\
\text { stickleback }\end{array}$ & wb & $\begin{array}{l}15- \\
20 \mathrm{c}\end{array}$ & 102 & -- & 1.31 & -- & $<.10$ & $<.10$ & 1.31 & 55.0 & $<.45$ & $\begin{array}{l}\text { USFWS } \\
(1994 c)\end{array}$ \\
\hline Rock Creek & 1.5 & 1994 & $\begin{array}{l}\text { Largemouth } \\
\text { bass }\end{array}$ & wb & $2 \mathrm{c}$ & 5.10 & -- & .43 & -- & $<.10$ & 1.71 & .71 & 43.1 & $<.45$ & $\begin{array}{l}\text { USFWS } \\
(1994 c)\end{array}$ \\
\hline Rock Creek & $1.7-2.0$ & 1994 & $\begin{array}{l}\text { Three-spined } \\
\text { stickleback }\end{array}$ & $w b$ & $9 \mathrm{c}$ & 11.0 & -- & 1.70 & -- & $<.10$ & 1.60 & 2.40 & 73.2 & $<.45$ & $\begin{array}{l}\text { USFWS } \\
(1994 c)\end{array}$ \\
\hline Rock Creek & $1.7-2.0$ & 1994 & Sculpin & wb & $6 c$ & 2.61 & -- & 1.70 & -- & $<.10$ & .58 & 2.10 & 32.1 & $<.45$ & $\begin{array}{l}\text { USFWS } \\
(1994 c)\end{array}$ \\
\hline Rock Creek & 2 & 1994 & $\begin{array}{l}\text { Three-spined } \\
\text { stickleback }\end{array}$ & wb & $9 \mathrm{c}$ & 11.0 & -- & 2.00 & -- & $<.10$ & .84 & 3.81 & 57.9 & .84 & $\begin{array}{l}\text { USFWS } \\
(1994 c)\end{array}$ \\
\hline Rock Creek & 2 & 1994 & Sculpin & wb & 1 & 4.56 & -- & 1.31 & -- & 1.23 & 3.68 & 7.34 & 48.1 & 1.31 & $\begin{array}{l}\text { USFWS } \\
(1994 c)\end{array}$ \\
\hline Rock Creek & 2.9 & 1994 & $\begin{array}{l}\text { Three-spined } \\
\text { stickleback }\end{array}$ & wb & 1 & 5.39 & -- & 2.90 & -- & $<.48$ & .77 & 9.30 & 27.0 & $<2.16$ & $\begin{array}{l}\text { USFWS } \\
(1994 c)\end{array}$ \\
\hline Rock Creek & 2.9 & 1994 & Crappie & wb & 1 & 2.20 & -- & 1.10 & -- & .58 & 2.10 & 1.20 & 30.1 & $<.45$ & $\begin{array}{l}\text { USFWS } \\
(1994 c)\end{array}$ \\
\hline
\end{tabular}

${ }^{1}$ Conser Slough is a tributary of the Willamette River near Albany, Oregon (Willamette Subbasin).

${ }^{2}$ Rock Creek is a tributary of the Tualatin River near Sherwood, Oregon (Tualatin Subbasin). 


\section{APPENDIX G-2. TRACE ELEMENTS IN TISSUE OF AQUATIC BIOTA FROM THE WILLAMETTE BASIN, OREGON}

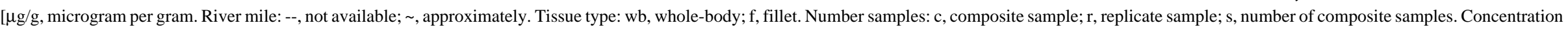

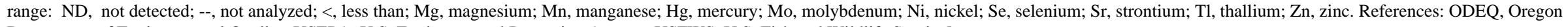
Department of Environmental Quality; USEPA, U.S. Environmental Protection Agency; USFWS, U.S. Fish and Wildlife Service

\begin{tabular}{|c|c|c|c|c|c|c|c|c|c|c|c|c|c|c|c|}
\hline \multirow[b]{2}{*}{ River } & \multirow[b]{2}{*}{$\begin{array}{l}\text { River } \\
\text { mile }\end{array}$} & \multirow[b]{2}{*}{ Years } & \multirow[b]{2}{*}{ Species } & \multirow[b]{2}{*}{$\begin{array}{l}\text { Tissue } \\
\text { type }\end{array}$} & \multirow[b]{2}{*}{$\begin{array}{l}\text { Number } \\
\text { samples }\end{array}$} & \multicolumn{9}{|c|}{ Concentration range ( $\mu \mathrm{g} / \mathrm{g}$, wet weight) } & \multirow[b]{2}{*}{ Reference } \\
\hline & & & & & & Mg & Mn & $\mathrm{Hg}$ & Mo & $\mathrm{Ni}$ & $\mathrm{Se}$ & $\mathrm{Sr}$ & TI & $\mathrm{Zn}$ & \\
\hline $\begin{array}{l}\text { Willamette } \\
\text { Newberg Pool }\end{array}$ & -- & 1987 & $\begin{array}{l}\text { Northern } \\
\text { squawfish }\end{array}$ & wb & $3-5 c$ & -- & -- & 0.11 & -- & -- & -- & -- & -- & -- & USEPA (1992a) \\
\hline $\begin{array}{l}\text { Willamette } \\
\text { Halsey }\end{array}$ & -- & 1987 & $\begin{array}{l}\text { Mountain } \\
\text { whitefish }\end{array}$ & $\mathrm{f}$ & $3-5 c$ & -- & -- & .06 & -- & -- & -- & -- & -- & -- & USEPA (1992a) \\
\hline $\begin{array}{l}\text { Willamette } \\
\text { Halsey }\end{array}$ & -- & 1987 & Sucker & wb & $3-5 c$ & -- & -- & .07 & -- & -- & -- & -- & -- & -- & USEPA (1992a) \\
\hline Willamette & $\sim 7$ & 1987 & Sucker & $w b$ & $3-5 c$ & -- & -- & ND & -- & -- & -- & -- & -- & -- & USEPA (1992a) \\
\hline Willamette & 7 & 1989 & Common carp & $\mathrm{f}$ & 3 & -- & -- & $\begin{array}{l}.11- \\
.17\end{array}$ & -- & -- & -- & -- & -- & $9.55-12.37$ & ODEQ (1994b) \\
\hline Willamette & 7 & 1989 & Common carp & $\mathrm{f}$ & $5 c, 2 s$ & -- & -- & $\begin{array}{l}.17- \\
.19\end{array}$ & -- & -- & -- & -- & -- & $8.14-12.47$ & ODEQ (1994b) \\
\hline Willamette & 18 & 1989 & Common carp & $\mathrm{f}$ & $4 \mathrm{c}$ & -- & -- & .14 & -- & -- & -- & -- & -- & 7.07 & ODEQ (1994b) \\
\hline Willamette & 18 & 1989 & Sucker & $\mathrm{f}$ & $3 \mathrm{c}$ & -- & -- & .05 & -- & -- & -- & -- & -- & 5.64 & ODEQ (1994b) \\
\hline Willamette & $\sim 26$ & 1971 & $\begin{array}{l}\text { Largescale } \\
\text { sucker }\end{array}$ & wb & $5 c$ & -- & -- & .28 & -- & -- & -- & -- & -- & -- & $\begin{array}{l}\text { Walsh and others } \\
\text { (1977) }\end{array}$ \\
\hline Willamette & $\sim 26$ & 1971 & $\begin{array}{l}\text { Largescale } \\
\text { sucker }\end{array}$ & $w b$ & $5 \mathrm{c}, \mathrm{r}$ & -- & -- & .32 & -- & -- & -- & -- & -- & -- & $\begin{array}{l}\text { Walsh and others } \\
\text { (1977) }\end{array}$ \\
\hline Willamette & $\sim 26$ & 1971 & $\begin{array}{l}\text { Northern } \\
\text { squawfish }\end{array}$ & $w b$ & $3 \mathrm{c}$ & -- & -- & 1.10 & -- & -- & -- & -- & -- & -- & $\begin{array}{l}\text { Walsh and others } \\
\text { (1977) }\end{array}$ \\
\hline Willamette & $\sim 26$ & 1971 & $\begin{array}{l}\text { Northern } \\
\text { squawfish }\end{array}$ & $w b$ & $3 \mathrm{c}, \mathrm{r}$ & -- & -- & .99 & -- & -- & -- & -- & -- & -- & $\begin{array}{l}\text { Walsh and others } \\
\text { (1977) }\end{array}$ \\
\hline Willamette & $\sim 26$ & 1972 & Channel catfish & wb & $5 c$ & -- & -- & .29 & -- & -- & 0.06 & -- & -- & -- & $\begin{array}{l}\text { Walsh and others } \\
\text { (1977) }\end{array}$ \\
\hline Willamette & $\sim 26$ & 1972 & $\begin{array}{l}\text { Northern } \\
\text { squawfish }\end{array}$ & $w b$ & $5 \mathrm{c}$ & -- & -- & .04 & -- & -- & .04 & -- & -- & -- & $\begin{array}{l}\text { Walsh and others } \\
\text { (1977) }\end{array}$ \\
\hline Willamette & $\sim 26$ & 1972 & $\begin{array}{l}\text { Largescale } \\
\text { sucker }\end{array}$ & wb & $5 \mathrm{c}$ & -- & -- & .24 & -- & -- & .12 & -- & -- & -- & $\begin{array}{l}\text { Walsh and others } \\
\text { (1977) }\end{array}$ \\
\hline Willamette & $\sim 26$ & 1972 & $\begin{array}{l}\text { Largescale } \\
\text { sucker }\end{array}$ & $\mathrm{wb}$ & $5 \mathrm{c}, \mathrm{r}$ & -- & -- & .04 & -- & -- & .09 & -- & -- & -- & $\begin{array}{l}\text { Walsh and others } \\
\text { (1977) }\end{array}$ \\
\hline
\end{tabular}


APPENDIX G-2. TRACE ELEMENTS IN TISSUE OF AQUATIC BIOTA FROM THE WILLAMETTE BASIN, OREGON-Continued

\begin{tabular}{|c|c|c|c|c|c|c|c|c|c|c|c|c|c|c|c|}
\hline \multirow[b]{2}{*}{ River } & \multirow[b]{2}{*}{$\begin{array}{c}\text { River } \\
\text { mile }\end{array}$} & \multirow[b]{2}{*}{ Years } & \multirow[b]{2}{*}{ Species } & \multirow[b]{2}{*}{$\begin{array}{l}\text { Tissue } \\
\text { type }\end{array}$} & \multirow[b]{2}{*}{$\begin{array}{l}\text { Number } \\
\text { samples }\end{array}$} & \multicolumn{9}{|c|}{ Concentration range ( $\mu \mathrm{g} / \mathrm{g}$, wet weight) } & \multirow[b]{2}{*}{ Reference } \\
\hline & & & & & & Mg & Mn & $\mathrm{Hg}$ & Mo & $\mathrm{Ni}$ & Se & $\mathrm{Sr}$ & $\mathrm{TI}$ & Zn & \\
\hline Willamette & $\sim 26$ & 1973 & $\begin{array}{l}\text { Largescale } \\
\text { sucker }\end{array}$ & $w b$ & $5 \mathrm{c}$ & -- & -- & 0.08 & -- & -- & 0.09 & -- & -- & -- & $\begin{array}{l}\text { Walsh and others } \\
\text { (1977) }\end{array}$ \\
\hline Willamette & $\sim 26$ & 1973 & $\begin{array}{l}\text { Largescale } \\
\text { sucker }\end{array}$ & wb & $5 \mathrm{c}, \mathrm{r}$ & -- & -- & .20 & -- & -- & .05 & -- & -- & -- & $\begin{array}{l}\text { Walsh and others } \\
\text { (1977) }\end{array}$ \\
\hline Willamette & $\sim 26$ & 1973 & $\begin{array}{l}\text { Northern } \\
\text { squawfish }\end{array}$ & wb & $5 \mathrm{c}$ & -- & -- & .65 & -- & -- & $<.05$ & -- & -- & -- & $\begin{array}{l}\text { Walsh and others } \\
\text { (1977) }\end{array}$ \\
\hline Willamette & $\sim 26$ & 1973 & Common carp & wb & $5 \mathrm{c}$ & -- & -- & .15 & -- & -- & .18 & -- & -- & -- & $\begin{array}{l}\text { Walsh and others } \\
\text { (1977) }\end{array}$ \\
\hline Willamette & $\sim 26$ & $\begin{array}{l}1976- \\
77\end{array}$ & $\begin{array}{l}\text { Smallmouth } \\
\text { bass }\end{array}$ & wb & $3 c$ & -- & -- & .13 & -- & -- & -- & -- & -- & -- & $\begin{array}{l}\text { May and McKinney } \\
\text { (1981) }\end{array}$ \\
\hline Willamette & $\sim 26$ & 1976-77 & Chiselmouth & wb & $5 \mathrm{c}$ & -- & -- & $<.02$ & -- & -- & -- & -- & -- & -- & $\begin{array}{l}\text { May and McKinney } \\
\text { (1981) }\end{array}$ \\
\hline Willamette & $\sim 26$ & 1978 & $\begin{array}{l}\text { Northern } \\
\text { squawfish }\end{array}$ & wb & $3-5 c$ & -- & -- & .52 & -- & -- & .13 & -- & -- & 23.2 & $\begin{array}{l}\text { Lowe and others } \\
\text { (1985) }\end{array}$ \\
\hline Willamette & $\sim 26$ & 1978 & Chiselmouth & wb & $3-5 c$ & -- & -- & .04 & -- & -- & .17 & -- & -- & 31.9 & $\begin{array}{l}\text { Lowe and others } \\
\text { (1985) }\end{array}$ \\
\hline Willamette & $\sim 26$ & 1978 & Chiselmouth & wb & $3-5 c$ & -- & -- & .03 & -- & -- & .14 & -- & -- & 42.2 & $\begin{array}{l}\text { Lowe and others } \\
\text { (1985) }\end{array}$ \\
\hline Willamette & $\sim 26$ & 1980 & $\begin{array}{l}\text { Largescale } \\
\text { sucker }\end{array}$ & wb & $3-5 c$ & -- & -- & .15 & -- & -- & .20 & -- & -- & 22.4 & $\begin{array}{l}\text { Lowe and others } \\
\text { (1985) }\end{array}$ \\
\hline Willamette & $\sim 26$ & 1980 & $\begin{array}{l}\text { Largescale } \\
\text { sucker }\end{array}$ & wb & $3-5 c$ & -- & -- & .23 & -- & -- & .23 & -- & -- & 22.6 & $\begin{array}{l}\text { Lowe and others } \\
\text { (1985) }\end{array}$ \\
\hline Willamette & $\sim 26$ & 1980 & $\begin{array}{l}\text { Northern } \\
\text { squawfish }\end{array}$ & wb & $3-5 c$ & -- & -- & .77 & -- & -- & .45 & -- & -- & 17.6 & $\begin{array}{l}\text { Lowe and others } \\
\text { (1985) }\end{array}$ \\
\hline Willamette & $\sim 26$ & 1984 & $\begin{array}{l}\text { Northern } \\
\text { squawfish }\end{array}$ & wb & $3-5 c$ & -- & -- & .21 & -- & -- & .25 & -- & -- & 16.35 & $\begin{array}{l}\text { Schmitt and } \\
\text { Brumbaugh (1990) }\end{array}$ \\
\hline Willamette & $\sim 26$ & 1984 & Peamouth & wb & $3-5 c$ & -- & -- & .05 & -- & -- & .11 & -- & -- & 17.48 & $\begin{array}{l}\text { Schmitt and } \\
\text { Brumbaugh (1990) }\end{array}$ \\
\hline Willamette & $\sim 26$ & 1984 & Peamouth & wb & $3-5 c$ & -- & -- & .04 & -- & -- & .13 & -- & -- & 17.55 & $\begin{array}{l}\text { Schmitt and } \\
\text { Brumbaugh (1990) }\end{array}$ \\
\hline Willamette & 27 & 1988 & Bass & $\mathrm{f}$ & $3 c$ & -- & -- & .1 & -- & -- & -- & -- & -- & 5.8 & ODEQ (1994b) \\
\hline Willamette & 27 & 1988 & Common carp & $\mathrm{f}$ & $3 \mathrm{c}, 2 \mathrm{~s}$ & -- & -- & $\begin{array}{l}.2- \\
.46\end{array}$ & -- & -- & -- & -- & -- & $\begin{array}{l}4.85- \\
7.28\end{array}$ & ODEQ (1994b) \\
\hline
\end{tabular}


APPENDIX G-2. TRACE ELEMENTS IN TISSUE OF AQUATIC BIOTA FROM THE WILLAMETTE BASIN, OREGON-Continued

\begin{tabular}{|c|c|c|c|c|c|c|c|c|c|c|c|c|c|c|c|}
\hline \multirow[b]{2}{*}{ River } & \multirow{2}{*}{$\begin{array}{c}\text { River } \\
\text { mile }\end{array}$} & \multirow[b]{2}{*}{ Years } & \multirow[b]{2}{*}{ Species } & \multirow{2}{*}{$\begin{array}{c}\text { Tissue } \\
\text { type }\end{array}$} & \multirow{2}{*}{$\begin{array}{l}\text { Number } \\
\text { samples }\end{array}$} & \multicolumn{9}{|c|}{ Concentration range ( $\mu \mathrm{g} / \mathrm{g}$, wet weight) } & \multirow[b]{2}{*}{ Reference } \\
\hline & & & & & & Mg & Mn & $\mathrm{Hg}$ & Mo & $\mathbf{N i}$ & $\mathrm{Se}$ & $\mathrm{Sr}$ & TI & Zn & \\
\hline Willamette & 27 & 1988 & $\begin{array}{l}\text { Northern } \\
\text { squawfish }\end{array}$ & $\mathrm{f}$ & $3 \mathrm{c}$ & -- & -- & 0.34 & -- & -- & -- & -- & -- & 4.98 & ODEQ (1994b) \\
\hline Willamette & 28 & 1989 & Common carp & $\mathrm{f}$ & 3 & -- & -- & $\begin{array}{l}.14- \\
.16\end{array}$ & -- & -- & -- & -- & -- & $\begin{array}{l}6.7-1 \\
4.56\end{array}$ & ODEQ (1994b) \\
\hline Willamette & 38 & 1989 & Sucker & $\mathrm{f}$ & $9 \mathrm{c}$ & -- & -- & .11 & -- & -- & -- & -- & -- & 5.1 & ODEQ (1994b) \\
\hline Willamette & 38 & $1988-89$ & $\begin{array}{l}\text { Northern } \\
\text { squawfish }\end{array}$ & f & $5 \mathrm{c}, 2 \mathrm{~s}$ & -- & -- & $\begin{array}{l}.14- \\
.23\end{array}$ & -- & -- & -- & -- & -- & $\begin{array}{l}6.06- \\
7.68\end{array}$ & ODEQ (1994b) \\
\hline Willamette & 38 & 1988 & Common carp & $\mathrm{f}$ & $3 \mathrm{c}$ & -- & -- & .12 & -- & -- & -- & -- & -- & 16.28 & ODEQ (1994b) \\
\hline Willamette & 48 & 1989 & Common carp & $\mathrm{f}$ & 2 & -- & -- & $\begin{array}{l}.02- \\
.1\end{array}$ & -- & -- & -- & -- & -- & $\begin{array}{l}4.97- \\
6.91\end{array}$ & ODEQ (1994b) \\
\hline Willamette & 48 & 1988 & Common carp & $\mathrm{f}$ & $5 \mathrm{c}$ & -- & -- & .16 & -- & -- & -- & -- & -- & 9.9 & ODEQ (1994b) \\
\hline Willamette & 48 & 1988 & $\begin{array}{l}\text { Northern } \\
\text { squawfish }\end{array}$ & $\mathrm{f}$ & $5 \mathrm{c}$ & -- & -- & .44 & -- & -- & -- & -- & -- & 4.65 & ODEQ (1994b) \\
\hline Willamette & 74 & 1989 & Common carp & $\mathrm{f}$ & 3 & -- & -- & $\begin{array}{l}.12- \\
.2\end{array}$ & -- & -- & -- & -- & -- & $\begin{array}{l}5.91- \\
9.11\end{array}$ & ODEQ (1994b) \\
\hline $\begin{array}{l}\text { Coast Fork } \\
\text { Willamette }\end{array}$ & -- & 1994 & Bluegill & $\mathrm{f}$ & 1 & -- & -- & .37 & -- & -- & -- & -- & -- & -- & ODEQ (1996) \\
\hline $\begin{array}{l}\text { Coast Fork } \\
\text { Willamette }\end{array}$ & -- & 1994 & Cutthroat trout & $\mathrm{f}$ & 5 & -- & -- & $\begin{array}{l}.24- \\
.42\end{array}$ & -- & -- & -- & -- & -- & -- & ODEQ (1996) \\
\hline $\begin{array}{l}\text { Coast Fork } \\
\text { Willamette }\end{array}$ & -- & 1994 & $\begin{array}{l}\text { Mountain } \\
\text { whitefish }\end{array}$ & $\mathrm{f}$ & 3 & -- & -- & $\begin{array}{l}.06- \\
.11\end{array}$ & -- & -- & -- & -- & -- & -- & ODEQ (1996) \\
\hline Row & -- & 1994 & Cutthroat trout & f & 5 & -- & -- & $\begin{array}{l}.09- \\
.13\end{array}$ & -- & -- & -- & -- & -- & -- & ODEQ (1996) \\
\hline Row & -- & 1994 & $\begin{array}{l}\text { Largemouth } \\
\text { bass }\end{array}$ & $\mathrm{f}$ & 5 & -- & -- & $\begin{array}{l}.29- \\
.58\end{array}$ & -- & -- & -- & -- & -- & -- & ODEQ (1996) \\
\hline Santiam & 0.5 & 1988 & $\begin{array}{l}\text { Northern } \\
\text { squawfish }\end{array}$ & $\mathrm{f}$ & 1 & -- & -- & .10 & -- & -- & -- & -- & -- & 8.11 & ODEQ (1994b) \\
\hline $\begin{array}{l}\text { Tualatin, } \\
\text { Cherry Grove }\end{array}$ & -- & 1987 & Cutthroat trout & $\mathrm{f}$ & $3-5 c$ & -- & -- & .07 & -- & -- & -- & -- & -- & -- & USEPA (1992a) \\
\hline $\begin{array}{l}\text { Tualatin, } \\
\text { Cherry Grove }\end{array}$ & -- & 1987 & Crayfish & wb & $3-5 c$ & -- & -- & ND & -- & -- & -- & -- & -- & -- & USEPA (1992a) \\
\hline
\end{tabular}


APPENDIX G-2. TRACE ELEMENTS IN TISSUE OF AQUATIC BIOTA FROM THE WILLAMETTE BASIN, OREGON-Continued

\begin{tabular}{|c|c|c|c|c|c|c|c|c|c|c|c|c|c|c|c|}
\hline \multirow[b]{2}{*}{ River } & \multirow[b]{2}{*}{$\begin{array}{c}\text { River } \\
\text { mile }\end{array}$} & \multirow[b]{2}{*}{ Years } & \multirow[b]{2}{*}{ Species } & \multirow[b]{2}{*}{$\begin{array}{l}\text { Tissue } \\
\text { type }\end{array}$} & \multirow[b]{2}{*}{$\begin{array}{l}\text { Number } \\
\text { samples }\end{array}$} & \multicolumn{9}{|c|}{ Concentration range $(\mu \mathrm{g} / \mathrm{g}$, wet weight) } & \multirow[b]{2}{*}{ Reference } \\
\hline & & & & & & Mg & Mn & $\mathrm{Hg}$ & Mo & $\mathrm{Ni}$ & $\mathrm{Se}$ & $\mathrm{Sr}$ & $\mathrm{TI}$ & $\mathrm{Zn}$ & \\
\hline $\begin{array}{l}\text { Tualatin, } \\
\text { Cook Park }\end{array}$ & -- & 1987 & Sucker & wb & $3-5 c$ & -- & -- & 0.18 & -- & -- & -- & -- & -- & -- & USEPA (1992a) \\
\hline $\begin{array}{l}\text { Conser } \\
\text { Slough }^{1}\end{array}$ & 0.1 & 1989 & Sucker & f & $5 \mathrm{c}$ & -- & -- & .08 & -- & -- & -- & -- & -- & 5.21 & ODEQ (1994b) \\
\hline $\begin{array}{l}\text { Conser } \\
\text { Slough }\end{array}$ & 0.1 & 1989 & $\begin{array}{l}\text { Northern } \\
\text { squawfish }\end{array}$ & f & $3 \mathrm{c}$ & -- & -- & .49 & -- & -- & -- & -- & -- & 5.57 & ODEQ (1994b) \\
\hline $\begin{array}{l}\text { Johnson } \\
\text { Creek }\end{array}$ & 1.5 & 1991 & Crayfish & wb & 1 & -- & -- & .03 & -- & -- & $<2.53$ & -- & $<5.05$ & 17.98 & ODEQ (1994b) \\
\hline $\begin{array}{l}\text { Johnson } \\
\text { Creek }\end{array}$ & 3 & 1991 & Crayfish & wb & 1 & -- & -- & .09 & -- & -- & $<2.53$ & -- & $<5.05$ & 19.02 & ODEQ (1994b) \\
\hline $\begin{array}{l}\text { Johnson } \\
\text { Creek }\end{array}$ & 6.1 & 1991 & Crayfish & wb & 1 & -- & -- & .14 & -- & -- & $<2.11$ & -- & $<4.23$ & 15.04 & ODEQ (1994b) \\
\hline $\begin{array}{l}\text { Johnson } \\
\text { Creek }\end{array}$ & 8.3 & 1991 & Crayfish & wb & 1 & -- & -- & .12 & -- & -- & $<2.76$ & -- & $<5.53$ & 18.12 & ODEQ (1994b) \\
\hline $\begin{array}{l}\text { Johnson } \\
\text { Creek }\end{array}$ & -- & 1991 & Crayfish & wb & 1 & -- & -- & .11 & -- & -- & $<2.7$ & -- & $<5.4$ & 19.87 & ODEQ (1994b) \\
\hline $\begin{array}{l}\text { Johnson } \\
\text { Creek }\end{array}$ & 16.9 & 1991 & Crayfish & wb & 1 & -- & -- & .08 & -- & -- & $<2.91$ & -- & $<5.83$ & 18.41 & ODEQ (1994b) \\
\hline $\begin{array}{l}\text { Johnson } \\
\text { Creek }\end{array}$ & 21 & 1991 & Crayfish & wb & 1 & -- & -- & .05 & -- & -- & $<2.73$ & -- & $<5.45$ & 17.44 & ODEQ (1994b) \\
\hline $\begin{array}{l}\text { Johnson } \\
\text { Creek }\end{array}$ & -- & 1991 & Crayfish & wb & 1 & -- & -- & .09 & -- & -- & $<2.58$ & -- & $<5.5$ & 17.72 & ODEQ (1994b) \\
\hline Rock Creek ${ }^{2}$ & 1.5 & 1994 & Sculpin & wb & $9 \mathrm{c}$ & 320 & 7.41 & .09 & $<0.10$ & $<0.16$ & -- & 14.0 & -- & 19.0 & USFWS (1994c) \\
\hline Rock Creek & 1.5 & 1994 & $\begin{array}{l}\text { Largemouth } \\
\text { bass }\end{array}$ & wb & $2 \mathrm{c}$ & 450 & 3.39 & .08 & $<.10$ & .56 & -- & 20.0 & -- & 22.0 & USFWS (1994c) \\
\hline Rock Creek & $1.7-2$ & 1994 & $\begin{array}{l}\text { Three-spined } \\
\text { stickleback }\end{array}$ & wb & $9 \mathrm{c}$ & 390 & 11.0 & .11 & $<.10$ & .42 & -- & 12.0 & -- & 39.9 & USFWS (1994c) \\
\hline Rock Creek & $1.7-2$ & 1994 & Sculpin & wb & $6 \mathrm{c}$ & 340 & 3.40 & .12 & $<.10$ & .18 & -- & 19.0 & -- & 22.0 & USFWS (1994c) \\
\hline Rock Creek & 2 & 1994 & $\begin{array}{l}\text { Three-spined } \\
\text { stickleback }\end{array}$ & wb & $9 \mathrm{c}$ & 360 & 10.0 & .13 & .18 & .28 & -- & 12.0 & -- & 35.1 & USFWS (1994c) \\
\hline Rock Creek & 2 & 1994 & Sculpin & $\mathrm{wb}$ & 1 & 306 & 4.20 & .10 & .10 & .86 & -- & 15.7 & -- & 23.6 & USFWS (1994c) \\
\hline
\end{tabular}


APPENDIX G-2. TRACE ELEMENTS IN TISSUE OF AQUATIC BIOTA FROM THE WILLAMETTE BASIN, OREGON-Continued

\begin{tabular}{|c|c|c|c|c|c|c|c|c|c|c|c|c|c|c|c|}
\hline \multirow[b]{2}{*}{ River } & \multirow[b]{2}{*}{$\begin{array}{c}\text { River } \\
\text { mile }\end{array}$} & \multirow[b]{2}{*}{ Years } & \multirow[b]{2}{*}{ Species } & \multirow[b]{2}{*}{$\begin{array}{l}\text { Tissue } \\
\text { type }\end{array}$} & \multirow[b]{2}{*}{$\begin{array}{l}\text { Number } \\
\text { samples }\end{array}$} & \multicolumn{9}{|c|}{ Concentration range $(\mu \mathrm{g} / \mathrm{g}$, wet weight) } & \multirow[b]{2}{*}{ Reference } \\
\hline & & & & & & Mg & Mn & $\mathrm{Hg}$ & Mo & $\mathbf{N i}$ & $\mathrm{Se}$ & $\mathrm{Sr}$ & TI & $\mathrm{Zn}$ & \\
\hline Rock Creek & 2.9 & 1994 & $\begin{array}{l}\text { Three-spined } \\
\text { stickleback }\end{array}$ & wb & 1 & 500 & 12.0 & -- & $<0.48$ & $<0.77$ & -- & 15.0 & -- & 29.0 & USFWS (1994c) \\
\hline Rock Creek & 2.9 & 1994 & Crappie & wb & 1 & 430 & 2.10 & $<0.05$ & $<.10$ & .67 & -- & 26.0 & -- & 27.0 & USFWS (1994c) \\
\hline $\begin{array}{l}\text { Cottage Grove } \\
\text { Lake }\end{array}$ & -- & 1974 & $\begin{array}{l}\text { Brown } \\
\text { bullhead }\end{array}$ & f & 68 & -- & -- & $\begin{array}{l}.17- \\
.68\end{array}$ & -- & -- & -- & -- & -- & -- & Worcester (1979) \\
\hline $\begin{array}{l}\text { Cottage Grove } \\
\text { Lake }\end{array}$ & -- & 1974 & $\begin{array}{l}\text { Spring chinook } \\
\text { salmon }\end{array}$ & $\mathrm{f}$ & 122 & -- & -- & $\begin{array}{l}.09- \\
.82\end{array}$ & -- & -- & -- & -- & -- & -- & Worcester (1979) \\
\hline $\begin{array}{l}\text { Cottage Grove } \\
\text { Lake }\end{array}$ & -- & 1974 & Cutthroat trout & $\mathrm{f}$ & 33 & -- & -- & $\begin{array}{l}.10- \\
1.36\end{array}$ & -- & -- & -- & -- & -- & -- & Worcester (1979) \\
\hline $\begin{array}{l}\text { Cottage Grove } \\
\text { Lake }\end{array}$ & -- & 1974 & Rainbow trout & $\mathrm{f}$ & 20 & -- & -- & $\begin{array}{l}.05- \\
.48\end{array}$ & -- & -- & -- & -- & -- & -- & Worcester (1979) \\
\hline $\begin{array}{l}\text { Cottage Grove } \\
\text { Lake }\end{array}$ & -- & 1974 & $\begin{array}{l}\text { Largemouth } \\
\text { bass }\end{array}$ & $\mathrm{f}$ & 35 & -- & -- & $\begin{array}{l}.15- \\
1.44\end{array}$ & -- & -- & -- & -- & -- & -- & Worcester (1979) \\
\hline $\begin{array}{l}\text { Cottage Grove } \\
\text { Lake }\end{array}$ & -- & 1975 & $\begin{array}{l}\text { Brown } \\
\text { bullhead }\end{array}$ & $\mathrm{f}$ & 14 & -- & -- & $\begin{array}{l}.08- \\
.35\end{array}$ & -- & -- & -- & -- & -- & -- & Worcester (1979) \\
\hline $\begin{array}{l}\text { Cottage Grove } \\
\text { Lake }\end{array}$ & -- & $1975-76$ & $\begin{array}{l}\text { Spring chinook } \\
\text { salmon }\end{array}$ & $\mathrm{f}$ & 84 & -- & -- & $\begin{array}{l}.10- \\
.96\end{array}$ & -- & -- & -- & -- & -- & -- & Worcester (1979) \\
\hline $\begin{array}{l}\text { Cottage Grove } \\
\text { Lake }\end{array}$ & -- & 1975 & Cutthroat trout & $\mathrm{f}$ & 12 & -- & -- & $\begin{array}{l}.06- \\
.35\end{array}$ & -- & -- & -- & -- & -- & -- & Worcester (1979) \\
\hline $\begin{array}{l}\text { Cottage Grove } \\
\text { Lake }\end{array}$ & -- & 1975 & Rainbow trout & $\mathrm{f}$ & 12 & -- & -- & $\begin{array}{l}.07- \\
.24\end{array}$ & -- & -- & -- & -- & -- & -- & Worcester (1979) \\
\hline $\begin{array}{l}\text { Cottage Grove } \\
\text { Lake }\end{array}$ & -- & 1990 & $\begin{array}{l}\text { Largemouth } \\
\text { bass }\end{array}$ & $\mathrm{f}$ & 5 & -- & -- & $\begin{array}{l}.22- \\
1.79\end{array}$ & -- & -- & -- & -- & -- & -- & $\begin{array}{l}\text { Allen and Curtis } \\
\text { (1991) }\end{array}$ \\
\hline $\begin{array}{l}\text { Cottage Grove } \\
\text { Lake }\end{array}$ & -- & 1993 & Black crappie & $\mathrm{f}$ & 6 & -- & -- & $\begin{array}{l}.38- \\
.75\end{array}$ & -- & -- & -- & -- & -- & -- & ODEQ (1996) \\
\hline $\begin{array}{l}\text { Cottage Grove } \\
\text { Lake }\end{array}$ & -- & 1993-94 & Bluegill & $\mathrm{f}$ & 7 & -- & -- & $\begin{array}{l}.46- \\
1.13\end{array}$ & -- & -- & -- & -- & -- & -- & ODEQ (1996) \\
\hline $\begin{array}{l}\text { Cottage Grove } \\
\text { Lake }\end{array}$ & -- & 1993-94 & Bullhead & $\mathrm{f}$ & 12 & -- & -- & $\begin{array}{l}.26- \\
.75\end{array}$ & -- & -- & -- & -- & -- & -- & ODEQ (1996) \\
\hline $\begin{array}{l}\text { Cottage Grove } \\
\text { Lake }\end{array}$ & -- & $1990-94$ & $\begin{array}{l}\text { Largemouth } \\
\text { bass }\end{array}$ & $\mathrm{f}$ & 23 & -- & -- & $\begin{array}{l}.22- \\
1.79\end{array}$ & -- & -- & -- & -- & -- & -- & ODEQ (1996) \\
\hline Dorena Lake & -- & 1993 & Black crappie & $\mathrm{f}$ & 8 & -- & -- & $\begin{array}{c}0.16- \\
.24\end{array}$ & -- & -- & -- & -- & -- & -- & ODEQ (1996) \\
\hline
\end{tabular}


APPENDIX G-2. TRACE ELEMENTS IN TISSUE OF AQUATIC BIOTA FROM THE WILLAMETTE BASIN, OREGON-Continued

\begin{tabular}{|c|c|c|c|c|c|c|c|c|c|c|c|c|c|c|c|}
\hline \multirow[b]{2}{*}{ River } & \multirow[b]{2}{*}{$\begin{array}{c}\text { River } \\
\text { mile }\end{array}$} & \multirow[b]{2}{*}{ Years } & \multirow[b]{2}{*}{ Species } & \multirow[b]{2}{*}{$\begin{array}{c}\text { Tissue } \\
\text { type }\end{array}$} & \multirow[b]{2}{*}{$\begin{array}{l}\text { Number } \\
\text { samples }\end{array}$} & \multicolumn{9}{|c|}{ Concentration range $(\mu \mathrm{g} / \mathrm{g}$, wet weight) } & \multirow[b]{2}{*}{ Reference } \\
\hline & & & & & & Mg & Mn & $\mathrm{Hg}$ & Mo & $\mathbf{N i}$ & $\mathrm{Se}$ & $\mathrm{Sr}$ & TI & Zn & \\
\hline Dorena Lake & -- & 1993-94 & Bluegill & $\mathrm{f}$ & 12 & -- & -- & $\begin{array}{l}.01- \\
.355\end{array}$ & -- & -- & -- & -- & -- & -- & ODEQ (1996) \\
\hline Dorena Lake & -- & 1994 & Bullhead & f & 2 & -- & -- & $\begin{array}{l}.25- \\
.37\end{array}$ & -- & -- & -- & -- & -- & -- & ODEQ (1996) \\
\hline Dorena Lake & -- & 1993-94 & $\begin{array}{l}\text { Largemouth } \\
\text { bass }\end{array}$ & f & 39 & -- & -- & $\begin{array}{l}.03- \\
.94\end{array}$ & -- & -- & -- & -- & -- & -- & ODEQ (1996) \\
\hline $\begin{array}{l}\text { Fern Ridge } \\
\text { Lake }\end{array}$ & -- & 1993 & Black crappie & $\mathrm{f}$ & 2 & -- & -- & $\begin{array}{l}.058- \\
.068\end{array}$ & -- & -- & -- & -- & -- & -- & ODEQ (1996) \\
\hline $\begin{array}{l}\text { Fern Ridge } \\
\text { Lake }\end{array}$ & -- & 1993 & Common carp & $\mathrm{wb}$ & 2 & -- & -- & $\begin{array}{l}.058- \\
.108\end{array}$ & -- & -- & -- & -- & -- & -- & ODEQ (1996) \\
\hline $\begin{array}{l}\text { Fern Ridge } \\
\text { Lake }\end{array}$ & -- & 1993 & $\begin{array}{l}\text { Largemouth } \\
\text { bass }\end{array}$ & f & 1 & -- & -- & .089 & -- & -- & -- & -- & -- & -- & ODEQ (1996) \\
\hline $\begin{array}{l}\text { Henry Hagg } \\
\text { Lake }\end{array}$ & -- & 1993 & $\begin{array}{l}\text { Largemouth } \\
\text { bass }\end{array}$ & $\mathrm{f}$ & 7 & -- & -- & $\begin{array}{l}.069- \\
.104\end{array}$ & -- & -- & -- & -- & -- & -- & ODEQ (1996) \\
\hline
\end{tabular}




\section{APPENDIX G-2. TRACE ELEMENTS IN TISSUE OF AQUATIC BIOTA FROM THE WILLAMETTE BASIN, OREGON}

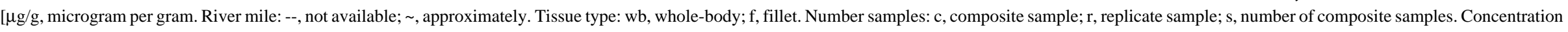

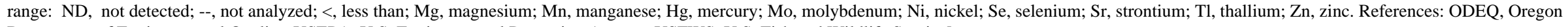
Department of Environmental Quality; USEPA, U.S. Environmental Protection Agency; USFWS, U.S. Fish and Wildlife Service

\begin{tabular}{|c|c|c|c|c|c|c|c|c|c|c|c|c|c|c|c|}
\hline \multirow[b]{2}{*}{ River } & \multirow[b]{2}{*}{$\begin{array}{l}\text { River } \\
\text { mile }\end{array}$} & \multirow[b]{2}{*}{ Years } & \multirow[b]{2}{*}{ Species } & \multirow[b]{2}{*}{$\begin{array}{l}\text { Tissue } \\
\text { type }\end{array}$} & \multirow[b]{2}{*}{$\begin{array}{l}\text { Number } \\
\text { samples }\end{array}$} & \multicolumn{9}{|c|}{ Concentration range ( $\mu \mathrm{g} / \mathrm{g}$, wet weight) } & \multirow[b]{2}{*}{ Reference } \\
\hline & & & & & & Mg & Mn & $\mathrm{Hg}$ & Mo & $\mathrm{Ni}$ & $\mathrm{Se}$ & $\mathrm{Sr}$ & TI & $\mathrm{Zn}$ & \\
\hline $\begin{array}{l}\text { Willamette } \\
\text { Newberg Pool }\end{array}$ & -- & 1987 & $\begin{array}{l}\text { Northern } \\
\text { squawfish }\end{array}$ & wb & $3-5 c$ & -- & -- & 0.11 & -- & -- & -- & -- & -- & -- & USEPA (1992a) \\
\hline $\begin{array}{l}\text { Willamette } \\
\text { Halsey }\end{array}$ & -- & 1987 & $\begin{array}{l}\text { Mountain } \\
\text { whitefish }\end{array}$ & $\mathrm{f}$ & $3-5 c$ & -- & -- & .06 & -- & -- & -- & -- & -- & -- & USEPA (1992a) \\
\hline $\begin{array}{l}\text { Willamette } \\
\text { Halsey }\end{array}$ & -- & 1987 & Sucker & wb & $3-5 c$ & -- & -- & .07 & -- & -- & -- & -- & -- & -- & USEPA (1992a) \\
\hline Willamette & $\sim 7$ & 1987 & Sucker & $w b$ & $3-5 c$ & -- & -- & ND & -- & -- & -- & -- & -- & -- & USEPA (1992a) \\
\hline Willamette & 7 & 1989 & Common carp & $\mathrm{f}$ & 3 & -- & -- & $\begin{array}{l}.11- \\
.17\end{array}$ & -- & -- & -- & -- & -- & $9.55-12.37$ & ODEQ (1994b) \\
\hline Willamette & 7 & 1989 & Common carp & $\mathrm{f}$ & $5 c, 2 s$ & -- & -- & $\begin{array}{l}.17- \\
.19\end{array}$ & -- & -- & -- & -- & -- & $8.14-12.47$ & ODEQ (1994b) \\
\hline Willamette & 18 & 1989 & Common carp & $\mathrm{f}$ & $4 \mathrm{c}$ & -- & -- & .14 & -- & -- & -- & -- & -- & 7.07 & ODEQ (1994b) \\
\hline Willamette & 18 & 1989 & Sucker & $\mathrm{f}$ & $3 \mathrm{c}$ & -- & -- & .05 & -- & -- & -- & -- & -- & 5.64 & ODEQ (1994b) \\
\hline Willamette & $\sim 26$ & 1971 & $\begin{array}{l}\text { Largescale } \\
\text { sucker }\end{array}$ & wb & $5 c$ & -- & -- & .28 & -- & -- & -- & -- & -- & -- & $\begin{array}{l}\text { Walsh and others } \\
\text { (1977) }\end{array}$ \\
\hline Willamette & $\sim 26$ & 1971 & $\begin{array}{l}\text { Largescale } \\
\text { sucker }\end{array}$ & $w b$ & $5 \mathrm{c}, \mathrm{r}$ & -- & -- & .32 & -- & -- & -- & -- & -- & -- & $\begin{array}{l}\text { Walsh and others } \\
\text { (1977) }\end{array}$ \\
\hline Willamette & $\sim 26$ & 1971 & $\begin{array}{l}\text { Northern } \\
\text { squawfish }\end{array}$ & $w b$ & $3 \mathrm{c}$ & -- & -- & 1.10 & -- & -- & -- & -- & -- & -- & $\begin{array}{l}\text { Walsh and others } \\
\text { (1977) }\end{array}$ \\
\hline Willamette & $\sim 26$ & 1971 & $\begin{array}{l}\text { Northern } \\
\text { squawfish }\end{array}$ & $w b$ & $3 \mathrm{c}, \mathrm{r}$ & -- & -- & .99 & -- & -- & -- & -- & -- & -- & $\begin{array}{l}\text { Walsh and others } \\
\text { (1977) }\end{array}$ \\
\hline Willamette & $\sim 26$ & 1972 & Channel catfish & wb & $5 c$ & -- & -- & .29 & -- & -- & 0.06 & -- & -- & -- & $\begin{array}{l}\text { Walsh and others } \\
\text { (1977) }\end{array}$ \\
\hline Willamette & $\sim 26$ & 1972 & $\begin{array}{l}\text { Northern } \\
\text { squawfish }\end{array}$ & $w b$ & $5 \mathrm{c}$ & -- & -- & .04 & -- & -- & .04 & -- & -- & -- & $\begin{array}{l}\text { Walsh and others } \\
\text { (1977) }\end{array}$ \\
\hline Willamette & $\sim 26$ & 1972 & $\begin{array}{l}\text { Largescale } \\
\text { sucker }\end{array}$ & wb & $5 \mathrm{c}$ & -- & -- & .24 & -- & -- & .12 & -- & -- & -- & $\begin{array}{l}\text { Walsh and others } \\
\text { (1977) }\end{array}$ \\
\hline Willamette & $\sim 26$ & 1972 & $\begin{array}{l}\text { Largescale } \\
\text { sucker }\end{array}$ & $\mathrm{wb}$ & $5 \mathrm{c}, \mathrm{r}$ & -- & -- & .04 & -- & -- & .09 & -- & -- & -- & $\begin{array}{l}\text { Walsh and others } \\
\text { (1977) }\end{array}$ \\
\hline
\end{tabular}


APPENDIX G-2. TRACE ELEMENTS IN TISSUE OF AQUATIC BIOTA FROM THE WILLAMETTE BASIN, OREGON-Continued

\begin{tabular}{|c|c|c|c|c|c|c|c|c|c|c|c|c|c|c|c|}
\hline \multirow[b]{2}{*}{ River } & \multirow[b]{2}{*}{$\begin{array}{c}\text { River } \\
\text { mile }\end{array}$} & \multirow[b]{2}{*}{ Years } & \multirow[b]{2}{*}{ Species } & \multirow[b]{2}{*}{$\begin{array}{l}\text { Tissue } \\
\text { type }\end{array}$} & \multirow[b]{2}{*}{$\begin{array}{l}\text { Number } \\
\text { samples }\end{array}$} & \multicolumn{9}{|c|}{ Concentration range ( $\mu \mathrm{g} / \mathrm{g}$, wet weight) } & \multirow[b]{2}{*}{ Reference } \\
\hline & & & & & & Mg & Mn & $\mathrm{Hg}$ & Mo & $\mathrm{Ni}$ & Se & $\mathrm{Sr}$ & $\mathrm{TI}$ & Zn & \\
\hline Willamette & $\sim 26$ & 1973 & $\begin{array}{l}\text { Largescale } \\
\text { sucker }\end{array}$ & $w b$ & $5 \mathrm{c}$ & -- & -- & 0.08 & -- & -- & 0.09 & -- & -- & -- & $\begin{array}{l}\text { Walsh and others } \\
\text { (1977) }\end{array}$ \\
\hline Willamette & $\sim 26$ & 1973 & $\begin{array}{l}\text { Largescale } \\
\text { sucker }\end{array}$ & wb & $5 \mathrm{c}, \mathrm{r}$ & -- & -- & .20 & -- & -- & .05 & -- & -- & -- & $\begin{array}{l}\text { Walsh and others } \\
\text { (1977) }\end{array}$ \\
\hline Willamette & $\sim 26$ & 1973 & $\begin{array}{l}\text { Northern } \\
\text { squawfish }\end{array}$ & wb & $5 \mathrm{c}$ & -- & -- & .65 & -- & -- & $<.05$ & -- & -- & -- & $\begin{array}{l}\text { Walsh and others } \\
\text { (1977) }\end{array}$ \\
\hline Willamette & $\sim 26$ & 1973 & Common carp & wb & $5 \mathrm{c}$ & -- & -- & .15 & -- & -- & .18 & -- & -- & -- & $\begin{array}{l}\text { Walsh and others } \\
\text { (1977) }\end{array}$ \\
\hline Willamette & $\sim 26$ & $\begin{array}{l}1976- \\
77\end{array}$ & $\begin{array}{l}\text { Smallmouth } \\
\text { bass }\end{array}$ & wb & $3 c$ & -- & -- & .13 & -- & -- & -- & -- & -- & -- & $\begin{array}{l}\text { May and McKinney } \\
\text { (1981) }\end{array}$ \\
\hline Willamette & $\sim 26$ & 1976-77 & Chiselmouth & wb & $5 \mathrm{c}$ & -- & -- & $<.02$ & -- & -- & -- & -- & -- & -- & $\begin{array}{l}\text { May and McKinney } \\
\text { (1981) }\end{array}$ \\
\hline Willamette & $\sim 26$ & 1978 & $\begin{array}{l}\text { Northern } \\
\text { squawfish }\end{array}$ & wb & $3-5 c$ & -- & -- & .52 & -- & -- & .13 & -- & -- & 23.2 & $\begin{array}{l}\text { Lowe and others } \\
\text { (1985) }\end{array}$ \\
\hline Willamette & $\sim 26$ & 1978 & Chiselmouth & wb & $3-5 c$ & -- & -- & .04 & -- & -- & .17 & -- & -- & 31.9 & $\begin{array}{l}\text { Lowe and others } \\
\text { (1985) }\end{array}$ \\
\hline Willamette & $\sim 26$ & 1978 & Chiselmouth & wb & $3-5 c$ & -- & -- & .03 & -- & -- & .14 & -- & -- & 42.2 & $\begin{array}{l}\text { Lowe and others } \\
\text { (1985) }\end{array}$ \\
\hline Willamette & $\sim 26$ & 1980 & $\begin{array}{l}\text { Largescale } \\
\text { sucker }\end{array}$ & wb & $3-5 c$ & -- & -- & .15 & -- & -- & .20 & -- & -- & 22.4 & $\begin{array}{l}\text { Lowe and others } \\
\text { (1985) }\end{array}$ \\
\hline Willamette & $\sim 26$ & 1980 & $\begin{array}{l}\text { Largescale } \\
\text { sucker }\end{array}$ & wb & $3-5 c$ & -- & -- & .23 & -- & -- & .23 & -- & -- & 22.6 & $\begin{array}{l}\text { Lowe and others } \\
\text { (1985) }\end{array}$ \\
\hline Willamette & $\sim 26$ & 1980 & $\begin{array}{l}\text { Northern } \\
\text { squawfish }\end{array}$ & wb & $3-5 c$ & -- & -- & .77 & -- & -- & .45 & -- & -- & 17.6 & $\begin{array}{l}\text { Lowe and others } \\
\text { (1985) }\end{array}$ \\
\hline Willamette & $\sim 26$ & 1984 & $\begin{array}{l}\text { Northern } \\
\text { squawfish }\end{array}$ & wb & $3-5 c$ & -- & -- & .21 & -- & -- & .25 & -- & -- & 16.35 & $\begin{array}{l}\text { Schmitt and } \\
\text { Brumbaugh (1990) }\end{array}$ \\
\hline Willamette & $\sim 26$ & 1984 & Peamouth & wb & $3-5 c$ & -- & -- & .05 & -- & -- & .11 & -- & -- & 17.48 & $\begin{array}{l}\text { Schmitt and } \\
\text { Brumbaugh (1990) }\end{array}$ \\
\hline Willamette & $\sim 26$ & 1984 & Peamouth & wb & $3-5 c$ & -- & -- & .04 & -- & -- & .13 & -- & -- & 17.55 & $\begin{array}{l}\text { Schmitt and } \\
\text { Brumbaugh (1990) }\end{array}$ \\
\hline Willamette & 27 & 1988 & Bass & $\mathrm{f}$ & $3 c$ & -- & -- & .1 & -- & -- & -- & -- & -- & 5.8 & ODEQ (1994b) \\
\hline Willamette & 27 & 1988 & Common carp & $\mathrm{f}$ & $3 \mathrm{c}, 2 \mathrm{~s}$ & -- & -- & $\begin{array}{l}.2- \\
.46\end{array}$ & -- & -- & -- & -- & -- & $\begin{array}{l}4.85- \\
7.28\end{array}$ & ODEQ (1994b) \\
\hline
\end{tabular}


APPENDIX G-2. TRACE ELEMENTS IN TISSUE OF AQUATIC BIOTA FROM THE WILLAMETTE BASIN, OREGON-Continued

\begin{tabular}{|c|c|c|c|c|c|c|c|c|c|c|c|c|c|c|c|}
\hline \multirow[b]{2}{*}{ River } & \multirow{2}{*}{$\begin{array}{c}\text { River } \\
\text { mile }\end{array}$} & \multirow[b]{2}{*}{ Years } & \multirow[b]{2}{*}{ Species } & \multirow{2}{*}{$\begin{array}{c}\text { Tissue } \\
\text { type }\end{array}$} & \multirow{2}{*}{$\begin{array}{l}\text { Number } \\
\text { samples }\end{array}$} & \multicolumn{9}{|c|}{ Concentration range ( $\mu \mathrm{g} / \mathrm{g}$, wet weight) } & \multirow[b]{2}{*}{ Reference } \\
\hline & & & & & & Mg & Mn & $\mathrm{Hg}$ & Mo & $\mathbf{N i}$ & $\mathrm{Se}$ & $\mathrm{Sr}$ & TI & Zn & \\
\hline Willamette & 27 & 1988 & $\begin{array}{l}\text { Northern } \\
\text { squawfish }\end{array}$ & $\mathrm{f}$ & $3 \mathrm{c}$ & -- & -- & 0.34 & -- & -- & -- & -- & -- & 4.98 & ODEQ (1994b) \\
\hline Willamette & 28 & 1989 & Common carp & $\mathrm{f}$ & 3 & -- & -- & $\begin{array}{l}.14- \\
.16\end{array}$ & -- & -- & -- & -- & -- & $\begin{array}{l}6.7-1 \\
4.56\end{array}$ & ODEQ (1994b) \\
\hline Willamette & 38 & 1989 & Sucker & $\mathrm{f}$ & $9 \mathrm{c}$ & -- & -- & .11 & -- & -- & -- & -- & -- & 5.1 & ODEQ (1994b) \\
\hline Willamette & 38 & $1988-89$ & $\begin{array}{l}\text { Northern } \\
\text { squawfish }\end{array}$ & f & $5 \mathrm{c}, 2 \mathrm{~s}$ & -- & -- & $\begin{array}{l}.14- \\
.23\end{array}$ & -- & -- & -- & -- & -- & $\begin{array}{l}6.06- \\
7.68\end{array}$ & ODEQ (1994b) \\
\hline Willamette & 38 & 1988 & Common carp & $\mathrm{f}$ & $3 \mathrm{c}$ & -- & -- & .12 & -- & -- & -- & -- & -- & 16.28 & ODEQ (1994b) \\
\hline Willamette & 48 & 1989 & Common carp & $\mathrm{f}$ & 2 & -- & -- & $\begin{array}{l}.02- \\
.1\end{array}$ & -- & -- & -- & -- & -- & $\begin{array}{l}4.97- \\
6.91\end{array}$ & ODEQ (1994b) \\
\hline Willamette & 48 & 1988 & Common carp & $\mathrm{f}$ & $5 \mathrm{c}$ & -- & -- & .16 & -- & -- & -- & -- & -- & 9.9 & ODEQ (1994b) \\
\hline Willamette & 48 & 1988 & $\begin{array}{l}\text { Northern } \\
\text { squawfish }\end{array}$ & $\mathrm{f}$ & $5 \mathrm{c}$ & -- & -- & .44 & -- & -- & -- & -- & -- & 4.65 & ODEQ (1994b) \\
\hline Willamette & 74 & 1989 & Common carp & $\mathrm{f}$ & 3 & -- & -- & $\begin{array}{l}.12- \\
.2\end{array}$ & -- & -- & -- & -- & -- & $\begin{array}{l}5.91- \\
9.11\end{array}$ & ODEQ (1994b) \\
\hline $\begin{array}{l}\text { Coast Fork } \\
\text { Willamette }\end{array}$ & -- & 1994 & Bluegill & $\mathrm{f}$ & 1 & -- & -- & .37 & -- & -- & -- & -- & -- & -- & ODEQ (1996) \\
\hline $\begin{array}{l}\text { Coast Fork } \\
\text { Willamette }\end{array}$ & -- & 1994 & Cutthroat trout & $\mathrm{f}$ & 5 & -- & -- & $\begin{array}{l}.24- \\
.42\end{array}$ & -- & -- & -- & -- & -- & -- & ODEQ (1996) \\
\hline $\begin{array}{l}\text { Coast Fork } \\
\text { Willamette }\end{array}$ & -- & 1994 & $\begin{array}{l}\text { Mountain } \\
\text { whitefish }\end{array}$ & $\mathrm{f}$ & 3 & -- & -- & $\begin{array}{l}.06- \\
.11\end{array}$ & -- & -- & -- & -- & -- & -- & ODEQ (1996) \\
\hline Row & -- & 1994 & Cutthroat trout & f & 5 & -- & -- & $\begin{array}{l}.09- \\
.13\end{array}$ & -- & -- & -- & -- & -- & -- & ODEQ (1996) \\
\hline Row & -- & 1994 & $\begin{array}{l}\text { Largemouth } \\
\text { bass }\end{array}$ & $\mathrm{f}$ & 5 & -- & -- & $\begin{array}{l}.29- \\
.58\end{array}$ & -- & -- & -- & -- & -- & -- & ODEQ (1996) \\
\hline Santiam & 0.5 & 1988 & $\begin{array}{l}\text { Northern } \\
\text { squawfish }\end{array}$ & $\mathrm{f}$ & 1 & -- & -- & .10 & -- & -- & -- & -- & -- & 8.11 & ODEQ (1994b) \\
\hline $\begin{array}{l}\text { Tualatin, } \\
\text { Cherry Grove }\end{array}$ & -- & 1987 & Cutthroat trout & $\mathrm{f}$ & $3-5 c$ & -- & -- & .07 & -- & -- & -- & -- & -- & -- & USEPA (1992a) \\
\hline $\begin{array}{l}\text { Tualatin, } \\
\text { Cherry Grove }\end{array}$ & -- & 1987 & Crayfish & wb & $3-5 c$ & -- & -- & ND & -- & -- & -- & -- & -- & -- & USEPA (1992a) \\
\hline
\end{tabular}


APPENDIX G-2. TRACE ELEMENTS IN TISSUE OF AQUATIC BIOTA FROM THE WILLAMETTE BASIN, OREGON-Continued

\begin{tabular}{|c|c|c|c|c|c|c|c|c|c|c|c|c|c|c|c|}
\hline \multirow[b]{2}{*}{ River } & \multirow[b]{2}{*}{$\begin{array}{c}\text { River } \\
\text { mile }\end{array}$} & \multirow[b]{2}{*}{ Years } & \multirow[b]{2}{*}{ Species } & \multirow[b]{2}{*}{$\begin{array}{l}\text { Tissue } \\
\text { type }\end{array}$} & \multirow[b]{2}{*}{$\begin{array}{l}\text { Number } \\
\text { samples }\end{array}$} & \multicolumn{9}{|c|}{ Concentration range $(\mu \mathrm{g} / \mathrm{g}$, wet weight) } & \multirow[b]{2}{*}{ Reference } \\
\hline & & & & & & Mg & Mn & $\mathrm{Hg}$ & Mo & $\mathrm{Ni}$ & $\mathrm{Se}$ & $\mathrm{Sr}$ & $\mathrm{TI}$ & $\mathrm{Zn}$ & \\
\hline $\begin{array}{l}\text { Tualatin, } \\
\text { Cook Park }\end{array}$ & -- & 1987 & Sucker & wb & $3-5 c$ & -- & -- & 0.18 & -- & -- & -- & -- & -- & -- & USEPA (1992a) \\
\hline $\begin{array}{l}\text { Conser } \\
\text { Slough }^{1}\end{array}$ & 0.1 & 1989 & Sucker & f & $5 \mathrm{c}$ & -- & -- & .08 & -- & -- & -- & -- & -- & 5.21 & ODEQ (1994b) \\
\hline $\begin{array}{l}\text { Conser } \\
\text { Slough }\end{array}$ & 0.1 & 1989 & $\begin{array}{l}\text { Northern } \\
\text { squawfish }\end{array}$ & f & $3 \mathrm{c}$ & -- & -- & .49 & -- & -- & -- & -- & -- & 5.57 & ODEQ (1994b) \\
\hline $\begin{array}{l}\text { Johnson } \\
\text { Creek }\end{array}$ & 1.5 & 1991 & Crayfish & wb & 1 & -- & -- & .03 & -- & -- & $<2.53$ & -- & $<5.05$ & 17.98 & ODEQ (1994b) \\
\hline $\begin{array}{l}\text { Johnson } \\
\text { Creek }\end{array}$ & 3 & 1991 & Crayfish & wb & 1 & -- & -- & .09 & -- & -- & $<2.53$ & -- & $<5.05$ & 19.02 & ODEQ (1994b) \\
\hline $\begin{array}{l}\text { Johnson } \\
\text { Creek }\end{array}$ & 6.1 & 1991 & Crayfish & wb & 1 & -- & -- & .14 & -- & -- & $<2.11$ & -- & $<4.23$ & 15.04 & ODEQ (1994b) \\
\hline $\begin{array}{l}\text { Johnson } \\
\text { Creek }\end{array}$ & 8.3 & 1991 & Crayfish & wb & 1 & -- & -- & .12 & -- & -- & $<2.76$ & -- & $<5.53$ & 18.12 & ODEQ (1994b) \\
\hline $\begin{array}{l}\text { Johnson } \\
\text { Creek }\end{array}$ & -- & 1991 & Crayfish & wb & 1 & -- & -- & .11 & -- & -- & $<2.7$ & -- & $<5.4$ & 19.87 & ODEQ (1994b) \\
\hline $\begin{array}{l}\text { Johnson } \\
\text { Creek }\end{array}$ & 16.9 & 1991 & Crayfish & wb & 1 & -- & -- & .08 & -- & -- & $<2.91$ & -- & $<5.83$ & 18.41 & ODEQ (1994b) \\
\hline $\begin{array}{l}\text { Johnson } \\
\text { Creek }\end{array}$ & 21 & 1991 & Crayfish & wb & 1 & -- & -- & .05 & -- & -- & $<2.73$ & -- & $<5.45$ & 17.44 & ODEQ (1994b) \\
\hline $\begin{array}{l}\text { Johnson } \\
\text { Creek }\end{array}$ & -- & 1991 & Crayfish & wb & 1 & -- & -- & .09 & -- & -- & $<2.58$ & -- & $<5.5$ & 17.72 & ODEQ (1994b) \\
\hline Rock Creek ${ }^{2}$ & 1.5 & 1994 & Sculpin & wb & $9 \mathrm{c}$ & 320 & 7.41 & .09 & $<0.10$ & $<0.16$ & -- & 14.0 & -- & 19.0 & USFWS (1994c) \\
\hline Rock Creek & 1.5 & 1994 & $\begin{array}{l}\text { Largemouth } \\
\text { bass }\end{array}$ & wb & $2 \mathrm{c}$ & 450 & 3.39 & .08 & $<.10$ & .56 & -- & 20.0 & -- & 22.0 & USFWS (1994c) \\
\hline Rock Creek & $1.7-2$ & 1994 & $\begin{array}{l}\text { Three-spined } \\
\text { stickleback }\end{array}$ & wb & $9 \mathrm{c}$ & 390 & 11.0 & .11 & $<.10$ & .42 & -- & 12.0 & -- & 39.9 & USFWS (1994c) \\
\hline Rock Creek & $1.7-2$ & 1994 & Sculpin & wb & $6 \mathrm{c}$ & 340 & 3.40 & .12 & $<.10$ & .18 & -- & 19.0 & -- & 22.0 & USFWS (1994c) \\
\hline Rock Creek & 2 & 1994 & $\begin{array}{l}\text { Three-spined } \\
\text { stickleback }\end{array}$ & wb & $9 \mathrm{c}$ & 360 & 10.0 & .13 & .18 & .28 & -- & 12.0 & -- & 35.1 & USFWS (1994c) \\
\hline Rock Creek & 2 & 1994 & Sculpin & $\mathrm{wb}$ & 1 & 306 & 4.20 & .10 & .10 & .86 & -- & 15.7 & -- & 23.6 & USFWS (1994c) \\
\hline
\end{tabular}


APPENDIX G-2. TRACE ELEMENTS IN TISSUE OF AQUATIC BIOTA FROM THE WILLAMETTE BASIN, OREGON-Continued

\begin{tabular}{|c|c|c|c|c|c|c|c|c|c|c|c|c|c|c|c|}
\hline \multirow[b]{2}{*}{ River } & \multirow[b]{2}{*}{$\begin{array}{c}\text { River } \\
\text { mile }\end{array}$} & \multirow[b]{2}{*}{ Years } & \multirow[b]{2}{*}{ Species } & \multirow[b]{2}{*}{$\begin{array}{l}\text { Tissue } \\
\text { type }\end{array}$} & \multirow[b]{2}{*}{$\begin{array}{l}\text { Number } \\
\text { samples }\end{array}$} & \multicolumn{9}{|c|}{ Concentration range $(\mu \mathrm{g} / \mathrm{g}$, wet weight) } & \multirow[b]{2}{*}{ Reference } \\
\hline & & & & & & Mg & Mn & $\mathrm{Hg}$ & Mo & $\mathbf{N i}$ & $\mathrm{Se}$ & $\mathrm{Sr}$ & TI & $\mathrm{Zn}$ & \\
\hline Rock Creek & 2.9 & 1994 & $\begin{array}{l}\text { Three-spined } \\
\text { stickleback }\end{array}$ & wb & 1 & 500 & 12.0 & -- & $<0.48$ & $<0.77$ & -- & 15.0 & -- & 29.0 & USFWS (1994c) \\
\hline Rock Creek & 2.9 & 1994 & Crappie & wb & 1 & 430 & 2.10 & $<0.05$ & $<.10$ & .67 & -- & 26.0 & -- & 27.0 & USFWS (1994c) \\
\hline $\begin{array}{l}\text { Cottage Grove } \\
\text { Lake }\end{array}$ & -- & 1974 & $\begin{array}{l}\text { Brown } \\
\text { bullhead }\end{array}$ & f & 68 & -- & -- & $\begin{array}{l}.17- \\
.68\end{array}$ & -- & -- & -- & -- & -- & -- & Worcester (1979) \\
\hline $\begin{array}{l}\text { Cottage Grove } \\
\text { Lake }\end{array}$ & -- & 1974 & $\begin{array}{l}\text { Spring chinook } \\
\text { salmon }\end{array}$ & $\mathrm{f}$ & 122 & -- & -- & $\begin{array}{l}.09- \\
.82\end{array}$ & -- & -- & -- & -- & -- & -- & Worcester (1979) \\
\hline $\begin{array}{l}\text { Cottage Grove } \\
\text { Lake }\end{array}$ & -- & 1974 & Cutthroat trout & $\mathrm{f}$ & 33 & -- & -- & $\begin{array}{l}.10- \\
1.36\end{array}$ & -- & -- & -- & -- & -- & -- & Worcester (1979) \\
\hline $\begin{array}{l}\text { Cottage Grove } \\
\text { Lake }\end{array}$ & -- & 1974 & Rainbow trout & $\mathrm{f}$ & 20 & -- & -- & $\begin{array}{l}.05- \\
.48\end{array}$ & -- & -- & -- & -- & -- & -- & Worcester (1979) \\
\hline $\begin{array}{l}\text { Cottage Grove } \\
\text { Lake }\end{array}$ & -- & 1974 & $\begin{array}{l}\text { Largemouth } \\
\text { bass }\end{array}$ & $\mathrm{f}$ & 35 & -- & -- & $\begin{array}{l}.15- \\
1.44\end{array}$ & -- & -- & -- & -- & -- & -- & Worcester (1979) \\
\hline $\begin{array}{l}\text { Cottage Grove } \\
\text { Lake }\end{array}$ & -- & 1975 & $\begin{array}{l}\text { Brown } \\
\text { bullhead }\end{array}$ & $\mathrm{f}$ & 14 & -- & -- & $\begin{array}{l}.08- \\
.35\end{array}$ & -- & -- & -- & -- & -- & -- & Worcester (1979) \\
\hline $\begin{array}{l}\text { Cottage Grove } \\
\text { Lake }\end{array}$ & -- & $1975-76$ & $\begin{array}{l}\text { Spring chinook } \\
\text { salmon }\end{array}$ & $\mathrm{f}$ & 84 & -- & -- & $\begin{array}{l}.10- \\
.96\end{array}$ & -- & -- & -- & -- & -- & -- & Worcester (1979) \\
\hline $\begin{array}{l}\text { Cottage Grove } \\
\text { Lake }\end{array}$ & -- & 1975 & Cutthroat trout & $\mathrm{f}$ & 12 & -- & -- & $\begin{array}{l}.06- \\
.35\end{array}$ & -- & -- & -- & -- & -- & -- & Worcester (1979) \\
\hline $\begin{array}{l}\text { Cottage Grove } \\
\text { Lake }\end{array}$ & -- & 1975 & Rainbow trout & $\mathrm{f}$ & 12 & -- & -- & $\begin{array}{l}.07- \\
.24\end{array}$ & -- & -- & -- & -- & -- & -- & Worcester (1979) \\
\hline $\begin{array}{l}\text { Cottage Grove } \\
\text { Lake }\end{array}$ & -- & 1990 & $\begin{array}{l}\text { Largemouth } \\
\text { bass }\end{array}$ & $\mathrm{f}$ & 5 & -- & -- & $\begin{array}{l}.22- \\
1.79\end{array}$ & -- & -- & -- & -- & -- & -- & $\begin{array}{l}\text { Allen and Curtis } \\
\text { (1991) }\end{array}$ \\
\hline $\begin{array}{l}\text { Cottage Grove } \\
\text { Lake }\end{array}$ & -- & 1993 & Black crappie & $\mathrm{f}$ & 6 & -- & -- & $\begin{array}{l}.38- \\
.75\end{array}$ & -- & -- & -- & -- & -- & -- & ODEQ (1996) \\
\hline $\begin{array}{l}\text { Cottage Grove } \\
\text { Lake }\end{array}$ & -- & 1993-94 & Bluegill & $\mathrm{f}$ & 7 & -- & -- & $\begin{array}{l}.46- \\
1.13\end{array}$ & -- & -- & -- & -- & -- & -- & ODEQ (1996) \\
\hline $\begin{array}{l}\text { Cottage Grove } \\
\text { Lake }\end{array}$ & -- & 1993-94 & Bullhead & $\mathrm{f}$ & 12 & -- & -- & $\begin{array}{l}.26- \\
.75\end{array}$ & -- & -- & -- & -- & -- & -- & ODEQ (1996) \\
\hline $\begin{array}{l}\text { Cottage Grove } \\
\text { Lake }\end{array}$ & -- & $1990-94$ & $\begin{array}{l}\text { Largemouth } \\
\text { bass }\end{array}$ & $\mathrm{f}$ & 23 & -- & -- & $\begin{array}{l}.22- \\
1.79\end{array}$ & -- & -- & -- & -- & -- & -- & ODEQ (1996) \\
\hline Dorena Lake & -- & 1993 & Black crappie & $\mathrm{f}$ & 8 & -- & -- & $\begin{array}{c}0.16- \\
.24\end{array}$ & -- & -- & -- & -- & -- & -- & ODEQ (1996) \\
\hline
\end{tabular}


APPENDIX G-2. TRACE ELEMENTS IN TISSUE OF AQUATIC BIOTA FROM THE WILLAMETTE BASIN, OREGON-Continued

\begin{tabular}{|c|c|c|c|c|c|c|c|c|c|c|c|c|c|c|c|}
\hline \multirow[b]{2}{*}{ River } & \multirow[b]{2}{*}{$\begin{array}{c}\text { River } \\
\text { mile }\end{array}$} & \multirow[b]{2}{*}{ Years } & \multirow[b]{2}{*}{ Species } & \multirow[b]{2}{*}{$\begin{array}{c}\text { Tissue } \\
\text { type }\end{array}$} & \multirow[b]{2}{*}{$\begin{array}{l}\text { Number } \\
\text { samples }\end{array}$} & \multicolumn{9}{|c|}{ Concentration range $(\mu \mathrm{g} / \mathrm{g}$, wet weight) } & \multirow[b]{2}{*}{ Reference } \\
\hline & & & & & & Mg & Mn & $\mathrm{Hg}$ & Mo & $\mathbf{N i}$ & $\mathrm{Se}$ & $\mathrm{Sr}$ & TI & Zn & \\
\hline Dorena Lake & -- & 1993-94 & Bluegill & $\mathrm{f}$ & 12 & -- & -- & $\begin{array}{l}.01- \\
.355\end{array}$ & -- & -- & -- & -- & -- & -- & ODEQ (1996) \\
\hline Dorena Lake & -- & 1994 & Bullhead & f & 2 & -- & -- & $\begin{array}{l}.25- \\
.37\end{array}$ & -- & -- & -- & -- & -- & -- & ODEQ (1996) \\
\hline Dorena Lake & -- & 1993-94 & $\begin{array}{l}\text { Largemouth } \\
\text { bass }\end{array}$ & f & 39 & -- & -- & $\begin{array}{l}.03- \\
.94\end{array}$ & -- & -- & -- & -- & -- & -- & ODEQ (1996) \\
\hline $\begin{array}{l}\text { Fern Ridge } \\
\text { Lake }\end{array}$ & -- & 1993 & Black crappie & $\mathrm{f}$ & 2 & -- & -- & $\begin{array}{l}.058- \\
.068\end{array}$ & -- & -- & -- & -- & -- & -- & ODEQ (1996) \\
\hline $\begin{array}{l}\text { Fern Ridge } \\
\text { Lake }\end{array}$ & -- & 1993 & Common carp & $\mathrm{wb}$ & 2 & -- & -- & $\begin{array}{l}.058- \\
.108\end{array}$ & -- & -- & -- & -- & -- & -- & ODEQ (1996) \\
\hline $\begin{array}{l}\text { Fern Ridge } \\
\text { Lake }\end{array}$ & -- & 1993 & $\begin{array}{l}\text { Largemouth } \\
\text { bass }\end{array}$ & f & 1 & -- & -- & .089 & -- & -- & -- & -- & -- & -- & ODEQ (1996) \\
\hline $\begin{array}{l}\text { Henry Hagg } \\
\text { Lake }\end{array}$ & -- & 1993 & $\begin{array}{l}\text { Largemouth } \\
\text { bass }\end{array}$ & $\mathrm{f}$ & 7 & -- & -- & $\begin{array}{l}.069- \\
.104\end{array}$ & -- & -- & -- & -- & -- & -- & ODEQ (1996) \\
\hline
\end{tabular}

